\title{
Geology of the Carlin Gold Deposit, Nevada
}

$\begin{array}{llll}\text { U.S. GEOLOGICAL SURVEY PROFESSIONAL PAPER } 1267 & \end{array}$

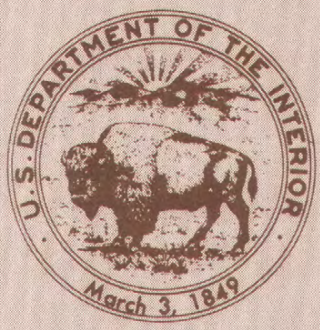




$$
\begin{aligned}
& \text { LIPA ARP } \\
& \text { JAN } 07 \text { '86 } \\
& \text { anow of Reclamation }
\end{aligned}
$$




\section{Carlin Gold Deposit, Nevada}

By ARTHUR S. RADTKE

U.S. GEOLOGICAL SURVEY PROFESSIONAL PAPER 1267

A detailed study of one of the largest disseminated-replacement gold deposits in North America

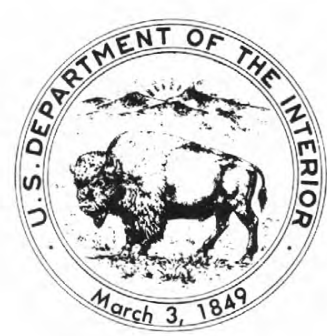




\section{DEPARTMENT OF THE INTERIOR}

DONALD PAUL HODEL, Secretary

\section{U.S. GEOLOGICAL SURVEY}

Dallas L. Peck, Director

\section{Library of Congress Cataloging in Publication Data}

Radtke, Arthur S., 1936-

Geology of the Carlin gold deposit, Nevada.

(Geological Survey professional paper ; 1267)

Bibliography: p. 120

Supt. of Docs. no.: I 19.16:1267

1. Gold ores-Nevada-Carlin region. 2. Geology-Nevada-Carlin region. I. Title. II. Series. TN423.N3R33 $553.4^{\prime} 1^{\prime} 0979316$ $82-600080$

AACR2

For sale by the Distribution Branch, U.S. Geological Survey 604 South Pickett Street, Alexandria, VA 22304 


\section{CONTENTS}

Abstract

Introduction

Location and accessibility _. . . . . . . . . . .

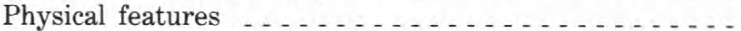

Climate and vegetation . . . . . . . . . . .

Purpose of report and methods of investigation . . . .

Acknowledgments . . . . . . . . . . . . . . . .

Previous work … . . . . . . . . . . .

History of the Lynn mining district $\ldots \ldots \ldots . . . .$.

Sedimentary rocks

Paleozoic rocks ... . . . . . . . . . . .

Lower plate . . . . . . . . . . . . . . . .

Ordovician System - . . . . . . . .

Pogonip Group . . . . . . . . . . .

Eureka Quartzite ............ . .

Ordovician and Silúrian Systems .......

Hanson Creek Formation . . . . . . . .

Silurian and Devonian Systems ....... . .

Roberts Mountains Formation .... .

Devonian System ... . . . . . . . . . .

Popovich Formation ..........

Upper plate . . . . . . . . . . . . . . . .

Ordovician and Silurian Systems ......

Lower zone .................

Middle zone ..............

Upper zone

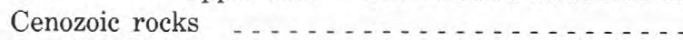

Lakebeds . . . . . . . . . . . . . . . .

Carlin Formation of Regnier (1960) _. . . . . .

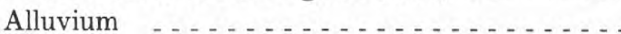

Igneous rocks $\ldots \ldots \ldots \ldots \ldots$

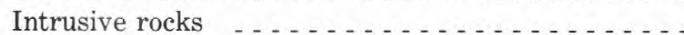

Extrusive rocks

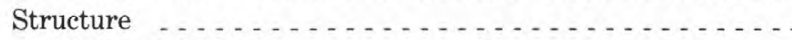

General features . . . . . . . . . . . . . . . .

Roberts Mountains thrust _. . . . . . . . . . .

Tuscarora Mountains anticline _. . . . . . . . . . . .

High-angle normal faults . . . . . . . . . . . . . .

High-angle faults in the lower plate . . . . . . . . .

High-angle faults in the upper plate . . . . . . . . .

Regional or major high-angle faults . . . . . . . . .

Blue Star Canyon fault . . . . . . . . . . . . .

Sheep Creek fault . . . . . . . . . . . . . .

Sheep Creek Canyon fault . . . . . . . . . . .

Hardie fault . . . . . . . . . . . . . . .

Mill fault . . . . . . . . . . . . . .

Leeville fault . . . . . . . . . . . . . .

Basin-and-range faults $\ldots \ldots \ldots \ldots$

General features of the Carlin deposit . . . . . . . . . . .

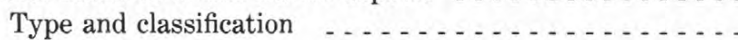

Stratigraphic relations _. . . . . . . . . . . . .

Structural setting $\ldots \ldots \ldots \ldots \ldots$
General features of the Carlin deposit — Continued

West ore zone . . . . . . . . . . . . . . . . . 40

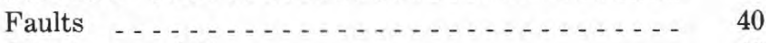

Ore characteristics . . . . . . . . . . . . . 40

Main ore zone . . . . . . . . . . . . . . . . 41

Structures 2. . . . . . . . . . . . . . . . 42

Ore characteristics _. . . . . . . . . . . . . . 44

South Extension ore zone _................ . . 45

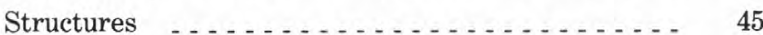

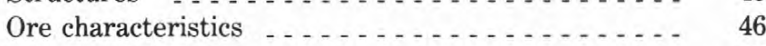

East ore zone $\ldots . . . \ldots 46$

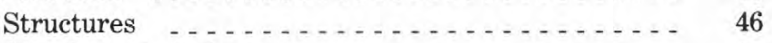

Ore characteristics . . . . . . . . . . . . . . 48

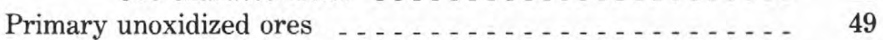

Normal ore _. . . . . . . . . . . . . . 49

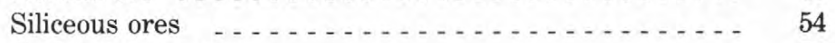

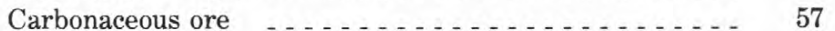

Pyritic ore $\ldots \ldots \ldots \ldots$

Arsenical ores . . . . . . . . . . . . . . . . . . . . 61

Mineralogy and distribution of elements in unoxidized ores .. 63

Iron . . . . . . . . . . . . . . . . . . 63

Gold $\ldots 30 \ldots$

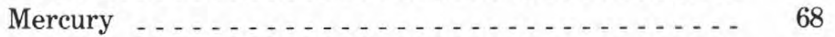

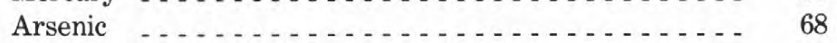

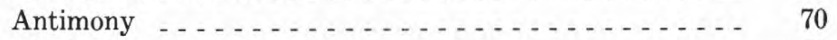

Thallium _... $\ldots \ldots \ldots \ldots \ldots$

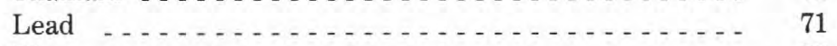

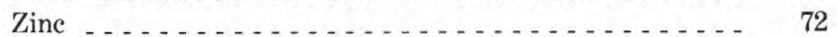

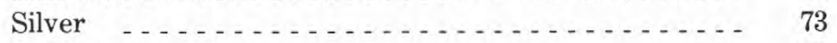

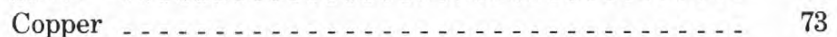

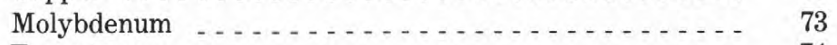

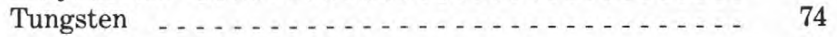

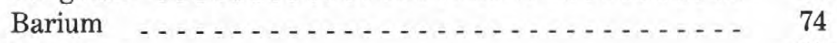

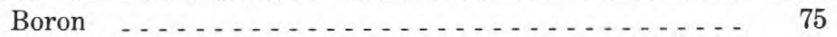

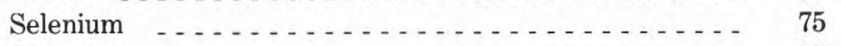

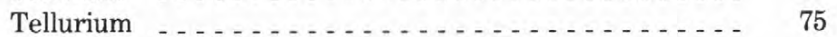

Rare-earth elements . . . . . . . . . . . . . . . . 75

Statistical study of elemental distributions _ . . . . . . . . . 76

Gold-arsenic-mercury-antimony suite _. . . . . . . . . 76

Gold-barium-copper-molybdenum-lead-zine suite _ . . . . 78

Gold-boron-selenium-tellurium-tungsten suite _. . . . . . 79

Hydrothermal alteration _. . . . . . . . . . . . . . . 80

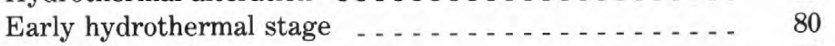

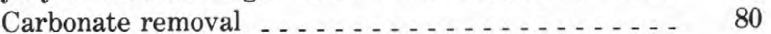

Main hydrothermal stage $\ldots \ldots \ldots$

Potassic-argillic alteration

Pyrite, gold, and associated metals _. . . . . . . 82

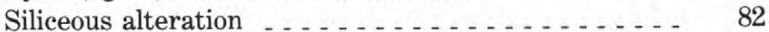

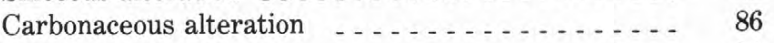

Late hydrothermal stage . . . . . . . . . . . . . . . . . 88

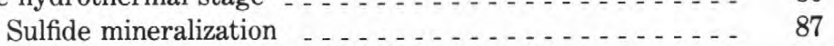

Arsenic, mercury, antimony, and thallium _. . . . . 87

Base metals _... . . . . . . . . . . . . 87 
Late hydrothermal stage — Continued Quartz veinlets

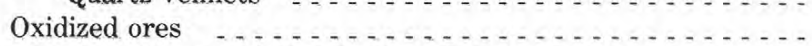
Mineralogy and distribution of elements in oxidized ores Iron - . . . . . . . . . . . . . . . . . .

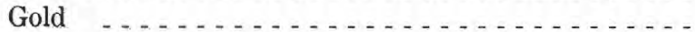

Mercury _................

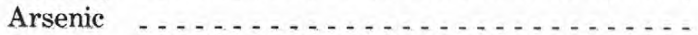

Antimony _................

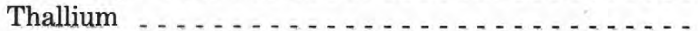

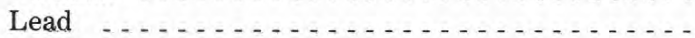

Zine $\ldots \ldots \ldots \ldots$

Silver . . . . . . . . . . . . . . . . . . . .

Copper . . . . . . . . . . . . . . . .

Molybdenum and tungsten ............

Barium - . . . . . . . . . . . . . .

Boron ... . . . . . . . . . . . . . .

Selenium and tellurium $\ldots \ldots \ldots \ldots \ldots \ldots \ldots$

Hydrothermal acid-leaching alteration ...............

Alteration of igneous rocks ...............

Chemical and mineralogic aspects . . . . . . . . . .

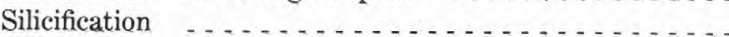

Barite veins

Calcite veins $\ldots \ldots \ldots \ldots \ldots$

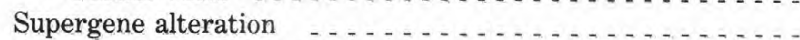

Fluid-inclusion and stable-isotope studies . . . . . . . . .

Fluid-inclusion studies _. . . . . . . . . . . . . . .

Materials and fluid-inclusion properties ......

Main-and late-hydrothermal-stage fluid inclusions . . -

Acid-leaching-oxidation fluid inclusions . . . . . . . . .

Posthydrothermal-supergene-oxidation-and-weathering fluid inclusions
Fluid Inclusion and stable-isotope studies-Continued Stable-isotope studies-introduction . . . . . . . . . . Hydrogen isotope data

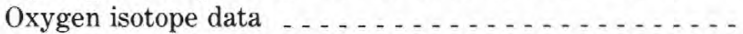
Unaltered host rocks Mineralized and hydrothermally altered rocks Acid-leached oxidized rocks . . . . . . . . . . . . .

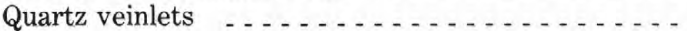
Jasperoid bodies . . . . . . . . . . . . . . . Barite veins 2. . . . . . . . . . . . . . . Calcite veins . . . . . . . . . . . . . . .

Carbon isotope data . . . . . . . . . . . . . Host rocks and ores . . . . . . . . . . . . Calcite veins . . . . . . . . . . . . . . . .

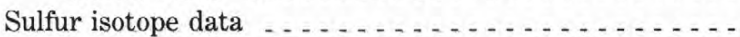
Host rocks 2. . . . . . . . . . . . . . Hydrothermal sulfides and barite . . . . . . . . . Origin of the sulfur .............. Lead isotope data $\ldots \ldots \ldots \ldots \ldots \ldots \ldots$ Genesis of the deposit ... . . . . . . . . . . . Origin and mobilization of ore components . . . . . . . Migration of fluids . . . . . . . . . . . . . . . Hydrothermal ore deposition . . . . . . . . . . .

Late-stage veins . . . . . . . . . . . . . . .

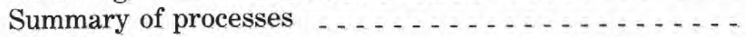

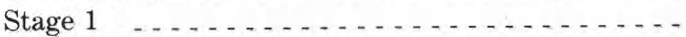

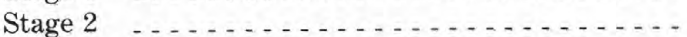

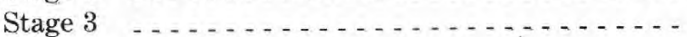

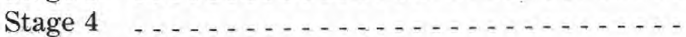

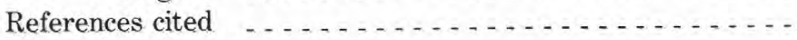
103
Page

103

104

105

105

106

108

109

109

109

110

111

111

111

111

112

112

112

113

113

115

116

116

117

119

119

119

119

120

120

\section{ILLUSTRATIONS}

[Plates are in pocket]

Plate 1. Geologic map of the Lynn mining district, Eureka County, Nev.

2. Cross sections to accompany geologic map of the Lynn mining district, Eureka County, Nev.

3. Geologic map of the Carlin gold deposit, Eureka County, Nev.

4. Cross sections to accompany geologic map of the Carlin gold deposit, Eureka County, Nev.

5. Map showing areas of hydrothermal alteration, Carlin gold deposit, Eureka County, Nev.

6. Map showing areas of hydrothermal acid-leaching alteration, Carlin gold deposit, Eureka County, Nev.

7. Map showing areas of supergene oxidation alteration, Carlin gold deposit, Eureka County, Nev.

FIGURE 1. Index map of Nevada, showing location of Carlin gold deposit

2. Photomicrograph of thin section of argillaceous-arenaceous dolomite (lime mudstone) of the Roberts Mountains

Page

3. Photomicrograph of thin section of arenaceous peloidal wackestone of the Roberts Mountains Formation - . -

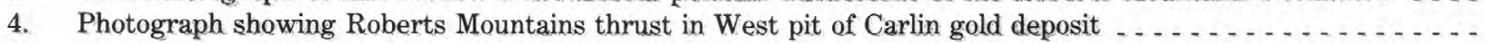

5. Block diagrams illustrating contact relations between upper-and lower-plate rocks and typical surface and subsur-

face expressions of Roberts Mountains thrust, in northern part of Lynn mining district ...........

6-11. Photographs showing:

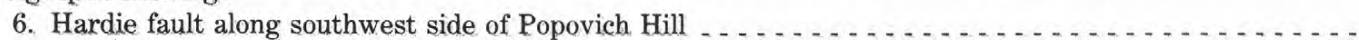

7. Mill fault at northwest end of Main pit

8. Leeville fault and other high-angle faults in north face at east end of East pit $\ldots \ldots$

9. Typical features in gold ores at base of supergene-oxidation zone in Main pit

10. Horst structure on east side of Popovich Hill

11. Specimens of fresh unmineralized host rock of the Roberts Mountains Formation and normal gold ore 


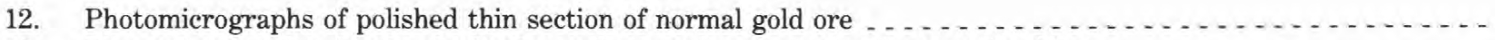

13. Photomicrographs showing hydrothermal mineral replacement in normal gold ore . . . . . . . . . . . . .

14. Photomicrograph showing fine-grained metallic gold and pyrite locked in hydrothermal quartz in normal gold ore -

15. Bar graph illustrating chemical changes in dolomitic carbonate rocks of the Roberts Mountains Formation during

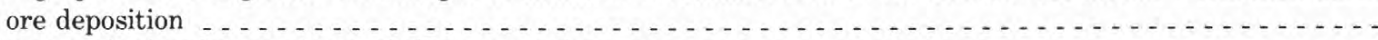

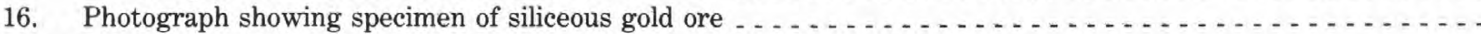

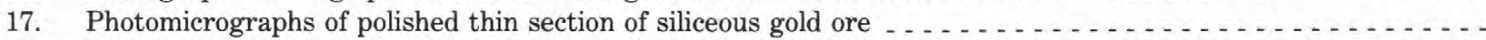

18. Photomicrographs showing varieties of auriferous pyrite and their textural relations to hydrothermal quartz in silice-

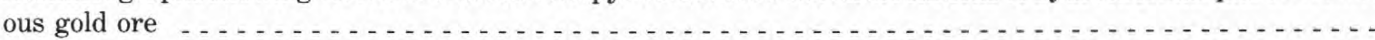

19. Photograph showing thin-bedded laminated specimen of carbonaceous gold ore . . . . . . . . . . . . . .

20. Photomicrograph of polished thin section of carbonaceous gold ore . . . . . . . . . . . . . . . .

21. Photomicrographs showing framboidal crystals of hydrothermal pyrite associated with carbonaceous materials in

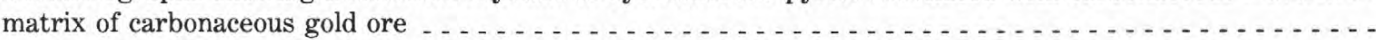

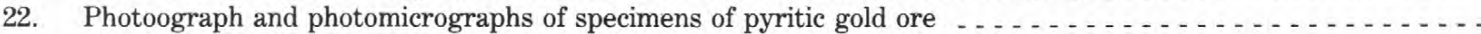

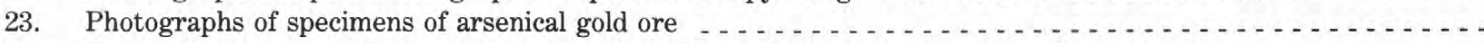

24. Photographing mass of blocky carbonaceous gold ore from southwest end of East ore zone ............

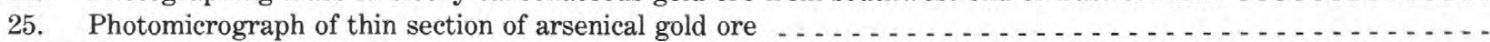

26. Photographs showing electron microprobe analyses of sectioned grain of cubic pyrite in arsenical gold ore ...

27. Photographs showing electron microprobe analyses of carbonaceous materials in sectioned specimen of carbonaceous

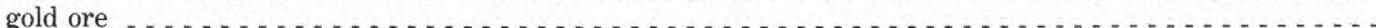

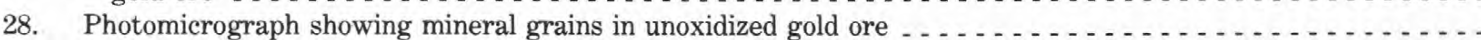

29. Schematic diagram illustrating paragenesis of the Carlin gold deposit . . . . . . . . . . . . . . . . . .

30. Photomicrograph showing potassic-argillic alteration features associated with mineralization ............

31-36. Photographs showing:

31. Thick craggy masses of hydrothermal silica along north-south-striking high-angle normal faults in south wall

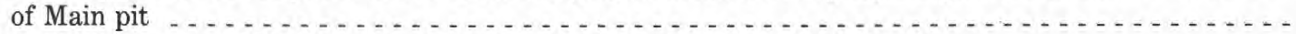

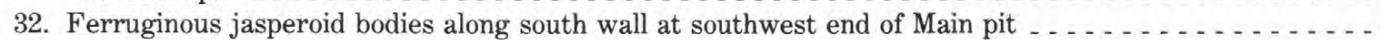

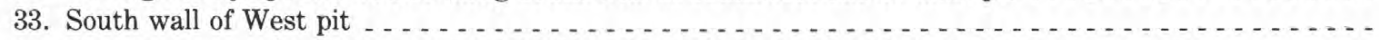

34. Enriched zone of carbonaceous materials near southwest end of East ore zone . . . . . . . . .

35. Carbonaceous alteration in shale of upper plate along southwest side of Popovich Hill in Main pit ...-

36. Specimens of unleached and acid-leached oxidized gold ores . . . . . . . . . . . . . . . . . .

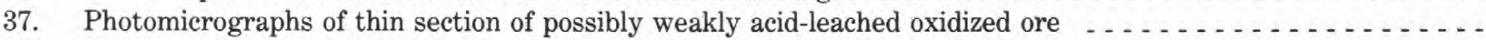

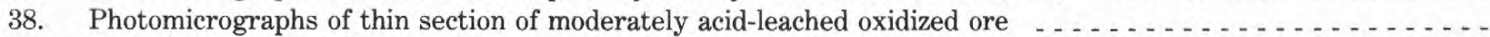

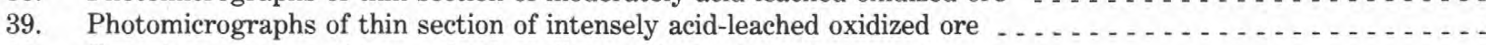

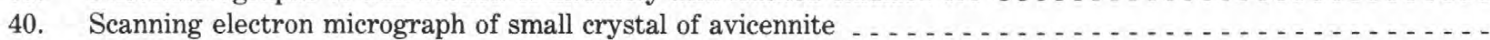

41. Photograph showing structurally controlled acid-leaching alteration in rocks of the Roberts Mountains Formation

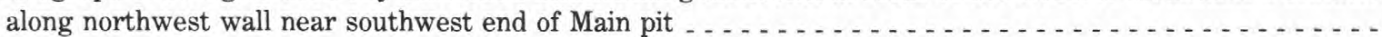

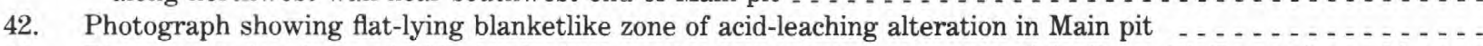

43. Photograph showing typical hydrothermal acid-leaching alteration in rocks of the Popovich Formation and in upper beds of the Roberts Mountains Formation along southeast side of Popovich Hill above East ore zone ...-.

44. Bar graph illustrating chemical changes in dolomitic carbonate rocks of the Roberts Mountains Formation during

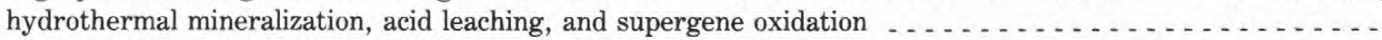

45. Photograph showing vein of calcite filling fracture in blocky limestone of the Popovich Formation .........

46. Photograph showing features in lower oxidized zone in Main pit southwest of Popovich Hill ............ 47-50. Diagrams showing:

47. Schematic north-south cross section through Main ore zone and Popovich Hill

48. Schematic cross sections illustrating genetic evolution of Carlin gold deposit

49. Schematic cross section illustrating hydrothermal system inferred for formation of Carlin gold deposit -

50. Schematic cross sections illustrating hydrothermal evolution of Carlin gold deposit . . . . . . . . .

\section{TABLES}

1. Generalized diagrammatic cross section showing principal lithologic units in the Rodeo Creek NE quadrangle .

2. Chemical and spectrographic analyses of Paleozoic sedimentary rocks of the lower plate in the Lynn window, Eureka County, Nev.

3. Graptolite species in the Roberts Mountains Fo Nev.

4. Conodont species in the Roberts Mountains Formation in the northern part of the Lynn window, Eureka County, 
5. Ostracode, brachiopod, and coral species in the Roberts Mountains Formation in the northern part of the Lynn window, Eureka County, Nev. . . . . . . . . . . . . . . . . . . . . . . . . . . . . . . . .

6. Conodont species in the Popovich Formation in the northern part of the Lynn window, Eureka County, Nev. -

7. Chemical and spectrographic analyses of Paleozoic sedimentary rocks of the upper plate in the Lynn mining district, Eureka County, Nev.

8. Graptolite species in strata of the upper plate in the northern part of the Lynn mining district, Eureka County, Nev.

9. Chemical and spectrographic analyses of tuffaceous lakebeds in the northern part of the Lynn mining district, Eureka

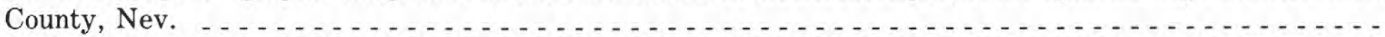

10. Chemical and spectrographic analyses of intrusive and extrusive igneous rocks in the northern part of the Lynn min-

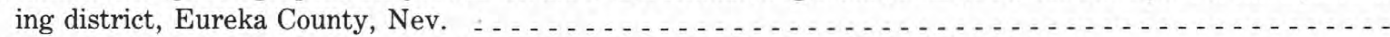

11. Carlin-type disseminated-replacement gold deposits in the Western United States _... . . . . . . . .

12. Chemical and spectrographic analyses of unoxidized-ore types in the Carlin gold deposit . . . . . . . . . .

13. Microprobe and spectrographic analyses of sulfide minerals in unoxidized ores of the Carlin gold deposit . . . -

14. Microprobe analyses of sulfosalt minerals in unoxidized ores of the Carlin gold deposit . . . . . . . . . . . .

15. Linear correlation coefficients between gold, arsenic, mercury, and antimony in unoxidized ores of the West, Main, and East ore zones and for the entire Carlin gold deposit . . . . . . . . . . . . . . . . . . . .

16. Stepwise discriminant analyses of gold, arsenic, mercury, and antimony in the West, Main, and East ore zones -

17. Linear correlation coefficients between gold, barium, copper, molybdenum, lead, and zinc in unoxidized ores of the West, Main, and East ore zones and for the entire Carlin gold deposit . . . . . . . . . . . . . . . .

18. Stepwise discriminant analyses of gold, barium, copper, molybdenum, lead, and zinc in the West, Main, and East ore zones

19. Linear correlation coefficients between gold, boron, selenium, tellurium, and tungsten in unoxidized ores of the West, Main, and East ore zones and for the entire Carlin gold deposit

20. Stepwise discriminant analyses of gold, boron, selenium, tellurium, and tungsten in the West, Main, and East ore zones

21. Chemical and spectrographic analyses of heavily silicified carbonate rocks in the Carlin gold deposit

22. Chemical and spectrographic analyses of unleached and acid-leached oxidized ores in the Carlin gold deposit . .

23. Temperature and salinity of fluid inclusions in quartz, barite, calcite, realgar, and sphalerite in the Carlin gold deposit

24. $\delta \mathrm{D}$ values of water in fluid inclusions in vein minerals and in hydrous minerals from dikes . . . . . . . . . .

25. $\delta^{18} \mathrm{O}$ and $\delta^{13} \mathrm{C}$ values of calcite and dolomite in unaltered rocks of the Roberts Mountains Formation .......

26. $\delta^{18} \mathrm{O}$ and $\delta^{13} \mathrm{C}$ values of calcite and dolomite in unmineralized progressively acid-leached oxidized rocks of the Roberts

Mountains Formation and the Popovich Formation

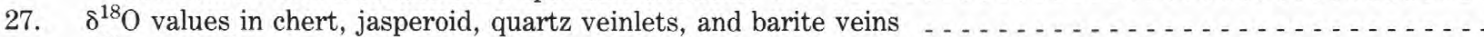

28. $\delta^{18} \mathrm{O}$ and $\delta^{13} \mathrm{C}$ values of calcite and dolomite in, and chemical data on samples from a drill hole through, mineralized rocks of the Roberts Mountains Formation and the Popovich Formation in the East ore zone . . . . . . . . .

29. $\delta^{18} \mathrm{O}$ and $\delta^{1} 3^{\mathrm{C}}$ values of calcite and dolomite from across interfaces between oxidized/unoxidized and acid-leached/unleached oxidized zones in mineralized rocks of the Roberts Mountains Formation in the Main ore zone . . . .

30. $\delta^{18} \mathrm{O}$ and $\delta^{13} \mathrm{C}$ values of calcite veins in the Roberts Mountains Formation and the Popovich Formation . . . .

31. $\delta^{34} \mathrm{~S}$ values and isotopic temperatures of diagenetic pyrite, hydrothermal sulfide minerals, and barite . . . . .

32. Amounts of solution required to transport selected ore components within the Carlin gold deposit . . . . . . . 


\title{
GEOLOGY OF THE CARLIN GOLD DEPOSIT, NEVADA
}

\author{
By ARTHUR S. RADTKE
}

\author{
ABSTRACT
}

The Carlin gold deposit, near the crest of the Tuscarora Mountains in the Lynn mining district, about $35 \mathrm{~km}$ north of Carlin, Nev., is one of the largest hydrothermal disseminated-replacement deposits discovered to date in North America. The mine began production in 1965 and between 1965 and 1976 produced about 2 million troy ounces of gold.

The Roberts Mountains thrust divides sedimentary rocks near the deposit into two assemblages. Units below the thrust, here collectively referred to as the lower plate, include more than $670 \mathrm{~m}$ of limestone and an upper dolomite bed (about $70 \mathrm{~m}$ thick) of the Pogonip Group, here of Early and Middle Ordovician age, overlain successively by: (1) the Middle Ordovician Eureka Quartzite (about 170-180 m thick); (2) Middle Ordovician to Early Silurian dolomite of the Hanson Creek Formation (about 160-180m thick); (3) limestone and dolomite beds of the Roberts Mountains Formation (about 550-600m thick), here of Middle Silurian to Early Devonian age; and (4) limestone of the Early, Middle, and Late Devonian Popovich Formation (about 50-275m thick). Units above the thrust, ranging in age from Early Ordovician to Early Silurian, here collectively referred to as the upper plate, are subdivided into (1) a lower zone, 60 to $80 \mathrm{~m}$ thick, of interbedded chert and shale, as well as minor sandstone, limestone, and quartzite; (2) a middle zone, more than $760 \mathrm{~m}$ thick, of interbedded chert and shale in a chert/shale ratio of more than $2: 1$, as well as minor sandstone, limestone, and carbonaceous shale; and (3) an upper zone, more than $900 \mathrm{~m}$ thick, of interbedded chert and shale in a chert/shale ratio of from 1:1 to 2:1, as well as quartzite that includes silicified shale and recrystallized chert.

Sedimentary rocks of Cenozoic age include: Miocene and Pliocene lakebeds; conglomerate, sandstone, and mudstone of the Pliocene Carlin Formation of Regnier (1960); and Quaternary alluvium. Small gold placers occur in stream channels and fans along the east side of the range.

Igneous rocks in the Lynn mining district include (1) intrusive granodiorite, diorite, and quartz diorite dikes and stocks of Late Jurassic to Early Cretaceous age, and (2) extrusive flows and sparse dikes of rhyodacite and rhyolite of Miocene age. The younger igneous rocks are confined to the west flank of the range.

Important structural features in the Lynn district include the Roberts Mountains thrust, the Tuscarora Mountains anticline, numerous highangle normal faults, and basin-and-range faults along the flanks of the range. The Roberts Mountains thrust, on which the upper plate moved eastward over the lower plate during Late Devonian to Early Mississippian time, is poorly exposed in most areas of the district. The thrust fault does not appear to localize ore either at the Carlin deposit or elsewhere in the district. Uplift of the Tuscarora Mountains anticline may have accompanied Late Jurassic to Early Cretaceous intrusive igneous activity. Displacement on the high-angle normal faults chiefly occurred during and after Oligocene time, although a few of these faults are invaded by dikes of Late Jurassic to Early Cretaceous age. Some high-angle faults apparently were channelways for hydrothermal solutions.
The Carlin gold deposit is situated in the northeastern part of the Lynn structural window, which exposes carbonate rocks in the lower plate of the Roberts Mountains thrust. In that area these strata strike approximately east-west and $\operatorname{dip} 33^{\circ} \mathrm{N}$. The deposit contains four zones of gold mineralization, called the West, Main, South Extension, and East ore zones. Although all these ore zones show many similar structural and stratigraphic controls, they differ significantly in degree of hydrothermal alteration, chemical composition of the ores, and intensity of oxidation and acid leaching.

Most of the known gold ore bodies occur in the upper $250 \mathrm{~m}$ of the Roberts Mountains Formation. A small amount of ore at the east end of the East ore zone occurs in calcareous shale of the upper plate on the hanging-wall side of the Leeville fault. Thin-bedded units in the basal part of the Popovich Formation contain small amounts of ore, and minor amounts of gold occur throughout hydrothermally altered zones in the Popovich Formation above the deeper ore bodies.

The West ore zone contains a tabular veinlike body, striking about $\mathrm{N} .60^{\circ} \mathrm{W}$. and dipping $60^{\circ}-70^{\circ} \mathrm{N}$., that lies on the hanging-wall side of a normal fault with similar attitudes. The ore body extends horizontally for about $335 \mathrm{~m}$; its width varies considerably but reaches a maximum of about $9 \mathrm{~m}$. At its southeast end the ore body widens into a pipe-shaped mass 25 to $30 \mathrm{~m}$ in diameter, that plunges about $70^{\circ} \mathrm{N}$. Principal ore controls are east-west- to N. $69^{\circ} \mathrm{W}$.-striking normal faults, and intersections between these and later normal faults trending N.45 W. to north-south. Carbonaceous materials and sulfide and sulfosalt minerals of all types are very sparse. Chemical and spectrographic analyses of the ores in the West ore zone average $8.7 \mathrm{ppm} \mathrm{Au}, 22 \mathrm{ppm} \mathrm{Hg}, 222 \mathrm{ppm} \mathrm{As}$, and $52 \mathrm{ppm}$ $\mathrm{Sb}$; the values for arsenic and antimony are considerably lower in the West than in the Main and East ore zones. The average barium content $(650 \mathrm{ppm})$ is also higher there than in the Main and East ore zones. The oxidized ores contain an average of $9.1 \mathrm{ppm} \mathrm{Au}$, and the average contents of other metals except for barium are either lower or unchanged relative to values in the unoxidized ores; the average barium content is higher: $1,600 \mathrm{ppm}$.

Acid-leaching alteration is mild in the West ore zone, although pervasive alteration by oxygen-bearing solutions affected most of the shallow ores and rocks in that part of the deposit. Significant amounts of calcite and dolomite remain, and large zones of weathered pyritic alteration are common.

The Main ore zone contains a series of irregular ore bodies along a zone $914 \mathrm{~m}$ long trending S. $60^{\circ} \mathrm{W}$, on the southwest side of Popovich Hill, as well as several large connected sheetlike ore bodies trending approximately east-west for about $460 \mathrm{~m}$ and dipping $30^{\circ}-35^{\circ} \mathrm{N}$. along the south side of the hill. Important ore controls for these irregular ore bodies are intersections between north-south- and northeast-striking normal faults; controls for the sheetlike ore bodies were provided by sets of normal faults, trending between $\mathrm{N} .30^{\circ} \mathrm{W}$. and N. $45^{\circ} \mathrm{E}$., that intersect with favorable dolomitic beds in the upper $75 \mathrm{~m}$ of the Roberts Mountains Formation. 
Unoxidized ores in the Main ore zone contain fine-grained quartz, pyrite, and carbonaceous materials, as well as locally high concentrations of sulfide minerals, particularly those containing arsenic. The content of organic carbon reaches 5.0weight percent in areas where hydrocarbons were introduced. The unoxidized ores contain an average of $7.1 \mathrm{ppm} \mathrm{Au}$, $20 \mathrm{ppm} \mathrm{Hg}, 409 \mathrm{ppm} \mathrm{As}$, and 106ppm Sb. Most of the gold occurs as coatings on pyrite grains or in association with earbonaceous materials; sparse fine particles of metallic gold occur in hydrothermal quartz or dispersed in clay minerals. The average barium content reflects a systematic decrease in the element from west to east through the deposit. The oxidized ores in the Main ore zone contain an average of $9.0 \mathrm{ppm}$ Au. Barium (avg 1,500ppm) is the only minor element more abundant in the oxidized than in the unoxidized ores.

Potassic-argillic alteration is pervasive throughout the Main ore zone. Large masses of jasperoid were formed along normal faults on the footwall side of the ore zone. Introduced organic materials were concentrated along and near faults throughout the areas of gold deposition and in carbonate rocks and siliceous upper-plate units above the ore bodies. Acid leaching varies from weak to intense throughout the ore zone, and variations in the intensity of acid leaching and late supergene oxidation correlate well with the degree of rock shattering.

The South Extension ore zone lies south of the east end of the Main ore zone. The largest ore body and two smaller ore bodies occur in extensively shattered carbonate rocks along closely spaced normal faults trending $\mathrm{N} .40^{\circ}-50^{\circ} \mathrm{E}$. or at intersections between these faults and earlier ones, which strike nearly north-south. Jasperoid and small ore bodies occur along north-south-striking faults between the Main and South Extension ore zones. All the ores in the South Extension ore zone have been oxidized, and fine particles of metallic gold occur in iron oxides, dispersed through mixtures of quartz, illite, and kaolinite, and locked in quartz. The average gold content of the ores is $4 \mathrm{ppm}$.

The East ore zone, which begins along the south side of Popovich Hill and continues about $730 \mathrm{~m}$ to the northeast, contains two principal ore bodies. The largest ore body is an elongate tabular hook-shaped mass of mineralized rockhaving a longitudinal axis and plunge, similar in attitude to the host rocks. The smaller ore body, which lies at the southwest end of the East ore zone, is a long, pipe-shaped mass of mineralized rock, 12 to $60 \mathrm{~m}$ thick, plunging about $30^{\circ} \mathrm{NE}$. Ore controls were provided by intersections between two sets of normal faults and between the faults and silty dolomitic beds near the top of the Roberts Mountains Formation. These faults include a strong, conspicuous set striking $\mathrm{N} .40^{\circ}-45^{\circ} \mathrm{W}$., some members of which contain preore igneous dikes and served as main channels for the ore solutions, and a later, weak set striking from north-south to $\mathrm{N} .40^{\circ} \mathrm{E}$.

Unoxidized ores in the East ore zone are characterized by abundant sulfide minerals, much carbonaceous material, and only small amounts of barite. Large amounts of sulfide and sulfosalt minerals containing arsenic, mercury, antimony, and thallium occur in the zone, and basemetal sulfides are concentrated locally. The average gold content of the unoxidized ores is $7.4 \mathrm{ppm}$. The oxidized ores in the East ore zone commonly contain large amounts of remnant calcite and organic carbon, incompletely oxidized pyrite and remnant sulfides of arsenic and antimony, and large amounts of dispersed arsenic and antimony in unknown forms. Other features are the absence of intense bleaching and acid leaching, and only minor zones of weathered pyritic alteration. The oxidized ores contain an average of $8.0 \mathrm{ppm} \mathrm{Au}$.

Sulfide and sulfosalt minerals identified in unoxidized ores from the Carlin deposit include pyrite (both framboidal and cubic varieties), pyrrhotite (very rare), cinnabar, realgar, orpiment (both antimony- and thallium-bearing varieties), stibnite, lorandite, tennantite, getchellite, iordanite, galkhaite, gratonite, christite, ellisite, weissbergite, boulangerite, tetrahedrite, carlinite, galena, sphalerite, chalcopyrite, covellite, chalcocite, and molybdenite. Other hydrothermal minerals include quartz, kaolinite, sericite, barite, scheelite, fluorite, frankdicksonite, and very sparse amounts of metallic gold and elemental arsenic. Residual or redistributed minerals include calcite, dolomite, illite, and carbonaceous materials.
Stable-isotope studies were done on hydrogen, oxygen, carbon, and sulfur. The $\delta \mathrm{D}$ values in whole-rock samples of altered igneous dikes, and in quartz, calcite, and barite veins and veinlets, are all highly negative and range from -160 to -139 permil. The $\delta^{18} \mathrm{O}$ values of sedimentary chert range from 24 to 25 permil, of hydrothermal jasperoid from 9 to 18 permil, and of quartz veinlets from 18 to 22 permil. Calculated $\delta^{18} \mathrm{O}$ values, ranging from -0.2 to +6.5 permil, for hydrothermal fluids in equilibrium with most of the jasperoid bodies over the temperature interval $200^{\circ}-225^{\circ} \mathrm{C}$ are compatible with a meteoric-water origin of the ore fluids and considerable isotopic exchange between ore fluids and carbonate-rich host rocks. Calculated $\delta^{18} \mathrm{O}$ values, ranging from 3.0 to 5.9 permil, for fluids at $175^{\circ}$ to $200^{\circ} \mathrm{C}$ during the main hydrothermal stage that included ore deposition reflect solution buffering by wallrocks and large rock/water ratios. The $\delta^{18} \mathrm{O}$ values, ranging from 5.4 to 11.0 permil, in barite veins over the temperature interval $250^{\circ}-275^{\circ} \mathrm{C}$ probably reflect variations in temperature, solution boiling, fluid mixing, and fluid-wallrock exchange reactions. Most of the calcite, barite, and barren quartz veins probably formed late in the hydrothermal cycle accompanying boiling of the fluids and acid leaching of the enclosing rocks.

Some of the observed oxygen isotopic variations may be related in part to lithologic variations in the Roberts Mountains Formation. Two distinct types of carbonate facies are here recognized: (type I) laminated argillaceous-arenaceous dolomite, favorable for ore deposition and alteration; and (type II) laminated arenaceous peloidal wackestone, generally unfavorable for mineralization. The $\delta^{18} \mathrm{O}$ values of about 21 permil for calcite and 23 permil for dolomite in type I facies rocks compare well with values for these minerals in favorable beds of the formation elsewhere in Nevada. The $\delta^{18} \mathrm{O}$ values in type II facies rocks having a very large calcite/dolomite ratio range from about 13 to 19 permil for calcite and are about 24 permil for dolomite. In mineralized beds the $\delta^{18} \mathrm{O}$ values of remnant calcite, ranging from about 14 to 18.0 permil, indicate that the calcite was recrystallized and that isotopic exchange took place with the ore fluids. Most of the calcite in shallow veins was probably formed from calcite dissolved out of the underlying acid-leached zone. The $\delta^{18} \mathrm{O}$ values of dolomite in mineralized beds, which range from about 19 to 25 permil, suggest that exchange reactions between the dolomite and the ore fluids were very limited and agree with the chemical data and petrographic evidence.

Oxygen isotope data on carbonate minerals in acid-leached oxidized zones and in rocks subjected only to late supergene oxidation indicate that isotopic exchange between the minerals and the interacting fluids varied directly with the intensity of alteration and that little exchange and recrystallization took place during acid-leaching or late supergene oxidation.

The $\delta^{13} \mathrm{C}$ values of calcite and dolomite in type I facies rocks resemble those in the mineralized beds; values ranging from about -1 to +1 permil for calcite and from -0.1 to +1 permil for dolomite indicate that $\mathrm{CO}_{2}$ in the ore fluids was generated by the dissolution of calcite from the sedimentary terrane. The $\delta^{34} \mathrm{~S}$ values in barite veins range from about 28 to 32 permil, and the range for sulfide minerals is about 4 to 16 permil. Values include 11.7 to 14.3 permil for diagenetic pyrite in the host rocks and 4.2 to 16.1 permil for hydrothermal pyrite in unoxidized ores, igneous dikes, and quartz veinlets. Most of the hydrothermal sulfide sulfur was of sedimentary origin and was derived from diagenetic pyrite in lower Paleozoic carbonate rocks below the deposit. Sulfate sulfur may have been derived from disseminated sedimentary barite at depth, or from the same source as the sulfide sulfur by equilibrium distribution of the sulfur species. Lead isotope data on galena in barite veins suggest that part or all of the lead was derived from the Roberts Mountains Formation.

In general, the geology and geochemistry of the Carlin gold deposit suggest that the deposit was formed during Tertiary time as a result of interrelated processes, including high-angle faulting, igneous activity, and hydrothermal activity. Ore deposition apparently took place from low-temperature fluids under physical and chemical conditions similar to those in the roots of hot-springs systems. Igneous activity provided the heat source, and the fluids were probably nearly all meteoric or 
meteoric-connate waters. Most of the ore components could have been derived from sedimentary units below the deposit. The hot ore fluids moved up along prominent high-angle normal faults under conditions of decreasing temperature and pressure, and penetrated into shattered thin-bedded carbonate rocks favorable for ore deposition.

The early fluids were weakly acidic and contained about 2 to 4 equivalent-weight percent $\mathrm{NaCl}$ at temperatures of about $175^{\circ}$ to $200^{\circ} \mathrm{C}$. They transported silica, aluminum, potassium, iron, sulfur, organic carbon compounds, and minor amounts of arsenic, antimony, mercury, thal lium, gold, barium, and possibly copper, lead, and zinc. Calcite was dissolved from the host rocks, silica was precipitated, and sericite and kaolinite were formed. The presence of fine-grained material and reactive organic materials, as well as the deposition of quartz, clay, and pyrite, probably aided deposition of the heavy elements gold, arsenic, mercury, antimony, and thallium. Gold and mercury were removed from solution by reaction with carbonaceous materials to form gold-organic and goldmercury-organic compounds, and both elements, along with arsenic, antimony, and thallium, were deposited on the surfaces of pyrite grains. Sulfides and sulfosalts of arsenic, mercury, antimony, and thallium, as well as base-metal sulfides, probably formed later in the paragenesis.

As temperatures increased, boiling took place at intermediate depths, and such relatively soluble minerals as carlinite and frankdicksonite were precipitated. Loss of $\mathrm{CO}_{2}$ and $\mathrm{H}_{2} \mathrm{~S}$ caused the solutions to become deficient in sulfur and more alkaline, and promoted deposition of the arsenic-mercury-antimony-thallium suite of minerals. The $\mathrm{H}_{2} \mathrm{~S}$ boiled off into the aerated zone, mixed with atmospherically derived oxygen, and was oxidized to $\mathrm{H}_{2} \mathrm{SO}_{4}$, which, in turn, attacked the country rock and the previously mineralized zones, removed calcite and dolomite, and introduced additional silica. The barite and quartz veins formed during boiling and acid leaching were deposited at temperatures of $250^{\circ}$ to $300^{\circ} \mathrm{C}$ from solutions containing as much as 17 equivalent-weight percent $\mathrm{NaCl}$.

The acid leaching probably postdated the main hydrothermal stage of ore deposition and is distinct from the later oxidation induced by supergene or meteoric waters. In many areas the effects of these two processes are superimposed, although the effects of late supergene oxidation extend deeper below the acid-leached zone.

Simple calculations involving the solubilities of ore-forming components of hydrothermal origin and the amounts of these components introduced into the volume of mineralized and altered rocks show that about 1 billion $t$ of solution was required to transport the components and 10 billion $t$ of solution was involved in the late vein-forming acidleaching alteration. The hydrothermal system responsible for the formation of the Carlin deposit likely operated over a period of at least 100,000 years.

\section{INTRODUCTION}

\section{LOCATION AND ACCESSIBILITY}

This report describes the geology of the Carlin gold deposit and the Lynn mining district, including an area of about $80 \mathrm{~km}^{2}$ in northern Eureka County, Nev. (fig. 1). The Carlin mine is located in secs. 13 and 14, T.35N., R.50E., at an elevation of $6,400 \mathrm{ft}$ near the crest of the Tuscarora Mountains. The map area (pl. 1), centered approximately on the Carlin mine, measures about $10 \mathrm{~km}$ east-west by $8 \mathrm{~km}$ north-south and forms approximately the south two-thirds of the Rodeo Creek NE. 7\{1/2\}-minute quadrangle. Boundaries for the map area are meridians $116^{\circ} 15^{\prime} 00^{\prime \prime}$ and $116^{\circ} 22^{\prime} 30^{\prime \prime} \mathrm{W}$. and parallels $40^{\circ} 52^{\prime} 30^{\prime \prime}$ and $40^{\circ} 57^{\prime} 30^{\prime \prime} \mathrm{N}$.

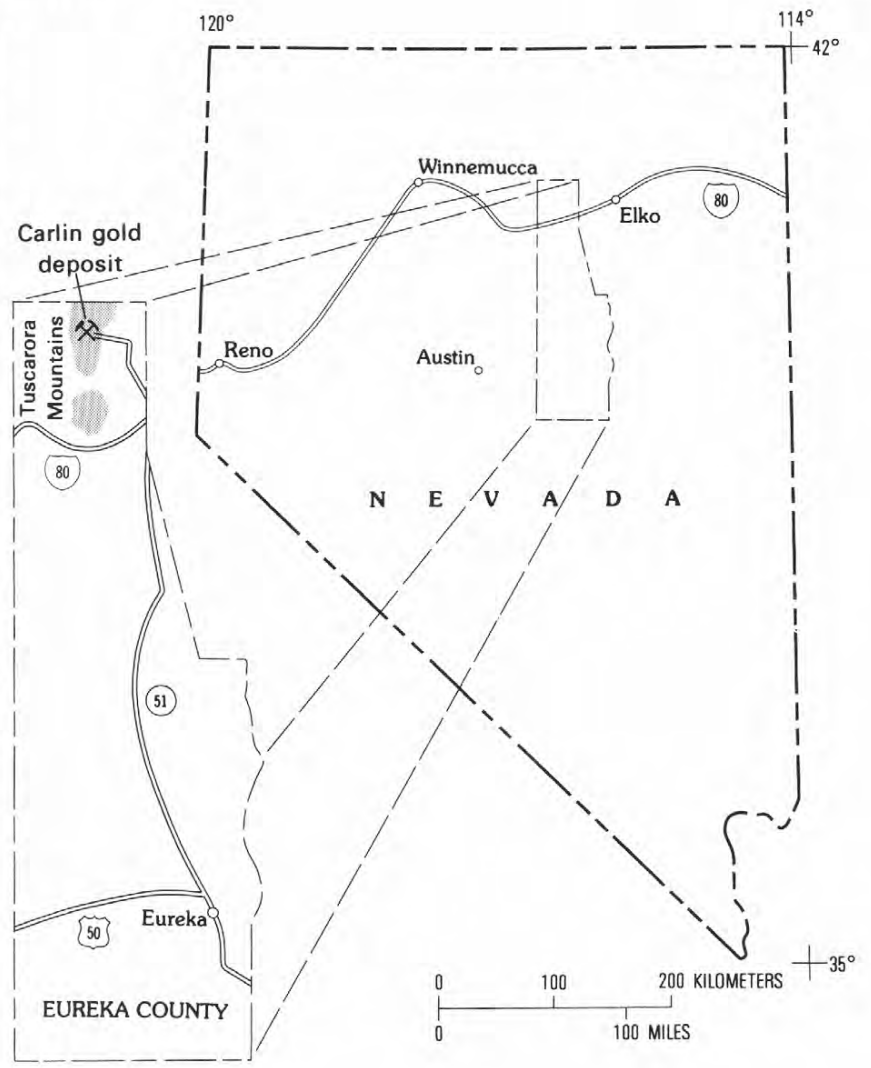

Figure 1.- Index map of Nevada showing location of Carlin gold deposit.

The Carlin mine is accessible by an asphalt-surfaced road extending about $35 \mathrm{~km}$ northward from the town of Carlin, Nev., which is on U.S. Highway 40. A secondary improved road extends from the Carlin mine westward into Boulder Valley and connects with both State Highway 18 to the north and U.S. Highway 40 to the south near the town of Dunphy. An unimproved road extends from the Carlin mine northward, along the west side of Little Boulder Basin, to the Blue Star mine, and continues northward and westward along Rodeo Creek to connect with a graded road extending northeastward along Boulder Valley. Numerous unimproved roads have been built to provide access to the different mining prospects.

\section{PHYSICAL FEATURES}

The Tuscarora Mountains are typical of ranges in the north-central part of the Basin and Range province. The main axis of the range trends north-northeast and is flanked by alluviated valleys. The highest peak in the study area is $7,290 \mathrm{ft}$ above sea level, and the lowest point is approximately $4,960 \mathrm{ft}$, at the southwest corner of the map area (pl. 1).

The east side of the Tuscarora Mountains is dissected locally by eastward-flowing intermittent streams that empty into an unnamed alluvium-filled valley. Two of the most prominent canyons on the east side of the Tuscarora Mountains have been eroded by Simon and Lynn creeks. 
Relief along the east flank of the range is from about 100 to $300 \mathrm{~m}$. Another deep canyon cut by intermittent streams running southeastward from Richmond Mountain, together with the steep southwest side of Richmond Mountain, forms the south boundary of the map area (pl. 1).

The west side of the Tuscarora Mountains in the area southwest of the Carlin mine has about $240 \mathrm{~m}$ of relief and slopes smoothly down into an alluvium-filled valley. Low rounded hills of volcanic flows overlapping Paleozoic sedimentary rocks separate this small valley from Boulder Valley immediately west of the map area (pl. 1).

Many important physiographic features near the Carlin mine were created by erosion along the Sheep Creek drainage. The upper drainage begins about $1 \frac{1}{2} \mathrm{~km}$ north of the Carlin mine on the west side of a north-south- to northeast-trending divide. This intermittent creek flows westward through a deeply eroded canyon just north of the mine; about $1 \frac{1}{2} \mathrm{~km}$ northwest of the Carlin mine it turns southward down Sheep Creek Canyon for $11 / 2 \mathrm{~km}$ before turning westward toward Boulder Valley. Another important tributary of Sheep Creek has eroded a deep east-west-trending canyon $3 / 4 \mathrm{~km}$ south of the Carlin mine.

Although the main axis of the Tuscarora Mountains runs north-northeastward, a prominent north-northwesttrending topographic extension breaks away from the range about $1 \frac{1}{2} \mathrm{~km}$ west of the Carlin mine. This ridge, a series of generally smooth rolling hills, separates Little Boulder Basin on the east from Boulder Valley to the west. Relief in this area ranges from about 90 to $180 \mathrm{~m}$. The Blue Star gold deposit is near the crest of this ridge, about $5 \mathrm{~km}$ northwest of the Carlin mine.

North of the Carlin mine the Tuscarora Mountains have a maximum relief of about $300 \mathrm{~m}$; the average slope along the margins of the range is between $10^{\circ}$ and $15^{\circ}$. This part of the Tuscarora Mountains is characterized by round crests, relatively flat spurs and ridges, and generally smooth long uniform slopes and shallow canyons.

\section{CLIMATE AND VEGETATION}

The climate in this part of Nevada is semiarid and typical of the northern Great Basin. Average summer temperatures range between $18^{\circ}$ and $24^{\circ} \mathrm{C}$ in the valleys, somewhat cooler at higher elevations. According to Roberts and others (1967), the northern part of Eureka County averages more than 50 days a year when the maximum temperature reaches $32^{\circ} \mathrm{C}$ or higher. During the winter, low temperatures average between $-7^{\circ}$ and $-1^{\circ} \mathrm{C}$. Annual rainfall averages 250 to $380 \mathrm{~mm}$.

Vegetation includes sagebrush (Artemisia sp.), rabbitbrush (Chrysothamnus sp.), juniper (Juniperus sp.), and pinyon (Pinus monophylla) in the mountains. The alluviated valleys and lower slopes of the mountains also have sagebrush, as well as white sage (Eurotia lanata), cheatgrass (Bromus secalinus), bitterbrush (Purshia tridentata), wheat bunch (Agropyron spicatum), and giant ryegrass (Elymus condensatus).

\section{PURPOSE OF REPORT AND METHODS OF INVESTIGATION}

The discovery of the Carlin gold deposit in the Tuscarora Mountains by geologists of the Newmont Mining Corp. stimulated both economic and scientific interest in northern Nevada. The U.S. Geological Survey initiated a detailed investigation of both the Carlin gold deposit and its regional geologic setting. The results of that study, presented here, include descriptions of the regional geologic setting, the structural and stratigraphic features in the areas of gold deposition, and the geochemistry and mineralogy of the host rocks and gold ores. Finally, available information on the chemistry and mineralogy of the ores is examined within the general framework of the geologic setting, and conclusions are presented as to the paragenesis of the deposit.

Mapping of the Carlin gold deposit was begun in August 1966. During the fall of 1966 and the summer of 1968 , all exposed faces between benches were mapped at a scale of 1:240; the data were subsequently compiled on bench maps, at a scale of $1: 1,200$, provided by the engineering staff of the Carlin Gold Mining Co. Concurrently with the mapping, 550 samples were collected, representing all rock, alteration, and oxidized-ore types in the upper 45 to $60 \mathrm{~m}$ of the deposit. Concurrent with development of the mine, additional mapping was done on updated bench maps at a scale of 1:1,200 during the summer and fall field seasons of 1968 through 1973. During this period, approximately 250 additional samples were collected, mostly from deeper levels, that represented different types of hydrothermally altered rocks and unoxidized ores throughout the West, Main, and East pit areas. The small South pit containing the South Extension ore body, about $520 \mathrm{~m}$ south of the crest of Popovich Hill, was mapped and sampled in September 1972. Between 1973 and 1976 new exposures were mapped and sampled on brief visits to the mine, and the geologic staff at the mine provided additional samples and data on areas of specific interest.

Additional samples of unoxidized ores and hydrothermally altered host rocks were provided by cores taken from a diamond-drill hole begun and completed in the summer of 1969. This vertical hole, identified as U.S. Geological Survey Carlin No. 1, was collared at an elevation of about $6,450 \mathrm{ft}$ on the northeast side of Popovich Hill; the drill hole penetrated several gold-bearing zones in the East ore body before terminating at a depth of $293 \mathrm{~m}$ (see pl. 3). 
Mapping of an area of approximately $80 \mathrm{~km}^{2}$, centered on the Carlin deposit and covering most of the Lynn mining district, was begun in September 1969 and completed in October 1970. For the purposes of this investigation, the mapping was done and compiled on an enlarged topographic base of the Rodeo Creek NE. 71/2-minute quadrangle at a scale of 1:12,000. Mapping at this scale was extended about $5 \mathrm{~km}$ northwest of the Carlin gold deposit to include the Blue Star gold deposit. The different rock types throughout the district were collected for chemical and mineralogic study.

As part of the Carlin project, regional mapping was done over an area of about $650 \mathrm{~km}^{2}$ during the summers of 1968 to 1971; the major part of this work was done by Iames G. Evans and Leland D. Cress. This area includes the Rodeo Creek NE., Welches Canyon, and Schroeder Mountain 71/2-minute quadrangles; mapping was done on topographic base maps at a scale of 1:24,000.

Laboratory investigations on the mineralogy, chemical composition, and trace-element contents of the host rocks and gold ores were begun in January 1967 at facilities of the U.S. Geological Survey, the U.S. Bureau of Mines, and Stanford University, Stanford, Calif. Typical analyses of the different types of rocks and ores are tabulated here.

About 400 thin sections and polished thin sections, as well as 200 polished sections, prepared from 350 samples of wallrocks and gold ores of the Carlin deposit were studied by conventional petrographic and mineralographic methods; about 100 thin sections of samples from other lithologic units elsewhere in the Lynn mining district were also examined. Additional mineralogic studies were carried out by X-ray diffraction techniques on powdered whole-rock samples of all specimens. For selected specimens, additional X-ray diffraction work was done on both the heavy and light fractions, as well as clay-mineral identification using standard glycolation and heating methods.

Because the ores are consistently fine grained, an electron microprobe was extensively used to identify different minerals and to determine their compositions in 160 polished sections, polished thin sections, and grain-mount sections from 80 samples of host rocks and gold ores. This work confirmed the fact that gold has several associations in the ores and permitted the gold ores to be divided into types on the basis of their chemical composition and mineralogy. In addition, five new minerals and several new varieties of known minerals were identified. Representative samples of altered and unaltered host rocks and of oxidized and unoxidized ores were examined with a scanning electron microscope to study the morphology of the clays and the textural fabric of the rocks.

About 500 samples of wallrocks and ores were analyzed by several methods to determine both major- and minor- element constituents of typical materials, to compare the ranges of values and the differences with respect to location, ore type, and degree of hydrothermal and supergene alterations, and to gain information on the geochemical history of the deposit. Specifically, the methods were: (a) chemical analyses for major-element constituents by the rapid-analysis technique described by Shapiro and Brannock (1962) and Shapiro (1967); (b) semiquantitative spectrographic analyses for both major and minor elements; (c) atomic-absorption analyses for gold, selenium, tellurium, and zinc, as well as several fire-assay determinations for gold; (d) instrumental mercury-meter and Lemaire sniffer atomic-absorption analyses for mercury; (e) Leco combustion analyses for organic carbon; (f) X-ray fluorescence analyses for sulfur, arsenic, antimony, barium, and zinc; and (g) colorimetric analyses for arsenic, antimony, and tungsten.

In order to obtain the samples needed to examine the three-dimensional distribution of certain elements and to study typical unoxidized ores, about 300 samples were chosen from 96 rotary-drill holes covering the West, Main, and East ore zones. Each sample consisted of cuttings from composite 1.5-m intervals. These samples also were analyzed by the methods listed above, with the exception for rapid rock analysis. The chemical data were treated statistically by linear-regression and discriminant-analysis techniques to gain information on the paragenesis of the ores.

Stable-isotope determinations by Robert O. Rye provided information on the conditions of ore formation and the hydrothermal fluids, and on the source of the sulfur and carbon concentrated in the ores. Stable-isotope data for hydrogen, oxygen, carbon, and sulfur are tabulated and discussed in later sections of this report.

The data and conclusions presented here were based on studies done 10 years or more before this report was published. No samples from the deep unoxidized ore bodies currently being mined were available for study. Detailed study of these materials combined with recent advances in fluid inclusion study techniques and other material analyses methods on key materials at deep and shallower levels in the deposit are needed. Results of this will likely modify the conditions of ore genesis presented in this report.

\section{ACKNOWLEDGMENTS}

This study of the Carlin gold deposit was made possible by the close cooperation of the Carlin Gold Mining Co. and its parent corporation, the Newmont Mining Corp. I am especially indebted to the late Robert B. Fulton, formerly vice president-exploration, Newmont Mining Corp., for his cooperation, assistance, and encouragement in both the field and laboratory studies. The Carlin project benefited greatly from joint field mapping by the author and 
Perry W. West, exploration geologist, Newmont Exploration, Ltd.; West's experience in regional mapping was of inestimable value in resolving structural and stratigraphic problems within the Lynn mining district. Byron S. Hardie, manager, Newmont Exploration, Ltd., generously allowed access to material and information, and took part in many stimulating discussions relating to geologic problems at the Carlin deposit. Donald M. Hausen of the Metallurgical Department, Newmont Exploration, Ltd., provided valuable information on radiometric-age determinations, as well as selected polished sections and polished thin sections.

I owe a debt of gratitude to many other members of the staff of the Carlin Gold Mining Co. for their close cooperation and many personal favors and hospitality during field studies: Among these are Jay McBeth, Peter N. Loncar, Dan Higley, D. Calcacorda, Harry Trewick, David Peterson, Jim McFarland, the late Larry L. Noble, and George M. Essington.

With pleasure I extend special thanks to Robert L. Akright, formerly mine geologist, Carlin Gold Mining Co., for his cooperation and assistance in detailed mapping and sampling of the deposit, and for his personal interest in the overall geologic study.

In addition, I acknowledge the assistance of the many members of the U.S. Geological Survey who have contributed directly to the project and who have exchanged visits and discussed problems of mutual interest: Among these are Ralph J. Roberts, Ralph L. Erickson, Chester T. Wrucke, James G. Evans, Leland D. Cress, Charles L. Christ, Keith B. Ketner, R. C. Erd, J. Fred Smith, T. E. Mullens, Hal T. Morris, Miles L. Silberman, Robert O. Rye, James R. O'Neil, Roger P. Ashley, Chris Heropoulos, Brent P. Fabbi, Randolf A. Koski, David J. Grimes, and John D. Wells.

Throughout the course of this study, I worked closely with Bernard J. Scheiner of the U.S. Bureau of Mines Experimental Station in Reno, Nev. Scheiner was principally responsible for developing two processes for extracting gold from carbonaceous ores and first recognized the association between gold and organic carbon in the unoxidized ores. His cooperation and assistance in the study of carbonaceous gold ores are gratefully recognized.

Frank W. Dickson of Stanford University, Stanford, Calif., worked closely with me to develop a chemical model for paragenesis of the Carlin gold deposit. With pleasure I acknowledge his help in evaluating the physical and chemical parameters involved in the formation of the deposit, and his encouragement in the preparation of this report. The use of Dickson's hydrothermal laboratory at Stanford University made it possible experimentally to evaluate the mechanisms for solubilization, transport, and deposition of the components in the Carlin ores.
During the project, numerous other individuals associated with academic institutions made very useful contributions: these include: William C. Kelly of the University of Michigan, Ann Arbor; Robert M. Garrels of Northwestern University, Evanston, Ill.; Harold C. Helgeson of the University of California, Berkeley; and Charles M. Taylor of Stanford University, Stanford, Calif.

Valuable discussions and a free exchange of ideas with many individuals associated with mining companies were extremely rewarding: These individuals include: Joe Wargo of the Homestake Mining Corp.; Cliff Purdy, formerly mine geologist, Cortez Gold Mines, Inc.; Peter E. Galli of Galli Explorations; and John Livermore of Cordex Exploration. Livermore, formerly with the Newmont Mining Corp., and Robert B. Fulton provided information on the history of discovery and development of the Carlin deposit.

\section{PREVIOUS WORK}

The first comprehensive geologic investigation of this area of Nevada was begun in 1869 by Clarence King and Arnold Hague as part of their survey of the 40th parallel. The results of their study were included in the report by King (1878), and an atlas of geologic and topographic maps was prepared by King (1876) as geologist in charge. In these reports the Tuscarora Mountains were referred to as the Cortez Range, and the rocks in the Lynn window were subdivided into two map units, the Weber Quartzite and Tertiary rhyolite.

Emmons (1908) summarized the results of field investigations in north-central Nevada carried out in 1908, and briefly described the geology of the Lynn mining district and placer gold operations at the Big Six and several other mines. Although Emmons referred to silicified sedimentary rocks of the Vinini Formation of present usage as bedded rhyolite, he recognized that granodiorite intrudes the limestone and quartzite of the area. Naramore (1911) and Hill (1912) briefly described placer operations in the Lynn mining district and included the Lynn district in their compilation of mining districts of the Western United States. Early reconnaissance maps of northern Eureka County, Nev., were compiled by Lee and others (1916).

Numerous reports have been published describing locations and production figures for the small gold placer operations in the Lynn mining district (Lincoln, 1923; Smith and Vanderburg, 1932; Vanderburg, 1936, 1938; Southern Pacific Co., 1964). Koschmann and Bergendahl (1968) briefly mentioned data on gold production from the Lynn district in their compilation of principal gold-producing districts of the United States. Johnson (1973) gave an excellent description of these placer deposits, summarized their geologic features, and suggested that although their 
source probably was auriferous quartz veins in the Vinini Formation, these veins could in turn be genetically related to the disseminated ores in the Carlin deposit. The first detailed description of the geology of the study area (Roen, 1961) emphasized the structure, stratigraphy, and paleontology of sedimentary rocks of the area.

Hardie (1966) was the first to describe the Carlin gold deposit. Roberts (1966) attempted to relate the position of the Carlin deposit to mineral belts; Roberts and others (1967) compiled information on the geology and mineral resources of Eureka County, Nev. Excellent descriptions of many geologic and mineralogic features of the upper, near-surface parts of the Carlin gold deposit were given by Hausen (1967) and Hausen and Kerr (1968). Preliminary results of laboratory and field studies on deeper primary unoxidized ores and host rocks in the deposit were reported by Radtke and Scheiner (1970b). Roberts and others, (1971) summarized a large amount of data on all types of gold deposits in Nevada.

In 1969 J. G. Evans and I began regional mapping of the Lynn mining district. Preliminary geologic maps at a scale of 1:24,000 covering most of the Lynn district were prepared by Evans (1972a, b), and finalized maps of the Rodeo Creek NE. and Welches Canyon quadrangles were prepared at the same scale (Evans, 1974a, b). More detailed geologic maps include those of the Carlin gold deposit (scale $1: 3,600$ ) by Radtke (1973) and of the area surrounding and including the deposit (scale 1:12,000) by Radtke (1974). A summary paper on the Carlin deposit was prepared by Noble and Radtke (1978). Numerous other reports dealing with specific mineralogic and geochemical studies of the Carlin deposit, and summarizing the geologic characteristies of the Carlin and other disseminated-replacement gold deposits, have also been published and are cited throughout this report.

\section{HISTORY OF THE LYNN MINING DISTRICT}

According to Johnson (1973), the earliest mining activity in the Lynn district began in 1907 with the discovery of small placer gold deposits along Lynn Creek. These deposits, as well as others along Sheep and Rodeo Creeks, have been mined intermittently up to the present; yearly production has averaged a few hundred troy ounces of gold and smaller amounts of silver.

In 1907 small, narrow auriferous quartz veins were discovered along the crest of the Tuscarora Mountains between the Lynn Creek and Sheep Creek drainages. This series of veins, collectively known as the Big Six deposit, has had a very small production and apparently achieved maximum production of about 500 troy oz of gold between the years 1935 and 1936 .
During the 1920 's the Morning Glory prospect was located in sec. 13, T.35N., R.50E., on the south side of

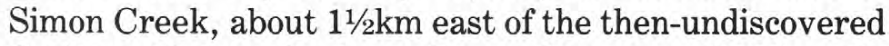
Carlin gold deposit. According to Lawrence (1963), stibnite occurs with barite in a quartz vein in the prospect. Roberts and others (1967) indicated that the gold was associated with stibnite and antimony oxide minerals along a northwest-trending shear zone, but stated that no production is recorded.

Small bodies of gem-grade turquoise were discovered in 1929 along the ridge forming the west edge of Little Boulder Basin. This deposit, about $5 \mathrm{~km}$ northwest of the Carlin deposit and about $3 / 4 \mathrm{~km}$ east of the Blue Star deposit, is referred to as the Number Eight mine. According to Murphy (1964), turquoise has been mined from the deposit since 1929; total production value is estimated at $\$ 1,500,000$. Gold ore was discovered along a thrust fault at the mine in 1959 (Roberts and others, 1967). Between 1960 and 1964 a 100-t- per-day cyanide mill processed about 4,000 $\mathrm{t}$ of gold ore. The property has been mined by the Carlin Gold Mining Co. for disseminated gold in upper-plate calcareous shale and altered limestone since 1977.

Roberts (1960) pointed out that the mining districts in north-central Nevada are localized by major structural features; he reasoned that because the major ore deposits are in carbonate rocks below the Roberts Mountains thrust and because the windows are related to uplift accompanying igneous activity, the lower-plate carbonate beds near the thrust should be promising exploration targets. On the basis of this hypothesis, the Newmont Mining Corp., under the direction of Robert B. Fulton, vice president-exploration, evaluated the potential of numerous windows and chose the Lynn window for detailed exploration. Field studies, including mapping and sampling along the Roberts Mountains thrust, were begun in the spring of 1961 under the supervision of John Livermore. Claims were staked in October and November 1961, and exploration rotary drilling under the direction of Fulton was begun in July 1962. The first oregrade material was discovered in September 1962, and when gold production began in May 1965, 11 million $t$ of ore averaging approximately 0.3 troy oz of gold per ton had been delineated. The mine and cyanide mill, with a capacity of 2,000 t per day, has produced approximately 200,000 troy oz of gold per year and is currently the second largest gold mine in the United States.

In addition to the Carlin deposit, the Newmont Mining Corp. has mined disseminated gold from a more recent discovery near the Number Eight mine. This deposit, known as the Blue Star, is about $5 \mathrm{~km}$ northwest of the Carlin deposit and $3 / 4 \mathrm{~km}$ west of the Number Eight mine. The Blue Star, also a disseminated-replacement gold plo R A R P
posit, is, however, much smaller than the Carlin deposit

JAN 07 '86

Bureau of Reclamation Denver, Colorado 
and holds ore reserves of 3 to 4 million $t$ (L. L. Noble, oral commun., 1976).

A small intrusive gold-bearing stock about $3 \mathrm{~km}$ northnortheast of the Blue Star deposit, referred to as the Gold Strike intrusive (not shown on pl. 1 but included in the maps by Evans, 1972a, 1974a), holds some potential as a large-tonnage low-grade deposit. This area is currently being evaluated by the Western States Minerals Corp., which is mining disseminated gold from limestone and shale near the intrusive.

Between 1962 and 1971 numerous other companies conducted exploration and evaluation programs within the Lynn mining district. No other gold ore bodies of commercial size, however, had been found in the district up to 1977.

\section{GEOLOGY}

The northeastern part of the Lynn window, which includes the Carlin gold deposit, is made up of sedimentary rocks of Ordovician to Devonian age. These rocks, mainly limestone, dolomite, and quartzite, were deposited under shallow-water miogeosynclinal conditions and form part of the lower plate of the Roberts Mountains thrust (Roberts and others, 1967, p. 5). The rocks of the window are tectonically overlain by a thick sequence of interbedded chert, shale, and limestone of Ordovician and Silurian age, originally deposited in a eugeosynclinal environment in western Nevada. This upper-plate assemblage moved eastward on the Roberts Mountains thrust and overrode the lower plate during the Antler orogeny in Late Devonian or Early Mississippian time (Merriam and Anderson, 1942; Gilluly, 1954; Roberts and Lehner, 1955; Roberts and others, 1958).

During and after the formation of the Roberts Mountains thrust, clastic sedimentary rocks were shed eastward from the Antler orogenic belt to form several overlapping assemblages. Dott (1955) and Roberts and others (1958) gave detailed stratigraphic data on some of these rocks, which are exposed several kilometers east of the town of Carlin, Nev. This section (table 1) is approximately 2,750 $\mathrm{m}$ thick, and the rocks range in age from Early Mississippian(?) to Permian. In the Lynn window area, about $50 \mathrm{~km}$ northwest of this type area, the overlapping rocks are absent. If the Lynn window area was domed and uplifted during or shortly after thrusting (Roberts and others, 1967), then it is possible that the overlapping rocks never were present, or that a much thinner sequence was deposited and completely removed by later erosion.

Tectonic events since the early Paleozoic in the CarlinPinon Range area, about $50 \mathrm{~km}$ south-southeast of the Carlin deposit, were discussed by Smith and Ketner (1977), who recognized seven distinct deformation events: (1) formation of the Roberts Mountains thrust during the
Late Devonian to Early Mississippian; (2) deep basin subsidence and uplift of the west margin during the middle Early Mississippian; (3) regional uplift, folding, and thrusting during the late Middle to early Late Pennsylvanian; (4) renewed uplift and termination of marine conditions during the early Mesozoic; (5) intrusive igneous activity and strong folding during the Late Jurassic and Early Cretaceous; (6) igneous activity and local folding during the early Oligocene; and (7) normal faulting climaxing in the Miocene.

During Late Jurassic or Early Cretaceous time, stocks and dikes were emplaced in the Lynn window area. Because most of these dikes are fault controlled, some faulting must predate this igneous activity. However, the initial basin-and-range faulting along the flanks of, and most normal faulting within, the emerging Tuscarora Mountains postdate this igneous activity.

Additional orogenic events during Tertiary and Quaternary time include basin-and-range faulting, tilting of the range to the east, extensive normal faulting, and volcanism. Hydrothermal activity, resulting in the formation of the Carlin gold deposit and of barite veins both at the Carlin deposit and elsewhere in the window, took place during Oligocene or Miocene time. Thin lakebeds, formed in shallow basins, are preserved locally along the flanks of the range.

\section{SEDIMENTARY ROCKS}

\section{PALEOZOIC ROCKS}

\section{LOWER PLATE}

Ordovician System

Pogonip Group

The oldest rocks exposed in the Rodeo Creek NE. quadrangle are more than $600 \mathrm{~m}$ of limestone of the Pogonip Group, which crops out along the sides of a deep canyon southeast of Richmond Mountain (pl. 1). The Hamburg Dolomite of Middle and Late Cambrian age underlies the Pogonip Group but does not crop out in the Rodeo Creek NE. quadrangle. In the Welches Canyon quadrangle, however, dolomite beds exposed on the east flank of the Tuscarora Mountains about $3 / 4 \mathrm{~km}$ southeast of Richmond Mountain (mapped as lower units of the Pogonip Group by Evans, 1974b) probably represent the Hamburg Dolomite. The approximate position of the contact between the Hamburg Dolomite and the Pogonip Group is shown on the geologic map of the Lynn mining district (cross sec. D-D', pl. 1).

As originally used by King (1878), the term "Pogonip" referred to the limestone on Pogonip Ridge in the Hamilton mining district, White Pine County, Nev.; the term was later restricted by Hague (1883) to strata below the 
TABLE 1.-Generalized diagrammatic cross section showing principal lithologic units in the Rodeo Creek NE quadrangle

\begin{tabular}{|c|c|c|c|}
\hline Age & Formation & $\begin{array}{c}\text { Thickness } \\
(\mathrm{m})\end{array}$ & Lithology \\
\hline Quaternary & \multicolumn{3}{|c|}{$\begin{array}{c}\text { Unconsolidated deposits ........3-300 …............ Gravel, stream alluvium, and slope wash } \\
\text { Chert and shale in cobble- to sand-size fragments, and silt, } \\
\text { occur in unconsolidated alluvial fans. }\end{array}$} \\
\hline Pliocene........... & \multicolumn{2}{|c|}{ Carlin Formation $\ldots . \ldots 60-150$} & $\begin{array}{l}\text { Tuffaceous and nontuffaceous sandstone, mudstone, and welded } \\
\text { tuff, thin-bedded to poorly bedded. Conglomerate containing } \\
\text { abundant chert pebbles, poorly consolidated. }\end{array}$ \\
\hline Pliocene or Miocene...... & \multirow{2}{*}{$\begin{array}{l}\text { Extrusive and intrusive } \\
\text { igneous rocks }\end{array}$} & $3-6 ?$ & Crystal tuff, tuffaceous siltstone and sandstone. \\
\hline Miocene & & $30-220 ?$ & Rhyodacite and rhyolite flows and dikes. \\
\hline $\begin{array}{l}\text { Early Cretaceous and } \\
\text { Late Jurassic }\end{array}$ & \multicolumn{2}{|c|}{ Intrusive igneous rocks .........--- } & Quartz diorite, diorite, and granodiorite stocks and dikes. \\
\hline \multicolumn{4}{|c|}{ Upper plate of Roberts Mountains thrust } \\
\hline \multirow[t]{4}{*}{$\begin{array}{l}\text { Early Silurian to Early } \\
\text { Ordovician }\end{array}$} & \multirow[t]{4}{*}{ Siliceous assemblage...... } & .920 & $\begin{array}{l}\text { Chert interbedded with shale predominant; chert/shale ratio, } \\
1: 1 \text { to } 2: 1 \text {. Carbonaceous shale is minor. Quartzite occurs with } \\
\text { recrystallized chert and silicified shale. }\end{array}$ \\
\hline & & 760 & $\begin{array}{l}\text { Shale interbedded with chert and small amounts of thin-bedded } \\
\text { sandy limestone, calcareous sandstone, and carbonaceous } \\
\text { shale. Shale/chert ratio, }>2: 1 \text {. }\end{array}$ \\
\hline & & $60-180$ & $\begin{array}{l}\text { Chert and shale interbedded with lesser amounts of sandstone, } \\
\text { limestone, and quartzite. }\end{array}$ \\
\hline & & Total, 1,860 & \\
\hline
\end{tabular}

Lower plate of Roberts Mountains thrust

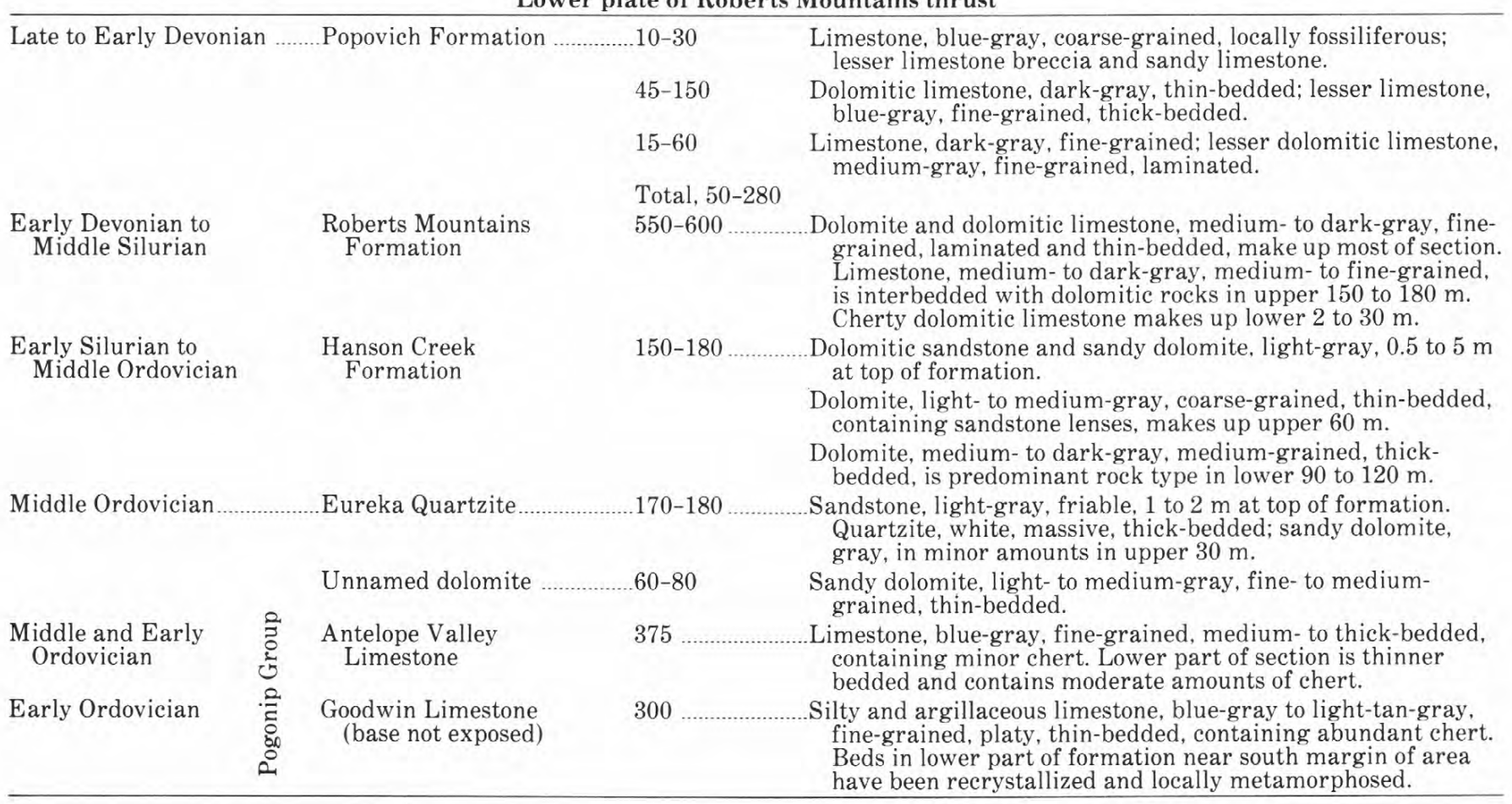

Eureka Quartzite and above a unit now named the "Dunderberg Shale" (Roberts and others, 1967). Finally, Nolan and others (1956) further restricted the Pogonip to include rocks below the Eureka Quartzite and above the Cambrian Windfall Formation; in the vicinity of Eureka, Nev., this group includes the Goodwin Limestone, the Ninemile Formation, and the Antelope Valley Limestone, all of Ordovician age.

In the Lynn window, the contact between the Pogonip Group and the overlying Eureka Quartzite is obscured in most places by talus and soil cover; on the slopes its posi- tion may be approximated by an abrupt decrease in quartzite float and a change in dip of the slope.

The uppermost beds of the Pogonip Group, 60 to $75 \mathrm{~m}$ of thin-bedded fine to medium-grained light- to mediumgray sandy dolomite, are exposed along the north side of the canyon east of Richmond Mountain (pl. 1). These rocks were first recognized as a distinct unit at the top of the Pogonip Group in the Lynn window by Roen (1961) and were mapped as such by Evans (1972a, 1974a). Although the upper beds of the Pogonip in most areas of Nevada where they have been described are not dolomite, 
in the section at Lone Mountain, northwest of Eureka, Nev., Kirk (1933) found $15 \mathrm{~m}$ of sandy dolomite between “* * *typical Pogonip and vitreous Eureka" (Nolan and others, 1956, p. 30).

Limestone beds of the Pogonip below the upper dolomite unit are well exposed along a bulldozer road that begins on Richmond Mountain and heads southeastward, following the south wall of the canyon. These rocks, about $370 \mathrm{~m}$ thick, are massive medium- to thick-bedded finegrained medium-blue-gray limestone that closely resembles the Antelope Valley Limestone described by Nolan and others (1956). Thin beds of chert are scattered throughout the section, and fracture surfaces commonly are coated with thin layers of fine-grained dusty-white calcite. The lower half of the formation is thinner bedded and contains numerous thin, ribbonlike shale beds.

About 430 to $460 \mathrm{~m}$ below the Pogonip-Eureka contact, the Pogonip becomes platy and contains interbedded shale, as well as shaly limestone including much detrital quartz and clay. These rocks have been tentatively assigned to the Goodwin Limestone. Chert lenses and nodules, as large as $13 \mathrm{~cm}$ across, are abundant, and organic carbon is locally concentrated in patches and seams. Overall, the rocks are blue gray, except where light-tan or gray chert is present. Along joints and bedding surfaces the rocks commonly show surficial alteration in the form of an increase in silica and a decrease in calcite, and are bleached to light gray. Locally these rocks have been recrystallized to hornblende, clinopyroxene, and mica (Evans, 1974a). Geologic mapping by Evans (1974b) in the Welches Canyon quadrangle to the south indicated that the total thickness of the Pogonip Group is at least $670 \mathrm{~m}$ and that the thickness of these lower thin-bedded platy units is $300 \mathrm{~m}$ or more.

Table 2 lists chemical and spectrographic analyses of a composite sample representing about a 60-m section of the Goodwin Limestone and a $30-\mathrm{m}$ section of the Antelope Valley Limestone (samples 1 and 2, respectively). The higher content of $\mathrm{SiO}_{2}, \mathrm{Al}_{2} \mathrm{O}_{3}$, total $\mathrm{Fe}, \mathrm{MgO}, \mathrm{K}_{2} \mathrm{O}$, $\mathrm{Na}_{2} \mathrm{O}$, and $\mathrm{TiO}_{2}$, and the lower content of $\mathrm{CaO}$, in the analyses reflect the abundant quartz clasts, chert, and shale beds in the section.

Fossils in collections made by J. G. Evans indicate that the Pogonip Group is Early and early Middle Ordovician. Conodonts in two fossils collections (Evans, 1974a, locs. M540, M541) from near the base of the Antelope Valley Limestone were identified as early Middle Ordovician by I. W. Huddle (written commun., 1969):

USGS collection 6966-CO (field No. M540), Nevada coordinates E.297,860,

N.2,231,260; Palisades No. 2 NE. quadrangle

$$
\begin{aligned}
& \text { Acontiodus sp. } \\
& \text { staufferi Firm }
\end{aligned}
$$$$
\text { Drepanodus? sp. }
$$

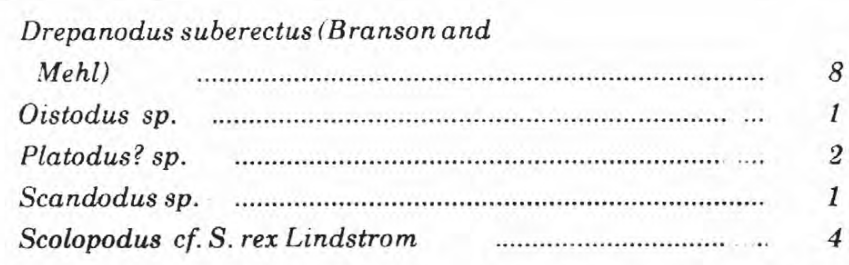

This collection is early Middle Ordovician and could be equivalent in age to the lower part of the Antelope Valley Limestone (J. W. Huddle, written commun., 1969).

USGS collection 6967-CO (field No. M541), Nevada coordinates E.298,060, N.2,231,560; Palisades No. 2 NE. quadrangle

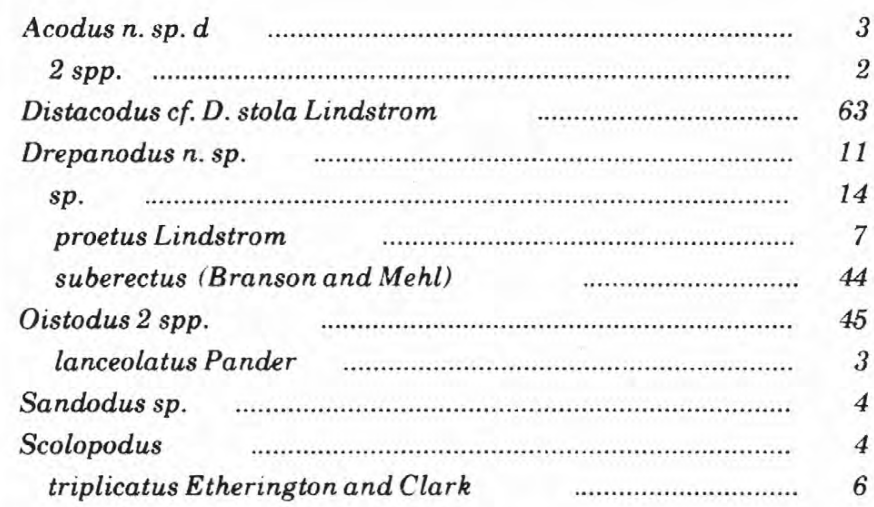

This fauna occurs in the lower part of the Antelope Valley Limestone at Dobbins Summit in the Monitor Range, in the Timpanute Range, and on Antelope Peak (USGS locs. D1495-CO, D1581-CO, D1657-CO, D2048-CO, D2055$\mathrm{CO}$ ), and also is probably early Middle Ordovician (J. W. Huddle, written commun., 1969).

Roen (1961) reported the presence of the lower Ordovician brachiopod Archaeorthis costellata Ulrich and Cooper in limestone of the Pogonip Group collected on Richmond Mountain.

A collection of conodonts from lower thin-bedded platy siliceous limestone (Evans, 1974a) was dated as Early Ordovician by J. W. Huddle (written commun., 1969):

USGS collection 6902-CO (field. No. M475), Nevada coordinates E. 299,200, N.2,231,900; Palisades No. 2 NE. quadrangle

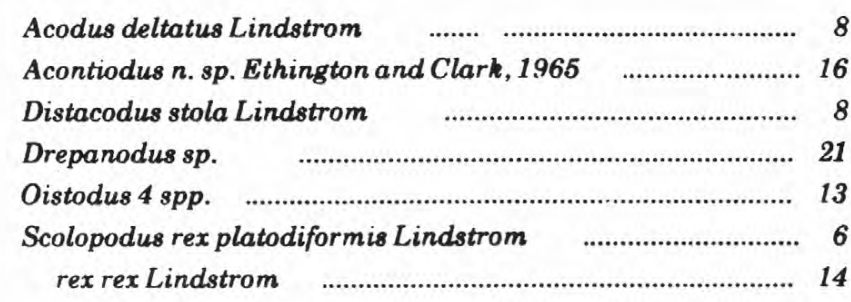

In summary, the lower $300 \mathrm{~m}$ or more of limestone of the Pogonip Group closely resembles the Goodwin Limestone (Roberts and others, 1967). This evidence, combined with their stratigraphic position and age, makes it reasonable 
TABLE 2,-Chemical and spectrographic analyses of Paleozoic sedimentary rocks of the lower plate in the Lynn window, Eureka County, Nev.

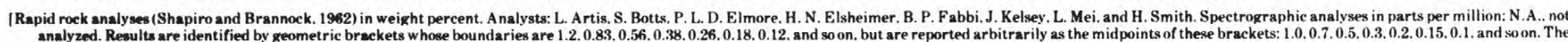
precision of a AR (0.7), Bi (7), Cd (7), Ce (70). Hf (50). In (2). Li (100). Mo (2). Pb (7). Pd (1). Pt (10). Re (15). Sn (7). Ta (70). Te (300). Th (150). U (150). W (10). Analyst: Chris Heropoulowt

\begin{tabular}{|c|c|c|c|c|c|c|c|c|c|c|c|c|c|c|}
\hline \multirow[b]{3}{*}{ Sample. } & \multicolumn{2}{|c|}{ Poronip Group } & \multirow{3}{*}{$\begin{array}{c}\begin{array}{c}\text { Eureka } \\
\text { Quartzite }\end{array} \\
3\end{array}$} & \multirow{3}{*}{$\begin{array}{c}\begin{array}{c}\text { Hanson } \\
\text { Creek } \\
\text { Formation }\end{array} \\
4 \\
\end{array}$} & \multirow{2}{*}{\multicolumn{6}{|c|}{ Roberts Mountains Formation }} & \multirow{2}{*}{\multicolumn{4}{|c|}{ Popovich Formation }} \\
\hline & \multirow{2}{*}{$\begin{array}{c}\begin{array}{c}\text { Antelope } \\
\text { Valley } \\
\text { Limestone }\end{array} \\
1 \\
\end{array}$} & \multirow{2}{*}{$\begin{array}{c}\text { Goodwin } \\
\text { Limestone }\end{array}$} & & & & & & & & & & & & \\
\hline & & & & & 5 & 67 & 8 & 9 & 10 & 11 & 12 & 13 & 14 & \\
\hline \multicolumn{15}{|c|}{ Rapid rock analyses } \\
\hline $\begin{array}{l}\mathrm{SiO}_{2} \\
\mathrm{Al}_{2} \mathrm{O}_{3} \\
\mathrm{Fe}_{2} \mathrm{O}_{3} \\
\mathrm{FeO}_{3} \\
\mathrm{MgO}\end{array}$ & $\begin{array}{l}3.6 \\
.90 \\
.16 \\
.32 \\
.78\end{array}$ & $\begin{array}{r}48.4 \\
10.6 \\
1.7 \\
2.1 \\
2.9\end{array}$ & $\begin{array}{l}96.6 \\
.00 \\
.00 \\
.16 \\
.88\end{array}$ & $\begin{array}{c}1.7 \\
.00 \\
.05 \\
.16 \\
20.6\end{array}$ & $\begin{array}{c}56.0 \\
1.5 \\
.44 \\
.24 \\
1.1\end{array}$ & $\begin{array}{r}32.3 \\
2.4 \\
.73 \\
10 \\
4.0\end{array}$ & $\begin{array}{c}19.3 \\
1.8 \\
.61 \\
2.4 \\
7.4\end{array}$ & $\begin{array}{c}29.6 \\
3.1 \\
.63 \\
.28 \\
10.9\end{array}$ & $\begin{array}{c}12.0 \\
.72 \\
.48 \\
.12 \\
.61\end{array}$ & $\begin{array}{c}37.6 \\
3.5 \\
.58 \\
.24 \\
3.5\end{array}$ & $\begin{array}{c}4.8 \\
.20 \\
.36 \\
.08 \\
2.3\end{array}$ & $\begin{array}{l}21.1 \\
7.2 \\
2.0 \\
.88 \\
8.2\end{array}$ & $\begin{array}{l}28.1 \\
5.6 \\
1.5 \\
.34 \\
5.8\end{array}$ & $\begin{array}{l}6.6 \\
.04 \\
.58 \\
.04 \\
.28\end{array}$ \\
\hline $\begin{array}{l}\mathrm{CaO} \\
\mathrm{BaO} \\
\mathrm{BnO}^{1} \\
\mathrm{MnO} \\
\mathrm{Na} \mathrm{O}_{2} \mathrm{O} \\
\mathrm{K}_{2} \mathrm{O}\end{array}$ & $\begin{array}{l}51.5 \\
.08 \\
.06 \\
.20 \\
.37\end{array}$ & $\begin{array}{c}15.9 \\
.10 \\
.03 \\
.59 \\
5.5\end{array}$ & $\begin{array}{l}.32 \\
.01 \\
.00 \\
.14 \\
.08\end{array}$ & $\begin{array}{r}29.3 \\
.03 \\
.01 \\
.24 \\
.08\end{array}$ & $\begin{array}{r}.22 .1 \\
.04 \\
.02 \\
.42 \\
.18\end{array}$ & $\begin{array}{l}30.0 \\
.03 \\
.00 \\
.02 \\
.70\end{array}$ & $\begin{array}{l}33.7 \\
.04 \\
.00 \\
.00 \\
.63\end{array}$ & $\begin{array}{c}23.0 \\
.02 \\
.00 \\
.00 \\
1.2\end{array}$ & $\begin{array}{l}47.8 \\
.01 \\
.00 \\
.00 \\
.13\end{array}$ & $\begin{array}{r}26.5 \\
.03 \\
.00 \\
.68 \\
.96\end{array}$ & $\begin{array}{r}50.1 \\
.01 \\
.01 \\
.02 \\
.09\end{array}$ & $\begin{array}{c}26.5 \\
.02 \\
.00 \\
.03 \\
1.8\end{array}$ & $\begin{array}{r}26.7 \\
.06 \\
.00 \\
.03 \\
2.1\end{array}$ & $\begin{array}{r}51.2 \\
.01 \\
.00 \\
.00 \\
.15\end{array}$ \\
\hline $\begin{array}{l}\mathrm{TiO}_{2} \\
\mathrm{P}_{2} \mathrm{O}_{5}^{2} \\
\mathrm{H}_{2}^{2} \mathrm{O}^{2}+1 \\
\mathrm{H}_{2}^{2} \mathrm{Ol}-1 \\
\mathrm{CO}_{2}\end{array}$ & $\begin{array}{r}.2 \\
.30 \\
.08 \\
.27 \\
40.4\end{array}$ & $\begin{array}{r}.47 \\
.21 \\
.09 \\
1.3 \\
11.4\end{array}$ & $\begin{array}{l}.00 \\
.00 \\
.01 \\
.26 \\
.07\end{array}$ & $\begin{array}{r}.00 \\
.04 \\
.04 \\
.27 \\
46.8\end{array}$ & $\begin{array}{r}.00 \\
.02 \\
.11 \\
.51 \\
17.5\end{array}$ & $\begin{array}{r}.18 \\
.00 \\
.18 \\
.92 \\
28.1\end{array}$ & $\begin{array}{r}.07 \\
.86 \\
.16 \\
33.3\end{array}$ & $\begin{array}{c}.11 \\
.32 \\
1.19 \\
1.0 \\
29.0\end{array}$ & $\begin{array}{r}.09 \\
.06 \\
.09 \\
.61 \\
38.4\end{array}$ & $\begin{array}{r}.21 \\
.00 \\
.12 \\
2.65 \\
25.3\end{array}$ & $\begin{array}{r}.00 \\
.05 \\
.05 \\
.51 \\
42.0\end{array}$ & $\begin{array}{r}.30 \\
.06 \\
.49 \\
2.0 \\
30.0\end{array}$ & $\begin{array}{r}.27 \\
.00 \\
.29 \\
1.3 \\
28.0\end{array}$ & $\begin{array}{r}.03 \\
.09 \\
.08 \\
.51 \\
40.2\end{array}$ \\
\hline $\begin{array}{l}S(\text { total })^{2} \\
C \text { (organic) }\end{array}$ & $\begin{array}{r}.22 \\
.19\end{array}$ & $\begin{array}{l}.44 \\
.76\end{array}$ & $\begin{array}{l}.19 \\
.13\end{array}$ & $\begin{array}{l}.14 \\
.21\end{array}$ & $\begin{array}{l}.14 \\
.35\end{array}$ & $\begin{array}{l}.27 \\
.23\end{array}$ & $\begin{array}{l}.20 \\
.31\end{array}$ & $\begin{array}{l}.24 \\
.33\end{array}$ & $\begin{array}{l}.05 \\
.20 \\
\end{array}$ & $\begin{array}{l}.08 \\
.15 \\
\end{array}$ & $\begin{array}{l}.06 \\
.17 \\
\end{array}$ & $\begin{array}{l}.11 \\
.25 \\
\end{array}$ & $\begin{array}{l}.56 \\
.28 \\
\end{array}$ & $\begin{array}{l}.03 \\
.15 \\
\end{array}$ \\
\hline Total & 99.6 & 102.5 & 98.9 & 99.7 & 100.7 & 100.2 & 99.3 & 99.9 & 101.4 & 100.1 & 100.8 & 100.7 & 100.9 & 100.0 \\
\hline
\end{tabular}

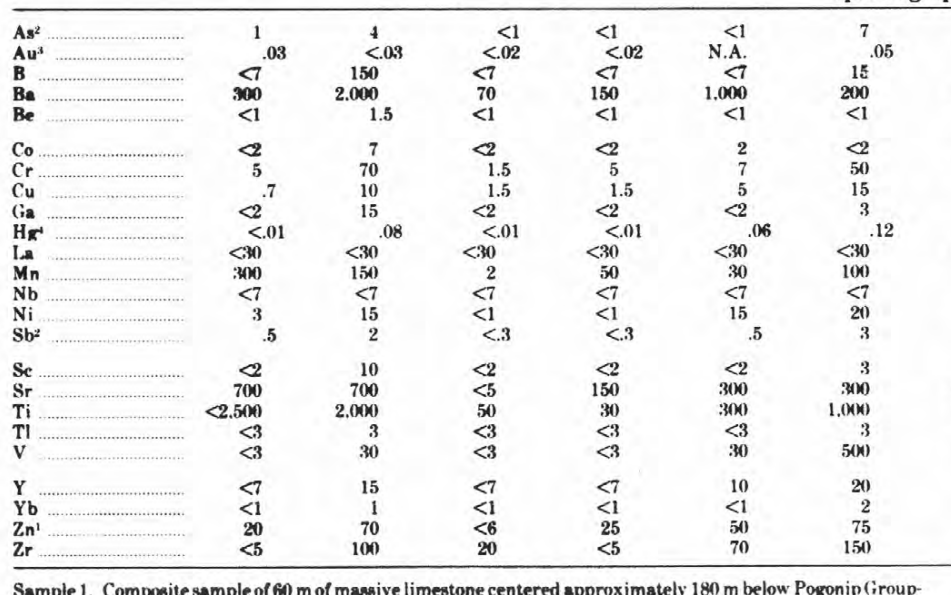

Sample 1. Composite sample of $60 \mathrm{~m}$ of massive limestone centered approximately $180 \mathrm{~m}$ below Pogonip (iroup -

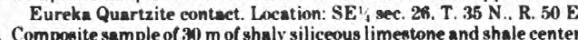

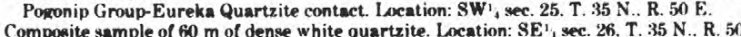

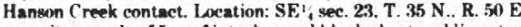

Formation. Location: NW', sec. 24. T. 35 N. R. 50 E.

\begin{tabular}{|c|c|c|c|c|c|c|c|}
\hline $\begin{array}{l}<5 \\
<.03 \\
<7 \\
150 \\
<1\end{array}$ & $\begin{array}{l}{ }^{10} \\
<{ }^{06} \\
200 \\
<1\end{array}$ & $\begin{array}{l}<5 \\
<03 \\
<7 \\
30 \\
<1\end{array}$ & $\begin{array}{r}<5 \\
\text { N.A. } \\
<7 \\
200 \\
<1\end{array}$ & $\begin{array}{r}<1 \\
\text { N.A. } \\
10 \\
50 \\
<1\end{array}$ & $\begin{array}{c}<1.5 \\
\text { N.A. } \\
100 \\
200 \\
<1 \\
<1\end{array}$ & $\begin{array}{r}<1 \\
\text { N.A. } \\
100 \\
700 \\
<1\end{array}$ & $\begin{array}{r}<1 \\
\text { N.A. } \\
7 \\
50 \\
<1\end{array}$ \\
\hline $\begin{array}{r}<2 \\
20 \\
2\end{array}$ & $\begin{array}{l}<2 \\
50 \\
10\end{array}$ & $\begin{array}{l}<2 \\
10 \\
1.5\end{array}$ & $\begin{array}{l}<2 \\
30 \\
10\end{array}$ & $\begin{array}{r}<2 \\
7 \\
2\end{array}$ & $\begin{array}{r}<2 \\
150 \\
7\end{array}$ & $\begin{array}{r}<2 \\
150 \\
30\end{array}$ & $\begin{array}{c}<2 \\
3 \\
1.5\end{array}$ \\
\hline$<2$ & ${ }^{2}{ }_{16}$ & $<2$ & ${ }^{3}{ }_{05}$ & $\begin{array}{l}<2 \\
\mathrm{~N} . \mathrm{A}\end{array}$ & N. ${ }^{7}$ & N.A. & ${ }_{.04}^{<2}$ \\
\hline$<30^{\circ}$ & $<30^{\circ}$ & $<30^{\circ}$ & $<30$ & $<30$ & 70 & 30 & $<30$ \\
\hline & 30 & 200 & 100 & 50 & 150 & 150 & 70 \\
\hline$<7$ & $<7$ & $<7$ & $<7$ & $<7$ & ${ }^{7}$ & 10 & \\
\hline $\begin{array}{c}15 \\
15 \\
\end{array}$ & $\begin{array}{r}20 \\
4 \\
4\end{array}$ & ${ }^{2} .5$ & ${ }^{10}<.5$ & $<1$ & $\begin{array}{r}20 \\
1\end{array}$ & $\begin{array}{l}20 \\
<.3\end{array}$ & $\stackrel{2}{<3}$ \\
\hline$<2$ & $\begin{array}{r}5 \\
150\end{array}$ & $\begin{array}{c}<2 \\
700\end{array}$ & 500 & $<2$ & $\begin{array}{l}10 \\
300\end{array}$ & $\begin{array}{r}10 \\
300\end{array}$ & $\begin{array}{r}<2 \\
300)\end{array}$ \\
\hline 700 & $1.000)$ & 200 & 1.500 & 150 & 3.000 & 3.0000 & 50 \\
\hline 3 & $<3$ & $<3$ & $<3$ & $<3$ & $<3$ & $<3$ & $<3$ \\
\hline 20 & 10 & 20 & 20 & 10 & 50 & 3 & $<7$ \\
\hline 1 & 1 & 1 & 2 & $<1$ & 3 & 2 & $<1$ \\
\hline $\begin{array}{l}98 \\
30\end{array}$ & $\begin{array}{r}195 \\
50\end{array}$ & $\begin{array}{l}<6 \\
15\end{array}$ & $\begin{array}{l}195 \\
150\end{array}$ & $\begin{array}{l}25 \\
15\end{array}$ & $\begin{array}{l}35 \\
150\end{array}$ & $\begin{array}{l}50 \\
70\end{array}$ & $\begin{array}{l}10 \\
<5\end{array}$ \\
\hline
\end{tabular}
arenact 45 to 90 dotomite and limestone (peloidal wackestone) representing stratigraphic interval

9. Composite of three samples of thin-bedded weakly laminated arenaceous peloidal wackestone from three
beds 45 to $55 \mathrm{~m}$ below upper contact of the Roberts Mountains Formation. Lacation: $\mathrm{NE}^{\prime}$, sec. 24 and $\mathrm{NE}$, sec. 15. T.

10. Composite of 10 samples of weathered thin-bedded platy silty laminated dolomitic limestone from surface outcrops. Location: $\mathrm{SE}$, weec. 24. T. $35 \mathrm{~N}$.. R. .50 E.
Composite sample of five beds of thick-bedded fine-grained dark-gray limestone in lower $6 \mathrm{~m}$ of the Popovich Formation. Location: 6.400 bench. east end of West pit, Carlin gold deposit.

mitic limestone from middle zone of the Popovich Formation. Location: 6.700 to 7.000 bench. south side of Popovich Hill. Carlin zold deposi. Composite sample of $21 \mathrm{~m}$ of inter bedded laminated dolomitic limestone and thin- to medium-thick-bedded

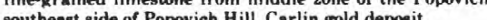
14. Composite of three samples of thick-bedded massive dense dark-gray bioclastic limestone from upper $3 \mathrm{mof}$

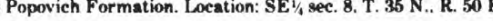
$1 X$.rav fuorescence analysis.

(11-14 also were analyzed by emission samp and $11-14$ al

sectroscopy. Using Kodak short-wavelength radiation
s Neutron-activation and atomic-abeorption analysen. 
to assign these rocks to the Goodwin Limestone. The upper $360 \mathrm{~m}$ or more of limestone of the Pogonip Group is correlated with the type Antelope Valley Limestone and accordingly is here assigned to the Antelope Valley Limestone (pl. 1).

\section{Eureka Quartzite}

White quartzite of the Eureka mining district, Nev., was first named and described by Hague (1883) as the Eureka Quartzite. In the Eureka district, however, the original lithologic features of the quartzite and its relations to other units have been obscured by extensive faulting, brecciation, and alteration from hydrothermal solutions. Therefore, Kirk (1933) proposed that the type section be changed and suggested that a well-exposed complete section at Lone Mountain, about $25 \mathrm{~km}$ northwest of Eureka, Nev., be designated the new type section; the U.S. Geological Survey has accepted this redesignation.

In the Rodeo Creek NE. quadrangle the Eureka Quartzite crops out in three areas: (1) from the crest of Richmond Mountain, along a northeast-striking zone following the crest of the Tuscarora Mountains anticline; (2) in fault contact against the younger Hanson Creek Formation, along the sides and floor of a canyon heading northwestward from Richmond Mountain; and (3) in normal stratigraphic as well as fault contact with the Hanson Creek Formation, on the west side of Sheep Creek Canyon $1 \frac{1}{2} \mathrm{~km}$ west of the Carlin deposit (pl. 1).

The best exposures of the Eureka Quartzite are along the top of the north wall of the canyon just east of Richmond Mountain, where it rests on upper dolomite beds of the Pogonip Group. The basal contact is displaced locally by normal faults and is traceable eastward about $11 / 2 \mathrm{~km}$, where it ends against a normal fault dipping steeply to the east. Beds of the Eureka Quartzite east of the fault, displaced vertically about $300 \mathrm{~m}$, continue eastward to the prominent Leeville fault (pl. 1).

Physically, the Eureka Quartzite in the Rodeo Creek NE. quadrangle closely resembles the unit exposed elsewhere in Nevada (Ketner, 1966, 1968). The Eureka is composed of 170 to $180 \mathrm{~m}$ of fine- to medium-grained massive sugary vitreous white quartzite. Weathered surfaces and fractures are stained with red-brown to brown iron oxides. Roen (1961) estimated the total thickness of the quartzite at about $120 \mathrm{~m}$, and Evans (1974a) reported the thicknesses of partial sections to be 60 to $210 \mathrm{~m}$.

Seen in thin section, most of the Eureka Quartzite is composed of subangular to well-rounded well-sorted quartz grains cemented by quartz. Accessory minerals, making up about 1 percent of most samples, include hematite, zircon, epidote, illite, tourmaline, sphene, and barite. In general, the unit is very clean and is classified as an orthoquartzite. Chemical and spectrographic analyses of a composite sample from outcrops of a $60-\mathrm{m}$ stratigraphic section of quartzite beginning about $6 \mathrm{~m}$ above the base (sample 3, table1) reflect the low levels of components other than $\mathrm{SiO}_{2}$.

Locally, the upper $30 \mathrm{~m}$ or more of the quartzite contains small amounts of dolomite, and at least one bed 5 to $6 \mathrm{~m}$ thick near the top of the formation is gray sandy dolomite. Roen (1961) suggested that this dolomitic quartzite bed could be correlative with the upper dolomite member of the formation at Cortez, Nev., and in other localities (Webb, 1958).

The upper 1 to $2 \mathrm{~m}$ of the Eureka Quartzite is poorly consolidated sandstone, similar to that described by Merriam (1940) and Merriam and Anderson (1942) at the top of the Eureka in the Roberts Mountains. Roen (1961, p. 46) gave a good description of these sandy beds in the Lynn window:

At the upper boundary of the Eureka there is a relatively less resistant, light-gray quartz sandstone cemented by calcite. In thin section the quartz grains average about $0.25 \mathrm{~mm}$ in size and constitute about 60 percent of the rock. These grains are embayed by the calcite cement; however, their outline was originally round to subround. The remaining 40 percent of the rock is the matrix of which about 35 percent is calcite and 5 percent is illite.

The age of the Eureka Quartzite in the Tuscarora Mountains is bracketed by the Middle Ordovician age of the underlying Antelope Valley Limestone and the Middle and Late Ordovician age of the overlying Hanson Creek Formation.

\section{Ordovician And Silurian Systems Hanson Creek Formation}

The name "Hanson Creek Formation" was first proposed by Merriam (1940) for dolomite and limestone beds, about $150 \mathrm{~m}$ thick, between the Eureka Quartzite and the Roberts Mountains Formation near Eureka, Nev. The type section is along Pete Hanson Creek on the northwest side of Roberts Creek Mountain, $56 \mathrm{~km}$ northwest of Eureka.

In the Lynn window the Hanson Creek Formation, chiefly dolomite and lesser amounts of dolomitic limestone, is well exposed in the highly faulted anticline south of the Carlin gold deposit. About $3 / 4 \mathrm{~km}$ south of the mouth of Sheep Creek Canyon, the formation forms the west limb of the main anticline; from this area a group of fault blocks crops out eastward for $3 \mathrm{~km}$ and turns southeastward to form the east limb of the anticline (see pl. 1). Throughout most of this area the apparent thickness of the formation is much greater than its true thickness, owing to closely spaced sets of high-angle normal faults. Because of the complex fault patterns, the generally poor exposure of contacts, and the overall attitude of the Hanson Creek Formation, which commonly dips roughly parallel to slopes, its true thickness is difficult to measure. 
The thickness of the formation is estimated at between 150 and 185m; Roen (1961) estimated its thickness at about $175 \mathrm{~m}$. This thickness of the Hanson Creek Formation in the Lynn window is greater than that reported in other areas of Nevada; Nolan and others (1956) reported thicknesses of $110 \mathrm{~m}$ at Pete Hanson Creek, $97 \mathrm{~m}$ at Lone Mountain, and 90m in Antelope Valley. Nolan (1962) reported the thickness in the Eureka, Nev., area to be $90 \mathrm{~m}$ or less. The thickness of 330m given by Evans (1974a) for the formation in the Lynn window, on the basis of exposures in the Welches Canyon quadrangle, is not easily substantiated from exposures in the Rodeo Creek NE quadrangle.

An incomplete section is exposed about $1 \frac{1}{2} \mathrm{~km}$ west of the Carlin gold deposit on the west side of Sheep Creek Canyon; in that area the formation lies in inferred normal stratigraphic and fault contact with both the underlying Eureka Quartzite and the overlying Roberts Mountains Formation (pl.1).

The lower contact of the Hanson Creek Formation is poorly exposed in the northern part of the Lynn window; where the contact is exposed locally north and northeast of Richmond Mountain, the irregular moderate-relief upper surface of sandy beds at the top of the Eureka Quartzite suggests that the rocks were eroded before the Hanson Creek Formation was deposited. Roen (1961, p. 54) stated, "***the lack of noticeable angular discordance between the attitudes of the two formations and the intervening hiatus suggests a disconformable contact between the Hanson Creek Formation and the underlying Eureka Quartzite."

The lower 90 to $120 \mathrm{~m}$ of the Hanson Creek Formation is fine- to medium-grained thick-bedded medium- to darkgray dolomite that locally contains white calcite seams and small lenses and seams of black chert; most of the chert is in the lower $30 \mathrm{~m}$ of the formation. Weathered surfaces are light gray and commonly coated with finegrained calcite. The dolomite, which is relatively pure, contains small amounts of calcite, illite, and quartz, as reflected in the low contents of $\mathrm{SiO}_{2}, \mathrm{Al}_{2} \mathrm{O}_{3}, \mathrm{~K}_{2} \mathrm{O}$, and other constituents in a $60-\mathrm{m}$ composite sample (sample 4 , table 2 ). In the upper $60 \mathrm{~m}$ of the formation the dolomite becomes coarser grained, thinner bedded, and lighter gray, and contains lenses as thick as $10 \mathrm{~m}$ of thick-bedded darkblue-gray dolomitic limestone.

A persistent interbedded thick-bedded light-gray sandy dolomite and dolomitic sandstone, 0.5-10.0 $\mathrm{m}$ thick, that makes up the top of the formation contains as much as 70 percent silt- to sand-size grains of rounded detrital quartz, commonly weathering light brown. Mullens and Poole (1972) indicated that these sandy beds constitute a good stratigraphic marker and occur in the upper part of the Hanson Creek Formation throughout Eureka County, Nev.
The Hanson Creek Formation at the type locality ranges in age from Middle into Late Ordovician (Merriam, 1940); Roberts and others (1967) reported a similar age range for these rocks throughout Eureka County. Later, Mullens and Poole (1972) showed that the sandy marker zone at the top of the formation in an area $11 / 2 \mathrm{~km}$ south of the Carlin mine contains conodonts of Early Silurian age.

The amount of paleontologic data available on the Hanson Creek Formation in the Rodeo Creek NE. quadrangle is very limited and includes suites of fossils from three localities. One suite collected by J. G. Evans from about $1 \frac{1}{2} \mathrm{~km}$ south-southwest of the Carlin mine (Evans, 1974a) probably represents material from a stratigraphic interval $60-90 \mathrm{~m}$ above the base of the formation. The following remarks are from notes by R. J. Ross, L. A. Wilson, and C. W. Merriam (written communs., 1969):

USGS collection D2151-CO (field No. M418), Nevada coordinates E.293,760, N. 2,235,240; Palisades No. 2 NE. quadrangle. Hanson Creek Formation containing brachiopods, corals, and conodonts.

R. J. Ross (written commun., 1969) reported the following brachiopod forms in these rocks.
Glyptorthis sp.
Lepidocyclus? sp.
Leptellina sp.
Paucicrurasp.
Plaesiomys? sp.
Rhynchotremasp.
Thaerodonta sp.
Zygospira cf. Z. recurvirostris

The presence of Leptellina, which is not supposed to be younger than Middle Ordovician, suggests that the Hanson Creek may be Trentonian rather than Richmondian (Late Ordovician), the age generally assigned. L. A. Wilson (written commun., 1969) reported that these rocks contain the following suite of conodonts:

\section{Belodina compressa (Branson and Mehl) inclinata (Branson and Mehl) \\ Drepanodus sp. \\ Oistodus inclinatus Branson and Mehl \\ Ozarkodinasp. \\ Panderodus sp. feulneri (Glenister) \\ Prioniodina cf. $P$. rotunda Sweet, Turco, Warner, and Wilkie}

L. A. Wilson (written commun., 1969) concluded that the age is more likely late Middle or early Late Ordovician.

C. W. Merriam (written commun., 1969) studied the corals in these rocks and reported the following forms:

Halysites (Catenipora) sp.

Palaeofavosites sp.

Palaeophyllum cf. P. thomi(Hall)

Streptelasma sp. (small monangulate form) 
In conclusion, C. W. Merriam (written commun., 1969) stated, "This coral association is characteristic of the Late Ordovician Hanson Creek and the Ely Springs Dolomite."

Roberts and others (1967) reported another suite of corals in a sample from the Hanson Creek Formation of the Tuscarora Mountains. The locality shown by Evans (1974a) for this sample indicates that it was collected within a zone about 90 to $120 \mathrm{~m}$ above the base of the formation.

The suite of corals identified by J. M. Berdan (Roberts and others, 1967, p. 118) includes

(field No. 54-F-68) Tuscarora Mountains, Ammann photo index $29 \mathrm{NW}$., photograph $34 \mathrm{~N}-12$; locality approximately in center of N-1/2 sec. 25 , T.35N., R.50E.

Cateniporasp.

Favosites sp.

Palaeophyllum sp.

Streptelasmasp.

trilobatum (Whiteaves)

Berdan reported that this association is typical of the Fish Haven Dolomite and of parts of the Hanson Creek Formation.

Fossil data on a conodont-bearing sample from a nonsandy dolomite bed near the top of the Hanson Creek Formation were reported by Mullens and Poole (1972). The collection of conodonts was identified by J. W. Huddle (written commun., 1971):

USGS collection 8823-SD (field No. TM-F21-70), $1.5 \mathrm{~m}$ below top of the Hanson Creek Formation in SE $1 / 4 \mathrm{NE}$ $1 / 4$ sec. 23, T.35N., R.50E., Tuscarora Mountains, Rodeo Creek NE. quadrangle

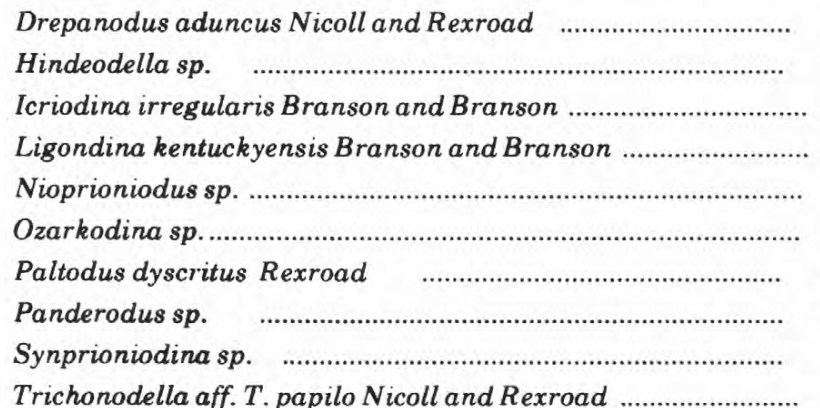

2

1 1 9 3 2 17 60

On the basis of information from J. W. Huddle (written commun., 1971), Mullens and Poole (1972, p. B22-B23) concluded that the conodonts in these beds $* * *$ are Early Silurian in age. The critical species [is] Icriodina ir-
rregularis, which [is] confined to the I. irregularis Assemblage Zone of
Rexroad (1967). The other species and genera listed are common in the
Lower Silurian Brassfield Limestone and in the Silurian Salamonie
Dolomite of Pinsak and Shaver (1964) along the Cincinnati arch in the
Eastern United States, according to Nicoll and Rexroad (1968). They
also occur in the Early Silurian in northern Michigan and Ontario, ac-
cording to Pollock, Rexroad, and Nicoll (1970).

W. B. N. Berry identified Climacograptus cf. C. rectangularis (McCoy), Dimorphograptus confertus cf. var. Swanstoni (Lapworth), and Glyptograptus from $31 \mathrm{~m}$ above the base of the Roberts Mountains Formation in the Copenhagen Canyon section. According to Berry (written commun., 1970), these graptolites are indicative of zone 18 of the Great Basin section, although this position in the Great Basin is not firmly established. The conodonts at Copenhagen Canyon, therefore, are possibly no younger than zone 18.

The conodont fauna from near the Carlin mine area probably are of the same age; there, however, the first graptolite found above the Hanson Creek is Monograptus spiralis, indicative of the uppermost Lower Silurian (zone 25; W. B. N. Berry, written commun., 1970). M. spiralis is only $11 \mathrm{~m}$ above the conodont collection.

In summary, the Hanson Creek Formation in the Rodeo Creek NE. quadrangle ranges in age from Middle Ordovician to Early Silurian.

\section{Silurian And Devonian Systems \\ Roberts Mountains Formation}

Hague (1892) defined the Lone Mountain limestone to include all the strata between the Middle Ordovician Eureka Quartzite and the Devonian Nevada Formation. Merriam (1940) applied the name "Roberts Mountains Formation" to the strata lying below dolomite in the Lone Mountain and above the Hanson Creek Formation. Winterer and Murphy (1960) indicated that the Roberts Mountains Formation is probably the lateral time-stratigraphic equivalent of the Lone Mountain Dolomite; they considered the Lone Mountain Dolomite to be a reef-andbank complex and the Roberts Mountains Formation to be an off-reef deeper water basin deposit. In a recent comprehensive report on the Roberts Mountains Formation, Mullens (1980, p. 2) stated, “The Roberts Mountains Formation grades eastward into the Lone Mountain and Laketown Dolomites and south and southwestward into the Lone Mountain Dolomite."

The type locality of the Roberts Mountains Formation is between the south and middle forks of the upper part of Pete Hanson Creek on the northwest side of Roberts Creek Mountain in the Roberts Mountains, about $50 \mathrm{~km}$ northwest of Eureka, Nev. The Roberts Mountains Formation is the host rock for all but a very small volume of the gold ore bodies in the Carlin deposit and elsewhere within the Lynn window. The formation crops out over a zone about $1 \frac{1}{2} \mathrm{~km}$ wide along the north and west margins of the window (pl. 1). Good exposures of the formation are also present on the east flank of the Tuscarora Range, where the beds are offset to the southeast along the Leeville fault, and it also is well exposed along the hills from the north side of Sheep Creek over a distance of about $5 \mathrm{~km}$ to the north-northwest (pl. 1). 
Roen (1961) described the Roberts Mountains Formation in the Lynn window. Radtke and Scheiner (1970b) presented chemical and mineralogic data on the formation; Merriam and McKee (1976) summarized information on its stratigraphy, depositional facies, and stratigraphic paleontology; and Mullens (1980) made a comprehensive study of its petrology and stratigraphy, including the section exposed in the Lynn window.

The Roberts Mountains Formation in the Tuscarora Mountains is composed of a basal cherty dolomitic limestone ranging from 1 to $30 \mathrm{~m}$ in thickness, overlain by thinbedded laminated silty dolomite and dolomitic limestone having an estimated thickness of 550 to $600 \mathrm{~m}$; locally the upper 210 to $240 \mathrm{~m}$ of the formation contains fine- to medium-grained limestone (peloidal wackestone) interbedded with the laminated dolomitic beds. The upper boundary of the Roberts Mountains Formation is placed at the contact between the underlying laminated carbonate beds and the first overlying thick-bedded coarsegrained limestone; this boundary proved very satisfactory for regional mapping in most areas of the Lynn window, as well as in the Carlin mine. In areas where the boundary is transitional, the contact was chosen to be where coarse-grained limestone becomes more abundant than laminated rocks of the interbedded sequence; this mapping procedure corresponds to that followed by Evans (1974a), Mullens (1980), and the geologic staff of the Carlin Gold Mining Co.

The basal cherty carbonate beds of the Roberts Mountains Formation rest disconformably on the dolomitic sandstone unit at the top of the underlying Hanson Creek Formation. Nullens (1980) emphasized that these cherty carbonate beds are the only distinctive unit of regional extent in the Roberts Mountains Formation. The best exposures in the northern part of the Lynn window are about $11 / 2 \mathrm{~km}$ south and southeast of the Carlin mine; Berry and Roen (1963) described similar beds that crop out about $11 / 2 \mathrm{~km}$ southwest of the Carlin mine and $3 / 4 \mathrm{~km}$ southeast of the mouth of Sheep Creek Canyon.

The basal cherty zone is made up of 25- to 100 -mm-thick bands of brown and black chert alternating with zones 25 to $250 \mathrm{~mm}$ thick of dark-gray dolomite or dolomitic limestone. The irregular chert bands pinch and swell, and locally cut across the carbonate bands. Detailed descriptions of this basal zone in the Roberts Mountains Formation were included in the reports by Roen (1961) and Mullens (1980). Chemical and spectrographic analyses of a sample from across the basal cherty zone, as well as of samples of other rock types in the Roberts Mountains Formation, are listed in table 2 (sample 5).

Most of the Roberts Mountains Formation consists of a thick section of thin-bedded laminated medium- to darkgray silty dolomite and dolomitic limestone that lies conformably on the basal chert zone. Small amounts of black chert are locally present, but they account for less than 1 percent of the formation.

The laminated silty dolomite and dolomitic limestone have been described petrographically by Mullens (1980, p. 14). They consist

$* * *$ of varying amounts of angular quartz and feldspar silt and very fine sand, silt-sized irregular grains to euhedral rhombs of dolomite and calcite, and clay minerals all set in an extremely fine-grained calcite matrix. Fresh rock contains disseminated grains and tiny stringers of pyrite; specks, films, and coatings of carbonaceous material; and minute inclusions of carbonaceous material and pyrite in the calcite matrix. Weathered rock contains grains and stringers of iron oxide. In general, a slice the size of a thin section, cut across the laminations, is representative of the sample; but the sample is heterogeneous at a 1 - to 2 -mm scale ** *. Graded bedding [is] extremely scarce in rocks collected during this study $* * *$

In order to establish a useful mineralogic mode and average chemical composition for the fresh laminated carbonate rocks, and to establish a reference for comparison with mineralized rocks, two rotary-drill holes were systematically sampled over 30 - and $45-\mathrm{m}$ intervals. Chemical and spectrographic analyses of these composite samples, representing intervals within the middle and upper parts of the formation, are listed in table 2 (samples 6,7). Comparison of these two chemical analyses suggests that the upper part of the Roberts Mountains Formation is more dolomitic and less siliceous than the middle part.

The middle part contains larger amounts of such elements as boron, chromium, nickel, titanium, vanadium, and zirconium that reflect a higher content of clastic materials. The contents of heavy elements, including gold, arsenic, copper, mercury, and antimony, are also higher in fresh rocks from the middle of the section.

Rocks in the stratigraphic interval from about $240 \mathrm{~m}$ below the top of the formation down to the top of the basal cherty zone are siliceous argillaceous dolomitic limestone. Chemical analyses and X-ray diffraction studies show that the contents of the major constituents - calcite, dolomite, quartz, and clay-vary widely between individual samples. Ranges for calcite (20-40 percent), dolomite (1050 percent), quartz (5-30 percent), and clay (5-14 percent), as well as averages for calcite ( 35 percent), dolomite (25 percent), quartz (25 percent), and clay (15 percent), agree well with the values reported by Mullens (1980) for samples from numerous areas in Nevada, including the Lynn window. Illite is the most abundant clay mineral; chlorite and kaolinite are minor. A few near-surface samples contained small amounts of montmorillonite, probably formed during late weathering. Detrital potassium feldspar and plagioclase, in amounts ranging from less than 1 to 3 percent, were present in all the samples studied. Minor constituents, collectively totaling less than 3 percent, include zircon, hornblende, monazite, tourmaline, rutile, magnetite, hematite, pyrite, and carbonaceous materials. In addition to pyrite, other sulfides identified in several samples of fresh limestone include 
small diagenetic(?) grains of chalcopyrite, sphalerite, and galena.

The upper 230 to $245 \mathrm{~m}$ of the Roberts Mountains Formation is made up of two distinct facies (types I and II) of interbedded carbonate rocks; although these two facies differ in composition, texture, and fabric, physically they appear similar. Chemical and spectrographic analyses of rocks of both facies types are listed in table 2 (samples 8 , 9).

The dominant type I facies is strongly laminated argillaceous-arenaceous dolomite or lime mudstone (fig. 2) that was very favorable for gold mineralization. About 25 to 45 percent of the rock is composed of dolomite rhombs, from 25 to $50 \mu \mathrm{m}$ in diameter, of early diagenetic origin. Other major constituents include 20 to 30 percent angular 50 - to $100-\mu \mathrm{m}$ quartz grains, 15 to 20 percent argillaceous materials (mainly illite), and 5 to 15 percent fine-grained calcite. Authigenic(?) chert (1-3 percent), pyrite (less than 0.5-1 percent), and carbonaceous materials (about $0.4-0.8$ weight percent) were ubiquitous in the samples studied. Accessory minerals present in minor amounts include feldspar, hornblende, monazite, tourmaline, zircon, rutile, magnetite, hematite, galena, sphalerite, and chalcopyrite. The carbonaceous materials and the illite commonly are admixed and concentrated in 0.5- to 2-mm-thick current-induced laminations. Pelletoid calcium carbonate is absent, and although spicules are common, other fossil fragments are sparse.

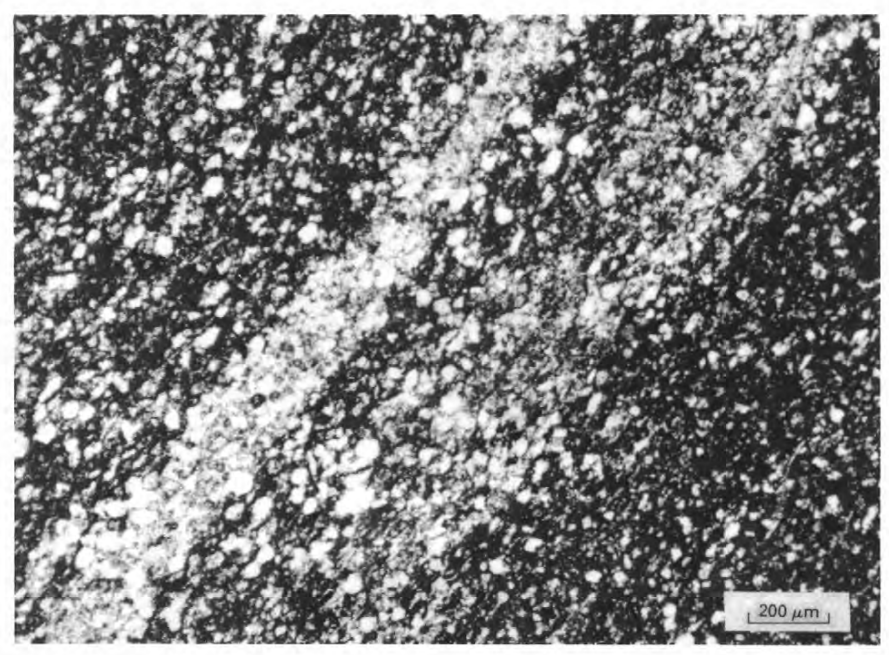

FIGURE 2.-Thin section of laminated argillaceous-arenaceous dolomite (lime mudstone) of the Roberts Mountains Formation. Rhombs of authigenic dolomite (white) formed by replacement of mud, and angular fine-sand-size quartz grains (white), are dispersed throughout current-induced(?) laminations rich in organic material and illite (dark areas) and are concentrated in laminations containing minor amounts of organic material and illite. Diagenetic pyrite is most abundant in the laminations rich in organic material.

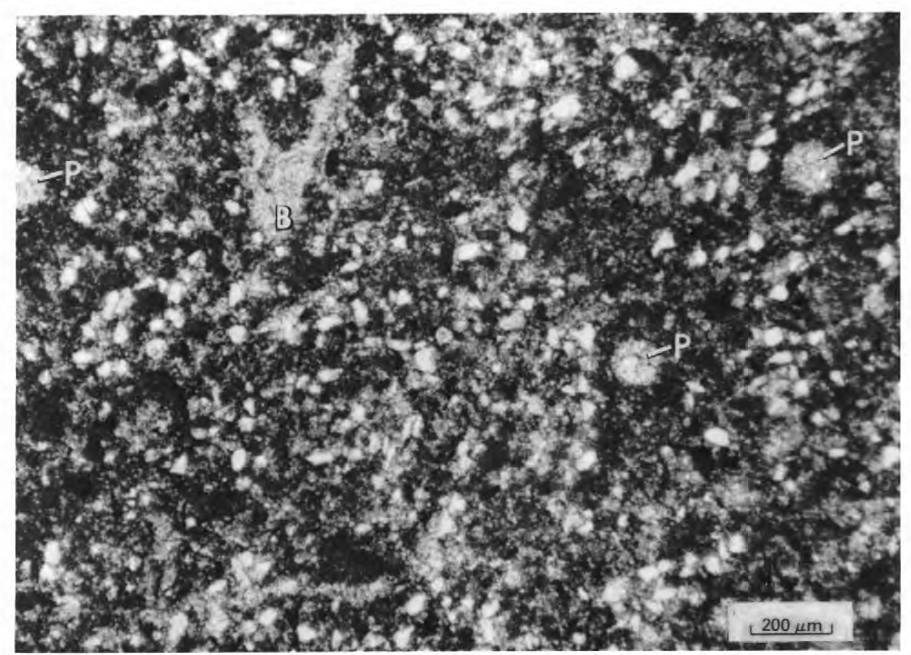

FIGURE 3.-Thin section of weakly laminated arenaceous peloidal wackestone of the Roberts Mountains Formation. Peloids (P), bioclasts (B), and angular fine-sand-size quarts grains (largest white grains) are dispersed throughout matrix of calcite rhombs, silt, organic material, and illite. Clumps of fine-grained diagenetic pyrite are randomly scattered throughout matrix.

The type II facies is thin-bedded weakly laminated arenaceous peloidal wackestone (fig. 3). About 40 to 65 percent of the rock is pelletoid, ranging from 50 to $300 \mu \mathrm{m}$ in pellet diameter. Angular silt-to sand-size quartz grains make up 10 to 20 percent of the rock, argillaceous materials (principally illite) account for 1 to 5 percent, and dolomite is scarce (less than $1-3$ percent). Bioclasts, including fragments of brachiopods, echinoderms, crinoids, and spicules, are abundant and made up as much as 20 to 25 percent of some samples. Although the content of carbonaceous materials $(0.3-0.6$ weight percent) is lower in this facies, the rocks generally contain the same minor accessory detrital and diagenetic minerals. Near-surface samples of both facies contained small amounts of montmorillonite formed during weathering. Comparison of these samples $(8,9$, table 2$)$ shows that the contents of minor elements-gold, arsenic, barium, chromium, copper, mercury, nickel, antimony, scandium, vanadium, zinc, and zirconium - are significantly higher in fresh type I facies rocks than in type II facies rocks.

Although the arenaceous peloidal wackestone contains large amounts of calcite, this facies was an unfavorable host rock for mineralization; even within gold ore bodies and zones of intense hydrothermal alteration, beds of type II facies rocks are commonly deficient in gold or are weakly mineralized, and show only slight hydrothermal alteration. The fact that the type II facies was not so favorable for mineralization probably reflects a lower porosity and permeability rather than a less favorable chemical composition. 
Surface exposures of the silty laminated beds tend to weather to light gray, tan, or light brown. The beds become platy and show a marked decrease in carbonates, sulfur, and organic carbon, and an increase in silica and alumina (sample 10, table 2). These effects could be due to the oxidation of pyrite by oxygen-bearing water; the hydrogen ions thus produced would react with and remove the carbonates, and ferric ions would oxidize the organic components (A. S. Radtke and C. L. Christ, unpub. data, 1970).

This surface and near-surface alteration is typical of these facies rocks in the Lynn window and commonly extends to depths of 5 to $6 \mathrm{~m}$, even deeper in highly fractured areas. Evans (1972a, 1974a) mapped some large areas of the Roberts Mountains Formation in the northern Lynn window as having undergone intensive hydrothermal alteration and other large areas as jasperoid, also intensely hydrothermally altered. Except for jasperoid formed locally along faults, however, most of this alteration probably represents normal weathering unrelated to regional hydrothermal activity.

Numerous paleontologic data are available on the Roberts Mountains Formation of the Tuscarora Mountains; however, a detailed discussion of the assemblages and zones reported by previous workers, including Roen (1961), Berry and Roen (1963), Roberts and others (1967), and Mullens (1980), is beyond the scope of this report. Emphasis is placed below on new, previously unpublished fossil data on the Roberts Mountains Formation from samples collected by J. G. Evans and T. E. Mullens during geologic study of the Carlin deposit and regional study of that part of the Lynn window included in the Rodeo Creek NE quadrangle.

Roen (1961) and Berry and Roen (1963) reported that rocks 3 to $5 \mathrm{~m}$ above the base of the Roberts Mountains Formation and 1 to $1.5 \mathrm{~m}$ above the top of the basal cherty zone from six localities near the center of and in the $\mathrm{E}^{1 / 2}$ SW $1 / 4$ sec. 27, T. 35 N., R. 50 E., contain a large, diverse graptolite assemblage. The species identified include:

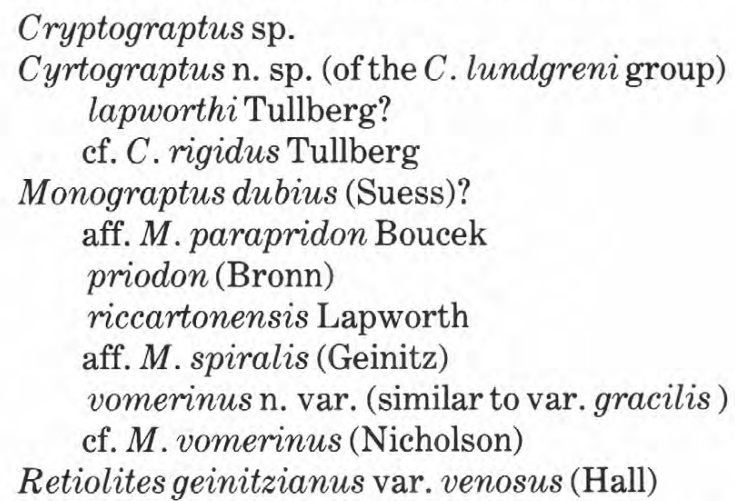

They concluded that the basal part of the formation in this area is early Wenlockian and is within the zone of Monograptus riccartonensis. The age of lower beds of the Roberts Mountains Formation was later extended to late Llandoverian (Early Silurian) on the basis of graptolite fauna in the Monograptus spiralis zone (W. B. N. Berry, written commun., 1969).

Table 3 lists graptolites identified in samples from the Roberts Mountains Formation collected by J. G. Evans and T. E. Mullens, and table 4 lists conodonts; ostracodes,

TABLE 3.-Graptolite species in the Roberts Mountains Formation in the northern part of the Lynn window, Eureka County, Nev. [Fossil identifications and ages by W. B. N. Berry]

\begin{tabular}{|c|c|c|c|c|c|c|c|c|}
\hline \multirow{2}{*}{ Species } & USGS fossil collection. & D253-SD & D275 & D253-SD & $\mathrm{D} 253-\mathrm{SD}$ & $\mathrm{D} 270-\mathrm{SD}$ & D254-SD & D255-SD \\
\hline & Field number. & $\mathrm{TM}-\mathrm{F}-52-69 \mathrm{~A}$ & M437 & TM-F-52-69B & TM-F-52-69C & M420 & TM-F-53-69 & TM-F-54-69 \\
\hline \multicolumn{2}{|c|}{ Cyrtograptus sp. } & -- & -- & $\mathrm{X}$ & $\mathrm{X}$ & $\mathrm{X}$ & -- & -- \\
\hline \multicolumn{2}{|c|}{ lapuorthi Tullbert } & $\mathrm{X}$ & -- & -- & -- & -- & - & -- \\
\hline \multirow{2}{*}{\multicolumn{2}{|c|}{ Dendrograptus sp. }} & - & -. & -- & -- & -- & -- & $\mathrm{X}$ \\
\hline & (1) & -- & -- & -- & -- & -- & $\mathrm{x}$ & -- \\
\hline \multicolumn{2}{|c|}{ Monograptus sp. of $M$. dubius group } & -- & -- & -. & $\mathrm{X}$ & -- & - & -- \\
\hline & - & $\mathrm{X}$ & - & -. & $\mathrm{X}$ ? & -- & -- \\
\hline \multicolumn{2}{|c|}{$\begin{array}{l}\text { geinitzianus var, angustidens (Ellis } \\
\text { and Wood) }\end{array}$} & $\mathrm{X}$ & -- & -- & -- & -- & - & - \\
\hline \multicolumn{2}{|c|}{ sp. of M. hercynicus group } & -. & - & -- & - & - & $\mathrm{x}$ & -- \\
\hline \multicolumn{2}{|c|}{ hercynicus Perner } & -- & -- & -- & - & -- & -- & $\mathrm{X}$ \\
\hline \multicolumn{2}{|c|}{ ef. M. praedubius (Boucek) } & -- & -. & $\mathrm{x}$ & -- & -. & -- & -- \\
\hline \multicolumn{2}{|c|}{ praehercynicus Jaeger ......... } & - & -- & -. & -- & -- & -- & $\mathrm{X}$ ? \\
\hline \multicolumn{2}{|c|}{ sp. (of $M$. priodon group) } & $\mathrm{X}$ & -- & -- & -- & -- & - & $\ldots$ \\
\hline \multicolumn{2}{|c|}{ priodon (Brown) ……............ } & -- & -- & -- & -- & $\mathrm{X}$ & -- & -- \\
\hline \multicolumn{2}{|c|}{ spiralis (Geinitz) } & $\mathrm{x}$ & - & -- & -- & - & -- & -- \\
\hline \multicolumn{2}{|c|}{ testis (Barrande) } & -- & - & -- & $\mathrm{X}$ & -- & -- & -- \\
\hline \multicolumn{2}{|c|}{ sp. (of $M$. romerinus group) } & -- & -- & .. & -- & $\mathrm{X}$ & - & -- \\
\hline \multicolumn{2}{|c|}{ romeriuus var. gracilis (Ellis and Wood) ...... } & -- & -- & $\mathrm{X}$ & -- & -- & -- & -- \\
\hline \multicolumn{2}{|c|}{ ef. M. romerimus (Nicholson) } & -- & $\mathrm{x}$ & -- & -- & -- & -- & -- \\
\hline \multicolumn{2}{|l|}{ Age } & $\begin{array}{l}\text { Late Llandoverian } \\
\text { M. spiralis zone }\end{array}$ & Wenlockian & Wenlockian & $\begin{array}{c}\text { Late Wenlockian } \\
\text { M. testis zone }\end{array}$ & $\begin{array}{l}\text { Wenlockian, } \\
\text { probably } \\
\text { middle late } \\
\text { Wenlockian }\end{array}$ & Early Devonian & $\begin{array}{c}\text { Early Devonian, } \\
\text { probably } \\
\text { Siegenian }\end{array}$ \\
\hline \multicolumn{2}{|c|}{ Approximate position in section ... } & $\begin{array}{l}\text { Near base of } \\
\text { section, } 0 \text { to } 15 \\
\mathrm{~m} \text { above base }\end{array}$ & $\begin{array}{l}\text { Near base of } \\
\text { section, } 0 \text { to } 30 \\
m \text { above base }\end{array}$ & $\begin{array}{l}15 \text { to } 30 \mathrm{~m} \text { above } \\
\text { base }\end{array}$ & $\begin{array}{l}30 \text { to } 90 \mathrm{~m} \text { above } \\
\text { base }\end{array}$ & $\begin{array}{l}\text { Uncertain, prob- } \\
\text { ably within } \\
\text { lowest } 90 \mathrm{~m}\end{array}$ & $\begin{array}{l}\text { Within upper } \\
180 \mathrm{~m} \text { of top }\end{array}$ & $\begin{array}{l}\text { Within upper } \\
60 \mathrm{~m} \text { of top }\end{array}$ \\
\hline
\end{tabular}


TABLE 4.-Conodont species in the Roberts Mountains Formation in the northern part of the Lynn window, Eureka County, Nev. [Fossil identifications and ages by J. W. Huddle]

\begin{tabular}{|c|c|c|c|c|c|c|}
\hline USGS fossil collection & $8440-\mathrm{SD}$ & $8471-\mathrm{SD}$ & $8860-\mathrm{SD}$ & $8426-\mathrm{SD}$ & $8472-\mathrm{SD}$ & $8468-\mathrm{SD}$ \\
\hline Field number... & TM-F-14-69A & M406 & M465 & M484A & M546 & M527 \\
\hline Acodina sp. & 2 & 3 & - & -- & -- & -- \\
\hline Acodus sp. $\quad-$ & - & 1 & -- & -- & - & -- \\
\hline Augulodus sp. & -- & -- & -- & 1 & -- & -- \\
\hline Belodella deronica (Stauffer) . & -- & 1 & -- & 3 & -- & -- \\
\hline triangularis (Stauffer) & -- & -- & - & 2 & -- & -- \\
\hline 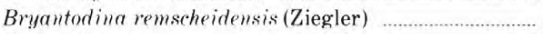 & 8 & -- & - & -- & -- & -- \\
\hline Distacodus sp. & -- & -- & -- & -- & 1 & -- \\
\hline Hindeodella sp. . & -- & -- & -- & 3 & -- & -- \\
\hline Icriodussp. & - & -- & -- & -- & 1 & -- \\
\hline pesatis (Bischoff and Sannemann) & -- & -- & 4 & - & -- & -- \\
\hline Ligonodina sp. . & -. & 1 & - & -- & -- & -- \\
\hline 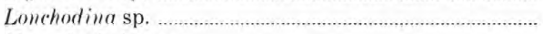 & -- & - & 1 & -- & -- & -- \\
\hline Neopriomiodussp. & -- & - & 3 & -- & -- & -- \\
\hline excacatus (Branson and Mehl) & -- & -. & -- & -- & -- & 2 \\
\hline "Oneotodus" beckmanni (Bischoff and Sannemann)........ & 10 & -- & -- & -- & -- & -- \\
\hline Ozarkodina sp. . & -- & 1 & 3 & - & -- & -- \\
\hline media Walliser & - & $\cdots$ & - & 9 & -- & -- \\
\hline cf. O. media Walliser & - & 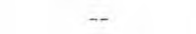 & - & -- & -- & 1 \\
\hline Panderodussp. . - - - - & - & $\ldots$ & 1 & 1 & 1 & 2 \\
\hline Plectospathodus ertensus Rhodes ... & - & -- & -- & 8 & -- & -- \\
\hline Prioniodina sp. . & - & -- & - & 1 & -- & -- \\
\hline Scolopodus sp. & -- & -- & 1 & -- & -- & -- \\
\hline Spathograthodus sp. & -. & - & - & 4 & -- & -- \\
\hline inclinatus (Rhodes) & -- & -- & 7 & 5 & -- & 5 \\
\hline johnson i Klapper & -- & -- & 3 & -- & -- & -- \\
\hline steinhornesis s. I. Ziegler & -- & 3 & -- & 3 & -- & -- \\
\hline transitans Bischoff and Sannemann & -- & -- & 1 & -- & -- & -- \\
\hline 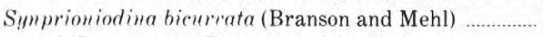 & -- & -- & - & 3 & -- & -- \\
\hline cf. S. excaratus (Branson and Mehl) & - & -. & - & 1 & -- & -- \\
\hline Trichonodella excarata (Branson and Mehl) & -- & -- & -- & 5 & -- & -- \\
\hline s!jmmetrica (Branson and Mehl) & -- & 2 & -- & -- & -- & 3 \\
\hline Age & $\begin{array}{l}\text { Probably Early } \\
\text { Devonian, indi- } \\
\text { cated by presence } \\
\text { of } B \text {. remscheiden- } \\
\text { sis and "O." } \\
\text { beckmanni }\end{array}$ & $\begin{array}{l}\text { Silurian or } \\
\text { Early Devonian }\end{array}$ & Early Devonian & $\begin{array}{l}\text { Late Silurian to } \\
\text { Early Devonian }\end{array}$ & Early Devonian & $\begin{array}{l}\text { Late Silurian or } \\
\text { Early Devonian }\end{array}$ \\
\hline Approximate position in section & $\begin{array}{l}\text { Within upper } 60 \mathrm{~m} \\
\text { of formation }\end{array}$ & $\begin{array}{l}\text { Within upper } 90 \\
\mathrm{~m} \text { of formation }\end{array}$ & $\begin{array}{l}\text { Within upper } 60 \\
\mathrm{~m} \text { of formation }\end{array}$ & $\begin{array}{l}120 \text { to } 210 \mathrm{~m} \\
\text { below top of } \\
\text { formation }\end{array}$ & $\begin{array}{l}\text { Within upper } 30 \\
m \text { of formation }\end{array}$ & $\begin{array}{l}\text { "Uncertain" map } \\
\text { position (Evans), } \\
\text { 1974) indicates } \\
\text { lower part; fossil } \\
\text { assemblage } \\
\text { characteristic of } \\
\text { upper part }\end{array}$ \\
\hline
\end{tabular}

brachiopods, and corals are summarized in table 5. Fossil localities are shown on the map by Evans (1974a).

In summary, graptolite faunal data indicate that the strata of the Roberts Mountains Formation in the northern part of the Lynn window range in age from Early Silurian to Early Devonian. Although fossil data on forms other than graptolites are not available for the lower and middle strata of the formation, data on ostracodes, conodonts, brachiopods, and corals from the upper strata confirm that these beds are Early Devonian.

Devonian System

Popovich Formation

The Popovich Formation, a limestone, overlies the Roberts Mountains Formation in the northern part of the Lynn window. The name "Popovich" was first applied to this formation by Hardie (1966), in recognition of an early prospector in the area. The Popovich Formation was formally named and described by Akright and others (1969) from exposures on Popovich Hill, about $460 \mathrm{~m}$ southeast of the plant millsite of the Carlin mine, as well as along the north face of the Main pit.

The Popovich is also exposed in a series of outcrops cut by north-south- trending high-angle faults about $1 \frac{1}{2}$ to $21 / 2 \mathrm{~km}$ southeast of the Carlin mine on the east side of the Leeville fault. From the Carlin mine, the Popovich Formation has been mapped northwestward from about $11 / 2 \mathrm{~km}$ in the downthrown block on the east side of the Sheep Creek Canyon fault (pl. 1). Other excellent exposures of the Popovich are along the east and west flanks of a prominent series of hills 3 to $5 \mathrm{~km}$ northwest of the Carlin mine (pl. 1). On the basis of its stratigraphic position, poorly exposed limestone in secs. 21 and 28 (pl. 1) along the west flank of the Tuscarora Mountains has also 
TABLE 5.-Ostracode, brachiopod, and coral species in the Roberts Mountains Formation

in the northern part of the Lynn window, Eureka County, Nev

[Fossil identifications and ages by J. M. Berdan, J. T. Dutro, Jr., and C. W. Merriam]

\begin{tabular}{|c|c|c|c|c|c|}
\hline USGS fossil collection.................. & $8468-\mathrm{SD}$ & $8472-\mathrm{SD}$ & --- & 8453-SD & --- \\
\hline Field number & M527 & M536 & $69-\mathrm{FP}-268 \mathrm{~F}$ & M424B & M476 \\
\hline \multicolumn{6}{|c|}{ Ostracodes } \\
\hline Aechmina sp. & - & $\times$ & -- & - & -- \\
\hline Beyrichia sp. …ㄴ... & $x$ & -- & -. & -- & - \\
\hline Garniella sp. & $\times$ & -- & -- & -- & -- \\
\hline Hanaitessp. . & -- & $x$ & -- & -- & -. \\
\hline Hesslandella? sp. cf. H.? tomtchumyschensis Polenova & -- & $\times$ & -- & -- & -- \\
\hline Jonesites? sp. cf. J.? circa (Coryell and Cuskley) .............. & -- & $\times$ & -- & -- & -- \\
\hline Libumella sp. . & $x$ & -- & - & -- & -- \\
\hline Marginia? sp. & $x$ & $\ldots$ & -- & -- & -- \\
\hline Miraculum?sp. . & $\times$ & -- & -- & -- & -- \\
\hline Scophina? sp. & $\times$ & - & -- & - & -- \\
\hline Strepula sp. . - & $\times$ & - & -- & -- & -- \\
\hline 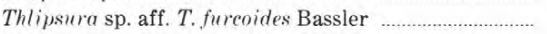 & -. & $x$ & -- & -- & -- \\
\hline Tricornina sp. & $\times$ & -- & - & - & -- \\
\hline Tubulibairdiasp. & $\times$ & -- & - & -- & -- \\
\hline Ulrichia sp. & -- & $\times$ & -- & -- & -- \\
\hline \multicolumn{6}{|c|}{ Brachiopods } \\
\hline Atrypa sp. & -- & -- & $x$ & -- & -- \\
\hline Atrypids, indet. & - & - & -- & $\times$ & -- \\
\hline Cortezorthis sp. & -- & -- & -. & $\times$ & -. \\
\hline Isorthis? sp. & -. & .- & $x$ & -. & -. \\
\hline Megakozloskiella sp. & -- & -- & $x$ & -- & -- \\
\hline Reticulariopsis? sp. & -- & -- & -. & $\times$ & -- \\
\hline Rostrospiroids, indet. & -- & -- & $\times$ & -- & -- \\
\hline \multicolumn{6}{|c|}{ Corals } \\
\hline Cyathophylloides n. sp. ef. C. burksae Flower & - & -- & -- & -- & $x$ \\
\hline Age & $\begin{array}{l}\text { Early Devonian, pos- } \\
\text { sibly Late Silurian }\end{array}$ & Early Devonian & Probably Gedinnian & $\begin{array}{l}\text { Probably Early } \\
\text { Devonian }\end{array}$ & Early Silurian(?) \\
\hline Approximate position in section . & $\begin{array}{l}\text { "Uncertain" map posi- } \\
\text { tion (Evans, 1974a) } \\
\text { indicates lower part; } \\
\text { fossil assemblage } \\
\text { characteristic of } \\
\text { upper part }\end{array}$ & $\begin{array}{l}\text { Within upper } 30 \mathrm{~m} \text { of } \\
\text { formation }\end{array}$ & $\begin{array}{l}\text { Probably within upper } \\
90 \text { to } 180 \mathrm{~m} \text { of } \\
\text { formation }\end{array}$ & $\begin{array}{l}\text { Within upper } 30 \mathrm{~m} \text { of } \\
\text { formation }\end{array}$ & $\begin{array}{l}\text { Within upper } 150 \text { to } 240 \\
\mathrm{~m} \text { formation }\end{array}$ \\
\hline
\end{tabular}

been mapped as the Popovich Formation(Evans, 1972a, 1974a; Radtke, 1974).

The Popovich Formation thins from northwest to southeast; $11 / 2 \mathrm{~km}$ south of the Blue Star gold deposit the formation is about 240 to $275 \mathrm{~m}$ thick, west of the Carlin mine it is about 180 to $215 \mathrm{~m}$ thick, and in the area of the mine it ranges from 60 to $125 \mathrm{~m}$ in thickness. Roen (1961) estimated the total thickness of Devonian rocks at $460 \mathrm{~m}$; he unquestionably included in this total thickness the upper part of the Roberts Mountains Formation, now recognized to include Devonian rocks. The Popovich is truncated by the Roberts Mountains thrust.

Basal strata of the Popovich Formation, 15 to $60 \mathrm{~m}$ thick, are composed of fine-grained limestone beds ranging from about 0.15 to $0.6 \mathrm{~m}$ in thickness, lesser amounts of laminated silty dolomitic limestone, and scattered thin bioclastic zones and seams of black chert. The mineralogy of the laminated dolomitic limestone closely resembles that of the bulk of the Roberts Mountains Formation but differs from that of the medium- to thick-bedded limestone. Approximate percentages of the principal minerals in this bedded limestone are: calcite, 60 to 80 percent; dolomite, 5 to 10 percent; quartz, 2 to 10 percent; and illite, less than 5 percent.

Above the lower unit is a sequence of thin-bedded finegrained medium- gray silty dolomitic limestone interbedded with lesser amounts of thick-bedded fine-grained dark-gray limestone. The sequence ranges from about 30 to $75 \mathrm{~m}$ in thickness near the Carlin mine; several kilometers to the northwest it can be as thick as $150 \mathrm{~m}$. Chemically and mineralogically these thin-bedded silty units also closely resemble the Roberts Mountains Formation. Radtke and Scheiner (1970b, p. 90) described these beds in the Popovich and the bulk of the Roberts Mountains Formation as "siliceous, argillaceous, dolomitic limestones"; they also reported, "**** the rocks are composed of 30 to 45 percent calcite, 15 to 30 percent dolomite, 10 to 20 percent clays (mainly illite with minor kaolin), 15 to 20 percent quartz, and minor amounts of pyrite, $\mathrm{K}$ feldspar, zircon, rutile, sphene(?), and carbonaceous material."

The upper part of the Popovich Formation is composed of thick-bedded dark-gray limestone, locally coarse grained and highly fossiliferous; beds of quartz-rich sandy 
limestone; and limestone breccia. This part of the Popovich ranges from about 10 to $30 \mathrm{~m}$ in thickness. In describing these beds, Roen (1961, p. 69-70) stated:

The ridge-forming, resistant, thick limestone beds are well bedded and range from about 1 foot to 8 feet in thickness. The fine-grained beds with smooth-weathered surfaces are usually about 1 foot to 3 feet thick, whereas the coarse-grained beds that have rough-weathered surfaces are as much as 7 or 8 feet thick. The coarse-grained rocks $* * *$ have a diversified, clastic lithology. The beds are composed of tabular, lighter weathering clasts set in a darker gray limestone matrix. The tabular clasts are shaly limestones that range from 0.25 inches to about 3 or 4 inches in length. The clasts are similar to the shaly interbedded limestones suggesting the unit is an intraformational conglomerate. Besides the numerous shaly clasts there are a few rounded and irregular clasts derived from bioclastic limestones. Irregular clastic chert nodules are occasionally present. A distinct lithologic feature are the "edgewise conglomerates."

Chemical data on the Popovich Formation are listed in table 2 (samples 11-14). Analyzed samples of thick-bedded fine-grained limestone from the base and thick-bedded bioclastic limestone from the upper part of the formation (samples 11 and 14, respectively) indicate that these rocks are low in $\mathrm{SiO}_{2}, \mathrm{Al}_{2} \mathrm{O}_{3}, \mathrm{~K}_{2} \mathrm{O}$; and $\mathrm{MgO}$; these contents reflect the small amounts of quartz, clay, and dolomite. By comparison, analyses of thin-bedded silty dolomitic limestone (sample 12) and of composite samples of this facies and of thin-bedded limestone from the middle of the formation (sample 13), indicate that these rocks contain much more $\mathrm{SiO}_{2}, \mathrm{Al}_{2} \mathrm{O}_{3}, \mathrm{~K}_{2} \mathrm{O}$, and $\mathrm{MgO}$, and less $\mathrm{CO}_{2}$ contents that reflect a greater abundance of quartz, illite, and dolomite, and less calcite.

The contents of minor elements in the cleaner thickbedded limestone in the lower and upper parts of the formation also differ significantly from those in the thin-bedded silty dolomitic rocks in the middle of the formation, which contain more clay and detrital minerals. The thinbedded silty dolomitic rocks contain much more boron, barium, cobalt, chromium, copper, gallium, lanthanum, nickel, scandium, titanium, vanadium, yttrium, ytterbium, zinc, and zirconium than does the cleaner limestone (samples 11-14, table 2; A. S. Radtke, unpub. data, 1969). Although the thin-bedded laminated silty dolomitic rocks in the Popovich Formation resemble those of the bulk of the Roberts Mountains Formation in physical appearance and major-element chemistry, differences exist in traceelement abundances. Analyses of typical samples (table 2). and of 30 other samples (A. S. Radtke, unpub. data, 1969) suggest that these beds in the Popovich Formation contain more boron, cobalt, chromium, gallium, lanthanum, manganese(?), scandium, titanium, yttrium, and zirconium, and less arsenic, antimony, thallium(?), vanadium, and zinc.

Collections of conodonts from six localities in the northern part of the Lynn window indicate that the Popovich Formation ranges in age from Early into Late Devonian (table 6). In the area to the southeast of the Carlin deposit, within the deposit, and continuing for about $1 \frac{1}{2} \mathrm{~km}$ to the northwest, where the total thickness of the formation increases from about 60 to $210 \mathrm{~m}$, the strata range in age from Early into Middle Devonian; however, farther to the northwest, in secs. $4,5,8$, and 9, T.35 N., R.50E. (pl. 1), its thickness increases to $275 \mathrm{~m}$ and includes Late Devonian beds.

Two collections of fossils from basal beds of the Popovich in a thin section $2 \frac{1}{2} 2 \mathrm{~km}$ southeast of the deposit (pl. 1) contained coral forms as well as conodonts (Evans, 1974a, locs. M422, M424A). The following remarks are from notes by C. W. Merriam (written commun., 1969) on the corals in the Popovich Formation of this area:

(field No. M422) at the base of section, Nevada coordinates E.304,360, N.2,241,100; Palisades No. 2 NE. quadrangle
Australophyllum n. sp.
?Chaetetes sp.
?Chonophyllum sp.
?Heliolites sp.

Concerning this assemblage, Merriam (written commun., 1969) wrote:

The well-preserved colonial rugose coral referred to Australophyllum n. sp. resembles, but is not conspecific with a new subgenus and species I have described from the Rabbit Hill Early Devonian (Helderbergian). Another subgenus of Australophyllum characterizes Silurian coral zone E. in the upper part of this system. Your form is structurally closer to the Rabbit Hill species, but the associated corals are perhaps a little more suggestive of Late Silurian.

(field No. M424A) lower part of section, Nevada coordinates E.302,400, N. 2,240,380; Palisades No. 2 NE. quadrangle

?Australophyllum sp.

?Entelophyllum sp.

?Palaeophyllum sp.

Ramose tabulate corals, possibly Coenites (abundant)

Merriam (written commun., 1969), wrote: "The ? Australophyllum sp. may be the same as that from locality M422, but is too fragmentary for thin sectioning. The fragmentary brachiopods are not identifiable, but may include Atrypa, ribbed and smooth pentameroids."

Specimens of limestone collected from the basal $50 \mathrm{~m}$ of the Popovich Formation about $1 / 2 \mathrm{~km}$ west of the West pit of the Carlin deposit (Evans, 1974a, loc. M412) contained corals and brachiopods in addition to conodonts (table 6). C. W. Merriam studied the corals, and J. T. Dutro, Jr., reported on the brachiopods.

USGS collection 8540-SD (field No. M412), Nevada coordinates E.292,200, N.2,240,000; Palisades No. 2 NE. quadrangle, near base of the Popovich Formation

C. W. Merriam (written commun., 1969) identified the following coral species.

Dalmanophyllum? sp.

digitate favositid (Cladopora? or Thamnopora)

fragmentary brachiopods, including the ventral 
TABLE 6.-Conodont species in the Popovich Formation in the northern part of the Lynn window, Eureka County, Nev.

\begin{tabular}{|c|c|c|c|c|c|c|}
\hline USGS fossil collection & $8862-\mathrm{SD}$ & $8450-\mathrm{SD}$ & $8461-\mathrm{SD}$ & $8469-\mathrm{SD}$ & $8425-\mathrm{SD}$ & $8863-\mathrm{SD}$ \\
\hline Field number. & M665 & M412 & M649 & M537 & M424 & M735 \\
\hline Acodus!sp. ................ & 1 & -- & -- & -- & -- & -- \\
\hline Apatognathus?sp. & -- & -- & -- & -- & -- & -- \\
\hline Belodella deronica (Stauffer) & -- & -- & - & 1 & 1 & -- \\
\hline triangularis (Stauffer) & -- & -- & -- & 1 & 2 & -- \\
\hline Bryantodinasp. & -- & 2 & -- & -- & -- & -- \\
\hline fundamentatus (Bischoff and Sannemann) & -- & 2 & -- & -- & -- & -- \\
\hline steinhormensis (Ziegler) & -- & 4 & -- & -- & -- & -- \\
\hline Hurmi (Bischoff and Sannemann) .. & -- & 3 & - & -- & -- & -- \\
\hline Bryantodus radiatus (Hindl) ..................... & - & -- & -- & 5 & -- & -- \\
\hline Hindeodella sp. $\quad \ldots$ & 3 & -- & 1 & 19 & -- & 1 \\
\hline Icriod us pesaris (Bischoff and Sannemann) ... & -- & 1 & -- & -- & -- & -- \\
\hline Ligomodina sp. . & -- & 1 & -- & -- & -- & 1 \\
\hline 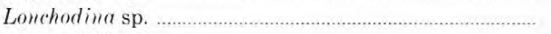 & -- & 1 & -- & -- & -- & -- \\
\hline torta Huddle & -- & -- & -- & -- & -- & 1 \\
\hline Neopriouiodus sp. & -- & -- & -- & 1 & -- & -- \\
\hline Ozarkodiuasp. . _ _ _ & -- & -- & -- & 1 & -- & 1 \\
\hline aff. O. media Walliser & - & 1 & -- & -- & -- & -- \\
\hline Panderodus sp. & 4 & -- & -- & - & -- & -- \\
\hline 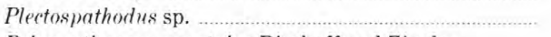 & -- & 1 & -- & -- & -- & -- \\
\hline Polygmathus asymmetrica Bischoff and Ziegler & -- & -- & -- & -- & -- & 1 \\
\hline dubius Hinde . & -- & -- & -- & -- & -- & 2 \\
\hline 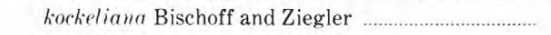 & -- & -- & -- & 2 & - & -- \\
\hline kockeliams & -- & -- & -- & -- & 7 & -- \\
\hline linguiformis Hinde & -- & -- & -. & 3 & 2 & -- \\
\hline aff. P. linguiform is & -- & -- & -- & 14 & -- & -- \\
\hline robusticostatus Bischoff and Ziegler & -- & -- & -- & -- & 2 & -- \\
\hline 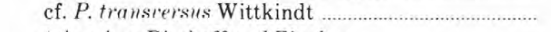 & -- & -- & -- & -- & 5 & -- \\
\hline 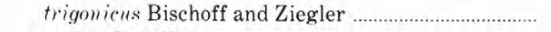 & -- & -- & -- & -- & 1 & -- \\
\hline rarcus Stauffer & -- & -- & -- & -- & 4 & -- \\
\hline Prioniodina sp. . & -- & -- & 1 & -- & -- & -- \\
\hline Spathognathoduss sp. & 4 & -- & -. & -- & -- & -- \\
\hline inclinatus Rhodes & 10 & -- & -- & -- & -- & -- \\
\hline remscheidensis Ziegler & -- & -- & 9 & -- & -- & -- \\
\hline Synprioniodina sp. & -- & -- & 1 & 1 & -- & -- \\
\hline Trichonodella sp. & 1 & -- & 1 & -- & -- & -- \\
\hline Age & $\begin{array}{l}\text { Middle Silurian to } \\
\text { Middle Devonian } \\
\text { (Early Devonian?) }\end{array}$ & $\begin{array}{l}\text { Early Devonian } \\
\text { (Early Siegenian) }\end{array}$ & $\begin{array}{l}\text { Probably Early } \\
\text { Devonian }\end{array}$ & $\begin{array}{l}\text { Middle Devonian } \\
\text { (Eifelian) }\end{array}$ & $\begin{array}{r}\text { Middle Devonian } \\
\text { (Late Eifelian) }\end{array}$ & $\begin{array}{l}\text { Late Devonian } \\
\text { P. asymmetricus } \\
\text { Zone }\end{array}$ \\
\hline Approximate position in section & Base of formation & $\begin{array}{l}\text { Within lower } 45 \mathrm{~m} \\
\text { of formation }\end{array}$ & $\begin{array}{l}\text { Within lower } 45 \text { to } \\
60 \mathrm{~m} \text { of forma- }\end{array}$ & $\begin{array}{l}\text { About } 80 \mathrm{~m} \text { above } \\
\text { base of formation }\end{array}$ & $\begin{array}{l}\text { About } 120 \mathrm{~m} \text { above } \\
\text { base of formation }\end{array}$ & $\begin{array}{l}\text { Top of formation, } \\
\text { about } 260 \text { to } 270 \\
\text { m above base of } \\
\text { thick section } \\
\text { south of Blue } \\
\text { Star deposit }\end{array}$ \\
\hline
\end{tabular}

valve of a possible Atrypina

C. W. Merriam (written commun., 1969) commented: "The silicified Dalmanophyllum? shows fairly well preserved internal structure in thin section, having an incipient axial structure. Streptelasmatidae of this kind range from Late Ordovician to Silurian. This coral also suggests the Devonian genus Scenophyllum to a somewhat lesser degree."

J. T. Dutro, Jr. (written commun., 1969) reported the following brachiopod species.
Clorinda? sp.
Cyrtina sp.
Protocortezorthis sp.
Spirigerina sp.

I. T. Dutro, Jr. (written commun., 1969) concluded, "These almost eertainly are from the Quadrithyris Zone of the Lower Devonian."
Limestone beds about 90 to $140 \mathrm{~m}$ above the base of the Popovich along the boundary between secs. 8 and 9, T. 35 N., R. 50 E. contain abundant fossils, including well-preserved ostracode, trilobite, and brachiopod forms (Evans, 1974a, loc. M470). Ostracodes in these samples were studied by J. M. Berdan (written commun., 1970), who identified the following forms:

USGS collection D273-SD (field No. M470), Nevada coordinates E.282,500, N.2,249,400; Palisades No. 2 NE. quadrangle

Abditoloculina? sp.

Acanthoscapha sp. cf. A. navicula ((Ulrich)

Aechmina sp.

Berounella sp.

Birdsallella sp.

Falsipollex sp.

Jonesites ? sp. aff. J .? circa (Coryell and Cuskley)

Smooth ostracods, indet. 
Thlipsura sp. aff. T. furcoides Bassler

Ulrichiasp.

\section{M. Berdan reported:}

The new species here listed as Thlipsura sp. aff. T. furcoides has been found in several collections from the Cortez and Horse Creek quadrangles associated with leptocoeliid brachiopods. Unfortunately, leptocoeliid brachiopods occur both in the Spinoplasia Zone and also in the lower part of the Eurekaspirifer pinyonensis Zone, and to date is is not clear whether Thlipsura sp. aff. T. furcoides is restricted to one zone or the other, or ranges through both zones. However, these collections are not older than the Spinoplasia Zone and not younger than the Eurekaspirifer pinyonensis Zone on the basis of the ostracodes.

R. J. Ross (written commun., 1969) reported the following trilobite forms:

\section{Phacops ( Phacops ) claviger Haas \\ Phacops (Reedops) sp.}

On this basis, this collection seems to be equivalent to the Spinoplasia zone of Johnson (1965) from the Wenban Limestone - that is, upper Helderbergian (Haas, 1969).

Braciopods in the sample from locality M470 (Evans, 1974a) were studied by J.T.Dutro, Jr., (written commun., 1970), who reported: "The brachiopods from this collection include a large number of chonetids, Strophochonetes filistriata (Walcott), and a few specimens of Leptocoelia infrequens (Walcott), and Anoplia? sp. The first two species are abundant in the Eurekaspirifer pinyonensis Zone and suggest that the collection represents this high Emsian equivalent."

In summary, the fossil data indicate that the Popovich Formation ranges in age from Early into Late Devonian. The rock types of the basal and middle parts of the Popovich in many aspects resemble those of the Early Devonian Windmill Limestone of Early Devonian age and the overlying Rabbit Hill Limestone in Copenhagen Canyon, Nev. (Matti and others, 1975, p.15-16). Merriam (1973, p. 9-10) reported that a Rabbit Hill fauna occurs in thick-bedded limestone overlying strata of the Roberts Mountains Formation in the Carlin window at Maggie Creek, about $13 \mathrm{~km}$ southeast of the Carlin mine. The Popovich is also equivalent in age to the Early and Middle Devonian Nevada Formation, the Late Devonian Devils Gate Limestone, and the Early to Late Devonian Wenban Limestone of the Cortez Mountains (Gilluly and Masursky, 1965).

\section{UPPER PLATE}

\section{Ordovician And Silurian Systems}

The north margin of the Lynn window is bordered by a thick sequence of dominantly siliceous and clastic rocks, designated the "siliceous assemblage" by Roberts and others (1967) and here called the upper plate of the Roberts Mountains thrust. Because these upper-plate rocks lithologically resemble those in the type section of the Vinini Formation, these rocks were assigned to the
Vinini Formation by Hardie (1966), Roberts and others (1967), Radtke and Scheiner (1970b), and Radtke (1973, 1974). Although the age of the Vinini has been extended from Early Ordovician in the original description (Merriam and Anderson, 1942) to Early, Middle, and Late Ordovician (Smith and Ketner, 1975), no known Silurian fossils have yet been identified in rocks clearly assigned to the Vinini (R. W. Kopf, oral commun., 1980). Because graptolites of both Ordovician and Silurian age have been identified in samples of rocks collected at several localities near the Carlin deposit (Evans, 1974a), these upper-plate rocks are here referred to as undifferentiated Ordovician and Silurian rocks.

Merriam and Anderson (1942) named and described the Vinini Formation from exposures along Vinini Creek on the east side of Roberts Creek Mountain, about $40 \mathrm{~km}$ northwest of Eureka, Nev. They divided the Vinini into two parts and stated (1942, p. 1694-1695):

"LowerVinini .* * * Lower strata of the Vinini formation * * * consist of dark-gray, brownish-weathering bedded quartzites, gray arenaceous limestone or calcareous sandstones commonly showing cross-lamination, and fine laminated sandy and brownish-gray and greenish-brown silty sediments. Locally the silty beds have a shaly parting, and in some localities true black shales are present in the lower Vinini. * * *

Near the top of the lower Vinini, lava flows and tuffs occur $* * *$ tuffbreccia grades upward into several feet of greenish volcanic sand overlain by cherty shale, typical of the upper Vinini. ***an amygdaloidal lava $* * *$ is $* * *$ overlain by cherty shale of the upper Vinini* $* *$. The tuffs and lavas presumably were hornblende andesites that have been chloritized, and $* * *$ extensive albitization has taken place. $* * *$ Upper Vinini.*** A succession of bedded cherts and black organic shales constitutes the upper Vinini which follows the lavas and tuffs of the lower division. In most sections studied the chert beds and lenses make up more of the thickness than the shale interbeds, though at certain exposures only the shale was recognized. Except where the resistant cherts are exposed, outcrops of this unit are often poor.

With the exception of the lava flows and tuff, all the rocktypes in the Vinini described by Merriam and Anderson have been recognized in the upper plate in the area surrounding the Lynn window.

Rocks of the upper plate are very poorly exposed in the Rodeo Creek NE. quadrangle, owing to extensive soil and talus cover. Exposures good enough to permit description of the strata occur along stream channels, bulldozer cuts, and roadcuts, and in faces within the Carlin mine. On the basis of recent mapping, the upper plate may be divided into three zones: (1) a lower zone containing interbedded chert and shale, and lesser quartzite, sandstone, and limestone; (2) a middle zone composed mainly of shale and lesser chert; and (3) an upper zone containing mainly chert and shale in a lower shale/chert ratio. The division between the middle and upper zones is indefinite and is based on the apparent ratio of shale to chert beds. General descriptions of the Vinini in the Tuscarora Mountains were included in the report by Roberts and others (1967, p. 30-32), and a preliminary description of the rocks near the Carlin mine was given by Radtke and Scheiner (1970b) and Evans (1974a). 
The regional strike of most strata of the upper plate is northeastward, in contrast to the east-westward strike of the Roberts Mountains thrust (pl. 1; Evans, 1974a). However, the general similarity of the attitudes of upper-plate rocks in the lower zone immediately above the thrust to the attitude of the thrust (pls.1-4) implies that a major structural feature exists within the lower zone that could consist either of concealed high-angle faults or of a subsidiary thrust above the main exposed thrust.

\section{Lower Zone}

The lower zone of the upper plate, which ranges in thickness from about 60 to $180 \mathrm{~m}$, is composed chiefly of interbedded chert and shale, and minor amounts of sandstone and quartzite. The chert/shale ratio ranges from about 1:2 to 2:1. Thin-bedded black chert seams, as thick as several centimeters, are interbedded with hard dense dark-gray to black siliceous shale and smaller amounts of brown, tan, and green dolomitic shale. The shale is composed chiefly of illite, quartz, and minor amounts of montmorillonite, kaolinite(?), calcite, and dolomite. The siliceous shale is made up of about equal proportions of illite and quartz, and only small amounts (less than 5 percent) of kaolin and montmorillonite; organic carbon content ranges from about 0.05 to 0.3 weight percent (Radtke and Scheiner, 1970b). The dolomitic shale contains 40 to 60 percent clay (predominantly illite and minor kaolin and montmorillonite(?)), 15 to 35 percent quartz, 10 to 20 percent dolomite, 1 to 10 percent calcite, and 0.3 to more than 3.0 weight percent organic carbon (Radtke and Scheiner, 1970b). Table 7 lists chemical and spectrographic analyses of a 30-m composite sample, consisting of about 70 percent siliceous shale and 30 percent chert, and of samples of the dolomitic shale (samples 1 and 2 , respectively.)

Several zones of dark-brown bedded quartzite, ranging from 1.5 to $6 \mathrm{~m}$ in thickness, that are exposed in the West pit of the Carlin mine appear as distinct, mappable units within the lower $60 \mathrm{~m}$ of the strata above the Roberts Mountains thrust. Other, similar quartzite beds have been recognized within a zone about 60 to $90 \mathrm{~m}$ above the thrust along the west and east slopes of Popovich Hill. About $1 \frac{1}{1} 2 \mathrm{~km}$ southeast of the Carlin mine, thin,poorly exposed quartzite beds have been mapped at an apparently similar stratigraphic position above the Roberts Mountains thrust (pl, 1).

Limestone beds, as thick as $9 \mathrm{~m}$, interbedded with shale and chert occur within the lower zone of the upper plate near the Carlin mine. Chemical and spectrographic analyses of this limestone are listed in table 7 (sample 3).

Upper-plate limestone in the lower zone, as well as thicker limestone in the middle zone (described below), commonly contains less clay and dolomite and considerably less detrital quartz than do most fresh carbonate rocks of both the Roberts Mountains Formation and the Popovich Formation, as reflected in the smaller amounts of $\mathrm{SiO}_{2}, \mathrm{Al}_{2} \mathrm{O}_{3}, \mathrm{~K}_{2} \mathrm{O}$, and $\mathrm{MgO}$ in analyzed samples of upper-plate limestone (samples 3,4 , table 7) relative to most analyzed samples of the Roberts Mountains Formation and the Popovich Formation (samples 6-10, 12, 13, table 2). However, the mineralogic and chemical compositions of the upper-plate limestone correspond closely to those of thick-bedded units of the Popovich (samples 11, 14 , table 2). The contents of minor elements in upperplate limestone do not differ significantly from those in either of the lower-plate formations.

Radtke and Scheiner (1970b, table 2) reported a chemical analysis of a sample of rocks designated "siliceous Vinini limestone" collected in the Carlin mine; the sample contained about 8 percent clay and 40 percent quartz. Later petrographic study showed that these rocks were altered and that the silica and clay were introduced during hydrothermal mineralization.

\section{Middle Zone}

The middle zone of the upper plate is made up of interbedded tan to brown shale, thin-bedded sandy limestone, gray to black chert, light-brown calcareous sandstone, and small amounts of black carbonaceous shale. This part of the upper plate is more than $750 \mathrm{~m}$ thick; however, owing to poor exposures and extensive faulting, more accurate measurement of its thickness is not possible. Although surface exposures are limited and the lithology varies over short distances, in most places the ratio of shale to chert is greater than 2:1. Rocks of the lower zone were not distinguished from those of the middle zone by Evans (1974a).

Chemical and spectrographic analyses of a 50-m composite sample from the middle zone are listed in table 7 (sample 5); the sample contained about 70 percent siliceous shale, 25 percent chert, and 5 percent black carbonaceous shale. The mineralogy of this sample resembles that of the composite sample from the lower zone, as reflected in the chemical analyses (samples 5 and 1, respectively, table 7). Comparison of these analyses suggests that the interbedded shale and chert in the middle zone contain less aluminum, calcium, potassium, and titanium, and more barium, iron, magnesium, phosphorus, and organic carbon, relative to similar rocks in the lower zone.

Differences in minor-element compositions may be more diagnostic. Data from spectrograhic analyses (table 7 ; A. S. Radtke, unpub. data, 1970) show that the middlezone rocks contain significantly less boron, cobalt, chromium, lanthanum, manganese, niobium, lead, and strontium, and more barium, molybdenum, nickel, vanadium, yttrium, and zinc.

Limestone units that may be as thick as $100 \mathrm{~m}$ occur within the lower $450 \mathrm{~m}$ of the middle zone. These units 
TABLE 7.-Chemical and spectrographic analyses of Paleozoic sedimentary rocks of the upper plate in the Lynn mining district, Eureka County, Nev:

[Rapid rock analyses (Shapiro and Brannock, 1962) in weight percent. Analysts: L. Artis, P. Elmore. L. Espos, B. P. Fabbi, J. Kelsey, and H. Smith. Spectrographic analyses in parts per million: N.A.. not analyzed. Results are identified by geometric brackets whose boundaries are $1.2,0.83,0.56,0.38,0.26,0.18,0.12$, and so on, but are reported arbitrarily as the midpoints of these brackets: $1.0,0.7,0.5,0.3,0.2,0.15,0.1$, and so on. The precision of a given value is approximately plus or minus one bracket at the 78 -percent, or two brackets at the 95-percent, confidence level. The following elements were below limits of detection in all samples (in ppm as ind icated): $\mathrm{Ag}(0.7) . \mathrm{Bi}(7) . \mathrm{Cd}(7) . \mathrm{Ce}(70) . \mathrm{Ge}(7)$. $\mathrm{Hf}(50)$. In (2). $\mathrm{Li}(100)$. Pd (1), Pt (10). Re (15), Sb (20), Sn (7), Ta (50), Te (300), Th (150), Tl (3), U (150), W (10). Analyst: Chris Heropoulos]

\begin{tabular}{|c|c|c|c|c|c|c|}
\hline Sample & 1 & 2 & 3 & 4 & 5 & 6 \\
\hline \multicolumn{7}{|c|}{ Rapid rock analyses } \\
\hline $\mathrm{SiO}_{2}$ & 71.7 & 51.3 & 9.4 & 10.4 & 72.3 & 77.6 \\
\hline $\mathrm{Al}_{2} \mathrm{O}_{3}$ & 14.7 & 13.0 & 1.6 & .19 & 10.2 & 8.2 \\
\hline $\mathrm{Fe}_{2} \mathrm{O}_{3}$ & 2.3 & 1.7 & .64 & .29 & 6.2 & 3.6 \\
\hline $\mathrm{FeO}$ & .16 & 3.3 & .24 & .10 & .48 & .28 \\
\hline $\mathrm{MgO}$ & .82 & 4.3 & 2.5 & .53 & 1.1 & .93 \\
\hline $\mathrm{CaO}$ & 1.2 & 7.5 & 45.1 & 47.9 & .30 & .77 \\
\hline $\mathrm{BaO}^{1}$ & .09 & .17 & .08 & .01 & .20 & .13 \\
\hline 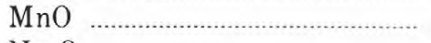 & .00 & .07 & .00 & .02 & .01 & .01 \\
\hline $\mathrm{Na}_{2} \mathrm{O}$ & 65 & .24 & .01 & .04 & .39 & .38 \\
\hline $\mathrm{K}_{2} \mathrm{O}$ & 3.5 & 3.0 & .43 & .15 & 2.6 & 2.9 \\
\hline $\mathrm{TiO}_{2}$ & .66 & .56 & .00 & .04 & .25 & .27 \\
\hline $\mathrm{P}_{2} \mathrm{O}_{5}$ & .13 & .04 & .02 & .02 & .37 & .42 \\
\hline $\mathrm{H}_{2} \mathrm{O}(+)$ & 1.1 & .96 & .14 & .06 & 1.7 & 1.2 \\
\hline $\mathrm{H}_{2} \mathrm{O}(-)$ & 2.9 & 2.6 & .85 & .73 & 3.1 & 2.7 \\
\hline $\mathrm{CO}_{2}$ & .09 & 11.0 & 38.7 & 38.6 & .07 & .08 \\
\hline $\mathrm{S}(\text { total })^{1}$ & .05 & .09 & .37 & .00 & .02 & .01 \\
\hline C (organic) & .22 & .30 & .55 & .60 & .64 & .32 \\
\hline Total & 100.3 & 100.1 & 100.6 & 99.7 & 99.9 & 99.8 \\
\hline \multicolumn{7}{|c|}{ Spectrographic analyses } \\
\hline $\mathrm{As}^{1} \ldots \ldots \ldots$ & $<15$ & $<15$ & 8 & $<15$ & $<8$ & $<8$ \\
\hline $\mathrm{Au}^{2}$ & $<.02$ & $<.02$ & $<.02$ & $<.02$ & N.A. & N.A. \\
\hline В & 500 & 150 & 10 & $<7$ & 100 & 200 \\
\hline $\mathrm{Ba}$ & 1,000 & 2,000 & 1,000 & 100 & 2,000 & 1,000 \\
\hline $\mathrm{Be}$ & 3 & 2 & $<1$ & $<1$ & 2 & 2 \\
\hline $\mathrm{Co}$ & 10 & 10 & $<2$ & $<2$ & 5 & 5 \\
\hline $\mathrm{Cr}$ & 100 & 70 & 50 & 7 & 70 & 70 \\
\hline $\mathrm{Cu}$ & 100 & 30 & 1.5 & 5 & 100 & 100 \\
\hline $\mathrm{Ga}$ & 20 & 15 & 3 & $<2$ & 20 & 15 \\
\hline $\mathrm{Hg}^{3}$ & $<.01$ & .03 & $<.01$ & $<.01$ & .02 & $<.01$ \\
\hline $\mathrm{La}$ & 50 & 50 & $<30$ & $<30$ & $<30$ & $<30$ \\
\hline $\mathrm{Mn}$ & 70 & 700 & 100 & 300 & 30 & 50 \\
\hline Mo & $<2$ & $<2$ & $<2$ & $<2$ & 5 & $<2$ \\
\hline $\mathrm{Nb}$ & 30 & 15 & $<7$ & $<7$ & $<7$ & 10 \\
\hline $\mathrm{Ni}$ & 30 & 50 & 7 & 1.5 & 70 & 30 \\
\hline $\mathrm{Pb}$ & 10 & $<7$ & $<7$ & $<7$ & $<7$ & $<7$ \\
\hline $\mathrm{Sc}$ & 15 & 20 & 5 & $<2$ & 15 & 7 \\
\hline $\mathrm{Sr}$ & 200 & 200 & 1,500 & 2,000 & 70 & 100 \\
\hline $\mathrm{Ti}$ & 7.000 & 5.000 & 1,000 & 300 & 3,000 & 5,000 \\
\hline $\mathrm{V}$ & 70 & 100 & 20 & $<3$ & 150 & 150 \\
\hline $\mathrm{Y} \quad \ldots$ & 20 & 30 & 15 & 10 & 50 & 20 \\
\hline $\mathrm{Yb}$ & 3 & 2 & $<1$ & $<1$ & 3 & 2 \\
\hline $\mathrm{Zn}^{1}$ & $<10$ & 30 & $<6$ & $<10$ & 330 & 90 \\
\hline $\mathrm{Zr}$ & 200 & 100 & 50 & 20 & 150 & 200 \\
\hline
\end{tabular}

Sample 1. Composite sample of $30 \mathrm{~m}$ of dark-gray siliceous shale and lesser amounts of interbedded black chert from the lower zone in the upper plate. Location $\mathrm{NW}^{1 / 4}$ sec. 19 , T. 35 N.. R. $50 \mathrm{~F}$

2. Composite of five samples of thin-bedded dark-gray dolomitic shale from the lower zone in the upper plate. Location: NE $1 / 4$ sec. 14. T. 35 N.. R. $50 \mathrm{~F}$.

3. Composite of five samples of fine-grained medium-bedded dark-gray limeston from the lower zone in the upper plate. Location: $\mathrm{SE}^{1}{ }_{4} \mathrm{NW}^{1} / 4$ sec. $14 . \mathrm{T} .35 \mathrm{~N}$ R. $50 \mathrm{E}$.

4. Composite sample of $3 \mathrm{~m}$ of fine-grained thin-to medium-bedded medium-gray limestone from the middle zone in the upper plate. Location: $\mathrm{NW}^{1 / 4} \mathrm{NE}^{1 / 4} \mathrm{sec}$ 19. T. $35 \mathrm{~N}, \mathrm{R}, 50 \mathrm{E}$.
5. Composite sample of $45 \mathrm{~m}$ of interbedded tan to brown shale. lesser amounts of gray chert, and minor amounts of dark-gray to black carbonaceous shale from the middle zone in the upper plate. Location: $\mathrm{SE}^{1 / 4}$ sec. 11 , T. 35 N.. R. 50 E.

6. Composite sample of $30 \mathrm{~m}$ of interbedded medium-gray and brown chert, lesser amounts of tan to brown shale, and minor amounts of dark-gray to black carbonaceous shale from the upper zone in the upper plate. Location: NE/1/4 sec. 11, T. $35 \mathrm{~N}$. R. $50 \mathrm{E}$.

' X-rav fluorescence analysis.

2 Fire-assay and atomic-absorption analyses.

3 Leico mercury-vapor analysis. 
have been recognized and mapped east and southeast of the mine (pl. 1; Evans, 1974a; Radtke, 1974). Lithologically, these upper-plate units closely resemble the Popovich Formation of the lower plate, and Hardie (1966, p. 77-78) stated: "The upper-plate Vinini formation *** contains limy horizons that are apparently discontinuous within the more abundant siliceous shale and quartzite. These limy horizons are indistinguishable from the Devonian 'Popovich' unit of the lower-plate ***.***These limy lenses in places resemble the lower plate rocks and have been erroneously mistaken for them." These limestone units commonly contain only small amounts of detrital quartz, clay, and dolomite; the content of $\mathrm{SiO}_{2}, \mathrm{Al}_{2} \mathrm{O}_{3}$, $\mathrm{MgO}, \mathrm{TiO}_{2}, \mathrm{P}_{2} \mathrm{O}_{5}$, and total $\mathrm{Fe}$ also are low (sample 5, table 7.)

$$
\text { Upper Zone }
$$

The content of chert in the upper zone of the upper plate increases northward and northeastward of the Carlin mine. The ratio of chert to shale ranges from about 1:1 and $2: 1$, and the shale beds commonly are highly siliceous; however, changes in the ratio of chert to shale are gradational, and no sharp boundary has been recognized. Chemical and spectrographic analyses of a 30-m composite sample from the upper zone are listed in table 7 (sample 6).

Thin beds of black carbonaceous shale occur throughout the upper part of the section. Evans (1972a, 1974a) indicated that the upper plate about $2 \frac{1}{2} \mathrm{~km}$ north of the Carlin deposit contains a quartzite unit as thick as $600 \mathrm{~m}$ and reported (Evans, 1974a), "*** some of the quartzite is interpreted to be recrystallized chert." Although these strata are shown as quartzite on the geologic map (pl. 1), I agree with Evans that some, and possibly all, of these rocks are bleached recrystallized chert and silicified shale; the mineralogic changes probably are due to metamorphic and metasomatic processes associated with the intrusive igneous body (pl. 1). The total thickness of the upper zone can be estimated only to be greater than $900 \mathrm{~m}$.

The upper plate in that part of the Tuscarora Mountains discussed here is estimated to be thicker than $2,400 \mathrm{~m}$, a value comparing well with the estimate of over $2,100 \mathrm{~m}$ by Roberts and others (1958) for an area in the southern part of the Tuscarora Mountains.

Conodonts collected from limestone of the upper plate in the SE $1 / 4 \mathrm{SW}^{1} \frac{1}{4}$ sec. 19 , T. 35 N., R. 51 E. (Evans, $1974 a$, loc. M426), and in the center of the W1/2 NE1/4 sec. 19, T. 35 N., R. 51 E. (Evans, 1974a, loc. M428), indicate that the age of these rocks is probably Middle to Late Ordovician (J. W. Huddle, written commun., 1969):

\footnotetext{
Acontiodus sp.

Cordylodus sp.

Cyrtoniodus flexuosus (Branson and Mehl)

Platodus spp.

Plectodina? sp.
}

USGS collection 6754-CO (field No. M428), East Nevada coordinates E.306,780, N.2,244,240; Palisades No. 2 NE. quadrangle

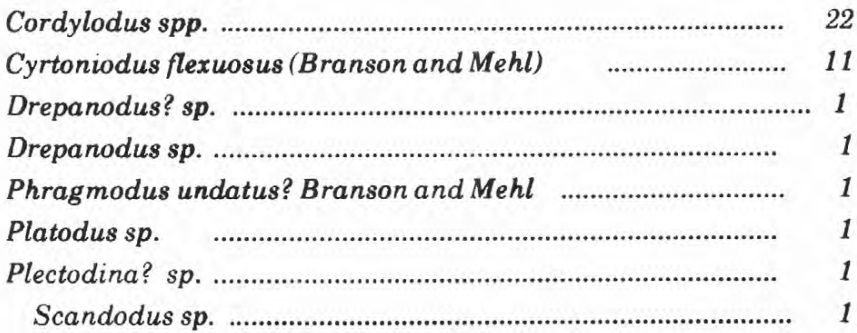

In reference to these samples, J. W. Huddle (written commun., 1969) wrote: "These two collections seem to represent the same fauna. The age is probably Middle or Upper Ordovician. Phragmodus has been found in the uppermost Antelope Valley Limestone and Copenhagen Limestone in Nevada."

Collections of graptolites from chert and shale beds within the upper plate range in age from Early Ordovician to Early Silurian. Table 8 summarizes data on graptolite assemblages reported by Roberts and others (1967) and from the fossil localities in the report by Evans (1974a). The Silurian graptolite Monograptus spiralis of late Llandoverian (Silurian) age has been identified in shale units in the NE $1 / 4 \mathrm{NE}^{1 / 4}$ sec. 15 , T. 35 N., R. 50 E., about $300 \mathrm{~m}$ northwest of the tailings pond dam of the Carlin deposit (Homestake Mining Co., oral commun., 1975). The location of this sample (HM), only 180 m north of locality M548 (Evans, 1974a) of late Early or early Middle Ordovician age (table 8), suggests the existence of a fault between these two localities, concealed beneath alluvium in the canyon below the tailings pond and trending southeast beneath the tailings pond (see pl. 1). However, the presence of Silurian rocks at such an apparently low stratigraphic position in the upper plate is an unresolved problem and suggests that these areas are much more complex structurally than has been indicated on previous maps (pl. 1; Evans, 1974a; Radtke, 1974).

In summary, the fossil data indicate that rocks of the upper plate near the Carlin mine range in age from Early Ordovician to Early Silurian. If regional studies should show that these rocks are equivalent to the Vinini Formation, then the age of the Vinini should be extended through the Early Silurian.

\section{CENOZOIC ROCKS}

\section{LAKEBEDS}

Thin remnants of crystalline tuff interbedded with lesser amounts of tuffaceous siltstone and sandstone crop out along the west flank of the Tuscarora Range. These rocks were previously mapped and described as tuffaceous siltstone and conglomerate of Tertiary and (or) Quaternary age (Evans, 1972a, 1974a), and as tuffaceous 
TABLE 8.-Graptolite species in strata of the upper plate in the northern part of the Lynn mining district, Eureka County, Nev. [Fossil identifications and ages by R. J. Ross. Jr., and W. B. N. Berry]

\begin{tabular}{|c|c|c|c|c|c|c|c|c|c|}
\hline USGS fossil collection ................... & D2005-CO & $\mathrm{D} 2133-\mathrm{CO}$ & D166-CO & D2002-CO & D2001-CO & D165-CO & D2004-CO & D2003-CO & D240-SD \\
\hline Field number. & M278 & M548 & $54-\mathrm{F}-71$ & M222 & M180 & $54-F-70$ & M158 & M159 & M193 \\
\hline 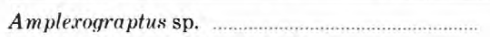 & $x$ & -- & - & -. & -- & -- & -- & -- & -- \\
\hline cf. A. confertus (Lapworth) & $x$ & -- & -- & -. & -- & -- & -- & -- & -- \\
\hline Caryocaris sp. & $x$ & -- & -- & -- & -- & - & - & -- & -- \\
\hline Climacograptus sp. & -- & -- & -- & -- & - & - & $x$ & - & - \\
\hline cf. C. bicornis & -- & - & - & -- & -- & $\times$ & -- & -- & -- \\
\hline ef. C. minimus Carruthers & -- & -- & -- & - & $x$ & -- & -- & -- & -- \\
\hline ef. C. typicalis & -- & -- & -- & -- & -- & -- & - & $\times$ & -- \\
\hline 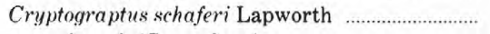 & $x$ & -- & -- & -- & -- & - & -- & -- & -- \\
\hline tricornis (Carruthers) & $x$ & -- & -- & -. & -- & -- & -- & -- & -- \\
\hline $\begin{array}{l}\text { Dicellograptus cf. D. gurleys Lapworth } \\
\text { sp. (probably close to D. sextans var. }\end{array}$ & -- & -- & -- & - & $x$ & -- & -- & -- & -- \\
\hline exilis) & -- & -- & -- & $x$ & -- & -- & -- & - & - \\
\hline Dichograptid uniserial, 3 spp. & $x$ & -- & -- & -- & -- & -- & $x$ & -- & - \\
\hline $\begin{array}{l}\text { Diplograptus? sp. } \\
\text { (possibly var. Glyptograptus cf. } G \text {. }\end{array}$ & -- & -- & -- & -- & -- & - & $x$ & -- & -- \\
\hline $\begin{array}{l}\text { teretiusculus) } \\
\text { Diplograptus decoratus var. amplexograptoides }\end{array}$ & -- & $\times$ & - & -- & - & $x$ & +- & -- & -- \\
\hline (Ross and Berry) & $x$ & -- & -- & -- & -- & - & - & -- & -- \\
\hline Glossograptus?sp. & -- & -. & $x$ & $\therefore$ & -. & +- & - & -- & -- \\
\hline $\begin{array}{l}\text { Glossograptus hincksii (Hopkinson) } \\
\text { cf. G. hincksii var. fimbriatus }\end{array}$ & $x$ & -- & - & - & - & -- & +- & -- & -- \\
\hline (Hopkinson), possibly n. sp. & -- & -- & -- & $\times$ & -- & -- & -- & -- & -- \\
\hline Glyptograptus sp. & -- & -- & -- & $\times$ & - & -- & $x$ & - & -- \\
\hline Monograptids (possibly of $M$. dubius type) & -- & -- & -- & -- & -- & -- & - & -.. & $x$ \\
\hline Orthograptus? sp. & -. & - & -- & -- & -- & -- & $x$ & - & -- \\
\hline of $O$. quadrimucronatus type & -- & -. & -- & $\times$ & -- & -- & -- & -- & -- \\
\hline truncatus var. intermedius ................................ & -- & -- & $x$ & -- & -- & -- & -- & $\times$ & -- \\
\hline 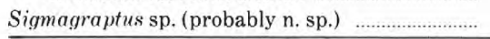 & -- & $\times$ & -- & -- & -- & - & - & - & - \\
\hline Age & $\begin{array}{l}\text { Llanvirnian } \\
\text { or } \\
\text { Llandeilian }\end{array}$ & $\begin{array}{l}\text { Uppermost } \\
\text { Llanvirnian } \\
\text { or } \\
\text { Llandeilian }\end{array}$ & $\begin{array}{l}\text { Uncertain; } \\
\text { Llanvirnian } \\
\text { to } \\
\text { Caradocian }\end{array}$ & $\begin{array}{l}\text { Lower } \\
\text { Caradocian }\end{array}$ & \multicolumn{3}{|c|}{ Lower to middle Caradocian } & $\begin{array}{l}\text { Lower upper } \\
\text { Caradocian }\end{array}$ & $\begin{array}{l}\text { Uppermost } \\
\text { Llandoverian } \\
\text { to Ludlovian; } \\
\text { possibly late } \\
\text { Llandoverian } \\
\text { to Pridolian }\end{array}$ \\
\hline Approximate position in section & Lower zone & Lower zone & Lower zone & Middle zone & Middle zone & Middle zone & Middle zone & Middle zone & $\begin{array}{l}\text { Middle or } \\
\text { upper zone }\end{array}$ \\
\hline
\end{tabular}

siltstone, sandstone, and clay of Tertiary age (Radtke, 1974). A paucity of both fossil evidence and radiometric data precludes establishing a more precise age for these units. Lithologic similarities between these units and others in Maggie Creek and Pine Valley described by Regnier (1960) suggest that the rocks could be correlative with either Regnier's (1960) Carlin Formation of early Pliocene age or the Hay Ranch Formation of middle Pliocene to middle Pleistocene age. However, the presence of crystalline tuff beds in the units and the close spatial association between these sedimentary rocks and the 14-m.y.-old igneous flows suggest that the lakebeds are early Pliocene.

The lacustrine deposits along the west flank of the Tuscarora Mountains are composed mainly of poorly bedded light-gray vitric crystalline tuff, as thick as $6 \mathrm{~m}$. Table 9 lists chemical and spectrographic analyses of the tuff (sample 1).

\section{CARLIN FORMATION OF REGNIER (1960)}

Clastic sedimentary rocks that closely resemble the Carlin Formation as named and described by Regnier (1960) were first recognized and mapped in the northeast corner of the Rodeo Creek NE. quadrangle by Evans (1972a, 1974a). The formation is composed of several rock types that include poorly consolidated conglomerate containing abundant angular to rounded chert pebbles, poorly bedded to thin-bedded tuffaceous and nontuffaceous sandstone, mudstone, and welded tuff.

Although these beds occur over a large area (pl. 1), they are poorly exposed in outcrops, and stratigraphic mapping is virtually impossible. The thickness of the Carlin Formation in the Rodeo Creek NE. quadrangle is difficult to estimate (see pl. 1); J. G. Evans (oral commun., 1974) reported a minimum thickness of more than $180 \mathrm{~m}$ that corresponds closely to a minimum thickness of $190 \mathrm{~m}$ about 
TABLE 9.-Chemical and spectrographic analyses of tuffaceous lakebeds in the northern part of the Lynn mining district, Eureka County, Nev. [Rapid rock analyses (Shapiro and Brannock, 1962) in weight percent. Analysts: P. Elmore, L. F. Espos, and B. P. Fabbi. Spectrographic analyses in parts per million. Results are identified by geometric brackets whose boundaries are $1.2,0.83,0.56,0.38,0.26,0.18,0.12$, and so on, but are reported arbitrarily as the midpoints of these brackets: $1.0,0.7,0.5,0.3$, $0.2,0.15,0.1$, and so on. The precision of a given value is approximately plus or minus one bracket at the 78 -percent, or two brackets at the 95 -percent, confidence level. Analyst: Chris Heropoulos]

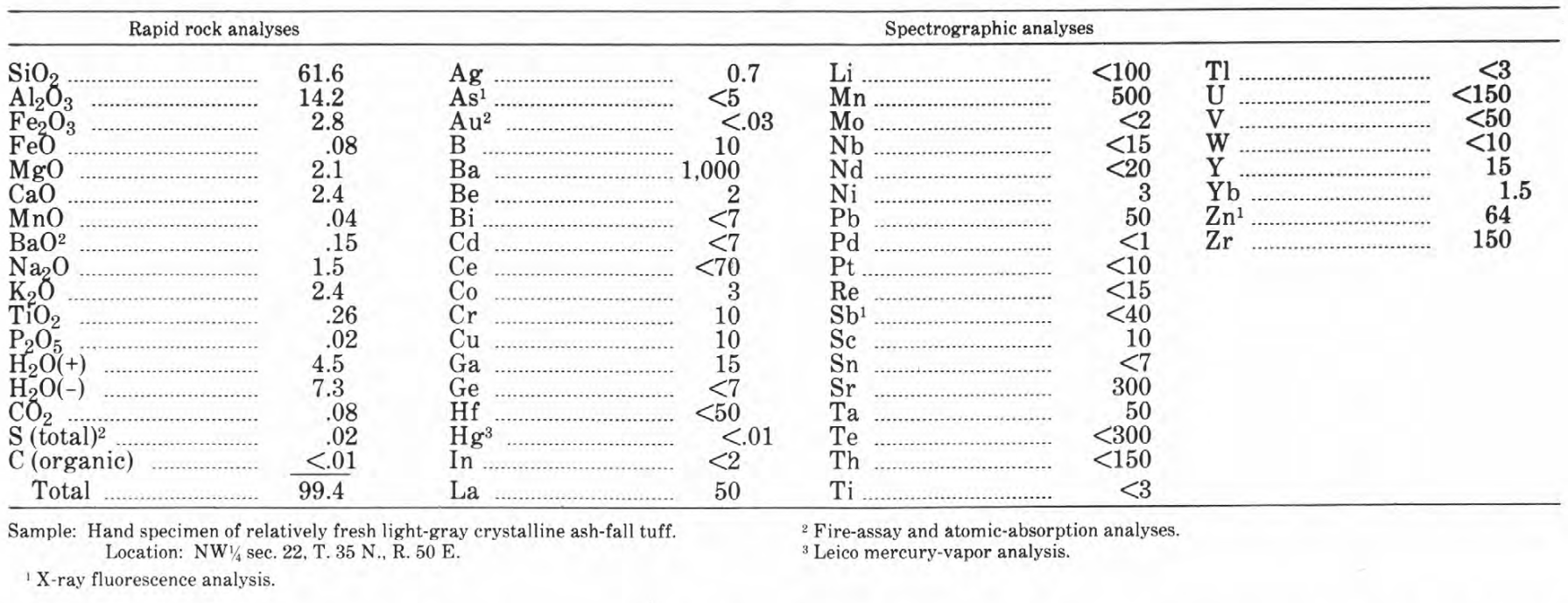

$16 \mathrm{~km}$ southeast in the Maggie Creek area. No fossil data are available on the Carlin Formation, in the study area, but Evans (1974) considered it to be Pliocene.

\section{ALLUVIUM}

Several types of surficial sedimentary deposits of Pleistocene and Holocene age are here mapped together as undifferentiated Quaternary alluvium (pl. 1). Most of these surficial deposits are composed of unconsolidated stream alluvium, gravel, and slope wash. Alluvial fans, composed mainly of unconsolidated pebble- and cobble-size chert containing sand-size material and lesser amounts of silt, occur along the east side of the Tuscarora Mountains north of the access road to the Carlin mine and were mapped separately as fanglomerate by Evans (1972a, 1974a).

Waste dumps and low-grade ore stockpiles of the Carlin mine are shown on the geologic map of the Lynn mining district (pl. 1); because the bedrock geology was mapped before these manmade deposits were formed, they are not included or shown as alluvium. Landslide deposits are also omitted from the map (pl. 1).

\section{IGNEOUS ROCKS}

\section{INTRUSIVE ROCKS}

The oldest intrusive igneous rocks in the study area are quartz diorite, diorite, and granodiorite of Late Jurassic and Early Cretaceous age in two small stocks and numerous dikes (pl. 1; Evans, 1974a). One small poorly exposed stock, here referred to as the North Big Six intrusive, intrudes the upper plate and crops out about $4 \mathrm{~km}$ north of the Carlin mine on the west flank of the Tuscarora Mountains. The intrusive rock is medium grained and contains abundant chlorite formed by deuteric or hydrothermal alteration of biotite and hornblende. Petrographic examination, calculated mineral norms, and chemical analyses (sample 1, table 10) indicate that the rock ranges in composition from diorite to quartz diorite. Radiometric-age determinations were not made owing to alteration of the ferromagnesian minerals. The North Big Six intrusive is tentatively assigned a Late Jurassic and Early Cretaceous age because of its chemical and mineralogic similarities to other intrusive rocks of that age in the Lynn mining district.

Another stock, the Gold Strike intrusive, is $21 / 2 \mathrm{~km}$ north of the Blue Star gold deposit in sec. 30, T.36N., R.50E. (Evans, 1972a, 1974a). Surface exposures are poor, but the upper few meters are well exposed in numerous bulldozer cuts made by the Newmont Mining Corp. Most of the intrusive rock is light- to medium-gray fine-grained granodiorite, although locally its composition approximates quartz diorite and diorite. Chemical and spectrographic analyses of samples of the deep relatively fresh and the shallow weathered and hydrothermally altered intrusive rocks are included in table 10 (samples 2 and 3 , respectively). Limestone and shale of the upper plate near the intrusive rocks are recrystallized and bleached; locally, skarn minerals, including wollastonite, hedenbergite, and iron-rich garnet, are present.

The granodiorite contains about 20 to 25 percent quartz, 10 to 15 percent orthoclase, 30 to 35 percent plagioclase $\left(A n_{35-40}\right), 10$ to 15 percent biotite, 5 to 10 percent hornblende, and small amounts of sphene, apatite, and rutile, and chlorite formed by alteration of both hormblende and biotite. Hausen and Kerr (1968, p. 922) 
TABLE 10.-Chemical and spectrographic analyses of intrusive and extrusive igneous rocks in the northern part of the Lynn mining district, Eureka County, Nev.

[Rapid rock analyses i Shapiro and Brannock. 1962) in weight percent: N. A.. not analyzed. A nalysts: L. Artis. P. Elmore, L. F. Espos, and B. P. Fabbi. Spectrographic analyses in parts per million. Results are identified by geometric

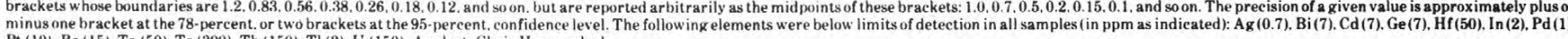
$\mathrm{Pt}(10), \operatorname{Re}(15), \mathrm{Ta}(60)$

\begin{tabular}{|c|c|c|c|c|c|c|c|c|c|c|c|c|c|c|c|}
\hline \multirow[b]{2}{*}{ Iamplo . } & \multirow{2}{*}{$\begin{array}{c}\begin{array}{c}\text { North } \\
\text { Big Six } \\
\text { intrusive }\end{array} \\
1 \\
\end{array}$} & \multicolumn{2}{|c|}{$\begin{array}{l}\text { Gold Strike } \\
\text { intrusive }\end{array}$} & \multicolumn{10}{|c|}{ Intrusive dikes } & \multicolumn{2}{|c|}{ Extrusive dikes } \\
\hline & & 2 & 3 & 4 & 5 & 6 & 7 & 8 & 9 & 10 & 11 & 12 & 13 & 14 & 15 \\
\hline \multicolumn{16}{|c|}{ Rapid rock analyses } \\
\hline 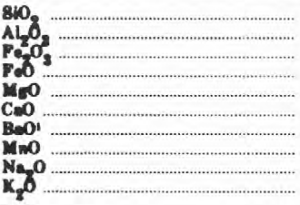 & $\begin{array}{r}57.8 \\
16.7 \\
1.2 \\
5.5 \\
5.0 \\
8.4 \\
\text { N.4. } \\
.00 \\
.3 .0 \\
2.4\end{array}$ & $\begin{array}{c}59.4 \\
17.3 \\
3.2 \\
2.1 \\
2.9 \\
4.5 \\
.09 \\
.02 \\
2.5 \\
2.7\end{array}$ & $\begin{array}{c}60.1 \\
17.9 \\
6.9 \\
.12 \\
.97 \\
1.0 \\
.08 \\
.00 \\
.03 \\
5.8\end{array}$ & $\begin{array}{c}70.4 \\
15.3 \\
1.7 \\
.80 \\
.86 \\
1.4 \\
.21 \\
.00 \\
4.0 \\
3.9\end{array}$ & $\begin{array}{c}58.5 \\
14.6 \\
6.1 \\
.7 \\
4.1 \\
3.6 \\
.09 \\
.07 \\
1.1 \\
3.8\end{array}$ & $\begin{array}{r}69.9 \\
16.5 \\
.81 \\
.00 \\
.57 \\
.87 \\
1.42 \\
.00 \\
.08 \\
1.0\end{array}$ & $\begin{array}{r}73.5 \\
15.6 \\
.89 \\
.04 \\
.49 \\
.28 \\
.24 \\
.00 \\
.07 \\
.92\end{array}$ & $\begin{array}{c}49.6 \\
12.4 \\
5.2 \\
.60 \\
3.5 \\
9.3 \\
.39 \\
.06 \\
.09 \\
.3 .2\end{array}$ & $\begin{array}{r}40.0 \\
18.9 \\
14.7 \\
.24 \\
.81 \\
.26 \\
.28 \\
.01 \\
.14 \\
3.3\end{array}$ & $\begin{array}{r}42.6 \\
17.0 \\
14.2 \\
.76 \\
.30 \\
.16 \\
.02 \\
.02 \\
.14 \\
.68\end{array}$ & $\begin{array}{c}56.6 \\
22.4 \\
6.1 \\
.48 \\
.22 \\
.42 \\
.01 \\
.01 \\
.11 \\
.57\end{array}$ & $\begin{array}{c}63.5 \\
21.9 \\
1.6 \\
.16 \\
.36 \\
.12 \\
.55 \\
.01 \\
.14 \\
1.7\end{array}$ & $\begin{array}{r}59.6 \\
25.4 \\
.50 \\
.08 \\
.20 \\
.64 \\
.03 \\
.01 \\
.13 \\
.81\end{array}$ & $\begin{array}{c}73.4 \\
12.3 \\
2.4 \\
.76 \\
.13 \\
1.4 \\
.05 \\
.02 \\
3.3 \\
5.2\end{array}$ & $\begin{array}{r}73.9 \\
13.0 \\
2.5 \\
.12 \\
.03 \\
.42 \\
\mathrm{~N} . \mathrm{A} \\
.03 \\
\mathbf{3 . 4} \\
\mathbf{5 . 4}\end{array}$ \\
\hline 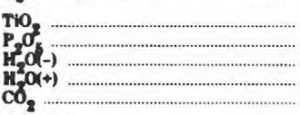 & $\begin{array}{l}1.0 \\
.24 \\
.12 \\
.48 \\
.06\end{array}$ & $\begin{array}{c}1.1 \\
.31 \\
1.5 \\
2.6 \\
.70\end{array}$ & $\begin{array}{l}1.1 \\
.44 \\
1.6 \\
3.7 \\
<.06\end{array}$ & $\begin{array}{r}.26 \\
.10 \\
.25 \\
1.6 \\
.04\end{array}$ & $\begin{array}{c}.91 \\
.18 \\
1.1 \\
3.6 \\
1.0\end{array}$ & $\begin{array}{l}1.1 \\
1.4 \\
1.6 \\
6.0 \\
.04\end{array}$ & $\begin{array}{l}1.1 \\
.08 \\
1.1 \\
4.8 \\
.07\end{array}$ & $\begin{array}{l}.77 \\
.15 \\
1.8 \\
3.9 \\
8.0\end{array}$ & $\begin{array}{l}4.6 \\
.57 \\
.74 \\
.08\end{array}$ & $\begin{array}{l}4.3 \\
.90 \\
1.9 \\
.02\end{array}$ & $\begin{array}{r}1.7 \\
.23 \\
.88 \\
\mathbf{3 . 7 6} \\
.03\end{array}$ & $\begin{array}{c}1.5 \\
.05 \\
.46 \\
7.0 \\
.03\end{array}$ & $\begin{array}{c}1.8 \\
.47 \\
.30 \\
8.6 \\
.02\end{array}$ & $\begin{array}{l}.24 \\
.03 \\
.45 \\
.95 \\
.03\end{array}$ & $\begin{array}{r}.22 \\
.07 \\
.27 \\
.59 \\
<.05\end{array}$ \\
\hline 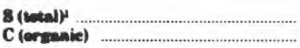 & .04 & $\begin{array}{l}.02 \\
\text { N.A. }\end{array}$ & $\begin{array}{c}\text { N.A. } \\
.01\end{array}$ & $\begin{array}{l}.02 \\
\text { N.A. }\end{array}$ & $\begin{aligned} .08 \\
\text { N.A. }\end{aligned}$ & .34 & $\begin{array}{l}.17 \\
.03\end{array}$ & $\begin{array}{r}.08 \\
\text { N.A. }\end{array}$ & $\begin{array}{r}13.24 \\
.62\end{array}$ & $\begin{array}{r}13.31 \\
.74 \\
\end{array}$ & $\begin{array}{l}5.72 \\
1.16\end{array}$ & $\begin{array}{l}.38 \\
.70\end{array}$ & $\begin{array}{l}.01 \\
.08\end{array}$ & $\begin{array}{l}.04 \\
.01\end{array}$ & .06 \\
\hline Tatal & 100.0 & 100.9 & 100.0 & 100.8 & 99.5 & 101.6 & 99.4 & 99.0 & - & • & 99.2 & 100.2 & 98.7 & 100.7 & 100.0 \\
\hline
\end{tabular}

High wifhr content interlerws with water analyzis and precludes calculation of total.

\begin{tabular}{|c|c|c|c|c|c|c|c|c|c|c|c|c|c|c|c|}
\hline \multicolumn{16}{|c|}{ Spectrographic analyses } \\
\hline $\begin{array}{l}\text { A } \\
\mathbf{A} \\
\mathbf{A} \\
\mathbf{B} \\
\mathbf{B}\end{array}$ & $\begin{array}{r}30 \\
2 \\
15 \\
700 \\
1\end{array}$ & $\begin{array}{r}15 \\
.1 \\
10 \\
1.000 \\
<1\end{array}$ & $\begin{array}{r}700 \\
5 \\
500 \\
1.000 \\
1.5\end{array}$ & $\begin{array}{c}\text { N.A. } \\
15 \\
1.500 \\
1.5\end{array}$ & $\begin{array}{c}<5 \\
<.03 \\
20 \\
700 \\
1\end{array}$ & $\begin{array}{c}230 \\
<.03 \\
20 \\
7,000 \\
<1\end{array}$ & $\begin{array}{c}140 \\
10 \\
1.500 \\
<1\end{array}$ & $\begin{array}{l}\stackrel{69}{<.03} \\
30 \\
5.000 \\
<1\end{array}$ & $\begin{array}{r}255 \\
3 \\
70 \\
2.000 \\
<1\end{array}$ & $\begin{array}{r}240 \\
3 \\
10 \\
150 \\
<1\end{array}$ & $\begin{array}{r}315 \\
15 \\
20 \\
70 \\
<1\end{array}$ & $\begin{array}{r}250 \\
20 \\
100 \\
5.000 \\
<1\end{array}$ & $\begin{array}{r}120 \\
1 \\
30 \\
150 \\
2\end{array}$ & $\begin{array}{r}<5 \\
\text { N.A. } \\
<7 \\
500 \\
5\end{array}$ & $\begin{array}{r}<5 \\
\text { N.A. } \\
7 \\
700 \\
5\end{array}$ \\
\hline $\begin{array}{l}\text { Ce } \\
\text { Co } \\
\text { Cr } \\
\text { Cu } \\
\text { Ga }\end{array}$ & $\begin{array}{r}100 \\
20 \\
200 \\
15 \\
20\end{array}$ & $\begin{array}{r}100 \\
10 \\
70 \\
15 \\
15\end{array}$ & $\begin{array}{r}150 \\
10 \\
50 \\
50 \\
30\end{array}$ & $\begin{array}{r}<70 \\
5 \\
20 \\
3 \\
15\end{array}$ & $\begin{array}{r}100 \\
15 \\
50 \\
30 \\
15\end{array}$ & $\begin{array}{r}300 \\
<2 \\
1,000 \\
20 \\
20\end{array}$ & $\begin{array}{r}200 \\
<2 \\
1,000 \\
20 \\
15\end{array}$ & $\begin{array}{r}200 \\
20 \\
100 \\
100 \\
10\end{array}$ & $\begin{array}{r}100 \\
50 \\
50 \\
30 \\
30\end{array}$ & $\begin{array}{r}<70 \\
50 \\
50 \\
70 \\
20\end{array}$ & $\begin{array}{r}<70 \\
30 \\
150 \\
70 \\
30\end{array}$ & $\begin{array}{r}<70 \\
2 \\
100 \\
20 \\
30\end{array}$ & $\begin{array}{r}100 \\
30 \\
200 \\
20 \\
20\end{array}$ & $\begin{array}{c}200 \\
<2 \\
1.5 \\
5 \\
20\end{array}$ & $\begin{array}{r}300 \\
4 \\
1 \\
2 \\
20\end{array}$ \\
\hline 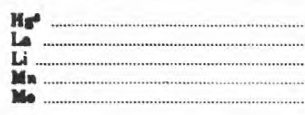 & $\begin{array}{r}\text { N.A. } \\
70 \\
<100 \\
1.000 \\
5\end{array}$ & $\begin{array}{r}1 \\
50 \\
<100 \\
500 \\
<2\end{array}$ & $\begin{array}{r}3 \\
150 \\
<100 \\
100 \\
<2\end{array}$ & $\begin{array}{r}\text { N.A. } \\
30 \\
<100 \\
150 \\
<2\end{array}$ & $\begin{array}{r}3 \\
70 \\
<100 \\
300 \\
<2\end{array}$ & $\begin{array}{r}10 \\
200 \\
<100 \\
7 \\
8\end{array}$ & $\begin{array}{r}3 \\
150 \\
<1.000 \\
10 \\
<2\end{array}$ & $\begin{array}{r}11 \\
150 \\
<100 \\
1.000 \\
<2\end{array}$ & $\begin{array}{r}20 \\
50 \\
<100 \\
15 \\
<2\end{array}$ & $\begin{array}{r}14 \\
70 \\
<100 \\
15 \\
<2\end{array}$ & $\begin{array}{r}50 \\
100 \\
<100 \\
7 \\
<2\end{array}$ & $\begin{array}{r}65 \\
50 \\
<100 \\
5 \\
<2\end{array}$ & $\begin{array}{r}15 \\
70 \\
<100 \\
70 \\
<2\end{array}$ & $\begin{array}{c}150 \\
<100 \\
300 \\
7\end{array}$ & $\begin{array}{c}200 \\
<100 \\
200 \\
10\end{array}$ \\
\hline 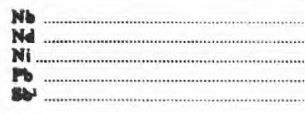 & $\begin{array}{l}10 \\
20 \\
50 \\
10 \\
40\end{array}$ & $\begin{array}{r}10 \\
<20 \\
10 \\
<7 \\
<40\end{array}$ & $\begin{array}{r}20 \\
100 \\
5 \\
15 \\
100\end{array}$ & $\begin{array}{r}7 \\
<20 \\
15 \\
15 \\
<40\end{array}$ & $\begin{array}{r}10 \\
<20 \\
30 \\
15 \\
<40\end{array}$ & $\begin{array}{r}10 \\
150 \\
30 \\
15 \\
<40\end{array}$ & $\begin{array}{r}15 \\
70 \\
20 \\
20 \\
<40\end{array}$ & $\begin{array}{r}<7 \\
100 \\
300 \\
7 \\
<40\end{array}$ & $\begin{array}{r}30 \\
<20 \\
30 \\
50 \\
<40\end{array}$ & $\begin{array}{r}20 \\
<20 \\
30 \\
<7 \\
56\end{array}$ & $\begin{array}{r}15 \\
<20 \\
150 \\
10 \\
<40\end{array}$ & $\begin{array}{r}15 \\
<20 \\
20 \\
15 \\
<40\end{array}$ & $\begin{array}{r}10 \\
<20 \\
15 \\
<7 \\
<40\end{array}$ & $\begin{array}{r}50 \\
100 \\
<1 \\
50 \\
<40\end{array}$ & $\begin{array}{r}50 \\
150 \\
2 \\
30 \\
<40\end{array}$ \\
\hline $\begin{array}{l}\text { Se } \\
\mathbf{S} \\
\mathbf{T} \\
\mathbf{T}\end{array}$ & $\begin{array}{r}30 \\
1.000 \\
5.000 \\
160\end{array}$ & $\begin{array}{r}20 \\
<7 \\
1,000 \\
7,000 \\
100\end{array}$ & $\begin{array}{r}20 \\
<7 \\
200 \\
7.000 \\
600\end{array}$ & $\begin{array}{r}77 \\
500 \\
1.500 \\
30\end{array}$ & $\begin{array}{r}30 \\
<7 \\
700 \\
7.000 \\
100\end{array}$ & $\begin{array}{r}20 \\
<7 \\
300 \\
10.000 \\
150\end{array}$ & $\begin{array}{r}15 \\
<7 \\
100 \\
10,000 \\
300\end{array}$ & $\begin{array}{r}30 \\
<7 \\
300 \\
5,000 \\
150\end{array}$ & $\begin{array}{r}30 \\
<7 \\
70 \\
20.000 \\
300\end{array}$ & $\begin{array}{r}30 \\
<7 \\
20 \\
15,000 \\
200\end{array}$ & $\begin{array}{r}20 \\
<7 \\
50 \\
10.000 \\
150\end{array}$ & $\begin{array}{r}15 \\
<7 \\
70 \\
10.000 \\
150\end{array}$ & $\begin{array}{r}20 \\
<7 \\
15 \\
10.000 \\
150\end{array}$ & $\begin{array}{r}3 \\
7 \\
50 \\
1.500 \\
5\end{array}$ & $\begin{array}{r}<2 \\
10 \\
30 \\
1.500 \\
15\end{array}$ \\
\hline $\begin{array}{l}\mathbf{W} \\
\mathbf{Y} \\
\mathbf{Y} \\
\mathbf{Z}_{\mathbf{m}} \\
\mathbf{Z}_{\mathbf{r}}\end{array}$ & $\begin{array}{r}10 \\
30 \\
3 \\
70 \\
.150\end{array}$ & $\begin{array}{r}<10 \\
30 \\
2 \\
96 \\
200\end{array}$ & $\begin{array}{r}15 \\
30 \\
3 \\
60 \\
200\end{array}$ & $\begin{array}{r}<10 \\
10 \\
1 \\
69 \\
150\end{array}$ & $\begin{array}{r}<10 \\
30 \\
2 \\
75 \\
200\end{array}$ & $\begin{array}{r}<10 \\
50 \\
<1 \\
20 \\
150\end{array}$ & $\begin{array}{r}100 \\
30 \\
3 \\
<6 \\
200\end{array}$ & $\begin{array}{c}<10 \\
20 \\
1.5 \\
131 \\
150\end{array}$ & $\begin{array}{r}<10 \\
30 \\
3 \\
31 \\
150\end{array}$ & $\begin{array}{r}10 \\
20 \\
2 \\
26 \\
100\end{array}$ & $\begin{array}{r}<10 \\
70 \\
5 \\
56 \\
200 \\
\end{array}$ & $\begin{array}{r}<10 \\
30 \\
3 \\
22 \\
200\end{array}$ & $\begin{array}{r}<10 \\
30 \\
2 \\
15 \\
150 \\
\end{array}$ & $\begin{array}{r}<10 \\
100 \\
10 \\
130 \\
500\end{array}$ & $\begin{array}{r}<10 \\
70 \\
7 \\
\text { N.A. } \\
700 \\
\end{array}$ \\
\hline
\end{tabular}

Sample 1. Single hand specimen of slightly altered medium-grained intrusive quartz diorite. Location: $\mathrm{NE} / 4$ sec. 2. T. 35 N., R. 50 E.

2. Composite sample from New mont Mining Corp. rotary-drill hole (SS-14 of a 5-m interval of relatively fresh fine-grained intrusive granodiorite. Location: $\mathrm{SE}_{1}^{1} \mathrm{SW}_{1}, \mathrm{sec} .30$. T. $36 \mathrm{~N} . \mathrm{R} .50 \mathrm{E}$.

Composite sample from several hand specimens of weathered mineralized hydrothermally altered hematite-rich shear zones. Location: $\mathrm{NE}_{4}$ sec. 30 . T. $36 \mathrm{~N}$.. R. 51) E.

4. Composite sample from several hand specimens of gray weakly altered fine-grained calc-alkalin granite or granodiorite dike. Location: $S E^{1}, N W_{1}$, sec. $16 . T .35$ N., R. $35 \mathrm{E}$.

Composite sample of several hand specimens of gray slightly altered fine-krained igneous dike. 7 Main pit, Carlin gold mine.

ach from chip samples across 3-m-wide light-gray hydrothermally altered acid-leached and bench. Main pit, Carlin $\mathrm{m}$ below $\mathrm{s}$

7. Composite sample from several had specimens of light-kray to tan hydrothermally altered acidleached and oxidized igneous dike, $91 \mathrm{~m}$ below surface. Location: mine coordinates $22.100 \mathrm{~N}$ 18.3. E.. 6.36 bench. Main pil, Carlin gold mine.

of golden-tan hydrothermally altered igneous dike Location: mine coordinates $20.375 \mathrm{~N}, 18,200 \mathrm{E}$. 63 alcite seams in matrix. $90 \mathrm{~m}$ below surface

9. Single hand specimen of medium-gray hydrothermally altered igneous dike containing abundant hydrothermal pyrite and sericite on fracture surfaces. $67 \mathrm{~m}$ below surface. Location: mine
10. Composite sample from several hand specimens of mottled-dark-gray and green-brown hydrothermally altered and mineralized igneous dike containing abundant fine-grained sooty hydrothermal pyrite on
fracture surfaces, $42 \mathrm{~m}$ below surface. Location: mine coord inates $23,150 \mathrm{~N}$., 20,575 E.; 6,340 bench. East

pit, Carlin gold mine.
1. Composite sample from several hand specimens of mottled-medium-gray and green-gray hydrothermally
altered and mineralized weakly oxidized igneous dike contsining fine-grained auriferous pyrite on fracture surfaces, $54 \mathrm{~m}$ below surface. Location: $\mathrm{mine}$ coord inates $23,050 \mathrm{~N}$., 20,400 E.; 6.320 bench, East

pit. Carlin gold mine.
12. Single hand specimen of light-gray hydrothermally altered and mineralized moderately acid-leached and oxidized east margin of igneous dike. Vugs and fractures contain mixtures of yellow to pinkish-brown iron oxides $51 \mathrm{~m}$ below surface. Location: mine coordinates $23.100 \mathrm{~N} . .20 .250$ E... 6.320 bench. East pit. Carlin
gold mine. gold mine.

Composite sample from several hand specimens of white soft hydrothermally altered and mineralized coordinates $23.100 \mathrm{~N}$. $20.25 \mathrm{f}$ E 14. Composite sample from several hand specimens of dark-gray to brown vesicular rhyodacite flow. Location: NW $1 / \mathrm{SW} / \mathrm{s}$ sec. 16. T. 35 N.. R. $50 \mathrm{E}$.

15. Single hand

' X-ray fluorescence analysis.

Fire-2ssay and atomic-absorption analyses. 
reported: "Thin sections reveal a hypidiomorphic granular texture consisting mostly of anhedral plagioclase and quartz with moderate amounts of biotite and hornblende. $* *$ Plagioclase, near sodic andesine in composition, is locally sericitized and argillized."

The intrusive rock has been hydrothermally altered, and the most intense alteration is confined to gouge within shear zones and the walls of numerous fractures. Petrographic and X-ray diffraction studies indicate that pyrite and both sericite and kaolinite were formed, and that ferromagnesian minerals, including biotite and hornblende, were removed; small hydrothermal quartz veinlets were formed in the shear zones. Gold, together with significant amounts of arsenic, antimony, and mercury, was introduced and concentrated in the shear zones (sample 3, table 10).

Supergene alteration reached a depth of at least $8 \mathrm{~m}$ and may extend much deeper. This alteration, probably induced by oxidation of pyrite, has been superimposed on the hydrothermal alteration. Upon weathering, the rocks turn greenish gray and brownish buff and become soft and friable. Plagioclase alters to clay, mainly montmorillonite, and the mafic minerals alter almost completely to chlorite and iron oxides.

A radiometric-age determination on biotite separated from unaltered rocks indicates that the Gold Strike intrusive is $121 \pm 5 \mathrm{~m}$.y. old, that is, Early Cretaceous (Hausen and Kerr, 1968). No data are available on the age of sericite in the altered rocks presumably formed during hydrothermal mineralization. This K-Ar age of $121 \mathrm{~m} . \mathrm{y}$. on the Gold Strike intrusive is anomalous in that it falls midway between two of the intrusive epochs of 168-143 m.y. B.P. and $105-87$ m.y. B.P. in north-central Nevada, as defined by Silberman and McKee (1971).

Intrusive dikes of granodiorite, quartz diorite, and diorite occur throughout the Tuscarora Mountains. The fresh rock is light gray to pinkish gray, fine grained, holocrystalline, and locally contains plagioclase phenocrysts. A chemical analysis of a sample from a relatively fresh intrusive calc-alkaline granite or granodiorite dike in sec. $16,3 \mathrm{~km}$ west of the Carlin mine, is listed in table 10 (sample 4). Except for the dikes in that general area, many of which have altered borders, most dikes in the Lynn mining district have been intensely altered throughout to mixtures of clay, chlorite, iron oxides, and quartz.

In most areas the dikes were emplaced along high-angle faults that trend northwest or north-south. Although igneous dikes crop out in many areas, swarms of dikes are concentrated in only three areas: sec. $16,3 \mathrm{~km}$ west of the

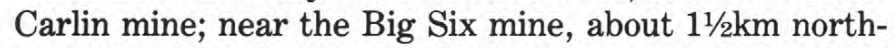
east of the Carlin mine; and in the immediate vicinity of the Carlin and the Blue Star deposits. In the areas of the Big Six, Carlin, and Blue Star deposits, a close spatial re- lation exists between the dikes and gold mineralization (pl. 1; Radtke, 1974).

Within the area of the Carlin deposit, igneous dikes were emplaced along sets of northwest-trending highangle faults (pls. 1-4; Radtke, 1973). Except for small areas within two dikes, all the igneous rocks in the Carlin mine are extensively hydrothermally altered; details of this alteration are discussed below in the section entitled "Hydrothermal Alteration."

One prominent dike, ranging in width from about 1.5 to more than $15 \mathrm{~m}$ and trending northwest along a high-angle fault, cuts through the southwest corner of the Main pit and has been traced through the Main pit over a distance of about $300 \mathrm{~m}(\mathrm{pl} .3)$. The weakly altered parts of the dike are a light-brown fine-grained granodiorite containing locally abundant biotite phenocrysts. Seen in thin section, this rock contains phenocrysts of quartz, biotite, bladed hornblende, and scattered orthoclase in a groundmass of cryptocrystalline quartz and plagioclase. The hornblende is altered locally to epidote, and the margins of biotite phenocrysts are altered to chlorite. The rock contains little, if any, sericite, clay, or carbonate minerals; secondary minerals present in minor amounts include iron oxides and hydroxides, and jarosite. A chemical analysis of this rock is listed in table 10 (sample 5). Hausen and Kerr (1968) indicated that the dikes are either dacite or quartz latite. D. M. Hausen (written commun., 1967) classified this rock as biotite-rich dacite and reported a $\mathrm{K}$-Ar age on the biotite of $149 \pm 6 \mathrm{~m}$.y. This age falls within the earliest epoch of igneous activity of 168-143 m.y. B.P. as outlined by Silberman and McKee (1971). The validity of this 149m.y. age, however, is highly questionable (see Evernden and Kistler, 1970) because of the low potassium content (3 weight percent) in the biotite and the fact that the concentrate analyzed contained only 85 percent biotite, whereas the whole rock contains 20 percent biotite and 5 to 10 percent chlorite (D. M. Hausen, written commun., 1967).

Another dike of granodioritic composition, several meters wide, intrudes the upper plate along the north wall in the southwest corner of the Main pit. Biotite separated from samples of this dike, collected on the 6,460 bench at mine coordinates $22,050 \mathrm{~N}$., $17,350 \mathrm{E}$. (pl. 3), gave a K-Ar age of $128 \pm 4$ m.y. that corresponds well to that of 121 m.y. reported by Hausen and Kerr (1968) for the Gold Strike intrusive but is significantly lower than the questionable 149-m.y. age reported for the other dike in the Carlin deposit.

In summary, K-Ar radiometric-age determinations outline an age range of $149(?)$ to 121 m.y., that is, Late Iurassic to Early Cretaceous, for intrusive igneous activity in this part of the Tuscarora Mountains. Although the radiometric-age determinations on samples of these rocks 
imply two different episodes of intrusive activity, chemical and petrographic similarities, geologic conditions, and the questionable validity of the $149-\mathrm{m} . \mathrm{y}$. age determination all suggest a common magmatic source and possibly a much narrower age range.

\section{EXTRUSIVE ROCKS}

Flows ranging in composition from rhyolite to rhyodacite are exposed over large areas along the west flank of the Tuscarora Mountains and overlap both lower- and upper-plate Paleozoic sedimentary units (pl. 1). These reddish-brown to dark-gray extrusive rocks form low rounded hills, have a westward regional dip of $15^{\circ}-30^{\circ}$, and reach an apparent maximum thickness of 180 to $220 \mathrm{~m}$. The rocks have a microcrystalline groundmass composed mainly of quartz, potassium feldspar, and hornblende, and contain phenocrysts of sanidine and, less commonly, quartz. Vesicular rocks are also present in the flows. In comparison with other igneous rocks in the district, the flows are fresh and unweathered. Chemical and spectrographic analyses of two samples of the extrusive rhyodacite flows are listed in table 10 (samples 14, 15).

$\mathrm{K}$-Ar age determinations on sanidine phenocrysts indicate that these extrusive rocks are $14.2 \pm 0.3 \mathrm{~m} . y$. old, that is, Miocene. This age is compatible with general geologic relations in the Tuscarora Mountains and correlates with the pulse of volcanic activity $17-13$ m.y. B.P. in north-central and northeastern Nevada, as recognized by McKee and others (1971) and Silberman and McKee (1974).

These igneous rocks are associated with a deep body of magma that could have supplied the heat for the Tertiary hydrothermal system responsible for formation of the Carlin gold deposit.

\section{STRUCTURE GENERAL FEATURES}

The Tuscarora Mountains south of the Carlin mine are composed mainly of lower-plate sedimentary rocks folded into a northwest-trending anticline. The oldest exposed rocks are in the southern part of the area in the core of the anticline, and successively younger rocks crop out toward the west, north, and northeast (pl. 1). This sequence is truncated by the Roberts Mountains thrust, which is exposed intermittently across the range in the middle of the Lynn mining district. Lower-plate sedimentary units below the Roberts Mountains thrust, as well as the thrust itself, are displaced by complex sets of high-angle faults.

Sedimentary rocks above the Roberts Mountains thrust in the northern half of the Lynn district are also broken by numerous high-angle faults. Poor surface exposures, similar lithology over large areas, and local changes in the attitude of beds over short distances make it difficult to recognize faults and other structures in the upper plate, so actual structural conditions are much more detailed and complex than those shown on the geologic map (pl.1). The anticlinal structure of the Tuscarora Mountains disappears north of the outcrop trace of the Roberts Mountains thrust; the thick sequence of upper-plate rocks has a regional strike of about N. $40^{\circ}-$ $45^{\circ} \mathrm{E}$. and $\operatorname{dips} 30^{\circ}-40^{\circ} \mathrm{NW}$.

The northwest-trending low hills about $1 \frac{1}{2} \mathrm{~km}$ west of the Carlin mine make up a separate structural block. These hills, here referred to as the Tuscarora Spur, are a horst bounded on the east by the Sheep Creek Canyon fault and probably bounded on the west by a concealed basin-and-range boundary fault. Most of the sedimentary rocks exposed in this block strike about N. $10^{\circ}-20^{\circ} \mathrm{W}$. and vary widely in westward dips. The overall structure is an anticline trending about $\mathrm{N} .25^{\circ} \mathrm{W}$. and having a more steeply dipping eastern limb. Most of this eastern limb either is covered by alluvium or has been removed by normal faulting, but it is exposed over a short distance about $3 / 4 \mathrm{~km}$ southeast of the Blue Star deposit on the south side of the Blue Star Canyon fault (pl. 1). Locally the rocks are strongly folded and vary widely in attitude. Other structures recognized during detailed field mapping include a series of northwest-trending synclinal and anticlinal folds with roughly parallel fold axes (pl. 1; Radtke, 1974).

Sedimentary rocks exposed in the downthrown block north of the Blue Star Canyon fault, including the host rocks for the Blue Star deposit, have previously been mapped as different rock types within the Vinini Formation (Radtke, 1974) or as units of the upper plate (pl. 1; Evans, 1972a, 1974a). However, these rocks could actually be altered thin- bedded carbonate rocks of the Roberts Mountains Formation and less altered thicker bedded limestone of the Popovich Formation. This uncertainty will most probably be resolved through examination of better surface and subsurface exposures developed during mining operations at the Blue Star deposit, or from deep-drilling data.

\section{ROBERTS MOUNTAINS THRUST}

The Roberts Mountains thrust fault, which placed the upper plate on top of the lower plate during Late Devonian or Early Mississippian time, is the oldest prominent structure in the study area. Although the thrust, or the numerous high-angle faults that displace it, crosses the Tuscarora Range over a distance of about $6 \mathrm{~km}$, the structure is very poorly exposed at the surface. In many places, the margins of the Lynn window are not the exposed eroded thrust but are complex sets of high-angle faults that have displaced the Roberts Mountains thrust. 


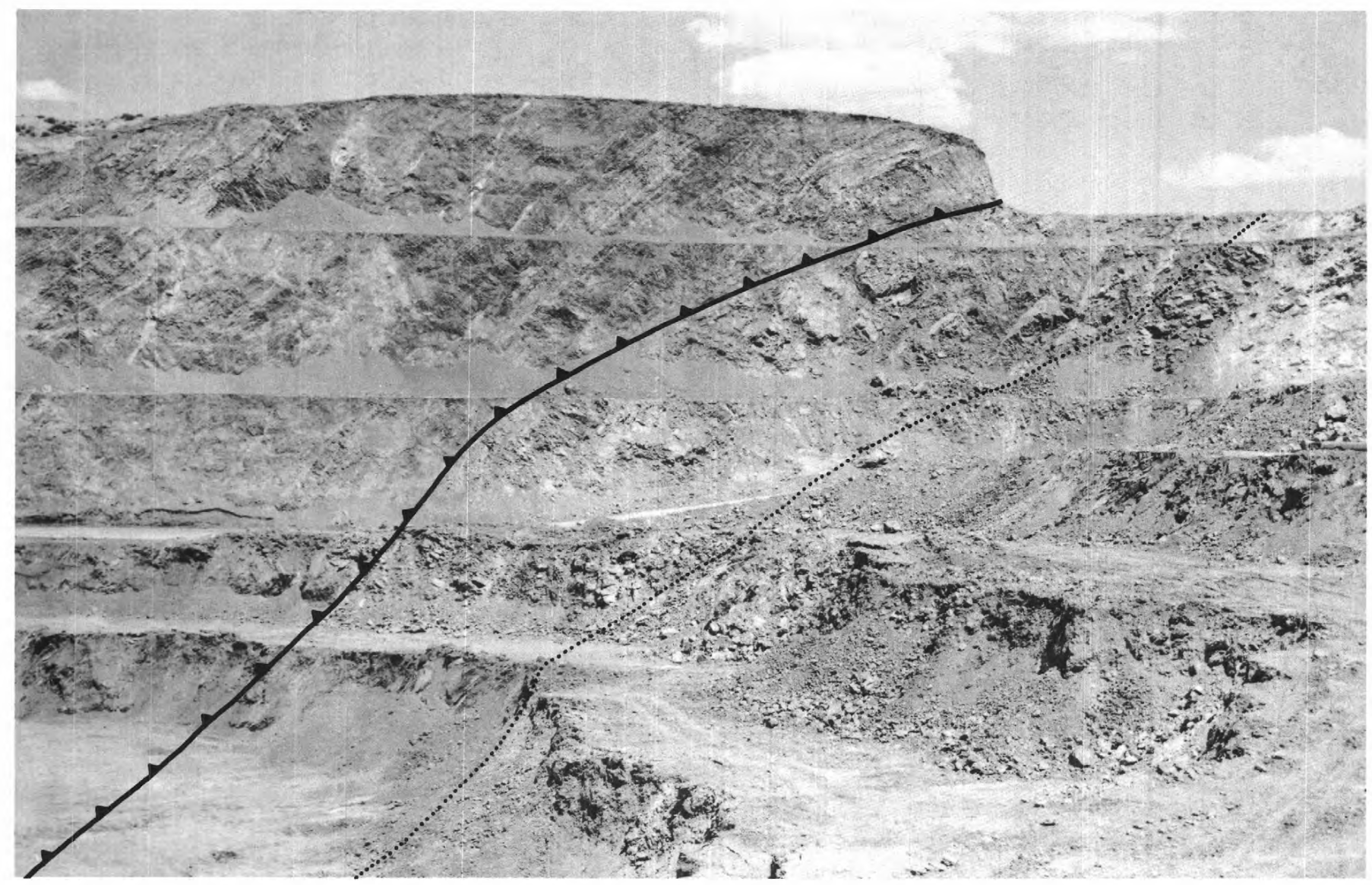

FIGURE 4.-Roberts Mountains thrust in West pit of Carlin gold deposit. Rocks above thrust are shale-chert beds of upper plate; rocks below thrust are limestone of the Popovich Formation and underlying Roberts Mountains Formation. Dots show approximate location of contact between formations in lower plate.

The best exposures of the thrust are along the eastern face of the West pit in the Carlin mine (fig. 4) and along the southern and eastern flanks of Popovich Hill. Within both areas on Popovich Hill, the outcrop pattern is offset by numerous high-angle faults (pls. 1-4). Between the West pit and Popovich Hill, two high-angle faults with large vertical displacements, here referred to as the Hardie and Mill faults, displace a block including the thrust downward and conceal the thrust along the northern and western sides of the Main pit (pls. 1-4).

The contact between the lower and upper plates can be traced along a zone trending about $\mathrm{N}$. $75^{\circ} \mathrm{W}$. from the Carlin mine over a distance of approximately $1 \frac{1}{2} \mathrm{~km}$ to the Sheep Creek Canyon fault. Throughout this zone the contact is poorly exposed. Detailed field mapping and study of drill logs show that complex sets of high-angle faults offset the lower-plate units and the thrust, and locally the lower-plate beds are folded and highly contorted. Thus the Popovich Formation has an apparent thickness much greater than its true thickness. Three distinct types of upper-plate/lower-plate contacts have been recognized (fig. 5): the Roberts Mountains thrust, high-angle faults, and a combination of the thrust and later nearly parallel high-angle normal faults.

The easternmost exposure of the Roberts Mountains thrust in the area of the Carlin mine is along the northwestern wall of the East pit, where the thrust is displaced and offset by a high-angle fault that in turn is offset by the prominent Leeville fault (pls. 1-4). The thrust crops out again in the $\mathrm{S} 1 / 2$ sec. 13 , east of the Leeville fault and $1 \frac{1}{4} \mathrm{~km}$ southeast of the Carlin mine. In that area also, the thrust is poorly exposed and is locally offset by a series of northwest-trending high-angle faults. Near the eastern flank of the range, a thin scab of upper-plate rocks has been faulted into a small synclinal structure (pl. 1).

The trace of the Roberts Mountains thrust is preserved along the flanks of the Tuscarora Spur south of the Blue Star deposit, and in the center of a northwest-plunging syncline along the west side, close to the crest of the spur. Along the west side of these hills the thrust is cut off by a high-angle fault, and along the east flank the thrust is 

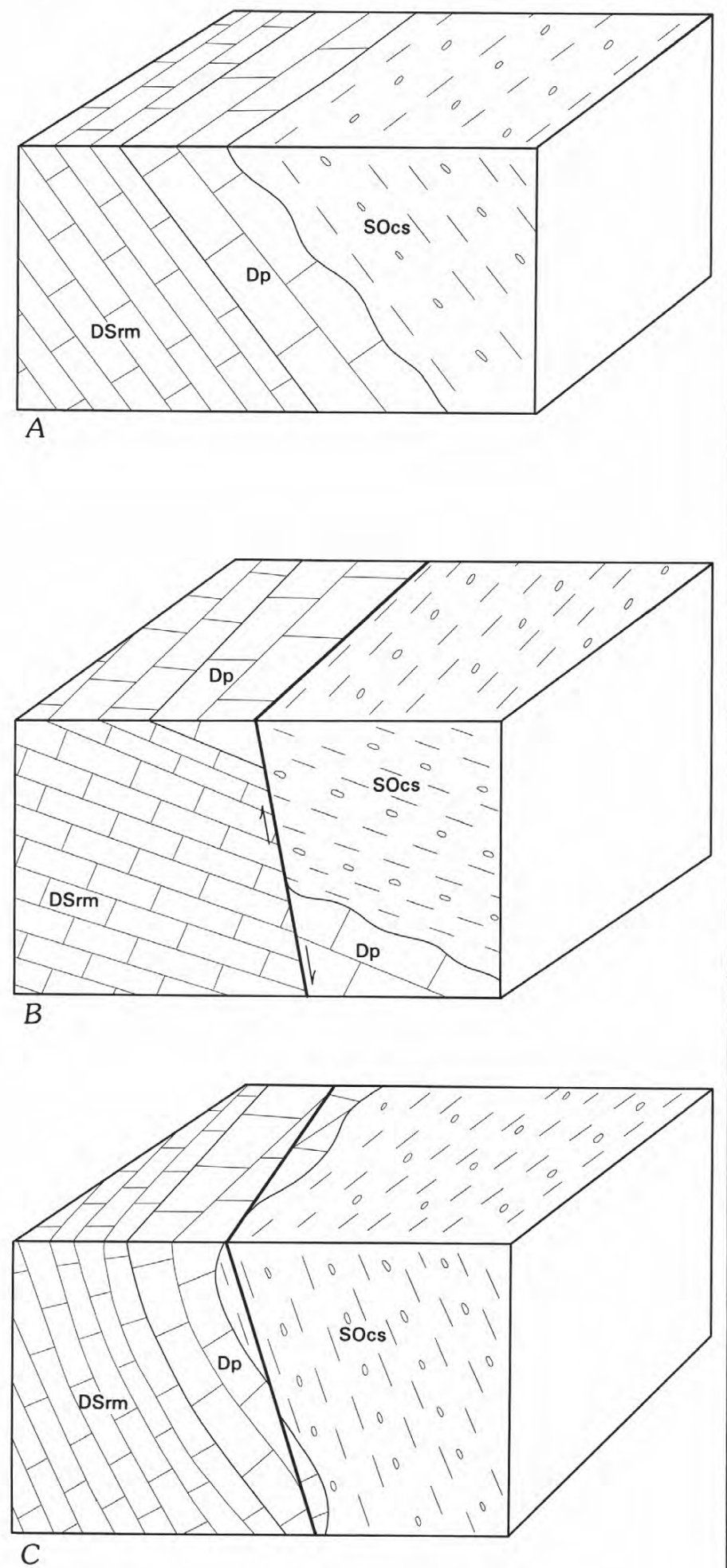

projected beneath alluvial cover and probably terminates against the concealed extension of the Sheep Creek Canyon fault.

The lower and upper plates also crop out in secs. 21 and 28 along a series of low hills west of the Tuscarora Mountains. In earlier studies, Evans (1972a, 1974a) discovered complex structural relations that include thrusting of the Roberts Mountains Formation over both the Popovich Formation and upper-plate limestone. Although surface exposures are poor and attitudes of most of the units are unclear, the structural relations in this area probably resemble those recognized farther to the north along the west side of the Tuscarora Spur and elsewhere in the Lynn mining district (pl. 1; Radtke, 1974).

\section{TUSCARORA MOUNTAINS ANTICLINE}

The Tuscarora Mountains anticline, which has deformed sedimentary rocks in the lower plate, is the largest fold in the study area. This large structure strikes $\mathrm{N} .20^{\circ}-30^{\circ} \mathrm{W}$. and plunges $25^{\circ}-35^{\circ} \mathrm{N}$. Although bedding attitudes vary locally and individual fault blocks are tilted by vertical movement on high-angle faults, the outline of the anticline is well shown by the position and outcrop pattern of the sedimentary units. Beds along the western limb of the anticline dip about $30^{\circ}-45^{\circ} \mathrm{W}$.; beds cropping out along the nose of the fold have a somewhat flatter dip, generally between $25^{\circ}$ and $35^{\circ}$. The eastern limb of the anticline is cut by the Leeville fault. Beds on the downthrown east side of the Leeville structure close to the fault vary widely in both strike and dip (pl. 1).

The age of folding has not been clearly established, although folding may have begun shortly after Early Mississippian time, as suggested by Roberts and others (1967). Strong uplift due to compressional tectonic forces probably accompanied intrusive igneous activity in the region during Late Jurassic and Early Cretaceous time, and could have continued until the early through middle Tertiary period of basin-and-range vertical tectonic activity.

FIGURE 5.-Three types of contact relations between upper- and lower-plate rocks and typical surface-subsurface expressions of Roberts Mountains thrust, in northern part of Lynn mining district. $A$, normal thrust contact. $B$, thrust offset vertically by highangle fault, creating apparent outcrop of thrust between plates; this type of faulting is common and widespread in and near Carlin deposit. $C$, thrust cut and offset by high-angle fault along or nearly parallel to thrust surface; this type of faulting probably created structural and stratigraphic complexities in secs. 10 and 15 west of deposit. 


\section{HIGH-ANGLE NORMAL FAULTS}

High-angle normal faults are common throughout the northern part of the Lynn mining district. This type of faulting was important in creating the structural setting of the district and provided both zones of weakness for the emplacement of igneous dikes and channels for the movement of hydrothermal ore-bearing solutions. These faults are classified here, on the basis of location, relative strength or influence on the regional structural setting, and age, as: (1) high-angle faults in the lower plate, (2) high-angle faults in the upper plate, (3) large or regional high-angle faults, and (4) basin-and-range faults.

\section{HIGH-ANGLE FAULTS IN THE LOWER PLATE}

Lower-plate rocks in the Tuscarora Mountains anticline are shattered and broken into blocks by numerous highangle normal faults. Most of these faults outside the immediate area of the Carlin deposit strike either N.20 $45^{\circ} \mathrm{W}$. or N. $20^{\circ}-45^{\circ} \mathrm{E}$. and are displaced vertically by a few tens of meters to more than $300 \mathrm{~m}$. Near the thrust contact and along the west side of the anticline these faults commonly strike between N. $20^{\circ} \mathrm{W}$. and N. $20^{\circ} \mathrm{E}$.

The high-angle faults show no apparent changes in attitude in crossing from one rock type into another. In many places in the district the northeast-trending faults cut and displace those striking differently. Most dikes in the lower plate in both the Tuscarora Mountains anticline and the Tuscarora Spur, and all but one dike in the Carlin mine, were emplaced along faults that trend between about N. $45^{\circ} \mathrm{W}$. and north-south. Within the Carlin mine, northeast-trending faults commonly offset the dikes as well as the other faults. Either the northeast-trending high-angle faults postdate the other sets, or they formed at the same time and moved later.

Initial movement on many of the high-angle faults probably took place during formation of the Tuscarora Mountains anticline. Since both the northwest- and northsouth-trending faults contain igneous dikes of Late Jurassic age, initial high-angle faulting must have begun before or during early Late Jurassic time. Many of the northeasttrending faults postdate the period of dike intrusion and predate the later Tertiary (probably Miocene) gold mineralization because they influenced the positions of ore deposition; some, and possibly all, movement on faults of this set in the Carlin mine area is, therefore, post-Late Iurassic and pre-Miocene.

\section{HIGH-ANGLE FAULTS IN THE UPPER PLATE}

High-angle normal faults with unknown amounts of displacement have been recognized and mapped in the upper plate of the Roberts Mountains thrust (Evans, 1972a, 1974a; Radtke, 1974). The intensity of faulting in upperplate rocks, apparently not so great as in lower-plate rocks (pl. 1), possibly reflects a decrease in tensional forces associated with diminished uplift and folding of the upper plate north of the Carlin deposit, or the tendency for the shale and shale-chert beds to deform without rupture. Areas where upper-plate rocks occur as bedrock, however, generally have a heavy soil and talus cover, and the bedrock, which varies little in general lithology over large distances, generally is very poorly exposed. Most faulting must be recognized through interpretation of aerial photographs, except along roadcuts - in places where linear zones of silicification are visible, where attitudes of beds vary greatly over short distances, or where changes in rock type indicate the presence of a fault. In summary, the faulting in the upper plate could be much more complex than that shown on the geologic map (pl. 1).

North-dipping upper-plate rocks near the thrust are commonly cut by high-angle faults, where the hangingwall block apparently is displaced to the south in response to vertical movement on the fault. Offsets measured on thin upper-plate quartzite marker beds near the thrust show that vertical movements on the faults generally range from about 15 to more than $120 \mathrm{~m}$. Several faults in sec. 13 and 24 , T. 35 N., R. 50 E., east of the large Leeville fault show a strike separation of $200 \mathrm{~m}$ or more.

Dikes in upper-plate rocks range in strike from about N. $15^{\circ} \mathrm{W}$. to N. $45^{\circ} \mathrm{E}$. At the Big Six mine, about $1 \frac{1}{2} \mathrm{~km}$ northeast of the Carlin mine and along a zone extending from the Big Six mine for a distance of about $1 \frac{1 / 4 \mathrm{~km}}{\text { to }}$ the southeast, swarms of dikes spatially related to gold-bearing quartz veins were emplaced along sets of northwesttrending faults. About $1 \frac{1}{2} \mathrm{~km}$ southeast of the Big Six mine and north of the road along Simon Creek, other dikes occupy poorly exposed northeast-trending faults; still other small fault-controlled dikes occur in upper-plate shale units south of the road. At the Blue Star deposit, northeast-trending high-angle faults provided zones of weakness for the emplacement of igneous dikes and, together with apparently later northwest-trending faults, served as channelways for the movement of ore-bearing solutions and thus as controls on ore deposition.

\section{REGIONAL OR MAJOR HIGH-ANGLE NORMAL FAULTS}

Six high-angle normal faults may be traced over great distances, have large vertical displacements, and separate important structural blocks. These faults are the Blue Star Canyon, Sheep Creek, Sheep Creek Canyon, Hardie, Mill, and Leeville faults (pl. 1); the Hardie, Mill, and Leeville faults have strongly influenced structural conditions at the Carlin gold deposit (pl. 3).

\section{BLUE STAR CANYON FAULT}

The Blue Star Canyon fault, in the N1/2 sec. 4, T. 35 N., R.50E., crosses the crest of the Tuscarora Spur about $1 / 2 \mathrm{~km}$ south of the Blue Star gold deposit. The fault strikes N. $60^{\circ} \mathrm{E}$., and prominent drainages trending both northeast and southwest have formed on either side of the crest 
along parts of the fault trace. Vertical movement, estimated to be more than $450 \mathrm{~m}$, on the steeply north-dipping fault has dropped shale, chert, and limestone units of the upper plate against carbonate rocks of the Popovich and Roberts Mountains Formations (pl. 1).

Rocks along the fault are shattered, brecciated, and locally contorted and folded, and calcite veins are common in lower-plate rocks on the south side of the fault. Movement on the Blue Star Canyon fault is more recent than on northwest- and other north- south- to northeast-striking faults in the area. This large fault had no obvious influence on gold deposition at the Blue Star deposit, and upper beds in the Roberts Mountains Formation south of the fault, which are favorable sites for gold deposition at the Carlin deposit, apparently are not mineralized in that part of the Lynn mining district.

\section{SHEEPCREEK FAULT}

The poorly exposed east-west-striking Sheep Creek fault forms the south margin of the Tuscarora Spur. Near the mouth of Sheep Creek Canyon the fault intersects the Sheep Creek Canyon fault at approximately a $90^{\circ}$ angle. In that locality, highly shattered and folded rocks of the Roberts Mountains Formation south of the fault are downthrown more than $300 \mathrm{~m}$ against the Eureka Quartzite and the Hanson Creek Formation (pl. 1). The fault continues to the west but is concealed by alluvium.

Although a deep canyon lies along the projected strike of the fault to the east for about $2 \frac{1 / 2}{\mathrm{~km}}$ from the mouth of Sheep Creek Canyon, field evidence indicates that the Sheep Creek fault terminates against the Sheep Creek Canyon fault. More specifically, on either side of the eastwest-trending canyon the attitudes of units are similar, and contacts between formations are not offset except by unrelated north-south- and northwest-striking sets of faults. The intersection between the Sheep Creek and Sheep Creek Canyon faults evidently marks the southeast corner of the structural block forming the Tuscarora Spur.

In conclusion, the Sheep Creek and Sheep Creek Canyon faults are similar in age because all other intersecting faults appear to terminate against them, and movement on these two large faults apparently postdates other tectonic activity but predates Miocene extrusive flows, which are not offset across the projection of the Sheep Creek fault to the west.

\section{SHEEP CREEK CANYON FAULT}

The Sheep Creek Canyon fault separates the Tuscarora Spur from the Tuscarora Mountains and intersects the Sheep Creek fault near the mouth of Sheep Creek Canyon in the $\mathrm{SW}^{1 / 1} / 4$ sec. $15, \mathrm{~T} .35 \mathrm{~N}$., R. 50 E. From this locality the fault strikes north-northwest along Sheep Creek Canyon, passes into the southernmost extension of Little Boulder Valley, and continues to the north-northwest, concealed by alluvium along the east flank of the Tuscarora Spur (pl. 1). Along most of Sheep Creek Canyon, units of the Roberts Mountains Formation and the Popovich Formation east of the fault are downthrown against the Eureka Quartzite and the Hanson Creek Formation. Vertical movement on the fault is estimated at between 900 and $1,200 \mathrm{~m}$.

Movement on the Sheep Creek Canyon fault, as discussed above, is believed to be of similar age to that on the Sheep Creek fault. In terms of the sequence of faulting along the western part of the range, some, if not all, movement on the Sheep Creek Canyon fault is younger than that on all other faults recognized to date.

HARDIEFAULT

Although the horizontal distance of approximately 550 $\mathrm{m}$ along which the Hardie fault has been traced is much shorter than that for the other major or regional faults, the Hardie is classified as a major fault because of its large vertical displacement and the strong influence it had on the creation of the structural setting of the Carlin deposit. The Hardie fault was named for Byron S. Hardie of Newmont Exploration, Ltd., who first recognized its existence and importance. The fault strikes approximately $\mathrm{N}$. $60^{\circ}$ E., dips $50^{\circ}-65^{\circ} \mathrm{N}$., and has been mapped from the crest of Popovich Hill southwest to the northwest corner of the Main pit, where it apparently terminates against the Mill fault (pl. 3). Vertical movement on the fault, estimated to be more than $300 \mathrm{~m}$, has placed siliceous upperplate units in the downthrown block north of the fault against the Popovich and Roberts Mountains Formations, and cuts the Roberts Mountains thrust from that part of the Carlin deposit (fig. 6).

The Hardie fault is poorly exposed at the surface and, like many other faults of its type (see fig. $5 B$ ), is difficult to distinguish from the Roberts Mountains thrust solely on the basis of an examination of surface exposures. Subsurface exposures on numerous benches and faces in the mine, as well as data from rotary-drill holes, confirm the type and extent of movement on the Hardie fault. The trace of the fault is marked by a zone of gouge and breccia, ranging from about 1 to more than $25 \mathrm{~m}$ in width; breccia fragments consist of fresh and silicified rocks from upper and lower-plate formations. Intense alteration of the rocks within this fault zone and along its brecciated margins by hydrothermal solutions suggests that the Hardie is a preore fault. Alteration along the fault includes zones of intense silicification and the introduction of hydrocarbons (see pl. 5).

Detailed geologic mapping shows that movement on the Hardie fault and other closely spaced northeast-striking faults probably postdates movement on most other faults 


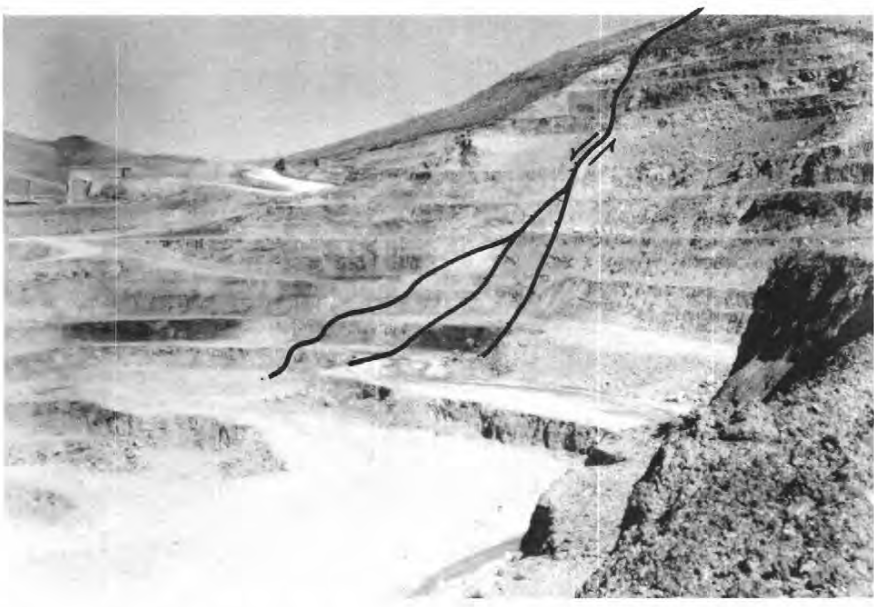

Figure 6.--Hardie fault along southwest side of Popovich Hill. Shale beds in upper plate on left of fault are downthrown against limestone beds of the Popovich Formation along flank of hill and against the Roberts Mountains Formation in lower levels of Main pit. At lower levels, Hardie fault breaks into several strands in which left side is downthrown relative to right.

of varying attitudes in the mine area. Alternatively, $P$. W. West of Newmont Exploration, Ltd. (oral commun., 1972, 1973), suggested that some large north-south-striking faults may cut the Hardie fault on the southwest side of Popovich Hill.

\section{MILL FAULT}

The Mill fault, referred to as the Northeast fault by Hausen (1967) and the Lynn fault by Evans (1972a, 1974a), is an important and conspicuous structural feature at the Carlin gold deposit. Near the mine the fault is well exposed at the north end of the Main pit (fig. 7); from there it trends about $\mathrm{S} .30^{\circ} \mathrm{W}$., dips $60^{\circ}-75^{\circ} \mathrm{W}$., and closely follows the west side of the pit (pl. 3). Near the southwest end of the Main pit it separates into two main branches, which in turn separate into numerous small strands, before intersecting a strong set of northwest-trending shears and faults (pl. 3). The two main branches as well as the numerous small strands provided important structural control on gold deposition in that part of the deposit.

Except in the southwestern part of the Main pit, vertical displacement on the Mill fault south of its intersection with the Hardie fault, estimated to be about $300 \mathrm{~m}$, has placed siliceous upper-plate rocks against the Robert Mountains Formation. Dan Higley (oral commun., 1975), however, reported that beds resembling the Popovich Formation were exposed briefly during mining operations along the west side of that part of the Main pit. This observation indicates that the vertical movement on this section of the Mill fault may be only about $150 \mathrm{~m}$.

Vertical movement of between 90 and $150 \mathrm{~m}$ on the westermost strand of the Mill fault in the southwest end of the
Main pit has positioned the Popovich Formation and upper beds of the Roberts Mountain Formation against lower beds of the Roberts Mountains Formation (pl. 3). This extent of displacement supports the probable existence of units of the Popovich Formation farther northeastward along the Mill fault, as reported by Larry Noble (oral commun., 1975), and would accord with a vertical displacement of about $150 \mathrm{~m}$ along that section of the fault.

A change in the extent of vertical movement from about 100 to $300 \mathrm{~m}$ over a relatively short horizontal distance of 180 to $300 \mathrm{~m}$ would suggest a hinge-type fault. The possibility that many of the high-angle normal faults in the district may actually be hinge faults was first proposed by $P$. W. West (oral commun., 1968), who pointed out that hinge faulting could explain many of the structural problems in the district, including the apparent termination and intersections of large faults near the mouth of Sheep Creek Canyon.

Beyond the north end of the Main pit the Mill fault trends about N. $30^{\circ}-40^{\circ}$ E., extends about $100 \mathrm{~m}$ east of the mill at the Carlin plant, and continues about $1,000 \mathrm{~m}$ to the northeast, where it apparently terminates against the Leeville fault (pl. 1). Evans (1972a, 1974a) did not recognize the Leeville fault and projected the Mill fault $6 \frac{1}{2}$ $\mathrm{km}$ farther to the northeast beyond the intersection with the Leeville fault.

Field relations show that the Mill fault is one of a set of northeast-trending faults that, in the area of the Carlin mine, show movement which postdates that on other faults. No other structures cutting the Mill fault have been identified, and the structurally prominent Hardie fault apparently terminates against it. Although the Mill fault was an important preore structure, it had little influence on ore deposition throughout most of its length. Over a distance of about 210 to $240 \mathrm{~m}$ in the southwest end of the Main pit, however, intersections of several branches of the Mill fault with other faults provided a strong local control on gold deposition.

\section{LEEVILLE FAULT}

The Leeville fault strikes N. $20^{\circ}-25^{\circ} \mathrm{E}$. and roughly bisects that part of the Tuscarora Mountains shown on the geologic map of the Lynn mining district (pl. 1). The fault extends from the southeast corner of the northern part of the Lynn district to the north end of the map area (pl. 1) on the west side of the Tuscarora Mountains and ranges from a single well-defined fracture to a zone of parallel and branching faults. The extent of vertical displacement along the zone ranges from about 300 to more than $450 \mathrm{~m}$. The dip along the fault is steeply to the east and in the East pit of the Carlin mine ranges from $70^{\circ}$ to $85^{\circ} \mathrm{E}$.

Except within and near the East pit of the Carlin mine, the Leeville fault is poorly exposed. From the Carlin mine 


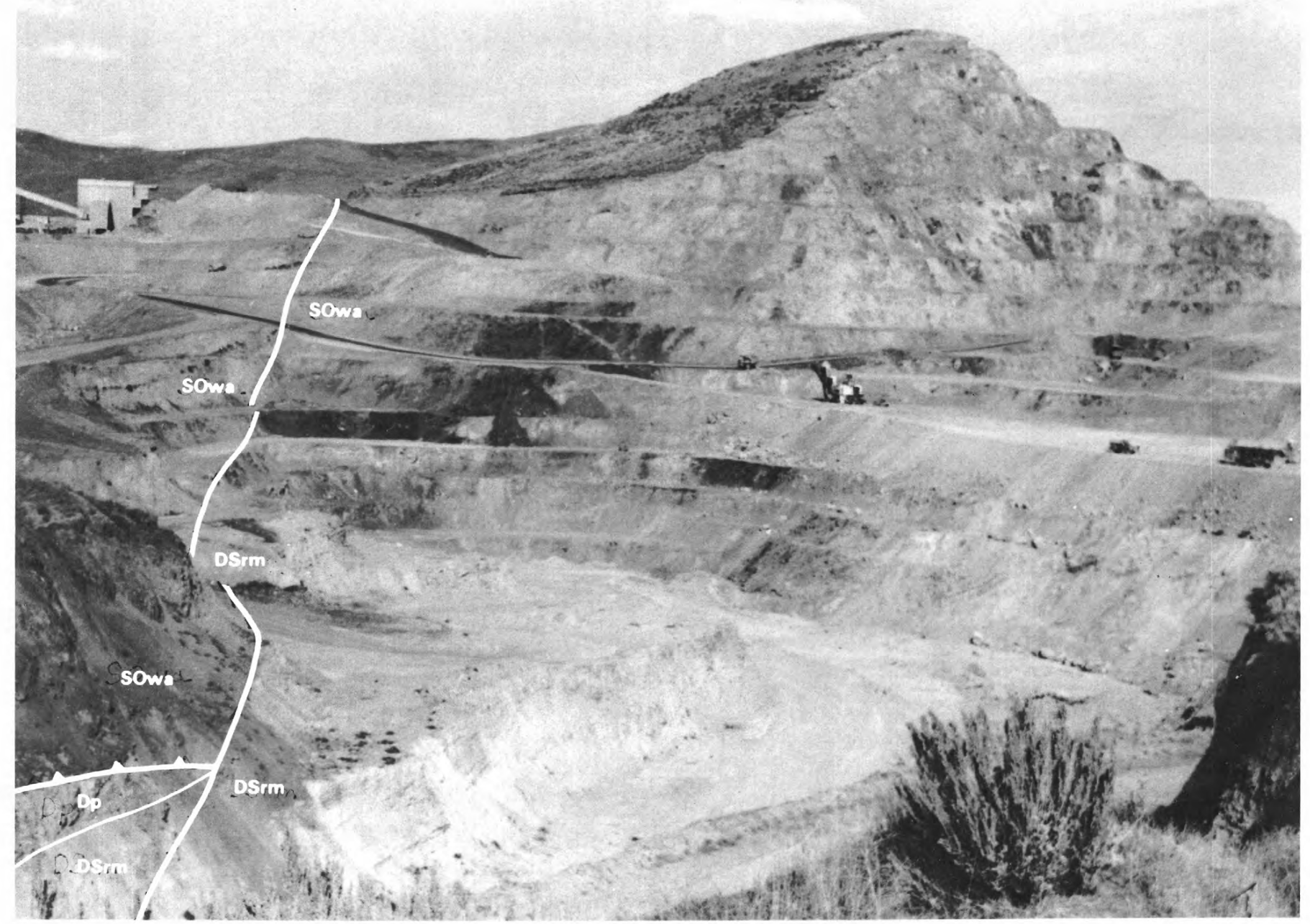

FIGURE 7.-Mill fault at northwest end of Main pit. Movement on fault has placed upper-plate rocks (SOwa) against upper units of the Roberts Mountains Formation (DSrm) in most of area shown as far as north end of Main pit.

it has been traced southeast for approximately $5 \mathrm{~km}$ to the east flank of the range, where it is concealed by alluvium and presumably terminates against the Tuscarora fault (pl. 1). Although the Leeville fault is exposed in only a few places, its position is established relatively well by lithologic differences, changes in the attitudes of beds, and data from rotary drilling.

The Leeville fault has been mapped for more than $3 \mathrm{~km}$ to the northwest from the Carlin mine, across the crest of the Tuscarora Mountains, and through thick sequences of upper-plate chert and shale. Although rock types are commonly the same across the fault, its position can be established on the basis of differences in the attitudes of beds, breccia zones, areas of silicification, and topographic expression. The extent of movement on the fault appears to decrease to the northwest away from the Carlin mine area.
At the east end of the East pit in the Carlin mine, the Leeville fault and numerous branching faults are well exposed on several benches and faces (fig. 8). Here, the fault is best described as a zone, ranging in width from about 6 to $11 \mathrm{~m}$, composed of gouge and breccia fragments and bounded by two well-defined planes. Vertical movement on the Leeville fault has placed stratigraphically higher units of the upper plate east of the fault against lower units, as well as against the lower-plate Popovich and Roberts Mountains Formations (pl. 1). East of the Leeville fault the Roberts Mountains thrust is concealed; in the area immediately west of the Leeville fault the thrust also is not exposed, owing to vertical movement on another pre-Leeville high-angle fault (pl. 3; Radtke, 1973).

Some, if not all, movement on the Leeville fault postdates much of the other faulting throughout the Tuscar- 


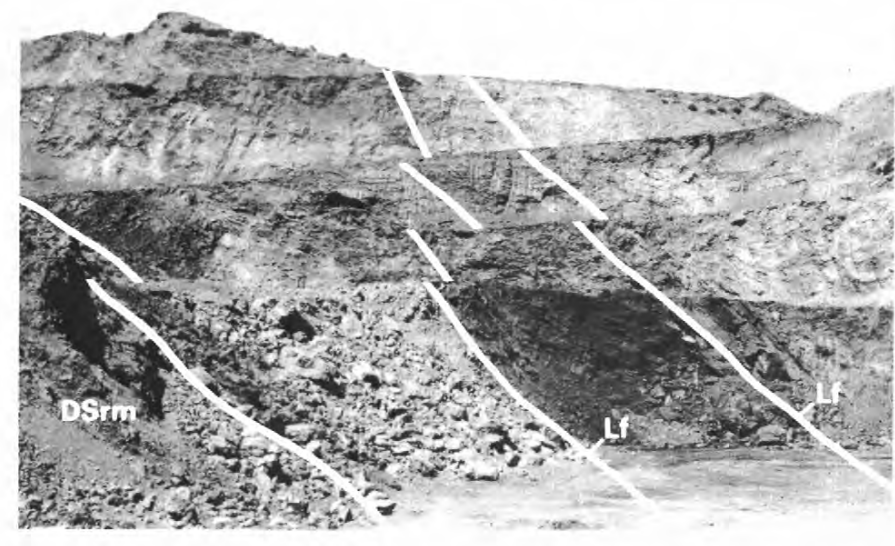

Figure 8.-Leeville fault (Lf) and other high-angle faults in north face at east end of East pit. All rocks shown are in upper plate except for those at lower left corner, where mineralized beds of the Roberts Mountains Formation (DSrm) lie in fault contact with upper plate. Note enrichment of carbonaceous materials (dark zones) along Leeville fault and bleaching of shale beds (light zones) near fault.

ora Mountains because virtually all other structures, including dike- filled faults, are displaced by the Leeville fault. The gold mineralization in the eastern part of the East ore body, however, crosses the fault into the Vinini Formation in the hanging wall with no apparent change in attitude. Movement on the Leeville fault was possibly contemporaneous with late basin-and-range tectonic activity, yet predated gold mineralization at the Carlin deposit. Although the Leeville fault is a conspicuous feature of regional scope and was important in creating the structural setting for the deposit, it exerted no apparent structural control on gold deposition.

\section{BASIN-AND-RANGE FAULTS}

A basin-and-range normal fault, striking roughly north-south, borders the east side of the Tuscarora Mountains (pl. 1). This fault, the Tuscarora, is concealed by Quaternary alluvium along most of its length but is exposed about $1 \frac{1}{2} \mathrm{~km}$ north of the map area (pl. 1), where it places Pliocene sedimentary rocks of the Carlin Formation in contact with chert and shale of the upper plate. Movement on the Tuscarora basin-and-range boundary fault postdates that on most other faults in the Tuscarora Mountains; movement could have begun during the early Oligocene and continued intermittently into the Pleistocene.

Another basin-and-range fault lies concealed along the east side of the Tuscarora Spur. The concealed trace of this fault is marked by the position of the main northwardflowing stream in Little Boulder Basin and represents the northward extension of the Sheep Creek Canyon fault.
Initial movement on this fault probably accompanied that on the Sheep Creek and Sheep Creek Canyon faults to the south. Some later movement, probably of Pliocene or Pleistocene age, is suggested by the strong control that the buried fault trace has had on the drainage in Little Boulder Basin.

\section{GENERAL FEATURES OF THE GARLIN DEPOSIT}

\section{TYPE AND CLASSIFICATION}

The Carlin gold deposit belongs to the group commonly referred to as hydrothermal disseminated-replacement gold deposits; these deposits possess distinct geologic, geochemical, and mineralogic features distinguishing them from other gold deposits, particularly those of the lode or vein type. Numerous Carlin-type deposits have been recognized in the Western United States; the most important of these deposits are listed in table 11. Because of the size and economic importance of these deposits and because they have all the general features partly shown in other individual deposits, Radtke and Dickson (1974b) applied the term "Carlin type" to this group.

Many of the important and characteristic features of the Carlin and other disseminated deposits were summarized by Radtke and Dickson (1974a, 1975b), who stated (1974a, p. 68):

They are characterized by: gold-pyrite-silica association; exceedingly fine-grained ore minerals; organic compounds; gold ore localized along high-angle faults which commonly contain altered igneous dikes, and in brecciated permeable thin-bedded carbonaceous, silty carbonate rocks; fine- grained silicified rocks and jasperoids; zones of oxidized rocks above unoxidized rocks; and argillized rocks. Visible gold is rare. Base-metal minerals are very uncommon. Gold ore and surrounding country rocks contain abnormally large amounts of arsenic, antimony, and mercury. Several deposits (including Carlin) contain discrete sulfide minerals of these elements. Thallium occurs in high arsenic ores. Most deposits (including Carlin) show late crosscutting veinlets of gangue quartz, barite, and calcite. Pyrite occurs as preore syngenetic or diagenetic grains in host rocks and with the ore, and also was deposited from the hydrothermal solutions before and during gold deposition.

Among the numerous lines of evidence supporting a Tertiary age for the Carlin deposit are (1) ore control by young faults, (2) extension of ore bodies across basinand-range faults without offsets and crosscutting through Iurassic and Cretaceous igneous dikes, (3) correspondence in the shape of alteration zones to the present topography, (4) isotopic composition of fluid inclusions, (5) degree of erosion from levels of ore formation on the basis of fluid-inclusion temperature and salinity data, (6) physical and chemical similarity to young hot-springs systems, and (7) K-Ar age data. Points 1 through 6 are discussed in appropriate sections of this report.

$\mathrm{K}$-Ar data on sericite containing dispersed gold in a sample from along the contact of an igneous dike gave an age of $57.6 \pm 2.5$ m.y. (R. L. Akright, written commun., 
TABLE 11.-Carlin-type disseminated-replacement gold deposits in the Western United States

\begin{tabular}{|c|c|c|}
\hline Name & Location & References \\
\hline Alligator Ridge & Sec. 23 , T. 22 N., R. 57 E., White Pine & $-\ldots$ \\
\hline 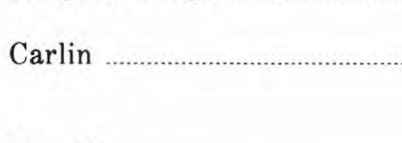 & $\begin{array}{l}\text { Secs. } 13,14 \text {, T. } 35 \text { N., R. } 50 \text { E., Eureka } \\
\text { County, Nev. }\end{array}$ & $\begin{array}{l}\text { County, Nev. } \\
\text { Hardie (1966), Hausen and Kerr (1968), Radtke (1973, } \\
\text { 1974), Harris and Radtke (1976), Noble and Radtke } \\
\text { (1978), Radtke and others (1979), (1980). }\end{array}$ \\
\hline Blue Star & $\begin{array}{l}\text { Sec. } 4 \text {, T. } 35 \text { N., R. } 50 \text { E., Eureka } \\
\text { County, Nev. }\end{array}$ & Radtke (1974), Noble and others (1977). \\
\hline Bootstrap & $\begin{array}{l}\text { Secs. } 3,10,11, \text { T. } 36 \text { N., R. } 49 \text { E., } \\
\text { Elko County, Nev. }\end{array}$ & Lawrence (1963), Evans and Mullens (1975) \\
\hline Cortez & $\begin{array}{l}\text { Secs. } 24,25 \text {, T. } 27 \text { N., R. } 47 \text { E., Lander } \\
\text { County, Nev. }\end{array}$ & $\begin{array}{l}\text { Erickson and others (1966), Wells and others (1969), Rye } \\
\text { and others (1974), Radtke and Dickson (1976). }\end{array}$ \\
\hline 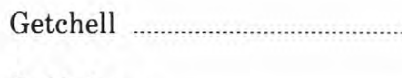 & $\begin{array}{l}\text { Sec. } 33 \text {, T. } 39 \text { N., R. } 42 \text { E., Humboldt } \\
\text { County, Nev. }\end{array}$ & $\begin{array}{l}\text { Joralemon (1951), Erickson and others (1964), Hotz and } \\
\text { Willden (1964), Silberman and others (1974). }\end{array}$ \\
\hline Gold Acres ... & $\begin{array}{l}\text {..Sec. } 31 \text {, T. } 28 \text { N., R. } 47 \text { E.; sec. } 36 \text {, T. } \\
28 \text { N., R. } 46 \text { E., Lander County, Nev. }\end{array}$ & $\begin{array}{l}\text { Wrucke and others (1968), Wrucke and Armbrust- } \\
\text { macher, }(1969,1975) \text {. }\end{array}$ \\
\hline Gold Quarry (Maggie Creek). & $\begin{array}{l}\text { Sec. } 3 \text {, T. } 33 \text { N., R. } 51 \text { E.; sec. } 34,35 \text {, T. } \\
34 \text { N., R. } 51 \text { E., Eureka County, Nev. }\end{array}$ & -- \\
\hline Jerrett Canyon .......................... & $\begin{array}{l}\text { Secs. } 2,4,6,10-12,22, \text { T. } 40 \text { N., R. } 53 \\
\text { E.; sec. } 34 \text {, T. } 41 \text { N., R. } 53 \text { E., Elko } \\
\text { County, Nev. }\end{array}$ & Hawkins (1973) \\
\hline Kendall (North Mocassin) & $\begin{array}{l}\text { Secs. } 29-32 \text {, T. } 18 \text { N., R. } 18 \text { E., Fergus } \\
\text { County, Mont. }\end{array}$ & Blixt (1933) \\
\hline Manhattan (White Caps). & $\begin{array}{l}\text { Sec. } 28 \text {, T. } 8 \text { N., R. } 44 \text { E., Nye } \\
\text { County, Nev. }\end{array}$ & Ferguson (1924), Chapman (1976) \\
\hline Mercur & $\begin{array}{l}\text { Secs. } 5-8, \text { T. } 6 \text { N., R. } 3 \text { W., Tooele } \\
\text { Utah }\end{array}$ & Butler and others (1920), Gilluly (1932), Tafuri (1976). \\
\hline Northumberland ....................... & $\begin{array}{l}\text { Sec. } 18, \text { T. } 13 \text { N., R. } 46 \text { E., Nye } \\
\text { County, Nev. }\end{array}$ & Kral (1950) \\
\hline Ogee-Pinson ............................ & $\begin{array}{l}\text { Sec. } 32 \text {, T. } 38 \text { N., R. } 42 \text { E., Humboldt } \\
\text { County, Nev. }\end{array}$ & Willden (1964), Galli and others (1976) \\
\hline Preble .................. & $\begin{array}{l}\text { Secs. } 17,18, \text { T. } 36 \text { N., R. } 41 \text { E., } \\
\text { Humboldt County, Nev. }\end{array}$ & Galli and others (1976) \\
\hline Standard & $\begin{array}{l}\text { Sec. } 35 \text {, T. } 31 \text { N., R. } 33 \text { E., Pershing } \\
\text { County, Nev. }\end{array}$ & Johnson (1977) \\
\hline Tallman (Duval) ..................... & $\begin{array}{l}\text { Sec. } 34 \text {, T. } 15 \text { S., R. } 29 \text { E., Cassia } \\
\text { County, Idaho }\end{array}$ & -- \\
\hline Windfall & $\begin{array}{l}\text { Sec. } 11 \text {, T. } 18 \text { N., R. } 53 \text { E., Eureka } \\
\text { County, Nev. }\end{array}$ & Nolan (1962), Wilson (1976) \\
\hline
\end{tabular}

1967). These data indicate that the hydrothermal activity responsible for gold mineralization postdated the igneous dikes of Jurassic and Cretaceous age by at least 90 to 100 m.y. The 57.6-m.y. age is a maximum because any inclusion of original older material from the dike would have increased the apparent age, and the sample analyzed contained only 30 to 40 percent sericite.

\section{STRATIGRAPHIC RELATIONS}

The Carlin gold deposit is situated in the northeastern part of the Lynn window in thin-bedded carbonate rocks that show a general east-westward strike and a regional dip of about $33^{\circ} \mathrm{N}$. Sedimentary rocks of the upper plate, as well as the Popovich and Roberts Mountains Formations, are well exposed in the immediate area of the deposit and within the open pits of the mine. Stratigraphic relations between these three formations throughout the deposit, shown on the preliminary map by Radtke (1973), are included here on the geologic map of the deposit (pl. 3); lithologic decriptions and chemical analyses of the rocks in these formations are given above in the section entitled "Geology."

Most of the gold ore bodies at the Carlin deposit discovered to date lie within the upper $250 \mathrm{~m}$ of the Roberts Mountains Formation. Two exceptions are (1) the east end of the East ore body, which crosses the Leeville fault and extends into calcareous shale of the upper plate; and (2) the small South Extension ore body, which occurs about 250 to $300 \mathrm{~m}$ below the top of the Roberts Mountains Formation south of the Main ore body at intersections between north-south- and northeast-striking sets of faults (pls. 1-4).

Trace to small amounts (about $0.2-0.6 \mathrm{ppm}$ ) of gold are ubiquitous throughout hydrothermally altered rocks in 
the Popovich Formation above the ore bodies in the Roberts Mountains Formation. Locally, small pods and lenses of silty laminated dolomitic limestone of the Popovich Formation contain enough gold (more than 0.07 troy oz per ton) to be of ore grade.

The overall trend of the Main and East ore zones is about N. $60^{\circ} \mathrm{E}$., parallel to the overall strike of the Roberts Mountains Formation, for a distance of about 1 1/2 $\mathrm{km}$ (pl. 1). Although the ore body in the West ore zone has strong and obvious structural controls, its strike of N. 70 $\mathrm{W}$. over a distance of about $1 / 2 \mathrm{~km}$ is close to that of the host rocks (from east-west to about N. $80^{\circ} \mathrm{W}$.)

To date, only two small gold ore bodies have been found outside the area of the Carlin deposit. One, about $1 \frac{1 / 2}{\mathrm{~km}}$ west-northwest of the Carlin deposit, is in the upper 30 $\mathrm{m}$ of the Roberts Mountains Formation below a thin sequence of highly faulted beds of the Popovich Formation. The other, which is east of the Leeville fault and about 2.3 $\mathrm{km}$ southeast of the Carlin deposit, occurs within the upper 30 to $45 \mathrm{~m}$ of the Roberts Mountains Formation. The occurrence of these two ore bodies within both areas in apparently the same stratigraphic sequence as that of the large ore bodies at the Carlin deposit reflects the stratigraphic favorability for gold deposition in that part of the Roberts Mountains Formation.

Significant tonnages of ore could occur in upper plate rocks with favorable chemical and lithologic properties near the deposit. This includes areas up to a distance of $1 / 2 \mathrm{~km}$ east-northeast of the deposit on the east side of the Leeville fault, and near the intrusive stock and dike swarms due north of the deposit (pl.1).

\section{STRUCTURAL SETTING}

The Carlin gold deposit is spatially related to both the Tuscarora Mountains anticline and certain sets of highangle normal faults (Noble and Radtke, 1978). As shown by field studies, an apparent relation of the Carlin deposit to the Roberts Mountains thrust is coincidental, and the position of the thrust has had no influence on localization of the gold ore bodies.

From a regional structural standpoint, the Carlin deposit lies near the crest of the north-northwest-striking Tuscarora Mountains anticline. Although several small ore bodies and areas of anomalous gold content have been found along the west flank and in the down-faulted east flank, most of the gold is concentrated near the crest of the anticline.

High-angle normal faulting, which has broken the range into numerous blocks, is common in lower-plate rocks near the trace of the Roberts Mountains thrust; the zone of concentrated gold mineralization occurs in an area where closely spaced faults have intensely shattered the carbonate rocks. With the possible exception of the south- western end of the Mill fault, none of the regional or major high-angle faults discussed earlier had any apparent influence on gold deposition, although the Hardie, Mill, and Leeville faults all helped to create the structural setting for the deposit.

High-angle normal faults in and near the Carlin deposit may be classified into three sets on the basis of attitude and age: (1) an early set, striking about N. $60^{\circ}-80^{\circ} \mathrm{W}$., generally dipping steeply to the north; (2) a later set, ranging in strike from about $\mathrm{N}$. $45^{\circ} \mathrm{W}$. to north-south, dipping in either direction from $60^{\circ}$ to vertical; and (3) a set of late faults, generally with only minor offsets, commonly striking N. $40^{\circ}-60^{\circ} \mathrm{E}$. and dipping between $50^{\circ}$ and $80^{\circ}$ either northwest or southeast. Because of the small offsets, many of these faults are probably best described as zones of shearing or rock shattering. Examination of the available geologic maps shows that most of the faults in set 2 cut those of set 1 and are, in turn, commonly offset by those of set 3 . Although all the faults in each set did not form during a distinct or separate interval and a limited amount of late movement has occurred on many faults, the general sequence of faulting apparently took place in the order given. P. W. West (oral communs., $1971,1973)$ suggested that many of the north-south-striking faults exposed in the mine had late movement postdating that on the other faults.

The Hardie, Mill, and Leeville faults, which are defined as regional or major high-angle normal faults, were discussed earlier in this report. Vertical movements on all three faults apparently occurred at different times, although the combined effects were to position a block of thin-bedded carbonate rock to create a structural setting favorable for the trapping of gold-bearing solutions. A minimal amount of erosion may have been required to expose the discovery outcrops.

Some, perhaps all, movement on the Hardie fault accompanied formation of the relatively late set of northeast-striking faults. Beneath Popovich Hill the Hardie fault probably served as an important channel for the hydrothermal solutions. Because the Hardie fault apparently terminates against the Mill fault in the northwest corner of the Main pit, movement on the Mill fault was probably later and either accompanied or predated major movement on the Leeville fault (pls. 1-4).

The Roberts Mountains thrust is relatively well exposed near the Carlin deposit. The thrust is draped around the east and south sides of Popovich Hill, where both the overlying upper-plate rocks and the underlying Popovich Formation show few apparent changes in thickness due to faulting (pl. 1). As a result of vertical movements on high-angle faults, notably the Hardie and Mill faults, the thrust is concealed over a distance of about 600 $m$ southwest of Popovich Hill. From the southwest end of the Main pit on the west side of the Mill fault, the thrust trends west-northwestward and is exposed in natural out- 
crops as well as in numerous faces and along the floor of the West pit (see fig. 4), where the thrust is cut and locally offset by numerous high-angle faults. Although the long horizontal dimension of the West ore body is roughly similar in strike to the trace of the thrust, the most important structural features in terms of ore controls were the sets of high-angle faults striking about parallel to the thrust (pl. 3). Because of the large number of data and the differences between the ore zones, the important features of each principal ore zone are discussed separately below.

\section{WEST ORE ZONE}

The West ore zone contains one ore body that throughout most of its length is elongate and tabular, and overall resembles a typical vein deposit. The gold-bearing zone strikes about N. $60^{\circ} \mathrm{W}$. and dips $60^{\circ}-70^{\circ} \mathrm{N}$., similar to several spatially related preore high-angle normal faults (pl. 3 ). The west end of the ore body pinches out against a gouge zone formed by a north-south-striking high-angle fault interpreted to be preore in age. From that point the ore body continues to the southeast over a horizontal distance of about $330 \mathrm{~m}$; the ore zone ranges in width from about 1 to more than $10 \mathrm{~m}$ and extends more than $120 \mathrm{~m}$ along dip. At its southeast end the ore zone widens out into an oval pipe about 25 to $30 \mathrm{~m}$ in diameter, which plunges about $70^{\circ} \mathrm{N}$. (pl. 3).

The veinlike part of the West ore body is in the hanging wall of a prominent west-northwest-striking high-angle normal fault; the footwall is made up of a highly altered fine-grained igneous dike cut locally by veins and pods of barite. This close spatial relation between altered igneous dikes and gold ore is repeated in other parts of the deposit where lateral crosscutting of the dikes by ore bodies and altered zones indicates that the mineralization postdates the dikes and that the relation is nongenetic. Narrow veins and small irregular pods of white crystalline barite occur along the west- northwest-striking faults, and two distinct veins, similar in attitude to both the igneous dike and the ore body, parallel the southern or lower contact of the dike (cross sec. A-A', pl. 4).

Two large bodies of heavily silicified limestone or jasperoid are spatially related to the east-west-striking faults. These large bodies are stratigraphically lower than the ore bodies and form tabular masses that narrow and pinch out downward near the bottom of the zone of acid leaching (cross sec. A-A', pl. 4) discussed later in this report. The relation here between areas of intense hydrothermal silicification and gold deposition resembles that in other parts of the Carlin deposit.

\section{FAULTS}

Several sets of high-angle normal faults are well exposed near the West ore body. The earliest set, which strikes east-west to about N. $60^{\circ} \mathrm{W}$. and dips steeply northward, apparently provided a main channelway for the vertical movement of hydrothermal solutions. Several individual faults form the margins of this channelway, which is characterized by intense shattering and brecciation of limestone and the presence of heavy clay-rich gouge. Except for the pipe-shaped mass of ore at the southeast end of the ore zone, the entire West ore body lies within this zone of increased porosity and permeability. In this part of the Carlin deposit the ore body shows strong structural control.

A later set of normal faults, ranging in strike from $\mathrm{N}$. $45^{\circ} \mathrm{W}$. to about north-south, locally offsets the earlier set as well as the Roberts Mountains thrust. Although map patterns of earlier faults and contacts between lithologic units cut by the younger set of faults suggest strike-slip movement (pl. 3; Radtke, 1973), these features are only apparent and reflect vertical movement on high-angle structures cutting the dipping faults and lithologic units.

The pipe-shaped mass of gold ore was formed at intersections between the two prominent sets of high-angle normal faults. The position of the concealed part of this ore body indicated by drilling information, as well as the projected positions of several of the faults at depth, shows that these intersections coincide well with the axis of the pipe and that the ore body lies in favorable beds in the upper $60 \mathrm{~m}$ of the Roberts Mountains Formation.

The time of movement on the northwest- to northsouth-striking fault set was clearly postthrusting and premineral. In the north-central part of the West pit, the emplacement of fine-grained dikes, probably Late Jurassic or Early Cretaceous, along one of these faults indicates that at least some of the faulting predates the time of emplacement.

\section{ORE CHARACTERISTICS}

Deep mineralized unoxidized rocks in both the veinlike and pipe-shaped parts of the West ore body contain relatively less carbonaceous materials than do the unoxidized parts of the East and most of the Main ore zone; analyses of 55 samples show that the organic carbon content ranges from 0.11 to 0.24 weight percent and averages only 0.18 weight percent. The primary unoxidized ores contain significant amounts of arsenic, antimony, and mercury, but sulfide minerals containing these elements are sparse. Although the average mercury content (22 ppm) in the West ore zone corresponds closely to that in the Main and East ore zones, the average contents of arsenic (222 ppm) and antimony (52 ppm) are considerably lower than in the Main and East ore zones (Harris and Radtke, 1976).

The contents of base metals and other elements, including boron, selenium, tellurium, and tungsten, are low in unoxidized ores along the West ore zone in comparison with those in the other ore zones. Harris and Radtke (1976) reported average values of $25 \mathrm{ppm} \mathrm{Cu,} 6 \mathrm{ppm} \mathrm{Mo,}$ 26 ppm Pb, 72 ppm Zn, 54 ppm B, 10 ppm W, 1.5 ppm Se, 
and less than $0.2 \mathrm{ppm}$ Te. In contrast, the average barium content $(650 \mathrm{ppm})$ is higher here than in the other ore zones.

The average gold content ( $8.7 \mathrm{ppm})$ in unoxidized ores in the West ore zone is slightly higher than in the other ore zones at the deposit. This value corresponds well to the three median values of $7.5,8.3$, and $8.6 \mathrm{ppm} \mathrm{Au} \mathrm{re-}$ ported by Harris and Radtke (1976) from statistical treatments of analyses using different numbers of samples. This average value, which is 10 to 15 percent higher than in the other ore bodies, reflects the uncommonly high gold content in the western $75 \mathrm{~m}$ of the ore zone; along the West ore zone the gold content reaches as high as $150 \mathrm{ppm}$, owing in part to confinement of the ore solutions against impermeable gouge in the preore north-south-trending normal fault at the west end of the ore body (pl. 3). In the unoxidized to weakly oxidized ores, most of the gold occurs as coatings on pyrite grains and as micrometer-size dispersed particles of metallic gold; only minor amounts of gold are associated with carbonaceous materials.

Although most of the mineralized rocks in the West ore zone were pervasively altered by oxygen-bearing solutions, significant amounts of dolomite and lesser amounts of calcite in the host rocks survived. The altered carbonate rocks along the footwall of the ore zone, as well as the mineralized rocks themselves, contain large areas whose varying shades of pink, red, and orange represent iron oxides formed by weathering of pyritic altered rocks, referred to as weathered pyritic alteration by H. T. Morris (oral commun., 1976).

Data from analyses of 80 samples of oxidized ores indicate that, except for gold, the contents of most elements in these ores differ somewhat from those in the deeper unoxidized ores. The average content of gold is $9.1 \mathrm{ppm}$. Average contents of other elements, present in smaller amounts in the oxidized relative to the unoxidized ores, include $180 \mathrm{ppm} \mathrm{As,} \mathrm{45ppm} \mathrm{Sb,} \mathrm{20ppmHg,} \mathrm{8ppmW,} 10$ ppm $\mathrm{Cu}$, and $40 \mathrm{ppm} \mathrm{Zn}$. The average content of barium increases to $1,600 \mathrm{ppm}$, and the average contents of molybdenum, lead, selenium, and tellurium do not significantly differ.

\section{MAIN ORE ZONE}

The Main ore zone includes all of the mineralized rocks along a zone $900 \mathrm{~m}$ long, trending about N. $60^{\circ} \mathrm{E}$., between the southwest end of the Main pit and mine coordinate $19,500 \mathrm{E}$. (pl. 3). Several ore bodies lying south of mine coordinate $22,000 \mathrm{~N}$, not included in the Main ore zone and here designated collectively the "South Extension ore zone," are discussed in the next section.

The central and northeastern parts of the Main ore zone contain several large connected ore bodies whose positions reflect the influence of strong stratigraphic as well as structural controls. The southwestern part of the Main ore zone contains numerous small irregular ore bodies whose longest dimensions and positions show that they are closely related to north-south-and northeast-trending high-angle normal faults. Approximately 50 to 60 percent of the gold ore in the Carlin deposit was contained within the Main ore zone.

The northeast end of the Main ore zone begins almost due south of the crest of Popovich Hill. In this area a sheetlike mass of ore, as thick as $30 \mathrm{~m}$, strikes roughly east-west, plunges $30^{\circ}-40^{\circ} \mathrm{N}$. parallel to bedding in the host rocks, and continues for a distance of more than $250 \mathrm{~m}$ downdip. Attitudes of this ore body suggest its continuation below Popovich Hill, and Larry Noble (oral commun., 1975) confirmed that mineralized rocks had been found by deep drilling beneath the south and southwest sides of Popovich Hill. This mineralized zone could well extend downdip to the Hardie fault.

Most of the ore in the northeastern part of the Main ore zone lies within a 75-m-thick section near the top of the Roberts Mountains Formation. In that area, the ore body apparently is spatially related to intersections between east-west and north-south-striking normal faults; the subsurface configuration of the ore body, however, indicates that intersections between late northeast-striking normal faults and favorable host rocks may also have influenced the sites of ore deposition. About $150 \mathrm{~m}$ west of the east end of the Main ore zone, at mine coordinate $19,000 \mathrm{E}$., the strike of this large ore body changes to N. $70^{\circ} \mathrm{E}$., and its plunge steepens slightly to $35^{\circ}-45^{\circ} \mathrm{N}$. The ore body connects with the sheetlike ore body in the central part of the Main ore zone below the 6,420 bench (cross sec. B-B', pl.4).

A series of small oval to tabular ore bodies occur along the south margin of the Main ore zone between mine coordinates 18,500 and $19,500 \mathrm{E}$. These ore bodies formed along northwest- to north-south-striking high-angle normal faults and exhibit strong structural controls (pl. 3). Tabular bodies of jasperoid associated with these faults are common in this part of the deposit. One particularly large ore body, with a strike length of $90 \mathrm{~m}$, lies between mine coordinates 18,500 and $18,750 \mathrm{E}$., strikes N.25 $\mathrm{W}$., and connects with the main sheetlike ore body southwest of Popovich Hill (pl. 3). This ore body is spatially related to a pair of closely spaced faults, one of which contains a vein of barite. The position of this southwestern limb or southwestward extension of the main body of mineralized rocks is controlled by these faults and another pair of northwest-trending normal faults at mine coordinate 18,800 E. (pl. 3).

The large ore body in the central part of the Main ore zone joins the sheetlike ore body in the northeastern part of the zone to form a continuous mass of mineralized rock, more than $450 \mathrm{~m}$ long, that extends from the south side of Popovich Hill to the center of the Main pit. In the central area the ore body reaches a maximum thickness of more 
than $90 \mathrm{~m}$, strikes roughly $\mathrm{N} .45^{\circ} \mathrm{E}$., and plunges $45^{\circ}-$ $50^{\circ} \mathrm{NW}$. In horizontal section the ore body may be described as an irregular tabular body with a long dimension that strikes $\mathrm{N} .25^{\circ} \mathrm{W}$. parallel to a conspicuous dike-filled fault zone and plunges northwest parallel to the fault (cross sec. B-B', pl. 4). The position and shape of this ore body indicate that the prominent dike- filled northwesttrending fault zone, which also contains a large intermittent postdike barite vein, served as a main channel for ore solutions and provided an important structural control on ore deposition (cross sec. B-B', pl. 4).

A small tabular body of ore about $90 \mathrm{~m}$ long, in the hanging wall of a normal fault extends $\mathrm{S} .20^{\circ} \mathrm{W}$. from the larger ore body. This small body widens out and turns northward to form a continuous fishhook-shaped ore body near the intersection between the northeast-trending normal fault and numerous strong normal faults trending N. $10^{\circ}$ W. to north-south (pl. 3).

The southwestern part of the Main ore zone is made up of a tabular body of ore that begins near the intersection of mine coordinates $18,000 \mathrm{E}$. and $22,000 \mathrm{~N}$., strikes N. $60^{\circ} \mathrm{E}$., dips $50^{\circ}-70^{\circ} \mathrm{NW}$, and continues for about $400 \mathrm{~m}$ to the southwest (pl. 3). Although this ore body is about $30 \mathrm{~m}$ thick along most of this distance, near mine coordinate $17,500 \mathrm{E}$. it thickens to more than $45 \mathrm{~m}$ in response to extreme shattering of the host rocks caused by intersections between numerous northwest- to north-southtrending faults and one or more northeast-trending faults (pl. 3). Southwest of mine coordinate 17,300E., the ore zone progressively thins and pinches out against zones of heavy gouge and breccia composed of silicified and clayrich altered limestone near the intersection of mine coordinates $21,500 \mathrm{~N}$. and $16,800 \mathrm{E}$. The constricted part of the ore zone consists of a series of small ore bodies spatially related to the northeast-striking high-angle normal faults; the longest dimensions of these ore bodies parallel the trend of the faults and plunge parallel to their dip (pl. 3; Radtke, 1973).

Massive bodies of jasperoid were formed along conspicuous north-south-striking high-angle normal faults near the southwest end of the Main ore zone, close to the areas of gold deposition. These bodies of heavily silicified carbonate rocks are spatially and genetically related to the gold mineralization; although they lie stratigraphically below the zone of gold deposition, they are spatially higher and border the gold ore bodies, and appear to narrow and pinch out near the bottom of the zone of acidleaching alteration. Most of the jasperoid bodies were probably formed during the late hydrothermal stage accompanying acid leaching.

\section{STRUCTURES}

Structural conditions within the Main ore zone are complex. Many structures within the ore zone are better ex- posed in areas close to but outside the ore bodies. Major structural features exposed near the Main ore zone, including the Roberts Mountains thrust and the Hardie and Mill faults, have been discussed in the preceding section of this report. However, structural features that controlled the positions of ore deposition along this zone include sets of high-angle normal faults and intersections between these faults within the upper $250 \mathrm{~m}$ of the Roberts Mountains Formation.

The Roberts Mountains thrust did not influence the localization of ore in the Main ore zone. The thrust is exposed along the north wall near the southwestern end of the Main pit, where the thrust surface, dipping $50^{\circ}-$ $60^{\circ} \mathrm{NW}$., is locally displaced by high-angle normal faults and terminates against the Mill fault (pl. 3; Radtke, 1973). Hausen (1967, p. 14, fig. 3; p. 19, fig. 9) and Evans (1974a) showed that the Roberts Mountains thrust crops out approximately parallel to the Main ore zone for a distance of 275 to $300 \mathrm{~m}$ to the northeast beyond its termination against the Mill fault-an observation that, in turn, erroneously suggested a possible genetic relation between ore bodies and the thrust.

The Mill fault, which is classified as a regional or major high-angle normal fault, is well exposed along the west wall of the Main pit. This large structure had no apparent influence on gold deposition except where it intersects or crosses the southwest end of the Main ore zone, near mine coordinates $22,000 \mathrm{~N}$. and 17,500 E. (pl. 3). Ore occurs along the fault over a distance of 210 to $240 \mathrm{~m}$, and the fault branches into several strands separated by zones of extreme brecciation. Ore bodies in this area were formed along these northeast-trending faults, at intersections between north-south- and northeast-trending faults, and within highly shattered intervening areas (pl. 3).

The Hardie fault was important in creating the structural setting for the deposit but provided no structural control on the position of the ore bodies in the upper part of the deposit. The ore bodies in the northeastern and central parts of the Main ore zone plunge north to northwest toward the fault. By displacement of favorable beds in the upper part of the Roberts Mountains Formation, the subsurface position of the Hardie fault may represent the maximum possible downdip extension of the Main ore zone (cross sec. C-C', pl. 4).

Although minor late movement may have occurred along the Hardie fault, strong evidence indicates that this fault is a premineral feature. Bodies of jasperoid were formed along the footwall and within the fault zone, and hydrocarbons mobilized by hydrothermal fluids were introduced locally into heavily brecciated areas. Although no ore bodies have been found along the Hardie fault, detection of anomalous amounts of gold, mercury, and arsenic in samples of gouge and jasperoid along the fault zone suggests that the hydrothermal solutions moved along at 
least the shallower parts of the fault. If the ore solutions penetrated upward along the fault and subsequently moved updip through the upper beds of the Roberts Mountains Formation concealed below Popovich Hill, then steeply plunging hi-grade disseminated-replacement ore bodies conforming to the attitude of the Hardie fault could exist at deeper levels. Examples of this type of structurally controlled ore body include the West ore body at Carlin, described in this report, and the ore bodies in the Getchell deposit.

The three sets of high-angle normal faults, described above in the subsection entitled "Structural Setting," are well exposed throughout the Main pit. Within this area, generally consistent offset relations between faults suggest that each set may represent different episodes of movement, although all the faults are preore. Faults in the earliest set, striking roughly east- west, are present in the northeastern end of the Main ore zone and continue westward along the northern part of the Main pit. Many of these faults contain veinlike bodies of white crystalline barite that lack any associated sulfides within $55 \mathrm{~m}$ of the surface. The barite veins appear to pinch out horizontally, and the east-west-striking faults terminate near the eastern end of the Main ore zone; both features terminate to the west in the northwestern part of the Main pit (pl. 3).

Several faults that belong to this early set but strike about N. $60^{\circ} \mathrm{W}$. cross the southwest end of the Main pit. These faults, which represent the continuation of structures with the same strike, are well exposed in the West pit, where they provided important ore controls.

Numerous high-angle normal faults, striking between N. $20^{\circ} \mathrm{W}$. and north-south, shattered and locally offset the lower-plate carbonate rocks along the Main ore zone before ore deposition. The extent of displacement on most of these faults in unclear; however, along the southwest side of Popovich Hill and near the east end of the Main ore zone, measured offsets on earlier faults and at lithologic contacts indicate that in these areas the vertical displacement was generally less than $30 \mathrm{~m}$. Displacement on one north-south-striking fault running across the west side of Popovich Hill positioned shale beds of the upper plate against chert-shale-quartzite beds east of the fault (pl. 3). The extent of displacement on this fault could be as much as $90 \mathrm{~m}$. Near the east end of the Main ore zone, closely spaced faults, generally striking N. $20^{\circ} \mathrm{W}$. to north-south, have been traced from the south edge of the Main pit, northward through the Main ore zone, into overlying limestone units of the Popovich Formation on the south and southwest sides of Popovich Hill (Radtke, 1973). These faults offset the earlier east-west-striking set and are themselves offset to a small extent locally by some of the northeast-trending faults ( $\mathrm{pl} .3$ ). Intersections between the east-west- and north-south-striking normal faults provided important structural controls on ore deposition in the northeastern part of the Main ore zone.

The southern edge of the massive sheet of ore at the east end of the Main ore zone breaks up into many small ore bodies spatially associated with the north-southtrending faults within the area bounded by mine coordinates $18,500-19,500 \mathrm{E}$. and $22,000-22,300 \mathrm{~N}$. (pl. 3). The positions of these small ore bodies, as well as the extreme brecciation in mineralized areas along the faults, in contrast to that in barren rocks, show that these faults served as channels for the hydrothermal solutions and controlled the positions of ore deposition.

The central part of the Main ore zone also contains many high-angle normal faults and shear zones, ranging in strike from $\mathrm{N} .30^{\circ} \mathrm{W}$. to north-south. One particularly prominent fault in this set probably served as the main channel for the hydrothermal ore solutions and was the single most important structural control for the central part of the Main ore zone. Along the south wall of the Main pit this shear zone consists of several closely spaced faults, separated by zones of heavily brecciated altered limestone and small irregular jasperoid bodies. The intense alteration and local offset of the dike emplaced along the Main ore zone indicate minor postintrusive movement along the shear zone.

From the surface at the top of the south wall the dikefilled fault, striking N. $20^{\circ}-25^{\circ} \mathrm{W}$., continues over a horizontal distance of about $360 \mathrm{~m}$ through the central ore body in the Main ore zone and terminates against the Hardie fault in the northwest corner of the Main pit (pl. 3). From southeast to northwest the fault zone narrows progressively from more than 18 to less than $3 \mathrm{~m}$, the numerous parallel faults merge into a single fault, and the dike narrows to less than $1.5 \mathrm{~m}$ (width exaggerated in $\mathrm{pl}$. 3). Small stringers and pods of barite locally fill fractures in the dike. For a distance of about $60 \mathrm{~m}$ through the center of the Main ore zone, a massive vein of barite, as wide as $1 \mathrm{~m}$, in contact with the dike occurs along the hangingwall side of the fault (pl. 3; Radtke, 1973). This occurrence of massive barite along the margin of a dike-filled fault adiacent to gold ore resembles that in the veinlike part of the West ore body. The dike and the important northwesttrending structure are shattered or offset locally by late northeast-trending faults.

Sets of parallel high-angle faults and shear zones, striking between about $\mathrm{N} .25^{\circ} \mathrm{W}$. and N. $5^{\circ} \mathrm{E}$., are well exposed along the south wall of the Main pit both east and west of the dike-filled fault zone. Near mine coordinate $18,200 \mathrm{E}$., zones of heavy brecciation along numerous parallel faults, trending $\mathrm{N} .10^{\circ} \mathrm{W}$. to north-south, as well as intersections between these and other, northeast-trending faults, provided the favorable structural conditions for the southwestward extension of hydrothermal mineralization in the Main ore zone (pl. 3). As described above, the tabular 
southwestern part of the Main ore zone, west of mine coordinate $17,500 \mathrm{E}$. is structurally controlled by intersections between the numerous northwest- to north-southtrending and one or more northeast-trending faults. Although the northeast-trending fault between mine coordinates 17,500 and $18,000 \mathrm{E}$. generally is poorly exposed in the floor of the pit, the longest dimension of the ore body (trending $\mathrm{N} .45^{\circ} \mathrm{E}$.) and the absence of continuity in faults exposed in the pit walls north and south of the fault confirm its presence.

The hydrothermal solutions probably followed the northeast-trending fault to form the tabular ore body. In areas where northwest- to north-south-striking faults intersected the structure, the solutions spread outward into the shattered footwall and moved upward and laterally to the south to form small ore bodies along the north-southtrending high-angle faults.

Several types of intense alteration in carbonate rocks along the south wall of the Main pit west of the dike-filled fault (see pls. 3-6) are spatially related to the northwestand north-south-striking faults. Although most of the faults were preore, offset boundaries between alteration zones and the presence of some postalteration brecciation indicate that a limited amount of late movement took place along some of these faults.

The youngest high-angle normal faults in the area of the Main ore zone belong to the set trending $\mathrm{N} .40^{\circ}-60^{\circ} \mathrm{E}$. These faults are characterized by: (1) a limited amount of vertical movement, generally less than $6 \mathrm{~m}$ and commonly grading into breccia or shear zones lacking recognizable offsets; (2) heavy zones of brecciation and gouge locally formed along the borders; and (3) an important structural control on ore deposition along the northeastern and southwestern parts of the Main ore zone. At least three, and possibly more, faults of this set, all displaying a limited amount of vertical movement, parallel the Hardie fault and cross the northwest corner of the Main pit (Radtke, 1973). Although the Hardie fault is a member of the set of late northeast-trending normal faults, it is here designated a regional or major high-angle fault because of its great extent of vertical movement.

\section{ORE CHARACTERISTICS}

Oxidized gold ores occur in large amounts along the entire length of the Main ore zone, and deep sections in the central and northeastern parts contain significant tonnages of primary unoxidized ores. General features of the gold ores along this zone are described below, and detailed information on the chemistry and mineralogy of the different ore types are presented in later sections of this report.

Unoxidized ores of the Main ore zone are characterized by widely varying amounts of fine-grained quartz and pyrite, and an extremely wide variation in the content of organic carbon (Harris and Radtke, 1976). Analyses of 85 samples from throughout the Main ore zone show that the content of organic carbon ranges from 0.15 to 0.85 weight percent and averages 0.38 weight percent; these data do not include several areas in the central part of the zone where the organic carbon content ranged from 1.5 to 5.0 weight percent owing to apparent introduction of hydrocarbons by hydrothermal fluids (Radtke and Dickson, $1974 \mathrm{~b}, 1975 \mathrm{~b})$. The content of organic carbon is lower in the host rocks and ores in the southwestern part of the Main ore zone, and generally increases to the northeast through the central and northeastern parts.

Physically, most of the primary unoxidized ores closely resemble normal fresh rock of the Roberts Mountains Formation. These ores are thin bedded and medium to dark gray; except for scattered grains of pyrite, they lack visible sulfide minerals. Although the mineralized rocks are slightly less calcareous and more siliceous than the fresh rocks, whether or not they have been mineralized can be established only by analysis for gold.

The average content of gold in the unoxidized ores was determined to be $7.1 \mathrm{ppm}$, a value corresponding closely to the three values of $6.5,6.9$, and $6.9 \mathrm{ppm}$ Au reported by Harris and Radtke (1976). The average gold content in the Main ore zone (7.1 ppm) is close to that in the East ore zone $(7.4 \mathrm{ppm})$ and slightly less than that in the West ore zone $(8.7 \mathrm{ppm})$.

Most of the gold in unoxidized ores of the Main ore zone occurs either as coatings on grains of pyrite or in association with carbonaceous materials; very minor amounts are present as fine metallic particles (Radtke and others, 1972b). More recent studies have indicated that in samples containing little organic carbon, collected from both the central and northeastern parts of the zone, most of the sparse fine particles of metallic gold are dispersed in hydrothermal quartz, or are dispersed through or associated with clay minerals.

Data on mercury, arsenic, and antimony, reported by Harris and Radtke (1976), show that the average mercury content in the Main ore zone (20ppm) closely resembles that in both the West and East ore zones. In contrast, the average contents of both arsenic ( $490 \mathrm{ppm})$ and antimony (106 ppm) in the Main ore zone indicate that these elements are enriched by a factor of 2 over their average contents in the West ore zone but are depleted somewhat from their average contents in the East ore zone.

Except for arsenic, antimony, and selenium (0.9 ppm), the average contents of most other hydrothermally introduced minor elements are higher in unoxidized ores of the Main ore zone than in either the West or East ore zones. Average values for these elements, reported by

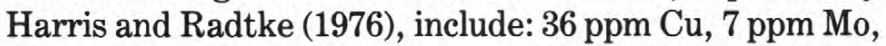
49 ppm Pb, 193 ppm Zn, 85 ppm B, 17ppmW, and 0.4 ppm Te. Excluding samples containing abnormally large amounts of barium derived from fragments of late barite veins, the average content of barium in the ore $(500 \mathrm{ppm})$ 


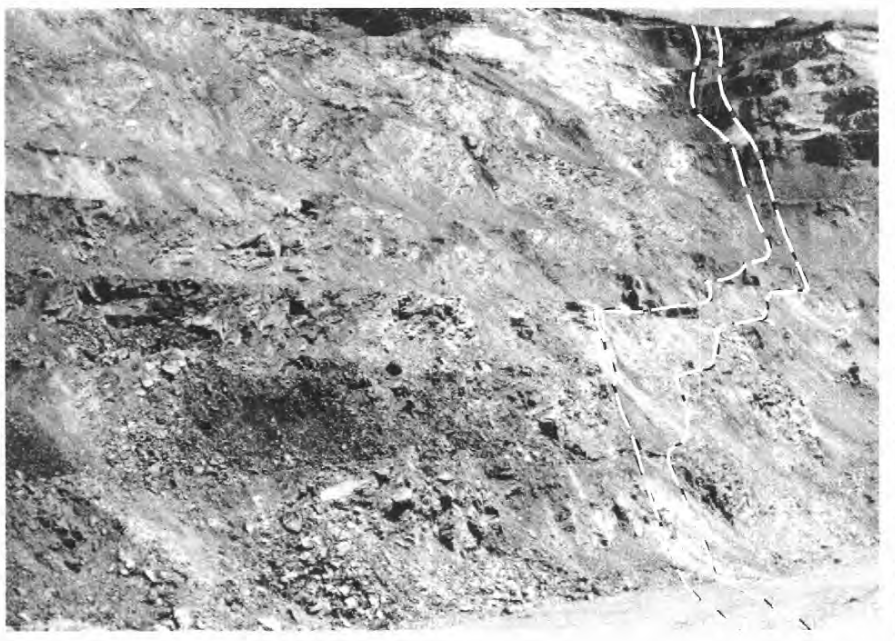

FIGURE 9,-Typical features in gold ores at base of supergene-oxidation zone in Main pit. All rocks shown are of the Roberts Mountains Formation. Dark zones on lower benches are unoxidized gold ores overlain by unleached oxidized ore. Dashed lines denote position of prominent igneous dike within important ore-solution-feeder fault zone. White areas along dike on lower benches are late barite. White areas in background at upper right are acid-leached zones.

reflects the general systematic decrease in barium content from west to east through the entire Carlin deposit.

The central part of the Main ore zone contains heavy local concentrations of pyrite, organic carbon, and various sulfides, predominantly those of arsenic. Detailed descriptions of the mineralogy and chemistry of the different types of gold ore, which are less abundant in the Main than in the East ore zone, are given in later sections of this report.

Throughout most of the southwestern and central parts of the Main ore zone the depth of supergene oxidation ranges from 90 to $120 \mathrm{~m}$ below the present land surface. The depth of this alteration in the eastern part of the Main ore zone ranges from about 60 to $90 \mathrm{~m}$ but locally reaches to greater depths along fault and breccia zones. Figure 9 shows the typically narrow boundary zone between oxidized and unoxidized gold ores in the central part of the Main ore zone.

The oxidized ores along the Main ore zone are composed of widely varying amounts of clay, fine-grained quartz, and minor remnant carbonates, mainly dolomite. Important changes due to oxidation include: destruction of sulfide minerals and carbonaceous materials; additional removal of calcite (previously depleted during hypogene alteration); formation of pink, red, and pale-red- brown zones by oxidation of pyrite; and bleaching of the rocks to tan and light gray. All these features are conspicuous in shallow rocks along the Main ore zone.

Analyses of 150 samples of oxidized ores systematically collected along the entire Main ore zone indicate that the average content of gold is $9.0 \mathrm{ppm}$, slightly higher than in the deeper, unoxidized ores. Although most other minor elements of hydrothermal origin are somewhat more abundant in ores of the Main ore zone than of the West ore zone, the changes in their abundance with oxidation show similar trends. Barium content (1,500 ppm) is slightly higher in oxidized than in unoxidized ores, and the average abundances of other elements are lower; these averages include: $380 \mathrm{ppm} \mathrm{As,} 95$ ppm Sb, 18ppmHg, 12 ppm W, 25 ppm Cu, 95 ppm Zn, 30 ppm Pb, 3 ppm Mo, 0.4 ppm Se, and less than $0.2 \mathrm{ppm}$ Te.

\section{SOUTH EXTENSION ORE ZONE}

The South Extension ore zone includes the mineralized rocks within the area bounded by mine coordinates $19,000-20,200 \mathrm{E}$. and 21,000-22,000 N. (pl. 3). The shape and position of the ore zone suggest that it represents a structurally defined extension of the east end of the Main ore zone (Radtke, 1973).

Most of the ore discovered to date in the South Extension ore zone occurs at its south end. The tabular ore body there is about 15 to $20 \mathrm{~m}$ thick and plunges about $20^{\circ} \mathrm{NW}$. In plan view, this ore body narrows to the north, where three or more northeast-trending faults appear to merge into a single fault, and progressively widens to the southwest, where these faults fan out from the main fault (pl. $3)$. Two other small ore bodies occur in the northeastern part of the ore zone (pl. 3).

Although only a small amount (less than 1 percent) of the total ore in the Carlin deposit was contained in the South Extension ore zone, the well- exposed geologic features within this area provide exceptionally good evidence of the close spatial relations between the positions of ore bodies, jasperoid, and high-angle normal faults.

\section{STRUCTURES}

The principal ore body as well as the two smaller ore bodies are in limestone adjacent to high-angle normal faults, striking about $\mathrm{N} .40^{\circ}-50^{\circ} \mathrm{E}$. Most of the ore occurs in extremely shattered rocks in areas characterized by the presence of numerous closely spaced northeast-trending faults or by the intersections of these faults with earlier N.20 W.- to north-south-trending faults (pl. 3). Although both sets of faults are preore and gouge within the faults is mineralized, the presence locally of brecciated iasperoid fragments in the gouge suggests some late movement along both fault sets.

Several closely spaced faults connect the north end of the principal ore body in the South Extension ore zone with the east end of the Main ore zone. Small bodies of gold ore occur along these faults, and jasperoid bodies, as thick as $6 \mathrm{~m}$, along and between these faults as well as within the principal ore body contain small amounts of gold. These structures probably served as channelways allowing some hydrothermal solutions to move outward 
from the main area of hydrothermal activity into adjacent areas favorable for ore deposition.

\section{ORE CHARACTERISTICS}

All the ore discovered to date within the South Extension ore zone has been oxidized. Owing to the relatively small size of the ore bodies and the unavailability of rotary-drill-hole samples, no statistical study of these ores has been done. Information on the ores is based on studies of 20 hand specimens collected by both the author and the staff of the Carlin Gold Mining Co.

The gold ores in this zone contain remnant dolomite and calcite. Fine particles of metallic gold are dispersed throughout mixtures of fine-grained quartz, illite, and minor kaolinite, and a lesser amount is dispersed in small grains of hydrothermal quartz. Jasperoid bodies within and along the margins of the ore zone locally contain small amounts of gold, both as dispersed particles and as coatings on small pyrite grains. Fine particles of metallic gold, mixed with various iron oxide minerals (predominantly hematite), occur sporadically along the closely spaced northeast-trending faults at the western limit of the principal ore body (pl. 3).

The content of gold in the 20 samples collected ranges from 2 to $6 \mathrm{ppm}$ and averages $3 \mathrm{ppm}$, values corresponding well to the average value of 0.12 troy oz of gold per ton (4ppm Au) from ore mined in this zone. These values indicate that the average gold content in the South Extension ore zone is significantly lower than in the other ore zones of the Carlin deposit.

The average contents of elements closely associated with gold are also lower than in oxidized ores of the Main ore zone and include $250 \mathrm{ppm} \mathrm{As,} 50 \mathrm{ppmSb}$, and $10 \mathrm{ppm}$ $\mathrm{Hg}$. Average abundances of additional elements include 8 ppm W, 15 ppm $\mathrm{Cu}, 30$ ppm Zn, 15 ppm $\mathrm{Pb}$, and 2 ppm Mo; selenium and tellurium were not determined.

Small veins of barite in faults lie close to but outside the ore bodies, and the average barium content in ore samples is $800 \mathrm{ppm}$. Except for small scattered remnant grains of pyrite in jasperoid, no sulfide minerals were identified in either the ores or altered rocks. No igneous dikes were exposed within the workings or in surface outcrops during mapping of that part of the deposit.

\section{EAST ORE ZONE}

The East ore zone includes the mineralized zone that begins south of Popovich Hill and east of mine coordinate $19,500 \mathrm{E}$. and continues to the northeast for a distance of about $730 \mathrm{~m}$ (pl. 3; Radtke, 1973). On the basis of location, ore controls, and chemical compositions, the ores within the East ore zone are here divided into two principal ore bodies.

The larger principal ore body is an irregular elongate tabular mass of mineralized rock, overall resembling a fishhook. The body extends from the intersection between mine coordinates $23,000 \mathrm{~N}$. and 20,200 E., continues along a zone trending about N. $20^{\circ} \mathrm{E}$. over a distance of $375 \mathrm{~m}$, and then turns eastward about 90 to $120 \mathrm{~m}$ (pl. 3). All the known ore bodies along the East ore zone are in the upper $90 \mathrm{~m}$ of the Roberts Mountains Formation, except for one small pocket of ore in calcareous shale of the upper plate on the hanging- wall side of the Leeville fault, several small zones in thin-bedded dolomitic limestone in the lower zone of the Popovich Formation, and several other small tabular bodies along dike-filled faults southeast of and downsection from the principal ore bodies.

The horizontal axis of the East ore zone parallels the strike of the host rocks, even in the northeastern part, where the strike of the host rocks changes to east-west, possibly at least partly owing to drag in beds near the Leeville fault. The degree and direction of plunge of the larger ore body correspond closely to the dip of the host rocks. Near the southwest end the plunge is approximately $35^{\circ} \mathrm{NW}$.; farther northeast it steepens to about $45^{\circ} \mathrm{W}$. (cross sec. D-D', pl. 2) and changes progressively to about $50^{\circ}-55^{\circ} \mathrm{N}$. along the northeastern limb.

The westward plunge of the larger ore body suggests that the mineralized zone should continue beneath the east side of Popovich Hill (cross sec. D-D' , pl. 4). Projected intersections of ore-controlling structures, including northwest-trending dike-filled faults and weak northeast-trending faults, with the upper part of the Roberts Mountains Formation beneath the east side of Popovich Hill would be favorable areas for gold deposition.

The second principal ore body, which lies at the southwest end of the East ore zone, is a thick continuous pipeshaped mass of mineralized carbonate rock, about $60 \mathrm{~m}$ wide at its southwest end, that narrows to $12 \mathrm{~m}$ wide to the northeast and plunges about $30^{\circ} \mathrm{NE}$. (pl. 3). In several areas in the southwestern part of the ore zone, small isolated bodies of mineralized carbonate rock occur along faults (Radtke, 1973).

\section{STRUCTURES}

In the East ore zone, the shapes and attitudes of the ore bodies reflect an overall stratigraphic control or influence on gold deposition. The positions of these ore bodies, however, indicate that strong structural controls were superimposed on the host rocks by two sets of high-angle normal faults —one strong set striking about N. $40^{\circ}-45^{\circ} \mathrm{W}$. and another, weaker set ranging in strike from northsouth to N.40 E.-both of which displace earlier faults. Fine-grained igneous dikes along at least five of the earlier northwest-trending faults are also offset slightly (generally less than $6 \mathrm{~m}$ ) by movement on the north-southto northeast-striking faults (pl. 3; Radtke, 1973). 


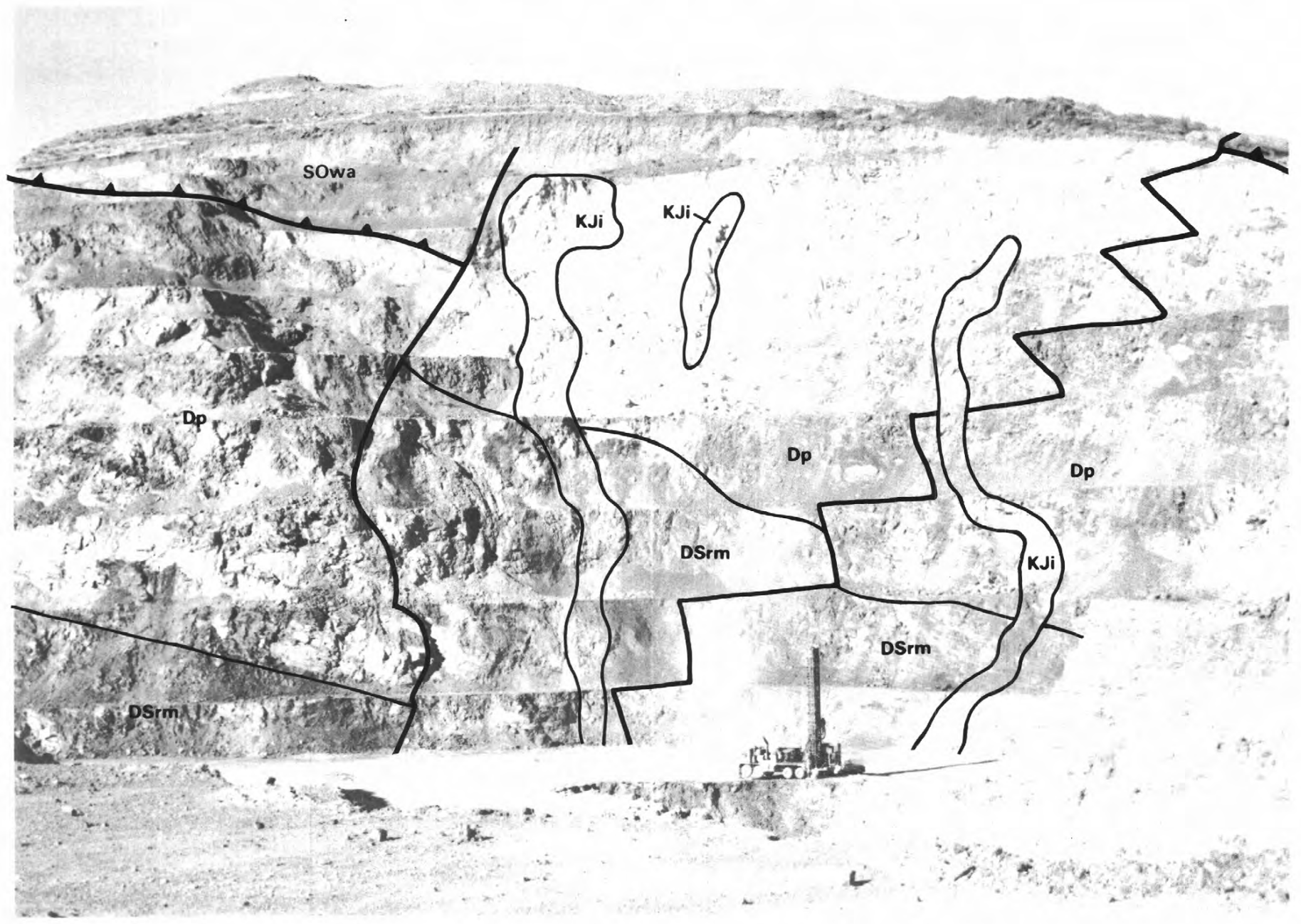

FIGURE 10.-Horst structure on east side of Popovich Hill, created by vertical displacement on steeply dipping high-angle normal faults. Units shown include upper-plate rocks (SOwa), Popovich Formation (Dp), and Roberts Mountains Formation (DSrm). White areas within horst are acid-leached oxidized limestone and talus of prominent poorly exposed igneous dikes (KJi). Note truck-mounted rotary drill operating in East ore body.

Near the East ore zone are a few early normal faults ranging in strike from east-west to N. $75^{\circ} \mathrm{W}$. Only in two areas has there been sufficient movement on these faults to contribute significantly to the overall structural controls (pl. 3). The first area, at the north end of the East pit, contains two conspicuous faults. The Roberts Mountains thrust terminates against the footwall of the more northerly fault, which strikes about N. $60^{\circ} \mathrm{W}$. On the north or hanging-wall side, a vertical movement of more than $90 \mathrm{~m}$ causes the thrust to be concealed (pl. 3). The other fault, which strikes about east-west and is about $50 \mathrm{~m}$ to the south, displaces the Popovich Formation-Roberts Mountains Formation contact by about $90 \mathrm{~m}$ of apparent right-lateral movement (pl. 3) that placed unfavorable massive limestone beds of the Popovich against favorable units in the Roberts Mountains Formation and locally set a northern limit to mineralization.
The second area, about $150 \mathrm{~m}$ southwest of the north end of the East pit, contains at least three closely spaced east-west-striking normal faults, well exposed along the pit walls on the east side of Popovich Hill (pl. 3). The southernmost of these three faults forms the south margin of a horst, which is wedge shaped in plan (fig. 10). Apparent left-lateral movement on the fault probably is due mainly to more than $150 \mathrm{~m}$ of vertical movement of westdipping beds and subsequent erosion and mining. Another parallel fault, about $20 \mathrm{~m}$ to the north, within the horst contains a highly altered igneous dike that represents the continuation of a conspicuous igneous body emplaced along a northwest-trending fault. The apparent westward change in trend of the dike at the point of intersection between the faults, following the east-west-striking fault, shows that both structures were formed before the period of igneous intrusion. 
The strong set of faults provided important structural controls on ore deposition and apparently served as channels for the ore solutions. Spatial relations between the dike-filled faults and the large fishhook-shaped ore body, as well as the shape of the ore body near these structures, show that the ore solutions probably moved upward along the faults and spread laterally through the favorable shaly limestone in the upper part of the Roberts Mountains Formation (pl. 3; Radtke, 1973); in some areas the lateral movement of solutions apparently followed north-southto northeast-trending faults. Jasperoid bodies related to north-south-trending faults lie stratigraphically below and along the lower margins of the tabular East ore body (pl. 3), in the same spatial relation as along the south edge of the Main ore zone.

The horizontal dimensions and plunge of the pipeshaped body of ore at the southwest end of the East ore zone indicate that it plunges to the northeast along several parallel closely spaced northeast-trending faults (pl.3); the ore body also widens and thickens along these northwest-trending faults. These features suggest that the ore solutions moved upward along parallel structures from northeast to southwest and spread laterally along northwest-trending faults. The constricted part of the ore body plunging northeast could connect with the westplunging part of the larger ore body beneath the east side of Popovich Hill.

\section{ORE CHARACTERISTICS}

Primary unoxidized ores in the East ore zone are characterized by extremely wide variations in chemical and mineralogic compositions, an abundance of sulfide minerals, an overall enrichment or introduction of hydrocarbons and numerous hydrocarbon-rich zones, and only small amounts of barite. Except for a paucity of sulfide minerals and a lower content of organic material, the oxidized ores show these same features. Approximately half the ore developed to date in the larger ore body is unoxidized, and 70 to 80 percent of the ore in the smaller, pipe-shaped ore body at the southwest end of the zone is unoxidized.

The average content of organic carbon in unoxidized ores is significantly larger in those of the East ore zone than in most other parts of the deposit; this is probably due to introductioin of some hydrocarbons by hydrothermal solutions throughout the zone and to large concentrations of these materials locally throughout the southwestern part of the ore zone (pl.3). Harris and Radtke (1976) reported that most samples of unoxidized ores from the East ore zone contain 0.5 to 1.0 weight percent organic carbon; however, samples from areas of heavy enrichment contain as much as 8.0 weight percent organic carbon. Comparison of data from 75 individual samples shows that the content of organic carbon in mineralized rocks increases progressively from the northeastern part of the ore zone (avg 0.2-0.4 weight percent), through the central part (avg 0.4-0.7 weight percent), to the southwestern part (avg 0.8 to more than 1.0 weight percent). A total of 50 samples analyzed from the southwestern part of the ore zone contained 2.0 to 5.0 weight percent organic carbon (A. S. Radtke, unpub. data, 1972).

The content of gold in 110 samples of unoxidized mineralized limestone from the East ore zone averaged $7.4 \mathrm{ppm}$. On the basis of varying numbers of samples, Harris and Radtke (1976) reported values of 6.4, 7.2, and $7.2 \mathrm{ppm} \mathrm{Au}$. Many elements are more abundant in the East ore zone than in the other ore zones; the average gold content $(7.4 \mathrm{ppm})$, however, compares closely with that in the Main ore zone (7.1 ppm) but is lower than that in the West ore zone ( $8.7 \mathrm{ppm}$ ).

Most of the gold in unoxidized ores along the East ore zone is associated both with subhedral cubic and spheroidal or framboidal grains of pyrite and with carbonaceous materials. Minor amounts of gold occur in realgar, either as fine metallic particles or in solid solution, and small sparse grains of metallic gold occur locked in fine-grained hydrothermal silica. No discrete particles of metallic gold have been recognized dispersed in other materials in the ores. Small particles of metallic gold associated with pyrite are present in small quartz veinlets in several areas; small amounts of fluorite and frankdicksonite $\left(\mathrm{BaF}_{2}\right)$ have also been identified in these quartz veinlets (Radtke and Brown, 1974).

Data reported by Harris and Radtke (1976) indicate that the contents of arsenic and antimony average 590 and $155 \mathrm{ppm}$, respectively, in unoxidized ores of the East ore zone. These values are significantly higher than those in the Main and West ore zones, although the content of mercury $(21 \mathrm{ppm})$ is about the same. The much lower average content of barium $(300 \mathrm{ppm})$ in the East ore zone than in the other ore zones reflects both the smaller amount of barite dispersed throughout the limestone and the infrequency of barite veins. The average selenium content (1.8 $\mathrm{ppm})$ rather resembles that in the West ore zone (1.5 ppm) and is higher than that in the Main ore zone $(0.9 \mathrm{ppm})$. The average contents of other elements include: $33 \mathrm{ppm} \mathrm{Cu}$, 5 ppm Mo, 20 ppm Pb, 177ppmZn, 84 ppm B, 10 ppm W, and $0.2 \mathrm{ppm} \mathrm{Te}$. Comparison of these data with those for the other ore zones suggests that these elements are less abundant in the East than in the Main ore zone but generally are more abundant than in the West ore zone.

Realgar is sporadically distributed in unoxidized rocks throughout the East ore zone. Near the southwest end of the elongate fishhook-shaped ore body and throughout the deeper parts of the pipe-shaped ore body, large amounts of coarse-grained realgar occur in both mineralized and barren limestone enriched in organic carbon. Lesser amounts of orpiment and stibnite are present along the East ore zone, and coarse-grained stibnite occurs filling open spaces in small bodies of heavily silicified brecciated limestone. 
The pipe-shaped ore body at the southwest end of the East ore zone has been informally referred to as the "garbage can" ore body by several geologists, owing to the presence there of large amounts of sulfide minerals and the abnormally high local enrichment in numerous elements, including mercury, arsenic, antimony, lead, zinc, and thallium. Mineralized rocks in this part of the deposit commonly contained more than 30,000 ppm (3 weight percent) As, 5,000 ppm Sb, 2,000 ppm Zn, 1,000 ppm Pb, and $500 \mathrm{ppm}$ Tl. The mineralogy of this ore body is described in the next section.

The depth of oxidation along most of the East ore zone is slightly shallower than in other parts of the deposit. The boundary separating oxidized from unoxidized ores generally lies about 60 to $75 \mathrm{~m}$ below the surface; locally the oxidation reaches as deep as $90 \mathrm{~m}$ in shattered rocks along fault zones. This selective fault-controlled oxidation is clearly shown in the pipe-shaped ore body, in which late oxidation proceeded to a depth of more than $60 \mathrm{~m}$ along closely spaced parallel northeast-striking faults that created a tabular core of oxidized ore surrounded by unoxidized ore (pls. 3, 7; Radtke, 1973).

The mineralogy of the oxidized ores in the East ore zone generally resembles that of other parts of the deposit. The bulk of the rocks are composed of fine-grained quartz, clay (mainly illite), and remnant carbonate minerals. Although dolomite is the dominant mineral, significant amounts of remnant calcite are abundant locally.

The arsenical ores commonly contain abnormally large amounts of certain minor elements, including barium, copper, mercury, antimony, thallium, tungsten, and zinc. Small amounts of barite are associated with realgar locally near the top of the unoxidized part of the ore zone. Tungsten occurs in the form of small disseminated scheelite grains. Chalcopyrite and sphalerite have also been recognized in the arsenical ores. Stibnite, though present, generally is not spatially associated with either realgar or orpiment.

The presence of large amounts of arsenic, together with antimony, mercury, and thallium, resulted in the formation of a suite of the relatively rare minerals that contain these elements (Dickson and Radtke, 1977), including realgar, orpiment (including antimony- and thallium-containing varieties), lorandite, getchellite, galkhaite, cinnabar, weissbergite, stibnite, christite, and ellisite.

The unoxidized ores in the "garbage can" ore body at the southwest end of the East ore zone were characterized by large amounts of the arsenic-mercury- antimonythallium-bearing sulfide and sulfosalt minerals. These ores also contained especially large amounts of sphalerite, galena, scheelite, chalcopyrite, and molybdenite in comparison with all other known unoxidized ores in the deposit. Other minerals recognized only in the "garbage can" area include small amounts of pyrrhotite, covellite, chalcocite, elemental arsenic, and carlinite in arsenic-deficient areas rich in carbonaceous materials.
Important differences between these oxidized ores and those in other parts of the deposit are: (1) the presence of larger amounts of remnant calcite; (2) a higher content of organic carbon, particularly near unoxidized ores; (3) the presence of incompletely oxidized fine-grained pyrite; (4) the presence of incompletely oxidized remnant sulfides of arsenic and antimony; (5) large amounts of arsenic and antimony in some form dispersed throughout the rocks; (6) a general paucity of intense bleaching and apparent argillic alteration; and (7) a paucity of zones of weathered pyritic alteration. The implications of these features for the history of the Carlin ores are discussed below in the section entitled "Genesis of the Deposit."

Chemical data on oxidized ores in the East ore zone were obtained from 120 samples collected from exposed ore and chosen from drill holes throughout the entire ore zone. The content of gold in these samples averages 8.0 ppm, slightly greater than the average in the deeper, unoxidized ores $(7.4 \mathrm{ppm})$. The abundances of other elements vary with the intensity of oxidation, as do those in ores of the Main ore zone. The average content of barium increases to $1,100 \mathrm{ppm}$, but the contents of other elements are lower; average values are $450 \mathrm{ppm} \mathrm{As,} 105 \mathrm{ppm} \mathrm{Sb}$, 18 ppm Hg, 8 ppm W, 20 ppm Cu, 80 ppm Zn, 15 ppm Pb, $3 \mathrm{ppm} \mathrm{Mo,} \mathrm{0.6} \mathrm{ppm} \mathrm{Se,} \mathrm{and} \mathrm{less} \mathrm{than} \mathrm{0.2} \mathrm{ppm} \mathrm{Te.}$

\section{PRIMARY UNOXIDIZED ORES}

Most of the unoxidized gold ores occur in the Main and East ore zones, and only small amounts in the West ore zone. Of the 11 million $t$ of ore known in 1965, about 4 to 4.5 million t was unoxidized, of which more than 90 percent was in the Main and East ore zones. This amount does not include certain deeper ore zones and the deep mineralized carbonate rocks beneath Popovich Hill (pl. 3). I estimate the total volume of mineralized rock of ore grade at Carlin to be 50 to 60 million $t$.

The unoxidized ores all contain quartz, calcite, dolomite, clay (mainly illite and minor kaolinite and sericite), pyrite, and carbonaceous materials in widely varying amounts, and the same accessory minerals are present in the unmineralized host rocks. The unoxidized ores, however, may be divided into five types on the basis of differences in mineral content, chemical composition, and associations of the gold: (1) normal, (2) siliceous, (3) carbonaceous, (4) pyritic, and (5) arsenical. Table 12 lists chemical and spectrographic analyses of samples of the primary unoxidized ores.

\section{NORMAL ORE}

The normal gold ore is medium to dark gray, thin bedded, and laminated, and physically resembles fresh unmineralized rocks of the Roberts Mountains Formation (fig. 11). This ore type makes up over 60 percent of the known unoxidized ores in the Carlin gold deposit and accounts for all the unoxidized ores in the West ore zone, 
TABLE 12.-Chemical and spectrographic analyses of unoxidized-ore types in the Carlin gold deposit

[Rapid rock analyzes (Shapiro and Brannock. 1962) in weight percent. Analysts: L. Artis. S. Botts. B. P. Fabbi. and L. Mei. Spectrographic analyses in parts per million. Results are identified by geometric brackets whose boundaries

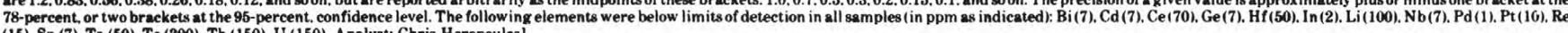

\begin{tabular}{|c|c|c|c|c|c|c|c|c|c|c|c|c|c|c|}
\hline \multirow{2}{*}{$\begin{array}{l}\text { ret type } \\
\text { ample }\end{array}$} & \multicolumn{5}{|c|}{ Normal } & \multicolumn{2}{|c|}{ Siliceous } & \multicolumn{3}{|c|}{ Carbonaceous } & \multicolumn{2}{|c|}{ Pyritic } & \multicolumn{2}{|c|}{ Arsenic a: } \\
\hline & 1 & 2 & 3 & 4 & 5 & 6 & 7 & 8 & 9 & 10 & 11 & 12 & 13 & 14 \\
\hline \multicolumn{15}{|c|}{ Rapid rock analyses } \\
\hline 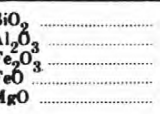 & $\begin{array}{l}42.2 \\
6.0 \\
2.1 \\
.16 \\
9.2\end{array}$ & $\begin{array}{r}\mathbf{4 7 . 0} \\
7.5 \\
1.4 \\
.72 \\
8.6\end{array}$ & $\begin{array}{c}32.6 \\
5.2 \\
1.69 \\
1.1 \\
8.0\end{array}$ & $\begin{array}{l}30.7 \\
5.7 \\
.76 \\
1.4 \\
9.3\end{array}$ & $\begin{array}{c}82.9 \\
8.4 \\
.74 \\
.20 \\
.49\end{array}$ & $\begin{array}{c}90.7 \\
2.5 \\
2.6 \\
.16 \\
.16\end{array}$ & $\begin{array}{c}95.7 \\
1.6 \\
.66 \\
.10 \\
.06\end{array}$ & $\begin{array}{r}41.9 \\
6.7 \\
1.3 \\
1.7 \\
9.4\end{array}$ & $\begin{array}{l}\mathbf{4 7 . 0} \\
7.5 \\
1.8 \\
.72 \\
8.1\end{array}$ & $\begin{array}{l}48.0 \\
7.5 \\
1.4 \\
8.72 \\
8.6\end{array}$ & $\begin{array}{c}51.9 \\
4.2 \\
3.3 \\
1.1 \\
7.3\end{array}$ & $\begin{array}{c}68.8 \\
4.2 \\
4.7 \\
.28 \\
3.2\end{array}$ & $\begin{array}{l}42.1 \\
6.0 \\
1.9 \\
9.68 \\
9.1\end{array}$ & $\begin{array}{r}43.5 \\
6.9 \\
2.6 \\
.80 \\
8.0\end{array}$ \\
\hline o & $\begin{array}{c}14.6 \\
.02 \\
.00 \\
.09 \\
1.4\end{array}$ & $\begin{array}{c}10.6 \\
\quad .02 \\
.02 \\
.20 \\
2.0\end{array}$ & $\begin{array}{c}22.1 \\
.02 \\
.04 \\
.12 \\
1.5\end{array}$ & $\begin{array}{c}21.4 \\
.02 \\
.04 \\
.49 \\
1.6\end{array}$ & $\begin{array}{r}.42 \\
.03 \\
.01 \\
.27 \\
1.7\end{array}$ & $\begin{array}{l}.26 \\
.05 \\
.00 \\
.00 \\
.38\end{array}$ & $\begin{array}{l}.00 \\
.05 \\
.21 \\
.00 \\
.26\end{array}$ & $\begin{array}{c}13.0 \\
.01 \\
.00 \\
.00 \\
1.6\end{array}$ & $\begin{array}{c}11.2 \\
.02 \\
.00 \\
.00 \\
1.8\end{array}$ & $\begin{array}{r}10.6 \\
.02 \\
.02 \\
.20 \\
2.0\end{array}$ & $\begin{array}{c}10.3 \\
.01 \\
.04 \\
.00 \\
1.0\end{array}$ & $\begin{array}{c}6.0 \\
.03 \\
.00 \\
.19 \\
.83\end{array}$ & $\begin{array}{c}13.1 \\
.08 \\
.04 \\
.03 \\
1.6\end{array}$ & $\begin{array}{r}11.2 \\
.06 \\
.04 \\
.12 \\
1.9\end{array}$ \\
\hline 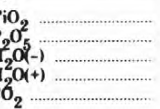 & $\begin{array}{r}.32 \\
.14 \\
.33 \\
1.6 \\
21.5\end{array}$ & $\begin{array}{r}.31 \\
.15 \\
.32 \\
1.1 \\
18.0\end{array}$ & $\begin{array}{r}26 \\
.07 \\
.17 \\
1.2 \\
26.0\end{array}$ & $\begin{array}{r}.23 \\
.07 \\
1.19 \\
1.2 \\
26.7\end{array}$ & $\begin{array}{c}.16 \\
.56 \\
.63 \\
2.0 \\
.03\end{array}$ & $\begin{array}{r}.10 \\
.24 \\
.26 \\
1.1 \\
.04\end{array}$ & $\begin{array}{l}.03 \\
.07 \\
.10 \\
.82 \\
.02\end{array}$ & $\begin{array}{r}.30 \\
.14 \\
.48 \\
1.4 \\
19.9\end{array}$ & $\begin{array}{r}.33 \\
.14 \\
.53 \\
2.2 \\
17.2\end{array}$ & $\begin{array}{r}.31 \\
.15 \\
.32 \\
1.6 \\
18.0\end{array}$ & $\begin{array}{r}.26 \\
.12 \\
.11 \\
1.1 \\
15.9\end{array}$ & $\begin{array}{c}.21 \\
.43 \\
.60 \\
1.0 \\
7.3\end{array}$ & $\begin{array}{r}.30 \\
.25 \\
. .9 \\
1.8 \\
19.1\end{array}$ & $\begin{array}{r}.35 \\
.26 \\
.24 \\
2.1 \\
16.8\end{array}$ \\
\hline (otal) & $\begin{array}{l}.90 \\
.25 \\
.08\end{array}$ & $\begin{array}{l}.92 \\
.84 \\
.08\end{array}$ & $\begin{array}{l}.72 \\
.43 \\
.02\end{array}$ & $\begin{array}{l}.67 \\
.24 \\
.02\end{array}$ & $\begin{array}{l}.23 \\
.80 \\
.02\end{array}$ & $\begin{array}{l}.31 \\
.55 \\
.18\end{array}$ & $\begin{array}{l}.11 \\
.17 \\
.04\end{array}$ & $\begin{array}{r}.74 \\
2.15 \\
.03\end{array}$ & $\begin{array}{r}.76 \\
1.68 \\
.09\end{array}$ & $\begin{array}{r}.92 \\
1.52 \\
.08\end{array}$ & $\begin{array}{r}2.88 \\
.51 \\
.02\end{array}$ & $\begin{array}{r}3.16 \\
.65 \\
.06\end{array}$ & $\begin{array}{r}2.21 \\
.50 \\
1.11\end{array}$ & $\begin{array}{l}3.25 \\
1.2 \\
2.47\end{array}$ \\
\hline Total & 100.9 & 99.8 & 100.2 & 100.7 & 99.6 & 99.6 & 100.0 & 100.8 & 101.1 & 102.0 & 100.8 & 101.6 & 100.3 & 101.8 \\
\hline
\end{tabular}

\begin{tabular}{|c|c|c|c|c|c|c|}
\hline 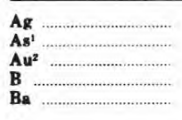 & $\begin{array}{c}<0.7 \\
840 \\
5 \\
50 \\
200\end{array}$ & $\begin{array}{l}<0.7 \\
760 \\
12 \\
150 \\
190\end{array}$ & $\begin{array}{l}<0.7 \\
154 \\
6 \\
70 \\
180\end{array}$ & $\begin{array}{l}<0.7 \\
148 \\
10 \\
70 \\
170\end{array}$ & $\begin{array}{c}1.5 \\
194 \\
5 \\
100 \\
300\end{array}$ & $\begin{array}{r}0 \\
1.750 \\
8 \\
10 \\
520\end{array}$ \\
\hline 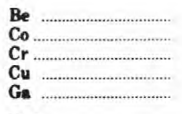 & $\begin{array}{l}<1 \\
3 \\
70 \\
15 \\
10\end{array}$ & $\begin{array}{l}<1 \\
7 \\
70 \\
50 \\
15\end{array}$ & $\begin{array}{l}<1 \\
5 \\
50 \\
15 \\
10\end{array}$ & $\begin{array}{r}<1 \\
3 \\
50 \\
15 \\
7\end{array}$ & $\begin{array}{l}2 \\
<2 \\
70 \\
50 \\
10\end{array}$ & $\begin{array}{c}<1 \\
2 \\
10 \\
30 \\
<2\end{array}$ \\
\hline 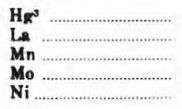 & $\begin{array}{r}23 \\
<30 \\
200 \\
<2 \\
15\end{array}$ & $\begin{array}{r}35 \\
50 \\
100 \\
15 \\
50\end{array}$ & $\begin{array}{l}\begin{array}{c}48 \\
<30 \\
150 \\
<2 \\
20\end{array} \\
20\end{array}$ & $\begin{array}{r}28 \\
50 \\
100 \\
<2 \\
30\end{array}$ & $\begin{array}{r}12 \\
<30 \\
10 \\
<2 \\
20\end{array}$ & $\begin{array}{r}20 \\
30 \\
7 \\
5 \\
30\end{array}$ \\
\hline 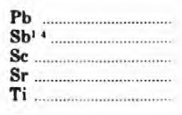 & $\begin{array}{r}<7 \\
140 \\
10 \\
200 \\
2.000\end{array}$ & $\begin{array}{r}15 \\
60 \\
10 \\
150 \\
2.000\end{array}$ & $\begin{array}{r}<7 \\
<20 \\
10 \\
500 \\
2,000\end{array}$ & $\begin{array}{r}<7 \\
<20 \\
10 \\
500 \\
1.500\end{array}$ & $\begin{array}{r}<7 \\
<20 \\
7 \\
150 \\
2.000\end{array}$ & $\begin{array}{r}27 \\
250 \\
7 \\
50 \\
500\end{array}$ \\
\hline 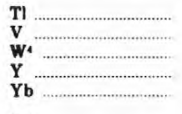 & $\begin{array}{r}200 \\
30 \\
20 \\
30 \\
2\end{array}$ & $\begin{array}{r}70 \\
200 \\
<20 \\
20 \\
2\end{array}$ & $\begin{array}{l}<3 \\
50 \\
25 \\
30 \\
2\end{array}$ & $\begin{array}{r}<3 \\
50 \\
<20 \\
20 \\
2\end{array}$ & $\begin{array}{r}<3 \\
70 \\
<20 \\
50 \\
3\end{array}$ & $\begin{array}{r}<3 \\
30 \\
<20 \\
10 \\
1\end{array}$ \\
\hline $\begin{array}{l}\mathrm{Zn}^{1} \\
\mathrm{Zr}_{\mathrm{r}}\end{array}$ & $\begin{array}{r}38 \\
100 \\
\end{array}$ & $\begin{array}{r}62 \\
100 \\
\end{array}$ & $\begin{array}{r}51 \\
150 \\
\end{array}$ & $\begin{array}{r}25 \\
100\end{array}$ & $\begin{array}{r}53 \\
150\end{array}$ & $\begin{array}{r}119 \\
30\end{array}$ \\
\hline
\end{tabular}

Formation. Location: : 6.300 bench. Main ore zone.

Lains Formmation. Location: 6.220 bench. Main ore zone.
Composite of 8 samples of medium-to dark-gray silty thin-bedded low-grade normal gold ore in the

. Composite of 8 samples of medium- to dark-gray silty thin-bedded low--rrade normal kold ore in the
Roberts Mountains Formation. Location: 6.260 bench. Main ore zone. Compositeof 5 samples of medium-gray silty thin-bedded averave-xrade

ic analyses

Cothe Poporich Formation. Location: 6,440 bench, East ore zone.

ous shale units of the upper plate. Location: 6.280 bench. East ore zone.

6. Hand specimen of dark-brown denae maasive averase-grade siliceous gold ore in the Roberts Moun C.

tains Formation. Location: 6.320 bench. Enat ore zone.

Hand apecimen of blacks sity thin-bedded Low-grade carbonsceous gold ore in the Roberts Mountain

Hand specimen of dark-xray to black silty denoe high-rrade carbonaceous gold ore in the Roberts

\begin{tabular}{|c|c|c|c|c|c|c|}
\hline $\begin{array}{c}<0.7 \\
295 \\
40 \\
70 \\
145\end{array}$ & $\begin{array}{c}0.7 \\
940 \\
18 \\
70 \\
189\end{array}$ & $\begin{array}{c}<0.7 \\
760 \\
6 \\
150 \\
180\end{array}$ & $\begin{array}{c}<0.7 \\
180 \\
6 \\
20 \\
138\end{array}$ & $\begin{array}{c}<0.7 \\
610 \\
34 \\
90 \\
255\end{array}$ & $\begin{array}{c}<0.7 \\
11.100 \\
\mathbf{6 9} \\
\mathbf{3 0} \\
\mathbf{8 0 0}\end{array}$ & $\begin{array}{c}0.7 \\
24.700 \\
130 \\
30 \\
560\end{array}$ \\
\hline $\begin{array}{l}<1 \\
5 \\
70 \\
20 \\
15\end{array}$ & $\begin{array}{c}<1 \\
5 \\
100 \\
50 \\
15\end{array}$ & $\begin{array}{l}<1 \\
7 \\
20 \\
50 \\
15\end{array}$ & $\begin{array}{r}<1 \\
7 \\
\mathbf{3 0} \\
\mathbf{3 0} \\
7\end{array}$ & $\begin{array}{r}<1 \\
3 \\
30 \\
50 \\
5\end{array}$ & $\begin{array}{c}<1 \\
3 \\
70 \\
50 \\
10\end{array}$ & $\begin{array}{r}<1 \\
2 \\
100 \\
70 \\
15\end{array}$ \\
\hline $\begin{array}{r}15 \\
<30 \\
150 \\
15 \\
50\end{array}$ & $\begin{array}{r}70 \\
<30 \\
150 \\
3 \\
30\end{array}$ & $\begin{array}{r}35 \\
50 \\
100 \\
15 \\
50\end{array}$ & $\begin{array}{r}25 \\
50 \\
150 \\
70 \\
70\end{array}$ & $\begin{array}{r}150 \\
70 \\
70 \\
10 \\
15\end{array}$ & $\begin{array}{r}200 \\
50 \\
150 \\
10 \\
20\end{array}$ & $\begin{array}{r}280 \\
70 \\
100 \\
7 \\
20\end{array}$ \\
\hline $\begin{array}{r}10 \\
25 \\
10 \\
150 \\
2.000\end{array}$ & $\begin{array}{r}47 \\
45 \\
15 \\
150 \\
2.000\end{array}$ & $\begin{array}{r}15 \\
25 \\
10 \\
150 \\
2.000\end{array}$ & $\begin{array}{r}10 \\
30 \\
7 \\
100 \\
1.000\end{array}$ & $\begin{array}{r}87 \\
76 \\
3 \\
100 \\
1.000\end{array}$ & $\begin{array}{r}115 \\
10 \\
150 \\
1.500\end{array}$ & $\begin{array}{r}100 \\
100 \\
720 \\
1.500\end{array}$ \\
\hline $\begin{array}{r}70 \\
200 \\
30 \\
20 \\
2\end{array}$ & $\begin{array}{r}<3 \\
100 \\
35 \\
20 \\
2\end{array}$ & $\begin{array}{r}70 \\
200 \\
220 \\
20 \\
2 \\
2\end{array}$ & $\begin{array}{r}<3 \\
100 \\
<20 \\
15 \\
2\end{array}$ & $\begin{array}{c}100 \\
30 \\
820 \\
10 \\
1.5\end{array}$ & $\begin{array}{c}150 \\
70 \\
20 \\
\mathbf{2 0} \\
1.5\end{array}$ & $\begin{array}{r}150 \\
100 \\
220 \\
20 \\
2\end{array}$ \\
\hline $\begin{array}{l}<5 \\
70\end{array}$ & $\begin{array}{r}25 \\
150\end{array}$ & $\begin{array}{r}62 \\
100\end{array}$ & $100^{7}$ & $\begin{array}{l}22 \\
50\end{array}$ & $\begin{array}{l}<5 \\
150\end{array}$ & $\stackrel{9}{150}$ \\
\hline
\end{tabular}

10. Composite of 5 samples of dark-gray silt thin-bedded low-grade carbonsceous gold ore in the Roberts Moun1. Hond a Location: 6.300 bench. Main ore zone.
12. Hand sample of medium-gray fine-krained high-rrade pyritic gold ore in the Roberts Mountains Formation 13. Hand sample of high-grade arsenical gold ore: veinlets of realzar crowecut medium-gray silty thin-bedded

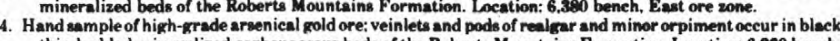
thin-bedded $m$. X-ray fluorescence analysis.

.

'Colorimetric analysis analysi 

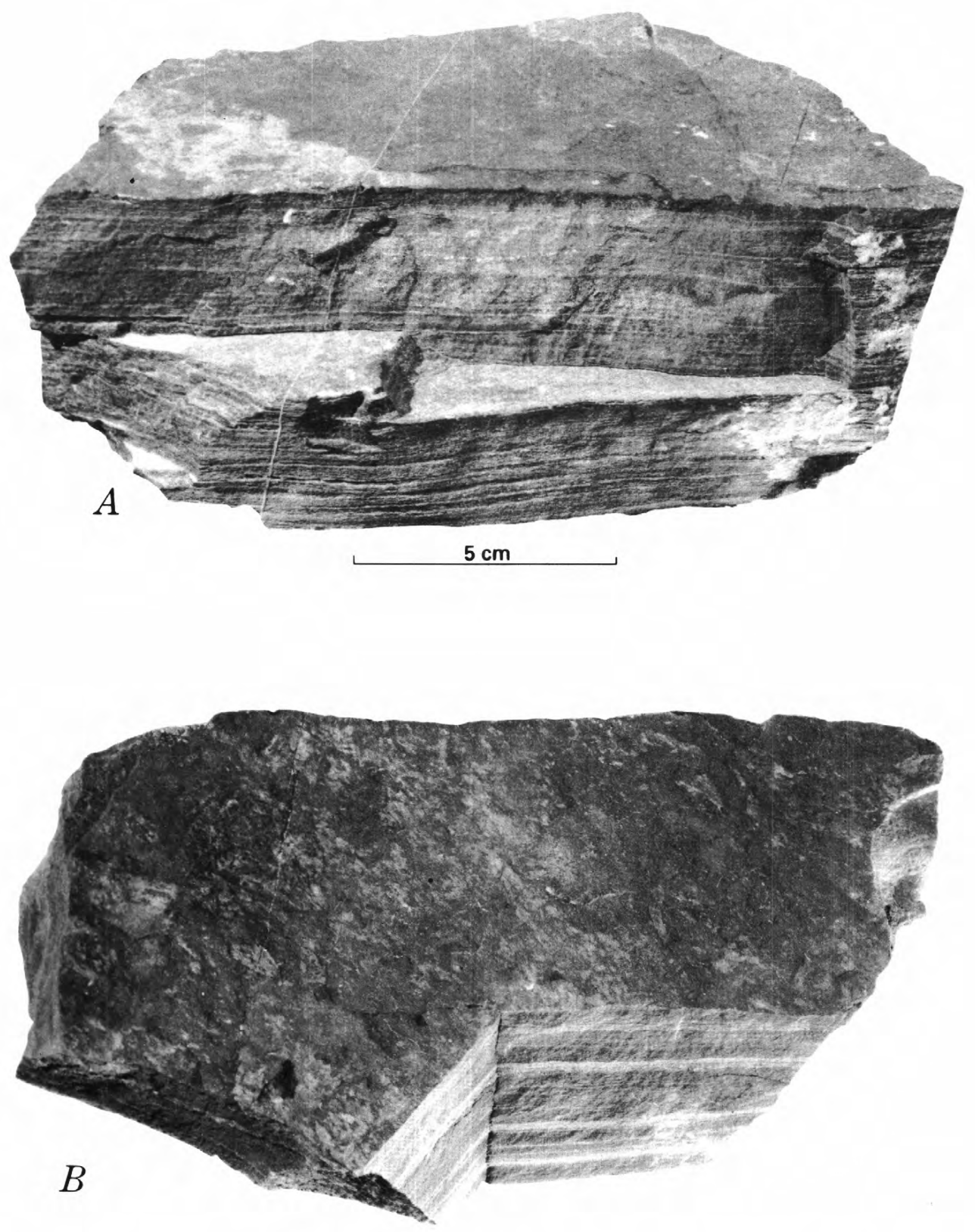

FIGURE 11.-Specimens of fresh unmineralized host rock of the Roberts Mountains Formation $(A)$ and normal gold ore $(B)$. 

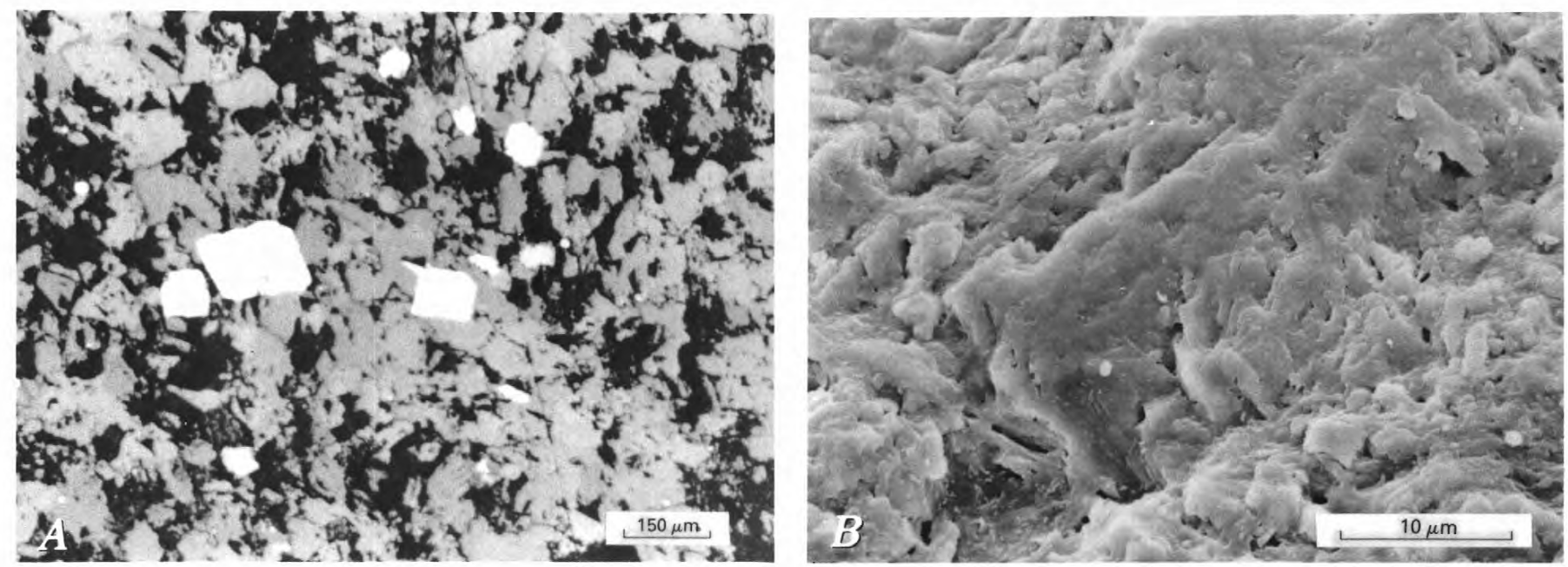

FIGURE 12.-A. Dolomite (light gray), quartz grains (dark gray), and cubic crystals of hydrothermal pyrite (white) in polished thin section of normal gold ore. Black areas contain principally clay and fine-grained quartz. B. Scanning electron micrograph showing corroded borders of dolomite replaced or overgrown by fine-grained hydrothermal quartz in normal gold ore.

over 50 percent of the unoxidized ores in the Main ore zone, and 30 to 40 percent of the unoxidized ores in the East ore zone.

The normal gold ore, which was well described by Wells and Mullens (1973), is composed mainly of dolomite, illite, and quartz, and contains lesser amounts of kaolinite, sericite, and remnant calcite. Anhedral to subhedral corroded rhombs of diagenetic dolomite, ranging from about 20 to $80 \mu \mathrm{m}$ in length, and angular grains of sedimentary quartz, ranging from about 40 to $100 \mu \mathrm{m}$ in diameter, lie in a matrix of interlocking clay, fine-grained calcite and dolomite, and carbonaceous materials. Grain size of the matrix minerals ranges from the submicroscopic to about $10 \mu \mathrm{m}$. Many dolomite grains are corroded and exhibit poorly defined edges owing to reaction with the hydrothermal solutions.

Other features of the normal ore that indicate reaction with hydrothermal solutions include: several textural varieties of introduced silica in the form of irregular patches (max $80 \mu \mathrm{m}$ long) and small veinlets (less than $30 \mu \mathrm{m}$ wide); replaced carbonate grains (most commonly the margins of dolomite rhombs); fossil fragments and fine-grained calcite in the rock matrix; and overgrowths on quartz grains (figs. 12, 13). Small amounts of kaolinite were formed in the matrix, and calcite was recrystallized as small microveinlets.

In addition to the relatively large subhedral cubes (10$30 \mu \mathrm{m})$ and thin stringers of diagenetic pyrite inherited from the original limestone, the normal gold ore contains two forms of introduced pyrite. Hydrothermal pyrite occurs (1) as small dispersed subhedral cubes in the matrix and along the margins of dolomite rhombs; and (2) as clusters of small framboidal microspheres (less than $10 \mu \mathrm{m}$ diam) in the matrix, dispersed in patches of hydrothermal quartz, and along fractures in dolomite grains. Hydrothermal sulfide minerals other than pyrite are uncommon in this ore type.

Gold occurs in several forms and associations in the normal ore (Radtke and others, 1972b). Surfaces of both the subhedral cubes and the framboidal spheres of hydrothermal pyrite are commonly coated with thin films (less than $2 \mu \mathrm{m}$ thick) of gold, mercury, arsenic, and antimony, and locally with small amounts of thallium. From 70 to 80 percent of the gold in the normal ore is estimated to occur in this form. Small amounts of gold, in the form of either very fine (less than $1 \mu \mathrm{m}$ ) metallic particles or a gold-organic compound, are distributed in the mixed carbonaceous materials and clay within the rock matrix; sparse individual particles of metallic gold also occur locked in small patches and seams of hydrothermal quartz (fig. 14).

The types of carbonaceous materials in the fresh unmineralized host rocks and unoxidized ores are: (1) activated amorphous carbon, (2) mixtures of high-molecularweight hydrocarbons, and (3) organic acid(s) with properties similar to humic acid (Radtke and Scheiner, 1970b). The higher average content of organic carbon in normal gold ore (0.5-0.6 weight percent) than in fresh rocks $(0.2-$ 0.3 weight percent) suggests that small amounts of organic material, probably hydrocarbon compounds, were introduced during hydrothermal activity.

The contents of major and minor elements in typical samples of the normal gold ore listed in table 12 (samples 


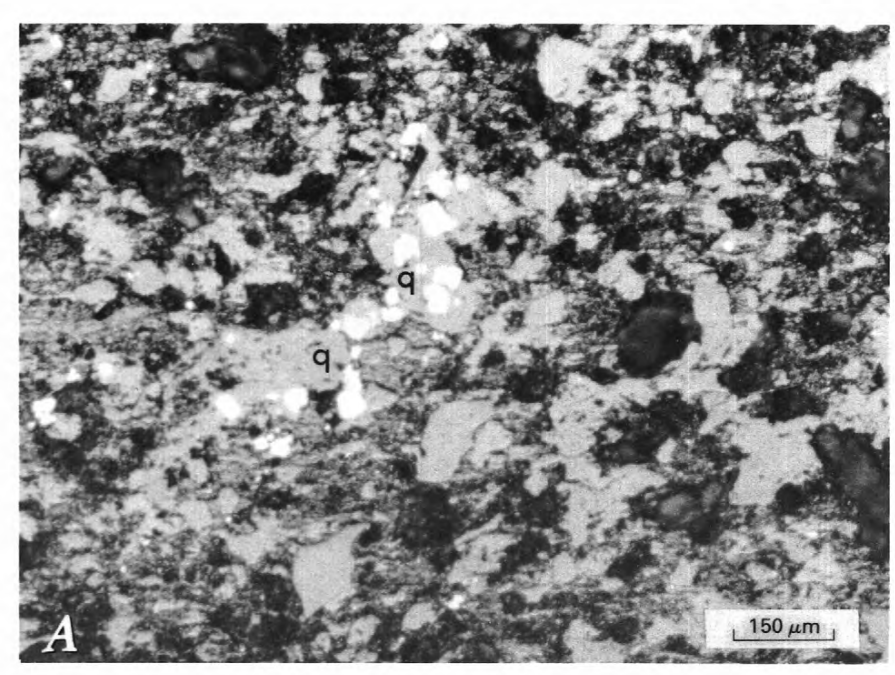

FIGURE 13.- $A$, Small seams and patches of hydrothermal quartz (q) in normal gold ore. Note spatial association between cubic and framboidal hydrothermal pyrite (white grains) and quartz. $B$, Scanning electron micrograph showing thin seams of hydrothermal quartz alined with laminations and bedding in normal gold ore. C. Scanning electron micrograph showing recrystallized calcite grain (center) enclosed in dolomite and quartz. White grains on surface of calcite are either kaolinite or illite.

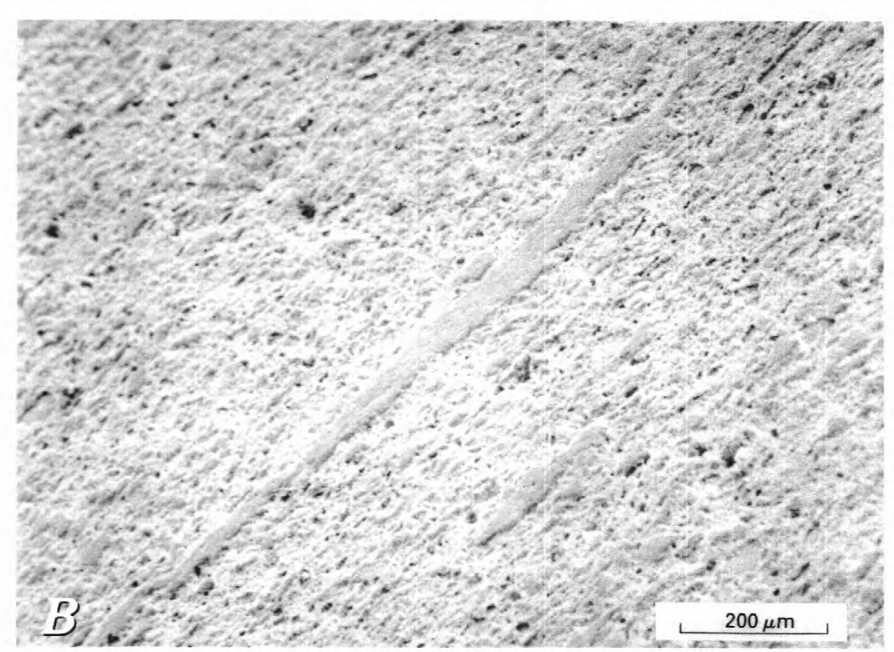

FIGURe 13.-Continued.

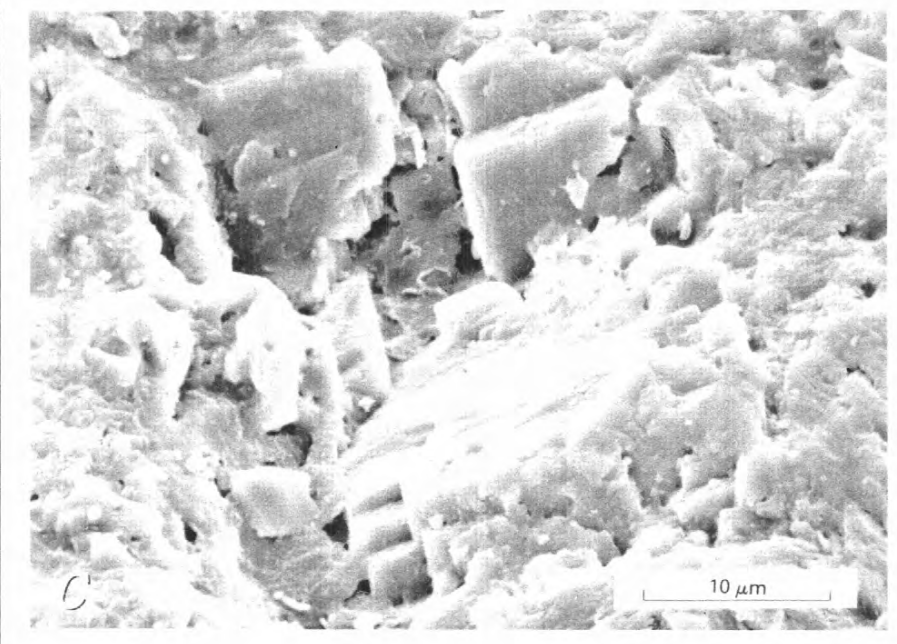

Figure 13.-Continued.

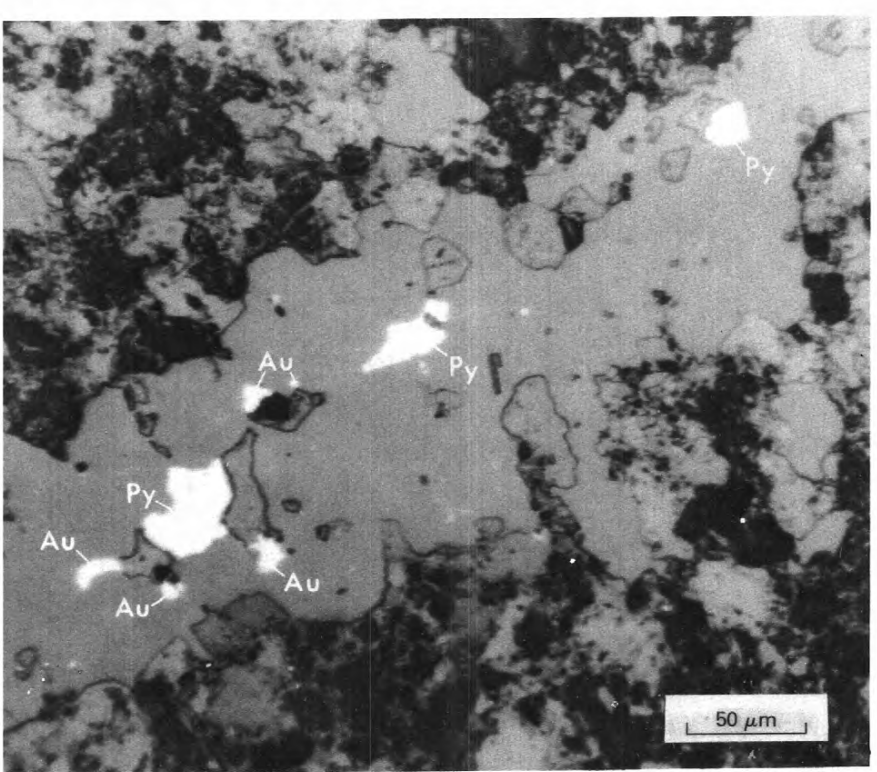

FIGURE 14.--Rare fine-grained metallic gold ( $\mathrm{Au}$ ) and pyrite (Py) locked in hydrothermal quartz in normal gold ore. 

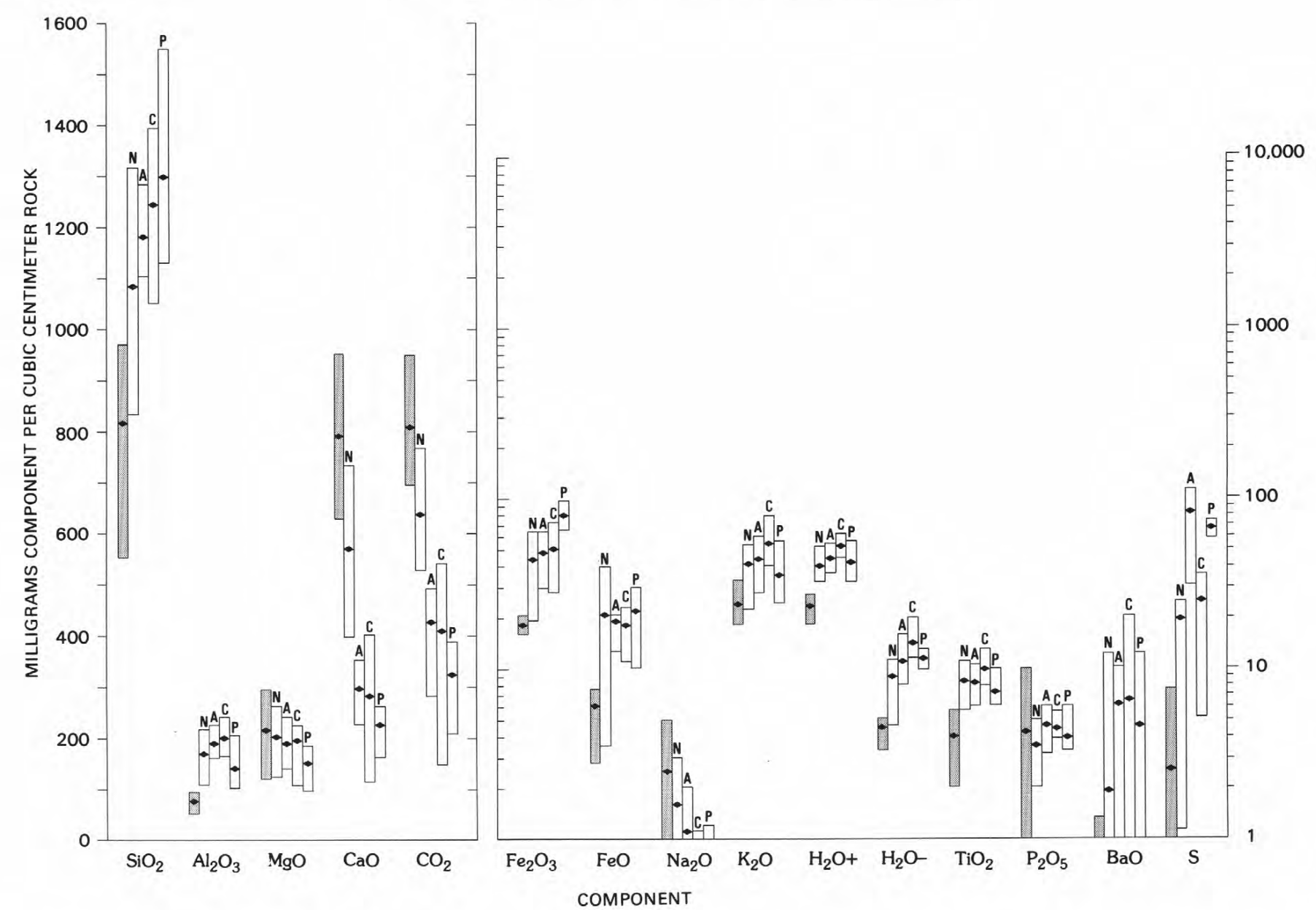

FIGURE 15.-Chemical changes in dolomitic carbonate rocks of the Roberts Mountains Formation during deposition. Bars show ranges and median values (black diamonds) in milligrams of component per cubic centimeter of rock (equal to weight percent of component times bulk specific gravity times 10). Shaded bars show composition of unmineralized host rocks, and open bars composition of different unoxidized ore types: N, normal; C, carbonaceous; $P$, pyritic; A, arsenical; siliceous, not shown.

1-5) and plotted in figure 15, were reported by A. S. Radtke (unpub. data, 1969), Wells and Mullens (1973), and Harris and Radtke (1976). Comparison of these data with those for fresh unmineralized rocks (fig. 15, table 2) A. S. Radtke, unpub. data, 1969; Radtke and others, 1972a; Harris and Radtke, 1976) shows that the normal ore contains more silicon, aluminum, total iron, potassium, sulfur, and organic carbon; slightly more barium; and more silver, arsenic, gold, boron, cobalt, chromium, copper, mercury, lanthanum, molybdenum, manganese, nickel, lead, antimony, selenium, tellurium, titanium, thallium, vanadium, tungsten, yttrium, ytterbium, zine, and zirconium. Increases in the contents of silicon, aluminum, potassium, iron, sulfur, and organic carbon reflect the introduction of quartz, kaolinite, pyrite, and hydrocarbons; and the larger titanium content is due to dispersed grains of a mineral of composition $\mathrm{TiO}_{2}$. Ferride elements, including cobalt, chromium, manganese, nickel, and vanadium, may be present in the hydrother- mal pyrite. Minor elements associated with gold, including arsenic, mercury, antimony, and thallium, occur with gold on the surfaces of pyrite grains, and small amounts of mercury are associated with carbonaceous materials.

\section{SILICEOUS ORES}

The siliceous gold ores are characterized by large amounts of introduced silica and only small amounts of remnant carbonate minerals. The ores are dark gray to black and grade from normal ore exhibiting faint remnant thin bedding and laminations to massive dense gold-bearing jasperoid (fig. 16).

Less than 10 percent of the known unoxidized gold ores are of the siliceous type, and the bulk of these are in the East ore zone. These ores commonly contain 80 to 95 percent quartz, 5 to 10 percent clay (including illite and small amounts of hydrothermal kaolinite and sericite), less than 1 to 5 percent dolomite, and smaller amounts of carbonaceous materials and pyrite. Hydrothermal silica has 


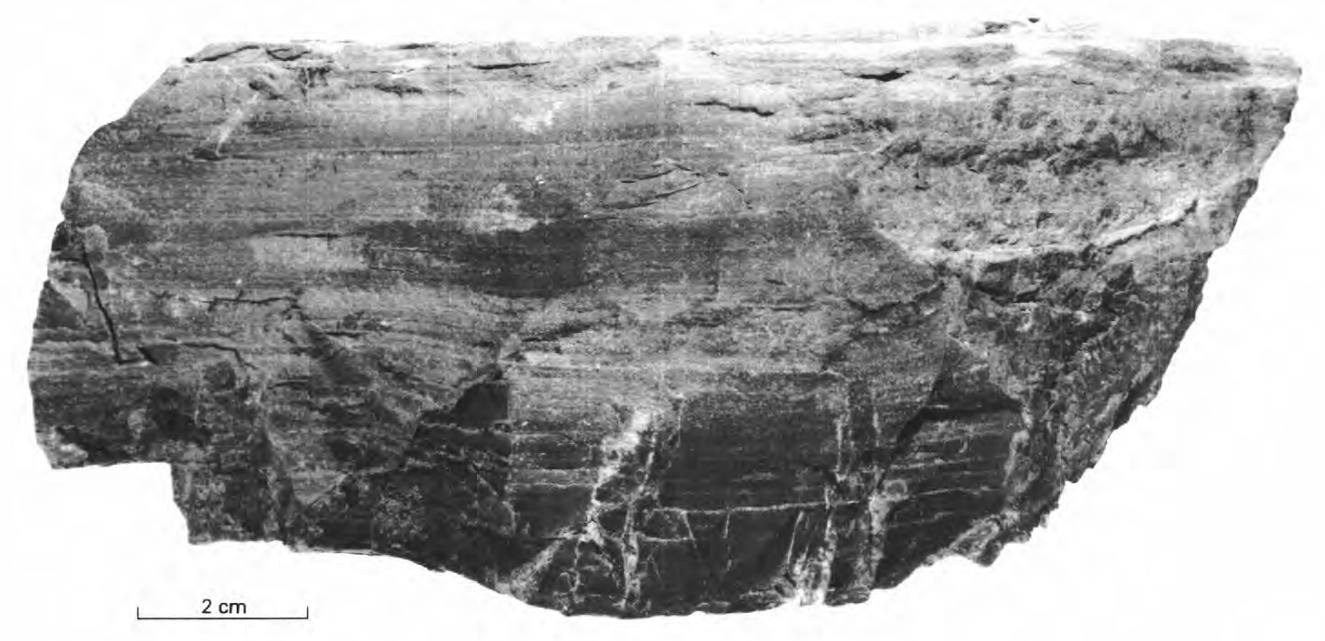

FIGURE 16. - Specimen of siliceous gold ore. Dark beds are intensely silicified, and progressively lighter beds reflect introduction of smaller amounts of silica.

replaced most of the dolomite rhombs, formed overgrowths on quartz grains, and replaced virtually all the calcareous fossil fragments and the grains of calcite and dolomite in the matrix. The presence of small veinlets ( $\max 50 \mu \mathrm{m}$ wide) of quartz, filling microfractures both parallel to and transecting the bedding suggests that the silica was introduced in several stages.

Small amounts of pyrite, in the form of subhedral cubic grains and rounded framboidal aggregates, occur in the hydrothermal silica and are scattered throughout the matrix (fig. 17). Small grains (less than $10 \mu \mathrm{m}$ diam), of pyrite, together with carbonaceous materials, also occur in the quartz veinlets (fig. 18). Other sulfide and sulfosalt minerals identified in the siliceous ores include galena, sphalerite, chalcopyrite, weissbergite, realgar, and stibnite. All these minerals are commonly sparse and fine grained.

In contrast to the other types of unoxidized ores, the siliceous ores contain fine particles (less than $10 \mu \mathrm{m}$ diam) of metallic gold dispersed in patches of hydrothermal quartz. However, most of the gold in this ore type-probably more than 80 percent of the total amount-accurs on the surfaces of grains of hydrothermal pyrite, including pyrite in the small quartz veinlets. No association of gold with carbonaceous materials has been recognized in the siliceous ores.

The chemical compositions, including both major and minor elements, and the mineralogy of the siliceous ores differ significantly from those of the other unoxidized ore types (samples 6, 7, table 2; A. S. Radtke, unpub. data, 1970). Elements less abundant in the siliceous ores than in most other ore types include aluminum, boron, calcium, cobalt, chromium, iron, gallium, potassium, lanthanum, magnesium, manganese, molybdenum, sodium, nickel, scandium, strontium, titanium, thallium, vanadium, yttrium, ytterbium, zirconium, sulfur, and organic carbon. The small amounts of aluminum, boron, gallium, potassium, sodium, and scandium reflect the comparatively small amounts of clay; the sparsity of calcium, magnesium, and strontium is due to virtually complete removal of calcite and dolomite; the small amounts of iron and sulfur, as well as of elements commonly found in pyrite (including cobalt, chromium, manganese, nickel, and vanadium), suggest that these ores contain less hydrothermal pyrite. R. L. Erickson (written commun., 1977) suggested that the sparsity of such elements as chromium, gallium, titanium, and zirconium could reflect lower contents in the original rocks, which were a purer carbonate facies.

Although titanium was introduced into the host rocks at Carlin during hydrothermal alteration, the exceptionally small amounts of this element in the siliceous ores suggest that it did not accompany the main hydrothermal stage. A hydrothermal mineral of composition $\mathrm{TiO}_{2}$ has been recognized in heavily silicified mineralized carbonate rocks in the Carlin deposit. Bailey (1974) previously reported a $\mathrm{TiO}_{2}$ phase in jasperoid of the Drum Mountains, Utah, but did not further identify the mineral. Except for thallium, the contents of elements closely associated with gold, including arsenic, mercury, and antimony, closely resemble those in the other ore types.

In addition to the high content of silica, the average content of barium $(700 \mathrm{ppm})$ in the siliceous ores is higher than that in the other ore types except for the carbonaceous. The presence of sparse randomly scattered irregular subrounded grains (less than $50 \mu \mathrm{m}$ diam) of barite replaced by quartz in the siliceous ores indicates that a small amount of barite was formed during the early or main hydrothermal stage before a later influx of silica. 


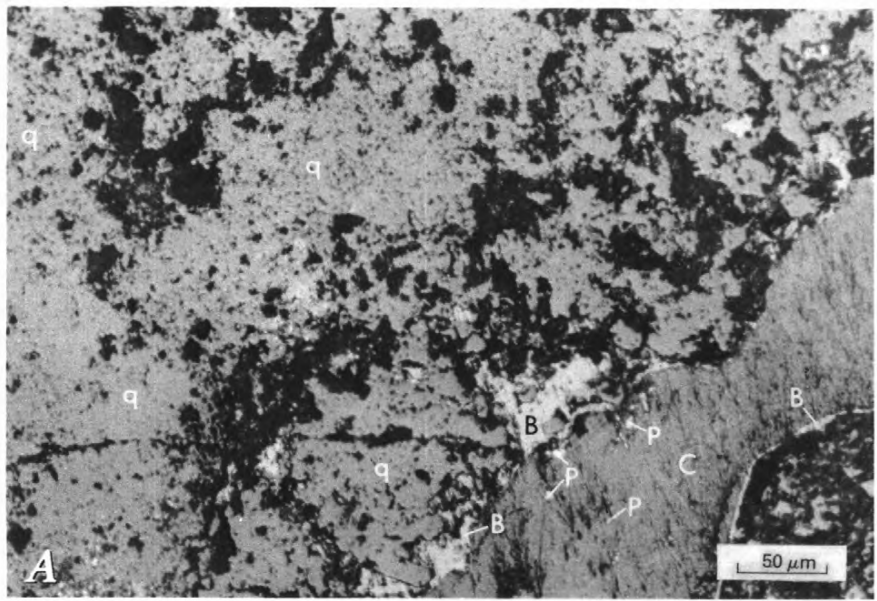

FigURE 17.-Progressive silicification accompanying mineralization. A, Dolomite rhombs and matrix calcite completely replaced by hydrothermal quartz (q) in polished thin section of siliceous gold ore. Note seam of carbonaceous materials (C) and minor amounts of barite (B) along margins. Very fine grained hydrothermal pyrite $(\mathrm{P})$ is locked in carbonaceous materials. Black areas contain clay and may represent voids from which pyrite was plucked during sample preparation. $B$, Scanning electron micrograph showing progressive silicification (S) advancing along front (dotted line) in direction of arrows. Quartz has replaced all carbonate minerals and filled most open spaces in matrix behind front with siliceous ore. Note initial penetration of dolomite rhombs (low relief) by hydrothermal quartz (high relief) near arrows.

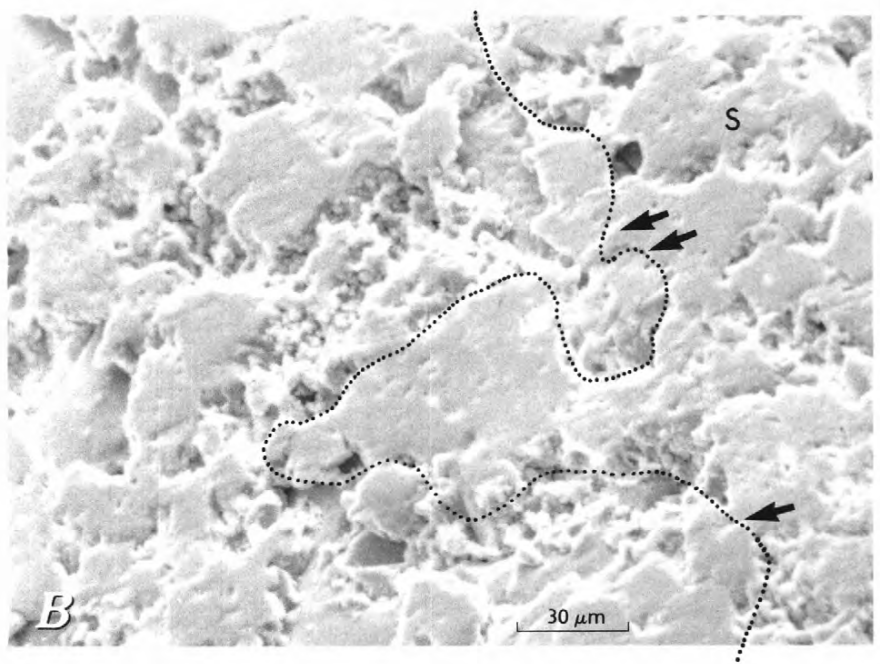

Figure 17.-Continued.

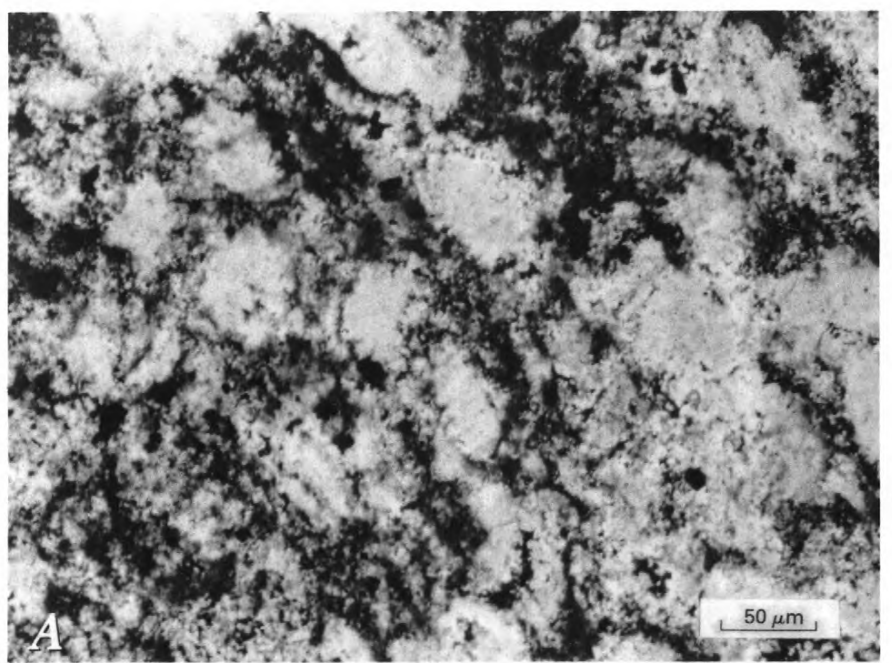

Figure 18.-Textural relations in siliceous gold ore. $A$, Varieties of auriferous pyrite, showing textural relations to hdydrothermal quartz. Cubic and framboidal crystals of pyrite (black grains) are scattered throughout silicified matrix, and larger pyrite grains tend to occur. along margins of dolomite rhombs replaced by quartz. Dark-gray areas in matrix represent concentrations of organic material, clay, and finegrained pyrite in hydrothermal quartz. Texture of original rock is well preserved in comparision with specimen shown in figure $17 \mathrm{~A}$. B, Scanning electron micrograph showing typical surface features of siliceous gold ore. Euhedral quartz crystals occur in openings along margins of dolomite rhombs replaced by quartz. Note flooding of rock by hydrothermal quartz.

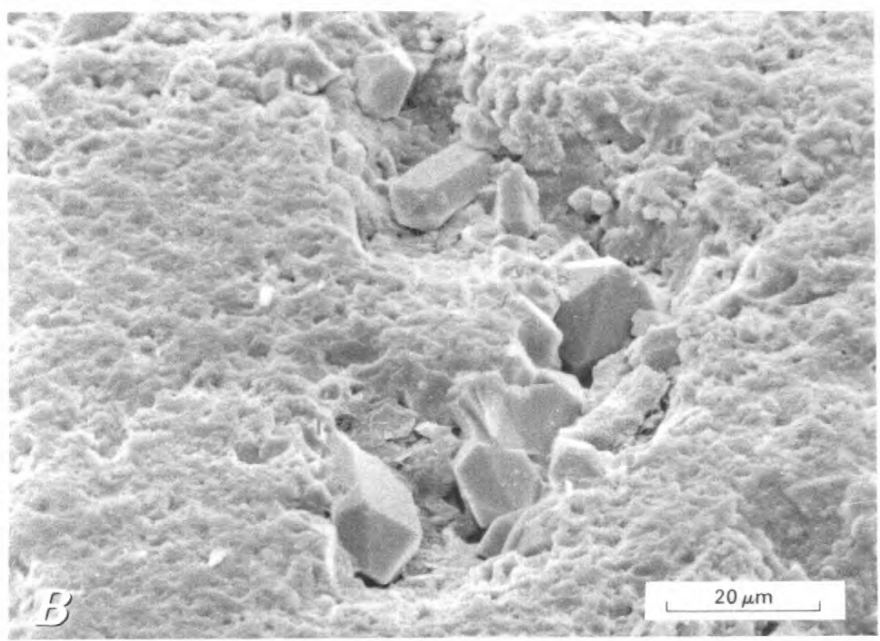

Figure 18.-Continued. 


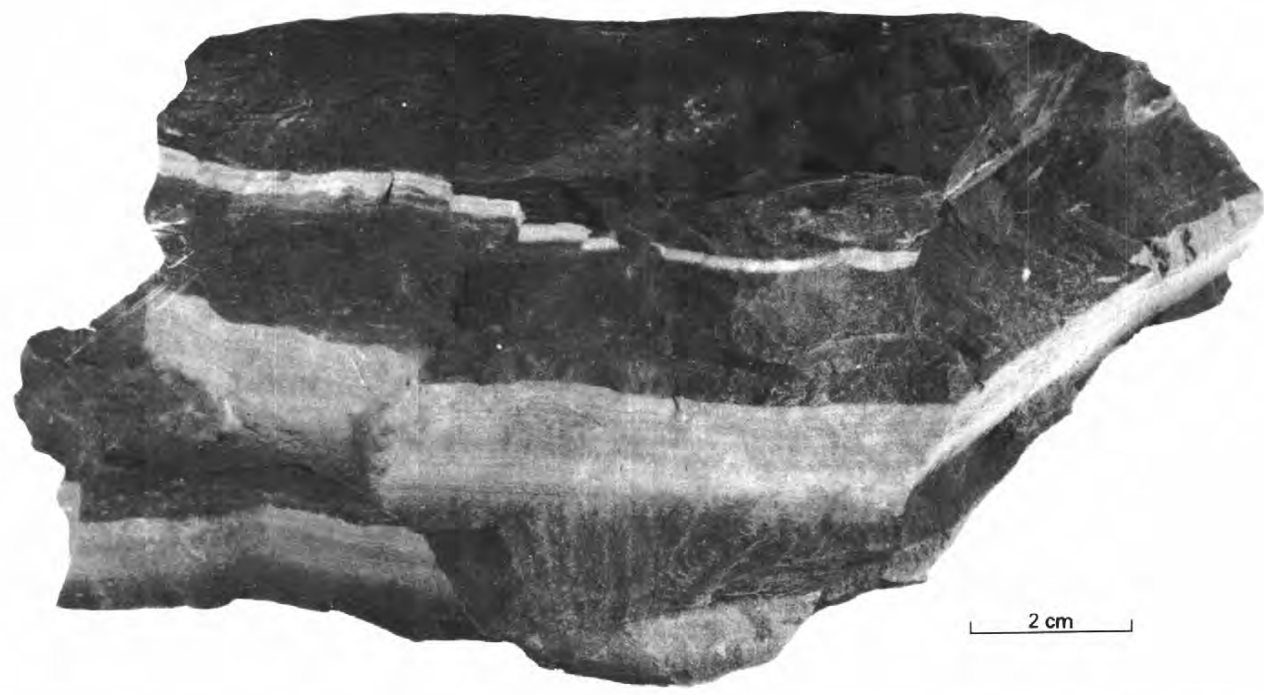

Figure 19.-Thin-bedded laminated specimen of carbonaceous gold ore, showing selective concentration of carbonaceous materials in seams parallel to bedding.

\section{CARBONACEOUS ORE}

The term "carbonaceous ore" has been loosely applied by numerous geologists to any unoxidized goldbearing carbonate rock. Radtke and Scheiner (1970b, p. 96) originally defined the term "**** as a refractory ore containing organic carbon constituents capable of interacting with gold cyanide complexes, thus making the ore non-amenable to conventional cyanidation treatment." This definition is satisfactory for metallurgic purposes but is too general and broad to be of much value geologically. Although many of the unoxidized ores contain organic carbon compounds in sufficient abundance (more than 0.2 weight percent) to interfere with gold extraction by cyanidation, the term "carbonaceous gold ore" is here restricted to mineralized rock containing an abnormally large amount of organic carbon, owing at least in part to hydrothermal introduction of hydrocarbons.

The carbonaceous gold ore is dark gray to black and ranges in appearance from thin bedded and laminated, displaying alternating dark-gray and black laminae, to dense, black, and unlaminated, displaying fractures coated with black amorphous carbon (fig. 19). Carbonaceous ore makes up about 15 to 20 percent of the known unoxidized ores; this percentage could become much larger once information is available on the composition of the unoxidized ores below Popovich Hill. Carbonaceous ore occurs along most of the East ore zone and in the deeper levels of the Main ore zone along the south and southwest sides of Popovich Hill (pls. 3-5).
The content of organic carbon in the massive dense carbonaceous gold ore is commonly greater than 1.0 weight percent and locally as high as 6.0 weight percent. Otherwise, most of the carbonaceous ore resembles the normal ore except for a slightly lower content of remnant calcite. Corroded rhombs of dolomite and angular detrital quartz grains are dispersed throughout a matrix of clay, finegrained quartz and dolomite, and carbonaceous materials. Much of the fine-grained calcite in the matrix has been dissolved out, and the voids filled by organic materials; the remainder of the calcite and some of the dolomite are replaced by quartz and small grains of pyrite, and remnant corroded dolomite grains occur as inclusions in hydrothermal silica. In addition to the carbonaceous materials in the matrix, organic carbon compounds also occur in small veinlets (less than $20 \mu \mathrm{m}$ wide), commonly parallel to the bedding, and in small patches ( $\max 70 \mu \mathrm{m}$ long) that may represent replaced dolomite rhombs.

The alternating gray and black laminae in the carbonaceous ore differ in mineralogy and chemical composition. The gray laminae are composed of angular detrital quartz grains and dolomite rhombs in a matrix of clay, fine-grained quartz, calcite, and dolomite. Subhedral to euhedral cubic grains ( $\max$ approx $150 \mu \mathrm{m}$ ) of pyrite are abundant; fragments of small silicified brachiopod shells are sparse and poorly preserved. The content of organic carbon ranges from about 0.4 to 1.2 weight percent. The black laminae contain corroded dolomite rhombs and angular quartz grains in a matrix of carbonaceous materials, 


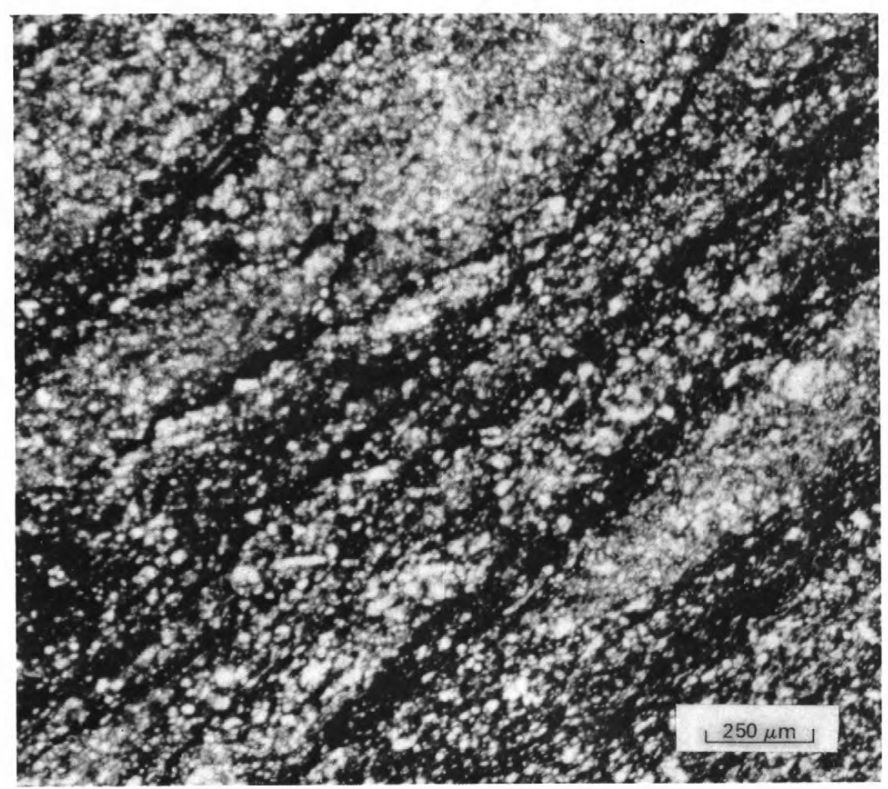

Figure 20.-Flooding of hydrocarbons (dark seams) along bedding in polished thin section of carbonaceous gold ore.

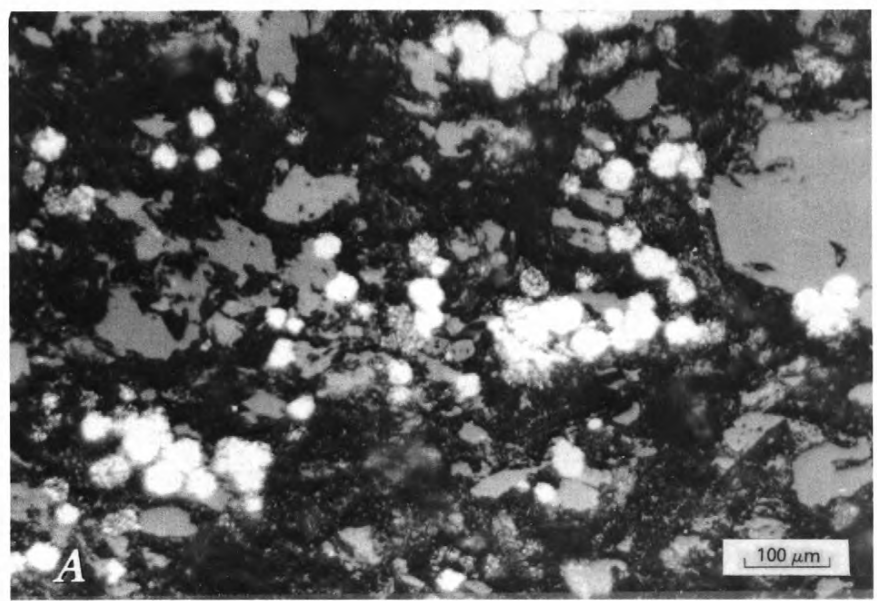

Figure 21.-Framboidal pyrite. A. Framboidal crystals of hydrothermal pyrite (light grains) associated with carbonaceous materials in matrix of carbonaceous gold ore. $B$, Scanning electron micrograph showing framboidal pyrite in matrix of fine-grained carbonaceous materials, clay, and quartz in carbonaceous ore. Smooth areas on surfaces of some framboids are thin overgrowths of quartz, or coatings containing sulfur, iron, and various heavy elements. Smooth dark-gray areas are corroded rhombs of dolomite. $C$, Scanning electron micrograph showing individual framboid of pyrite made up of tiny euhedral grains in carbonaceous ore. Coating on surface in area $Q$ is quartz; other coating is an unknown material, about $0.5 \mu \mathrm{m}$ thick, containing sulfur, iron, arsenic, antimony, mercury, and gold. Note distinct euhedral quartz crystals and fine-grained carbonaceous materials (C) along margins of framboid.

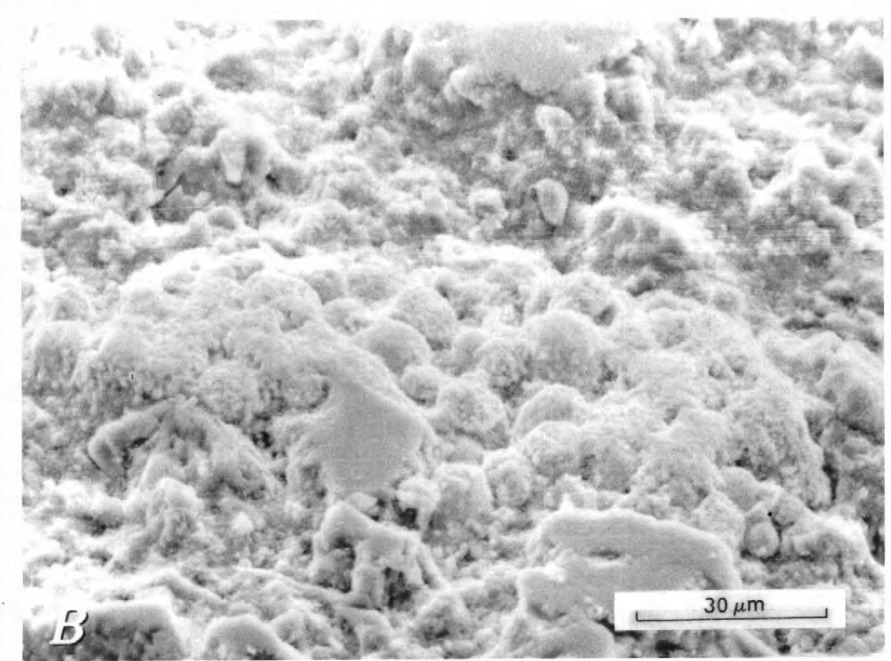

Figure 21.-Continued.

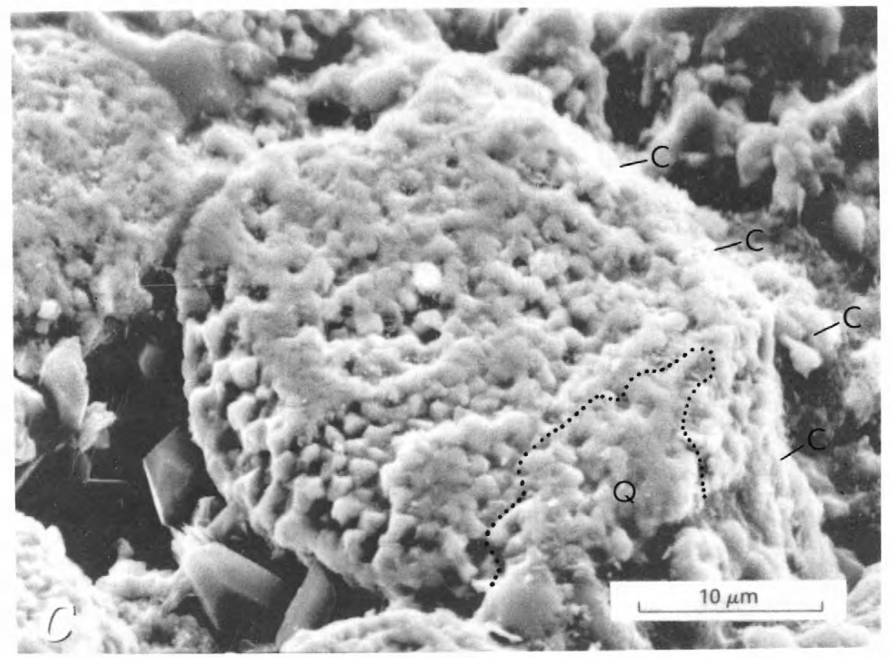

FIGURE 21.-Continued. 
clay, quartz, and small amounts of dolomite; shell fragments are silicified, abundant, and well preserved. Carbonaceous materials, flooded throughout the matrix (fig. 20 ), occur as small patches and seams parallel to bedding; organic carbon content ranges from 1.0 to more than 3.0 weight percent. Both the cubic and the framboidal varieties of pyrite are common, and pyrite grains and fragments commonly are concentrated along the seams of carbonaceous materials (fig. 21).

The carbonaceous gold ore contains relatively large amounts of the same three types of organic carbon compounds identified by Radtke and Scheiner (1970b) and discussed above in the subsection entitled "Normal Ore." In the carbonaceous ore, most of the amorphous carbon and those grains coated with hydrocarbons occur as blocky patches and seams. The organic acid(s) is (are) associated with clay, quartz, and remnant carbonate minerals in the matrix. Electron microprobe studies show that the gold is associated with both amorphous carbon and organic $\operatorname{acid}(\mathrm{s})$ in the carbonaceous ore, an association described below in the section entitled "Mineralogy and Distribution of Elements in Unoxidized Ores."

Much of the gold in the carbonaceous ore is associated with pyrite. Both the framboids (fig. 21) and the cubic grains (less than $40 \mu \mathrm{m}$ ) of pyrite commonly have coatings of gold, mercury, arsenic, and antimony. Larger cubic pyrite grains, probably representing early diagenetic pyrite, rarely contain detectable amounts of these elements. Grains of metallic gold have not been recognized in the carbonaceous ore.

Pyrite is the most abundant sulfide mineral in the carbonaceous gold ore. By comparison, other sulfide and sulfosalt minerals are sparse and occur randomly distributed throughout the ore; these minerals include realgar, orpiment, stibnite, lorandite, christite, weissbergite, ellisite, carlinite, cinnabar, sphalerite, galena, molybdenite, chalcopyrite, chalcocite, and covellite.

Table 12 lists chemical and spectrographic analyses of samples of the carbonaceous gold ore (samples 8-10); figure 15 plots data on the contents of major components in the carbonaceous ore in comparison with those in the other unoxidized ore types and in fresh host rocks. The average contents of several elements, including aluminum, gallium, potassium, titanium, vanadium, and organic carbon, are higher in the carbonaceous ore than in all the other ore types. Relative to the normal ore, the carbonaceous ore also contains more barium, phosphorus, silicon, and sulfur, and less calcium, sodium, and $\mathrm{CO}_{2}$. These differences reflect a greater abundance of quartz, hydrothermal clay (mainly kaolinite), carbonaceous materials, barite, and a $\mathrm{TiO}_{2}$ phase, and a sparsity of calcite. The higher content of phosphorus is due to the introduction of carbonaceous materials.
Important differences between the chemical and mineralogic compositions of the unoxidized ore types, including the carbonaceous gold ore, were discussed above in the subsection entitled "Siliceous Ores." Except for the great abundance of arsenic and the accompanying large amounts of associated elements (including antimony, mercury, thallium, and sulfur) that characterize the arsenical ores, the mineralogy and chemical compositions of the arsenical and carbonaceous gold ores are similar. In comparison with the pyritic gold ore, the carbonaceous ore contains more clay and remnant dolomite, as shown by the contents of aluminum, potassium, magnesium, calcium, and $\mathrm{CO}_{2}$, and smaller amounts of quartz and pyrite, as reflected in the contents of silica, total iron, and sulfur (fig. 15, table 12).

The abundance of carbonaceous materials in the carbonaceous gold ore provided a chemical environment favorable for the formation and preservation of at least two rare thallium-bearing minerals. These two minerals-carlinite $\left(\mathrm{Tl}_{2} \mathrm{~S}\right)$ and ellisite $\left(\mathrm{Tl}_{3} \mathrm{AsS}_{3}\right)$-are probably unstable except under strongly reducing, oxygen-deficient conditions, such as those provided by the surrounding carbonaceous materials in this ore type.

\section{PYRITIC ORE}

About 0.5 to 3 weight percent pyrite is a ubiquitous constituent of unoxidized Carlin ores. Locally, however, the content of pyrite is much higher; these mineralized carbonate rocks, which contain from 3 to 10 weight percent pyrite, are here classified as pyritic gold ore.

The pyritic ore is medium to dark gray and commonly contains sufficient pyrite to be visible in hand specimen. Pyrite occurs as bands, ranging from a few millimeters to $20 \mathrm{~mm}$ in thickness, interlayered with or crosscutting carbonaceous ores (fig.22); and as lenticular masses, 3 to $4 \mathrm{~m}$ wide, within either the normal or the carbonaceous ore. The pyritic ore occurs in both the Main and East ore zones and accounts for about 5 to 10 percent of the total known unoxidized ores in the deposit.

Most of the pyrite occurs as subhedral to euhedral cubic grains ( $\max 0.4 \mathrm{~mm})$, and smaller amounts as rounded framboidal grains. The pyrite and remnant corroded dolomite rhombs are set in a matrix composed mainly of finegrained dolomite, silt-size angular detrital quartz grains, and irregular patches and seams of hydrothermal quartz, much of which replaced the original carbonate minerals. The pyritic ore generally contains relatively small amounts of remnant dolomite, little, if any, calcite, and comparatively small amounts of hydrothermal clay. Carbonaceous materials are dispersed throughout the matrix, are concentrated in seams parallel to the bedding, and fill randomly oriented microfractures. Fossil fragments commonly are completely silicified. 


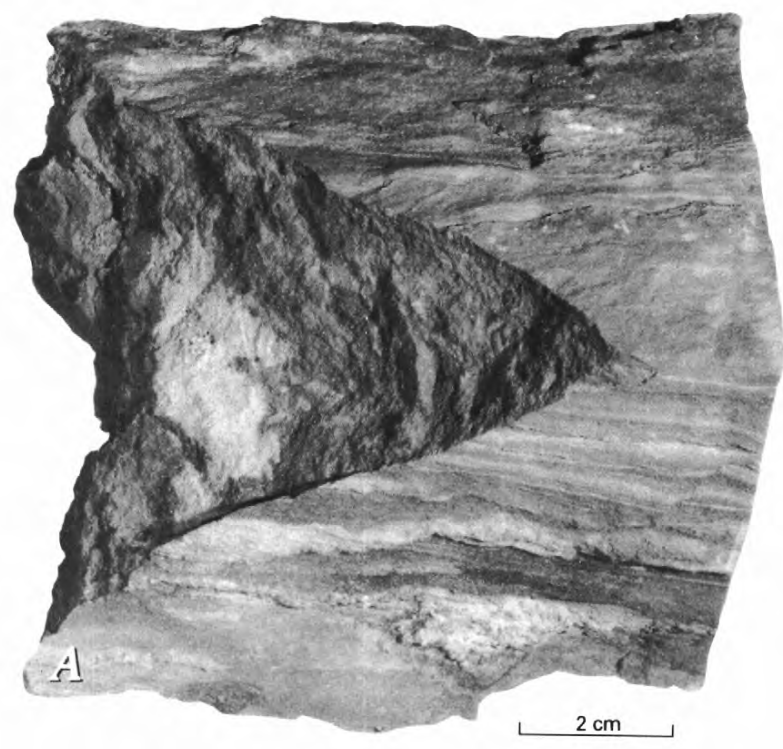

FiguRE 22.-Hydrothermal pyrite and pyritic gold ore. $A$. Specimen of pyritic gold ore. Light-gray areas are pyrite-rich seams that tend to parallel bedding. Dark zones contain large amounts of carbonaceous materials (more than 3 weight percent organic carbon). $B$, Textural relations between abundant coarse-grained hydrothermal pyrite (white) and other minerals in pyritic ore. Dolomite and quartz grains (gray) are set in matrix of clay and carbonaceous materials (black). C. Scanning electron micrograph showing cubic crystals of hydrothermal pyrite $(\mathrm{Py})$ in pyritic ore. Small veinlet of hydrothermal quartz and carbonaceous materials $(\mathrm{Q}+\mathrm{C})$ contacts pyrite and transects specimen. Highly corroded dolomite rhombs, quartz, and clay make up remainder of specimen.

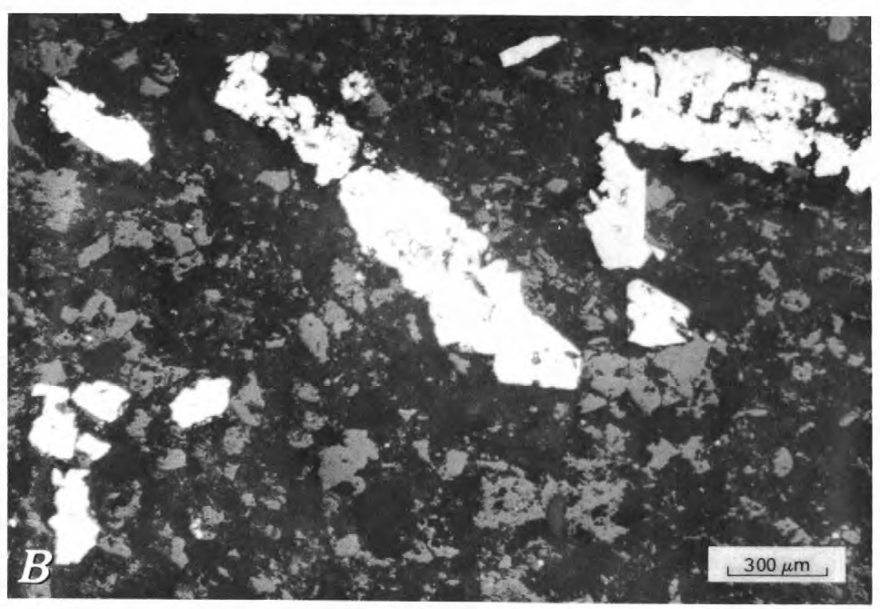

Figure 22.-Continued.

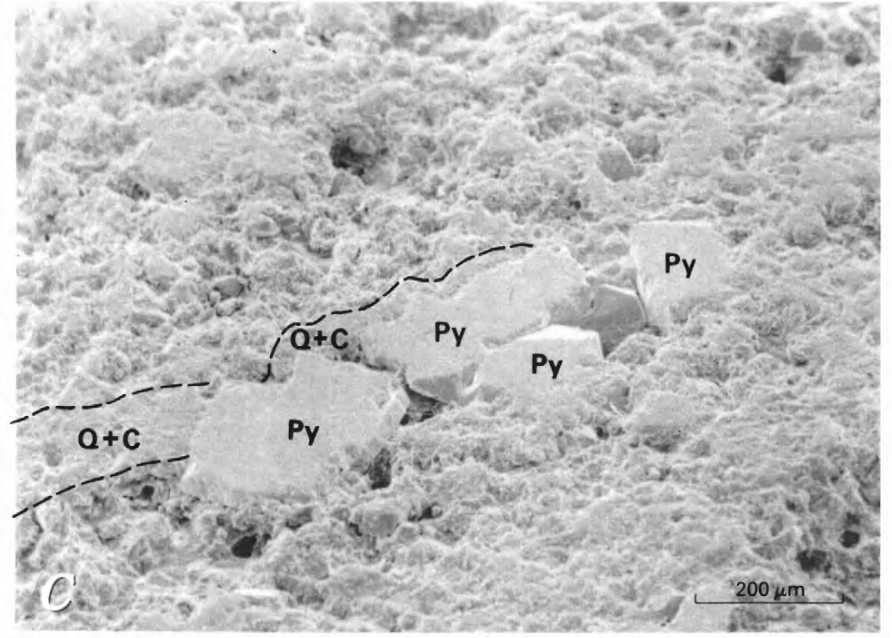

FIGURE 22.-Continued.

Chemical and spectrographic analyses of samples of the pyritic ore (samples 11, 12, table 12) indicate that its composition varies widely and that median values for many elements differ significantly from those in the other unoxidized ore types (fig. 15). Except for the siliceous ores, the pyritic ore contains the most silica and the least aluminum, calcium, potassium, magnesium, titanium, and $\mathrm{CO}_{2}$ of any unoxidized ore type. The high contents of both total iron and sulfur reflect the presence of abundant pyrite; the content of organic carbon generally is between 0.5 and 0.8 weight percent. Table 12 also lists the minorelement contents in samples of the pyritic ore (samples 11, 12). The abundances of most minor elements, including gold, vary widely between samples but resemble those in the other ore types except for the arsenical.

Electron microprobe studies show that most of the gold, together with mercury, arsenic, and antimony, occurs as coatings on both the framboidal and cubic varieties of pyrite. Surfaces of larger cubic pyrite grains generally lack detectable amounts of these elements. Small amounts of gold and mercury associated with carbonaceous material are sporadically distributed throughout the matrix of the rocks. Small particles (less than $5 \mu \mathrm{m}$ diam) of metallic gold occur in hydrothermal quartz but are very rare.

Sulfide minerals other than pyrite are uncommon in the pyritic ore. Sparse amounts of realgar, stibnite, cinnabar, sphalerite, galena, molybdenite, and chalcopyrite occur in randomly scattered grains (less than $50 \mu \mathrm{m}$ ). 

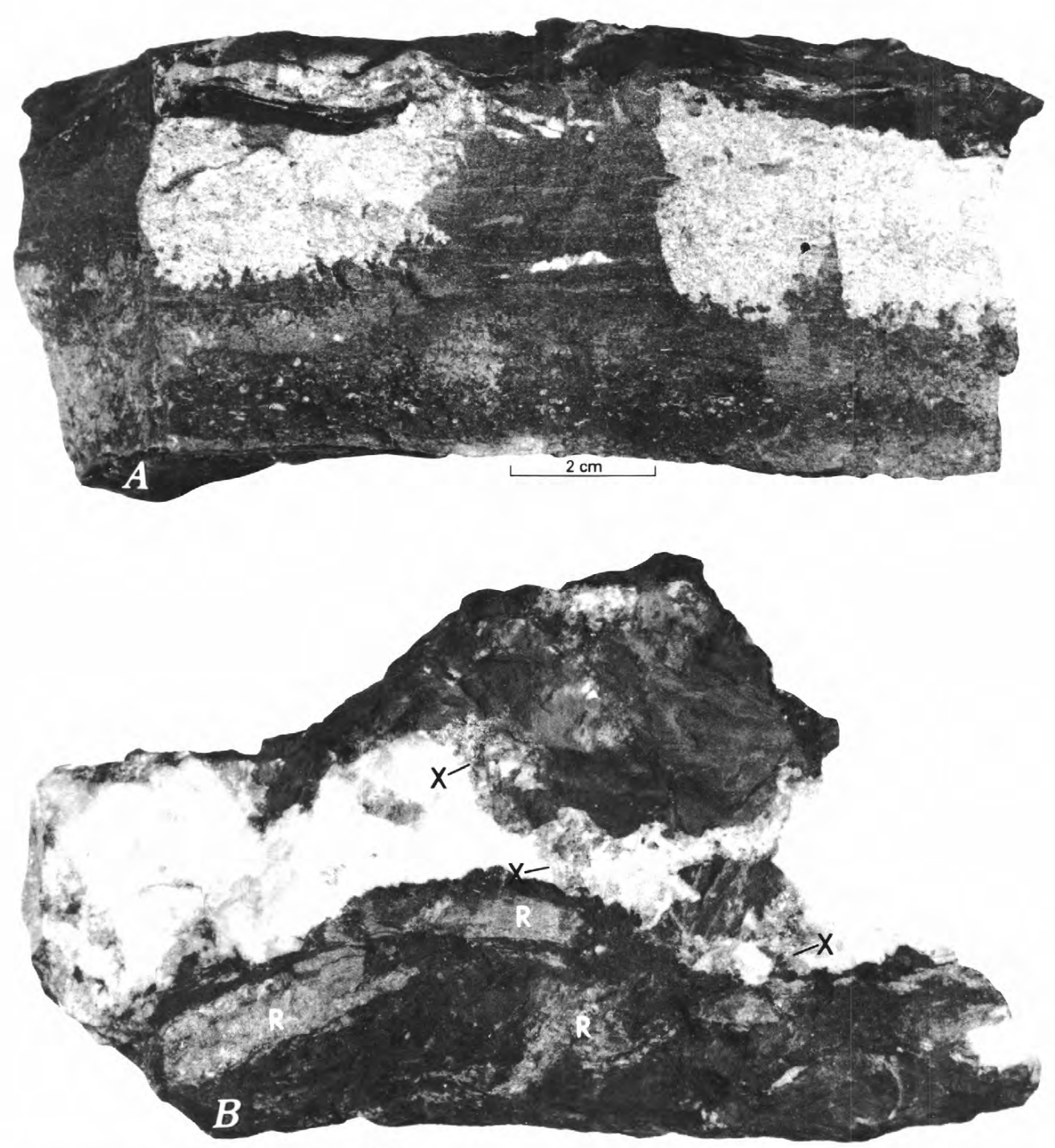

FIGURE 23.-Specimens of arsenical gold ore. A, Showing coating of realgar (gray white) on fracture surface and thin seams (less than $1 \mathrm{~mm}$ ) of realgar (light gray) following microfractures and paralleling bedding. Note thicker seam of realgar in black carbonaceous zone at top. $B$, Containing barite veinlet (white). Dark grains (X) concentrated along margins of barite are christite, lorandite, and realgar. Note heavy concentrations of realgar (R) close to barite seam.

\section{ARSENICAL ORES}

Unoxidized gold ores that contain especially large amounts of arsenic are here classified as a separate ore type (fig. 23). The content of arsenic in these ores ranges from 0.5 to more than 10.0 weight percent, mostly in the form of realgar but including lesser amounts of orpiment and various sulfosalt minerals. The arsenic sulfides, which occur in small veinlets ( $\max 20 \mu \mathrm{m}$ wide), as coatings on the walls of fractures, and as small discrete grains, were formed late in the paragenesis.

Though a distinct ore type, the arsenical gold ores were formed by introduction of large amounts of arsenic into either the carbonaceous or, less commonly, the normal gold ore. The irregular masses and veins of bright-red to red-orange arsenic sulfides that account for most of the arsenic in these rocks stand out against the black, typically carbonaceous host rocks. 


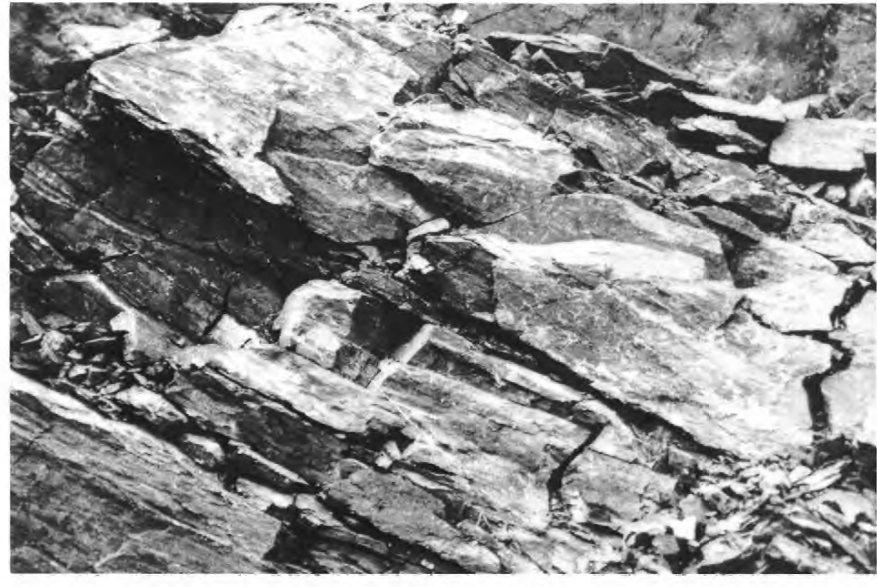

FIGURE 24.-Mass of blocky carbonaceous gold ore from southwest end of East ore zone, containing large amounts of arsenic sulfide minerals. Small white seams and patches are predominantly realgar and lesser amounts of orpiment and calcite.

Small bodies of arsenical ore were found along the entire length of the East ore zone; large amounts were near the southwestern part of the zone (fig.24). The pipeshaped ore body at the southwest end of the East ore zone (the "garbage can" ore body) contained large tonnages of arsenical ore. Small remnant unoxidized pods of arsenical ore occurred in oxidized ores in the central part of the Main ore zone southwest of Popovich Hill. Some deep unoxidized ores in the Main ore zone south and southwest of Popovich Hill contain large amounts of arsenic sulfide minerals. The arsenical ores are estimated to make up 5 to 10 percent of the known unoxidized ores in the Carlin deposit. Although no data are currently available on the deep unoxidized ores below Popovich Hill, these ores are probably rich in arsenic.

In thin section, most of the arsenical ores show deeply corroded dolomite rhombs and angular silt-size quartz grains in a matrix composed of dolomite grains $(2-4 \mu \mathrm{m})$, clay, and carbonaceous materials. Fossil fragments are completely silicified. Veinlets ranging from a few micrometers to about $200 \mu \mathrm{m}$ in width, of realgar and minor quartz, fill microfractures and follow bands of carbonaceous materials (fig. 25). Realgar also occurs filling vugs (50 to $300 \mu \mathrm{m}$ diam) that have walls lined with quartz crystals; local transection or replacement of realgar by small veinlets of chalcedony or quartz indicates late introduction of silica. Most of the hydrothermal quartz, however, occurs in small irregular patches and seams that replaced calcite and lesser amounts of dolomite during the early and main stages of hydrothermal activity. Small subhedral grains of hydrothermal pyrite occur in these patches of quartz, as well as in veinlets of quartz filling randomly oriented fractures. Thus, quartz was introduced by the hydrothermal solutions throughout the entire period of mineralization; quartz deposition ended after the relatively late formation of arsenic sulfides.
The occurrences, associations, and forms of pyrite in the arsenical gold ores resemble those in the carbonaceous ores discussed above. In addition, small corroded subhedral cubic grains (generally less than $20 \mu \mathrm{m}$ ) of pyrite, locked in realgar veinlets, appear to be partly replaced by realgar.

Table 12 lists chemical and spectrographic analyses of samples of the arsenical gold ore (samples 13,14). The introduction of large amounts of silica, the removal of calcite and lesser amounts of dolomite, and the resulting general mineralogic similarity between the arsenical and carbonaceous ores are reflected in the similar median values for calcium, magnesium, phosphorus, silicon, and $\mathrm{CO}_{2}$ in both ore types (fig. 15), and in the content of organic carbon, which commonly is more than 1.0 weight percent in the arsenical ores. The high content of sulfur in the arsenical ores is due to the presence of arsenic sulfide minerals.

The gold in arsenical ores has several modes of occurrence. Gold, together with arsenic, antimony, mercury, and, locally, thallium, forms thin films on both the framboidal and cubic varieties of pyrite. Pyrite grains associated with hydrothermal quartz, as well as those in realgar, commonly contain detectable amounts of gold and mercury. The associations of gold and mercury with carbonaceous materials in the arsenical ores resemble those described above in the subsection entitled "Carbonaceous Ore." Electron microprobe analyses indicate that small amounts of gold are present locally in realgar; whether the gold occurs as discrete particles of native gold or is in solid solution in the realgar has not been determined.

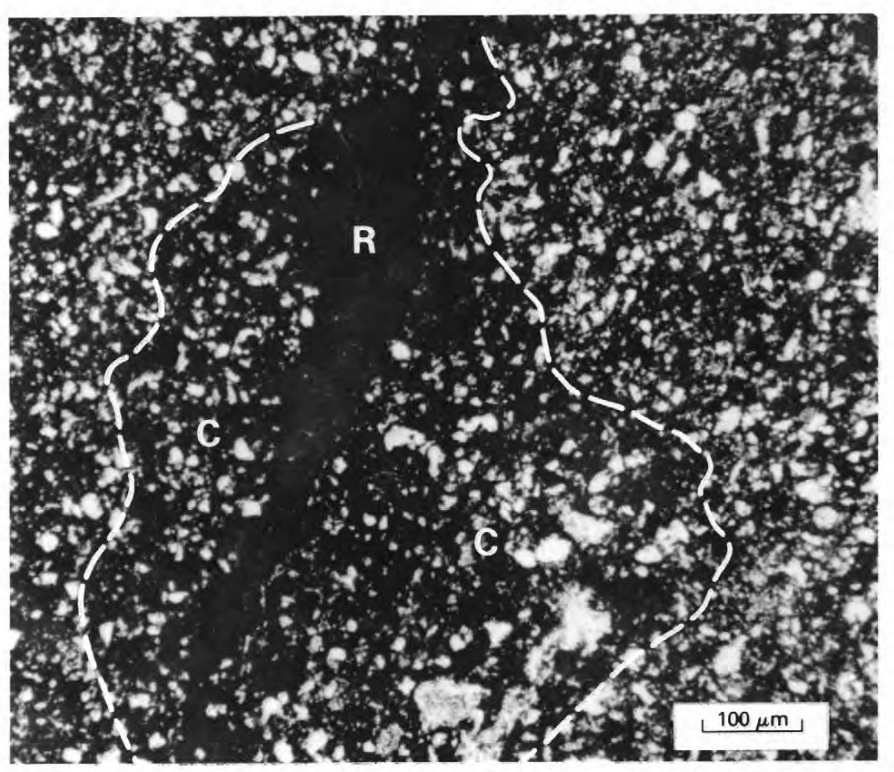

FIGURE 25. - Seam of realgả $(\mathrm{R})$ filling microfracture in thin section of arsenical gold ore. Zone of hydrocarbon enrichment (C) lines margins of microfracture. 
Although the arsenical gold ores make up only 5 to 10 percent of the total known unoxidized ores at Carlin, in other disseminated-replacement gold deposits, including these at Getchell, Nev., White Caps (Manhattan), Nev., and Mercur, Utah, it accounts for much larger percentages; particularly the Getchell and Mercur deposits probably contained large tonnages of arsenical ore. This ore type also occurs at Kendall (North Moccasin), Mont. (A. S. Radtke, unpub. data, 1970).

\section{MINERALOGY AND DISTRIBUTION OF ELEMENTS IN UNOXIDIZED ORES}

\section{IRON}

Most of the iron in unoxidized ores of the Carlin gold deposit occurs in pyrite, and both diagenetic and hydrothermal pyrite are present in all the unoxidized ore types. Diagenetic pyrite in unoxidized ores commonly occurs in relatively large euhedral cubes ( $\max 1 \mathrm{~mm}$ diam) that tend to be concentrated in narrow bands parallel to bedding. Pyrite of hydrothermal origin occurs in two forms: (1) subhedral to euhedral cubic grains, generally less than $0.3 \mathrm{~mm}$ and smaller than the diagenetic pyrite grains (figs. $12,18,22)$; and (2) rounded framboidal microspheres, generally less than $10 \mu \mathrm{m}$ in diameter (fig. 21). A few samples from the southwest end of the East ore zone contained small amounts of fine-grained pyrrhotite. No other iron sulfide minerals have been identified in the unoxidized ores, although the fine-grained texture of these minerals commonly precludes quantitative microprobe analysis.

The content of pyrite in fresh unmineralized rocks of the Roberts Mountains Formation is less than 0.5 weight percent. The total pyrite content in mineralized rocks ranges from less than 1 weight percent in the siliceous ores to as much as 10 weight percent in the pyritic ore. Pyrite is ubiquitous in all the unoxidized ore types. Surfaces of the small cubic pyrite grains commonly are altered to hematite or other iron oxide minerals; grains showing an apparent interlocking of pyrite and hematite represent a progressive oxidation outward from microfractures that cut the pyrite grains.

Other iron-bearing minerals include chalcopyrite and sphalerite. The hydrothermal sphalerite in Carlin ores commonly contains only 0.2 to 0.6 weight percent $\mathrm{Fe}$, in contrast to the fine-grained diagenetic or authigenic sphalerite in the Roberts Mountains Formation, which contains 5 to 8 weight percent Fe. Small amounts of iron (max 4.5 weight percent) are present in sparse grains of both tetrahedrite and tennantite.

Iron also occurs in detrital minerals, including hematite, magnetite, and ilmenite, and minor amounts (0.3-0.7 weight percent) are common in illite. Microprobe analysis shows that amorphous carbon frequently contains 0.05 to 0.1 weight percent $\mathrm{Fe}$; and an unidentified organic compound, probably an organic acid, may contain as much as 1.2 weight percent $\mathrm{Fe}$.

\section{GOLD}

Gold in unoxidized ores of the Carlin deposit occurs: (1) as coatings or thin films on pyrite, (2) sporadically distributed on surfaces of amorphous carbon grains, (3) in association with organic acid(s) as a gold-organic compound, (4) as metallic gold, (5) dispersed as particles of metallic gold in realgar or in solid solution in realgar, and (6) in solid solution in sparse grains of elemental arsenic. Results of electron microprobe analyses of 60 samples of unoxidized ores from throughout the deposit show that most of the gold in unoxidized ores occurs in forms 1 through 3 . The forms of gold in the unoxidized ore types were discussed in the preceding section of this report.

The presence of gold on surfaces of pyrite grains in Carlin ores was first reported by Radtke and others (1972b). Later, Wells and Mullens (1973) verified this result but, from study of one specimen, concluded that all the gold in unoxidized ores of the deposit was associated with pyrite.

Electron microprobe analyses show that gold, mercury, arsenic, antimony, and, locally, thallium occur together in thin films (less than $2 \mu \mathrm{m}$ ) coating the surfaces of cubic pyrite grains; these five elements also are associated with the rounded framboidal pyrite grains. Although the framboids generally are too small to locate the gold precisely, chemical analyses, as well as optical studies by electron microprobe and scanning electron microscope, of larger framboids show that the gold is associated with sulfur, iron, antimony, and mercury coating the surface, and is not within the pyrite structure (see fig $21 \mathrm{C}$ ). The gold content of coatings on pyrite grains commonly ranges from less than 0.01 to 0.35 weight percent and varies widely between individual grains (samples 1,2, table 13). X-ray scanning images show gold, mercury, arsenic, and antimony on surfaces of a sectioned pyrite grain in the arsenical ore (fig. 26).

On the basis of experimental studies of the extractive properties of carbonaceous materials on gold complexes in various solutions, Radtke and Scheiner (1970a) showed that unoxidized Carlin ores commonly contain three types of organic carbon compounds and postulated that gold in some form was associated with these carbonaceous materials. They pointed out (1970b) that certain organic carbon compounds could have removed gold complexes from ore solutions and thereby increased the amount of gold as + sociated with carbonaceous materials rather than pyrite. 
TABLE 13.-Microprobe and spectrographic analyses of sulfide minerals in unoxidized ores of the Carlin gold deposit

[Microprobe analyses in weight percent. Spectrographic analyses in parts per million: N.A., not analyzed: $\mathrm{M} .>10 \mathrm{ppm}$. Results are identified by geometric brackets whose boundaries are $1.2,0.83,0.56,0.38,0.26,0.18,0.12$, and so on, but are reported arbitrarily as the mid points of these brackets: $1.0,0,7,0.5,0.3,0.2,0.15,0.1$, and so on. The precision of a given value is approximately plus or minus one bracket at the 78 -percent, or two brackets at the 95 -percent, confidence level. Below limit of detection (10 ppm) in all samples: W. Analysts: Chris Heropoulos and A. S. Radtke]

\begin{tabular}{|c|c|c|c|c|c|c|c|c|c|c|c|c|c|c|c|c|c|}
\hline \multirow[b]{2}{*}{ Mineral Sample . } & \multicolumn{3}{|c|}{ Pyrite } & \multicolumn{2}{|c|}{ Realgar } & \multicolumn{3}{|c|}{ Orpiment } & \multicolumn{2}{|c|}{ Stibnite } & \multicolumn{2}{|c|}{ Cinnabar } & \multirow{2}{*}{$\frac{\text { Carlinite }}{13}$} & \multicolumn{2}{|c|}{ Galena } & \multicolumn{2}{|c|}{ Sphalerite } \\
\hline & 1 & 2 & 3 & 4 & 5 & 6 & 7 & 8 & 9 & 10 & 11 & 12 & & 14 & 15 & 16 & 17 \\
\hline \multicolumn{18}{|c|}{ Microprobe analyses } \\
\hline s & $52-55$ & $52-54$ & $53.1-53.8$ & $30.2-30.4$ & $30.1-30.6$ & $38.9-39.7$ & $39.1-39.4$ & $39.0-39.5$ & $27.9-28.6$ & $28.0-28.5$ & $13.6-13.9$ & $13.7-13.9$ & $7.0-7.2$ & $13.1-13.5$ & $13.1-13.4$ & $32.8-33.7$ & $32.5-33.4$ \\
\hline $\mathrm{Fe}$ & $44-47$ & $45.5-47$ & $46.0-46.7$ & $<.03-.04$ & $<.03$ & $<.04$ & $<.04$ & $<.04$ & $<.04$ & $<.04-.06$ & $<.05$ & $<.05$ & $<.04$ & $<.04$ & $<.04$ & $.20-.60$ & $<.04-.38$ \\
\hline $\mathrm{Au}$ & $<.01-.35$ & $.03-.3$ & $<.01$ & $<.02$ & $<.02-.05$ & $<.03$ & $<.03$ & $<.03$ & $<.03$ & $<.03$ & $<.03$ & $<.03$ & $<.04$ & $<.05$ & $<.05$ & $<.05$ & $<.05$ \\
\hline $\mathrm{Pb}$ & $<.05$ & $<.05$ & $<.05$ & $<.05$ & $<.05$ & $<.05$ & $<.05$ & $<.05$ & $<.06$ & $<.06$ & $<.05$ & $<.05$ & $<.05$ & $86.3-86.9$ & $86.5-87.3$ & $<.04$ & $<.04$ \\
\hline $\mathrm{Zn}$ & $<.06$ & $<.06$ & $<.06$ & $<.05$ & $<.05$ & $<.06$ & $<.06$ & $<.06$ & $<.06$ & $<.06$ & $<05$ & $<.05$ & $<.05$ & $\begin{array}{l}0.03-00.9 \\
<.06\end{array}$ & $\begin{array}{l}00.0-01.3 \\
<.06\end{array}$ & $65.6-67.4$ & $66.2-67.2$ \\
\hline As & $<.06-3.5$ & $<.06-6.0$ & $<.06$ & $69.1-69.5$ & $69.0-69.6$ & $59.8-60.6$ & $59.2-60.1$ & $60.1-61.2$ & $<.05-.4$ & $.5-7.0$ & $<.05$ & $<.05-.3$ & $<.05$ & $<.04$ & $<.04$ & $<.03$ & $<.03 .2$ \\
\hline $\mathrm{Sb}$ & $<.05-3.0$ & $<.05-4.0$ & $<.05$ & $<.05$ & $<.05$ & $<.05$ & $.5-1.5$ & $<.05$ & $71.0-72.0$ & $64.8-71.1$ & $<.06$ & $<.06$ & $<.06$ & $<.05-.15$ & $\leqslant .05$ & $<.04$ & $<.04$ \\
\hline $\mathrm{Hg}$ & $<.04-.7$ & $<.04-1.2$ & $<.04$ & $<.05$ & $<.05$ & $<.05$ & $<.05$ & $<.05$ & $<.05$ & $<.05-.06$ & $86.1-86.3$ & $85.8-86.1$ & $<.05$ & $<.02-<.04$ & $<.02-.06$ & $.07-.1$ & $<.05-.08$ \\
\hline …………......... & $<.08-.1$ & $<.08-.25$ & $<.08$ & $<.08$ & $<.08$ & $<.06$ & $<.06$ & $.1-.35$ & $<.06-.3$ & $<.06-.15$ & $<.06$ & $<.06$ & $92.7-93.1$ & $<.05$ & $<.05$ & $<.05$ & $<.05-.3$ \\
\hline$\ldots$ & $<.08$ & $<.08$ & $<.03$ & $<.06$ & $<.06$ & $<.06$ & $<.06$ & $<.06$ & $<.06$ & $<.06$ & $<.05$ & $<.05$ & $<.04$ & $<.06-.10$ & $<.02-.04$ & $<.04$ & $<.04$ \\
\hline $\mathrm{Bi}$ & $<.05$ & $<.05$ & $<.05$ & $<.05$ & $<.05$ & $<.05$ & $<.05$ & $<.05$ & $<.06$ & $<.06$ & $<.05$ & $<.05$ & $<.06$ & $<05$ & $<.06$ & $<.05$ & $<.05$ \\
\hline $\mathrm{Cd}$ & $<.05$ & $<.05$ & $<.05$ & $<.05$ & $<.05$ & $<.05$ & $<.05$ & $<.05$ & $<.06$ & $<.06$ & $<.06$ & $<.06$ & $<.05$ & $<.06$ & $<.06$ & $<.04-.5$ & $<.04-.6$ \\
\hline
\end{tabular}

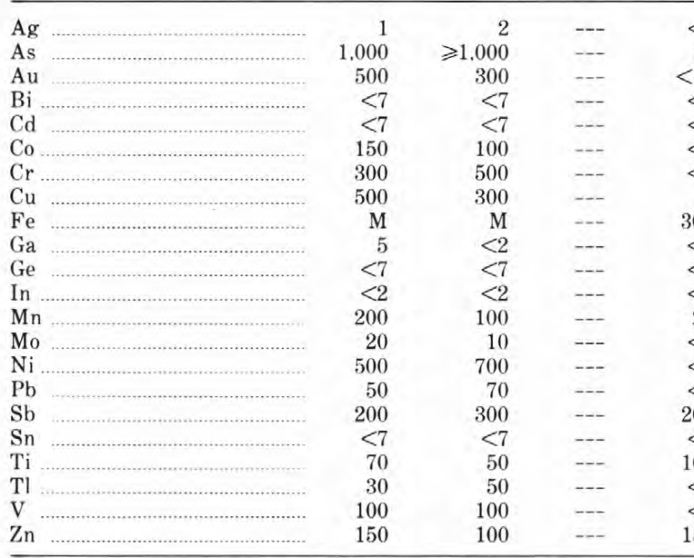

$<0.7$
$M$
$<10$
$<7$
$<7$
$<2$
$<1$
$<1$
1.5
300
$<2$
$<7$
$<2$
20
20
$<2$
$<1$
$<7$
200
$<7$
100
$<3$
$<3$
150

\begin{tabular}{cr}
$<0.7$ & $\leqslant 0.7$ \\
$\mathrm{M}$ & $\mathrm{M}$ \\
$<10$ & $<10$ \\
$<7$ & $<7$ \\
$<7$ & $<7$ \\
$<2$ & 3 \\
$<1$ & $<1$ \\
1 & 1 \\
10 & 30 \\
$<2$ & $<2$ \\
$<7$ & $<7$ \\
$<2$ & $<2$ \\
15 & $<1$ \\
$<2$ & $<2$ \\
1 & $<1$ \\
$<7$ & $<7$ \\
30 & $<20$ \\
$<7$ & $<7$ \\
20 & $<1$ \\
$<3$ & 20 \\
3 & $<3$ \\
30 & $<15$ \\
\hline
\end{tabular}

$\begin{array}{cr}\leqslant 0.7 & <0.7 \\ \mathrm{M} & \mathrm{M} \\ 10 & <10 \\ 10 & <7 \\ <7 & <7 \\ <7 & <2 \\ 3 & <2 \\ <1 & 2 \\ 1 & 2 \\ 30 & 50 \\ <2 & <2 \\ <7 & <7 \\ <2 & <2 \\ <1 & <1 \\ <2 & <2 \\ <1 & < \\ <7 & < \\ <20 & 10.000 \\ <7 & <7 \\ <1 & < \\ 20 & < \\ <3 & < \\ <15 & 30\end{array}$

$\begin{array}{rr}<0.7 & <0.7 \\ \mathbf{M} & \mathrm{M} \\ <10 & <10 \\ <7 & <7 \\ <7 & <7 \\ <2 & \leq 2 \\ <2 & <1 \\ 2 & <1 \\ 2 & 1 \\ 50 & 50 \\ <2 & <2 \\ <2 & <7 \\ <7 & <2 \\ <2 & <2 \\ <1 & <1 \\ <2 & <2 \\ <1 & 7 \\ <7 & <7 \\ .000 & <20 \\ <7 & <7 \\ <1 & <1 \\ <3 & 2.000 \\ <3 & <3 \\ 300 & 30\end{array}$

Sample 1. Microprobe analyses of 12 large pyrite framboids in ore samples from the Main and East ore zones: Pyrite from both the Main and East ore containing abundant framboidal as well

2. Microprobe analyses of 40 subhedral to euhedral cubic pyrite grains in ore samples from the West. Main, and East ore zones; spectrographic data are on a concentrate containing cubic and only minor amounts of framboidal pyrite. Pyrite from both the Main and East ore zones is included in

composite sample.
3. Microprobe analyses of central areas in 35 sectioned subhedral to euhedral cubic pyrite grains, 28 of which had surface coatings containing detectable amounts of gold and associated elements, from the West. Main, and East ore zones.

Microprobe analyses of 15 grains, seams, and patches of realgar in carbonaceous and arsenical ores and in barite veins from the Main and East ore zones. No grains contained gold detectable by
microprobe analysis: spectrographic data are on a composite sample of 10 specimens of realgar.

5. Microprobe analyses of 20 grains, seams, and patches of realgar in carbonaceous and arsenical ores from the Main and East ore zones. All grains included in sample contained detectable amounts gold in local areas; spectrographic data are on a composite sample of 8 specimens of realgar. Microprobe analyses of $18 \mathrm{grains}$ of orpiment in arsenical ores fr
data are on a composite sample of 6 specimens of orpiment.

7. Microprobe analyses of 5 grains of antimony-bearing orpiment in carbonaceous and arsenical ores Miom the East ore zone: spectrographic data areon a composite sam ple of 3 specimens oforplmest. calcite, and qurtz from the East ore zone; spectrographic data are on a single large grain.

$\begin{array}{rrr}2 & \\ 50 & 20,007 \\ <10 & < \\ <7 & \\ <7 & \\ <2 & \\ <1 & \\ 30 & \\ 30 & \\ <2 & \\ <7 & \\ <2 & \\ <1 & \\ 10 & \\ 10 & \\ <7 & \\ M & \\ 50 & \\ 7 & \\ 1.000 & \\ 20 & \\ <15 & \\ <15 & \\ & \end{array}$

\begin{tabular}{|c|c|c|}
\hline 0.7 & $\cdots$ & -- \\
\hline 000 & $\ldots$ & \\
\hline$<10$ & -..- & -.- \\
\hline$<7$ & -.. & $\ldots$ \\
\hline$<7$ & & \\
\hline$<2$ & -.- & -- \\
\hline$<1$ & --- & --- \\
\hline 20 & -- & -- \\
\hline 300 & --- & --- \\
\hline$<2$ & --- & -- \\
\hline$<7$ & --- & -- \\
\hline$<2$ & -- & -- \\
\hline$<1$ & -- & --- \\
\hline 5 & $\cdots$ & \\
\hline 20 & $\overline{-}$ & $\cdots$ \\
\hline $\begin{array}{l}<7 \\
\text { M }\end{array}$ & $\ldots$ & $\cdots$ \\
\hline 30 & ... & -- \\
\hline 20 & $\cdots$ & -- \\
\hline 700 & -- & --- \\
\hline $\begin{array}{r}30 \\
150\end{array}$ & $\cdots$ & $\overline{-}$ \\
\hline
\end{tabular}

$\begin{array}{rr}1 & 1.000 \\ <100 & 20.000 \\ <10 & <10 \\ <7 & 100 \\ <7 & <7 \\ 2 & <2 \\ <1 & 2 \\ 3 & 50 \\ 10 & 200 \\ <2 & <2 \\ <7 & <7 \\ <2 & <2 \\ <1 & 20 \\ <2 & <2 \\ 1 & <1 \\ <7 & \mathrm{M} \\ <20 & 1.000 \\ <7 & <7 \\ 2 & 10 \\ \mathrm{M} & \leq 3 \\ <3 & <3 \\ 20 & 15\end{array}$

$\begin{array}{rr}1.000 & 500 \\ 0.000 & 30.000 \\ <10 & <1 \\ 100 & 7 \\ <7 & < \\ <2 & < \\ 2 & \\ 50 & \\ 200 & 20 \\ <2 & < \\ <7 & < \\ <2 & < \\ 20 & 2 \\ <2 & < \\ <1 & < \\ \mathrm{M} & \\ 1.000 & 70 \\ <7 & < \\ 10 & 3 \\ \leq 3 & < \\ <3 & < \\ 15 & <1\end{array}$

$\begin{array}{rcr}500 & 10-20 & 20 \\ .000 & <50 & <50 \\ <10 & <10 & <10 \\ 70 & <7 & <7 \\ <7 & 2,000-5.000 & 2,000 \\ <2 & <2-2 & <2 \\ 3 & 1.5-2 & <1 \\ 1 & 200-700 & 200 \\ 200 & 1.500-7.000 & 1.500 \\ <2 & 200-300 & 300 \\ <7 & 200-300 & 200 \\ <2 & 7-10 & 10 \\ 20 & 7-50 & 15 \\ <2 & <2 & <2 \\ <1 & <1 & <1 \\ \mathrm{M} & 50-70 & 50 \\ 700 & 50-150 & 100 \\ <7 & <7 & <7 \\ 30 & 10-15 & 10 \\ <3 & <3 & 100 \\ <3 & <3 & <3 \\ <15 & \mathrm{M} & \mathrm{M} \\ <3 & \end{array}$

Microprobe analyses of 20 grains of stibnite in siliceous and carbonaceous ores from the East ore zone: spectrographic data are on a composite sample of 10 specimens of stibnite. all of which lacked visible realgar.

10. Microprobe analyses of 10 grains of stibnite in arsenical ores from the Main and East ore zones: spectrographic data are on a composite sample of 15 specimens of stibnite containing visible realgar.
Microprobe analyses of 8 grains of cinnabar dispersed in pyritic, carbonaceous. and arsenical ores from the

East ore zone.
12. Microprobe analyses of 5 grains of cinnabar intergrown with arsenic sulfide and sulfosalt minerals. from the

"garbage can" area in the East ore zone.
Microprobe analyses of 3 grains of carlinite in siliceous carbonaceous ore from the East ore zone; spectrographic data are on a composite sample of several large grains.

Microprobe analyses of 22 grains of galena genetically associated with hydrothermal quartz in siliceous. composite sample of 20 specimens of galena from the East ore zone; grains larger than $0.3 \mathrm{~mm}$ contained abundant sulfosalt inclusions.

15. Microprobe analyses of 20 grains of galena in barite veins from the Main ore zone: spectrographic data are on a composite sample of 35 galena grains containing abundant sulfosalt inclusions in 6 specimens from barite

veins in the Main ore zone,
16. Microprobe analyses of 35 grains of hydrothermal sphalerite in all ore types except the normal from the Main deta ar on 2 compite 18 grains or sphalerite in barte vin in the Min ore zone

Microprobe analyses of 30 grains of hyd rothermal sphalerite in carbonaceous, silicens, from the "garbage can" area in the East ore zone; spectrographic data are on a composite sample of 10 specimens of sphalerite. 


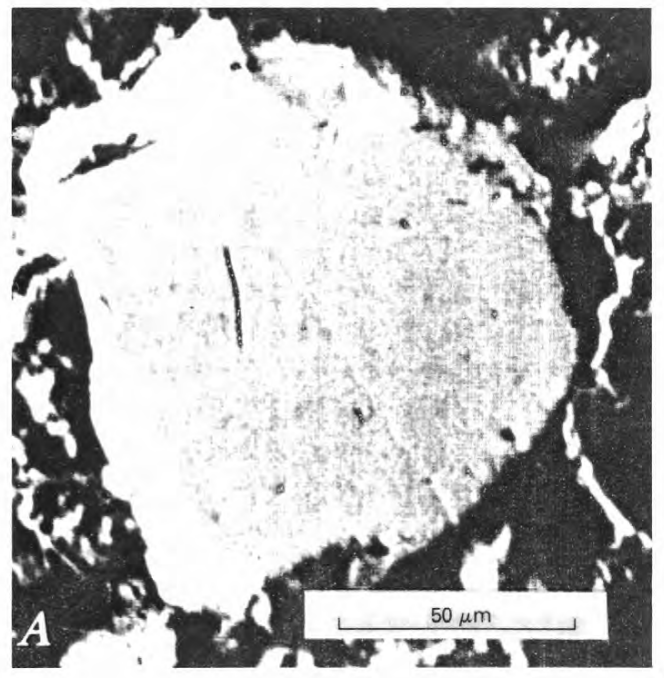

FIGURE 26.-Electron microprobe analyses of sectioned grain of cubic pyrite in arsenical gold ore. $A$, Back-scattered electron photomicrograph of pyrite grain. Electron-beam scanning images shown are of: $B$, iron; $C$, arsenic; $D$, antimony; $E$, mercury; and $F$, gold.

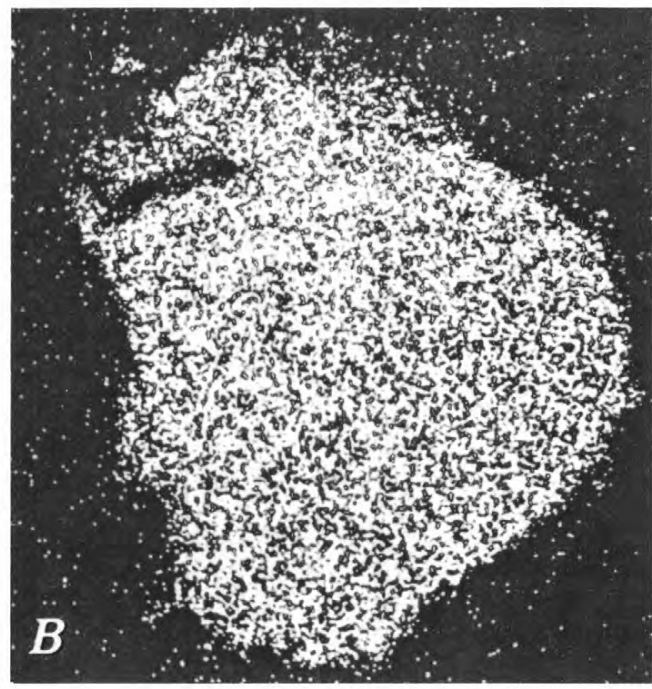

FIgUre 26.-Continued.

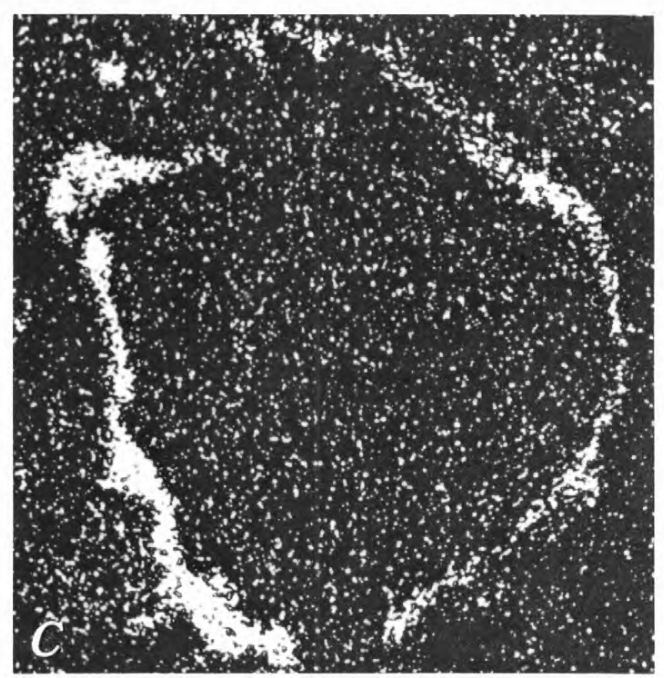

FIGURE 26.-Continued.

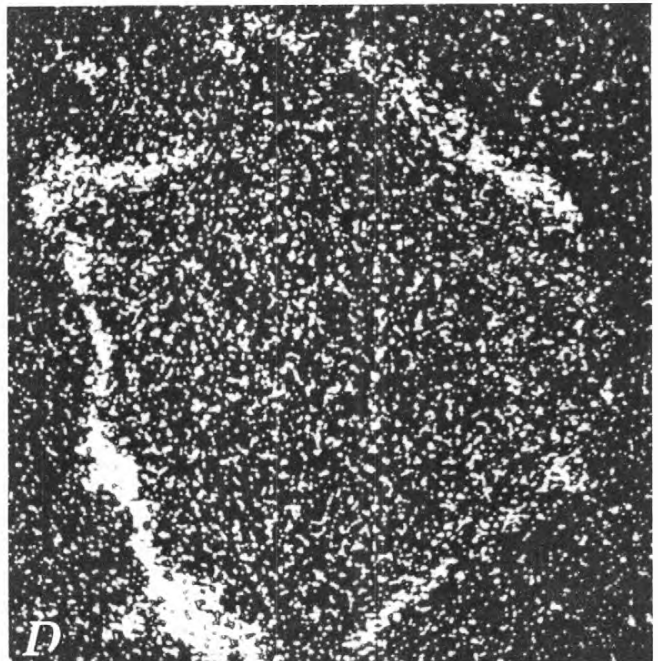

Figure 26.-Continued.

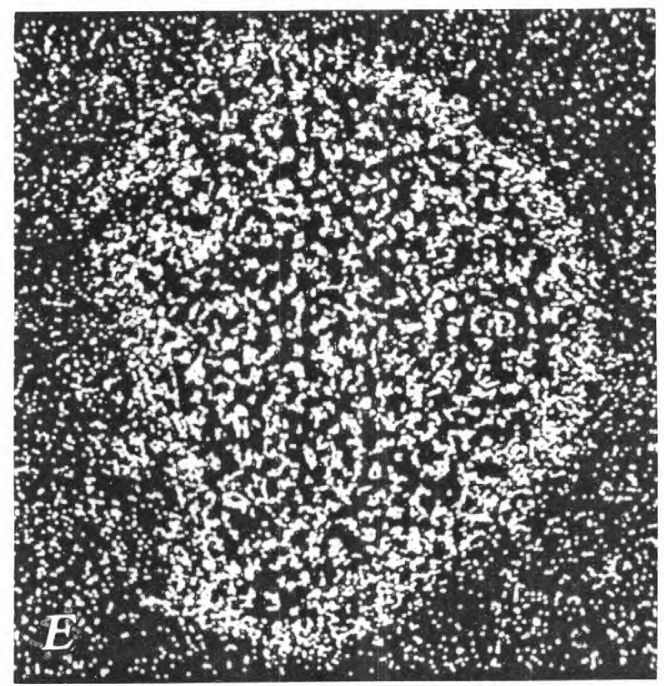

FIGURE 26.-Continued.

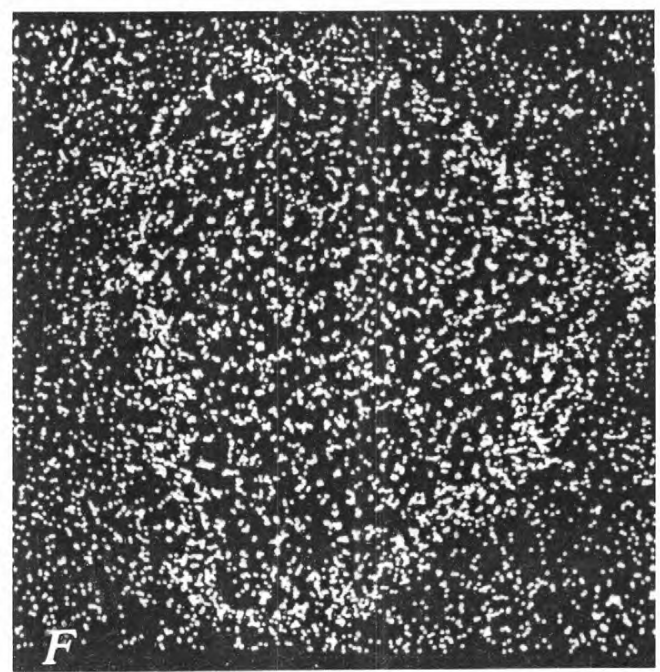

Figure 26.-Continued. 
Electron microprobe analyses of an activated amorphous-carbon compound show that it commonly contains 0.1 to 0.4 weight percent $S$ and trace amounts (less than 0.1 weight percent) of phosphorus, iron, vanadium, and chromium. Gold and mercury in unidentified forms are sporadically distributed and concentrated on the surfaces of the grains. In areas of carbon grains containing detectable amounts of gold, the element generally is present in concentrations of between 0.05 and 0.5 weight percent.

The unoxidized ores also contain an organic acid(s) with properties closely resembling those of humic acids extracted from leonardite, a partially oxidized form of lignite (Scheiner and others, 1968). The organic acid in the Carlin ores has major absorption peaks characteristic of long-chain carboxylic acids, contains sulfur and nitrogen groups, and has a neutralization equivalent of 1,500. Electron microprobe analyses show that this organic compound contains 1.0 to 1.5 weight percent $\mathrm{S}, 0.5$ to 1.0 weight percent $O$, and trace amounts of phosphorus and vanadium. Some grains contain detectable amounts of gold as well as at least 0.06 weight percent $\mathrm{Hg}, 0.08$ weight percent $\mathrm{Fe}, 1.0$ to 1.2 weight percent $\mathrm{F}$, and 0.1 to 0.2 weight percent $\mathrm{Cl}$. Although the gold content varies greatly between grains (less than $0.02-0.25$ weight percent), its uniformity across individual grains suggests that the gold occurs as a gold-organic compound. Scheiner and others (1968) reported that the organic acid(s) contains(s) CO-N-S functional groups capable of behaving as ligands in gold complexes, and that much of the gold in the ore probably occurs in a chelate.

Grains of the organic acid(s) contain detectable amounts of mercury, generally less than of gold, uniformly distributed across the grain. Mercury also is probably chemically bound to the organic carbon compound in a chelate. Although the gold and mercury are associated with carbonaceous materials, other elements, including silver, arsenic, antimony, thallium, copper, lead, zinc, molybdenum, and tungsten, were not detected in microprobe analyses of all types of the organic-carbon com- pounds. X-ray scanning images for gold, mercury, carbon, and sulfur that reveal the association of gold and mercury with carbonaceous materials in a grain-mount section of carbonaceous ore are shown in figure 27.

Microprobe analyses show that a small amount of gold in the unoxidized ores occurs in the metallic form. Most of this metallic gold, generally as particles smaller than $10 \mu \mathrm{m}$ in diameter, is contained in small patches and veinlets of hydrothermal silica. The siliceous ores contain the most metallic gold; ores containing abundant carbonaceous materials, including both the arsenical and carbonaceous gold ores, lack metallic gold. A few of the sparse quartz veinlets carry metallic gold; all but two of these auriferous veins recognized to date occur at shallow depths, less than $45 \mathrm{mbelow}$ the surface. Near the southwest end of the East ore zone, at mine coordinates $23,050 \mathrm{~N}$., $20,100 \mathrm{E}$. (pl. 3), a small quartz vein, as wide as $50 \mathrm{~mm}$, contained pyrite, metallic gold, and frankdicksonite $\left(\mathrm{BaF}_{2}\right)$ (Radtke and Brown, 1974).

Gold is also associated with realgar in the arsenical gold ores. Results of microprobe studies show that small auriferous pyrite grains occur locked in realgar. Locally, however, gold in some form is present in iron-deficient spaces (less than $5 \mu \mathrm{m}$ diam) within realgar (sample 9, table 13). Whether this gold occurs as fine metallic particles or is in solid solution is uncertain. The presence of small amounts of gold in realgar at Mercur, Utah, was reported by Dickson and others (1975b), who also indicated that synthetic realgar and orpiment may contain as much as 200 and $2,000 \mathrm{ppm} \mathrm{Au}$, respectively, in solid solution.

Wells and Mullens (1973) reported that sphalerite and chalcopyrite in Carlin ores contain detectable amounts of gold. However, results of more than 800 microprobe analyses (tables 13,14 ) encompassing all the sulfide and sulfosalt minerals recognized in Carlin ores, including sphalerite and chalcopyrite, show that only pyrite and realgar contain detectable amounts of gold.

The few grains of elemental arsenic analyzed from the East ore zone contained as much as 0.3 weight percent $\mathrm{Au}$. No gold tellurides have been found in Carlin ores.

TABLE 14.-Microprobe analyses of sulfosalt minerals in unoxidized ores in the Carlin gold deposit [Results in weight percent; N.D., not determined. Limits of detection: $\mathrm{Ag}, 0.06 ; \mathrm{As}, 0.1 ; \mathrm{Cu}, 0.05 ; \mathrm{Fe}, 0.05 ; \mathrm{Hg}, 0.08 ; \mathrm{Pb}, 0.08 ; \mathrm{Sb}, 0.05 ; \mathrm{Tl}, 0.1 ; \mathrm{Zn}, 0.05$. No other elements were detected in any of the minerals by microprobe analysis]

\begin{tabular}{|c|c|c|c|c|c|c|c|c|c|c|}
\hline $\begin{array}{l}\text { Mineral } \\
\text { Sample }\end{array}$ & $\begin{array}{c}\text { Lorandite } \\
1\end{array}$ & $\begin{array}{c}\text { Christite } \\
2 \\
\end{array}$ & $\begin{array}{c}\text { Ellisite } \\
3\end{array}$ & $\begin{array}{c}\text { Galkhaite } \\
4\end{array}$ & $\begin{array}{c}\text { Jordanite } \\
5\end{array}$ & $\begin{array}{c}\text { Gratonite } \\
6 \\
\end{array}$ & $\begin{array}{c}\text { Weissbergite } \\
7 \\
\end{array}$ & $\begin{array}{c}\text { Tennantite } \\
8\end{array}$ & $\begin{array}{c}\text { Tetrahedrite } \\
9 \\
\end{array}$ & $\begin{array}{c}\text { Boulangerite } \\
10\end{array}$ \\
\hline 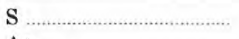 & $18.8 \pm 0.2$ & $16.6 \pm 0.2$ & $12.3 \pm 0.1$ & $21.5 \pm 0.5$ & $18.7 \pm 0.3$ & $18.1 \pm 0.3$ & $16.4 \pm 0.1$ & $27.6 \pm 0.5$ & $25.2 \pm 0.4$ & $18.8 \pm 0.5$ \\
\hline As & $21.6 \pm 0.1$ & $13.1 \pm 0.1$ & $9.6 \pm 0.1$ & $23.7 \pm 0.7$ & $12.5 \pm 0.2$ & $11.1 \pm 0.3$ & N.D. & $18.8 \pm 0.4$ & $1.0 \pm 0.2$ & N.D. \\
\hline 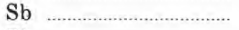 & N.D. & N.D. & N.D. & $.5 \pm 0.2$ & N.D. & N.D. & $31.2 \pm 0.2$ & $.8 \pm 0.1$ & $28.4 \pm 0.6$ & $25.3 \pm 0.6$ \\
\hline $\mathrm{Tl}$. & $59.5 \pm 0.1$ & $35.1 \pm 0.4$ & $78.2 \pm 0.3$ & $3.1 \pm 0.3$ & $.5 \pm 0.1$ & N.D. & $52.6 \pm 0.4$ & N.D. & N.D. & N.D. \\
\hline $\mathrm{Hg}$ & N.D. & $35.1 \pm 0.3$ & N.D. & $47.0 \pm 0.8$ & N.D. & N.D. & N.D. & N.D. & N.D. & N.D. \\
\hline $\mathrm{Pb}$ & N.D. & N.D. & N.D. & N.D. & $68.3 \pm 0.2$ & $70.7 \pm 0.7$ & N.D. & N.D. & N.D. & $55.1 \pm 0.9$ \\
\hline $\mathrm{Zn}$ & N.D. & N.D. & N.D. & $1.8 \pm 0.5$ & N.D. & N.D. & N.D. & $3.1 \pm 0.4$ & $2.5 \pm 0,3$ & N.D. \\
\hline $\mathrm{Fe}$ & N.D. & N.D. & N.D. & $.2 \pm 0.1$ & N.D. & N.D. & N.D. & $3.5 \pm 0.3$ & $.7 \pm 0.2$ & N.D. \\
\hline $\mathrm{Ag}$ & N.D. & N.D. & N.D. & N.D. & N.D. & N.D. & N.D. & $.9 \pm 0.2$ & $.8 \pm 0.2$ & N.D. \\
\hline $\mathrm{Cu}$ & N.D. & N.D. & N.D. & $2.9 \pm 0.3$ & N.D. & N.D. & N.D. & $44.8 \pm 1.1$ & $42.8 \pm 1.0$ & N.D. \\
\hline Number of analyses ...... & 5 & 8 & 5 & 5 & 5 & 7 & 10 & 12 & 15 & 8 \\
\hline
\end{tabular}




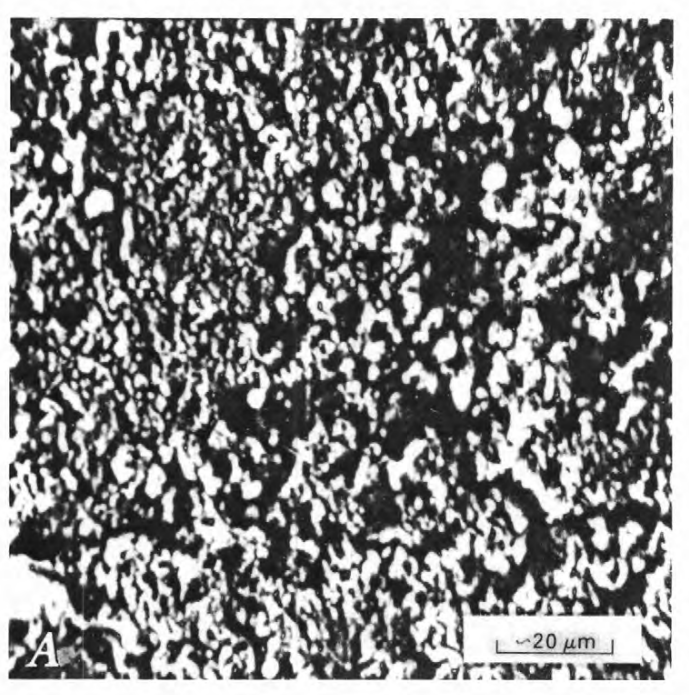

FIGURE 27.-Electron microprobe analyses of carbonaceous materials in sectioned specimen of carbonaceous gold ore. $A$, Specimen current photograph of grain mount containing organic carbon compounds. Electron-beam scanning images shown are of: $B$, carbon; $C$, sulfur; $D$, mercury: and $E$, gold.

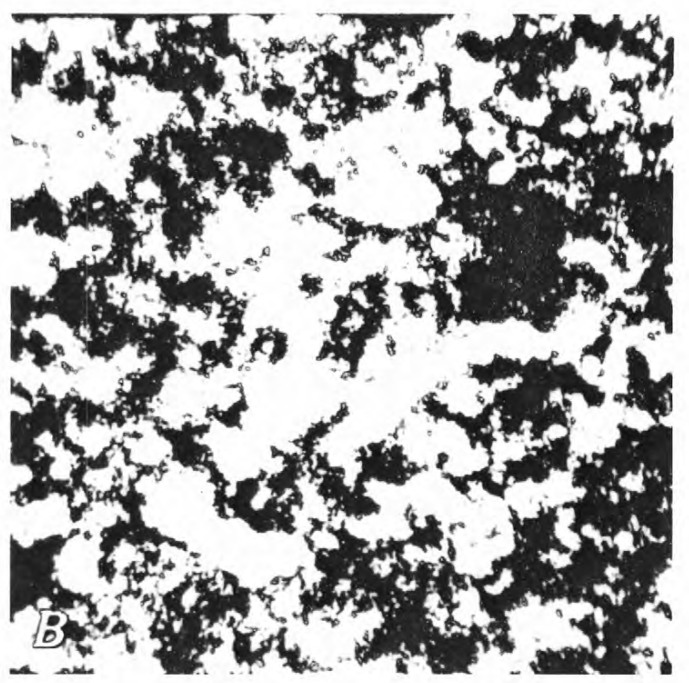

FIGURE 27.-Continued.

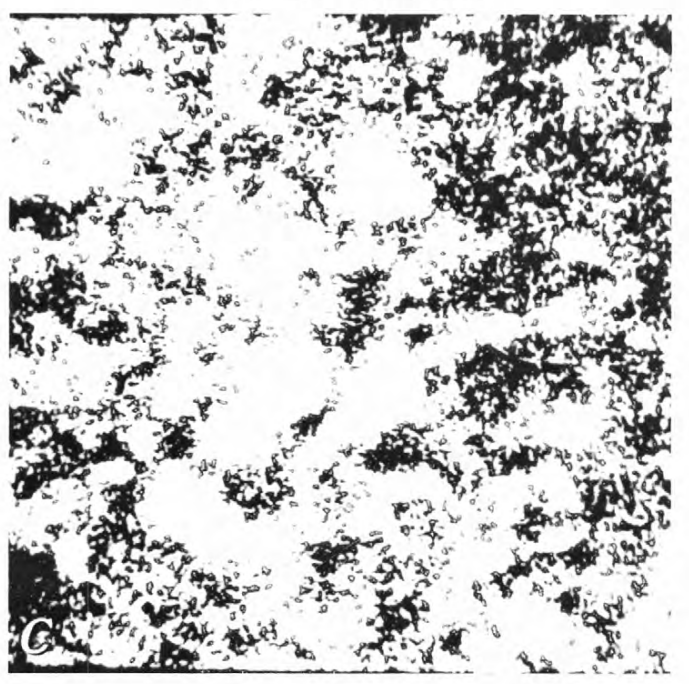

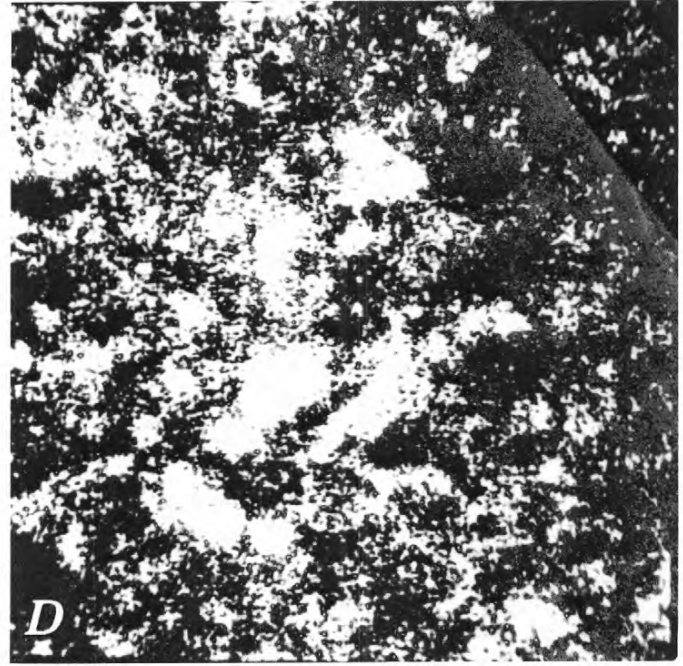

Figure 27.-Continued.

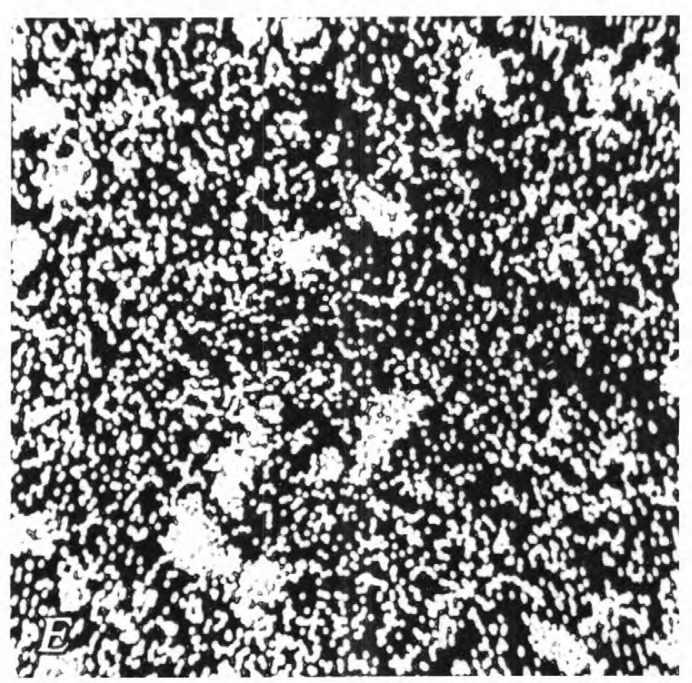

Figure 27.-Continued. 


\section{MERCURY}

Average and median contents of mercury (25 and 30 ppm, respectively) in unoxidized ores were reported by Radtke and others (1972a). Later, Harris and Radtke (1976) reported an average mercury content of $21 \mathrm{ppm}$ in samples of unoxidized ore from throughout the entire deposit, and of 22, 20, and $21 \mathrm{ppm}$ in the West, Main, and East ore zones, respectively. On the basis of the data presently available, the mercury/gold ratio in individual samples commonly falls between $2: 1$ and $4: 1$ and averages about 3:1 for each ore zone.

Mercury in unoxidized ores occurs: (1) in thin films coating grains of pyrite; (2) in association with carbonaceous materials, including both amorphous carbon and organic acid(s); (3) as small dispersed cinnabar grains; and (4) in other sulfides and in arsenic-antimony-thallium sulfosalts. Most of the mercury occurs in forms 1 and 2.

Mercury occurs as a surface coating on both the cubic and framboidal pyrite grains. Detectable amounts of the element (more than 0.04 weight percent $\mathrm{Hg}$ ) were present in about half of the 280 grains from 60 samples of ore analyzed on the electron microprobe. The content of mercury ranges from less than 0.04 to 1.2 weight percent (samples 1, 2, table 13), and the mercury/gold ratio ranges from 1:1 to 3:1. An X-ray scanning image for mercury on the surface of pyrite is shown in figure $26 \mathrm{E}$.

Electron microprobe analyses of carbonaceous materials show that the distribution and association of mercury resemble those of gold. Mercury is erratically distributed on the surfaces of amorphous-carbon grains; in grains of the organic acid(s), which contain detectable amounts of the element, mercury occurs rather uniformly throughout individual grains. The mercury in these grains, which is probably present as mercury-organic and mercury-goldorganic compounds, ranges from about 0.04 to 1.0 weight percent. Mercury associated with gold in carbonaceous materials is shown in an X-ray scanning image in figure $27 D$.

Sparse randomly distributed cinnabar grains (generally less than $50 \mu \mathrm{m}$ ), have been identified in the pyritic, carbonaceous, and arsenical gold ores. Microprobe analyses show that the cinnabar contains no detectable amounts of other elements (sample 11, table 13). The cinnabar in this occurrence probably formed with quartz and pyrite from the introduction of gold, mercury, arsenic, and antimony during the main hydrothermal stage.

The largest amounts of cinnabar are contained in arsenical ores in the East ore zone, where the mineral is associated with late arsenic-mercury-antimony-thallium sulfides and sulfosalts. Arsenical ores in the "garbage can" area contain relatively coarse-grained cinnabar. Individual grains ( $\max 1 \mathrm{~mm}$ ) occur both intergrown with and spatially associated with realgar, lorandite, christite,

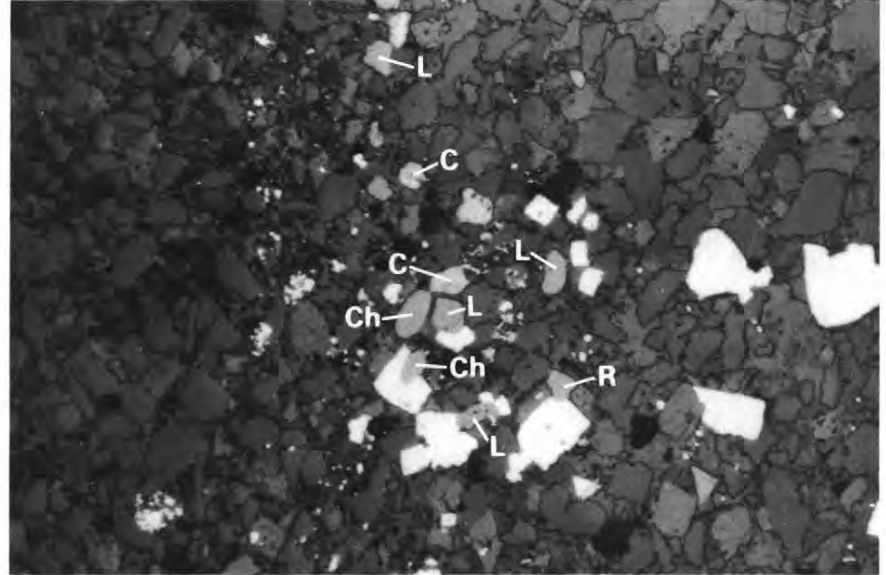

FiguRE 28.-Grains of cinnabar (C), realgar (R), lorandite (L), and christite $(\mathrm{Ch})$ in unoxidized gold ore in "garbage can" area of East ore zone. Note lorandite, christite, and realgar grains replacing(?) large cubic pyrite grains (white). Most small rounded white grains are clusters of framboidal pyrite.

and ellisite (fig. 28). Microprobe analyses show that cinnabar in this association may contain as much as several tenths of a weight percent of arsenic (sample 12, table 13). Sulfosalt minerals containing mercury identified to date in the arsenical ores are galkhaite $\left((\mathrm{Hg}, \mathrm{Cu}, \mathrm{Tl}, \mathrm{Zn}) \mathrm{AsS}_{2}\right)$ and christite (samples 2, 4, table 14). Galkhaite in arsenical ores at the Getchell gold deposit was described by Botinelly and others (1973), and the presence of the mineral at Carlin is its second reported occurrence in the United States. Sphalerite in Carlin ores contains as much as 0.1 weight percent $\mathrm{Hg}$, and some galena grains contain 200 to 400 ppm (0.02-0.04 weight percent) $\mathrm{Hg}$.

\section{ARSENIC}

Arsenic is found in all disseminated-replacement gold deposits of the Carlin type (Radtke and others, 1974a; Radtke and Dickson, 1976), although the average content varies widely between deposits. The element occurs: (1) in geochemical halos outside the ore zones in the host rocks, (2) in small joints and fractures in bedrock at shallow depths above ore bodies, and (3) in secondary dispersion halos in soil close to ore bodies (Erickson and others, 1964a, b; Wrucke and others, 1968; Akright and others, 1969).

In Carlin ores, arsenic is the most abundant of the arsenic-mercury-antimony-thallium suite of elements closely associated with gold. Values reported for the average content of arsenic in unoxidized ores include $480 \mathrm{ppm}$ (Radtke and others, 1972a) and $506 \mathrm{ppm}$ (Harris and Radtke, 1976). Although the average contents of gold and mercury are nearly constant in the West, Main, and East ore zones, the average arsenic content ranges from 222 
ppm in the West, through 490 ppm in the Main, to 590 ppm in the East ore zone (Harris and Radtke, 1976).

In unoxidized Carlin ores, arsenic occurs: (1) with gold, mercury, antimony, and thallium coating pyrite grains; (2) in sulfide and sulfosalt minerals; and (3) as elemental arsenic. Arsenic is not associated with any carbonaceous materials in Carlin ores.

The occurrence of arsenic coatings on the surfaces of pyrite grains is ubiquitous in all the unoxidized ore types. Surfaces of both euhedral cubic and framboidal pyrite grains commonly contain more arsenic than any of the other four associated metals (samples 1, 2, table 13). The content of arsenic between grains in the film, which ranges widely from less than 0.08 to about 6.0 weight percent (samples 1, 2, table 13), is rather uniform over the surfaces of individual grains, and the arsenic/gold ratio on the surface is commonly about 15:1. The higher arsenic/ gold ratio in hand specimens of ores, which lack arsenic sulfide minerals, is due to the presence of arsenic on the surfaces of gold-deficient as well as gold-bearing pyrite.

Results of electron microprobe analyses show that arsenic, as well as antimony and thallium, is not associated with the organic carbon compounds, and Wells and Mullens (1973) reported that the small amounts of arsenic in carbonaceous materials could be due to inclusions of submicrometer-size grains of arsenic-coated pyrite. These observations suggest that the organic carbon compounds had little, if any, influence on the deposition of arsenic.

A major amount of the arsenic in the arsenical ores, and lesser amounts (in decreasing order) in the carbonaceous pyritic, and siliceous ores, are in the form of arsenic sulfide minerals. Although both realgar and orpiment are present, in unoxidized Carlin ores exposed to date, realgar is much more abundant and makes up more than 90 percent by volume of the arsenic sulfide and sulfosalt minerals.

Realgar in Carlin ores is essentially AsS in composition and commonly carries as much as 200 ppm Sb (sample 4, table 13; Dickson and others, 1975b) and small amounts of gold (sample 5, table 13). The mineral occurs in many forms: (1) in veins ranging in size from a few micrometers wide following microfractures to as wide as $20 \mathrm{~mm}$ in open fractures and joints, (2) in small seams (narrower than 0.2 $\mathrm{mm}$ ) associated with carbonaceous materials, (3) in fillings in small vugs and cavities, and (4) in apparently randomly dispersed grains.

The realgar is generally associated with quartz, carbonaceous materials, and arsenic-bearing sulfosalts. In the ore samples studied to date, stibnite is scarce and only occurs locally with realgar. Within $30 \mathrm{~m}$ below the bottom of the oxidized zone, realgar is also associated with orpiment and minor amounts of stibnite, and within about 9 to $12 \mathrm{~m}$ of the oxidized zone it is concentrated in barite veins containing varying amounts of calcite. Figure 24 shows veinlets of realgar filling fractures in carbonaceous limestone in the East ore zone.

Orpiment, a primary mineral in Carlin ores, ranges in composition from relatively pure $\mathrm{As}_{2} \mathrm{~S}_{3}$ (sample 6, table 13) to an antimony-rich variety containing as much as 15,000 ppm (1.5 weight percent) $\mathrm{Sb}$ (sample 7, table 13; Radtke and others, 1973). Orpiment containing significant amounts of thallium $(1,000-3,500 \mathrm{ppm})$ has been recognized in the East ore zone (sample 8, table 13; Radtke and others, 1974b). This variety commonly lacks detectable amounts of antimony (less than $20 \mathrm{ppm}$ ) and is associated only with realgar, barite, calcite, and quartz.

Among the numerous other arsenic-bearing minerals recognized in relatively small amounts in Carlin ores are: stibnite (Dickson and others, 1975b), lorandite (Radtke and others, 1974c), tennantite (Hausen and Kerr, 1968), getchellite, jordanite, galkhaite, gratonite, christite (Radtke and others, 1977), and ellisite (Dickson and others, 1979).

Small amounts of arsenic, generally 0.1 to 0.4 weight percent, commonly are present in stibnite in Carlin ores (sample 10, table 13), and Dickson and others (1975) reported that stibnite associated with arsenic sulfides may contain as much as $15 \mathrm{~mol}$ percent $\mathrm{As}_{2} \mathrm{~S}_{3}$. Gratonite $\left(\mathrm{Pb}_{9} \mathrm{As}_{4} \mathrm{~S}_{15}\right)$ and jordanite $\left(\mathrm{Pb}_{13-14} \mathrm{As}_{6-7} \mathrm{~S}_{23-24}\right)$ have been identified in galena crystals dispersed throughout barite veins and in galena associated with other sulfides in the "garbage can" area. Table 14 lists chemical data on these minerals (samples 5, 6). Whether they were formed by exsolution or replacement is unclear. Hausen and Kerr $(1968$, p. 933) reported that jordanite rims and replaces galena crystals and locally replaces galena where it forms masses of jordanite, several millimeters thick, in barite. Results of microprobe analyses confirm that small amounts of tennantite occur with sphalerite in barite veins, as reported previously by Hausen and Kerr (1968). Tetrahedrite in Carlin ores contains as much as 1.2 weight percent As.

Five arsenic-bearing sulfosalts closely associated with realgar are lorandite $\left(\mathrm{TlAsS}_{2}\right)$, getchellite $\left(\mathrm{AsSbS}_{3}\right)$, galkhaite $\left(\mathrm{Hg}_{9}(\mathrm{Zn}, \mathrm{Cu})_{3} \mathrm{Tl}\left(\mathrm{AsS}_{3}\right)_{8}\right)$, christite $(\mathrm{TlHgAsS})$ and ellisite $\left(\mathrm{Tl}_{3} \mathrm{AsS}_{3}\right)$. In comparison with realgar, all five of these minerals are relatively scarce and were identified in about a third of the polished sections studied from 35 specimens of the arsenical ores. Textural relations suggest that lorandite, christite, and ellisite formed simultaneously with realgar; the paragenetic relations between getchellite, galkhaite, and realgar are uncertain.

Although arsenopyrite is present in many hydrothermal gold deposits and is closely associated with and a common host mineral for gold in such deposits as those at the Homestake mine and in the Northern Mines districts of California, it may be absent at Carlin. Arsenopyrite has 
not been positively identified in any detailed study of Carlin ores to date. Many of the grains identified earlier as arsenopyrite probably are iron sulfides with arsenic coatings.

A few small dispersed grains (less than $0.2 \mathrm{~mm}$ ) of elemental arsenic, containing a few tenths of a weight percent of antimony and less than 0.06 to 0.3 weight percent $\mathrm{Au}$, have been identified in several samples of carbonaceous ore in the "garbage can" area of the East ore zone. The mineral, which is surrounded by heavy concentrations of introduced carbonaceous materials or silica, apparently formed under strongly reducing conditions accompanying the introduction of silica and hydrocarbons during the late hydrothermal stage.

\section{ANTIMONY}

All known Carlin-type gold deposits contain anomalous amounts of antimony; the average antimony content in the ores ranges from about 25 to 40 percent that of arsenic. Antimony also occurs with arsenic in geochemical halos around the ore bodies; however, in contrast to arsenic halos, many of these antimony anomalies are weak, limited in extent, and correlate poorly with gold (A. S. Radtke, unpub. data, 1970).

The average content of antimony in unoxidized Carlin ores was reported as $130 \mathrm{ppm}$ (Radtke and others, 1972a) and $126 \mathrm{ppm}$ (Harris and Radtke, 1976). The average antimony content varies significantly between the principal ore zones at Carlin and ranges from $52 \mathrm{ppm}$ in the West, through $106 \mathrm{ppm}$ in the Main, to $155 \mathrm{ppm}$ in the East ore zone (Harris and Radtke, 1976).

Antimony in the unoxidized ores occurs (1) together with gold, mercury, arsenic, and thallium as a coating on pyrite grains; and (2) in sulfide and sulfosalt minerals. Probably more than 90 percent of the total antimony in the ores is in form 1 .

Antimony is present on pyrite grains in all the unoxidized ore types, and in the normal gold ore is recognized only in that form. Although the surfaces of individual pyrite grains contain rather evenly distributed amounts of antimony, the content of the element varies widely (more than 0.08 to about 4.0 weight percent $\mathrm{Sb}$ ) between grains (samples 1, 2, table 13). On most pyrite grains, including those that lack detectable gold, the antimony/arsenic ratio is between 1:4 and 1:3. An X-ray scanning image of antimony on the surface of pyrite is shown in figure 26.

Detectable amounts of antimony (more than 0.05 weight percent) have not been found in any of the carbonaceous materials in Carlin ores analyzed by standard electron microprobe methods. Wells and Mullens (1973) reported that the carbonaceous materials in unoxidized ores at the Cortez deposit contain antimony and that illite in Cortez ores contains about 1.5 weight percent Sb. Illite in Carlin ores does not contain detectable amounts of antimony, and results of electron microprobe analyses of clay and carbonaceous materials in Cortez ores (A. S. Radtke and C. M. Taylor, unpub. data, 1970) did not confirm the presence of antimony. Wells and Mullens may have misidentified the characteristic lines for antimony $\left(\mathrm{SbL} \alpha_{1}\right)$ and some other element, such as potassium $\left(K K \beta_{1}\right)$, in analyzing illite both apart from and mixed with carbonaceous materials.

In comparison with realgar, stibnite is rare in Carlin ores. Most of the stibnite is in the form of small grains (less than $0.2 \mathrm{~mm}$ ) associated with hydrothermal silica, pyrite, and hydrocarbons. This association is also found in the arsenical ores, where commonly only small amounts of stibnite are spatially associated with realgar.

Stibnite has been identified in all the unoxidized ore types except the normal. Although the mineral is present in ores of both the Main and the East ore zones, it apparently is absent in the West ore zone.

Stibnite in relatively large grains $(\max 18 \mathrm{~mm})$ is concentrated locally in both siliceous and carbonaceous gold ores in the East ore zone. The mineral also fills open spaces between broken fragments of heavily silicified limestone in breccia zones in the East ore zone.

In the "garbage can" area of the East ore zone, stibnite is associated with base-metal sulfides, including sphalerite and galena, and with weissbergite and realgar. Samples of stibnite from that area contained as much as $15 \mathrm{~mol}$ percent ( 7.0 weight percent) $\mathrm{As}_{2} \mathrm{~S}_{3}$ in solid solution (sample 10, table 13; Dickson and others, 1975b). Results of microprobe analyses show that dispersed stibnite grains not associated with arsenic sulfide minerals commonly contain 0.05 to 0.4 weight percent As (sample 9 , table 13 ).

Hausen and Kerr (1968) initially pointed out that small amounts of stibnite were associated with realgar and quartz in barite veins. In this association, finely crystalline stibnite needles occur both with realgar and quartz in the barite veins and in heavily silicified limestone bordering these veins; however, the ratio of realgar to stibnite is more than 50:1.

Results of microprobe and spectrographic analyses indicate that the stibnite in Carlin ores, including that associated with weissbergite $\left(\mathrm{TlSbS}_{2}\right.$ ), may contain as much as 0.3 weight percent $\mathrm{Tl}$ (sample 9 , table 13 ; A. S. Radtke, unpub. data, 1973). Reports on the thallium content of stibnite are not available, although Bohae and others (1974) studied phase relations in the system $\mathrm{Tl}_{2} \mathrm{~S}-\mathrm{Sb}_{2} \mathrm{~S}_{3}$.

Radtke and others (1973) reported the occurrence of orpiment in Carlin ores containing as much as 1.5 weight percent Sb (sample 7, table 13). Studies of synthetic stibnite and orpiment confirmed that large solid-solution fields exist in the system $\mathrm{Sb}_{2} \mathrm{~S}_{3}-\mathrm{As}_{2} \mathrm{~S}_{3}$ (Moore and Dickson, 1973) and that stibnite may contain as much as 40 mol percent $\mathrm{As}_{2} \mathrm{~S}_{3}$ (Dickson and others, 1975b). 
Sulfosalt minerals containing antimony, which are uncommon, include weissbergite $\left(\mathrm{TlSbS}_{2}\right)$, getchellite $\left(\mathrm{AsSbS}_{3}\right)$, boulangerite $\left(\mathrm{Pb}_{5} \mathrm{Sb}_{9} \mathrm{~S}_{11}\right)$, and tetrahedrite $\left((\mathrm{Cu}, \mathrm{Fe}, \mathrm{Zn}, \mathrm{Ag})_{12}(\mathrm{Sb}, \mathrm{As})_{4} \mathrm{~S}_{13}\right)$. Table 14 lists chemical analyses of weissbergite, tetrahedrite, and boulangerite (samples 7, 9, 10). Weissbergite is associated with stibnite, pyrite, quartz, and carbonaceous materials in siliceous and carbonaceous ores in the East ore zone (Dickson and Radtke, 1978). Getchellite in small amounts is intergrown with realgar, lorandite, quartz, and minor stibnite in arsenical ores in the East ore zone. Boulangerite and tetrahedrite occur in small isolated ellipsoidal to round patches in galena locked in barite veins in the Main ore zone. Tennantite, associated with sphalerite, contains as much as 1.2 weight percent $\mathrm{Sb}$ and averages about 0.8 weight percent $\mathrm{Sb}$ (sample 8, table 14). Textural relations suggest that both minerals were exsolved from the galena host. Elemental antimony has not been identified in Carlin ores, although a few tenths of a weight percent of antimony are present in elemental arsenic.

\section{THALLIUM}

The average content of thallium (40-50 ppm) in unoxidized Carlin ores represents a large increase over that (less than $3 \mathrm{ppm}$ ) in the fresh unmineralized host rocks. Using average values of less than $0.05 \mathrm{ppm} \mathrm{Tl}$ in limestone and dolomite (Graf, 1960), $1.4 \mathrm{ppm} \mathrm{Tl}$ in shales, and about $0.01 \mathrm{ppm} \mathrm{Tl}$ in limestone (Turekian and Wedepohl, 1961), the element evidently is concentrated by a factor of more than 100 in the mineralized rocks. Within the Carlin deposit, the average content of thallium ranges from $15 \mathrm{ppm}$ in the West, through $40 \mathrm{ppm}$ in the Main, to $60 \mathrm{ppm}$ in the East ore zone. The progressive enrichment in thallium from west to east through the deposit corresponds to similar trends for arsenic and antimony and reflects the strong associations between these three elements.

In the unoxidized ores, thallium occurs (1) on surfaces of pyrite grains and (2) in sulfide and sulfosalt minerals. Thallium has not been identified in microprobe analyses of carbonaceous materials.

Small amounts of thallium have been identified on the surfaces of some pyrite grains that contain large amounts of arsenic and antimony, including those that lack detectable gold and mercury. On grains that contain detectable thallium, the thallium content ranges from 0.08 to 0.25 weight percent, and the element is randomly distributed. Most of the thallium in unoxidized ores in the West ore zone, as well as in normal and siliceous ores throughout the deposit, probably occurs in this form.

Locally, samples of orpiment, stibnite, and sphalerite from Carlin ores contain several tenths of a weight percent of thallium (samples 8-10, 17, table 13). Radtke and others $(1974 b)$ reported that orpiment in the East ore zone contains as much as 0.2 weight percent T1. Stibnite in the same zone commonly contains 0.2 to 0.3 weight percent $\mathrm{T} 1$, and sphalerite in the "garbage can" area contains as much as 0.3 weight percent T1 (A.S. Radtke, unpub. date 1973).

Thallium-bearing sulpharsenite minerals identified in the unoxidized ores include lorandite $\left(\mathrm{TlAsS}_{2}\right)$ (Radtke and others, $1974 \mathrm{c})$, galkhaite $\left(\mathrm{Hg}_{9}(\mathrm{Zn}, \mathrm{Cu})_{3} \mathrm{Tl}\left(\mathrm{AsS}_{3}\right)_{8}\right.$, jordanite $\left(\mathrm{Pb}_{13-14} \mathrm{As}_{6-7} \mathrm{~S}_{23-24}\right)$ containing about 0.5 weight percent $\mathrm{Tl}$, christite $\left(\mathrm{TlHgAsS}{ }_{3}\right.$ ) (Radtke and others, 1977), and ellisite $\left(\mathrm{Tl}_{3} \mathrm{AsS}_{3}\right)$ (Dickson and others, 1979); weissbergite $\left(\mathrm{TlSbS}_{2}\right)$ (Dickson and Radtke, 1978) is the only sulphantimonite mineral recognized to date. Table 14 lists chemical analyses of samples of all the thallium-bearing sulfosalt minerals. Mineralogic studies indicate that these phases are most abundant in the southwest end of the East ore zone and in the "garbage can" area between the East and Main ore zones. All the arsenic-rich varieties occur in the arsenical gold ores, and lorandite, christite, and ellisite are present in the carbonaceous ore. In arsenical gold ores the thallium sulfosalt minerals commonly are intergrown or closely associated with realgar (fig. 28); they also occur with realgar in barite veins and as individual grains dispersed throughout the rock. In the carbonaceous ore these phases are fine grained and dispersed and can be identified only by electron microprobe analysis.

Weissbergite occurs in both the arsenical and siliceous gold ores and is closely associated with stibnite and hydrothermal silica. Table 14 lists a microprobe analysis of a sample of the weissbergite (sample 7). The system $\mathrm{TlSbS}_{2}-\mathrm{TlAsS}_{2}$ is currently under investigation by F. W. Dickson and A. S. Radtke.

Carlinite $\left(\mathrm{Tl}_{2} \mathrm{~S}\right)$ is present as small grains in silicified carbonate rocks at two localities in the East ore zone that contain abundant hydrocarbons and hydrothermal silica and only sparse arsenic and gold (Radtke and Dickson, 1975a). The presence of this mineral indicates that the hydrothermal solutions contained high concentrations of thallium, that such other elements as arsenic and antimony were essentially absent, that a mechanism existed which prevented dissolution, and that a reducing environment prevailed during and after deposition. Table 13 lists chemical and spectrographic analyses of a sample of the carlinite (sample 13).

Peterson (1976), who studied phase relations in the system $\mathrm{Tl}_{2} \mathrm{~S}-\mathrm{As}_{2} \mathrm{~S}_{3}$, showed that four stable phases exist, of compositions $\mathrm{Tl}_{2} \mathrm{~S}, \mathrm{Tl}_{3} \mathrm{AsS}_{3}, \mathrm{TlAsS}_{2}$, and $\mathrm{As}_{2} \mathrm{~S}_{3}$, none of which consists of more than a few percent solid solution. All these phases occur in unoxidized Carlin ores.

\section{LEAD}

The average content of lead in unoxidized ores $(30 \mathrm{ppm}$; Radtke and others, 1972a; Harris and Radtke, 1976) represents an increase by a factor of more than 4 over the average content $(7 \mathrm{ppm})$ in the fresh host rocks. The lead 
content varies widely throughout the deposit; in 292 samples analyzed, the content of lead ranged from less than 7 to $1,500 \mathrm{ppm}$. Harris and Radtke (1976) reported values of 26,51 , and $20 \mathrm{ppm}$ for average lead contents in unoxidized ores of the West, Main, and East ore zones, respectively.

Most of the lead in unoxidized ores occurs as galena; minor amounts are in the form of sparse grains of several lead-bearing sulfosalt minerals and secondary anglesite. Small grains (less than $80 \mu \mathrm{m}$ ) of galena, apparently only genetically associated with hydrothermal silica, have been identified in all the unoxidized ore types except the normal. Microprobe analysis of galena in this form (sample 14, table 13) shows that the mineral generally contains from less than 0.06 to 0.10 weight percent $\mathrm{Ag}$, from less than 0.05 to 0.15 weight percent $\mathrm{Sb}$, and no detectable amounts of either arsenic or bismuth. No inclusions of other phases were observed in any of the grains examined.

In the "garbage can" area, crystals of galena, ranging from 60 to $600 \mu \mathrm{m}$ in diameter occur spatially associated and commonly intergrown with fine-grained sphalerite, chalcopyrite, pyrite, and quartz. Galena in this area contains inclusions of other minerals, including jordanite, gratonite, and tetrahedrite.

Relatively coarse-grained ( $\max 5 \mathrm{~mm}$ ) galena is concentrated locally in deep parts of barite veins at the bottom of the oxidized zone in the central part of the Main ore zone. Areas in barite veins that contain galena or sphalerite also contain abundant veinlets of late quartz cutting the barite. Galena in this occurrence contains abundant inclusions, ranging in size from about 10 to $300 \mu \mathrm{m}$, of other minerals, including jordanite, gratonite, tetrahedrite, and boulangerite. Small grains of sphalerite occur with quartz along contacts between the galena crystals and barite.

Table 13 lists microprobe analyses of the galena and spectrographic analyses of composite samples of the galena, including samples containing abundant inclusions (samples 14, 15). Spectrographic analyses of composite samples of the coarse-grained inclusion-bearing galena from both the carbonate host rocks and the barite veins show abundances of silver (500-1,000 ppm), arsenic (20,000-30,000 ppm), and antimony (700-1,000 ppm). Results of microprobe analyses show that the galena contains only about 200 to $400 \mathrm{ppm} \mathrm{Ag}$, less than $400 \mathrm{ppm} \mathrm{As}$, about 500 ppm Sb, and less than 500 ppm Bi.

In a previous study, Hausen and $\operatorname{Kerr}(1968$, p. 933) identified jordanite replacing galena in barite veins, a relation that has not been observed in this study. In most samples, however, galena is altered to anglesite along cleavage planes, fractures, and grain margins.

Gold has not been detected either in the galena or in samples of barite veins containing base-metal sulfides.
Results of microprobe analyses show that lead is not concentrated in carbonaceous materials in the ores. Most of the galena, including that concentrated in barite veins, probably formed during the late hydrothermal stage after the deposition of gold.

\section{ZING}

Except for titanium and arsenic, zinc is the most abundant metal of hydrothermal origin in the unoxidized ores. Published values for the average zinc content, which include $185 \mathrm{ppm}$ (Radtke and others, 1972a) and $165 \mathrm{ppm}$ (Harris and Radtke, 1976), represent an increase by a factor of more than 10 above the average zinc content (14 ppm) of the carbonate host rocks. The average zinc content is $72 \mathrm{ppm}$ in the West, $193 \mathrm{ppm}$ in the Main, and 177 ppm in the East ore zone (Harris and Radtke, 1976).

Except for very minor amounts of galkhaite, tennantite, and tetrahedrite, as well as trace amounts of secondary smithsonite, all the zinc in unoxidized ores occurs as sphalerite. Dispersed irregular grains of sphalerite, ranging in size from about 60 to $150 \mu \mathrm{m}$, are present in all the unoxidized ore types. Sphalerite is closely associated with hydrothermal silica and commonly occurs in areas containing abundant hydrothermal pyrite and carbonaceous materials. Individual sphalerite grains commonly are intergrown with or contain inclusions (less than $15 \mu \mathrm{m}$ diam) of pyrite or chalcopyrite.

Sphalerite in fine particles (less than $30 \mu \mathrm{m}$ ), an accessory mineral in fresh unmineralized rocks of the Roberts Mountains Formation, is not intergrown with either pyrite or chalcopyrite and probably is of authigenic or diagenetic origin. Electron microprobe analyses show that the sphalerite contains large amounts of iron (commonly $5-8$ weight percent), 0.1 to 0.3 weight percent $\mathrm{Cd}$, and no detectable silver, copper, mercury, indium, or manganese-in contrast to the coarser grained hydrothermal sphalerite, which commonly is intergrown with pyrite or chalcopyrite and contains 0.2 to 0.6 weight percent $\mathrm{Fe}$, less than 0.04 to 0.05 weight percent $\mathrm{Cd}$, and 0.07 to 0.1 weight percent $\mathrm{Hg}$. The abundance ranges of iron, cadmium, and mercury in this variety of sphalerite resemble those in most of the coarse-grained sphalerite in barite veins (sample 16, table 13). Spectrographic analyses of two composite samples of coarse-grained sphalerite show that it commonly contains 200 to $700 \mathrm{ppm} \mathrm{Cu,} 200$ to 300 ppm Ga, 50 to 300 ppm Ge, 50 to 150 ppm Sb, 50 to 70 ppm $\mathrm{Pb}, 10$ to $20 \mathrm{ppm} \mathrm{Ag}, 7$ to $50 \mathrm{ppm} \mathrm{Mn}$, and 7 to $10 \mathrm{ppm}$ In (sample 16, table 13).

Unoxidized ores in the "garbage can" area contain sphalerite associated with galena, pyrite, chalcopyrite, and quartz. Sphalerite in that area also contains as much as 0.3 weight percent $\mathrm{Tl}$ (sample 17, table 13). Although the ores in that part of the deposit contain abundant sulfides and sulfosalts of arsenic, mercury, antimony, and 
thallium, sphalerite generally is not spatially associated or intergrown with any of these other minerals.

Sphalerite is concentrated locally in the deep parts of barite veins, which follow and cut through the conspicuous northwest-trending igneous dike in the central part of the Main ore zone along the southwest side of Popovich Hill (pl. 3). The sphalerite-rich pockets are generally confined to a 12 -m section within the barite veins at the base of the oxidized zone. Individual sphalerite crystals are coarse grained (5-12 $\mathrm{mm}$ ) and commonly intergrown with small amounts of fine-grained galena, pyrite, chalcopyrite, quartz, and, less commonly, tennantite. The pods of sphalerite-bearing barite lack coarse- grained galena, and areas within barite veins that contain large amounts of both these sulfides have not been observed. Smithsonite formed by the alteration of sphalerite is common on the surfaces of and in fractures cutting sphalerite grains.

Tennantite and tetrahedrite in Carlin ores generally contain 3.0 to 4.5 and 1.8 to 2.9 weight percent $\mathrm{Zn}$, respectively. Table 14 lists microprobe analyses of the tennantite and tetrahedrite (samples 8 and 9 , respectively). No zinc-rich sulfosalt minerals have been identified in Carlin ores, and electron microprobe studies indicate that zinc is not associated with carbonaceous materials and that the sphalerite lacks detectable amounts of gold.

\section{SILVER}

In contrast to most other types of gold deposits, the disseminated- replacement deposits of the Carlin type contain very small amounts of silver and have abnormally large gold/silver ratios. The average silver content in unoxidized ores of the Carlin deposit is $0.4 \mathrm{ppm}$ (Radtke and others, 1972a), and the gold/silver ratio about 20:1. The content of silver ranges from less than 0.7 to 3 ppm in 292 analyzed samples from throughout the deposit and is low in all the unoxidized ore types; the average silver content is $0.7 \mathrm{ppm}$ in the West and East ore zones, and $0.7 \mathrm{ppm}$ in the Main ore zone.

Silver in unoxidized Carlin ores apparently is associated with the base- metal sulfide and sulfosalt minerals formed during the late hydrothermal stage and not with the gold-arsenic-mercury-antimony-thallium suite of minerals. Spectrographic analyses (table 13) and microprobe analyses show that silver is much more abundant in the sulfide and sulfosalt minerals, and that carbonaceous materials and the surfaces of pyrite grains lack detectable amounts of silver. Galena in Carlin ores generally contains only very small amounts of silver (samples 14, 15, table 13), and both tetrahedrite inclusions in galena and tennantite associated with sphalerite contain 0.5 to 1.0 weight percent $\mathrm{Ag}$ (samples 8, 9, table 14); sphalerite contains trace amounts (10-20 ppm) of silver. None of the silver-rich sulfosalt and silver sulfide minerals typical of epithermal precious-metal deposits have been recognized.

\section{COPPER}

The average content of copper in unoxidized Carlin ores is relatively low, about the same as that of lead. Reported values of $35 \mathrm{ppm} \mathrm{Cu}$ (Radtke and others, 1972a) and 33 ppm $\mathrm{Cu}$ (Harris and Radtke, 1976) represent an increase by a factor of 3 over the average content $(10 \mathrm{ppm} \mathrm{Cu})$ in the fresh host rocks. The average copper contents are 25 ppm in the West, $36 \mathrm{ppm}$ in the Main, and $33 \mathrm{ppm}$ in the East ore zone (Harris and Radtke, 1976).

Chalcopyrite is the predominant copper mineral in the ores. Dispersed grains $(50-150 \mu \mathrm{m})$ of chalcopyrite have been recognized in all the unoxidized ore types except the normal. The mineral also occurs as fine-grained $(5-15 \mu \mathrm{m})$ particles locked in sphalerite, dispersed throughout the ores and concentrated locally in barite veins.

A substantial amount of total copper probably occurs in hydrothermal pyrite. Spectrographic analyses of coarsegrained pyrite separated from the pyritic ore show that the pyrite contains $300 \mathrm{ppm} \mathrm{Cu}$, and similar analyses of framboidal-pyrite concentrate including lesser cubic pyrite give $500 \mathrm{ppm} \mathrm{Cu}$. Microprobe analyses of grains of both the cubic and framboidal pyrite indicate a copper content of less than 0.1 weight percent.

Small amounts of covellite and chalcocite, in grains ranging in size from 15 to $40 \mu \mathrm{m}$, are present in carbonaceous and arsenical ores in the "garbage can" area. Both minerals occur in samples containing relatively large amounts of chalcopyrite, pyrite, and sphalerite, although paragenetic relations are uncertain. None of these three copper minerals is closely associated with the arsenicmercury-antimony-thallium suite of minerals, and galkhaite is the only mineral in this suite that contains significant amounts of copper.

The sparse grains of tennantite contain 44.0 to 47.3 weight percent $\mathrm{Cu}$, and those of tetrahedrite 41.5 to 43.8 weight percent $\mathrm{Cu}$ (samples 8 and 9, respectively, table 14). Although sphalerite commonly contains 200 to 700 ppm $\mathrm{Cu}$ and hydrothermal pyrite 300 to $500 \mathrm{ppm} \mathrm{Cu}$, other minerals analyzed contain much less (table 13). Results of microprobe analyses show that carbonaceous materials and the surfaces of pyrite grains lack detectable amounts of copper. The presence of the element in pyrite could reflect the introduction of copper throughout the hydrothermal cycle.

\section{MOLYBDENUM}

Molybdenum is a minor constituent in all the unoxidized ore types. Values for the average molybdenum content in Carlin ores include 6 ppm (Harris and Radtke, 1976) and $7 \mathrm{ppm}$ (Radtke and others, 1972a). Using a value of $2 \mathrm{ppm}$ Mo for the average content in fresh host rocks, this concentration by a factor of more than 3 corresponds closely to that for both copper and lead. The average content of molybdenum is rather uniform between individual ore 
zones and ranges from 5 to 7 ppm (Harris and Radtke, 1976).

Molybdenite, the only molybdenum mineral recognized to date, is very sparse, occurs in small grains (less than $20 \mu \mathrm{m}$ ), and has been identified in the carbonaceous, pyritic, and arsenical ores. Samples of ores from the "garbage can" area contained more molybdenite than those from other parts of the deposit. The mineral occurs in discrete grains, neither intergrown nor in contact with other sulfide minerals. Samples that contain molybdenite, however, also generally contain chalcopyrite, sphalerite, pyrite, and abundant hydrothermal silica and carbonaceous materials. Molybdenite probably formed with the basemetal sulfides late in the hydrothermal cycle.

\section{TUNGSTEN}

Unoxidized Carlin ores contain minor amounts of tungsten of hydrothermal origin. The tungsten content ranges from less than 20 to $400 \mathrm{ppm}$ and averages $18 \mathrm{ppm}$ (Radtke and others, 1972a); Harris and Radtke (1976) reported a lower value $(12 \mathrm{ppm})$ for the average content of tungsten. Radtke and others (1972a) reported that their failure to detect tungsten in 15 samples of fresh carbonate host rock indicated that these rocks contain less than 20 ppm W. Neutron-activation analyses subsequently showed that the tungsten content was below $10 \mathrm{ppm}$. Graf (1960) reported an average tungsten content of $0.5(?) \mathrm{ppm}$ in carbonate rocks in general, and Turekian and Wedepohl (1961) gave values of $0.6 \mathrm{ppm}$ for carbonate rocks and $1.8 \mathrm{ppm}$ for shales. The average tungsten content is $10 \mathrm{ppm}$ in the West and East ore zones and $17 \mathrm{ppm}$ in the Main ore zone (Harris and Radtke, 1976). The enrichment in tungsten in the rocks as a result of mineralization is greater than the enrichment in lead, copper, molybdenum, and zinc (R. L. Erickson, written commun., 1977).

The only tungsten mineral that has been identified in unoxidized Carlin ores is scheelite. The mineral is very rare and occurs in small particles (less than $25 \mu \mathrm{m}$ diam) randomly scattered throughout unoxidized ores of both the Main and East ore zones. Scheelite grains are contained in seams of hydrothermal quartz, but the mineral does not occur with any other hydrothermal mineral.

\section{BARIUM}

The average content of barium in unoxidized ores, determined from analyses of 292 samples from throughout the deposit, is $400 \mathrm{ppm}$ (Harris and Radtke, 1976). This value represents an increase by a factor of about 2 to 3 over the average barium content in samples of fresh unmineralized rocks of the Roberts Mountains Formation, reported as $150 \mathrm{ppm}$ (Radtke and others, 1972a). Some of the barium in the host rocks is in the form of fine-grained $(10-20 \mu \mathrm{m})$ particles of barite. Barium also occurs in small amounts ( $\max 200 \mathrm{ppm}$ ) in some original dolomite grains. In addition, the unoxidized ores contain minor amounts of fine-grained hydrothermal barite dispersed throughout the rocks. Shallow unoxidized ores also contain small amounts of barite closely associated with seams and patches of hydrothermal silica; this barite probably formed during the late hydrothermal stage.

The average barium content ranges from $300 \mathrm{ppm}$ in the East, through 500ppm in the Main, to $650 \mathrm{ppm}$ in the West ore zone (Harris and Radtke, 1976). This systematic increase also corresponds to the occurrence of barite veins, which increase in abundance through the deposit from east to west. Barite veins are very sparse in the unoxidized ores and generally pinch out within 6 to $9 \mathrm{~m}$ below the bottom of the oxidized zone. Details of the mineralogy and genesis of the barite veins are given below in the section entitled "Hydrothermal Acid-leaching Alteration."

The content of barium varies widely among individual samples in all the unoxidized ore types (fig. 15, table 12). The available data (A. S. Radtke, unpub. data, 1976) suggest that the average barium content is significantly higher in the siliceous and arsenical than in the normal and pyritic gold ores. Microprobe analyses show that small amounts of fine-grained barite, sporadically concentrated with carbonaceous materials in both the carbonaceous and arsenical ores, account for the high median value of $\mathrm{BaO}$ in the carbonaceous ore (fig. 15).

A rare mineral, frankdicksonite $\left(\mathrm{BaF}_{2}\right)$, present in small amounts in quartz veins at two localities in the East ore zone, was identified and described as a new mineral by Radtke and Brown (1974). No other hydrothermal minerals were associated with frankdicksonite in the quartz veins at either locality. However, small amounts of fluorite occurred about $5 \mathrm{~m}$ deeper in one quartz vein, and pyrite and metallic gold were present $5 \mathrm{~m}$ higher in the other vein.

Barite in the Carlin deposit, including that dispersed throughout mineralized limestone and that in veins, apparently formed by the combination of barium $\left(\mathrm{Ba}^{2+}\right)$ in the ore solutions with sulfate $\left(\mathrm{SO}_{4}{ }^{2+}\right)$ produced by the oxidation of sulfide minerals or of $\mathrm{H}_{2} \mathrm{~S}$ vapor derived by boiling (Dickson and others, 1975a). Although small amounts of dispersed barite formed throughout the hydrothermal episode, most of the barite veins were formed during the late stage after the deposition of gold. In several samples of unoxidized ores, small pods $(0.3-0.6 \mathrm{~mm}$ long) of early barite are replaced by later quartz containing auriferous pyrite. The quartz veins containing pyrite, gold, fluorite, and, locally, frankdicksonite were formed during the main hydrothermal stage in places lacking carbonate and sulfate.

Gold was not detected in 150 samples of barite veins analyzed from throughout the deposit. In addition, gold was nowhere found closely associated with dispersed barite grains in any of the ore specimens studied by optical 
methods, electron microprobe, or scanning electron microscope.

\section{BORON}

The significantly higher average content of boron in unoxidized ores than in the fresh host rocks reflects the introduction of boron by the hydrothermal fluids. Average values reported by Radtke and others (1972a) and Harris and Radtke (1976) include 70 and $79 \mathrm{ppm} \mathrm{B}$ in the ores and $15 \mathrm{ppm} \mathrm{B}$ in the host rocks. The average boron content is nearly the same (84-85 ppm) in both the Main and East ore zones, and $54 \mathrm{ppm}$ in the West ore zone (Harris and Radtke, 1976).

Results of spectrographic analyses show that the clay fractions separated from both host rocks and ores contain more than 90 percent of the total boron in the samples. Most clay fractions from the ores are composed of illite and smaller amounts of hydrothermal kaolin and sericite, and contain 300 to $700 \mathrm{ppm} \mathrm{B.} \mathrm{Boron} \mathrm{in} \mathrm{the} \mathrm{ore} \mathrm{solutions}$ likely was fixed in the illite by substitution of $\left[\mathrm{BO}_{3}(\mathrm{OH})\right]^{4-}$ for $\mathrm{SiO}_{4}{ }^{4-}$ (Christ, 1965). No borate minerals have been identified in the unoxidized ores.

\section{SELENIUM}

The selenium content in unoxidized Carlin ores is very low. In 288 samples analyzed from throughout the deposit, the selenium content ranges from less than 1 to $20 \mathrm{ppm}$ and averages $1.5 \mathrm{ppm}$ (Harris and Radtke, 1976). Harris and Radtke (1976) also reported values of 1.5, 0.9, and $1.8 \mathrm{ppm}$ for the average selenium content in the West, Main, and East ore zones, respectively. The content of selenium is below $1 \mathrm{ppm}$ in fresh host rocks; the element was not detected in 25 samples analyzed. The presence of little more than a trace of selenium in the ores at Carlin agrees with the selenium content in other gold deposits of the Carlin type, except for the Getchell deposit (A. S. Radtke, unpub. data, 1973), for which Erickson and others (1964) reported values as large as $10 \mathrm{ppm}$. The small amount of selenium in Carlin ores contrasts with its abundance in many other types of hydrothermal preciousmetal deposits, especially those of volcanic affiliation.

No selenide, or selenium-rich sulfide or sulfosalt, minerals have been identified, nor has selenium been detected in any phases, including carbonaceous materials and pyrite, analyzed on the electron microprobe. Most of the selenium is probably in hydrothermal pyrite in amounts below the detection limit of the microprobe.

\section{TELLURIUM}

Unoxidized ores at Carlin contain only trace amounts of tellurium. Harris and Radtke (1976) determined that the average content of tellurium is $0.04 \mathrm{ppm}$ in the Main and $0.02 \mathrm{ppm}$ in the East ore zone, and $0.02 \mathrm{ppm}$ in the entire deposit. The average content in the West ore zone is even lower (less than $0.02 \mathrm{ppm} \mathrm{Te}$ ), owing to a paucity of samples containing detectable amounts of tellurium. The absence of tellurium in 25 samples of host rocks but its presence in detectable amounts $(0.02-0.6 \mathrm{ppm})$ in 25 percent of 288 samples of the unoxidized ores suggests that very small amounts of the element were introduced by the hydrothermal fluids.

No telluride minerals have been found, and tellurium has not been detected in microprobe analyses of any phases in the ores. Harris and Radtke (1976) reported that the contents of gold and tellurium correlate reasonably well in the unoxidized ores. Correlation coefficients between gold and tellurium are 0.34 in the Main and 0.50 in the East ore zone, and 0.37 for the entire deposit. These data, as well as the known tendency for gold to combine with tellurium in deposits containing both elements, suggest that the small amounts of tellurium in the ores occur with gold on the surfaces of pyrite grains.

\section{RARE-EARTH ELEMENTS}

The contents of rare-earth elements in samples of both fresh and mineralized rocks of the Roberts Mountains Formation are very low; however, results from spectrographic analyses of 40 samples of the host rocks and of 282 samples of the unoxidized ores show that the mineralized rocks contain somewhat more lanthanum, yttrium, ytterbium, and possibly cerium (Radtke and others, 1972a). Other rare-earth elements generally are not present at the detection limit (more than 10ppm) in either the host rocks or the ores.

The content of lanthanum ranges from less than 20 to $30 \mathrm{ppm}$ and averages $20 \mathrm{ppm}$ in fresh limestone; a single sample analyzed by neutron activation contained 10.7 $\mathrm{ppm}$ La. These values compare well with the lanthanum content of less than $10 \mathrm{ppm}$ for carbonate rocks and of 10 ppm for deep-sea carbonates reported by Turekian and Wedepohl (1961). By comparison, the lanthanum content in unoxidized ores ranges from less than 20 to $100 \mathrm{ppm}$ and averages $30 \mathrm{ppm}$.

The direct variation in lanthanum content with the contents of potassium and aluminum suggests that the lanthanum is concentrated in clay. In addition, the content of lanthanum in concentrates of carbonaceous materials from two samples of the host rocks and unoxidized ores ranged from 160 to $222 \mathrm{ppm}$.

The abundance of yttrium in the unoxidized ores ranges from 10 to $50 \mathrm{ppm}$ and averages $20 \mathrm{ppm}$; corresponding data for the fresh host rocks are from less than 10 to 30 $\mathrm{ppm}$, and $15 \mathrm{ppm}$. Both sets of data give lower average yttrium contents relative to those obtained by Turekian and Wedepohl (1961): $30 \mathrm{ppm}$ for carbonate rocks and 42 ppm for deep-sea carbonates. 
Ytterbium is very scarce in both the host rocks and the ores. In carbonate rocks the content of ytterbium ranges from less than 1 to $2 \mathrm{ppm}$ (avg $1 \mathrm{ppm}$ ), and in the unoxidized ores from less than 1 to $3 \mathrm{ppm}$ (avg $2 \mathrm{ppm}$ ). Turekian and Wedepohl (1961) reported values of $0.5 \mathrm{ppm} \mathrm{Yb}$ for carbonate rocks and $1.5 \mathrm{ppm}$ Yb for deep-sea carbonates.

Cerium was not detected in 40 samples of the fresh carbonate rocks. Detectable amounts of the element (more than $70 \mathrm{ppm} \mathrm{Ce}$ ) were found in 8 of 282 samples of the unoxidized ores; in these ores the cerium content ranged from less than 70 to $200 \mathrm{ppm}$. Neodymium was detected in three samples of the unoxidized ores at an abundance of $70 \mathrm{ppm}$.

\section{STATISTICAL STUDY OF ELEMENTAL DISTRIBUTIONS}

Statistical analyses of chemical data on selected elements in the unoxidized ores were done by Harris (1974). Harris and Radtke $(1974,1976)$ used the results of Harris's study, together with information on the geology and mineralogy, to interpret the chemical associations in and the paragenesis of the Carlin deposit. The information presented here is summarized from these earlier reports.

Stepwise linear-regression analysis, using the computer techniques described by Dixon (1964), was employed to examine the correlations between elements. Here, the statistical dependence of gold content on the contents of other elements is calculated. Correlation coefficients between pairs of elements were determined for the entire deposit and for the West, Main, and East ore zones. Stepwise discriminant analyses were also done to compare the distributions of and relations between pairs of elements in the West, Main, and East ore zones.

Least-squares equations used to predict the mean gold content on the basis of the abundance of other elements, and multiple correlation coefficients used to determine the adequacy of these different values for predicting the mean gold content, were included in the reports by Harris (1974) and Harris and Radtke (1976), but are omitted here.

\section{GOLD-ARSENIC-MERCURY-ANTIMONY SUITE}

Table 15 lists linear correlation coefficients between pairs of elements in the gold-arsenic-mercury-antimony suite in unoxidized ores of the West, Main, and East ore zones and for the entire deposit. The relatively large correlation coefficients for the West ore zone suggest that strong spatial associations exist between these pairs of elements, and also agree with the results of mineralogic studies showing that most of the gold, mercury, arsenic, and antimony in samples from the West ore zone occur together on the surfaces of pyrite grains. Organic carbon is
TABLE 15.-Linear correlation coefficients between gold, arsenic mercury, and antimony in unoxidized ores of the West, Main, and East ore zones and for the entire Carlin gold deposit

\begin{tabular}{lrccc}
\hline \multicolumn{1}{c}{ Element pair } & West ore zone & Main ore zone & East ore zone & Entire deposit \\
\hline $\mathrm{Au}$ to $\mathrm{As} \ldots \ldots \ldots \ldots . .$. & 0.81 & 0.34 & 0.23 & 0.27 \\
$\mathrm{Au}$ to $\mathrm{Hg} \ldots \ldots \ldots .$. & .68 & .62 & .48 & .55 \\
$\mathrm{Au}$ to $\mathrm{Sb} \ldots \ldots \ldots \ldots . .$. & .85 & .62 & .19 & .12 \\
$\mathrm{As}$ to $\mathrm{Hg} \ldots \ldots \ldots \ldots$. & .54 & .41 & .19 & .27 \\
$\mathrm{As}$ to $\mathrm{Sb} \ldots \ldots \ldots \ldots$. & .87 & .47 & .19 & .22 \\
$\mathrm{Hg}$ to $\mathrm{Sb} \ldots \ldots \ldots \ldots$. & .56 & .40 & .00 & .05 \\
\hline
\end{tabular}

very scarce in that area and had little influence on concentrating gold and mercury. These ores apparently represent the product of the main hydrothermal stage (fig. 29). The paucity of arsenic, antimony, and mercury sulfides and the absence of introduced hydrocarbons substantiate the absence of late hydrothermal activity in that part of the deposit.

The suggestion by Krumbein (1959) that independent variables correlating most strongly with a dependent variable also relate most directly to the physical phenomenon under study accords with the mineralogic data on unoxidized Carlin ores for arsenic, mercury, and antimony taken as independent variables and for gold taken as a dependent variable. In all the ores zones and for the entire deposit, gold and mercury have large correlation coefficients. Both elements tend to occur together on the surfaces of pyrite and with carbonaceous materials, and only minor amounts are in other forms.

Although arsenic and antimony occur on pyrite grains, large amounts of both elements also occur as late sulfides. Realgar and orpiment are present in both the Main and East ore zones, and the gold-to-arsenic correlation coefficients in both areas are relatively small. Stibnite is present in the East ore zone, and the gold-to-antimony correlation coefficient is only 0.08 (table 15); in the Main ore zone, in which stibnite is much less abundant, the larger gold-to-antimony correlation coefficient of 0.62 (table 15) is due to the small amount of stibnite and the tendency for antimony to concentrate with gold on the surfaces of pyrite grains. Furthermore, the small correlation coefficients between gold and arsenic, arsenic and mercury, and mercury and antimony in the Main ore zone, and between gold and arsenic, gold and antimony, arsenic and mercury, and mercury and antimony in the East ore zone, probably reflect the tendency of carbonaceous materials, abundant in both zones, to concentrate gold and mercury preferentially and also suggest that gold and mercury were not deposited with the arsenic and antimony phases.

Although arsenic and antimony were introduced throughout the hydrothermal episode, the strongest correlation between these elements $(0.78)$ is in the West ore zone, where both elements occur together almost entirely 

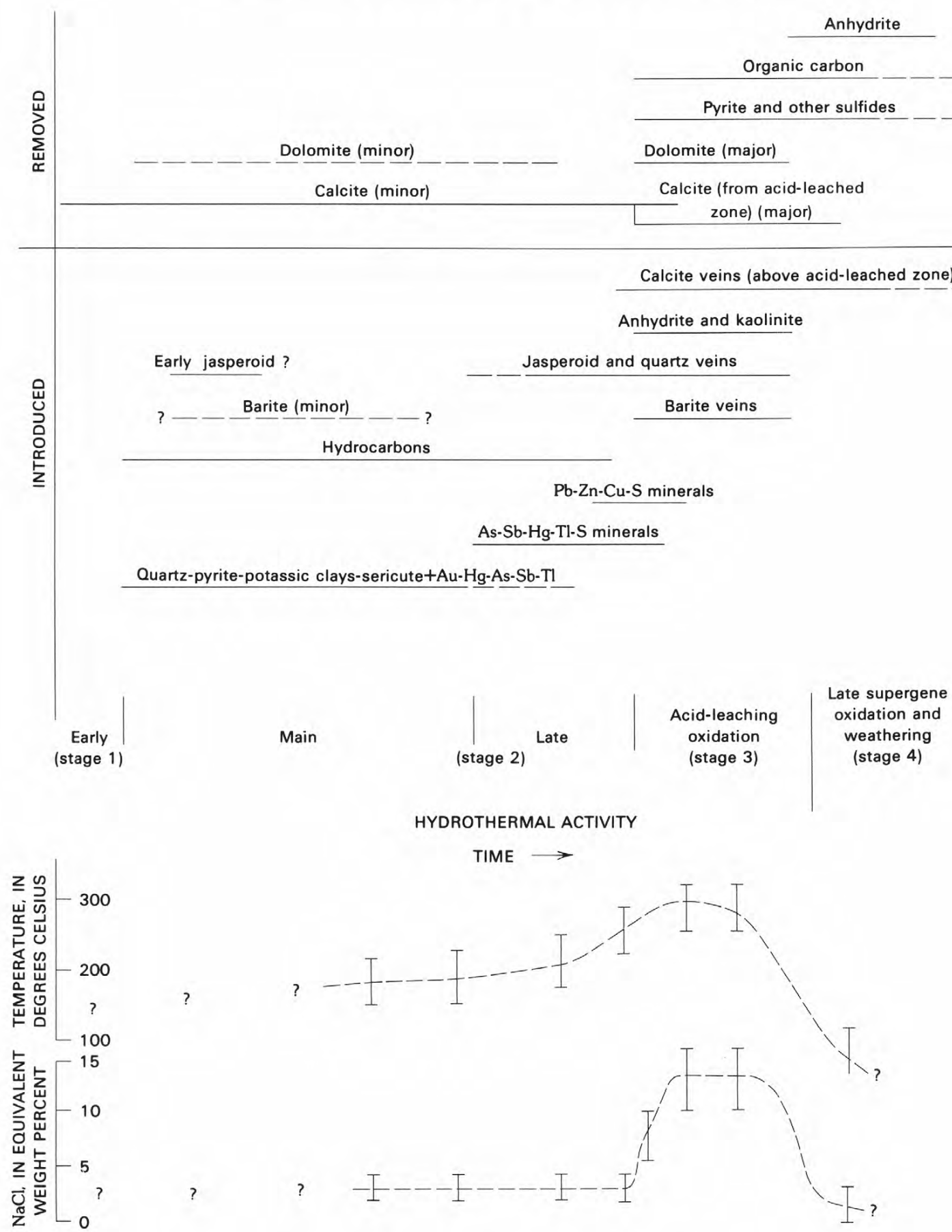

Figure 29.-Paragenesis of the Carlin gold deposit. 
on pyrite grains. The small arsenic-to-antimony correlation coefficients in the other ore zones accord with the tendency for the late sulfides of both elements to occur spatially separated. Many samples containing realgar or orpiment have little or no stibnite, and those containing stibnite commonly lack arsenic sulfide minerals.

The distributions of and relations between gold, arsenic, mercury, and antimony in the West, Main, and East ore zones were studied by stepwise discriminant analysis. Table 16 lists the percentages of the total number of samples from each ore zone containing a particular element or combination of elements closest to the mean value in each ore zone. These data indicate that the West ore zone differs significantly from the Main and East ore zones. The West ore zone shows the greatest polarization; that is, the values for arsenic and for the various groups of elements in the West ore zone are consistently much closer to the mean value in the West ore zone than to the mean values in both the Main and East ore zones. Furthermore, the values for these elemental suites in the Main ore zone tend to resemble the values in the West more than in the East ore zone. Through all the successive steps of the discriminant analysis, the polarization shown by the West ore zone persists because gold and mercury, which vary little in abundance between the three ore bodies, are added to the analysis alternately with arsenic and antimony, which vary significantly between the ore bodies. This result, in turn, accords with the paragenetic model, according to which the late arsenic, antimony, and mercury sulfide mineralization (fig. 29) failed to occur in the West ore zone.

TABLE 16.-Stepwise discriminant analyses of gold, arsenic, mercury, and antimony in the West, Main, and East ore zones

\begin{tabular}{|c|c|c|c|}
\hline \multirow[t]{2}{*}{ Reference ore zone } & \multicolumn{3}{|c|}{$\begin{array}{l}\text { Percentage of total samples in reference } \\
\text { ore zone closest to mean value }\end{array}$} \\
\hline & West ore zone & Main ore zone & East ore zone \\
\hline \multicolumn{4}{|c|}{ Step 1: arsenic } \\
\hline West. & 86.49 & 8.11 & \\
\hline 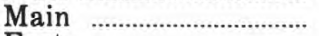 & 52.68 & 20.0 & 27.14 \\
\hline East …………………… & 38.71 & 20.16 & 41.13 \\
\hline \multicolumn{4}{|c|}{ Step 2: gold and arsenic } \\
\hline West & 91.89 & 8.11 & .0 \\
\hline 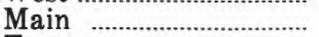 & 50.0 & 30.0 & 20.0 \\
\hline East …………………….......... & 26.62 & 42.74 & 30.64 \\
\hline \multicolumn{4}{|c|}{ Step 3: gold, arsenic, and antimony } \\
\hline West & 91.89 & 8.11 & .0 \\
\hline Main ……………………........ & 47.14 & 31.43 & 21.43 \\
\hline East & 24.19 & 43.55 & 32.26 \\
\hline \multicolumn{4}{|c|}{ Step 4: gold, arsenic, mercury, and antimony } \\
\hline West & 89.19 & 10.81 & .0 \\
\hline 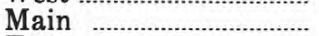 & 37.14 & 42.86 & 20.0 \\
\hline East …………………….... & 28.22 & 37.10 & 34.68 \\
\hline
\end{tabular}

\section{GOLD-BARIUM-COPPER-MOLYBDENUM-LEAD- ZINC SUITE}

The mineralogy of barium, copper, molybdenum, lead, and zinc, and the associations between minerals containing these elements, were discussed in earlier sections of this report. Although mineralized limestone in the Carlin deposit contains anomalous amounts of these elements, the concentration by factors of 3 to 10 over the respective abundances in the fresh host rocks are much less than those for arsenic, mercury, antimony, and thallium.

Table 17 lists linear correlation coefficients for pairs of elements in the gold-barium-base-metals suite in each ore zone and for the entire deposit. All the correlations between these elements are weak in the Main and East ore zones and for the entire deposit. The weak correlations between gold and barium, and between gold and the different base metals, are compatible with the paragenetic model, according to which gold was deposited during the main hydrothermal stage, the base metals were introduced later, and most of the barite formed during the late hydrothermal stage. These results are discussed below in the section entitled "Genesis of the Deposit." In addition, in the unoxidized ores most of the sparse barite and base-metal sulfide grains are not spatially associated with each other nor with auriferous pyrite or carbonaceous materials, and thus tend to give insignificant elemental correlations.

In the West ore zone, however, many of the correlation coefficients are significantly larger. Within the West ore zone, correlations between pairs of base metals and between barium and zinc are stronger than those between barium and the other base metals, gold and base metals, and gold and barium (table 15).

The consistently weak correlation between gold and barium in each ore zone and for the entire deposit is compatible with paragenetic separation of gold and barite and suggests that different mechanisms controlled the deposition of each element. Barite veins lack detectable amounts of gold, and the correlations show that in individual ore samples, gold and barite contents are unrelated. These factors support the idea that although small amounts of barium were introduced and deposited as dispersed fine grains of barite throughout the hydrothermal episode, most of the barite formed during a paragenetic stage different from that in which gold was deposited.

Table 18 lists the results of stepwise discriminant analyses of gold, barium, copper, molybdenum, lead, and zinc. Using all combinations of variables (steps 1-6), the percentages in the West and East ore zones consistently are strongly polarized toward their own means. In contrast, percentages in the Main ore zone, which contains the most base metals, resemble those in the ore bodies on either side. 
TABLE 17.-Linear correlation coefficients between gold, barium, copper, molybdenum, lead, and zinc in unoxidized ores of the West, Main, and East ore zones and for the entire Carlin gold deposit

\begin{tabular}{|c|c|c|c|c|}
\hline Element pair & West ore zone & Main ore zone & East ore zone & Entire deposit \\
\hline $\begin{array}{l}\mathrm{Au} \text { to } \mathrm{Ba} \\
\mathrm{Au} \text { to } \mathrm{Cu} \\
\mathrm{Au} \text { to } \mathrm{Mo} \\
\mathrm{Au} \text { to } \mathrm{Pb} \\
\mathrm{Au} \text { to } \mathrm{Zn}\end{array}$ & $\begin{array}{r}-0.17 \\
.13 \\
-.15 \\
-.14 \\
-.20\end{array}$ & $\begin{array}{r}-0.04 \\
.27 \\
.03 \\
-.08 \\
.12\end{array}$ & $\begin{array}{r}-0.01 \\
.15 \\
.16 \\
.00 \\
.26\end{array}$ & $\begin{array}{r}-0.06 \\
.17 \\
.06 \\
-.05 \\
.20\end{array}$ \\
\hline $\begin{array}{l}\text { Ba to } \mathrm{Cu} \\
\mathrm{Ba} \text { to } \mathrm{Mo} \\
\mathrm{Ba} \text { to } \mathrm{Pb} \\
\mathrm{Ba} \text { to } \mathrm{Zn} \\
\mathrm{Cu} \text { to.......................... } \\
\mathrm{Mo}\end{array}$ & $\begin{array}{r}-.23 \\
.07 \\
.10 \\
.28 \\
.28\end{array}$ & $\begin{array}{r}-.05 \\
-.09 \\
.01 \\
.17 \\
.16\end{array}$ & $\begin{array}{r}.00 \\
00 \\
.27 \\
-.02 \\
.17\end{array}$ & $\begin{array}{r}-.08 \\
.03 \\
.05 \\
.01 \\
.19\end{array}$ \\
\hline $\begin{array}{l}\text { Cu to } \mathrm{Pb} \\
\mathrm{Cu} \text { to } \mathrm{Zn} \\
\mathrm{M} \text { o to } \mathrm{Pb} \\
\mathrm{Mo} \text { to } \mathrm{Zn} \\
\mathrm{Pb} \text { to } \mathrm{Zn}\end{array}$ & $\begin{array}{l}.56 \\
.40 \\
.09 \\
.31 \\
.49\end{array}$ & $\begin{array}{r}-.15 \\
-.10 \\
-.14 \\
.07 \\
.11\end{array}$ & $\begin{array}{r}.18 \\
.06 \\
.05 \\
-.03 \\
.09\end{array}$ & $\begin{array}{r}-.02 \\
-.07 \\
-.05 \\
-.01 \\
.04\end{array}$ \\
\hline
\end{tabular}

TABLE 18.-Stepwise discriminant analyses of gold, barium, copper, molybdenum, lead, and zinc in the West, Main, and East ore zones

\begin{tabular}{|c|c|c|c|}
\hline \multirow[t]{2}{*}{ Reference ore zone } & \multicolumn{3}{|c|}{$\begin{array}{l}\text { Percentage of total samples in reference } \\
\text { ore zone closest to mean value }\end{array}$} \\
\hline & West ore zone & Main ore zone & East ore zone \\
\hline \multicolumn{4}{|c|}{ Step 1: copper } \\
\hline West. & 57.5 & 10.0 & 32.5 \\
\hline 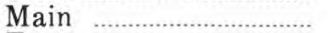 & 23.61 & 33.33 & 43.05 \\
\hline East & 10.77 & 13.85 & 75.38 \\
\hline \multicolumn{4}{|c|}{ Step z: barium and copper } \\
\hline 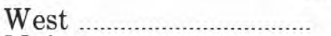 & 60.0 & 10.0 & 30.0 \\
\hline Main & 30.55 & 33.33 & 36.11 \\
\hline 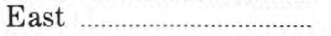 & 11.54 & 13.85 & 74.61 \\
\hline \multicolumn{4}{|c|}{ Step.3: barium, copper, and molybdemum } \\
\hline$\ldots$ & 60.0 & 17.5 & 22.5 \\
\hline 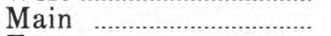 & 31.94 & 40.28 & 27.78 \\
\hline 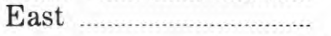 & 13.08 & 26.92 & 60.0 \\
\hline \multicolumn{4}{|c|}{ Step 4: barium, copper, molybdenum, and lead } \\
\hline$\ldots \ldots \ldots \ldots$ & 55.0 & 12.5 & 32.5 \\
\hline Main ………………… & 30.56 & 44.44 & 25.0 \\
\hline East & 22.31 & 16.15 & 61.54 \\
\hline \multicolumn{4}{|c|}{ Step 5: gold. barium. copper, molybdenum. and lead } \\
\hline$\ldots \ldots \ldots \ldots \ldots \ldots \ldots \ldots$ & 57.5 & 15.0 & 27.5 \\
\hline 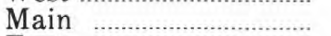 & 31.95 & 45.83 & 22.22 \\
\hline East $\ldots \ldots-\ldots-\ldots$ & 16.15 & 20.0 & 63.85 \\
\hline \multicolumn{4}{|c|}{ Step 6: gold, barium, copper, molybdenum, lead, and zine } \\
\hline West. & 60.0 & 15.0 & 25.0 \\
\hline 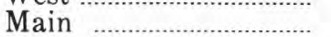 & 30.55 & 47.22 & 22.22 \\
\hline East …...... & 16.15 & 20.0 & 63.85 \\
\hline
\end{tabular}

\section{GOLD-BORON-SELENIUM-TELLURIUM- TUNGSTEN SUITE}

Boron, selenium, tellurium, and tungsten were introduced in small amounts by the hydrothermal ore solutions. The limited amount of information available on the minerals containing these elements, and their associations with other minerals, were presented in previous sections of this report. Tellurium is the only element of the suite to form natural compounds with gold. Although gold telluride minerals have not been found in Carlin ores, tellurium in amounts below the limit of detection by micro- probe analysis may occur with gold on the surfaces of pyrite grains.

Table 19 lists linear correlation coefficients for pairs of elements in the gold-boron-selenium-tellurium-tungsten suite. The only correlation of any significance is between gold and tellurium; this correlation is strongest in the East ore zone and becomes progressively weaker through the Main and West ore zones (table 19). For the entire deposit, the only significant correlation also is that between gold and tellurium, and this correlation coefficient (0.37) is considerably smaller than many others. The other correlations, none significant, suggest that the physical associations between gold and boron, selenium, and tungsten are weak.

TABLE 19.-Linear correlation coefficients between gold, boron, selenium, tellurium, and tungsten in unoxidized ores of the West, Main, and East ore zones and for the entire Carlin gold deposit

\begin{tabular}{|c|c|c|c|c|}
\hline Element pair & West ore zone & Main ore zone & East ore zone & Entire deposit \\
\hline $\mathrm{Au}$ to $\mathrm{B} \ldots$ & 0.25 & 0.09 & -0.06 & -0.02 \\
\hline $\mathrm{Au}$ to $\mathrm{Se}$ & -.5 & -.13 & .02 & -.04 \\
\hline $\mathrm{Au}$ to $\mathrm{Te} .$. & .00 & .34 & .50 & .37 \\
\hline $\mathrm{Au}$ to $\mathrm{W}$ & -.04 & .08 & .02 & .03 \\
\hline $\mathrm{B}$ to $\mathrm{Se}$ & -.12 & .02 & .04 & .02 \\
\hline $\mathrm{B}$ to $\mathrm{Te}$ & .00 & .03 & .06 & .08 \\
\hline $\mathrm{B}$ to $\mathrm{W}$ & .02 & -.06 & .04 & .01 \\
\hline $\mathrm{Se}$ to $\mathrm{Te}$ & .00 & .08 & -.06 & -.01 \\
\hline Se to W & -.13 & -.09 & .12 & .04 \\
\hline Te to W & .00 & -.09 & -.07 & -.07 \\
\hline
\end{tabular}

The distributions of these five elements between the West, Main, and East ore zones were evaluated by stepwise discriminant analysis (table 20). Results show that the abundances of these elements in the West ore zone consistently are strongly polarized toward their mean values in that ore zone.

TABLE 20.-Stepwise discriminant analyses of gold, boron, selenium, tellurium, and tungsten in the West, Main, and East ore zones

\begin{tabular}{|c|c|c|c|}
\hline \multirow[t]{2}{*}{ Reference ore zone } & \multicolumn{3}{|c|}{$\begin{array}{l}\text { Percentage of total samples in reference } \\
\text { ore zone closest to mean value }\end{array}$} \\
\hline & West ore zone & Main ore zone & East ore zone \\
\hline \multicolumn{4}{|c|}{ Step 1: boron } \\
\hline West & 64.1 & 0.0 & 35.9 \\
\hline Main & 22.22 & 41.67 & 36.11 \\
\hline East ...... & 20.0 & 26.4 & 53.6 \\
\hline \multicolumn{4}{|c|}{ Step 2: tellurium and boron } \\
\hline West. & 100.0 & .0 & .0 \\
\hline Main & 50.0 & 18.06 & 31.94 \\
\hline 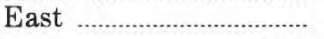 & 60.8 & 14.4 & 24.8 \\
\hline \multicolumn{4}{|c|}{ Step 3: selenium, tellurium, and boron } \\
\hline 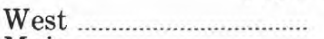 & 71.79 & 23.08 & 5.13 \\
\hline 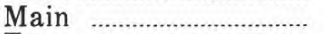 & 23.61 & 63.89 & 12.5 \\
\hline East ……........................... & 23.2 & 48.0 & 28.8 \\
\hline \multicolumn{4}{|c|}{ Step 4: gold, selenium, tellurium, and boron } \\
\hline West & 74.36 & 15.38 & 10.26 \\
\hline Main & 22.22 & 65.28 & 12.5 \\
\hline East ....................................... & 28.8 & 46.4 & 24.8 \\
\hline \multicolumn{4}{|c|}{ Step 5: tungsten, gold, selenium, tellurium, and boron } \\
\hline West & 74.36 & 15.38 & 10.26 \\
\hline Main & 25.0 & 62.5 & 12.5 \\
\hline East & 32.0 & 41.6 & 26.4 \\
\hline
\end{tabular}




\section{HYDROTHERMAL ALTERATION}

A useful description of the rock alteration at Carlin requires a discussion of the paragenetic model and its principal phases, which include: (1) hydrothermal mineralization, (2) acid-leaching oxidation, and (3) supergene oxidation. The hydrothermal phase is subdivided into early, main, and late stages. From a timing standpoint, certain processes during the late hydrothermal stage and during acid-leaching oxidation probably took place simultaneously at different depths. At some intermediate depth, perhaps 90 to $150 \mathrm{~m}$ below the present surface, rising hydrothermal fluids mixed with descending acid-leaching solutions to create a zone having some mineralogic features characteristic of the zones above and below, and others rather different.

It is difficult to sort out separate events at a given locality into a definitive time sequence and even more difficult to determine which events took place within a given interval at different localities in the deposit. Because so many of the alteration processes undoubtedly were intermittent and overlapping, only a general paragenetic model can be presented (fig. 29). The major sequence of events is consistent with the spatial distribution of geologic features in the Carlin deposit, as discussed in detail in this report.

The hydrothermal alteration at Carlin is here defined to include all changes in the host rocks caused by interaction with fluids during hydrothermal mineralization and acidleaching oxidation; the alteration effects and processes for each of the three hydrothermal stages, however, are discussed separately. In the shallower parts of the deposit, many of the hydrothermal alteration effects have been obliterated, owing to attack by the acidic solutions generated at elevated temperatures through boiling of the hydrothermal fluids and, later, to weaker interactions with low-temperature oxygen-bearing meteoric waters.

Rocks representative of the types of hydrothermal alteration (pls. 5-7) are well exposed below the zone of oxidation in the deeper levels of the Main and East pits and, locally, in isolated areas within the oxidized zone in the West, Main, and East pits. The important features of each type of alteration are discussed below according to the general paragenetic sequence of hydrothermal activity.

\section{EARLY HYDROTHERMAL STAGE}

\section{CARBONATE REMOVAL}

The early hydrothermal fluids responsible for formation of the Carlin gold deposit moved upward along complex sets of high-angle normal faults and breccia zones and spread out laterally through favorable laminated silty dolomitic beds in the Roberts Mountains Formation. Petrographic evidence indicates that these early fluids dissolved out small to moderate amounts of calcite from the matrix of the host rocks and precipitated lesser amounts of quartz. The early fluids probably were at relatively low temperatures (about $100^{\circ} \mathrm{C}$ ), were undersaturated with regard to calcite, and were supersaturated with regard to quartz. The silica content of the solutions at saturation near this temperature on the vapor-pressure curve of water would be only about 50 to $70 \mathrm{ppm}$ (Morey and others, 1962, fig. 1). The fluids moved through the thinbedded carbonate rocks away from feeder fractures and aggressively dissolved out calcite but deposited only small amounts of quartz. The relatively small changes in bulk rock composition are compatible with initial penetration of the rocks by solutions at significantly lower temperatures than those prevailing during the succeeding main hydrothermal stage.

The importance of the early hydrothermal stage was to increase the porosity and permeability of the host rocks and thus to make them more favorable for mineralization.

\section{MAIN HYDROTHERMAL STAGE}

Most of the hydrothermal alteration took place during the main hydrothermal stage, which included a potassicargillic alteration characterized by kaolinite, sericite, and fine-grained silica, limited local massive silicification, and initial introduction of carbonaceous materials. Plate 5 shows the distributions of these altered rocks.

\section{POTASSIC-ARGILLIC ALTERATION}

The potassic-argillic alteration, which is pervasive throughout the Carlin deposit, extends into rocks lateral to as well as above and below the zones of gold deposition (pl. 5). In addition to the Roberts Mountains Formation, large volumes of the Popovich Formation and shale-chert beds of the upper plate exhibit this alteration. Potassicargillic alteration is intimately associated with the gold mineralization and is evident in all the mineralized rocks and in all the unoxidized ore types of the deposit.

During the main hydrothermal stage, the fluids introduced $\mathrm{SiO}_{2}, \mathrm{~K}_{2} \mathrm{O}$, and $\mathrm{Al}_{2} \mathrm{O}_{3}$, and removed additional amounts of $\mathrm{CaO}$ and $\mathrm{CO}_{2}$. These effects are best shown by comparing the contents of these components in the fresh unmineralized rocks with those in the unoxidized ores (fig. 15). The most accurate comparison is between these values in the fresh rocks and in the normal gold ore, which was not affected by any overprint of carbonaceous materials, silica, or sulfide minerals. The increase in $\mathrm{SiO}_{2}$ reflects the formation of fine-grained quartz, and the values for $\mathrm{K}_{2} \mathrm{O}, \mathrm{Al}_{2} \mathrm{O}_{3}$, and $\mathrm{H}_{2} \mathrm{O}(+)$ are due to the formation of kaolinite and sericite. 
Results of experimental studies on the system $\mathrm{K}_{2} \mathrm{O}$ $\mathrm{Al}_{2} \mathrm{O}_{3}-\mathrm{SiO}_{2}-\mathrm{H}_{2} \mathrm{O}$ were reported by Hemley (1959) and Hemley and Jones (1964). Garrels and Christ (1965) presented data on stability relations of the various phases in this system at $25^{\circ} \mathrm{C}$ and $1 \mathrm{~atm}$ as a function of $\left[\mathrm{K}^{+}\right] /[\mathrm{H} \quad]$ and $\left[\mathrm{H}_{4} \mathrm{SiO}_{4}\right]$. Their diagram (Garrels and Christ, 1965, p. 361, fig. 10.6) implies a value for $\left[\mathrm{K}^{+}\right] /\left[\mathrm{H}^{+}\right]$of approximately $10^{6.5}$ and for $\left[\mathrm{H}_{4} \mathrm{SiO}_{4}\right]$ of $10^{-4}$ for potassium mica, kaolinite, and quartz in equilibrium at $25^{\circ} \mathrm{C}$ and $1 \mathrm{~atm}$. The observed mineral assemblage in mineralized carbonate rocks at Carlin consists principally of intimately intergrown sericite, kaolinite, and quartz. Quartz, however, is much more soluble at the temperatures at which this assemblage precipitated, which were between approximately $175^{\circ}$ and $200^{\circ} \mathrm{C}$ (thermometry is discussed below), than at $25^{\circ} \mathrm{C}$, and so Garrel and Christ's diagram cannot be used directly. At these temperatures the solubility of quartz along the vapor-presssure curve of water is $10^{-2.5}$ to $10^{-2.3}$ (Morey and others, 1962). Thus, if these three solid phases were precipitated at equilibrium, the fields for potassium mica and kaolinite at $175^{\circ}$ to $200^{\circ} \mathrm{C}$ would need to be shifted to the right of their position at $25^{\circ} \mathrm{C}$ in the diagram of Garrels and Christ.

The mineral assemblage muscovite + kaolinite + quartz, according to the calculations by Helgeson and others (1969) on the system $\mathrm{HCl}-\mathrm{H}_{2} \mathrm{O}-\mathrm{Al}_{2} \mathrm{O}_{3}-\mathrm{K}_{2} \mathrm{O}$ $\mathrm{SiO}_{2}$ at $200^{\circ} \mathrm{C}$ and $1 \mathrm{~atm}$, coexists stably with a solution in which the log activity ratios $a_{\mathrm{K}}+/ a_{\mathrm{H}}+$ and $a_{\mathrm{Al}} 3+1$ $\left(a_{H}+\right)^{3}$ are 3.5 and 1.5 , respectively. If the solutions at Carlin were nearly neutral at $200^{\circ} \mathrm{C}(\mathrm{pH}=5.6)$, the calculated $\log$ activities of $\mathrm{K}^{+}$and $\mathrm{Al}^{3+}$ would have been -2.1 and -15.3 , respectively. These solutions would have contained about $300 \mathrm{ppm} \mathrm{K}{ }^{+}$and $10 \times 10^{-12} \mathrm{ppm} \mathrm{Al}^{3+}$; under these conditions aluminum is essentially insoluble.

A solution containing a larger amount of $\mathrm{Al}^{3+}$ - say, 1 ppm or more - gained at elevated temperatures at depth would precipitate essentially all the aluminum by the formation of muscovite and kaolinite at $200^{\circ} \mathrm{C}$. This result implies that the solution which interacted with the source rocks at depth moved rapidly upward; otherwise, the aluminum would have been removed by wallrock-solution exchange reactions before reaching the near-surface environment represented by present exposures.

Activity diagrams (Helgeson and others, 1969) for the system $\mathrm{HCl}-\mathrm{H}_{2} \mathrm{O}-\mathrm{Al}_{2} \mathrm{O}_{3}-\mathrm{CaO}-\mathrm{CO}_{2}-\mathrm{K}_{2} \mathrm{O}-\mathrm{SiO}_{2}$ at $150^{\circ}$ and $200^{\circ} \mathrm{C}$ at quartz saturation give information on the possible temperature of ore deposition. Potassium montmorillonite, a stable phase between the kaolinite and muscovite stability fields at $200^{\circ} \mathrm{C}$, is absent at $150^{\circ} \mathrm{C}$; the apparent absence of this mineral in large volumes of Carlin ores suggests that the altered-mineral assemblage in these areas formed between $150^{\circ}$ and $200^{\circ} \mathrm{C}$.

During the main hydrothermal stage, fine-grained quartz, together with sericite and minor kaolinite, formed

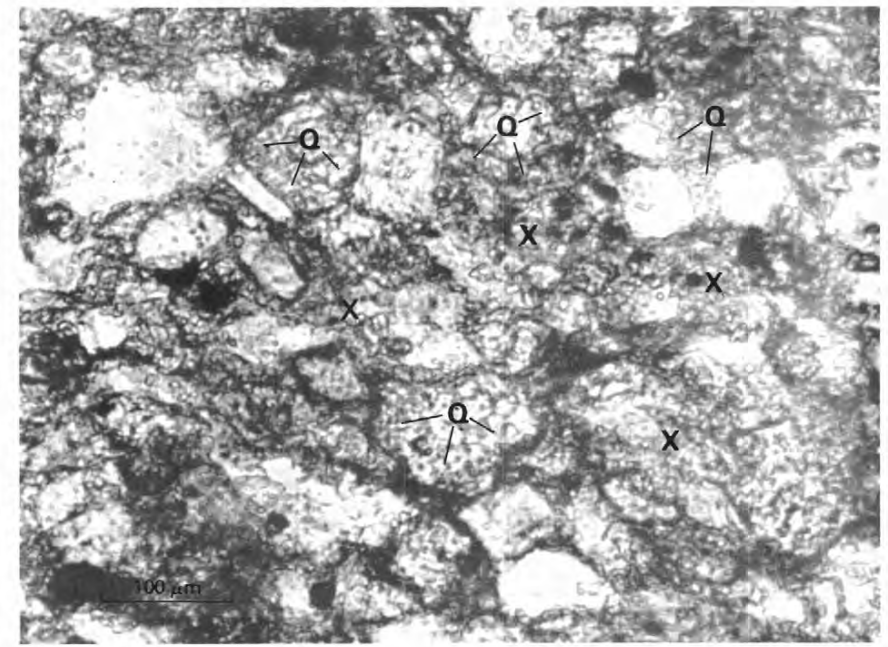

FIGURE 30.-Potassic-argillic alteration features associated with mineralization. Quartz, together with kaolinite and sericite, was formed in matrix of rock (X's), and quartz (Q) locally replaces margins of dolomite rhombs.

in the matrix of the carbonate rocks (fig. 30). Small amounts of quartz replaced borders of corroded dolomite rhombs and formed small patches and seams along bedding planes and microfractures (figs. 13A, 13B). Petrographic and chemical data indicate that these features are at least partly replacement in nature and accompanied the removal of calcite and minor amounts of dolomite. The chemical data also suggest that small amounts of titanium were added:a fine-grained phase of composition $\mathrm{TiO}_{2}$ dispersed throughout mineralized arenaceous dolomite has been recognized by electron microprobe analysis.

The hydrothermal solutions that caused the potassicargillic alteration probably were strongly undersaturated with regard to calcite and supersaturated with regard to quartz. At the point of initial penetration of the carbonate rocks along faults, the solutions were at temperatures above $200^{\circ} \mathrm{C}$ and possibly in the range $250^{\circ}-300^{\circ} \mathrm{C}$. In the areas of gold deposition they cooled to $170^{\circ}$ to $200^{\circ} \mathrm{C}$ (as discussed in later sections of this report), the probable range over which most of the potassic-argillic alteration took place. Using the vapor-pressure curve for water, the solubility of quartz in the hydrothermal solutions at $300^{\circ} \mathrm{C}$ would be 650 to $700 \mathrm{ppm} \mathrm{SiO}_{2}$, and over the range $170^{\circ}-$ $200^{\circ} \mathrm{C}$ it would decrease to about 170 to $270 \mathrm{ppm} \mathrm{SiO}_{2}$ (Morey and others, 1962, fig. 1).

The larger amounts of quartz deposited during the main than during the early hydrothermal stage probably reflect the larger amounts of silica carried in solution at the higher temperatures and the relatively broad range of the temperature decrease. In addition to the effect on calcite solubility from decreasing temperatures, another reaction, such as the separation of silica from solution, may 
have continuously regenerated undersaturation with respect to calcite. The energy released by crystallization of quartz would, in effect, have been consumed locally by dissolution of calcite.

The thin-bedded laminated carbonate rocks that have undergone potassic- argillic alteration, including those that have been mineralized, closely resemble the fresh unaltered rocks. No pronounced color changes accompanied the alteration, chemical changes are hardly noticeable in acid or hardness tests, and the alteration effects are difficult to recognize either on natural surfaces or in hand specimens.

\section{PYRITE, GOLD, AND ASSOCIATED METALS}

Petrographic evidence and correlated chemical data suggest that most of the hydrothermal pyrite, together with gold, mercury, arsenic, and antimony, were introduced during the main hydrothermal stage (fig. 28). Comparison between the chemical data on fresh unmineralized rocks and the normal gold ore (fig. 15, tables $2,12)$ shows that the hydrothermal fluids introduced both iron and sulfur. The increased barium content is compatible with the observation that small amounts of disseminated fine-grained barite also probably were formed during this stage.

Hydrothermal pyrite occurs as cubic and framboidal grains (figs. 12, 18, 21, 22), and both varieties are closely associated with hydrothermal silica. Locally, large amounts of hydrothermal pyrite have been added, and so the ore is classified as pyritic. Gold, mercury, arsenic, antimony, and, locally, thallium were deposited on the surfaces of these pyrite grains as well as on the smaller original diagenetic grains. No data are available on the composition of these surface coatings, except that they contain iron and sulfur in addition to the elements listed above. Both the mechanisms controlling this deposition and the reactions involved are poorly understood.

Most of the gold and mercury introduced during the main hydrothermal stage formed either on the surfaces of pyrite grains or in association with carbonaceous materials. Arsenic, antimony, and thallium were confined to the surfaces of pyrite grains, and so probably few, if any, sulfides of arsenic, antimony, mercury, or thallium were deposited during the main hydrothermal stage.

A detailed discussion or review of complex metal ions and of the dependency of their stabilities on solution $\mathrm{pH}$ is beyond the scope of this report. If the gold, mercury, arsenic, and antimony were introduced during the main hydrothermal stage, as all the available evidence suggests, then their transport mechanisms must be compatible with the slightly acidic solutions implied by the altered-mineral assemblage. An alternative explanation, however, agreeing with observations in some hot springs (R. O. Fournier, oral commun., 1976), would be that: (1) the alteration assemblage formed somewhat earlier under slightly acidic conditions, (2) over time the $\mathrm{pH}$ shifted to higher values, and thus (3) an alkaline solution, nearly saturated with respect to sulfur species and readily capable of transporting stable sulfide complexes of these metals was formed.

\section{SILICEOUS ALTERATION}

Although fine-grained silica was precipitated throughout the potassic-argillic-alteration zones, locally the carbonate rocks were flooded by large amounts of hydrothermal silica. The resulting zones of intense silicification, which include both jasperoid bodies and seams and lenses of dense hydrothermal silica, are classified as a distinct alteration type. Both the zones of siliceous alteration (jasperoid) and the areas containing heavy concentrations of thin irregular seams and lenses of hydrothermal silica are shown as distinct units on the hydrothermal-alteration map (pl. 5).

The zones of siliceous alteration occur within or close to gold ore bodies in all the ore zones. However, the timing between formation of these silica bodies and mineralization cannot be precisely determined from spatial relations within the deposit.

Petrographic evidence, and the presence of sericite and lesser amounts of kaolinite, suggest that the unoxidized gold-bearing parts of siliceous zones formed as a result of an influx of silica superimposed on mineralized dolomitic carbonate rocks showing earlier potassic-argillic alteration. Bodies of siliceous gold ore grade into normal ore over distances of 1 to $3 \mathrm{~m}$ in both the Main and East ore zones. The presence of small amounts of fine-grained metallic gold locked in silica in these ores suggests that at least some of the solutions that transported the silica may also have contained gold.

Small thin black seams and patches of hydrothermal silica, closely resembling black chert, occur locally throughout the shallow parts of all the ore zones. Most of the patches occur in zones that have undergone moderate to intense hydrothermal acid leaching as well as later supergene oxidation (fig. 31). The seams thicken and are more abundant along fractures and faults, and extend outward both parallel to and locally crosscutting bedding in the altered carbonate rocks; a typical seam, $0.15 \mathrm{~m}$ thick, thins or pinches out 3 to $6 \mathrm{~m}$ from the source fracture.

The position in the paragenesis of the large jasperoid bodies along the West and Main ore zones has not been precisely established. These bodies, which are spatially associated with high-angle faults (pls. 3-5), extend downward from the present surface $120 \mathrm{~m}$ or more and appear to diminish in width with increasing depth. Masses of jasperoid along the southwest wall of the Main pit (fig. 32), which locally near the margins contain hydrothermal pyrite and as much as $10 \mathrm{ppm} \mathrm{Au}$, form 


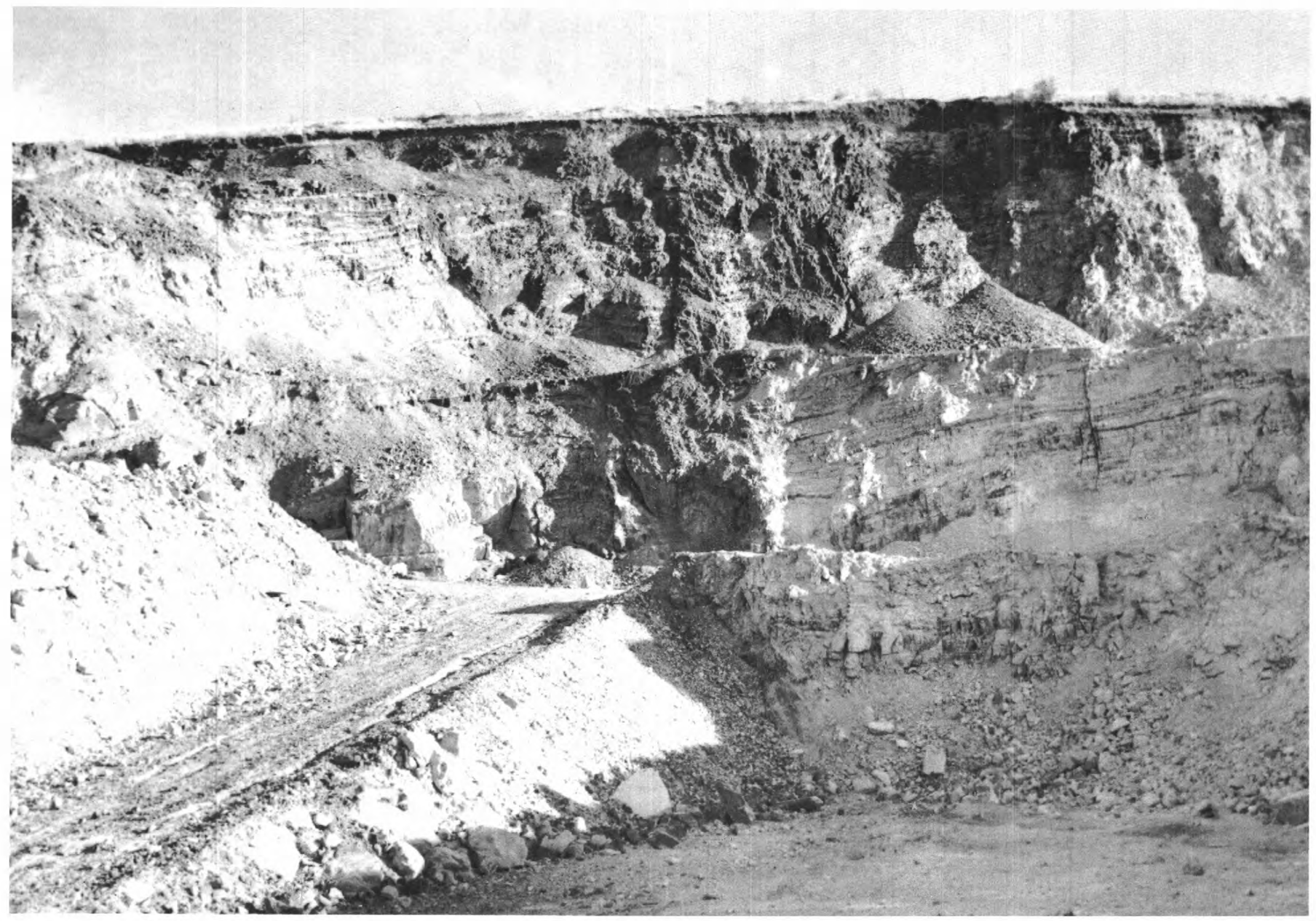

FIGURE 31.-Thick craggy masses of hydrothermal silica along north-south-striking high-angle normal faults in south wall of Main pit. Faults, which run from central part of Main ore zone to South Extension ore zone, were important channels for ore solutions. Note silica seams working outward from faults and following bedding through white zones of intense acid-leaching alteration.

saucer-shaped bodies peripheral to replacement ore bodies. These masses, though spatially related to faults intersecting the ore bodies, lie stratigraphically below and plunge to the northwest beneath the ore bodies.

Two large jasperoid bodies, as thick as $30 \mathrm{~m}$, occur in surface exposures along the footwall of the West ore zone (pls. 3-5). Both bodies formed as a result of progressive replacement of altered carbonate rocks by silica along conspicuous east-west- striking faults (fig. 33). Close to these faults, heavy dense dark-gray to black silicified rock grades progressively outward into gray silicified carbonate rock showing visible remnant bedding. The degree of silicification appears to decrease progressively and grade into argillic alteration; all the rocks within the silicified zone, however, are completely silicified, and the flooding by silica ends abruptly over a distance of about $50 \mathrm{~mm}$. Although these jasperoid bodies are related to faults paralleling the ore- controlling faults, they show the same spatial relations to the ore body as do the jasperoid bodies in the Main ore zone.

The large jasperoid bodies at the Carlin deposit formed during the late hydrothermal stage and during acid leaching. The silica bodies occur in carbonate rocks at shallow depths close to faults along which hydrothermal solutions, supersaturated with regard to quartz and undersaturated with regard to calcite, rapidly cooled and aggressively reacted with the wallrocks. Evidence that a large amount of silicification continued during acid leaching is: (1) the tendency for these silicified bodies to occur within the shallow zone of acid leaching; (2) the apparent decrease in silicification with depth, coinciding with diminished intensity of acid leaching; and (3) fluid inclusions indicating solution boiling. Many of the jasperoid bodies terminate at depth close to the bottom of the zone of acid leaching (fig. 30). 


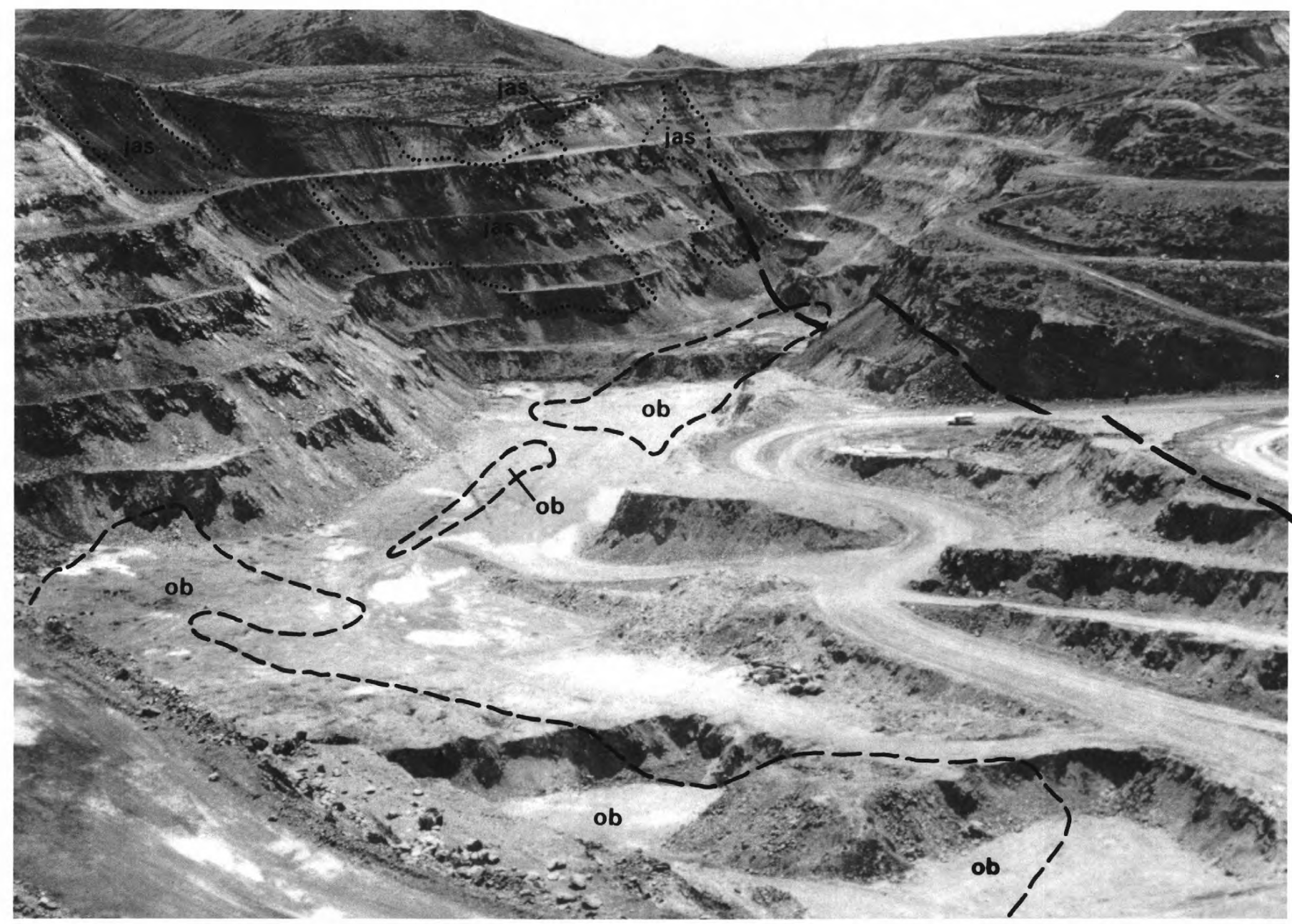

FIGURE 32.-Ferruginous jasperoid bodies (jas, outlined by dots) along south wall at southwest end of Main pit. Long-dashed denotes trace of Mill fault; short-dashed lines indicate approximate positions of ore bodies (ob) in Main ore zone. View south-southwestward.

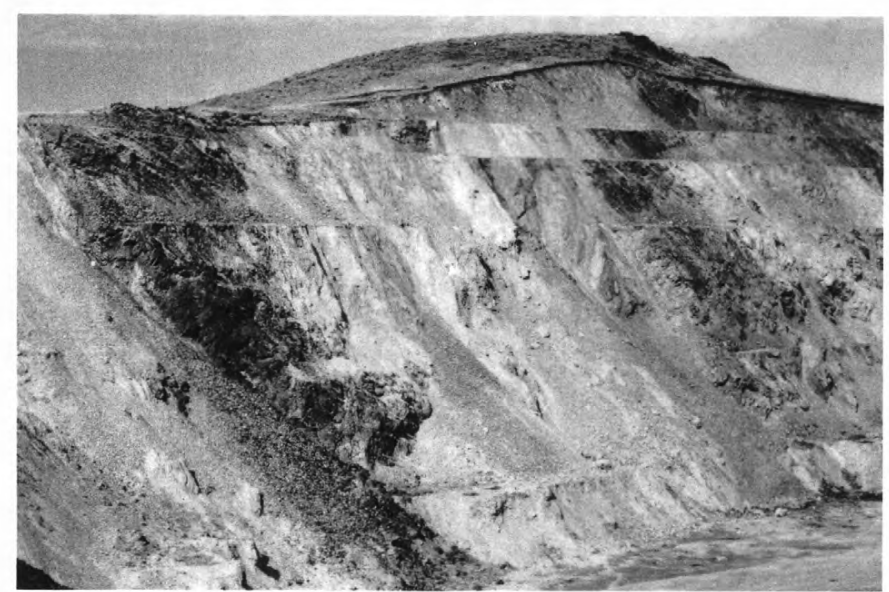

FIGURE 33.-South wall of West pit, showing masses of gold-deficient jasperoid (dark patches) in carbonate rocks of the Roberts Mountains Formation along faults close to footwall of West ore zone. Lighter areas, zones of hydrothermal acid leaching; darker areas, zones of scattered weakly weathered pyritic alteration.
Table 21 lists chemical and spectrographic analyses of samples of heavily silicified rocks of the Roberts Mountains Formation. A composite sample of several hand specimens from seams and lenses of the dense black hydrothermal silica spatially associated with gold ore and acid-leached rocks (fig. 31 ) contained $4,900 \mathrm{ppm} \mathrm{Ba}, 100$ ppm As, 55 ppm Sb, 6 ppm Hg, less than 0.03 ppm Au, and relatively little copper, lead, and zinc (sample 1, table 21). Samples of jasperoid range widely in contents of gold (less than 0.03-4.5ppm) and mercury (0.04 $28 \mathrm{ppm}$ ) and contain very little thallium (less than 3ppm); arsenic and antimony are abundant, and the content of antimony is greater than that of arsenic in the samples analyzed (samples $2-8$, table 21 ). 
TABLE 21.-Chemical and spectrographic analyses of hearily silicified carbonaterocks in the Carlin gold deposit

「Rapid rock analyses (Shapiro and Brannock, 1962) in weight percent: N.A., not analyzed. Analysts: L. Artis. S. Botts. and B. P. Fabbi. Spectrographic analyses in parts per million. Results are identified by geometric brackets whose boundaries are $1.2 .0 .83,0.56,0.38,0.26,0,18,0.12$. and so on, but are reported arbitrarily as the midpoints of these brackets: 1.0 . $0.7 .0 .5,0.3,0.2 .0 .15,0.1$, and so on. The precision of a given value is approximately plus or minus one bracket at the 78-percent, or two brackets at the 95-percent. confidence level. The following elements were below limits of detection in all samples (in ppm as indicated): Bi(7). Cd(7). Ce(70). Ge(7). Hf(50). La (30). Li(100). Nb (7). Pd (1). Pt (10). Re(15). Sn (7). Ta (50). Te (300), Th (150), Tl (3), U (150), W (20). Analyst: Chris Heropoulos]

\begin{tabular}{|c|c|c|c|c|c|c|c|c|}
\hline 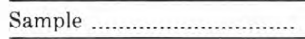 & 1 & 2 & 3 & 4 & 5 & 6 & 7 & 8 \\
\hline \multicolumn{9}{|c|}{ Rapid rock analyses } \\
\hline $\begin{array}{l}\mathrm{SiO}_{2} \\
\mathrm{Al}_{2} \mathrm{O}_{3} \\
\mathrm{Fe}_{2} \mathrm{O}_{3} \\
\mathrm{FeO} \\
\mathrm{Mg}\end{array}$ & $\begin{array}{r}93.7 \\
2.0 \\
.87 \\
.12 \\
.07\end{array}$ & $\begin{array}{r}88.1 \\
5.3 \\
1.4 \\
.12 \\
.60\end{array}$ & $\begin{array}{r}89.2 \\
4.2 \\
2.4 \\
.04 \\
.43\end{array}$ & $\begin{array}{r}88.4 \\
5.5 \\
1.7 \\
.08 \\
.52\end{array}$ & $\begin{array}{c}79.4 \\
7.0 \\
3.7 \\
.08 \\
.00\end{array}$ & $\begin{array}{c}93.3 \\
2.8 \\
1.7 \\
.16 \\
.01\end{array}$ & $\begin{array}{c}88.3 \\
5.4 \\
1.6 \\
.12 \\
.42\end{array}$ & $\begin{array}{r}91.0 \\
3.4 \\
.65 \\
.08 \\
.27\end{array}$ \\
\hline $\begin{array}{l}\mathrm{CaO} \\
\mathrm{BaO}^{1} \\
\mathrm{MnO}^{2} \\
\mathrm{Na}_{2} \mathrm{O} \\
\mathrm{K}_{2} \mathrm{O}\end{array}$ & $\begin{array}{l}.36 \\
.54 \\
.00 \\
.00 \\
.30\end{array}$ & $\begin{array}{l}.30 \\
.02 \\
.00 \\
.00 \\
1.4\end{array}$ & $\begin{array}{r}.28 \\
.02 \\
.00 \\
.00 \\
1.0\end{array}$ & $\begin{array}{l}.34 \\
.02 \\
.00 \\
.00 \\
1.3\end{array}$ & $\begin{array}{l}.24 \\
.06 \\
.00 \\
.00 \\
1.3\end{array}$ & $\begin{array}{l}.22 \\
.05 \\
.00 \\
.00 \\
4.7\end{array}$ & $\begin{array}{l}.26 \\
.03 \\
.00 \\
.00 \\
1.3\end{array}$ & $\begin{array}{l}.19 \\
.03 \\
.00 \\
.00 \\
.95\end{array}$ \\
\hline $\begin{array}{l}\mathrm{TiO}_{2} \\
\mathrm{P}_{2} \mathrm{O}_{5} \\
\mathrm{H}_{2} \mathrm{O}(-) \\
\mathrm{H}_{2} \mathrm{O}(+) \\
\mathrm{CO}_{2}\end{array}$ & $\begin{array}{l}.00 \\
.10 \\
.15 \\
.95 \\
.02\end{array}$ & $\begin{array}{c}.20 \\
.02 \\
.47 \\
1.2 \\
.02\end{array}$ & $\begin{array}{l}.16 \\
.04 \\
.70 \\
1.0 \\
.02\end{array}$ & $\begin{array}{c}.22 \\
.04 \\
.27 \\
1.6 \\
.02\end{array}$ & $\begin{array}{c}.34 \\
.26 \\
.18 \\
1.7 \\
.02\end{array}$ & $\begin{array}{c}.21 \\
.16 \\
.13 \\
1.3 \\
.02\end{array}$ & $\begin{array}{c}.20 \\
.04 \\
.33 \\
1.4 \\
.03\end{array}$ & $\begin{array}{c}.25 \\
.07 \\
.35 \\
1.3 \\
.03\end{array}$ \\
\hline $\begin{array}{l}\mathrm{S}(\text { total })^{1^{*}} \\
\mathrm{C}(\text { organic })\end{array}$ & N.A. & N.A. & $\begin{array}{l}.01 \\
.28 \\
\end{array}$ & $\begin{array}{l}.01 \\
.35 \\
\end{array}$ & $\begin{array}{c}6.18^{*} \\
.43 \\
\end{array}$ & $\begin{array}{l}.53 \\
\text { N.A. }\end{array}$ & N.A. & $\begin{array}{r}1.50 \\
.40 \\
\end{array}$ \\
\hline Total & 99.4 & 99.2 & 99.8 & 100.4 & 100.9 & 101.1 & 99.4 & 100.5 \\
\hline
\end{tabular}

\begin{tabular}{|c|c|c|c|c|c|c|c|c|}
\hline \multicolumn{9}{|c|}{ Spectrographic analyses } \\
\hline $\begin{array}{l}\mathrm{Ag} \\
\mathrm{As}^{1} \\
\mathrm{Au}^{2} \\
\mathrm{~B}\end{array}$ & $\begin{array}{c}1 \\
100 \\
<.03 \\
20 \\
4,900\end{array}$ & $\begin{array}{l}280 \\
50 \\
50 \\
165\end{array}$ & $\begin{array}{l}3 \\
370 \\
30 \\
205\end{array}$ & $\begin{array}{l}1.5 \\
235 \\
<.03 \\
70 \\
172\end{array}$ & $\begin{array}{l}240 \\
\quad .6 \\
<1 \\
510\end{array}$ & $\begin{array}{c}0.7 \\
400 \\
2.5 \\
7 \\
405\end{array}$ & $\begin{array}{c}<0.7 \\
185 \\
30 \\
30 \\
255\end{array}$ & $\begin{array}{c}1.5 \\
40 \\
4.5 \\
30 \\
240\end{array}$ \\
\hline $\begin{array}{l}\mathrm{Be} \\
\mathrm{Co} \\
\mathrm{Cr} \\
\mathrm{Cu} \\
\mathrm{Ga}\end{array}$ & $\begin{array}{l}<1 \\
<2 \\
10 \\
20 \\
<2\end{array}$ & $\begin{array}{l}1.5 \\
2 \\
30 \\
30 \\
7\end{array}$ & $\begin{array}{r}1.5 \\
3 \\
20 \\
20 \\
3\end{array}$ & $\begin{array}{l}1.5 \\
5 \\
30 \\
30 \\
10\end{array}$ & $\begin{array}{r}<1 \\
<2 \\
100 \\
7 \\
10\end{array}$ & $\begin{array}{r}1.5 \\
5 \\
20 \\
100 \\
3\end{array}$ & $\begin{array}{r}<1 \\
3 \\
30 \\
30 \\
10\end{array}$ & $\begin{array}{r}<1 \\
<2 \\
50 \\
10 \\
3\end{array}$ \\
\hline $\begin{array}{l}\mathrm{Hg}^{3} \\
\mathrm{In} \\
\mathrm{Mn} \\
\mathrm{Mo} \\
\mathrm{Ni}\end{array}$ & $\begin{array}{r}6 \\
<2 \\
3 \\
<2 \\
10\end{array}$ & $\begin{array}{l}<2^{.04} \\
15 \\
<2 \\
20\end{array}$ & $\begin{array}{l}14 \\
<2 \\
10 \\
<2 \\
30\end{array}$ & $\begin{array}{r}7 \\
<2 \\
50 \\
<2 \\
30\end{array}$ & $\begin{array}{r}13 \\
<2 \\
2 \\
15 \\
10\end{array}$ & $\begin{array}{r}10 \\
<2 \\
7 \\
20 \\
30\end{array}$ & $\begin{array}{r}11 \\
<2 \\
500 \\
7 \\
20\end{array}$ & $\begin{array}{l}28 \\
<2 \\
10 \\
<2 \\
<7\end{array}$ \\
\hline $\begin{array}{l}\mathrm{Pb} \\
\mathrm{Sb}^{1} \\
\mathrm{Sc}\end{array}$ & $\begin{array}{r}<7 \\
55 \\
<1 \\
30 \\
200\end{array}$ & $\begin{array}{r}10 \\
330 \\
5 \\
10 \\
1,500\end{array}$ & $\begin{array}{r}15 \\
435 \\
<1 \\
10 \\
1,000\end{array}$ & $\begin{array}{r}30 \\
365 \\
5 \\
10 \\
1,500\end{array}$ & $\begin{array}{r}30 \\
930 \\
7 \\
200 \\
3,000\end{array}$ & $\begin{array}{r}10 \\
500 \\
3 \\
50 \\
2,000\end{array}$ & $\begin{array}{r}20 \\
245 \\
5 \\
15 \\
1,500\end{array}$ & $\begin{array}{r}<7 \\
540 \\
<1 \\
50 \\
2,000\end{array}$ \\
\hline $\begin{array}{l}\mathrm{V} \\
\mathrm{Y} \\
\mathrm{Yb} \\
\mathrm{Zn}^{1}\end{array}$ & $\begin{array}{r}50 \\
15 \\
1 \\
15 \\
10\end{array}$ & $\begin{array}{r}500 \\
10 \\
2 \\
93 \\
70\end{array}$ & $\begin{array}{r}300 \\
30 \\
3 \\
161 \\
70\end{array}$ & $\begin{array}{r}700 \\
30 \\
3 \\
120 \\
50\end{array}$ & $\begin{array}{r}200 \\
15 \\
2 \\
52 \\
150\end{array}$ & $\begin{array}{c}150 \\
15 \\
1.5 \\
66 \\
150\end{array}$ & $\begin{array}{r}700 \\
15 \\
3 \\
145 \\
50\end{array}$ & $\begin{array}{c}100 \\
10 \\
1.5 \\
28 \\
200\end{array}$ \\
\hline
\end{tabular}

Sample 1. Composite sample from several hand specimens of massive craggy lenses and seams of black hyd rothermal silica. Location: mine coordinates $22.100 \mathrm{~N}$ 19.450 E.: 6.560 bench, south wall, Main pit.

2. Composite sample from several hand specimens of greenish-oray jasperoid. Location: mine coordinates 21 .

3. Composite sample from 10 small chips of reddish-brown jasperoid in which original bedding laminations were visible. Iocation: mine coordinate $21.890 \mathrm{~N}, 15.910 \mathrm{E} \cdot 6,540$ bench

4. Composite sample from 8 to 12 small chips of dark-gray-black dense massive jasperoid in which original bedding laminations were not visible Location: mine coordinates $21,885 \mathrm{~N} .15,915 \mathrm{E}: \mathrm{i}, 540$ bench, south wall. West pit.

5. Compositeordinates 21,885 N., 15,915 E.; 6,540 bench, south wall. West pit. red and moderate-reveral hand specimens of dense fine-grained moderateinations and 21.430 N., 17.630 E.: 6.460 bench, southwest wall. Main pit.
6. Hand specimen of greenish-brown and dark-gray jasperoid in which original bedding aminations were visible. Location: mine coordinates 21.410 N., 17,532 E.; 6.460 bench. southwest wall. Main pit.

7. Hand specimen of dense fine-grained moderate-red jasperoid in which original bedding laminations were visible. Location: mine coordinates 21.380 N.. 17.045 E.; 6.460 bench, southwest wall Main pit.

8. Hand specimen of may-black vuggy jasperoid breccia. Coarse grains of stibnite and weissbergite. which occur in open space in the breccia. were amitted from the samples analyzed. Location: mine coordinates 23.850 N., 22.700 E.: 6.350 bench. East pit.

$\mathrm{X}$-ray fluorescence analysis.

2 Fire-assay and atomic-absorption analyses.

${ }^{3}$ Leico mercury-vapor analysis. 


\section{CARBONACEOUS ALTERATION}

Data from analyses of several hundred samples of mineralized carbonate rocks show that these rocks are significantly richer in organic carbon than the fresh unmineralized rocks. The average organic carbon content in normal gold ore of about 0.5 to 0.6 weight percent, in contrast to only 0.2 to 0.4 weight percent in the host rocks, indicates that small amounts of carbonaceous materials, probably hydrocarbons, were introduced throughout the zones of mineralization. This introduction evidently took place during the main hydrothermal stage because the normal ore lacks any late overprint of hydrothermal sulfides and carbonaceous materials. The introduction of large amounts of hydrocarbons during the late hydrothermal stage after gold mineralization agrees with the poor correlation between the contents of total gold and organic carbon in bulk samples of unoxidized ores rich in carbonaceous materials. The close spatial association between concentrations of organic material and arsenic sulfide minerals in the arsenical ores, known to have formed late in the hydrothermal sequence, is further evidence for a late- stage influx of organic material. Figure 29 illustrates the total time range for the carbonaceous alteration.

High concentrations of carbonaceous materials occur locally within gold-bearing carbonate rocks along the East ore zone, in the "garbage can" area, and in deeper parts of the Main ore zone below the south side of Popovich Hill (pl. 5). The physical and chemical characteristics of this carbonaceous ore were described above in the section entitled "Primary Unoxidized Ores." Figure 34 shows a typical zone rich in carbonaceous materials and including both mineralized and unmineralized rocks, in the "garbage can" area near the southwest end of the East ore zone.

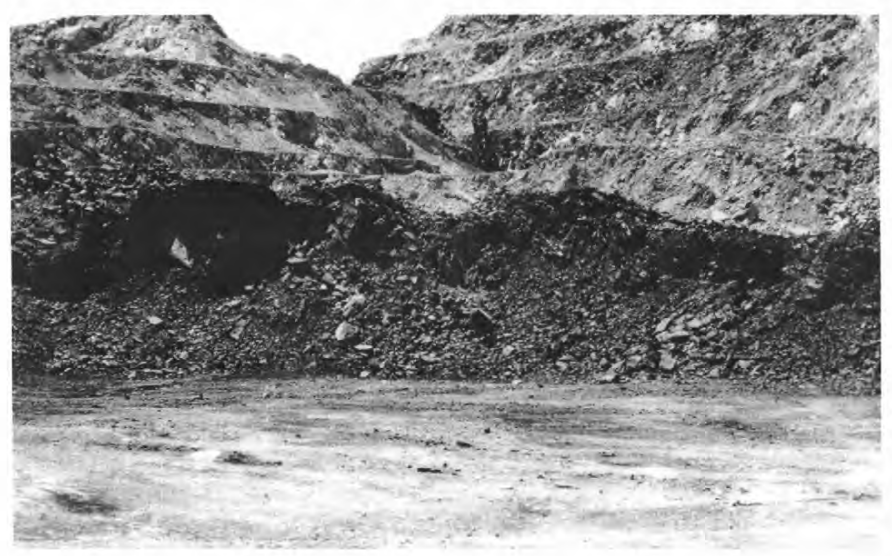

FIGURE 34.-Enriched zone of carbonaceous materials in mineralized dolomite of the Roberts Mountains Formation in "garbage can" area near southwest end of East ore zone. Unoxidized ores in this area include both carbonaceous and arsenical types. View southwestward.
Organic carbon compounds were also flushed through shattered zones and along prominent faults by the hydrothermal fluids and subsequently concentrated within and along these faults, both above and lateral to zones of gold deposition (pl. 5). Rocks of this alteration type are well exposed in the northwestern part of the Main pit, where hydrocarbon compounds(?) were concentrated along the Hardie fault and flooded through fractured shale units of the upper plate (fig. 35). Similar features along the Leeville fault at the east end of the East pit are visible in figure 8.

Spatial relations and petrographic data suggest that part, perhaps all, of the carbonaceous materials concentrated near prominent faults away from the ore bodies were also introduced during the late hydrothermal stage and were superimposed on the potassic- argillic hydrothermal alteration. Although large amounts of carbonaceous materials were introduced during the late hydrothermal stage and concentrated locally in the ore and along faults, a larger total amount may have been introduced during the main stage because of the much larger volumes of rock altered.

The introduction of hydrocarbon compounds and probably of several other varieties of carbonaceous materials with the hydrothermal fluids, and their apparent stability under the conditions of ore deposition, also allow setting some upper limit to the temperatures of ore deposition. Considering the composition and stabilities of the organic carbon compounds in the rocks, these temperatures were evidently below $250^{\circ}$ and probably even below $200^{\circ} \mathrm{C}$ (B. I. Scheiner, oral. commun., 1977).

\section{LATE HYDROTHERMAL STAGE}

Field relations and petrographic data indicate that formation of the barite veins, some of the sparse quartz veinlets, the jasperoid bodies, and most of the sulfide minerals (except pyrite), and the strong carbonaceous alteration, occurred relatively late in the hydrothermal period. These features represent a continuum of hydrothermal processes and not an episode distinct from the main hydrothermal stage.

Hydrothermal alteration probably reached the late stage in some parts of the deposit while the main stage was still in progress elsewhere. The solutions probably boiled throughout an indeterminate vertical zone; condensation and acid leaching occurred above this zone, while potassic-argillic hydrothermal alteration proceeded below. Any of the barite veins formed during the late hydrothermal stage may have resulted from interaction between $\mathrm{SO}_{4}{ }^{2-}$ formed in the acid-leached zone with $\mathrm{Ba}^{2+}$ in the hydrothermal fluids. The barite veins are discussed in the section entitled "Hydrothermal Acid- Leaching Alteration" and in subsequent sections of this report. 


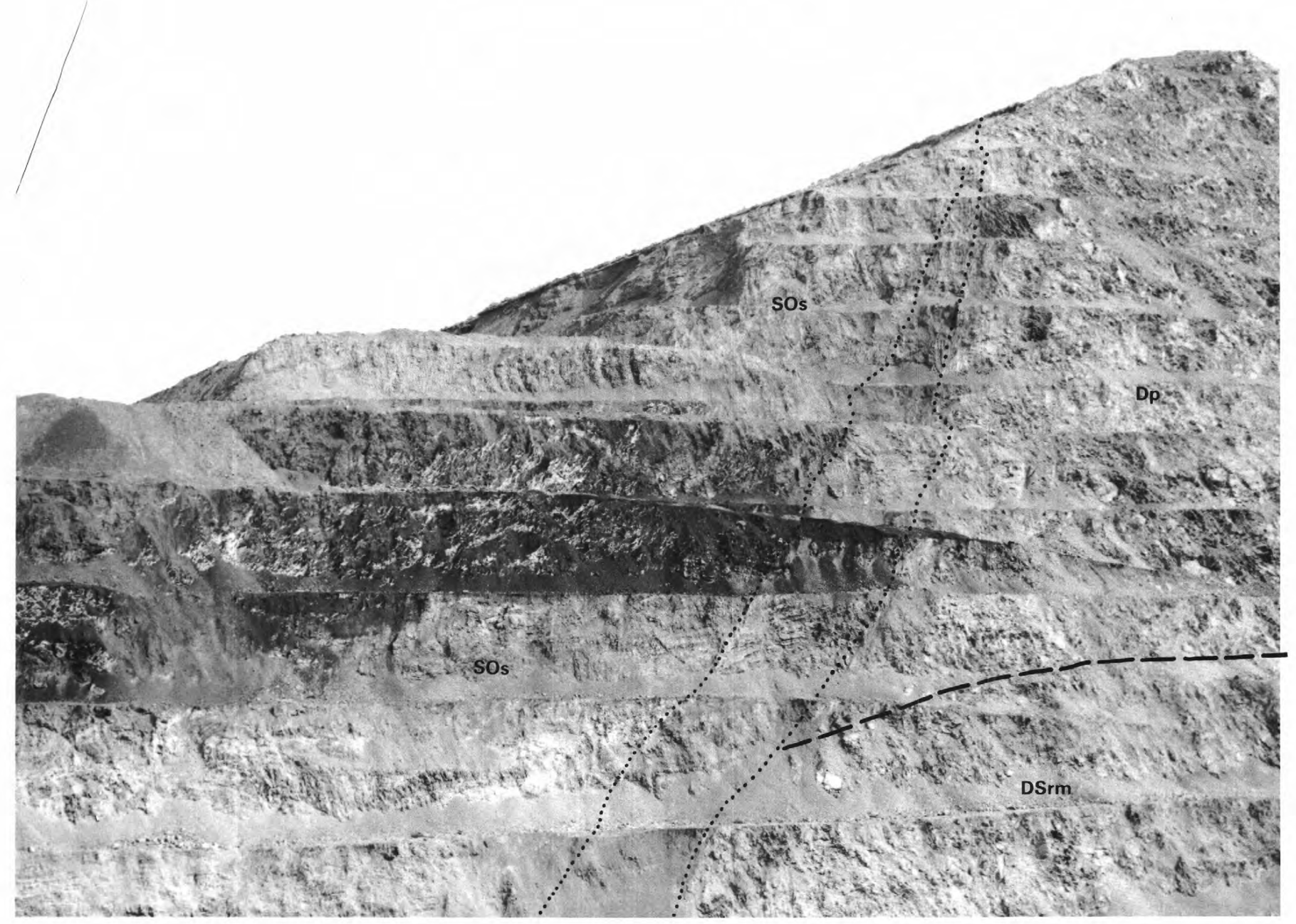

FIGURE 35.-Carbonaceous alteration in shale of upper plate ( $\mathrm{SOs}$ ) along southwest side of Popovich Hill in Main pit. Dotted lines mark strands of Hardie fault; dashed line denotes approximate position of contact between the Popovich Formation (Dp) and the Roberts Mountains Formation (DSrm). Zone of organic carbon enrichment crosses fault and extends in to the Popovich and, thus, postdates latest movement on fault. Lighter area, structurally controlled acid-leaching lateration; darker areas, siliceous alteration.

\section{SULFIDE MINERALIZATION}

\section{ARSENIC, MERCURY, ANTIMONY, AND THALLIUM}

With the exception of pyrite, most of the sulfide minerals formed relatively late in the hydrothermal episode and probably postdate the bulk of the gold mineralization. Small amounts of arsenic, mercury, antimony, and thallium were transported and deposited simultaneously with the gold. The formation of both sulfide and sulfosalt minerals containing these metals late in the paragenesis (as shown by their localization in open spaces and in veinlets cutting mineralized rocks) and their presence in late barite veins suggest that the hydrothermal fluids became enriched in these elements over time and possibly underwent an accompanying shift of $\mathrm{pH}$ into the neutral-to-alkaline range.
The rare thallium mineral carlinite $\left(\mathrm{Tl}_{2} \mathrm{~S}\right)$ has been recognized only in carbonaceous silicified rocks of the East ore zone; these rocks commonly contain as much as 6.0 weight percent of organic carbon in the form of mixtures of hydrocarbons and humic acids (Radtke and Dickson, 1975a). The intimate intergrowths of carlinite grains and hydrothermal quartz with the carbonaceous materials suggest that all these constituents are genetically related and probably were introduced simultaneously.

\section{BASE METALS}

The base-metal suite of elements, including copper, molybdenum, lead, and zinc, is not spatially associated with the gold suite, and sulfosalt minerals containing base metals are very rare. Although the contents of lead, zinc, 
and, locally, copper are large relative to those of antimony, mercury, and thallium, the significantly smaller enrichment factors for copper, lead, and zinc in the mineralized rocks suggest that the amounts of base metals transported in the ore fluids were also probably smaller. Base metals transported in early- and main-stage fluids may have been flushed out through the system or deposited at depths below the zone of gold mineralization.

The position of the base-metal sulfides in the paragenesis has not been conclusively established from the available data. The presence of local concentrations of galena and sphalerite in barite veins suggests that basemetal minerals elsewhere may have been formed during the late hydrothermal stage. This conclusion is reinforced by the small correlations between the base-metal elements and those of the gold-arsenic-mercury-antimony suite, and by the generally random scattering of basemetal sulfides throughout both mineralized and unmineralized areas in the deposit.

\section{QUARTZ VEINLETS}

Quartz veinlets are very sparse in the Carlin deposit and are not a common feature in Carlin-type deposits in general (Radtke and Dickson, 1974a). At Carlin these veinlets occur: (1) in small seams and patches containing pyrite and gold in unoxidized ores; (2) with and without such minerals as pyrite, gold, frankdicksonite, and fluorite in the upper parts of unoxidized ore bodies, in overlying oxidized ores and rocks, and along contacts between carbonate rocks and igneous dikes (pl. 3; Radtke, 1973); (3) in small fractures in jasperoid bodies; and (4) intergrown with barite with and without base-metal sulfide minerals in acid-leached and oxidized zones.

The quartz veinlets formed throughout the main and late hydrothermal stages and during acid leaching; small seams of remobilized quartz may also have formed during late supergene oxidation. Seams, patches, and veinlets of quartz containing pyrite and gold in unoxidized ores but lacking fluid-inclusion evidence of boiling formed during the main hydrothermal stage. Quartz veinlets containing frankdicksonite and pyrite probably formed somewhat later, during the late hydrothermal stage or early acid leaching. Many of the quartz veinlets, including those containing barite and sulfide minerals, as well as those filling fractures in jasperoid bodies, formed during acid leaching. Stable-isotope and fluid-inclusion data on the various phases of quartz formation are presented below in the section entitled "Fluid-Inclusion and Stable-Isotope Studies."

\section{OXIDIZED ORES}

Data available in 1965 indicated that the Carlin deposit contained about 7 million $t$ of oxidized gold ores. The total tonnage is probably in excess of 15 to 20 million t. Oxidized gold ores are here defined as those in which the condition and amount of carbonaceous materials have been changed by natural oxidation processes that rendered them incapable of either reacting with gold complexes or inhibiting the extraction of gold by cyanidation. The content of organic carbon is lower in the oxidized than in most of the unoxidized ores; the total content, however, varies greatly between individual samples and commonly ranges from about 0.03 to 0.35 weight percent.

The oxidized ores include those subjected to varying intensities of hydrothermal acid-leaching and later superimposed alterations by descending oxygen-bearing supergene solutions, as well as those ores commonly localized below the acid-leached zone that were affected only by the late descending supergene solutions. These lower ores commonly are only weakly oxidized and contain significant amounts of remnant organic carbon capable of adsorbing gold complexes.

Large volumes of ores and enclosing host rocks in the West, Main, and East ore zones were subjected to leaching and oxidation induced by acids (probably predominantly $\mathrm{H}_{2} \mathrm{SO}_{4}$ ) generated in the shallow near-surface environment as a consequence of boiling of the hydrothermal fluids or mixing of the fluids with ground water. The distributions of acid-leached zones and of the various intensities of leaching (weak, moderate, and intense) are shown on the acid-leaching-alteration map (pl. 6).

All the oxidized ores are composed mainly of widely varying amounts of fine-grained quartz, clay (mainly illite and lesser amounts of kaolinite, sericite, and montmorillonite), and dolomite. The content of calcite is lower in the oxidized than in the unoxidized ores and varies inversely with the intensity of acid leaching. Small amounts of barite, anhydrite, alunite, and various secondary iron oxides accessory minerals. Hausen and Kerr (1968) gave excellent descriptions of the mineralogy, textures, and physical features of the oxidized ores. Figure 36 shows typical specimens of oxidized ores, including both leached and unleached varieties.

Oxidized ores that were not acid leached or only weakly acid leached have many chemical and mineralogic features that closely resemble those of the normal gold ore. These oxidized ores commonly are medium tan, gray, or greenish gray and contain slightly less calcite and more silica than their unoxidized equivalents. Small amounts of montmorillonite were formed locally, most of the sulfides are partially oxidized, and the content of organic carbon is as low as about 0.15 to 0.25 weight percent. Figure 37 shows photomicrographs and scanning electron micrographs of typical mineralogic and textural features of the unleached oxidized ores.

The extremely wide ranges in the contents of principal minerals in the ores subjected to hydrothermal acid leaching before supergene oxidation reflect large variations in 


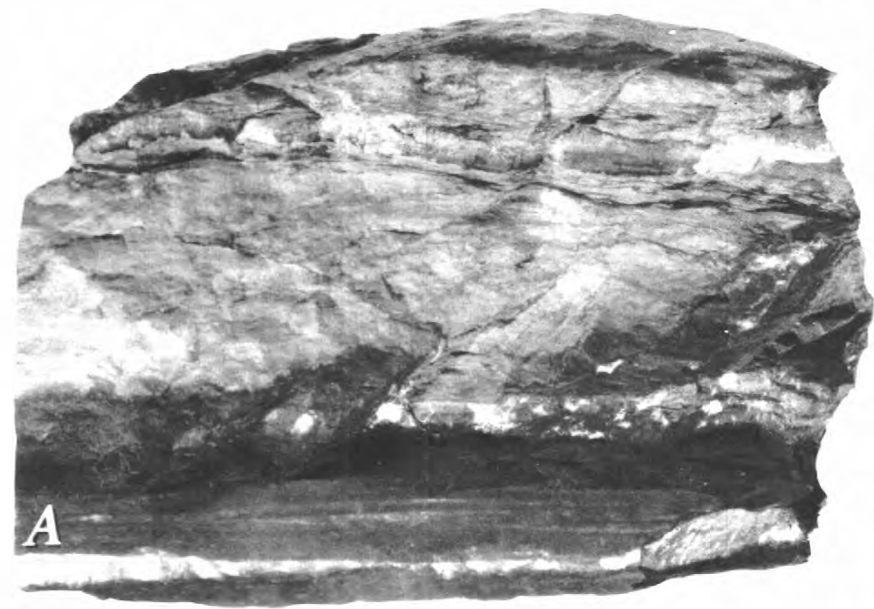

$4 \mathrm{~cm}$

Figure 36.-Specimens of oxidized gold ore. $A$. Progressive oxidation of arsenical-carbonaceous gold ore. Dark-gray-black zone along lower part of specimen contains heavy remnant concentrations of hydrocarbons. White seams in carbonaceous zone are mainly barite and realgar. $B$. Unleached oxidized high-grade zebra-type gold ore. Remnant bedding is well preserved. Dark lenticular area is sandy zone containing concentrations of iron oxides. $C$, Acid-leached oxidized gold ore composed mainly of clay and fine-grained quartz. Dark area near bottom is remnant zone of dense hydrothermal silica.
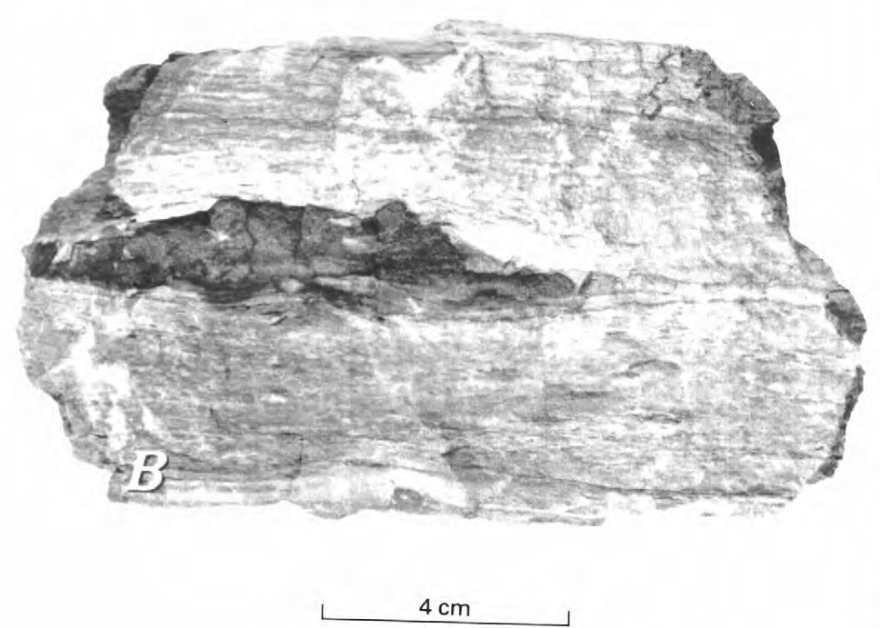

Figure 36.-Continued

the intensity of acid leaching. These ores range in color from white through tan to medium gray. The mineralogy ranges from weakly acid leached ore containing quartz, significant amounts of remnant dolomite and lesser calcite, illite, sericite, and minor kaolinite, to intensely acid leached ore composed of quartz, kaolinite, illite, lesser sericite, only minor amounts of dolomite, and little, if any, calcite. Sulfide minerals in the intensely acid leached ore have been oxidized, and the content of organic carbon is

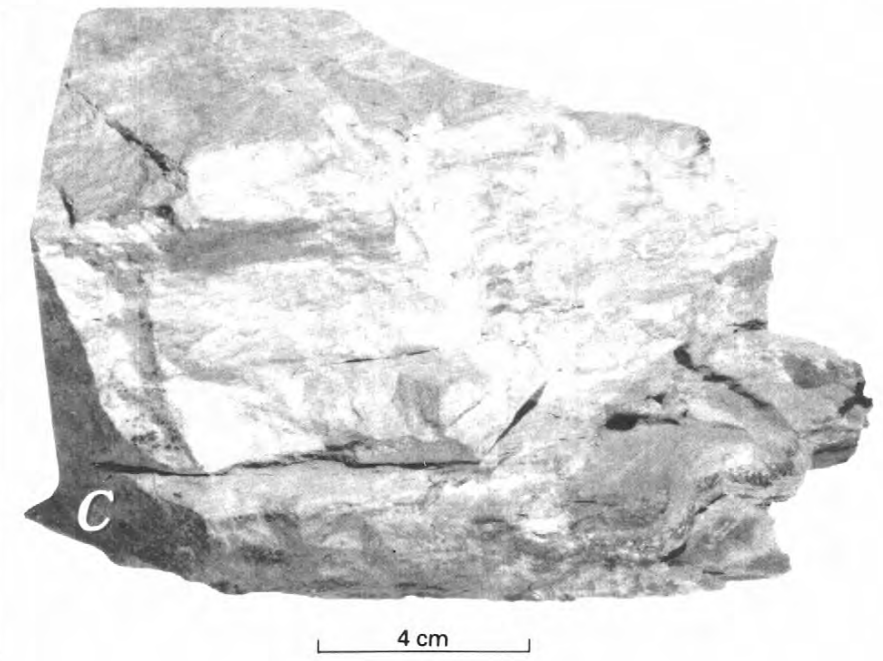

FigURE 36.-Continued.

as low as 0.03 to 0.15 weight percent. Photomicrographs and scanning electron micrographs showing typical textural and mineralogic features of the moderately and strongly acid leached oxidized ores are presented in figures 38 and 39 .

\section{MINERALOGY AND DISTRIBUTION OF ELEMENTS IN OXIDIZED ORES}

Data on the contents of major and minor elements in oxidized ores were previously reported by Radtke and others (1972a), and data on selected elements in oxidized ores were presented in the preceding section of this report. Table 22 lists chemical and spectrographic analyses of typical samples of the oxidized ores, including both acid- leached and unleached varieties. No statistical studies on element distributions and correlations in the oxidized ores have been performed to date.

\section{IRON}

Most of the iron in the oxidized ores is in the form of iron oxides, including hematite, goethite, and amorphous or poorly crystalline phases, formed by the oxidation of pyrite. Iron oxides occur throughout the matrix of the ores and commonly appear to be concentrated in thin seams parallel to remnant bedding. The partial in-place alteration of pyrite to iron oxide phases is a common feature in oxidized ores that have not been moderately or intensely acid leached. In grains where this alteration is complete, goethite or hematite pseudomorphs after either cubic or framboidal pyrite are common. Microprobe analyses show that occasional pyrite grains in the normal gold ore have thin layers $(1-2 \mu \mathrm{m})$ of iron oxide as a surface coating. This surface oxidation is recognizable in scanning electron micrographs; the oxidized layer generally is somewhat 


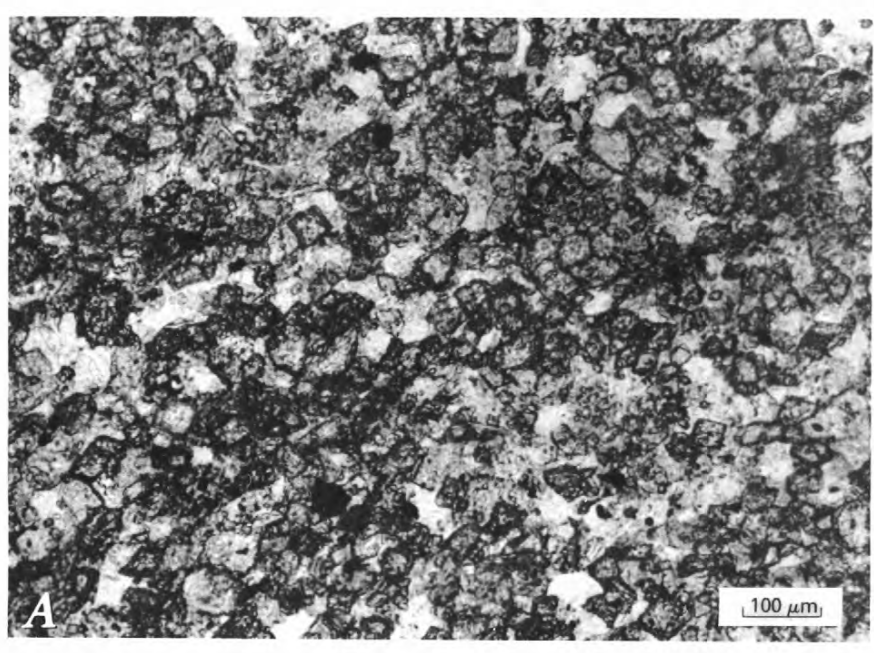

FIGURE 37.-Specimens of possibly weakly acid-leached oxidized ore. $A$, Characteristic petrographic features in thin section of sample of weakly acid-leached(?) oxidized ore. Remnant dolomite rhombs are well preserved, and pyrite grains are altered to irregular clumps of iron oxides (black areas). Gold in sample occurs in association with iron oxides and as fine metallic particles not visible at scale of photomicrograph. $B$, Scanning electron micrograph of sample of possibly weakly acid leached oxidized ore composed mainly of abundant slightly corroded dolomite rhombs and rounded sand (quartz) grains. Matrix consists mainly of clay, hydrothermal quartz, and minor remnant calcite. Note increased porosity due to dissolution of calcite. $C$. Enlargement of central area of figure $37 \mathrm{~B}$, showing overgrowths of hydrothermal clay and fine-grained quartz on surfaces of dolomite rhombs. Increased porosity is also clearly shown.

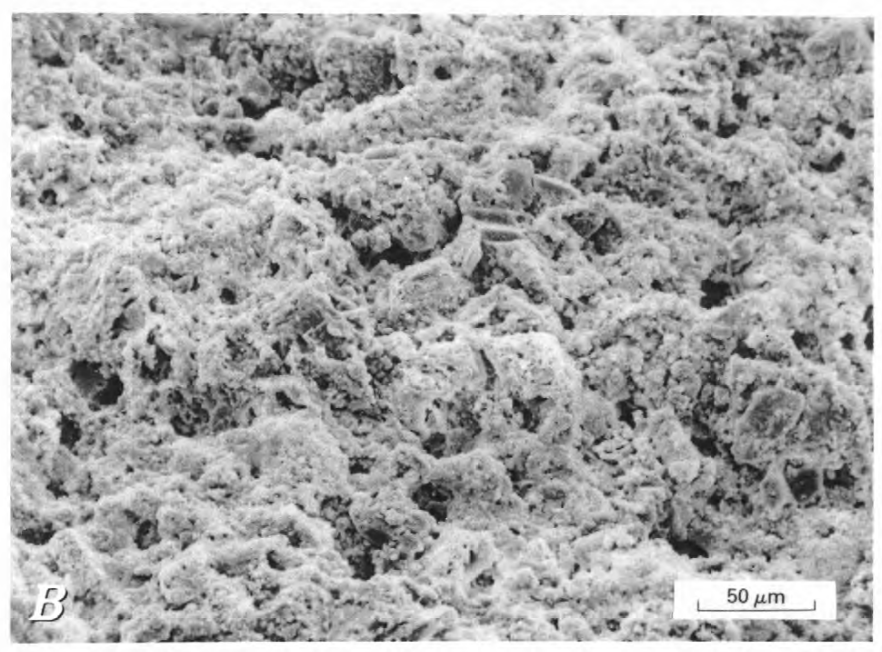

Figure 37.-Continued

thicker than the coating of gold-arsenic-mercury-antimony minerals.

Iron oxide minerals containing arsenic, such as scorodite, are discussed below in the subsection entitled "Arse-

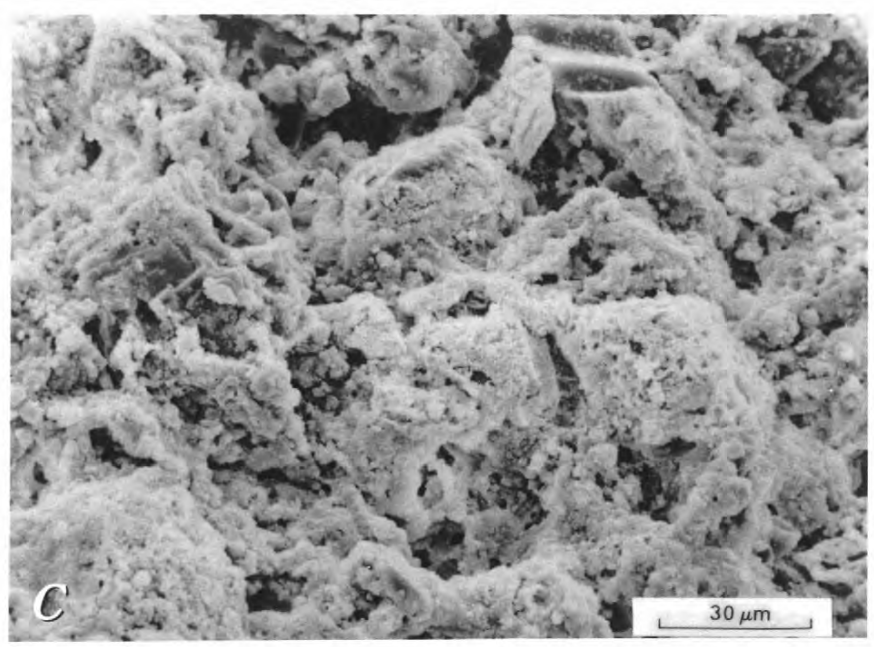

Figure 37.-Continued

nic." Clay minerals, probably illite or montmorillonite, in the oxidized ores commonly contain as much as 3 to 4 weight percent $\mathrm{Fe}$.

\section{GOLD}

The average content of gold in oxidized ores in the West, Main, and East ore zones resembles that in the deeper unoxidized ores; these values are 9.1, 9.0, and 8.0 ppm for the West, Main, and East ore zones, respectively. The gold content in 485 samples from oxidized ore bodies over the entire deposit ranges from 0.04 to $150 \mathrm{ppm}$ and averages 9 ppm.

Gold in oxidized ores has been identified in several occurrences and associations (Radtke and others, 1972b; A. S. Radtke, unpub. data, 1973): (1) as fine particles of metallic gold in seams and patches of silica, (2) concentrated on and near the borders of pyrite grains altered to iron oxides, (3) dispersed through iron-oxide-rich patches in the matrix of the rock, (4) associated with clay minerals in the matrix, and (5) as randomly dispersed particles. These randomly dispersed particles commonly are extremely fine (less than $0.5-3 \mu \mathrm{m}$ ). In areas containing remnant amorphous carbon, these particles of gold may contain as much as 10 to 15 weight percent $\mathrm{Hg}$, probably formed by the oxidation of gold-mercury-organic compounds.

Free grains of metallic gold in oxidized ores generally contain only very small amounts of other elements. Microprobe analyses show that small amounts of arsenic, antimony, mercury, and iron occasionally occur in the gold but that the total content of these elements in any association does not exceed about 1 percent by weight and generally is much less.

Patches of iron oxides, presumably formed by the oxidation of pyrite, contain anomalous amounts of gold, as 


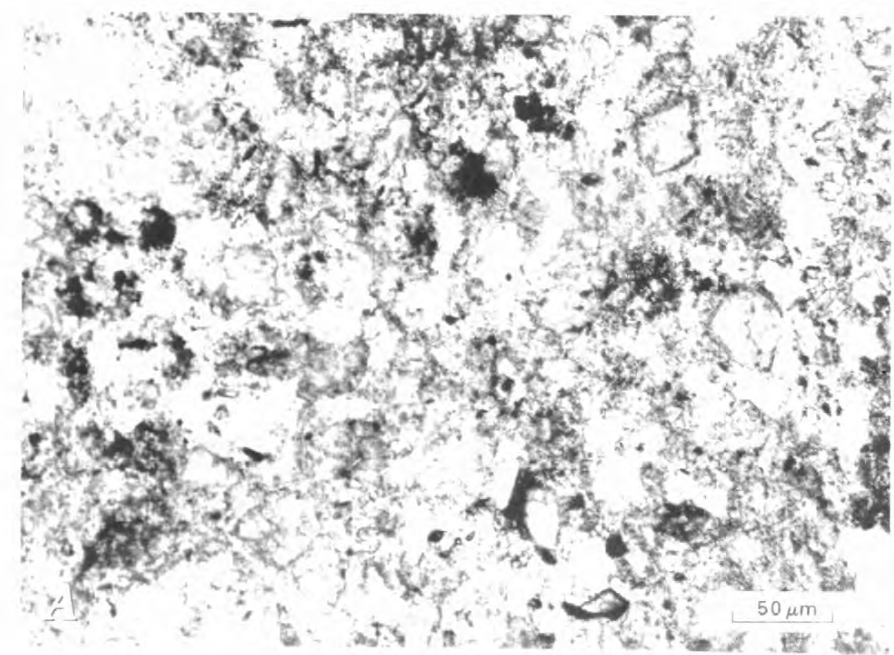

Figure 38.-Specimens of moderately acid-leached oxidized ore. $A$. Characteristic petrographic features in thin section. Most dolomite rhombs are heavily corroded. Iron oxides (black areas) formed by oxidation of pyrite are scattered throughout matrix. Porosity has been increased by removal of calcite. $B$, Scanning electron micrograph showing extensively corroded dolomite rhombs (dark gray) and rounded sand (quartz) grains in matrix of clay and fine-grained hydrothermal quartz. Light-gray pseudorhombohedral grains with concretionlike surfaces in lower left corner are gypsum crystals. All calcite was removed from matrix during acid leaching. C. Enlargement of lower central area of figure $38 B$, showing textural relations between corroded dolomite rhombs (dark gray) and pseudorhombohedral concretionlike or cauliflower-shaped aggregates of gypsum (light gray). Note small corroded remnant dolomite rhomb enclosed in gypsum crystal in upper left corner. Most clay on surfaces of quartz and remnant dolomite, and in matrix, is kaolinite and sericite.

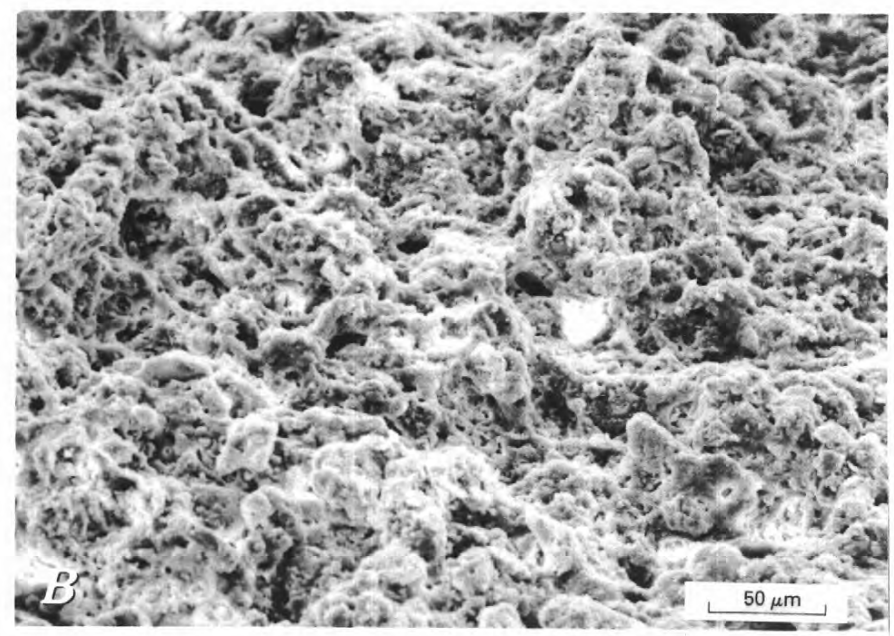

Figure 38.-Continued.

well as arsenic, antimony, and mercury. Microprobe analyses show that the content of gold and associated elements varies widely across or throughout these patches. The form of the gold is unclear; at extremely high magnifi-

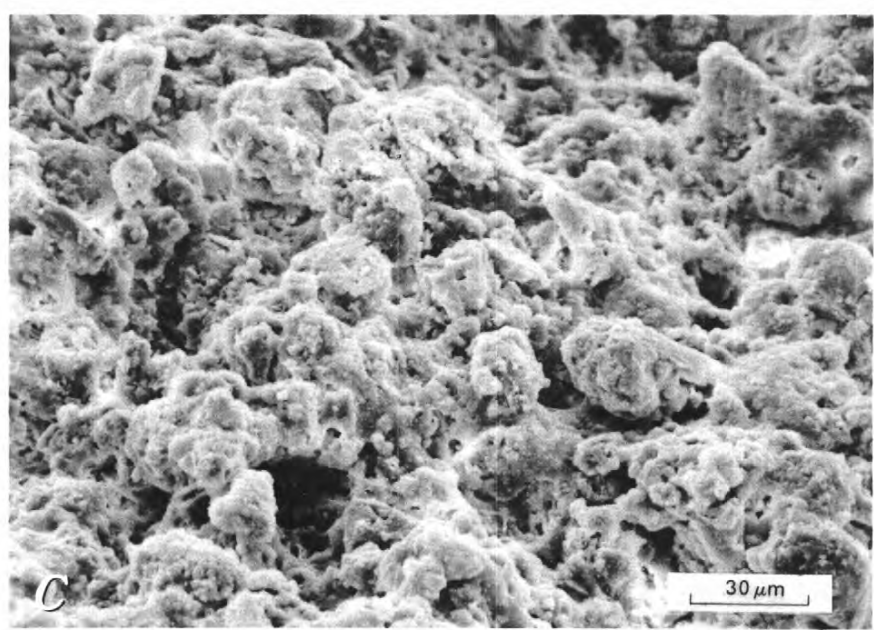

FIGURE 38.-Continued.

cation (greater than $1,000 \times$ ), discrete particles of metallic gold are recognizable, although the gold may also be adsorbed onto the iron oxides.

\section{MERCURY}

In contrast to gold, the average content of mercury is significantly lower in oxidized than in unoxidized ores of each of the principal ore zones. The average mercury content in oxidized ores is $20 \mathrm{ppm}$ in the West ore zone and $18 \mathrm{ppm}$ in both the Main and East ore zones. In 750 samples from throughout the entire deposit, the content of mercury ranges from 0.2 to $200 \mathrm{ppm}$ and averages $18 \mathrm{ppm}$.

Mercury has been identified in several forms in the oxidized ores. The element occurs: (1) in or adsorbed onto iron oxides formed by the oxidation of pyrite; (2) as sparse remnant grains of cinnabar coated by secondary schuetteite $\left(\mathrm{HgSO}_{4} \cdot 2 \mathrm{H}_{2} \mathrm{O}\right)$; (3) as a secondary mineral containing mercury, arsenic, and oxygen; and (4) in another phase containing mercury, traces of iron, and oxygen. Quantitative chemical analyses and X-ray diffraction data on forms 3 and 4 are unavailable. Preliminary data from microprobe analyses indicate that the composition of the secondary mineral is approximately $\mathrm{HgAsO}_{4}$.

Cinnabar is the only sulfide mineral identified that has survived oxidation in the moderately and intensely acidleached ores.

\section{ARSENIC}

Comparison of the data for arsenic in oxidized and unoxidized ores indicates that significant amounts of the element were removed from the ores during oxidation. Values for the average arsenic content in the oxidized ores include $180 \mathrm{ppm}$ in the West, $380 \mathrm{ppm}$ in the Main, and $450 \mathrm{ppm}$ in the East ore zone, in contrast to 222,490 , and $590 \mathrm{ppm}$ in unoxidized ores in the respective ore zones. Over the whole deposit the oxidized ores contain from 40 to more than $3,000 \mathrm{ppm}$ As and average $405 \mathrm{ppm}$ As. 


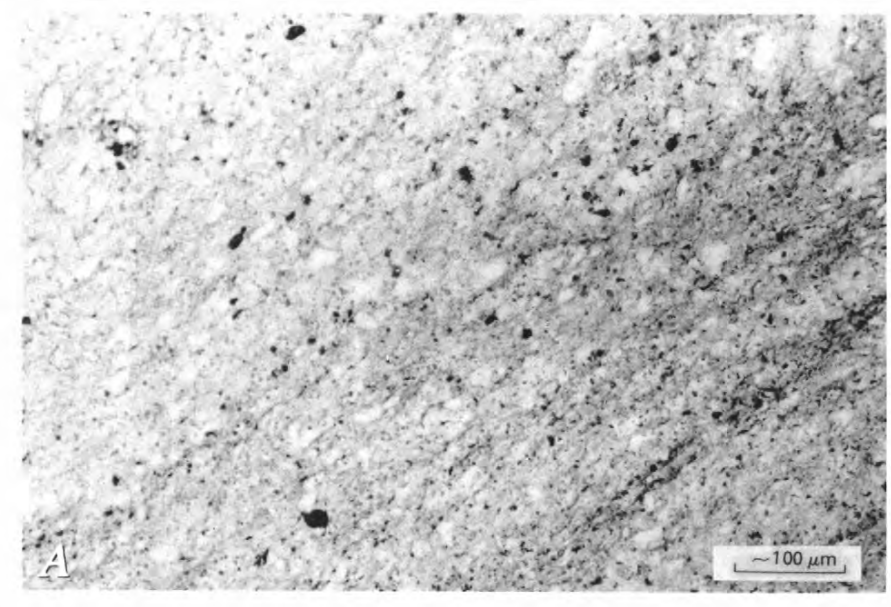

Figure 39.-Intensely acid-leached oxidized ore. $A$, Characteristic petrographic features in thin section. Rock is composed of angular detrital quartz (white), clay, and fine-grained hydrothermal quartz. Original texture is totally destroyed. Clumps of iron oxides after pyrite (black grains) are smeared throughout matrix. $B$. Scanning electron micrograph of intensely acid-leached oxi dized ore from which dolomite has been dissolved out or replaced by quartz. Rock is composed of poorly rounded to well-rounded detrital quartz grains, abundant irregular patches of late hydrothermal quartz, and clay minerals sericite and lesser kaolinite. Removal of all carbonate minerals and gypsum created highly porous rock. $C$, Enlargement of upper central area of figure $39 B$, showing effects of prolonged acid attack and oxidation. Pseudorhombohedral grains are silicified dolomite. Dog-biscuit-shaped area in upper left corner is hydrothermal quartz seam containing fine light-gray grains of metallic gold. Light-gray area across bottom contains sericite, kaolinite(?), and quartz.

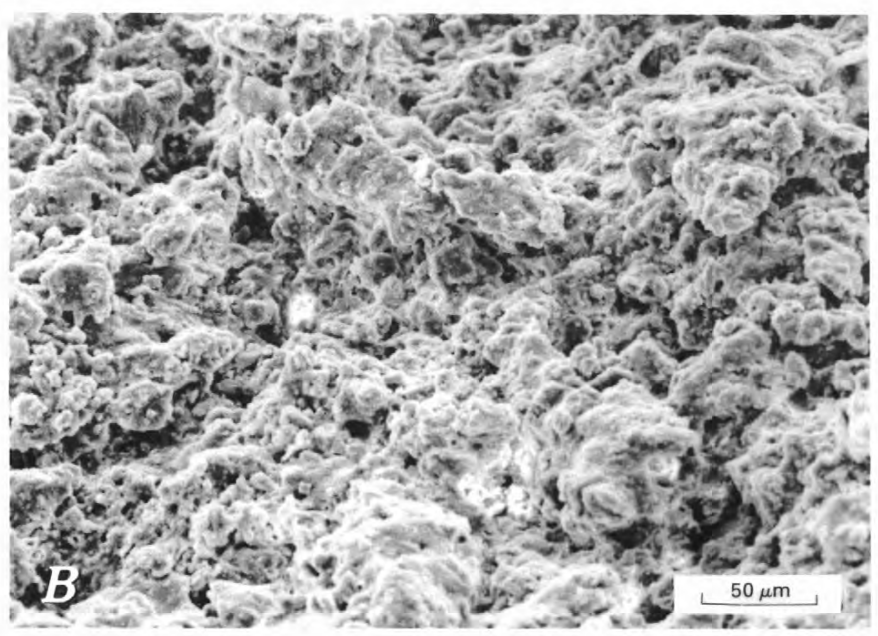

Figure 39.-Continued

In both oxidized and unoxidized ores, arsenic is the most abundant of the elements closely associated with gold. The element occurs in a wide variety of forms reflecting both the relatively large amounts of arsenic and the numerous arsenic minerals and compounds in the unoxidized ores. Most of the arsenic in oxidized ores occurs

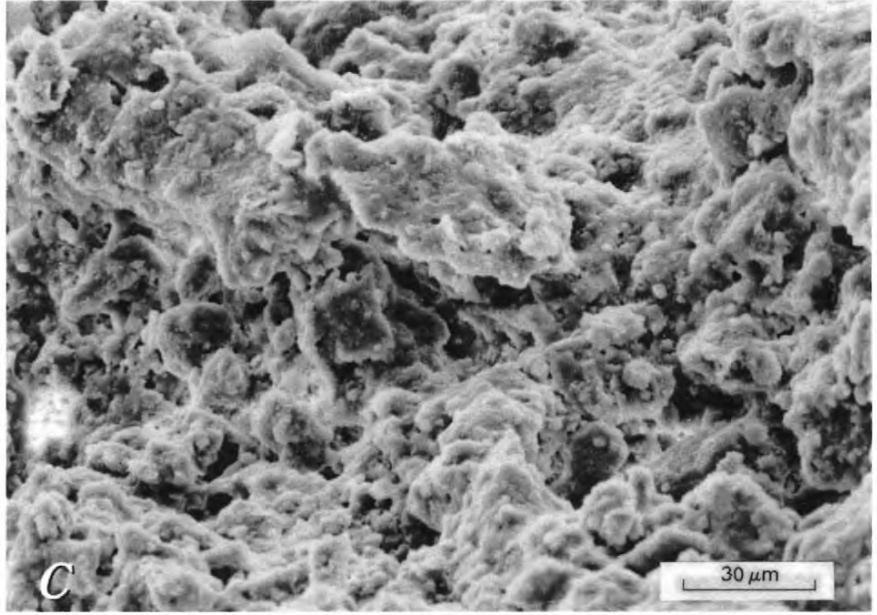

FIGURE 39.-Continued.

in varying abundances in iron oxides, including the amorphous iron oxide minerals formed by the oxidation of hydrothermal pyrite. Hausen and $\operatorname{Kerr}(1968$, p. 933) tentatively identified arsenolite $\left(\mathrm{As}_{2} \mathrm{O}_{3}\right)$, carminite $\left(\mathrm{PbFe}_{2}\left(\mathrm{AsO}_{4}\right)_{2}(\mathrm{OH})_{2}\right)$, and scorodite $\left(\mathrm{FeAsO}_{3} \cdot 2 \mathrm{H}_{2} \mathrm{O}\right)$. The presence of all these minerals has been confirmed by electron microprobe and X-ray diffraction methods. Other secondary minerals or phases identified include a hydrated(?) amorphous or poorly crystalline iron oxide phase containing as much as 7 weight percent As; hematite and goethite containing adsorbed arsenic; a hydrated(?) phase containing, calcium, arsenic, and oxygen; a hydrated(?) phase of composition $\mathrm{HgAsO}_{4}$; arseniosiderite $\left(\mathrm{Ca}_{3} \mathrm{Fe}_{4}\left(\mathrm{AsO}_{4}\right)_{4}(\mathrm{OH})_{6} \cdot 3 \mathrm{H}_{2} \mathrm{O}\right) ; \quad$ and mimetite $\left(\mathrm{Pb}_{5}\left(\mathrm{AsO}_{4}\right)_{3} \mathrm{Cl}\right)$.

Realgar in Carlin ores alters to arsenolite and an intermediate compound containing arsenic, sulfur, and oxygen; orpiment is not an alteration product of realgar in Carlin ores.

\section{ANTIMONY}

Oxidized ores in the West, Main, and East ore zones contain less antimony than their unoxidized counterparts. The average antimony content in oxidized ores is $45 \mathrm{ppm}$ in the West, 95 ppm in the Main, and 105 ppm in the East ore zone, in contrast to 222,490 , and $590 \mathrm{ppm}$ in unoxidized ores in the respective ore zones. The content of antimony in samples of oxidized ore from throughout the deposit ranges from less than 5 to $800 \mathrm{ppm}$ and averages $95 \mathrm{ppm}$.

Little information is available on the forms and occurrences of antimony in the oxidized ores. Small amounts (less than 0.08 weight percent $\mathrm{Sb}$ ) occur with arsenic in or adsorbed onto amorphous iron oxides, and scorodite commonly contains several tenths of a weight percent of 
TABLE 22. - Chemical and spectrographic analyses of unleached and acid-leached oxidized ores in the Carlin gold deposit.

IRapid rock analyses (Shapiro and Brannock, 1962) in weight percent; A nalysts: L. Artis, S. Botts, H. N. Elsheimer, B. P. Fabbi, and L. Mei. Spectrographic analyses in parts per million; N.A., not analyzed. Results are identified by geometric brackets whose boundaries are $1.2,0.83,0.56,0.38,0.26,0.18,0.12$, and so on, but are reported arbitrarily as the mid points of these brackets: $1,0,0.7,0.5,0.3,0.2,0.15,0.1$, and so on. The precision of a given value is approximately plus or minus one bracket at the 78-percent, or two brackets at the 95 -percent, confidence level. The following elements were below limits of detection in all samples (in ppm as indicated): $\mathrm{Ag}(0.7)$. $\mathrm{Be}(1)$. $\mathrm{Bi}(7)$. Cd (7). Ge(7). $\mathrm{Hf}(50)$. In (2). $\mathrm{Li}(100)$. $\mathrm{Pd}(1)$. $\mathrm{Pt}(10)$. Re (15), Sn (7), Ta (50), Te (300), Th (150), U (150). Analyst: Chris Heropoulos]

\begin{tabular}{|c|c|c|c|c|c|c|c|c|}
\hline \multirow[b]{2}{*}{ Sample } & \multicolumn{2}{|c|}{ Unleached } & \multicolumn{2}{|c|}{ Weakly acid-leached } & \multicolumn{2}{|c|}{ Moderately acid-leached } & \multicolumn{2}{|c|}{ Intensely acid-leached } \\
\hline & 1 & 2 & 3 & 4 & 5 & 6 & 7 & 8 \\
\hline \multicolumn{9}{|c|}{ Rapid rock analyses } \\
\hline $\begin{array}{l}\mathrm{SiO}_{2} \\
\mathrm{Al}_{2} \mathrm{O}_{3} \\
\mathrm{Fe}_{2} \mathrm{O}_{3} \\
\mathrm{FeO} \\
\mathrm{MgO}\end{array}$ & $\begin{array}{l}34.9 \\
6.7 \\
2.1 \\
.16 \\
6.7\end{array}$ & $\begin{array}{l}30.7 \\
5.7 \\
1.4 \\
.76 \\
9.3\end{array}$ & $\begin{array}{l}50.9 \\
5.5 \\
2.0 \\
.12 \\
4.9\end{array}$ & $\begin{array}{c}55.1 \\
10.2 \\
2.7 \\
.16 \\
5.9\end{array}$ & $\begin{array}{l}62.5 \\
8.6 \\
2.5 \\
.16 \\
5.3\end{array}$ & $\begin{array}{l}62.0 \\
9.0 \\
2.9 \\
.14 \\
4.9\end{array}$ & $\begin{array}{c}82.5 \\
9.0 \\
.52 \\
.20 \\
1.0\end{array}$ & $\begin{array}{c}72.4 \\
10.0 \\
6.6 \\
.16 \\
1.2\end{array}$ \\
\hline $\begin{array}{l}\mathrm{CaO} \\
\mathrm{BaO}^{1} \\
\mathrm{MnO} \\
\mathrm{Na}_{2} \mathrm{O} \\
\mathrm{K}_{2} \mathrm{O}\end{array}$ & $\begin{array}{c}20.8 \\
.04 \\
.00 \\
.00 \\
1.7\end{array}$ & $\begin{array}{r}21.4 \\
.02 \\
.04 \\
.49 \\
1.6\end{array}$ & $\begin{array}{l}15.6 \\
.02 \\
.03 \\
.20 \\
1.3\end{array}$ & $\begin{array}{l}7.6 \\
.04 \\
.00 \\
.00 \\
2.6\end{array}$ & $\begin{array}{l}5.9 \\
.03 \\
.00 \\
.00 \\
2.3\end{array}$ & $\begin{array}{l}6.0 \\
.03 \\
.00 \\
.02 \\
2.8\end{array}$ & $\begin{array}{l}.30 \\
.04 \\
.00 \\
.06 \\
2.4\end{array}$ & $\begin{array}{l}1.0 \\
.04 \\
.00 \\
.05 \\
3.1\end{array}$ \\
\hline $\begin{array}{l}\mathrm{TiO}_{2} \\
\mathrm{P}_{2} \mathrm{O}_{5} \\
\mathrm{H}_{2} \mathrm{O}(-) \\
\mathrm{H}_{2} \mathrm{O}(+) \\
\mathrm{CO}_{2}\end{array}$ & $\begin{array}{c}.37 \\
.16 \\
.65 \\
1.4 \\
23.4\end{array}$ & $\begin{array}{r}.23 \\
.07 \\
.19 \\
1.2 \\
26.7\end{array}$ & $\begin{array}{r}.23 \\
.12 \\
.24 \\
1.4 \\
16.9\end{array}$ & $\begin{aligned} .46 \\
.29 \\
.72 \\
2.2 \\
11.3\end{aligned}$ & $\begin{array}{l}.42 \\
.21 \\
.87 \\
2.0 \\
8.4\end{array}$ & $\begin{array}{l}.44 \\
.10 \\
.67 \\
2.3 \\
8.7\end{array}$ & $\begin{array}{l}.39 \\
.10 \\
.59 \\
2.3 \\
.02\end{array}$ & $\begin{array}{c}.40 \\
.18 \\
.95 \\
3.1 \\
.03\end{array}$ \\
\hline $\begin{array}{l}\mathrm{S}(\text { total })^{1} \\
\mathrm{C}(\text { organic }) \\
\mathrm{As}^{1}\end{array}$ & $\begin{array}{l}.02 \\
.01 \\
.07 \\
\end{array}$ & $\begin{array}{l}.67 \\
.14 \\
.01 \\
\end{array}$ & $\begin{array}{l}.50 \\
.24 \\
.15 \\
\end{array}$ & $\begin{array}{l}.03 \\
.11 \\
.06\end{array}$ & $\begin{array}{l}.05 \\
.18 \\
.09\end{array}$ & $\begin{array}{l}.13 \\
.15 \\
.15 \\
\end{array}$ & $\begin{array}{l}.08 \\
.06 \\
.02 \\
\end{array}$ & $\begin{array}{r}1.25 \\
.07 \\
.16 \\
\end{array}$ \\
\hline $\begin{array}{r}\text { Total } \\
\text { *Analyses } 3-8 \text { calculated as }\end{array}$ & 99.3 & 100.6 & 100.4 & 99.5 & 99.5 & 100.4 & 99.3 & 100.7 \\
\hline
\end{tabular}

\begin{tabular}{|c|c|c|c|c|c|c|c|c|}
\hline \multicolumn{9}{|c|}{ Spectrographic analyses } \\
\hline $\mathrm{As}^{1} \ldots \ldots$ & 740 & 148 & 1,450 & 640 & 860 & 1,470 & 220 & 1,580 \\
\hline $\mathrm{Au}^{2}$ & 9 & 5 & 50 & 30 & 16 & 75 & 23 & 100 \\
\hline B & 70 & 70 & 70 & 50 & 70 & 200 & 70 & 50 \\
\hline $\mathrm{Ba}$ & 200 & 170 & 180 & 400 & 285 & 150 & 430 & 380 \\
\hline $\mathrm{Ce}$ & $<70$ & $<70$ & $<70$ & $<70$ & 150 & 150 & $<70$ & $<70$ \\
\hline Co & $<2$ & 3 & 3 & 10 & 5 & 10 & 3 & 2 \\
\hline $\mathrm{Cr}$ & 70 & 50 & 50 & 100 & 70 & 100 & 70 & 70 \\
\hline $\mathrm{Cu}$ & 10 & 15 & 20 & 30 & 30 & 70 & 15 & 50 \\
\hline $\mathrm{Ga}$ & 15 & 7 & 10 & 10 & 20 & 20 & 15 & 15 \\
\hline $\mathrm{Hg}^{3}$ & 14 & 12 & 110 & 65 & 40 & 180 & 60 & 200 \\
\hline La & 50 & 50 & 70 & $<30$ & 50 & 30 & 30 & 50 \\
\hline Mn & 150 & 100 & 150 & 150 & 100 & 100 & 15 & 15 \\
\hline Mo & 3 & $<2$ & 5 & $<2$ & 7 & 7 & 3 & 10 \\
\hline $\mathrm{Nb}$ & $<7$ & $<7$ & $<7$ & $<7$ & $<7$ & 15 & $<7$ & 10 \\
\hline $\mathrm{Ni}$ & 15 & 30 & 20 & 50 & 50 & 100 & 7 & 20 \\
\hline $\mathrm{Pb}$ & $<7$ & $<7$ & 15 & $<7$ & 15 & 15 & 15 & 30 \\
\hline $\mathrm{Sb}^{14}$ & $<40$ & $<40$ & 129 & $<40$ & 182 & 135 & $<40$ & 800 \\
\hline $\mathrm{Sc}$ & 15 & 10 & 15 & 10 & 7 & 7 & 7 & 20 \\
\hline $\mathrm{Sr}$ & 500 & 500 & 100 & 70 & 100 & 150 & 100 & 100 \\
\hline $\mathrm{Ti}$ & 3,000 & 1,500 & 1,500 & 3,000 & 3,000 & 5,000 & 3,000 & 3,000 \\
\hline $\mathrm{Tl}$ & 100 & $<3$ & 50 & 5 & 70 & 30 & 10 & 50 \\
\hline 다. & 70 & 50 & 50 & 150 & 100 & 200 & 100 & 300 \\
\hline W & $<20$ & 20 & 30 & $<20$ & N.A. & N.A. & 20 & $<20$ \\
\hline Y & 30 & 20 & 30 & 10 & 20 & 20 & 15 & 20 \\
\hline $\mathrm{Yb}$ & 3 & 2 & 3 & 2 & 3 & 3 & 2 & 3 \\
\hline $\mathrm{Zn}{ }^{1}$ & 6 & $2 \overline{5}$ & 163 & 68 & 66 & 280 & 14 & 220 \\
\hline $\mathrm{Zr}$ & 150 & 100 & 200 & 150 & 200 & 300 & 200 & 200 \\
\hline
\end{tabular}

Sample 1. Hand specimen of massive greenish-tan average-grade ore. Location: 6.320 bench, East ore zone.

2. Hand specimen of thin-bedded light- to medium-gray low-grade ore. Location: 6.300 bench. Main ore zone

3. Hand specimen of blocky yellow ish-tan high-grade ore. Location: 6.340 bench Main ore zone.

4. Hand specimen of massive blocky reddish-tan high-grade ore. Location: 6.460 bench. West ore zone.

5. Hand specimen of massive tan moderate-grade ore containing gray zones rich in remnant organic carbon. Location: 6.380 bench. East ore zone

6. Hand specimen of blocky tan and gray "zebra striped" high-grade ore. Location: 6,360 bench. Main ore zone.

7. Hand specimen of thin-bedded light-gray moderate-grade ore. Location: 6,320

bench, East ore zone.
8. Hand specimen of massive light-yellowish-brown and gray "zebra-striped" high-grade ore. Location: 6,320 bench, Main ore zone.

${ }^{1} \mathrm{X}$-ray fluorescence analysis.

2Fire-assay and atomic-absorption analyses.

${ }^{3}$ Leico mercury-vapor analysis.

' Colorimetric analysis. 
antimony. Although the content of antimony is substantially less than that of arsenic, antimony-bearing analogs of some secondary arsenic minerals may exist in the ores.

Stibnite in Carlin ores, including a coarse-grained variety in jasperoid breccia, is partially oxidized to stibiconite $\left(\mathrm{Sb}_{3} \mathrm{O}_{6}(\mathrm{OH})\right)$, valentinite $\left(\mathrm{Sb}_{2} \mathrm{O}_{3}\right)$, and cervantite $\left(\mathrm{Sb}_{2} \mathrm{O}_{4}\right)$.

\section{THALLIUM}

Data on the thallium content in oxidized ores are very limited. Although several hundred samples were analyzed, in 220 of the analyses the limit of detection was $50 \mathrm{ppm} \mathrm{Tl}$; detectable amounts of the element (more than $50 \mathrm{ppm} \mathrm{Tl}$ ) were found in only about 10 percent of these samples. The content of thallium ranges from less than 50 to $150 \mathrm{ppm}$ and averages $50 \mathrm{ppm}$. Analyses of 85 samples at a detection limit of $3 \mathrm{ppm} \mathrm{Tl}$ show a thallium content ranging from less than 3 to $100 \mathrm{ppm}$ and averaging 20 ppm. These results, as well as the high solubility of most thallium compounds, suggest that the average content of the element in oxidized ores is considerably lower than in unoxidized ores (40-50 ppm).

Although thallium is closely associated with arsenic in the unoxidized ores, they are not so closely associated in the oxidized ores. Secondary arsenic or arsenic-bearing minerals seldom contain thallium in amounts (more than 0.05-0.06 weight percent) detectable by microprobe analysis. Thallium has been identified in dispersed finegrained secondary iron oxide minerals, but only below 0.1 weight percent.

Several secondary thallium minerals are present in the oxidized ores. Avicennite $\left(\mathrm{Tl}_{2} \mathrm{O}_{3}\right)$ occurs in intimate association with hematite (fig. 40) and probably represents the final oxidation product of carlinite (Radtke and others, 1978). Data on the oxidation of thallous sulfide (Lee, 1971) that would apply to the formation of secondary thallium minerals were summarized by Radtke and Dickson (1975a), who reported (p. 563):

$* * *$ the reactions that are most likely in the oxidation of carlinite under natural conditions are: first, $2 \mathrm{Tl}_{2} \mathrm{~S}+2 \mathrm{O}_{2} \rightarrow \mathrm{Tl}_{2} \mathrm{~S}_{2} \mathrm{O}_{3}+\mathrm{Tl}_{2} \mathrm{O}$; and second, $\mathrm{Tl}_{2} \mathrm{O}+\mathrm{O}_{2} \rightarrow \mathrm{Tl}_{2} \mathrm{O}_{3}$. Given sufficient time, under dry conditions the overall reaction would be: $2 \mathrm{Tl}_{2} \mathrm{~S}+3 \mathrm{O}_{2} \rightarrow \mathrm{Tl}_{2} \mathrm{~S}_{2} \mathrm{O}_{3}+\mathrm{Tl}_{2} \mathrm{O}_{3}$. With water present, thallous thiosulfate degrades according to the reaction: $\mathrm{Tl}_{2} \mathrm{~S}_{2} \mathrm{O}_{3}+$ $\mathrm{H}_{2} \mathrm{O} \rightarrow \mathrm{Tl}_{2} \mathrm{SO}_{4}+\mathrm{H}_{2} \mathrm{~S}$. Thallous sulfate, thiosulfate, and oxide are more soluble than $\mathrm{Tl}_{2} \mathrm{O}_{3}$; therefore in nature, where oxidation takes place in contact with aqueous solutions, they would tend to be leached, leaving $\mathrm{Tl}_{2} \mathrm{O}_{3}$.

Electron microprobe analyses and X-ray diffraction studies of weakly or partially oxidized ores containing large amounts of thallium show that carlinite alters to materials of different compositions, including $\mathrm{Tl}_{2} \mathrm{~S}_{2} \mathrm{O}_{3}, \mathrm{Tl}_{2} \mathrm{O}$, and $\mathrm{Tl}_{2} \mathrm{SO}_{4}$, in addition to avicennite (A. S. Radtke and $\mathrm{F}$. W. Dickson, unpub. data, 1975). These three thallous compounds represent intermediate phases formed by the oxidation of carlinite and have not been recognized previously as natural species.

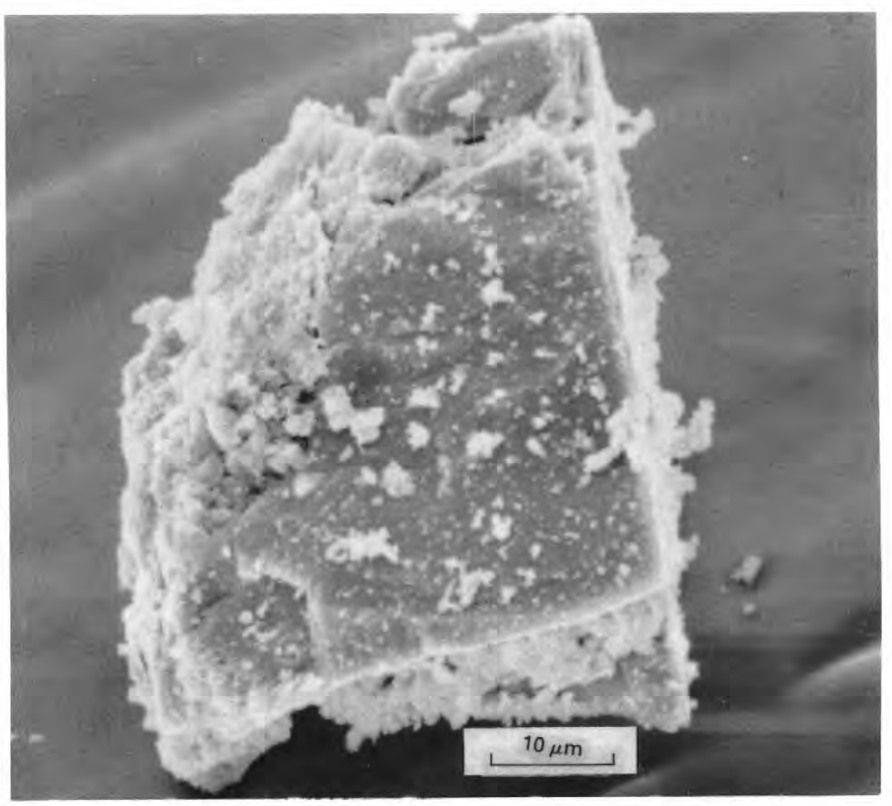

FIGURE 40.-Small crystal of avicennite $\left(\mathrm{Tl}_{2} \mathrm{O}_{3}\right)$ and fine-grained hematite on surface, from oxidized ore in East ore zone.

\section{LEAD}

The average lead content in oxidized ores is 25,30 , and $15 \mathrm{ppm}$ in the West, Main, and East ore zones, respectively, in contrast to 26,51 , and 20 ppm in unoxidized ores in the respective ore zones. Over the whole deposit the content of lead in oxidized ores ranges from less than 7 to $200 \mathrm{ppm}$ and averages $25 \mathrm{ppm}$.

Secondary lead minerals include carminite and litharge or massicot ( $\mathrm{PbO}$ ); anglesite, cerussite, and mimetite have been recognized as secondary minerals formed by the alteration of galena in barite veins.

\section{ZINC}

The content of zinc is significantly lower in the oxidized than in the unoxidized ores. In samples analyzed from throughout the deposit, the zinc content of oxidized ores ranges from 6 to $620 \mathrm{ppm}$ and averages $90 \mathrm{ppm}$, in contrast to average values of 165 to $185 \mathrm{ppm}$ in unoxidized ores (see subsection on zinc in section below entitled "Mineralogy and distribution ***"). The average zinc content in oxidized ores is $40 \mathrm{ppm}$ in the West, $95 \mathrm{ppm}$ in the Main, and 80 ppm in the East ore zone.

The form of the zinc in unoxidized ores has not been studied. Smithsonite $\left(\mathrm{ZnCO}_{3}\right)$, formed by the oxidation of sphalerite associated with barite veins, is the only secondary zinc mineral identified to date. 
SILVER

The average content of silver in oxidized ores is 0.7 ppm; in several hundred samples analyzed from throughout the deposit, the silver content ranges from less than 0.7 to $2 \mathrm{ppm}$. No secondary silver minerals have been identified, and silver has not been found in association with the fine particles of metallic gold analyzed on the electron microprobe.

\section{COPPER}

The content of copper in oxidized ores ranges from 3 to $200 \mathrm{ppm}$ and averages $22 \mathrm{ppm}$ over the entire deposit; the average copper content is 10,25 , and $20 \mathrm{ppm}$ in oxidized ores in the West, Main, and East ore zones, respectively. By comparison, the content of copper in unoxidized ores averages 33 to $35 \mathrm{ppm}$ over the entire deposit and 25, 36, and $33 \mathrm{ppm}$ in the West, Main, and East ore zones, respectively.

No secondary copper minerals have been recognized in the oxidized ores except for small sparse grains of cuprite, thin local films of malachite and azurite on silicified carbonate rocks, and phases associated with iron oxides along the sparse quartz veins in the "garbage can" area of the East ore zone.

\section{MOLYBDENUM AND TUNGSTEN}

The oxidized ores contain only very small amounts of molybdenum and tungsten. The average content of molybdenum is 3 ppm in oxidized ores in all three principal ore zones; tungsten values are $8 \mathrm{ppm}$ in the West and East and $12 \mathrm{ppm}$ in the Main ore zone.

No molybdenum minerals have been found in the oxidized ores. A few grains of scheelite $\left(\mathrm{CaWO}_{4}\right)$ have been identified in the oxidized ores, and most of the tungsten probably occurs in that form.

\section{BARIUM}

The content of barium is significantly higher in the oxidized than in the deeper unoxidized ores in the West, Main, and East ore zones. Average values for barium in the oxidized and unoxidized ores, respectively, include 1,600 and $650 \mathrm{ppm}$ in the West, 1,500 and $500 \mathrm{ppm}$ in the Main, and 1,100 and $300 \mathrm{ppm}$ in the East ore zone. The progressive increase in barium content throughout the deposit from east to west is the same in both the oxidized and unoxidized ores.

The enrichment of barium in oxidized ores and rocks reflects the generation of $\mathrm{SO}_{4}{ }^{2-}$ in the shallower parts of the deposit and the fixation of $\mathrm{Ba}^{2+}$ as barite throughout the zone of hydrothermal acid leaching. Within the oxidized zone, barite occurs both in veinlets and as dispersed fine-grained particles. No other barium minerals have been recognized in the oxidized ores.
BORON

The average content of boron in oxidized ores throughout the deposit is $75 \mathrm{ppm}$, and the content in individual samples analyzed ranges from 7 to $300 \mathrm{ppm}$. The average boron content in oxidized ores in the deposit is 50, 75, and $82 \mathrm{ppm}$ in the West, Main, and East ore zones, respectively. On the basis of averages of 54,85 , and $84 \mathrm{ppm}$ in unoxidized ores in the West, Main, and East ore zones, respectively (see subsection on boron in section below entitled "Mineralogy and Distribution ***"), boron content apparently changes little with oxidation.

Although boron was introduced from the hydrothermal fluids and could have been driven off during boiling, no evidence suggests that it was concentrated in upper parts of the deposit. Most of the boron apparently is associated with clay minerals, and the boron introduced during mineralization is present in sericite and kaolinite formed during that period. No discrete boron minerals, including borates, have been found.

\section{SELENIUM AND TELLURIUM}

The average contents of both selenium and tellurium are lower in oxidized than in unoxidized ores in each of the principal ore zones. Values for selenium in the oxidized and unoxidized ores, respectively, are 1.0 and $1.5 \mathrm{ppm}$ in the West, 0.4 and $0.9 \mathrm{ppm}$ in the Main, and 0.6 and 1.8 ppm in the East ore zone. Corresponding values for tellurium are less than 0.2 and $0.2 \mathrm{ppm}$ in the West, less than 0.2 and $0.4 \mathrm{ppm}$ in the Main, and less than 0.2 and $0.2 \mathrm{ppm}$ in the East ore zone. No minerals containing either selenium or tellurium have been found in the oxidized ores.

\section{HYDROTHERMAL ACID-LEACHING ALTERATION}

The ore bodies and many rocks in the upper part of the Carlin deposit have been attacked by acidic solutions generated by the oxidation of $\mathrm{H}_{2} \mathrm{~S}$ driven off by boiling of the hydrothermal fluids and mixing of the vapors with meteoric waters. Because the hydrothermal fluids undoubtedly contained large amounts of reduced-sulfur species and because barite and anhydrite were formed in the acid-leached zone, $\mathrm{H}_{2} \mathrm{SO}_{4}$ may have been the dominant acid responsible for the alteration. However, even the complete oxidation of all the diagenetic and hydrothermal pyrite would not produce enough $\mathrm{H}_{2} \mathrm{SO}_{4}$ to account for all the carbonate removed, and so most of the acid probably was formed by the oxidation of $\mathrm{H}_{2} \mathrm{~S}$.

The zone of acid leaching is about $75 \mathrm{~m}$ thick in most places, is irregular, and closely follows the present topography. This alteration is not confined to the Roberts Mountains Formation but has affected rocks of both the 


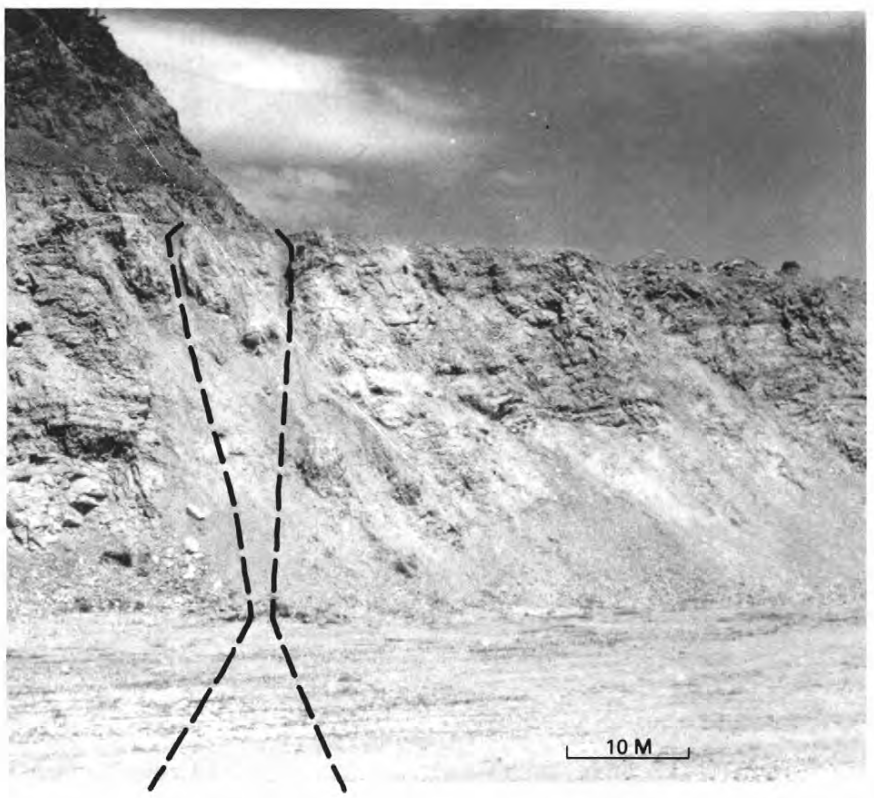

FIGURE 41.-Structurally controlled acid-leaching alteration in rocks of the Roberts Mountains Formation along northwest wall near southwest end of Main pit. Note that intensity of acid leaching decreases away from faults (dashed lines), as shown by color change from white intensely acid-leached, through light-gray moderately acid leached, to dark-gray weakly acid-leached rocks over a distance of about $50 \mathrm{~m}$.
Popovich Formation and the upper plate above and lateral to the Roberts Mountains Formation within about $75 \mathrm{~m}$ of the surface in and around the Carlin deposit (pl. 6).

The degrees of acid-leaching alteration may be classified as weak, moderate, or intense on the basis of the relative amounts of carbonate removed (pl. 6). Areas of intense acid leaching show a strong spatial relation to prominent high-angle normal faults and to the northwesttrending dike-filled faults representing major channels for the hydrothermal fluids (pl. 6). In many areas the acidic solutions were concentrated along these faults and soaked outward laterally into the shattered wallrocks; acid leaching is most intense near faults and weakens with increasing distance (fig. 41).

The intensity of alteration and the size and shape of the zones of intense acid leaching also depended on the volume of solutions that reacted with the rock. One flat-lying zone of intense acid leaching, as thick as $50 \mathrm{~m}$, cuts across the thick north- plunging sheetlike ore body in the Main ore zone. The host rocks and ores within that zone, removed during pit development (fig. 42), were bleached white, devoid of calcite, and contained fine-grained quartz, kaolinite, sericite, small amounts of alunite, and minor amounts of dolomite.

A significant amount of hydrothermal acid-leaching alteration took place in the Popovich Formation throughout
Popovich Hill (fig. 43). In most places the degree of acid leaching ranges from weak to moderate, and the positions of alteration zones and the areas of strongest acid leaching nearly coincide with those of faults, breccia, and shear zones (pl. 6).

\section{ALTERATION OF IGNEOUS ROCKS}

Most of the rocks in igneous dikes in the Carlin deposit have been altered. Both the type and intensity of alteration vary throughout the deposit and reflect differences in the composition and amount of the solutions that interacted with the rocks. Four processes in varying combinations have affected the dikes: (1) weak deuteric alteration, associated with emplacement; (2) hydrothermal mineralization; (3) acid leaching; and (4) late supergene oxidation.

The early deuteric alteration was apparently very weak. The freshest igneous rocks in the deposit, which have not been affected by hydrothermal acid leaching or late supergene oxidation, show the following features: (1) limited and local peripheral alteration of biotite to chlorite and of hornblende to epidote; (2) presence of minor amounts of hematite, goethite, limonite(?), and jarosite along fractures; (3) absence of argillic alteration; and (4) little, if any, sericite or carbonate minerals.

Changes in the igneous dikes probably caused by the hydrothermal fluids include: (1) alteration of feldspar minerals to clay minerals, principally kaolinite and montmorillonite; (2) formation of sericite, at least in part,

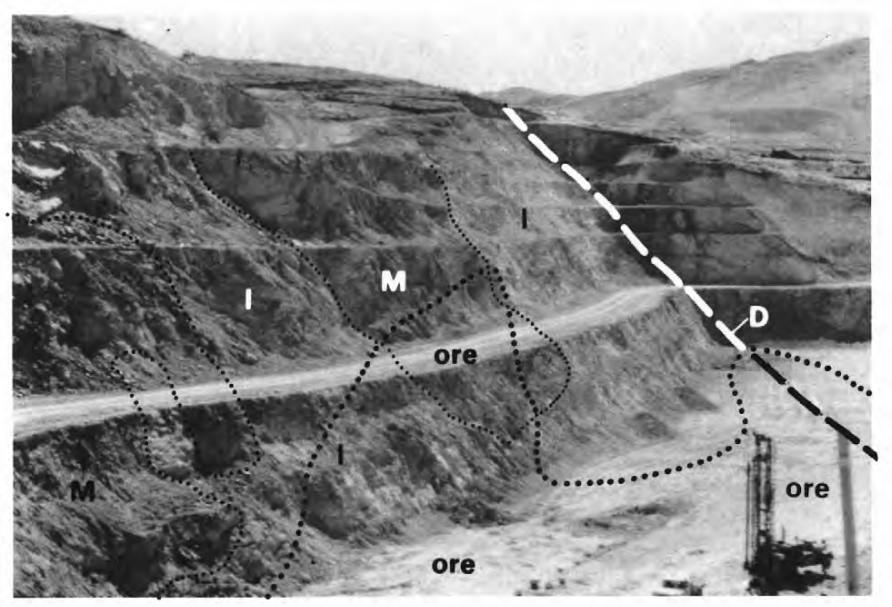

FIGURE 42.-Flat-lying blanketlike zone of acid-leaching alteration in Main pit. Intensely acid-leached light areas (I) separated (lines of small dots) by moderately acid-leached dark areas (M) form horizontal zone in carbonate rocks of the Roberts Mountains Formation above ore and cut across dipping shallow mineralized beds in Main ore zone. Base of acid-leached zone is below bottom of pit. Lines of large dots denote approximate boundaries of ore bodies. Prominent set of faults (D) containing igneous dike (exposed in far corner of pit) provided main channelways for hydrothermal solutions in this part of deposit. View southward. 


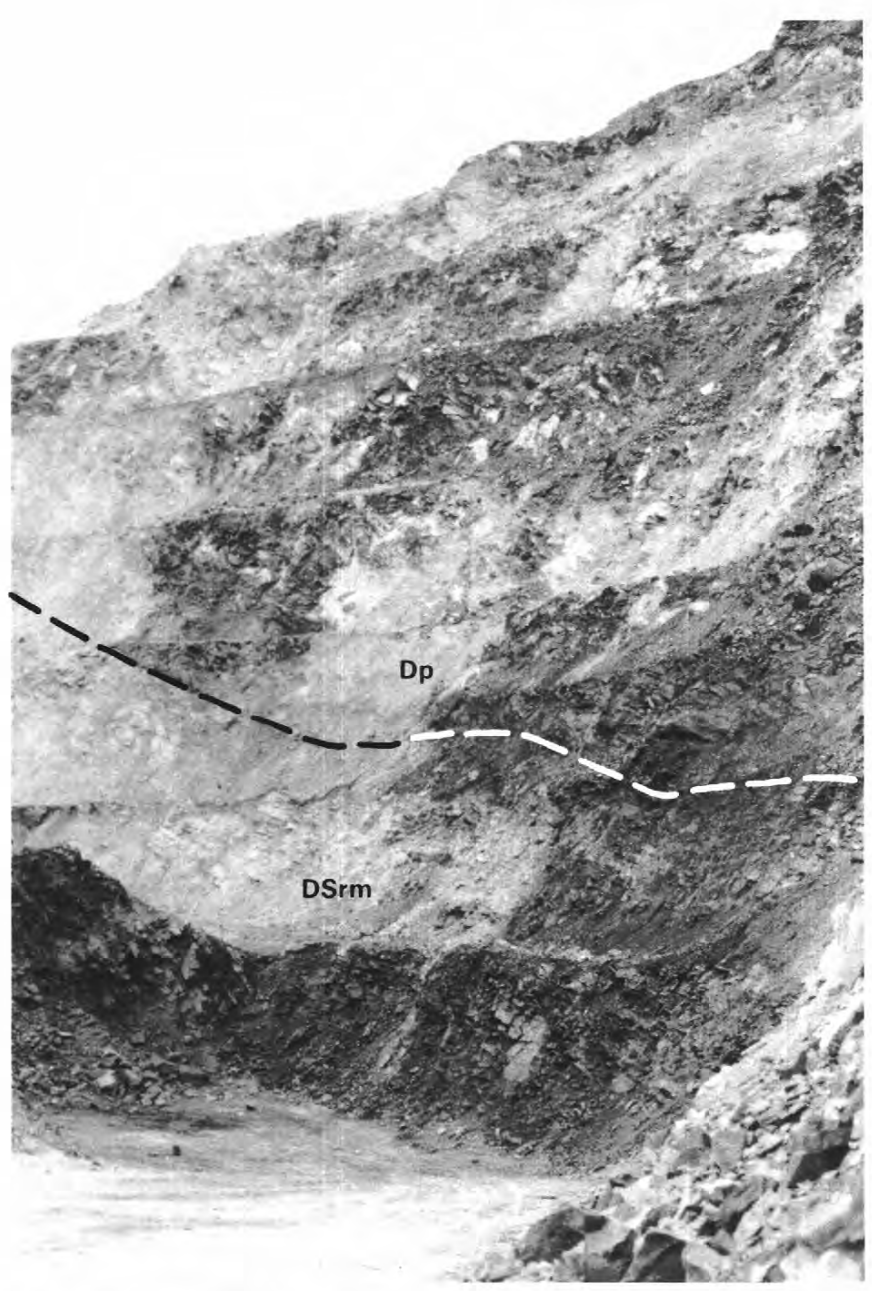

FiguRE 43.-Typical hydrothermal acid-leaching alteration (light areas) in rocks of the Popovich Formation (Dp) and in upper beds of the Roberts Mountains Formation (DSrm) along southeast side of Popovich Hill above East ore zone. Alteration is spatially controlled by faults, breccia, and shear zones. Acid-leached rocks in this part of deposit contain anomalous small amounts of gold, arsenic, mercury, and antimony.

by alteration of biotite; (3) introduction locally of hydrothermal pyrite, some of which contains coatings of gold and associated elements; (4) formation of small veinlets of microcrystalline quartz; and (5) replacement of both phenocrysts of plagioclase and potassium feldspar by microcrystalline quartz. In addition, some of the calcite that replaces hornblende and biotite phenocrysts may have been dissolved out of the carbonate rocks and introduced into the dikes during hydrothermal alteration.

Many of the alteration effects caused by the acid-leaching solutions were probably rather similar to those due to the hydrothermal solutions except for greater intensity. Larger amounts of clay minerals were formed, and so the intensely acid-leached igneous rocks are composed mainly of quartz, kaolinite, lesser sericite, montmorillonite, and, locally, dickite, as well as alunite jarosite, epidote, a color- less to pale- apple-green variety of chlorite, and iron oxide and hydroxide minerals.

Alteration effects caused by late supergene or meteoric waters are more difficult to establish precisely because they undoubtedly were much weaker than those due to hydrothermal mineralization and acid leaching, and were superimposed on igneous rocks varying widely in alteration mineralogy. Probably the principal effects were (1) formation of iron oxide and hydroxide minerals from oxidation of sulfides, mainly pyrite, and alteration of remnant biotite; and (2) introduction of calcite as small stringers and patches into the matrix, and replacing hornblende and corroding and replacing borders of biotite grains in rocks previously only weakly altered.

\section{CHEMICAL AND MINERALOGIC ASPECTS}

General features of the mineralogy of both the unleached and acid-leached ores were discussed above in the section entitled "Oxidized Ores." It should be emphasized that both the initial acid-leaching alteration in shallow zones, which took place simultaneously with the late hydrothermal stage at greater depths, and the late supergene oxidation affected large volumes of rock around the mineralized zones. The chemical and mineralogic changes that took place in both mineralized and unmineralized rocks by these two processes were nearly identical.

The observed mineralogic changes in the mineralized carbonate rocks, due to attack by oxidizing solutions during hydrothermal acid-leaching and supergene oxidation, are reflected in the chemical data summarized diagrammatically in figure 44 . The dissolution of large amounts of dolomite and of virtually all the calcite is shown in the large losses of $\mathrm{CaO}, \mathrm{MgO}$, and $\mathrm{CO}_{2}$. The decreases in $\mathrm{FeO}$ and $\mathrm{S}$ reflect the oxidation of pyrite. Comparison of the contents of all these components (except possibly $\mathrm{FeO}$ ) in the various kinds of carbonate rocks indicates that these chemical changes are attributable mainly to acid leaching. The relatively constant contents of $\mathrm{K}_{2} \mathrm{O}, \mathrm{Al}_{2} \mathrm{O}_{3}$, and $\mathrm{H}_{2} \mathrm{O}(+)$ confirm the fact that little additional potassic-argillic alteration took place during acid-leaching oxidation.

Only $\mathrm{BaO}$ and $\mathrm{SiO}_{2}$ show significant increases in abundance. The increase in $\mathrm{BaO}$ reflects the formation of barite, and the increase in $\mathrm{SiO}_{2}$ suggests that silica was introduced simultaneously. Petrographic evidence shows that many samples of the ores contain small seams and patches of late silica that appear to flood the rock locally and encase grains of oxidized pyrite and remnant dolomite rhombs.

The hydrothermal acid-leaching solutions were also oxidizing in nature and destroyed carbonaceous materials as well as pyrite and other sulfides. Data on the content of organic carbon in oxidized ores were discussed in earlier sections of this report and are not included in figure 44. 

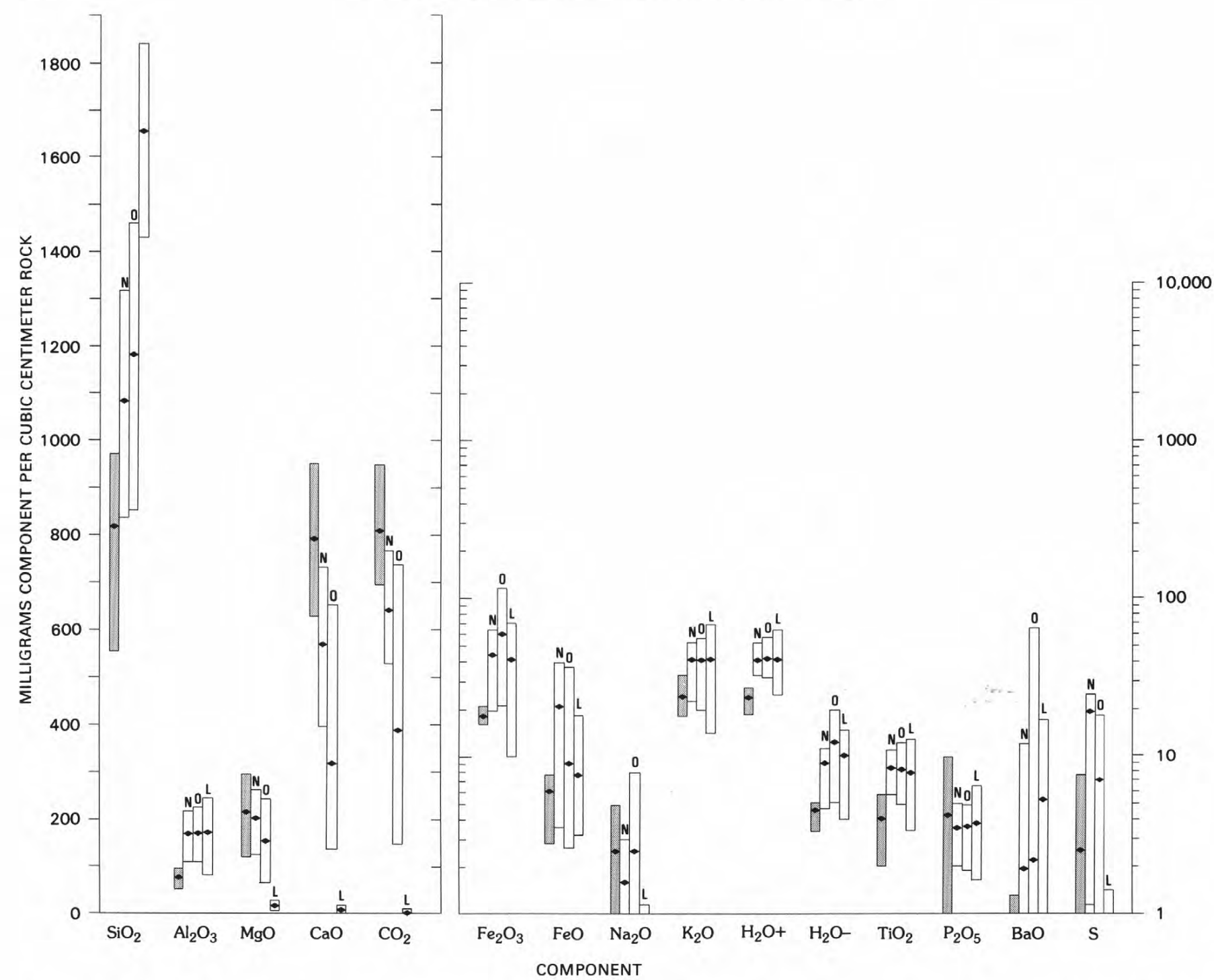

FIgURE 44.-Chemical changes in dolomitic carbonate rocks of the Roberts Mountains Formation during hydrothermal mineralization, acid leaching, and supergene oxidation. Bars show ranges and median values (black diamonds) in milligrams of component per cubic centimeter or rock (equal to weight percent of component times bulk specific gravity times 10). Shaded bars show composition of unmineralized host rocks, and open bars composition of normal gold ore $(\mathrm{N})$, unleached oxidized ore $(\mathrm{O})$, and acid-leached oxidized ore $(\mathrm{L})$.

\section{SILICIFICATION}

Although the earliest period of the acid-leaching alteration probably occurred simultaneously with the deeper late hydrothermal stage, the rocks in the shallow acidleached zone contain significantly more silica (fig. 44) than the unleached oxidized rocks. This result, as well as the petrographic data discussed above, suggests that more silica was introduced into the shallower parts of the deposit than into the intermediate levels below the zone of oxidation. It is unclear whether the silica was transported by the hydrothermal fluids or was produced by reactions between the acidic solutions and clay minerals (such as sericite) within the shallow zone. Even though these reac- tions probably took place in the upper shallow zone, no evidence exists of any peripheral area depleted in silica, as would be required for shallow mobilization and redeposition of $\mathrm{SiO}_{2}$.

The occurrence of large jasperoid bodies in the acidleached zone and their common pinchout or termination near the bottom of that zone also show that silica was concentrated locally in the shallower parts of the deposit along and close to voids represented by faults and breccia zones. The shape of these bodies and their near-surface position suggest that the barren ones, at least, probably formed from late-stage solutions supersaturated with quartz after the main hydrothermal stage. 


\section{BARITE VEINS}

Barite occurs locally in small pods and seams, and as narrow veins along fractures and faults, throughout the oxidized zone and the zone of acid leaching (pl. 6). The barite veins are widest and most persistent at intermediate depths in the acid- leached zone, narrow abruptly in oxidized rocks below the bottom of the zone, and appear to pinch out or terminate in the underlying unoxidized rocks. Concentrations of barite occur along the fault system and cut the altered igneous dike in the footwall of the West ore body. Prominent barite veins also occur along the northwest-trending dike-filled fault cutting through the Main pit, and along east-west-striking faults and fractures about $100 \mathrm{~m}$ southwest of Popovich Hill (pl.6). Minerals most commonly associated with barite are calcite and various silica phases, including both quartz and chalcedonic silica. Most of the barite veins are deficient in sulfides except at greater depths in areas just above and at the interface with the unoxidized zone. The most common sulfide minerals and their associations include sphalerite, sphalerite and galena, galena, and realgar; the base-metal sulfides and the realgar occur in different areas in the veins and are not spatially associated. Data on the isotopic compositions of barite and associated sulfides are given below in the section entitled "Fluid-Inclusion and Stable-Isotope Studies."

Most of the barite veins consist of rather pure $\mathrm{BaSO}_{4}$ and are deficient in most metals, including gold. Gold in detectable amounts was not found in 75 samples of barite analyzed from throughout the deposit. The mechanisms and reactions responsible for barite deposition in the acidleached and oxidized zone differed from those that deposited dispersed barite during the main and late hydrothermal stages, and the acid-leaching solutions were deficient in gold. Also, if the barium content of the hydrothermal solutions increased over time, the hydrothermal fluids that deposited the barite in veins must have contained significantly more barium than the main-stage fluids. Genesis of the barite veins is discussed below in the section entitled "Oxygen Isotope Data."

\section{CALGITE VEINS}

Calcite veins occur as open space fillings along faults, fractures, and breccia zones in three general vertical positions within the deposit: (1) in weakly acid-leached and unleached rocks at the top of and above the acid-leached zone, (2) in oxidized rocks below the acid-leached zone, and (3) in sparse amounts in deeper unoxidized ores. Calcite veins are extremely sparse within the zone of acid leaching.

Most of the calcite veins in form 1 are in rocks of the Popovich Formation and in the upper part of the Roberts Mountains Formation along the north side of the West pit, in the southwest end of the Main pit, and throughout the area of Popovich Hill (pl. 3). Bleaching of rocks on both sides of the calcite-filled fractures (fig. 45) suggests progressive, extensive acid leaching. This color change, however, is due to the oxidation of carbonaceous materials; the amount of calcite removed was minor, and the overall effects of acid leaching are very weak. Some of the calcite veins in form 1 probably formed during the late hydrothermal stage by the flushing out of calcite from deeper carbonate beds.

Calcite veins in oxidized rocks below the acid-leached zone occur both as white relatively clean $\mathrm{CaCO}_{3}$ and as small stringers admixed with barite, most of which are in the Roberts Mountains Formation within a 15-m interval below the bottom of the acid- leached zone. In most places the contact between the oxidized rocks and the underlying unoxidized rocks is gradational through a zone, ranging from 3 to $9 \mathrm{~m}$ in width, in which the volume of unoxidized rocks increases with depth as the oxidation effects diminish. Features characteristic of this zone include (1) pods of remnant unoxidized rocks enriched in hydrocarbons, and (2) sulfide minerals, especially realgar, sphalerite, and galena, associated with mixed barite-calcite veins (fig. 46).

Small amounts of white calcite occur with sulfide minerals, especially realgar and arsenic-rich sulfosalt minerals, in the upper parts of unoxidized ore bodies in the Main and East ore zones. These calcite veins undoubtedly formed simultaneously with the sulfide minerals and represent calcite removed from carbonate rocks in deeper zones by the hydrothermal ore fluids.

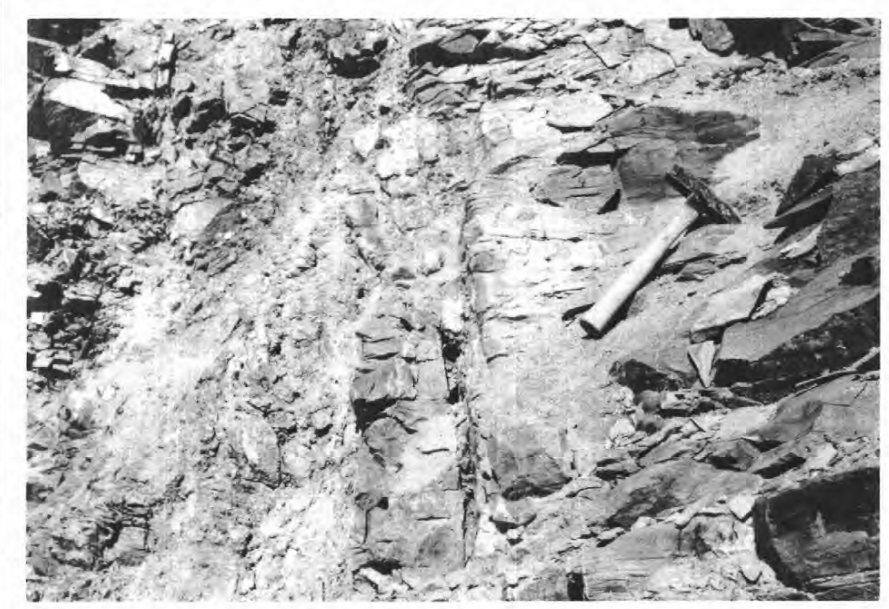

FIGURE 45.-Vein of calcite filling fracture in blocky limestone of the Popovich Formation. Note that intense oxidation and acid leaching along limestone close to fracture (light area) decrease progressively away from fracture (dark areas), a feature typical of fractures in relatively unaltered limestone above areas of gold mineralization. 


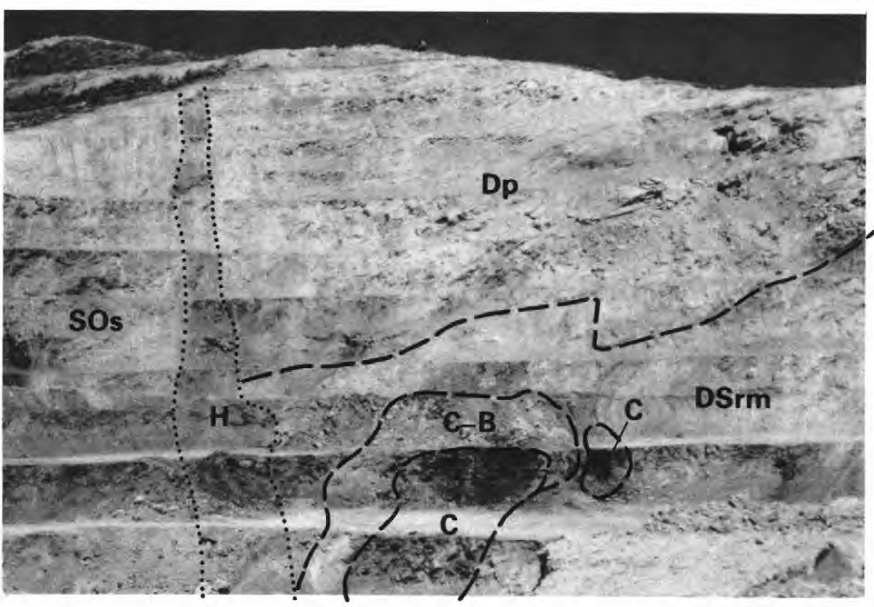

FIGURE 46.--Lower oxidized zone in Main pit southwest of Popovich Hill. Most rocks shown, except for remnant carbonaceous pod (C), have been oxidized. White areas $(\mathrm{C}-\mathrm{B})$ along margins of pod are mixed calcite-barite veins containing abundant realgar. Most oxidation effects fade out about $25 \mathrm{~m}$ below rocks shown at bottom. Dotted lines denote trace of Hardie fault $(\mathrm{H})$. Rocks on left are in upper plate (SOs), and on right in the Popovich Formation (Dp) overlying the Roberts Mountains Formation (DSrm).

As indicated by the relations described above, many of the shallow calcite veins probably resulted from a late, possibly the last, hydrothermal event. Some calcite veins, however, especially those in shallow zones in the Popovich Formation, may be posthydrothermal and have formed during supergene oxidation and weathering.

Data on isotopic compositions of the calcite are given below in the sections entitled "Fluid-Inclusion and StableIsotope Studies."

\section{SUPERGENE ALTERATION}

The host rocks and ores in the upper shallower parts of all the ore zones in the Carlin deposit have been altered by late posthydrothermal supergene oxidation. This alteration is superimposed on rocks previously altered by hydrothermal mineralization and acid leaching, commonly extends 15 to $30 \mathrm{~m}$ below the bottom of the acidleached zone (pl. 7), and reaches a depth of more than $90 \mathrm{~m}$ in most parts of the deposit.

Information on the mineralogy and physical properties of unleached oxidized ores was given above in the section entitled "Oxidized Ores." In summary, the overall chemical and mineralogic changes in the ores and host rocks are similar to, but much less intense than, those in weakly acid-leached zones (pl. 6). Except for their color, which ranges from medium gray to various shades of light gray, green, and tan, the oxidized ores closely resemble the unoxidized ores physically (see fig. 36). The unleached oxidized ores are composed of widely varying proportions of dolomite and lesser calcite, as well as quartz, illite, and minor kaolinite and sericite. Secondary iron oxide minerals formed by the oxidation of iron sulfides are scattered throughout the rocks and in a few areas, such as along the south wall of the West pit, are present in large enough amounts to form mappable zones of weathered pyritic alteration (not shown in pl. 7).

The changes in chemical composition that took place as a result of late supergene oxidation alone after hydrothermal alteration of the host rocks and ores are schematically represented in figure 44 . The losses of $\mathrm{CaO}$ and $\mathrm{CO}_{2}$ reflect the removal of small amounts of calcite, and the values for $\mathrm{MgO}$ show that only minor amounts of dolomite were removed. The contents of $\mathrm{K}_{2} \mathrm{O}, \mathrm{Al}_{2} \mathrm{O}_{3}$, and $\mathrm{H}_{2} \mathrm{O}(+)$ show that no late argillic alteration took place. The decrease in $\mathrm{FeO}$ and $\mathrm{S}$ and the increase in $\mathrm{Fe}_{2} \mathrm{O}_{3}$ correspond to the oxidation of pyrite and other sulfides. The increase in $\mathrm{SiO}_{2}$ reflects an introduction of late silica whose exact source is unknown. The content of $\mathrm{BaO}$ shows that little, if any, barite formed during late supergene oxidation.

Details on the content and vertical distribution of gold with depth are not given in this report, by agreement with the Newmont Mining Corp. However, information from rotary-drill holes throughout the deposit suggests that no selective enrichment of gold took place in the oxidized zones. The high acidity and oxidation potentials required for supergene transport of gold (Cloke and Kelly, 1964) probably were not reached within the zone of oxidation at Carlin.

\section{FLUID-INCLUSION AND STABLE-ISOTOPE STUDIES}

\section{FLUID-INCLUSION STUDIES}

Fluid inclusions in silicified carbonate rocks (jasperoid) and in a few quartz veinlets were studied by Nash (1972), who reported that these materials contain abundant fluid inclusions smaller than $10 \mu \mathrm{m}$ in diameter. Vapor fractions are generally low (about 5 volume percent) but range from 3 to 10 volume percent within many samples. No daughter minerals were observed, although inclusions in several samples contained liquid $\mathrm{CO}_{2}$. Although the properties of the inclusions and the limitations imposed by instrument optics precluded definitive homogenization- and freezingtemperature determinations, Nash estimated that the inclusions would homogenize at $175^{\circ} \pm 25^{\circ} \mathrm{C}$, on the basis of vapor fractions; he concluded (Nash, 1972, p. C17), "With provision for a pressure correction, $200^{\circ} \mathrm{C}$ would seem to be a reasonable estimate of the temperature of formation at Carlin***."

More recently, several minerals from the Carlin deposit, including quartz, barite, calcite, sphalerite, and 
TABLE 23.-Temperature and salinity of fluid inclusions in quartz, barite, calcite, realgar, and sphalerite in the Carlin gold deposit

[Stages in paragenesis: 1 , weak deuteric alteration; 2 , hydrothermal mineralization; 3 , acid-leaching alteration; 4 , supergene oxidation and weathering. n.d., not determined; n.m., not measurable]

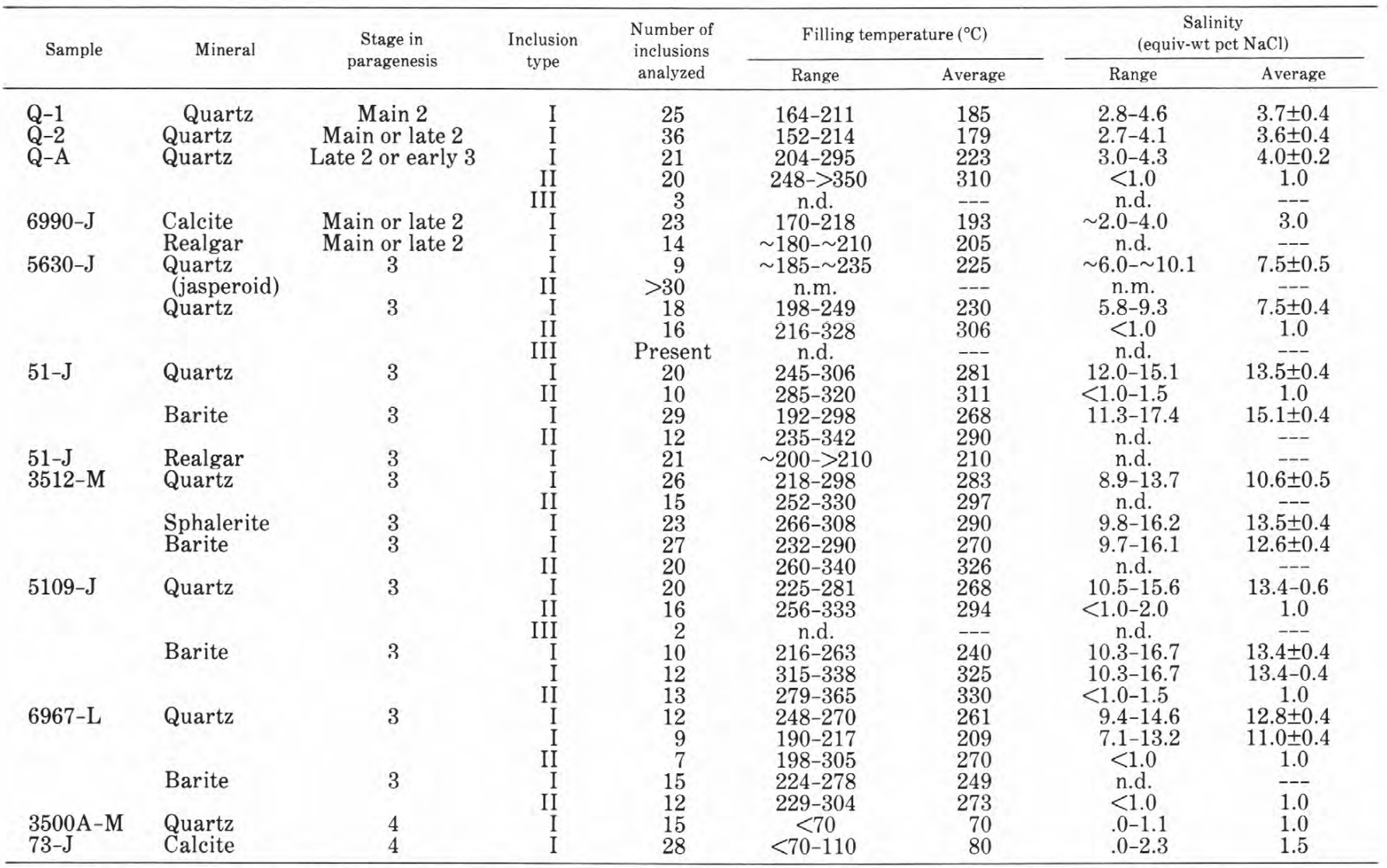

Sample Q-1. Quartz veinlets in fractures in deep mineralized unoxidized carbonaceous dolomitic carbonate rock. Quartz contains dispersed hydrocarbons, and pyrite coated with gold, arsenic, antimony, and mercury. Location: mine coordinates 23,000 N., 19,900 E.; 6,360 bench.

Q-2. Quartz veinlets along margin and crosscutting igneous dike at base of oxidized zone. Quartz contains minor partially oxidized pyrite, and iron oxides contain gold and associated elements. Location: mine coordinates $23,100 \mathrm{~N}$., $20,250 \mathrm{E}$.; 6,400 bench.

Q-A. Quartz veinlets along margin of igneous dike and in heavily silicified carbonate rock in zone of acid leaching; quartz con6990-J. tains frankdicksonite and pyrite. Location: mine coordinates 23,800 N., 20,750 E.; 6,325 bench.

6990-J. Realgar in calcite veinlets and along fractures in unoxidized carbonaceous dolomitic carbonate rock below ox idized zone. Location: mine coordinates 22,700 N., 19,000 E.; 6,220 bench.

5630-J. Quartz veinlets intergrown with jasperoid in surface outcrops. Location: mine coordinates $21,910 \mathrm{~N}$., $15,575 \mathrm{E} . ; 6,650$

bench.

51-J. Barite seams containing patches of quartz and realgar along fractures in remnant pod of unoxidized carbonaceous carbonate rock near base of acid-leached zone. Location: mine coordinates 22,510 N., $18,400 \mathrm{E} . ; 6,400$ bench.

3512-M. Barite vein containing dispersed grains of sphalerite and seams of quartz in center of acid-leached zone. Location: mine coordinates 22,700 N., 18,860 E.; 6,580 bench.

5109-J. Barite seams containing dispersed grains of galena and seams of quartz in center of acid-leached zone. Location: mine 6967-L. Barite and quartz interlocked in veins near top of acid-leached zone. Location: mine coordinates 22,300 N., 15,450 E.; 6,430 bench.

3500A-M. Quartz patches along fractures in shallow mineralized unleached oxidized carbonate rock. Location: mine coordinates

22,100 N., 18,150 E.; 6,460 bench.

73-J. Calcite vein filling fracture in weakly oxidized near-surface carbonate rock above acid-leached zone. Location: mine coordinates 22,580 N., 18,450 E.; 6,610 bench.

realgar, were studied by J. F. Slack (unpub. data, 1975), whose data on homogenization temperatures agree well with other data on the same minerals and are listed in table 23. Although inclusion sizes and limitations on instrument optics precluded J. F. Slack from obtaining freezing-temperature data, he reported that both liquid- and vapor-rich inclusions commonly are present in the same mineral plate and concluded, “* ** this indicates widespread fluid boiling and the trapping of vapor-rich inclusions along the boiling curve and explains the anomalously high temperatures of homogenization recorded for many inclusions." 


\section{MATERIALS AND FLUID-INCLUSION PROPERTIES}

Fluid inclusions were studied in doubly polished plates prepared from various materials, including quartz, barite, calcite, sphalerite, and realgar. Wherever possible, these plates were prepared to permit examination of inclusions in more than one mineral on the same plate. Samples studied include: (1) quartz in patches in unoxidized ores; in veinlets with and without such other phases as pyrite, frankdicksonite, and gold in unoxidized ores, as well as in deep parts of overlying oxidized rocks; intergrown with jasperoid in surface and near-surface acid-leached zones; and associated with barite veins in acid-leached zones; (2) barite in veins with quartz but lacking sulfide minerals, and in veins containing lesser amounts of quartz and scattered concentrations of sphalerite, galena, and realgar; (3) calcite in veinlets in deep unoxidized ores and in shallow oxidized rocks above the acid-leached zone; (4) sphalerite in barite veins; and (5) realgar in calcite veins in deep unoxidized ores, and with barite and quartz in veins within shallow pods of remnant unoxidized carbonaceous rocks near the bottom of the acid- leached zone. These materials cover the paragenesis from the main hydrothermal stage through posthydrothermal supergene oxidation (stages 2-4, table 23; see fig. 29).

Homogenization and freezing temperatures were determined by conventional techniques, using a modified Chaix Meca heating/liquid $\mathrm{N}_{2}$ freezing stage. The stage was calibrated using spectrographically analyzed $\mathrm{CO}_{2}$ fluid inclusions and solutions of known salinity. In the temperature range $0^{\circ}-400^{\circ} \mathrm{C}$ the stage was calibrated using National Bureau of Standards materials with known melting points.

Minerals studied in most of the plates contained numerous primary, secondary, and pseudosecondary inclusions. Samples of barite and calcite, and some of sphalerite, contained many secondary or pseudosecondary inclusions, mostly smaller than $20 \mu \mathrm{m}$, near or along fractures and cleavage planes. Except for a few large $(25 \mu \mathrm{m})$ secondary inclusions in barite, no homogenization- or freezing-temperature determinations were made on secondary inclusions. All the data listed in table 23 were determined by study of primary inclusions or inclusions having properties that could be either primary or pseudosecondary.

The three types of inclusions observed during this study were also reported by J. F. Slack (written commun., 1975):

Type I .-Fluid inclusions of this type contain both a liquid and a vapor phase; the bubble commonly makes up 5 to 30 percent of the total volume of the inclusion. Type I inclusions were the most abundant and were present in all the mineral plates examined. Measured salinities in all the minerals studied range from 0.0 to about 17 equivalent-weight percent $\mathrm{NaCl}$, depending on the type of mineral and the history of the transport solution.
Type II .-This type of inclusion also contains both a liquid and a vapor phase, but the volume of vapor equals or exceeds that of the liquid phase; in most inclusions the vapor phase makes up 50 to 70 percent of the inclusion volume. Type II inclusions are present in barite, in quartz associated with barite, in some samples of sphalerite and realgar(?), and in a few quartz veinlets. Some type II inclusions in barite also have vapor bubbles constituting more than 90 percent of the inclusion volume. In most of the samples studied, type II inclusions homogenize over a wide temperature range, and the lowest homogenization temperatures for type II inclusions in most samples compare well with average values for type I inclusions in the same samples (table 23). Measured salinities of most type II inclusions in all types of materials were less than 1.0 equivalent-weight percent $\mathrm{NaCl}$.

Type III .-Fluid inclusions of this type contain three phases-liquid water, liquid $\mathrm{CO}_{2}$, and vapor $\left(\mathrm{H}_{2} \mathrm{O}+\mathrm{CO}_{2}\right)$-and are rare in Carlin samples. Nash (1972) reported the presence of type III inclusions in quartz samples; the studies in this report as well as those by J. F. Slack confirmed the presence of this rare type of inclusion in two samples of quartz.

No daughter minerals or other phases, such as hydrocarbons or iron oxides, have been found in inclusions of any type in Carlin samples.

\section{MAIN- AND LATE-HYDROTHERMAL STAGE FLUID INCLUSIONS}

Quartz deposited with pyrite, gold, and associated elements during the main stage of hydrothermal mineralization (stage 2, table 23) contains only type I fluid inclusions. Measured homogenization temperatures of these inclusions, which range from $152^{\circ}$ to $214^{\circ} \mathrm{C}$ and average about $182^{\circ} \mathrm{C}$ (samples Q-1, Q-2, table 23), agree with those of type I inclusions in deep calcite veinlets of $170^{\circ}$ to $218^{\circ} \mathrm{C}$ (sample 6990-J, table 23). Type I inclusions in realgar crystals in the calcite veinlets have homogenization temperatures of about $180^{\circ}$ to more than $210^{\circ} \mathrm{C}$; however, owing to the behavior of realgar at temperatures above $200^{\circ} \mathrm{C}$ and its optical properties, it is difficult to measure these homogenization temperatures precisely. Fluids in type I inclusions in quartz have salinities that range from 2.7 to 4.6 equivalent-weight percent $\mathrm{NaCl}$, and those in calcite from about 2 to 4 equivalent-weight percent $\mathrm{NaCl}$ (table 23). The absence of type II vapor-rich inclusions in association with type I inclusions in samples of quartz or calcite deposited during hydrothermal mineralization suggests that the hydrothermal fluids did not boil at the sample localities during ore deposition. Temperatures of the hydrothermal fluids probably increased over time (fig. 29) and were above $200^{\circ} \mathrm{C}$ at the onset of boiling. 


\section{ACID-LEACHING OXIDATION FLUID INCLUSIONS}

Fluid-inclusion data obtained on minerals deposited during the acid-leaching stage of the paragenesis (stage 3 , table 23) indicate that the hydrothermal fluids were hotter and that the salinity increased accompanying boiling. Type I fluid inclusions in quartz veinlets formed at the onset of boiling (late stage 2 or early stage 3) show homogenization temperatures of $204^{\circ}$ to $295^{\circ} \mathrm{C}$ and average $223^{\circ} \mathrm{C}$ (sample $\mathrm{Q}-\mathrm{A}$, table 23 ). The presence of abundant type II inclusions with generally higher homogenization temperatures indicates that these fluids were boiling. The nearness of the salinities (3.0-4.3 equivalent-weight percent $\mathrm{NaCl}$ ) of type I fluid inclusions to those of mainhydrothermal-stage fluids suggests that these veinlets, which also contain frankdicksonite, pyrite, and, locally, gold, probably formed early during boiling.

Jasperoid bodies, formed by the near-complete replacement of calcite and dolomite in carbonate rocks along high-angle faults, contain small type I inclusions. The few inclusions in plates having satisfactory properties for study showed estimated homogenization temperatures of $185^{\circ}$ to $235^{\circ} \mathrm{C}$; the type II inclusions were too small for study. Narrow white to blue-white quartz veinlets occur locally within the jasperoid bodies and grade into darkgray to black jasperoid; these veinlets probably formed as a final stage of the silicification. Both type I and type II inclusions occur in these veinlets; homogenization temperatures for type I inclusions in one sample $(5630-\mathrm{J}$, table 23), which range from $198^{\circ}$ to $249^{\circ} \mathrm{C}$ and average $224^{\circ} \mathrm{C}$, indicate fluid-inclusion temperatures above those in minerals formed during the main hydrothermal stage. Nash (1972) reported the presence of liquid $\mathrm{CO}_{2}$ in type III fluid inclusions in this and other samples, but did not give temperature or salinity data. Salinities in type I inclusions range from 5.8 to 9.3 equivalent-weight percent $\mathrm{NaCl}$ and average $7.5 \pm 0.4$ equivalent-weight percent $\mathrm{NaCl}$.

Barite and intergrown quartz deposited during boiling and acid leaching contain fluid inclusions that show homogenization temperatures far above those in minerals formed during hydrothermal mineralization (samples 51J, 3512-M, 5109-J, 6967-L, table 23). All samples contained type I and less abundant type II inclusions varying widely in homogenization temperature. The ranges in homogenization temperature of type II inclusions overlap those of type I inclusions, and the lowest homogenization temperatures of type II inclusions generally agree well with the averages for type I inclusions. Homogenization temperatures of type I fluid inclusions in sphalerite, which range from $266^{\circ}$ to $308^{\circ} \mathrm{C}$ and average $290^{\circ} \mathrm{C}$, agree well with the average of $283^{\circ} \mathrm{C}$ for inclusions in coexisting quartz (sample 3512-M, table 23). Salinities of type I inclusions in quartz, barite, and sphalerite range from 8.9 to $15.6,9.7$ to 17.4 , and 9.8 to 16.2 equivalent-weight per- cent $\mathrm{NaCl}$, respectively - much larger than the salinities of hydrothermal stage fluids.

Using temperature and salinity data on fluid inclusions observed in materials deposited during solution boiling (plotted on the boiling-point curves of Haas, 1971), and taking into account the vertical range in depth of solution boiling at Carlin and the present thickness of rocks over the acid-leached zone, probably only about 300 to $500 \mathrm{~m}$ of overburden have been removed by erosion since ore deposition.

If future studies of suitable materials by better analytical techniques indicate that hydrothermal minerals such as quartz and barite contain significant amounts of entrapped carbon dioxide, methoane etc., then the conditions of temperature and pressure would have been much higher. This would, in turn, suggest ore genesis could have taken place at depths of up to $2,000 \mathrm{~m}$ or even greater.

\section{POSTHYDROTHERMAL SUPERGENE OXIDATION AND WEATHERING FLUID INCLUSIONS}

Unleached oxidized ores locally contain small patches of secondary quartz with fluid inclusions that have homogenization temperatures below $50^{\circ} \mathrm{C}$ and salinities of 0.0 to 1.1 equivalent weight percent $\mathrm{NaCl}$ (sample $3500 \mathrm{~A}$ $\mathrm{M}$, table 23). These data indicate that some silica was added by cool solutions during supergene oxidation (stage 4 , table 23). Fluid inclusions in stage 4 calcite veins show homogenization temperatures of less than $70^{\circ}$ to $110^{\circ} \mathrm{C}$ and salinities of 0.0 to 2.3 equivalent-weight percent $\mathrm{NaCl}$ (sample 73-J, table 23). These veins formed by deposition of calcite from low-temperature solutions near or after the close of hydrothermal activity. All the inclusions observed in minerals formed during supergene oxidation are type I, and all the fluids associated with the close of hydrothermal activity and with posthydrothermal processes are of low temperature and low salinity. The generalized temperature and salinity history of the fluids is summarized diagrammatically in figure 29.

\section{STABLE-ISOTOPE STUDIES-INTRODUCTION}

Stable-isotope data, provided by R. O. Rye (written commun., 1978), represent analyses of materials collected from throughout the deposit between 1967 and 1978. Many of the interpretations of stable-isotope data presented here correspond to those of A. S. Radtke, R. O. Rye, and F. W. Dickson (unpub. data, 1978). Figure 47 illustrates the general spatial relations between important geologic features pertaining to the materials studied to obtain stable-isotope data, as well as those features discussed below in the section entitled "Genesis of the Deposit." The locations and elevations of individual samples in the isotopic analyses are listed in tables 24 through 31 and plotted on the geologic map of the deposit (pl. 3). 


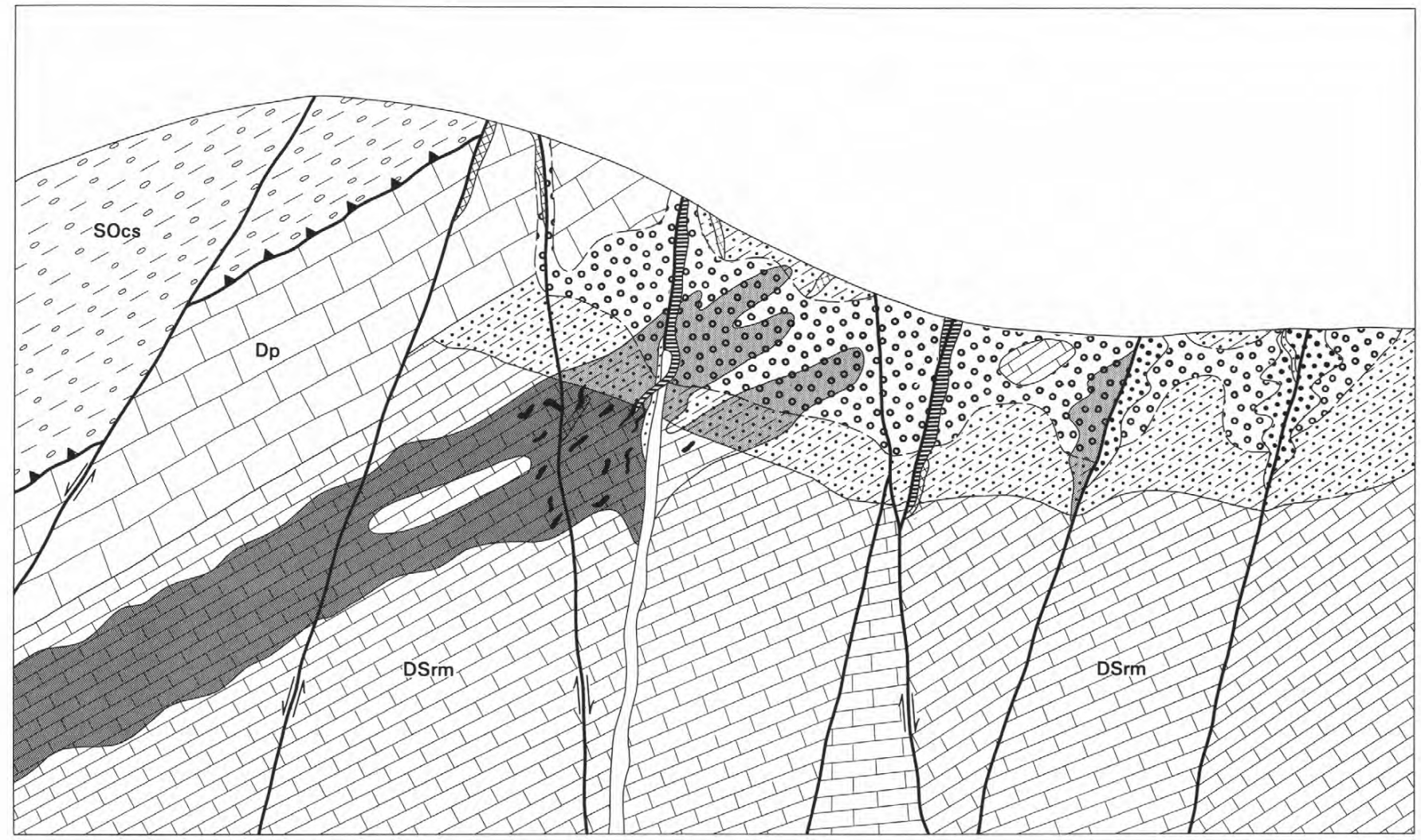

FIGURE 47.-Schematic north-south cross section through Main ore zone and Popovich Hill, illustrating important geologic features. Zone of late supergene oxidation (light dots and dashes) extends below zone of acid leaching (small circles). Main ore zone includes lower unoxidized (dark gray) and upper oxidized (light gray) ores. Cross hatching, calcite veins; horizontal bars, barite veins; heavy dots, quartz veins; black, arsenic-mercury-antimony-thallium sulfide mineralization: heavy dots and lines, jasperoid bodies; Dp. Popovich Formation; SOcs, chert and shale; DSrm, Roberts Mountains Formation. Note igneous dikes along fault near center.

A detailed discussion of the methods used in the isotopic analyses was given by Rye and Sawkins (1974). Other techniques, and the fractionation curves used in calculations, are referenced in the tables and below. All data are given in permil deviations from appropriate international standards, following the standard $\delta$-notations, where $\delta$ is defined by

$$
\delta=1,000\left(\frac{{ }^{R} \text { Sample }}{{ }^{R} \text { Standard }}-1\right)
$$

and $\mathrm{R}$ is the appropriate isotopic ratio. Analyses for carbon, oxygen, and sulfur were carried out on a modified 6-in. Nuclide 6-60-MS mass spectrometer analyses for hydrogen were done on a mass spectrometer built from a 3-in. Nuclide 3-60-RMS analyzer tube.

\section{HYDROGEN ISOTOPE DATA}

Materials analyzed for hydrogen isotope data (table 24) include hydrous minerals in whole-rock samples of altered igneous dikes, and waters from fluid inclusions in quartz, barite, and calcite veins. The whole-rock samples were treated with dilute $\mathrm{HCl}$ at $50^{\circ} \mathrm{C}$ to remove carbonate minerals before analysis, according to the technique of Godfrey (1962), and the waters in fluid inclusions in the vein minerals were analyzed by standard techniques (R. 0 . Rye, written commun., 1976). Whole-rock samples of mineralized carbonate rock were not analyzed because the resulting $\delta \mathrm{D}$ values would reflect the combined isotopic properties of both the original and the hydrothermal clay; no attempt was made to separate the clay from the rock for that reason and because of the probability of exchange reactions during separation.

Conclusions on main-stage and post-main-stage hydrothermal fluids may be drawn from the hydrogen isotope data on fluids from inclusions in the samples of vein minerals, including: (1) fluids from inclusions in vein quartz associated with gold and pyrite (sample Q-1, table 24), representative of main-stage solutions; (2) fluids from barite samples, representative of late-stage hydrothermal fluids (acid-leaching oxidation; stage 3, table 23); and (3) fluids from calcite in barren veins, representative of surface 
TABLE 24. $-\delta D$ values of water in fluid inclusions in vein minerals and in hydrous minerals from dikes [All $\delta$ D values relative to standard mean ocean water (SMOW)]

\begin{tabular}{|c|c|c|c|c|c|}
\hline Sample & Mineral & Ore zone & $\begin{array}{c}\text { Location } \\
\text { (mine coordinates) }\end{array}$ & Bench & $\delta \mathrm{D}$ (permil) \\
\hline \multicolumn{6}{|c|}{ Fluid inclusions } \\
\hline $38-\mathrm{J}$. & Barite & Main & 21,605 N., 18,650 E. & 6,610 & -140 \\
\hline $114-\mathrm{J}$ & $\ldots \ldots \ldots \ldots . . .$. do. & West & 22,045 N., 15,815 E. & 6.530 & -149 \\
\hline $6967-\mathrm{J} \quad \ldots \ldots \ldots \ldots$ & do. & do. & 22,300 N., 15,450 E. & 6,430 & -139 \\
\hline $5630-\mathrm{JA}$. & Quartz & do. & 22,870 N., 15,500 E. & 6,660 & -153 \\
\hline$Q-1$ & 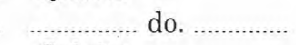 & East & 23,000 N., $19,900 \mathrm{E}$. & 6,360 & -153 \\
\hline $73-\mathrm{J} \ldots \ldots \ldots$ & Calcite & Main & 22,780 N., 18,850 E. & 6,610 & -142 \\
\hline 3501-J & do. & West & 22,225 N., 15,800 E. & 6,400 & -143 \\
\hline \multicolumn{6}{|c|}{ Hydrothermally altered dikes } \\
\hline $23-\mathrm{J}$ & $\begin{array}{l}\text { Whole rock } \\
\text { (sericite/ } \\
\text { kaolinite = 1:3) }\end{array}$ & Main & 21,765 N., 18,495 E. & 6,505 & -160 \\
\hline $5120-\mathrm{J}$ & $\begin{array}{l}\text { Whole rock } \\
\text { (sericite/ } \\
\text { kaolinite }=2: 1 \text { ) }\end{array}$ & West & 22,195 N., 15,665 E. & 6,410 & -145 \\
\hline
\end{tabular}

waters or of mixtures of surface water and late-stage hydrothermal fluids.

Many of the fluid inclusions in vein minerals are small and commonly are crowded along healed fractures, much like secondary or pseudosecondary inclusions. However, most of the fluid recovered for the isotopic determinations was from minute inclusions, densely crowded in milky zones, which have been demonstrated elsewhere to be primary (Rye, 1966).

Whole-rock samples of altered igneous dike rocks analyzed for $\delta \mathrm{D}$ values provide data on the fluids that altered the dikes. The hydrous dike minerals are almost entirely sericite and kaolinite, presumably formed at about the same time as the hydrothermal clay of the potassic-argillic alteration in the unoxidized ores during the main stage of hydrothermal mineralization.

The $\delta \mathrm{D}$ values of fluids in the vein minerals range from -153 to -139 permil (table 24 ). These values include those for quartz veins probably formed during the main hydrothermal stage, barite veins formed during acid leaching, and calcite veins formed during the late hydrothermal stage or late supergene oxidation, and indicate that throughout that period the $\delta \mathrm{D}$ values of the hydrothermal fluids were strongly negative.

The strongly negative $\delta \mathrm{D}$ values in Carlin rocks and vein minerals are compatible with the small $\delta \mathrm{D}$ values in similar materials from the Cortez disseminated-replacement gold deposit (Rye and others, 1974), which has been dated at 35 m.y. B.P., that is, Tertiary (Wells and others, 1971). O'Neil and Silberman (1974) reported small $\delta \mathrm{D}$ values for fluids in a wide variety of Tertiary preciousmetal deposits in the Western United States and also concluded that meteoric waters were important components of the hydrothermal systems. By comparison, the $\delta \mathrm{D}$ values are about 15 to 30 percent lower in the fluids at Carlin. The low $\delta \mathrm{D}$ values at Carlin are consistent with negative values of rainwater or melt waters of the progressively cooler and wetter climate in the Basin and Range province during Tertiary time (Axelrod, 1939, 1966; Shackleton and Kennett, 1975), and are compatible with a meteoric-water-dominated hydrothermal system related to Tertiary igneous and tectonic processes.

\section{OXYGEN ISOTOPE DATA}

Materials analyzed for oxygen isotopic composition include calcite, dolomite, and chert from unaltered rocks, remnant calcite and dolomite from mineralized rocks, jasperoid and quartz veinlets from hydrothermally altered rocks, calcite and dolomite from acid- leached oxidized rocks, and barite and calcite from late veins.

\section{UNALTERED HOST ROCKS}

Detailed physical, chemical, and mineralogic data on rocks of the Roberts Mountains Formation, together with information on the chemical and mineralogic changes in the host rocks during hydrothermal activity, were presented in earlier sections of this report. Information on the interactions between the hydrothermal fluids and the host rocks was obtained by examining and comparing the isotopic properties of calcite and dolomite in both mineralized and unmineralized rocks.

Samples of unmineralized rock from the Roberts Mountains Formation were collected at several localities within $2 \mathrm{~km}$ west and southeast of the Carlin deposit and within the deposit for $\delta^{18} \mathrm{O}$ analyses of calcite and dolomite (table 25). Samples were taken from both type I (laminated argillaceous-arenaceous dolomite, favorable for ore deposition) and type II (laminated arenaceous peloidal wackes- 
TABLE 25.- $\boldsymbol{\delta}^{18} \mathrm{O}$ and $\delta^{13} \mathrm{C}$ values of calcite and dolomite in unaltered rocks of the Roberts Mountains Formation [Facies types: I, laminated argillaceous-arenaceous dolomite; II, laminated arenaceous peloidal wackestone. All $\delta^{18} \mathrm{O}$ values relative to standard mean ocean water (SMOW): all $\delta^{13} \mathrm{C}$ values relative to Peedee belemnite $(\mathrm{PDB})]$

\begin{tabular}{|c|c|c|c|c|c|c|c|c|}
\hline \multirow{2}{*}{ Sample } & \multirow{2}{*}{$\begin{array}{c}\text { Facies } \\
\text { type }\end{array}$} & \multirow{2}{*}{ Location } & \multicolumn{2}{|c|}{ Calcite } & \multicolumn{2}{|c|}{ Dolomite } & \multirow{2}{*}{$\begin{array}{c}\text { Calcite/ } \\
\text { dolomite } \\
\text { ratio }\end{array}$} & \multirow{2}{*}{$\begin{array}{c}\mathrm{CO}_{2} \\
\text { (weight } \\
\text { percent) }\end{array}$} \\
\hline & & & $\begin{array}{c}\delta^{18} 0 \\
\text { (permil) } \\
\end{array}$ & $\begin{array}{c}\delta^{13} \mathrm{C} \\
\text { (permil) }\end{array}$ & $\begin{array}{c}\delta^{18} 0 \\
\text { (permil) }\end{array}$ & $\begin{array}{c}\delta^{13} \mathrm{C} \\
\text { (permil) }\end{array}$ & & \\
\hline DSrm-1 & I & $1 \frac{1}{2} \mathrm{~km}$ SE. of deposit & 21.2 & 0.4 & 22.5 & 0.2 & 1.3 & 29.9 \\
\hline DSrm-3 & I & $1 \mathrm{~km} \mathrm{SE}$. of deposit & 22.5 & .6 & 23.0 & .3 & .8 & 30.5 \\
\hline DSrm-1A & II & $11 / 2 \mathrm{~km} \mathrm{SE}$. of deposit & 18.6 & .6 & 24.1 & .4 & 16.8 & 34.3 \\
\hline DSrm-4 & II & $3 / 4 \mathrm{~km} \mathrm{~W}$. of deposit & 12.6 & -.1 & - & -- & Very large & 36.5 \\
\hline $5607-\mathrm{Ja}$ & II & Main pit & 16.3 & .8 & -- & -- & Very large & 40.6 \\
\hline
\end{tabular}

tone, unfavorable for mineralization) facies rocks. Samples also were taken from within the deposit of remnant unaltered rocks of the Roberts Mountains Formation and the overlying Popovich Formation (tables 25, 26).

The $\delta^{18} \mathrm{O}$ values of calcite in unaltered arenaceous dolomite collected away from the deposit range from 21.2 to 22.5 permil; corresponding values for dolomite are 22.5 and 23.0 permil. These values are comparable to those reported by Rye and others (1974, table 4) for samples of unaltered rocks of the Roberts Mountains Formation near the Cortez deposit and are representative of $\delta^{18} \mathrm{O}$ values of the carbonate minerals in that facies before mineralization.

The $\delta^{18} \mathrm{O}$ values of calcite in unaltered arenaceous peloidal wackestone both within and away from the deposit range from 12.6 to 18.6 permil; the $\delta^{18} \mathrm{O}$ value of dolomite in one sample that contained enough dolomite to be separated was 24.0 permil. The $\delta^{18} \mathrm{O}$ values of these rocks, which are significantly smaller than those of the arenaceous dolomite, presumably reflect a difference in diagenetic or depositional history between the two facies. No difference attributable to hydrothermal alteration were found in the wackestone units.

Thin seams of black sedimentary chert, which occur throughout the Roberts Mountains Formation, are well exposed in the open pits of the Carlin deposit. The chert, though commonly difficult to distinguish from hydrothermal silica, has an oxygen isotope composition distinct from that of both hydrothermal silica (jasperoid) and quartz veinlets (table 27). The $\delta^{18} \mathrm{O}$ values of the chert range from 24.0 to 25.2 permil and are typical of those of early Paleozoic sedimentary chert (Knauth and Epstein, 1976).

\section{MINERALIZED AND HYDROTHERMALLY ALTERED ROCKS}

Table 28 lists the $\delta^{18} \mathrm{O}$ values of calcite and dolomite in mineralized and hydrothermally altered beds of the Roberts Mountains Formation sampled from a 270-m vertical drill hole in the East ore zone, collared in the Popovich Formation, which bottomed about $240 \mathrm{~m}$ in the Roberts Mountains Formation. Samples from the upper $45 \mathrm{~m}$ have undergone late supergene oxidation. The abundance of calcite diminishes strongly with depth, and quartz increases; gold content does not correlate with the amount of silica present. Most of the rocks from this drill hole contained more than 0.3 weight percent organic carbon.

The $\delta^{18} \mathrm{O}$ values of calcite in mineralized rock range from 13.9 to 18.0 permil. These values, which are distinctly smaller than those of calcite in unaltered type I facies rocks, show that isotopic exchange took place between remnant calcite and the hydrothermal fluids during recrystallization. Previous work has shown that oxygen isotope exchange in wallrock carbonates depends on the

TABLE 26.- $\delta^{18} \mathrm{O}$ and $\boldsymbol{\delta}^{13} \mathrm{C}$ values of calcite and dolomite in unmineralized progressively acid-leached oxidized rocks of the Roberts Mountains Formation and the Popovich Formation

[Samples of the Roberts Mountains Formation (DSrm) from a suite from 6.300 bench, Main pit; samples of the Popovich Formation (Dp) from a suite from 6.400 bench, West pit. All $\delta^{18} 0$ values relative to standard mean ocean water $(\mathrm{SMOW})$; all $\delta^{13} \mathrm{C}$ values relative to Peedee belemnite (PDB)]

\begin{tabular}{|c|c|c|c|c|c|c|c|c|}
\hline \multirow[b]{2}{*}{ Sample } & \multirow{2}{*}{$\begin{array}{c}\text { Sample } \\
\text { distance from } \\
\text { fault }(\mathrm{m})\end{array}$} & \multirow[b]{2}{*}{ Description } & \multicolumn{2}{|c|}{ Calcite } & \multicolumn{2}{|c|}{ Dolomite } & \multirow{2}{*}{$\begin{array}{l}\text { Calcite/ } \\
\text { dolomite } \\
\text { ratio }\end{array}$} & \multirow{2}{*}{$\begin{array}{c}\mathrm{CO}_{2} \\
\text { (weight } \\
\text { percent }\end{array}$} \\
\hline & & & $\begin{array}{c}\delta^{18} \mathrm{O} \\
\text { (permil) }\end{array}$ & $\begin{array}{c}\delta^{13} \mathrm{C} \\
\text { (permil) }\end{array}$ & $\begin{array}{c}\delta^{18} \mathrm{O} \\
\text { (permil) }\end{array}$ & $\begin{array}{c}\delta^{13} \mathrm{C} \\
\text { (permil) }\end{array}$ & & \\
\hline $5607-\mathrm{Ja}$ & 30 & Unaltered type II facies DSrm & 16.3 & 0.8 & -- & -- & 50.6 & 40.6 \\
\hline $6979-\mathrm{La}$ & 27 & Slightly altered type II facies DSrm & 15.7 & $\begin{array}{r}0.0 \\
-\quad .6\end{array}$ & - & -- & 55.9 & 38.4 \\
\hline $5607-J c$ & 18 & Weakly altered type II facies DSrm & $\begin{array}{l}10.1 \\
13.9\end{array}$ & -.9 & -- & -- & 17.9 & 35.3 \\
\hline $5607-J d$ & 12 & Moderately altered type I facies DSrm & 12.7 & -1.0 & 1 & $1_{--}$ & 2.1 & 23.5 \\
\hline $6979-\mathrm{Lb}$ & 6 & Strongly altered type I facies DSrm & 13.4 & -1.7 & 25.2 & -.4 & 1.4 & 14.1 \\
\hline $5608-\mathrm{Jb}$ & 3 & $\begin{array}{l}\text { Very strongly altered, probably type } \\
\text { I facies DSrm }\end{array}$ & -- & -- & 24.3 & -.5 & $<1$ & 9.5 \\
\hline $5608-\mathrm{Ja}$ & 0 & $\begin{array}{l}\text { Intensely acid leached and oxidized } \\
\text { DSrm }\end{array}$ & -- & -- & -- & -- & --.03 & \\
\hline 6968-L1 & 3 & Unaltered Dp & 18.3 & .1 & 25.9 & .3 & 1.6 & 33.3 \\
\hline 6968-L2 & 0 & Slightly altered Dp & 18.5 & .3 & 26.0 & .1 & 1.3 & 31.4 \\
\hline
\end{tabular}


TABLE 27.- $\delta^{18} \mathrm{O}$ values in chert, jasperoid, quartz veinlets, and barite veins

[DSrm, Roberts Mountains Formation. $\delta^{18} \mathrm{O}$ of depositing fluids calculated from curves of Taylor (1974) and Kusakabe and Robinson (1977), and from probable depositional temperatures. Use of the curve of Clayton and others(1972) for

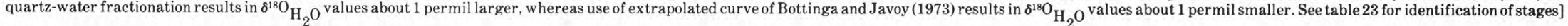

\begin{tabular}{|c|c|c|c|c|c|c|c|c|c|c|}
\hline \multirow{2}{*}{ Sample } & \multirow{2}{*}{ Ore zone } & \multirow{2}{*}{$\begin{array}{c}\text { Location } \\
\text { (mine coordinates) }\end{array}$} & \multirow{2}{*}{ Bench } & \multirow{2}{*}{ Description } & \multirow{2}{*}{$\begin{array}{c}\delta^{18} \mathrm{O} \\
\text { (permil) }\end{array}$} & \multicolumn{5}{|c|}{ Calculated $\delta^{18} \mathrm{O}$ of depositing fluids (permil) } \\
\hline & & & & & & $175^{\circ} \mathrm{C}$ & $200^{\circ} \mathrm{C}$ & $225^{\circ} \mathrm{C}$ & $250^{\circ} \mathrm{C}$ & $275^{\circ} \mathrm{C}$ \\
\hline \multicolumn{11}{|c|}{ Chert } \\
\hline $\begin{array}{l}5611-\mathrm{J} \\
3532-\mathrm{M} \\
5608-\mathrm{J}\end{array}$ & $\begin{array}{l}\text { Main } \\
\text { do. } \\
\text { do. }\end{array}$ & $\begin{array}{l}21,850 \text { N., } 17,450 \mathrm{E} . \\
22,050 \text { N., } 17,750 \mathrm{E} . \\
21,650 \text { N., } 17,650 \mathrm{E} .\end{array}$ & $\begin{array}{l}6,325 \\
6,330 \\
6,340\end{array}$ & $\begin{array}{l}\text { Black chert seam in moderately acid leached DSrm } \\
\text { Black chert seam in intensely acid leached DSrm } \\
\text { Black chert seam in weakly acid leached DSrm }\end{array}$ & $\begin{array}{l}25.2 \\
25.1 \\
24.0\end{array}$ & $\begin{array}{l}--- \\
---\end{array}$ & -- & $\begin{array}{l}--- \\
--- \\
--\end{array}$ & $\begin{array}{l}--- \\
--- \\
--\end{array}$ & $-\overline{--}$ \\
\hline \multicolumn{11}{|c|}{ Jasperoid } \\
\hline $5630-\mathrm{J}$ & West & 21,910 N., $15,575 \mathrm{E}$. & 6,650 & Dense black jasperoid with quartz veinlets in surface outcrop & 16.5 & 1.4 & 3.3 & 4.9 & --. & -- \\
\hline $\begin{array}{l}58-\mathrm{J} \\
6964-\mathrm{Lb}\end{array}$ & $\begin{array}{l}\text { do. } \\
\text { do. }\end{array}$ & $\begin{array}{l}21,950 \mathrm{~N} ., 15,995 \mathrm{E} . \\
21,980 \text { N., } 16,025 \mathrm{E} .\end{array}$ & $\begin{array}{l}6,570 \\
6,430\end{array}$ & $\begin{array}{l}\text { Dense dark-gray jasperoid } \\
\text { Silicified limestone with visible remnant bedding; } 9 \mathrm{~m} \text { from } \\
\text { fault }\end{array}$ & $\begin{array}{l}13.0 \\
13.3\end{array}$ & $\begin{array}{l}-2.1 \\
-1.8\end{array}$ & $\begin{array}{l}-.2 \\
-.1\end{array}$ & $\begin{array}{l}1.4 \\
1.7\end{array}$ & -- & --- \\
\hline 6964-Lc & do. & 21,975 N., $16,035 \mathrm{E}$. & 6,430 & $\begin{array}{l}\text { Heavily silicified limestone with faint remnant bedding; } 4.5 \mathrm{~m} \\
\text { from fault }\end{array}$ & 14.6 & -.5 & 1.4 & 3.0 & --- & -- \\
\hline $\begin{array}{l}\text { 6964-Ld } \\
11-\mathrm{J} \\
5136-\mathrm{J} \\
\text { AR-J2 } \\
\text { AR-J3 } \\
3526-\mathrm{M} \\
6952-\mathrm{Lbl}\end{array}$ & $\begin{array}{l}\text { do. } \\
\text { Main } \\
\text { do. } \\
\text { do. } \\
\text { do. } \\
\text { East } \\
\text { do. }\end{array}$ & 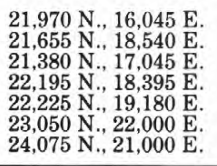 & $\begin{array}{l}6,430 \\
6,545 \\
6,465 \\
6,360 \\
6,510 \\
6,420 \\
6,320\end{array}$ & $\begin{array}{l}\text { Massive jasperoid; } 1.5 \mathrm{~m} \text { from fault } \\
\text { Brown jasperoid } \\
\text { Red jasperoid } \\
\text { Gray-black jasperoid } \\
\text { do. } \\
\text { Jasperoid containing minor gold and coarse-grained stibnite } \\
\text { Jasperoid with high gold content (siliceous ore) }\end{array}$ & $\begin{array}{l}14.9 \\
18.1 \\
13.8 \\
16.2 \\
16.6 \\
9.3 \\
15.8\end{array}$ & $\begin{array}{r}-.2 \\
3.7 \\
-1.3 \\
1.1 \\
1.5 \\
-5.8 \\
-.7\end{array}$ & $\begin{array}{r}1.7 \\
4.9 \\
.6 \\
3.0 \\
3.4 \\
-3.9 \\
2.6\end{array}$ & $\begin{array}{r}3.3 \\
6.5 \\
2.2 \\
4.6 \\
5.0 \\
-2.3 \\
4.2\end{array}$ & $\begin{array}{l}--- \\
-- \\
--- \\
---\end{array}$ & $\begin{array}{l}--- \\
\overline{--} \\
-- \\
--\end{array}$ \\
\hline \multicolumn{11}{|c|}{ Quartz veinlets } \\
\hline Q-1 & East & 23,000 N., $19,900 \mathrm{E}$. & 6,360 & Quartz veinlets containing hydrocarbons, pyrite, gold, and & 19.1 & 4.0 & 5.9 & -- & --- & --- \\
\hline Q-2 & do. & 23,100 N., $20,250 \mathrm{E}$. & 6,400 & Quartz veinlets containing partially oxidized pyrite, gold, and & 18.5 & 3.4 & 5.3 & -- & -- & -- \\
\hline $\begin{array}{l}X I \\
Q-A\end{array}$ & $\begin{array}{l}\text { Main } \\
\text { East }\end{array}$ & $\begin{array}{l}22,270 \mathrm{~N} ., 18,350 \mathrm{E} \\
23,800 \mathrm{~N} ., \\
20,750 \mathrm{E}\end{array}$ & $\begin{array}{l}6,340 \\
6,325\end{array}$ & $\begin{array}{l}\text { associated elements (main or ate stage 2). } \\
\text { Quartz veinlet containing minor sulfides (stage 2). } \\
\text { Quartz veinlets containing pyrite, fluorite, frankdicksonite, } \\
\text { and gold (late stage } 2 \text { or early stage } 3 \text { ). }\end{array}$ & $\begin{array}{l}18.1 \\
21.8\end{array}$ & 3.0 & $\begin{array}{l}4.9 \\
8.6\end{array}$ & 10.2 & $\overline{11.5}$ & - \\
\hline $5630-\mathrm{J}$ & West & 21,910 N., $15,575 \mathrm{E}$. & 6,650 & Quartz veinlets cutting jasperoid in surface outcrop (see & 20.5 & --- & 7.3 & 8.9 & 10.2 & -- \\
\hline $\begin{array}{l}35-\mathrm{J} \\
109-\mathrm{J} \\
51-\mathrm{J} \\
3512-\mathrm{M} \\
6967-\mathrm{L} \\
\end{array}$ & $\begin{array}{l}\text { Main } \\
\text { do. } \\
\text { do. } \\
\text { do. } \\
\text { West } \\
\end{array}$ & $\begin{array}{l}21,905 \mathrm{~N} ., 18,455 \mathrm{E} . \\
22,290 \mathrm{~N} ., 18,600 \mathrm{E} \\
22,510 \mathrm{~N} ., 18,400 \mathrm{E} \\
22,700 \mathrm{~N} . .1860 \\
22,300 \mathrm{~N} ., 15,450 \mathrm{E}\end{array}$ & $\begin{array}{l}6,430 \\
6,505 \\
6,400 \\
6,580 \\
6,430 \\
\end{array}$ & $\begin{array}{l}\text { Quartz with barite vein (stage } 3 \text { ) } \\
\text { Quartz veinlet cutting(?) barite vein (see below) (stage } 3 \text { ) } \\
\text { Quartz patches containing realgar in barite vein } \\
\text { Quartz seams in barite vein } \\
\text { Quartz interlocked with barite in vein }\end{array}$ & $\begin{array}{l}19.5 \\
18.6 \\
20.4 \\
18.8 \\
19.5\end{array}$ & $\begin{array}{l}--- \\
--- \\
--- \\
--\end{array}$ & $\begin{array}{c}6.3 \\
-- \\
-\overline{-} \\
6.3 \\
\end{array}$ & $\begin{array}{r}7.9 \\
7.0 \\
7.2 \\
7.9 \\
\end{array}$ & $\begin{array}{r}9.2 \\
8.4 \\
10.1 \\
8.7 \\
9.2 \\
\end{array}$ & $\begin{array}{r}10.3 \\
9.4 \\
11.2 \\
9.6 \\
10.3\end{array}$ \\
\hline \multicolumn{11}{|c|}{ Barite veins } \\
\hline $\begin{array}{l}38-\mathrm{J} \\
109-\mathrm{J} \\
3512-\mathrm{M} \\
5632-\mathrm{J}\end{array}$ & $\begin{array}{l}\text { Main } \\
\text { do. } \\
\text { do. } \\
\text { do. }\end{array}$ & $\begin{array}{l}21,605 \mathrm{~N} ., 18,650 \mathrm{E} . \\
22,290 \mathrm{~N} ., 18,600 \mathrm{E} \\
22,700 \mathrm{~N} ., 18,860 \mathrm{E} \\
22,520 \mathrm{~N} ., 18,260 \mathrm{E} .\end{array}$ & $\begin{array}{l}6,610 \\
6,505 \\
6,580 \\
6,300\end{array}$ & $\begin{array}{l}\text { Barite vein lacking sulfides } \\
\text { Barite vein containing quartz (see above) } \\
\text { Barite vein containing sphalerite } \\
\text { Barite vein containing galena }\end{array}$ & $\begin{array}{r}9.6 \\
12.0 \\
14.2 \\
12.2\end{array}$ & -- & $\begin{array}{l}--- \\
-- \\
---\end{array}$ & $\begin{array}{l}\overline{--} \\
\overline{--} \\
\overline{--}\end{array}$ & $\begin{array}{r}5.4 \\
7.8 \\
10.0 \\
8.0\end{array}$ & $\begin{array}{r}6.4 \\
8.8 \\
11.0 \\
9.0\end{array}$ \\
\hline
\end{tabular}


TABLE 28.- $\delta^{18} \mathrm{O}$ and $\delta^{1 S} \mathrm{C}$ values of calcite and dolomite in, and chemical data on samples from a drill hole through, mineralized rocks of the Roberts Mountains Formation and the Popovich Formation in the East ore zone

[DSrm, Roberts Mountains Formation; Dp, Popovich Formation. Samples taken from rotary-drill hole P-8 at mine coordinates $24,018 \mathrm{~N}$., 20,233 E.; all DSrm samples are of argillaceousarenaceous dolomite (type I facies). TR., trace]

\begin{tabular}{|c|c|c|c|c|c|c|c|c|c|c|}
\hline \multirow{2}{*}{$\begin{array}{l}\text { Depth } \\
\text { (m) }\end{array}$} & \multirow[b]{2}{*}{ Description } & \multicolumn{2}{|c|}{ Calcite } & \multicolumn{2}{|c|}{ Dolomite } & \multirow{2}{*}{$\begin{array}{l}\text { Calcite/ } \\
\text { dolomite } \\
\text { mole ratio }\end{array}$} & \multirow{2}{*}{$\mathrm{CO}_{2}$} & \multirow{2}{*}{$\begin{array}{c}\mathrm{SiO}_{2} \\
\text { (weight percent) }\end{array}$} & \multirow{2}{*}{$\mathrm{Al}_{2} \mathrm{O}_{3}$} & \multirow{2}{*}{$\begin{array}{c}\mathrm{Au} \\
\text { (troy oz } \\
\text { per ton) }\end{array}$} \\
\hline & & $\begin{array}{c}\delta^{18} \mathrm{O} \\
\text { (permil) }\end{array}$ & $\begin{array}{c}\delta^{13} \mathrm{C} \\
\text { (permil) }\end{array}$ & $\begin{array}{c}\delta^{18} 0 \\
\text { (permil) }\end{array}$ & $\begin{array}{c}\delta^{13} \mathrm{C} \\
\text { (permil) }\end{array}$ & & & & & \\
\hline $46-49$ & Oxidized Dp & 14.8 & -0.8 & 24.8 & 0.2 & 2.8 & 23.4 & 33.8 & 6.6 & $\operatorname{Tr}$. \\
\hline $134-136$ & Unoxidized DSrm & 13.9 & -.2 & 20.9 & 1.13 & 2.8 & 27.9 & 23.3 & 6.5 & .08 \\
\hline $152-154$ & .......... do ............ & 18.0 & -1.3 & 24.5 & -.1 & 1.1 & 35.6 & 17.5 & 1.8 & .01 \\
\hline $174-178$ & .......... do ........... & 16.9 & -.3 & 23.5 & .4 & .12 & 22.6 & 31.5 & 8.8 & Tr. \\
\hline $186-189$ & .......... do ............ & -- & -- & 21.5 & .1 & .15 & 25.6 & 33.4 & 3.3 & .04 \\
\hline $210-213$ & ......... do .......... & 15.8 & -.6 & -- & -- & .23 & 12.3 & 57.4 & 6.2 & .48 \\
\hline $264-268$ & .......... do .......... & -- & -- & 19.4 & .4 & .38 & 3.5 & 72.3 & 5.9 & .01 \\
\hline
\end{tabular}

degree of recrystallization (Pinckney and Rye, 1972). Petrographic examination indicates that the calcite in all samples is recrystallized.

The $\delta^{18} \mathrm{O}$ values of dolomite, which range from 19.4 to 24.5 permil, indicate that limited recrystallization of the dolomite and isotopic exchange with the hydrothermal fluids took place. This result agrees with petrographic evidence that the borders of dolomite rhombs commonly are corroded and locally show peripheral replacement or overgrowth by silica.

Of the various types of hydrothermal silica at Carlin, only jasperoid and sparsely developed quartz veinlets proved suitable for isotopic analyses. The dispersed finegrained quartz in unoxidized ores, however, could not be separated from quartz of sedimentary origin.

\section{ACID-LEACHED OXIDIZED ROGKS}

Data on the changes in $\delta^{18} \mathrm{O}$ and $\delta^{13} \mathrm{C}$ values that took place during hydrothermal acid leaching (table 26) were obtained by analyzing a series of samples collected systematically away from a fault on the 6,300 bench of the Main pit, through intensely acid-leached and progressively more weakly acid-leached oxidized rocks, into fresh arenaceous peloidal wackestone (see fig. 41). This sample suite is nonideal because the facies rocks change from type I to type II. The $\delta^{18} \mathrm{O}$ values of dolomite (24.3-25.2 permil), which are comparable to those in unaltered carbonate rocks (table 25), and mineralized carbonate rocks (table 28), accord with the minor amount of isotopic exchange expected for unrecrystallized dolomite. The $\delta^{18} \mathrm{O}$ values of 12.7 to 13.4 permil for calcite in the acid-leached arenaceous dolomite rocks, which fall within the range of values for calcite in unoxidized ores (table 28), indicate that little oxygen isotope exchange took place during acid leaching and oxidation.

The progressive increase in the $\delta^{18} 0$ values of calcite from intensely acid- leached oxidized rocks into progressively less altered rocks agrees with the petrographic data. This result shows that the amount of calcite removed and the degree of recrystallization of remnant cal- cite decrease away from the fault, and that the amount of oxygen isotope exchange between solutions and carbonate wallrocks depended on the degree of recrystallization of the carbonate minerals in the wallrocks (Pinckney and Rye, 1972). It is unclear whether recrystallization and isotopic exchange in these rocks occurred mainly during acid leaching and oxidation or earlier during the main stage of hydrothermal mineralization. The $\delta^{18} \mathrm{O}$ values of calcite in the acid-leached rocks, which fall within the range of those of calcite in unoxidized ores, indicate that mineralization and acid-leaching oxidation in the upper part of the deposit were produced by isotopically similar fluids, or that acid-leaching oxidation was not accompanied by significant isotopic exchange with remnant calcite in the host rock. The average $\delta^{18} \mathrm{O}$ value of recrystallized calcite in the host rock, which is less than the average values for quartz veinlets and jasperoid, indicates that the calcite in the host rocks probably obtained approximate equilibrium with the main-stage hydrothermal fluids at the temperatures of mineralization.

The isotopic changes in the carbonate minerals in mineralized rocks during hydrothermal acid-leaching and posthydrothermal late supergene oxidation were determined on a suite of samples at the same localities from different benches in the Main pit; the materials studied include normal gold ore, overlying oxidized ore, and acidleached oxidized ore (table 29). Only small amounts of calcite had been removed from the unleached oxidized sample-a feature typical of supergene oxidation-whereas significant amounts of calcite had been removed from the acid-leached oxidized sample. The $\delta^{18} \mathrm{O}$ value of calcite in the unleached weakly oxidized sample (15.4 permil) compares well with that of calcite in the underlying unoxidized ores (16.3 permil) and is consistent with the $\delta^{18} \mathrm{O}$ values in unoxidized mineralized rocks. These data indicate that the processes of posthydrothermal late supergene oxidation had little effect on the $\delta^{18} O$ values of the ores and host rocks, a result consistent with petrographic and chemical data showing that recrystallization or removal of calcite was very limited during late supergene oxidation. 
TABLE 29.- $\delta^{18} \mathrm{O}$ and $\delta^{18} \mathrm{C}$ values of calcite and dolomite from interfaces between oxidized/unoxidized and acid-leached/unleached oxidized zones in mineralized rocks of the Roberts Mountains Formation in the Main ore zone

[Location: mine coordinates $22,500 \mathrm{~N} ., 18,350 \mathrm{E}$.]

\begin{tabular}{|c|c|c|c|c|c|c|c|c|}
\hline \multirow[b]{2}{*}{ Sample } & \multirow[b]{2}{*}{ Bench } & \multirow[b]{2}{*}{ Description } & \multicolumn{2}{|c|}{ Calcite } & \multicolumn{2}{|c|}{ Dolomite } & \multirow{2}{*}{$\begin{array}{c}\text { Calcite/ } \\
\text { dolomite } \\
\text { ratio }\end{array}$} & \multirow{2}{*}{$\begin{array}{c}\mathrm{CO}_{2} \\
\text { (weight } \\
\text { percent }\end{array}$} \\
\hline & & & $\begin{array}{c}\delta^{18} \mathrm{O} \\
\text { (permil) }\end{array}$ & $\begin{array}{c}\delta^{13} \mathrm{C} \\
\text { (permil) }\end{array}$ & $\begin{array}{c}\delta^{18} \mathrm{O} \\
\text { (permil) }\end{array}$ & $\begin{array}{c}\delta^{13} \mathrm{C} \\
\text { (permil) }\end{array}$ & & \\
\hline $3504-\mathrm{M}$ & 6,340 & $\begin{array}{l}\text { Acid-leached oxidized type I facies } \\
\text { gold ore. }\end{array}$ & -- & -- & 24.0 & 0.3 & 0 & 16.0 \\
\hline $3505-\mathrm{M}$ & 6,300 & $\begin{array}{l}\text { Unleached weakly oxidized type I } \\
\text { facies gold ore. }\end{array}$ & 15.4 & 0.2 & 22.1 & .3 & 1.5 & 26.0 \\
\hline $3506-\mathrm{M}$ & 6,280 & Unoxidized type I facies gold ore. & 16.3 & .9 & 23.0 & .1 & 1.0 & 26.0 \\
\hline
\end{tabular}

\section{QUARTZ VEINLETS}

Quartz veinlets analyzed include those formed during the main and late stages of hydrothermal mineralization and acid-leaching oxidation (stages 2, 3, table 23). The $\delta^{18} \mathrm{O}$ values of all veinlets (table 27 ) range from 18.1 to 21.8 permil; the largest values are in quartz veinlets formed during stage 3 . The $\delta^{18} \mathrm{O}$ values of these quartz veinlets, including those of stage 3 that probably were contemporaneous with much of the jasperoid, are generally larger and more uniform than those of the jasperoid. The difference in $\delta^{18} \mathrm{O}$ value between the silicas from stages 2 and 3 probably reflects the influence of varying rock/ water ratios on $\delta^{18} \mathrm{O}$ values of the fluids in veinlets during replacement processes.

Fluid-inclusion data indicate temperatures of $175^{\circ}$ to $200^{\circ} \mathrm{C}$ for stage 2 fluids and of $250^{\circ}$ to $300^{\circ} \mathrm{C}$ for stage 3 fluids (table 23). Calculated $\delta^{18} \mathrm{O}$ values of stage 2 fluids that deposited quartz between $175^{\circ}$ and $200^{\circ} \mathrm{C}$ range from 3.0 to 5.9 permil, and those of stage 3 fluids that deposited quartz between $250^{\circ}$ and $275^{\circ} \mathrm{C}$ from 8.7 to 11.5 permil (table 23). The larger $\delta^{18} \mathrm{O}$ values for stage 3 fluids are consistent with the widespread boiling of hydrothermal fluids indicated by the fluid-inclusion data.

\section{JASPEROID BODIES}

With one exception, the measured $\delta^{18} \mathrm{O}$ values in samples of hydrothermal jasperoid from throughout the deposit range from 13.0 to 18.1 permil (table 27). The paragenetic relations between the various jasperoid bodies are unknown. Although the $\delta^{18} \mathrm{O}$ values show no systematic vertical variations with depth, the $\delta^{18} \mathrm{O}$ values within individual bodies show some lateral spatial variations. In many of the larger jasperoid masses the degree of silicification decreases outward from major feeder faults, and physical features of the original rock, including bedding, become more distinct away from the fault. In three samples from across a jasperoid body in the West pit (samples 6964-Lb, 6964-Lc, 6964-Ld, table 27) the $\delta^{18} \mathrm{O}$ values decrease regularly with increasing distance from the fault. This regular decrease probably reflects increased isotopic exchange between the hydrothermal fluids and the original carbonate minerals of low $\delta^{18} 0$ content in the host rock.

The $\delta^{18} \mathrm{O}$ values of the jasperoid bodies are difficult to interpret because data on their temperatures of formation are sparse. Data from jasperoid samples with usable fluid inclusions suggest that deposition temperatures range from about $185^{\circ}$ to $235^{\circ} \mathrm{C}$; these temperatures are reasonable in view of the apparent position of most jasperoid bodies in the paragenesis. Regardless of the depositional temperatures, the $\delta^{18} \mathrm{O}$ values of jasperoid bodies are smaller than those of vein quartz, and the $\delta^{18} \mathrm{O}$ values of hydrothermal fluids in equilibrium with the jasperoid (calculated for temperatures between $175^{\circ}$ and $225^{\circ} \mathrm{C}$ ) are smaller than those of vein quartz at equivalent temperatures (table 27). These results are consistent with smaller rock/water ratios during jasperoid formation than during quartz vein deposition.

All the $\delta^{18} \mathrm{O}$ values are compatible with meteoricwater-dominated hydrothermal fluids that were modified to varying degrees by isotopic exchange with the carbonate host rock. The differences in the $\delta^{18} \mathrm{O}$ values of the iasperoid (listed in table 27) are difficult to interpret in terms of local factors but may reflect variations in the isotopic composition of water due to mixing of deep and shallow meteoric waters, boiling of fluids, variations in the extent of isotopic exchange with wallrocks, or differences in temperatures from place to place. One exceptionally small value ( 9.3 permil) was measured on brecciated iasperoid from a prominent fault zone; presumably, nearsurface water of low $\delta^{18} \mathrm{O}$ content was able to penetrate along the fault.

\section{BARITE VEINS}

The $\delta^{18} \mathrm{O}$ values of vein barite from different depths in the deposit show a narrow range from 9.6 to 14.2 permil (table 27). Data from these samples suggest that no systematic lateral variations in the veins exist. In contrast to the $\delta^{18} \mathrm{O}$ values of the jasperoid, the smallest $\delta^{18} \mathrm{O}$ values in barite samples are from shallower depths in the deposit. 
TABLE 30.- $\delta^{18} \mathrm{O}$ and $\delta^{13} \mathrm{C}$ values of calcite veins in the Roberts Mountains Formation and the Popovich Formation [DSrm, Roberts Mountains Formation; Dp. Popovich Formation. All $\delta^{18} \mathrm{O}$ values relative to standard mean ocean water (SMOW); all $\delta^{13} \mathrm{C}$ values relative to Peedee belemnite (PDB)]

\begin{tabular}{|c|c|c|c|c|c|c|}
\hline Sample & Ore zone & $\begin{array}{c}\text { Location } \\
\text { (mine coordinates) }\end{array}$ & Bench & Description & $\begin{array}{c}\delta^{180} \\
\text { (permil) }\end{array}$ & $\begin{array}{c}\delta^{13} \mathrm{C} \\
\text { (permil) }\end{array}$ \\
\hline 5116-J & West & 22,230 N., $15,790 \mathrm{E}$. & 6,460 & In altered oxidized ore & 10.6 & -0.4 \\
\hline 3501-M & do. & 22,225 N., $15,800 \mathrm{E}$. & 6,400 & Massive vein near DSrm-Dp contact & 13.3 & -.6 \\
\hline $73-J$ & Main & 22,780 N., $18,850 \mathrm{E}$. & 6,610 & Vein in Dp & 2.5 & .4 \\
\hline $\mathrm{AR}-\mathrm{C} 3 \mathrm{a}$ & do. & 21,575 N., 16,925 E. & 6,320 & Small crystals in vug in oxidized ore & 5.9 & 0 \\
\hline 6979-La & do. & 22,105 N., 17,910 E. & 6,300 & In fracture in oxidized rocks below acid-leached zone .... & 14.8 & -.2 \\
\hline $6990-J$ & do. & 22,700 N., $19,000 \mathrm{E}$. & 6,220 & In fracture in unoxidized ore & 12.3 & -6.2 \\
\hline $\mathrm{AR}-\mathrm{C} 4 \mathrm{a}$ & East & 23,250 N., $20,200 \mathrm{E}$. & $\sim 6,600$ & In surface outcrop of $\mathrm{Dp}$ & 22.9 & -1.0 \\
\hline
\end{tabular}

The $\delta^{18} \mathrm{O}$ values for water in equilibrium with barite were calculated using the data of Kusakabe and Robinson (1977) for depositional temperatures of $250^{\circ}$ and $275^{\circ} \mathrm{C}$. The calculated $\delta^{18} \mathrm{O}$ values (5.4-11.0 permil) fall within the range of $\delta^{18} \mathrm{O}$ values for fluids from coexisting quartz, and the larger values are consistent with widespread boiling of fluids during barite deposition.

\section{CALCITE VEINS}

Samples of calcite veins and veinlets used for isotopic study were collected from abundant occurrences in oxidized host rocks and ores in upper parts of the deposit in the Roberts Mountains Formation and in the overlying Popovich Formation, and from small scattered veinlets and pods of calcite in upper parts of the underlying unoxidized-ore zones. None of the very sparse occurrences of calcite in acid-leached rocks were studied.

The $\delta^{18} \mathrm{O}$ values in nearly all samples of vein calcite in shallow oxidized rocks range from 2.5 to 14.9 permil (table 30). One sample (AR-C4a), with a large $\delta^{18} \mathrm{O}$ value of 22.9 permil, probably reflects deposition from fluids at low temperatures (about $\left.50^{\circ} \mathrm{C}\right)$. One sample $(6990-\mathrm{J})$ of veinlet calcite from deep unoxidized mineralized rock had a $\delta^{18} \mathrm{O}$ value of 12.3 permil.

Interpretation of the calcite data is complicated by the absence of fluid inclusions suitable for filling-temperature measurement. The small $\delta^{18} \mathrm{O}$ values of 2.5 and 5.9 permil for calcite from a near-surface vein in the Popovich Formation and from a later vug, respectively, probably reflect deposition from shallow surface water. Most of the intermediate $\delta^{18} \mathrm{O}$ values in table 30 fall within the range of values of remnant recrystallized calcite in mineralized rocks. Possibly, some of this vein calcite was derived from host rocks at depth during mineralization and was precipitated from low-temperature hydrothermal fluids higher up because of loss of $\mathrm{CO}_{2}$ during boiling. Most of the calcite, however, was probably derived from the acidleached zone.

The calculated $\delta^{18} \mathrm{O}$ values of the fluids that deposited calcite in the unoxidized mineralized zone, using filling temperatures of $175^{\circ}$ to $200^{\circ} \mathrm{C}$, range from 0.8 to 2.8 permil. These values are consistent with the calculated values for exchanged heated meteoric fluids that deposited some of the jasperoid.

The hydrogen and oxygen isotopic data permit several conclusions to be drawn on the genesis of the deposit:

1. The $\delta \mathrm{D}$ values in quartz and altered igneous dikes, and the $\delta^{18} \mathrm{O}$ values in main- and late-hydrothermal-stage quartz and jasperoid, indicate that the hydrothermal fluids were highly exchanged meteoric waters with ${ }^{18} \mathrm{O}$ contents varying over time and space. These variations reflect differences in the degree of isotopic exchange with host rocks, mixing with local ground waters, varying rock/water ratios, and perhaps initial boiling of latestage fluids.

2. The $\delta^{18} \mathrm{O}$ data on barite and associated quartz indicate that the $\delta^{18} \mathrm{O}$ values of the hydrothermal fluids increased during later acid leaching and oxidation in the upper part of the deposit. This increase probably resulted largely from boiling of the fluids.

3. The $\delta^{18} \mathrm{O}$ values of calcite veins fall into three groups that reflect different origins of the calcite: (a) veins with large $\delta^{18} \mathrm{O}$ values formed at low temperatures from hydrothermal fluids, (b) veins with small $\delta^{18} \mathrm{O}$ values formed from low-temperature ground waters, and (c) calcite veins with intermediate $\delta^{18} \mathrm{O}$ values probably formed from calcite dissolved out of carbonate rocks in the acid-leached zone by the hydrothermal fluids and precipitated higher up in response to loss of $\mathrm{CO}_{2}$ during boiling. Some of this calcite may have originated at greater depths below the acid-leached zone.

4. The degree of isotopic exchange in the carbonate minerals is related to the extent of recrystallization of these minerals in the altered rocks. Carbonate minerals in type II facies rocks unfavorable for mineralization are generally unrecrystallized and retain primary $\delta^{18} \mathrm{O}$ values. In contrast, calcite in the favorable type I facies rocks generally shows some recrystallization; the extent of this recrystallization and attendant ${ }^{18} \mathrm{O}$ isotope exchange is related to the distance from faults that served as solution conduits and to the volume of fluid passing through the rocks. Dolomite in type I facies rocks is only very weakly recrystallized and shows little attendant isotopic exchange. 
TABLE 31. $-\delta^{84}$ S values and isotopic temperatures of diagenetic pyrite, hydrothermal sulfide minerals, and barite [ $\delta^{34} \mathrm{~S}$ values relative to Canon Diablo troilite. Isotopic temperatures: $T_{1}$, calculated from Ohmoto and Rye (1979); $T_{2}$, calculated from experimental value of 20.0 permil for $\delta^{34} \mathrm{~S}$

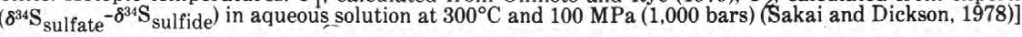

\begin{tabular}{|c|c|c|c|c|c|c|c|}
\hline \multirow{2}{*}{ Sample } & \multirow{2}{*}{ Ore zone } & \multirow{2}{*}{$\begin{array}{c}\text { Location } \\
\text { (mine coordinates) }\end{array}$} & \multirow{2}{*}{ Bench } & \multicolumn{2}{|r|}{$\delta^{34} \mathrm{~S}$ (permil) } & \multirow{2}{*}{$\begin{array}{c}T_{1} \\
\left({ }^{\circ} \mathrm{C}\right) \\
\end{array}$} & \multirow{2}{*}{$\begin{array}{l}T_{2} \\
\left({ }^{\circ} \mathrm{C}\right)\end{array}$} \\
\hline & & & & Barite & Sulfide minerals & & \\
\hline 114-J & Main & 22,045 N., 15,815 E. & 6,530 & 29.0 & --- & -- & --- \\
\hline $6960-\mathrm{L}$ & do. & 22,210 N., 16,790 E. & 6,505 & 30.4 & -- & -- & -- \\
\hline $5632-J$ & Main & 22,520 N., 18,260 E. & 6,300 & 29.8 & 6.5 (galena) & 300 & 284 \\
\hline $51-J$ & Main & 22,510 N., $18,400 \mathrm{E}$. & 6,400 & 30.3 & 15.2 (realgar) & -- & -- \\
\hline 5109-J & do. & 22,550 N., 18,380 E. & 6,360 & 31.4 & 5.1 (galena) & 270 & 251 \\
\hline $3512-\mathrm{M}$ & do. & 22,700 N., 18,860 E. & 6,580 & 31.2 & 10.1 (sphalerite) & 300 & 285 \\
\hline $5633-J$ & do. & 22,410 N., 18,260 E. & 6,260 & 31.7 & 10.7 (sphalerite) & 305 & 280 \\
\hline $35-J$ & do. & 21,905 N., 18,455 E. & 6,430 & 30.6 & --- & -- & -- \\
\hline 38-J & do. & 21,605, N., 18,650 E. & 6,610 & 29.1 & --- & --- & -- \\
\hline 109-J & do. & 22,290 N., 18,600 E. & 6,505 & 27.8 & -- & -- & -- \\
\hline $3526-\mathrm{M}$ & East & 23,050 N., 20,000 E. & 6,420 & -- & 8.7 (stibnite) & --- & -- \\
\hline 6955-Le & Main & 22,440 N., 18,300 E. & 6,300 & --- & 4.2 (pyrite in ore) & --- & --- \\
\hline 6956-Lb & East & 23,200 N., 20,600 E. & 6,360 & --- & 16.1 (pyrite in ore) & -- & -- \\
\hline $3523-\mathrm{M}$ & do. & 23,880 N., $20,650 \mathrm{E}$. & 6,300 & --- & 9.7 (pyrite in mineralized & --- & -- \\
\hline Q-A & do. & 23,800 N., 20,750 E. & 6,325 & -- & $\begin{array}{l}15.4 \text { (pyrite in quartz veinlet) } \\
\text { dikes) }\end{array}$ & -- & -- \\
\hline DSrm-1 & --- & $1 \frac{1}{2} \mathrm{~km} \mathrm{SE}$. of deposit & --- & --- & 11.7 (diagenetic pyrite) & -- & --- \\
\hline DSrm-2 & --- & $5 \mathrm{~km} \mathrm{NW}$. of deposit & -- & -- & 14.3 (diagenetic pyrite) & -- & --- \\
\hline
\end{tabular}

5. Most of the recrystallization and isotopic exchange in carbonate minerals in the host rocks apparently took place during the main stage of hydrothermal mineralization and before acid leaching and oxidation. Posthydrothermal late supergene oxidation had no detectable effect on the $\delta^{18} \mathrm{O}$ values of either calcite or dolomite in the host rocks.

\section{CARBON ISOTOPE DATA}

\section{HOST ROCKS AND ORES}

Tables 25, 28, and 29 list data on the $\delta^{13} \mathrm{C}$ values of calcite and dolomite in samples of the host rocks and unoxidized ores, and tables 26 and 29 on the $\delta^{13} \mathrm{C}$ values of these carbonate minerals in acid-leached oxidized rocks. All these values, which fall within the range of $\delta^{13} \mathrm{C}$ values of unaltered marine carbonate rocks, show that the hydrothermal fluids did not contain significant amounts of $\mathrm{CO}_{2}$ from a source other than the carbonate rock terranes. Because the solutions exchanged ${ }^{18} \mathrm{O}$ with recrystallizing calcite and are known from fluid-inclusion studies to have contained $\mathrm{CO}_{2}$, they likewise probably exchanged ${ }^{13} \mathrm{C}$ with calcite. The similarity between the $\delta^{13} \mathrm{C}$ values of recrystallized calcite in altered rocks (over the temperature range $175^{\circ}-200^{\circ} \mathrm{C}$ ) and those of calcite in unaltered host rocks suggests that the ${ }^{13} \mathrm{C}$ content of the hydrothermal solutions was about the same as that of the host rocks, as shown by the fractionation curves of Bottinga (1968), and thus that much of the carbon in solution was derived from the host rocks.

\section{CALCITE VEINS}

The $\delta^{13} \mathrm{C}$ values of most calcite in veins and veinlets have a narrow range from -1.0 to +0.4 permil (table 29 ), values typical of the $\delta^{13} \mathrm{C}$ values in altered and unaltered host rocks (tables 25, 26, 28, 29). The carbon in the calcite veins was introduced during the hydrothermal episode, probably by dissolution of calcite deeper down in the carbonate rock sequence, migration to near-surface fractures, and precipitation over a temperature range of about $50^{\circ}$ to $110^{\circ} \mathrm{C}$. Some of the carbon in posthydrothermal (stage 4 , table 23) calcite veins was probably derived from wallrocks close to the veins and deposited by cool surface waters. The $\delta^{13} \mathrm{C}$ value of -6.2 permil for calcite in one sample from deep in the unoxidized zone indicates that some organic or possibly deep seated carbon was present in hydrothermal fluids during the main or late stage of hydrothermal mineralization.

\section{SULFUR ISOTOPE DATA}

Information on the sources of sulfur, temperatures of vein formation, and chemical parameters during the stages of hydrothermal mineralization was evaluated from sulfur isotopic data on several minerals in Carlin ores and rocks (table 31 ), including diagenetic pyrite from unaltered carbonate rocks; hydrothermal pyrite from unoxidized ores and igneous dikes; the hydrothermal sulfide minerals realgar, stibnite, galena, and sphalerite; and vein barite. 


\section{HOST ROCKS}

Most of the sulfur in rocks of the Roberts Mountains Formation and in the older underlying sedimentary carbonate units occurs in diagenetic pyrite, and only small amounts in dispersed fine-grained barite and carbonaceous materials. Information on the occurrences and chemical composition of materials in unaltered rocks of the Roberts Mountains Formation was given above in the section entitled "Geology." The occurrence of bedded barite, common in early Paleozoic carbonate rocks in other areas of north-central Nevada, has not been recognized near the Carlin deposit. However, as much as 0.05 weight percent fine-grained dispersed barite is present in the carbonate rocks.

The $\delta^{34} \mathrm{~S}$ values of diagenetic pyrite in two samples from fresh unmineralized rocks of the Roberts Mountains Formation near the Carlin deposit were 11.7 and 14.3 permil (samples DSrm-1 and DSrm-2, respectively, table 31 ); Rye and others (1974) reported 11.4 permil. The sulfur isotope composition of the carbonaceous materials has not been determined. Thode and Monster (1965) indicated that the $\delta^{34} \mathrm{~S}$ values of $\mathrm{H}_{2} \mathrm{~S}$ derived from sulfur in such organic compounds as petroleum commonly are about 15 permil smaller than those of seawater sulfate.

Because the $\delta^{34} \mathrm{~S}$ value of seawater sulfate during deposition of the Roberts Mountains Formation was probably 25 to 30 permil (Holser and Kaplan, 1966), the $\delta^{34} \mathrm{~S}$ value of any $\mathrm{H}_{2} \mathrm{~S}$ derived from organic material would have been close to and indistinguishable from that of diagenetic pyrite. Attempts to leach $\mathrm{SO}_{4}{ }^{2-}$ from unaltered Paleozoic carbonate rocks near the deposit, which contain minor amounts of disseminated barite, were unsuccessful. However, bedded and disseminated barite in early Paleozoic carbonate rocks of Nevada (Rye and others, 1978) have average $\delta^{34} \mathrm{~S}$ values of 30 permil.

\section{HYDROTHERMAL SULFIDES AND BARITE}

Sulfur isotope data were obtained on hydrothermal pyrite in mineralized carbonate rocks (pyritic gold ore), in altered igneous dikes, and in quartz veinlets. The $\delta^{34} \mathrm{~S}$ values are: 4.2 and 16.1 permil for hydrothermal pyrite in the ore (samples 6955-Le and 6956-Lb, respectively, table 31), 9.7 permil for pyrite in mineralized altered igneous dikes (sample 3523-M), and 15.4 permil for pyrite in auriferous quartz veinlets (sample Q-A). Although small amounts of diagenetic pyrite were present in hydrothermal-pyrite concentrates from the pyritic gold ore, this original pyrite makes up less than 10 percent of the concentrate. The range in $\delta^{34} \mathrm{~S}$ values for hydrothermal pyrite is consistent with a common sulfur source for both the disseminated pyrite in the ore and the pyrite in quartz veins and dikes.

Information on the distribution of barite veins and the occurrences of sulfide and sulfosalt minerals associated with the barite veins was presented in previous sections of this report. The $\delta^{34} \mathrm{~S}$ values of barite in veins range from 27.8 to 31.7 permil (table 31); no significant differences exist in the $\delta^{34} \mathrm{~S}$ values of barite between or within the West and Main ore zones. The $\delta^{34} \mathrm{~S}$ values of barite at Carlin correspond closely to those of 25 to 32 permil for barite in the disseminated-replacement gold deposits at Getchell, White Caps, Cortez, Northumberland, Blue Star, Bootstrap, and Jerrett Canyon, Nev., and at Mercur, Utah (A. S. Radtke, R. O. Rye, and F. W. Dickson, unpub. data, 1977).

Sphalerite-galena pairs suitable for the sulfur isotope fractionation necessary to determine temperatures of deposition have not been found in the deposit. However, temperatures of deposition for the barite veins may be calculated from the $\delta^{34} \mathrm{~S}$ data on barite-galena and baritesphalerite mineral pairs. These temperatures (table 31 ) range from $270^{\circ}$ to $305^{\circ} \mathrm{C}$, according to the data of Rye and Ohmoto (1974) and Ohmoto and Rye (1979), and from $251^{\circ}$ to $288^{\circ} \mathrm{C}$, using the newer experimental data of Sakai and Dickson (1978). These values are in excellent agreement with filling temperatures measured on fluid inclusions in vein barite and associated quartz and sphalerite. Studies by Igumnov (1976) and Sakai and Dickson (1978) indicate that both the total sulfur concentration and the $\mathrm{pH}$ affect the rate of isotopic exchange between sulfide and sulfate in solution. Equilibration at $300^{\circ} \mathrm{C}$ would take place over a few days to several months in solutions equimolar in sulfide and sulfate and with total sulfur concentrations of 500 to $1,000 \mathrm{ppm}$ at a $\mathrm{pH}$ of 4 to 5 (neutral $\mathrm{pH}$ is 5.6 at $300^{\circ} \mathrm{C}$ and $100 \mathrm{MPa}$ [1,000 bars]); such solutions would require about 1,000 years to reach equilibrium at $250^{\circ} \mathrm{C}$.

\section{ORIGIN OF THE SULFUR}

Most of the sulfur in the Carlin deposit occurs as sulfide sulfur in hydrothermal pyrite in carbonate rocks within the ore bodies; smaller amounts occur as sulfates, mostly in barite veins. The sulfide sulfur and probably the sulfate sulfur have $\delta^{34} \mathrm{~S}$ values corresponding closely to those of diagenetic pyrite and to those expected for disseminated barite in sedimentary carbonate rocks around and below the deposit.

Any discussion of the origin of the sulfur in the deposit requires that the sulfur isotope values be interpreted in terms of the $\delta^{34} \mathrm{~S}$ values in the hydrothermal fluids during deposition of the sulfide minerals and, in turn, for equilibrium conditions requires a knowledge of the physicochemical environment of ore deposition, including such variables as the temperature, $\mathrm{pH}$, and oxygen fugacity $\left(f_{\mathrm{O} 2}\right)$ of the ore fluids (Ohmoto, 1972). Fluid inclusions indicate temperatures of $175^{\circ}$ to $200^{\circ} \mathrm{C}$ during the main stage of hydrothermal mineralization and of $275^{\circ} \mathrm{C}$ or higher during barite vein formation. The presence of sericite and kaolinite in the unoxidized ores and the dissolution of calcite 
suggest mildly acidic conditions. The presence of hydrocarbon compounds in the country rocks and in the hydrothermal fluids indicates that the $f_{\mathrm{O} 2}$ of the fluids was low. At equilibrium, under reducing conditions, the $\mathrm{H}_{2} \mathrm{~S}$ / $\mathrm{SO}_{4}{ }^{2-}$ ratio in the hydrothermal solutions was high, and most of the sulfur was in solution as sulfide and had a $\delta^{34} \mathrm{~S}$ value of probably about 10 permil, a value that agrees well with that of diagenetic pyrite. Whether or not any of this sulfur could have come from sulfur in organic material or from disseminated sedimentary barite cannot be determined. The range of $\delta^{34} \mathrm{~S}$ values in hydrothermal pyrite suggests either mixing of sulfur sources or an isotopically heterogeneous source similar to most sedimentary sources. The average $\delta^{34} \mathrm{~S}$ value (about 30 permil) of barite in the veins at Carlin agrees closely with the range in $\delta^{34} \mathrm{~S}$ values (27-30 permil) of barite in eight other Carlin-type deposits (F. W. Dickson, A. S. Radtke, and R. O. Rye, unpub. data, 1977) and indicate a sedimentary origin for the sulfate sulfur (Dickson and others, 1975). The marked similarities between the $\delta^{34} \mathrm{~S}$ values of sulfate sulfur in these deposits suggest a remarkably common sulfur isotope geochemistry.

As discussed earlier, the $\delta^{34} \mathrm{~S}$ value of 30 permil for vein barite falls within the range of $\delta^{34} \mathrm{~S}$ values for bedded and disseminated barite widespread in the early Paleozoic section of north-central Nevada (Rye and others, 1978; R. O. Rye, unpub. data, 1979) and falls close to the $\delta^{34} \mathrm{~S}$ value for early Paleozoic seawater sulfate (Holser and Kaplan, 1966). The sulfate sulfur in barite in the deposit probably was derived from dispersed sedimentary barite in carbonate rocks below the deposit, and so its $\delta^{34} \mathrm{~S}$ content would not have been altered by isotopic exchange with sulfide sulfur in the hydrothermal system. Thus, the system may not have been at equilibrium, and the close agreement between isotopic temperatures calculated from sulfide-sulfate pairs in the veins (see table 14) and those measured on fluid inclusions in vein minerals could be fortuitous. Disequilibrium is not uncommon in hydrothermal systems below $350^{\circ} \mathrm{C}$ (Rye and Ohmoto, 1974).

Boiling of the hydrothermal solutions in fractures with silicified walls resulted in a preferential loss of $\mathrm{H}_{2} \mathrm{~S}$ and an enrichment in $\mathrm{SO}_{4}{ }^{2-}$ relative to $\mathrm{H}_{2} \mathrm{~S}$ in the fluids. This process could separate the sulfur species without changing the isotopic composition of either. The $\mathrm{pH}$ of the fluids in fractures during boiling would rise because of losses of both $\mathrm{H}_{2} \mathrm{~S}$ and $\mathrm{CO}_{2}$. Oxidation of $\mathrm{H}_{2} \mathrm{~S}$, in turn, would produce low-pH high- $f_{02}$ waters in the shallow acid-leached zone.

Small amounts of anhydrite occur in rocks near the surface, where the $\mathrm{SO}_{4}{ }^{2-}$ produced by oxidation of $\mathrm{H}_{2} \mathrm{~S}$ reacted with carbonate minerals. However, because most of this anhydrite was dissolved by low-temperature ground waters, no samples contained sufficient amounts of anhydrite for isotopic analysis. Because oxidation of
$\mathrm{H}_{2} \mathrm{~S}$ under near-surface conditions should occur without isotopic fractionation, the anhydrite formed in that way would have a $\delta^{34} \mathrm{~S}$ value of about 10 permil (Schoen and Rye, 1970).

Several conclusions may be drawn from the carbon and sulfur isotopic data:

1. Most of the carbon in the hydrothermal fluids was derived mainly from dissolution of host-rock carbonates. During acid-leaching oxidation, a considerable amounts of organic carbon was added to the shallow fluids in the upper part of the deposit.

2. The sulfur in the deposit was derived mostly from diagenetic pyrite in the underlying Paleozoic sedimentary rocks. The sulfur in late barite veins probably was derived from dispersed sedimentary barite.

3. Although temperatures as high as $305^{\circ} \mathrm{C}$, as implied by the isotopic compositions of sulfide-sulfate mineral pairs, agree with the fluid-inclusion data, this agreement may be fortuitous because the system was not at equilibrium.

4. Boiling of solutions in fractures with silicified walls separated $\mathrm{H}_{2} \mathrm{~S}$ from solution and concentrated $\mathrm{SO}_{4}{ }^{2-}$ relative to $\mathrm{H}_{2} \mathrm{~S}$ without changing the isotopic composition of either. Boiling of the vein fluids was accompanied by shifts in $\mathrm{pH}$ toward alkalinity.

\section{LEAD ISOTOPE DATA}

Lead isotope ratios in galena from barite veins in the Main ore zone, analyzed by B. R. Doe and M. H. Delevaux (written commun., 1968), were:

${ }^{206} \mathrm{~Pb} /{ }^{204} \mathrm{~Pb}=19.92, \quad{ }^{207} \mathrm{~Pb} /{ }^{204} \mathrm{~Pb}=16.04$, and ${ }^{208} \mathrm{~Pb} /$ ${ }^{204} \mathrm{~Pb}=40.10$. According to $\mathrm{B}$. $\mathrm{R}$. Doe, the vein barite contained the highest percentage of radiogenic lead thus far found in Nevada. These isotopic ratios fall within the range of values for lead in rocks of the Roberts Mountains Formation and exceed those in Cenozoic igneous rocks of Nevada. B. R. Doe concluded that all, or at least part, of the lead was derived from the Roberts Mountains Formation.

\section{GENESIS OF THE DEPOSIT}

The geologic, mineralogic, and geochemical data presented in earlier sections of this report provide a framework for establishing a model for the genesis of the Carlin gold deposit. The Carlin deposit formed during the Tertiary as a consequence of interrelated geologic processes, including basin-and-range faulting, igneous activity (volcanism), and hydrothermal processes. The probable sequence of events is summarized diagrammatically in figure 48.

The characteristic features of rocks enclosing thermalspring systems, and the similarities between many of 

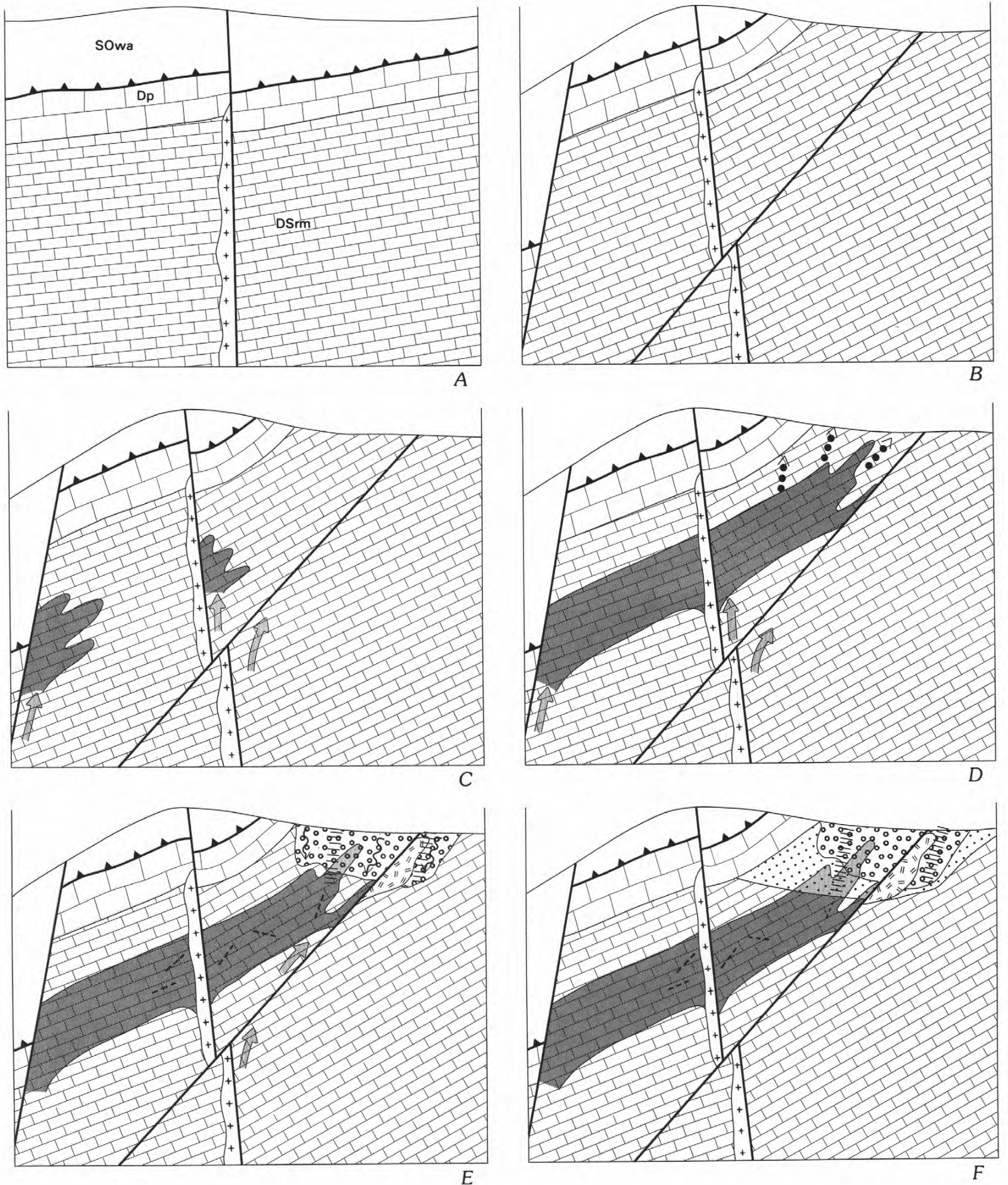
these systems and epithermal ore deposits, have been discussed in numerous reports, including those by White and Brannock (1950), White (1955, 1957a, 1957b, 1965), Schoen and White (1965), Dickson and Tunell (1968), Weissberg (1969), and Browne and Ellis (1970). Hausen and Kerr (1968) stated that the Carlin deposit formed under low-temperature conditions, possibly in the depths of a thermal-spring system. All the available data support this conclusion and indicate that the deposit formed from low-temperature hydrothermal fluids under physical and chemical conditions similar to those in many hot-springs systems.

Igneous activity during Tertiary time provided the heat source, and the hydrothermal fluids probably were almost entirely waters of meteoric origin, although a small and undetected amount of magmatically derived fluids cannot be ruled out. Although most, possibly all, of the elements transported in the ore fluids could have been leached from sedimentary carbonate rocks at deeper levels below the deposit (Dickson and others, 1978), ore components could also have been leached from igneous rocks at depth. Possible source rocks would include the lower part of the Roberts Mountains Formation, the Hanson Creek Formation, the units in the Pogonip Group, the Hamburg Dolomite, and shale or graywacke sandstone in the deep basement.

Hydrothermal fluids passed upward through the source rocks, leached out ore and gangue components, and exited along high-angle normal faults and breccia zones. Important channels for the movement of fluids include faults formed before the emplacement of Late Jurassic and Early Cretaceous igneous dikes, as well as faults associated with basin-and- range tectonism. Although hydrothermal activity was widespread in a general eastwest direction across the range, most of the hydrothermal fluids were guided into favorable horizons near the crest of the Tuscarora Mountains anticline.

\section{ORIGIN AND MOBILIZATION OF ORE COMPONENTS}

The source of the hydrothermal fluids probably was trapped formational or connate water, ranging in salinity from 1 to more than 3 equivalent-weight percent $\mathrm{NaCl}$, that was heated to $350^{\circ} \mathrm{C}$ or higher by igneous processes.

Figure 48.-Genetic evolution of Carlin gold deposit. A, Geologic conditions at close of Mesozoic time. Carbonate rocks of the Roberts Mountains Formation (DSrm) and the Popovich Formation (Dp) are in lower plate, and siliceous rocks (SOwa) are in upper plate above Roberts Mountains thrust. Igneous dikes (crosses) of Late Jurassic and Early Cretaceous age intrude along earlier faults. $B$, Uplift and high-angle normal faulting accompany basin-andrange tectonism during early Tertiary time. $C$. Initial hydrothermal activity. Ore bodies (dark gray) are formed from fluids rising (gray arrows) along faults and replacing carbonate rocks. $D$. Upwelling fluids (gray arrows) reach shallowdepths and boil
The hot fluids were in contact with sedimentary carbonate rocks containing calcite, dolomite, quartz, illite, pyrite, carbonaceous materials, detrital minerals, and minor amounts of barite. Because of the absence of oxygen and the presence of organic material, the environment must have been strongly reducing. The solutions would tend toward saturation with regard to calcite, dolomite, quartz, illite, and pyrite (also barite, if sufficient amounts were present). Much of the sulfate would be reduced to sulfide by the action of organic material; the solutions would be neutral to weakly alkaline because of reaction with carbonate minerals. These slightly alkaline solutions, charged with sulfur compounds, would react with gold, mercury, arsenic, and antimony in the source rocks and form sulfide and bisulfide complexes. Presumably, thallium would also dissolve in these solutions, although the precise mechanism is not understood. This is the set of components needed to form a Carlin-type gold deposit.

The hydrothermal fluids contained sulfide and sulfate sulfur, hydrocarbons, and lead leached from the sedimentary carbonate rocks, and transported aluminum, silica, potassium, iron, barium, and carbon dioxide. The solutions also contained gold, arsenic, antimony, thallium, mercury, copper, lead, and zinc. The paucity of chloride in the solutions would tend to preclude the transport of significant amounts of copper, lead, zinc, or silver.

In a preliminary effort to evaluate the conditions of extraction, Dickson and others (1977) reacted powdered fresh silty carbonaceous calcareous dolomite from the base of the Roberts Mountains Formation with a solution containing 1 equivalent-weight percent $\mathrm{NaCl}$ at $275^{\circ} \mathrm{C}$ and $50 \mathrm{MPa}$ (500 bars) in Dickson-type hydrothermal equipment for 3 days. The resulting solutions contained: 4,400 ppm $\mathrm{CO}_{2}, 750$ ppm $\mathrm{SiO}_{2}, 750$ ppm K, 500 ppm Ca, 25 ppm $\mathrm{Ba}, 10 \mathrm{ppmMg}, 5 \mathrm{ppm} \mathrm{Sr}, 5 \mathrm{ppm} \mathrm{B}, 1.5 \mathrm{ppm} \mathrm{Fe}$, and 0.5 ppm Al, as well as 2.5ppmAs, 1.0 ppm Sb, 0.05 ppm $\mathrm{Hg}$, $0.05 \mathrm{ppm} \mathrm{Tl}$, and $0.03 \mathrm{ppm} \mathrm{Au}$. The $\mathrm{CO}_{2}$-free solution had a $\mathrm{pH}$ of 5 under ambient conditions and contained 2 to 3 ppm $\mathrm{H}_{2} \mathrm{~S}$. The experimental results show that even at $275^{\circ} \mathrm{C}$ and $50 \mathrm{MPa}$ (500 bars), a fluid can be formed that would contain the components necessary to produce a Carlin-type gold deposit. If its temperature had dropped to $175^{\circ} \mathrm{C}$, the solution would have been supersaturated with regard to quartz, pyrite, and gold, and also presumably arsenic, antimony, mercury, and thallium compounds.

(heavy dots). Ore bodies (dark gray) continue to form, and early jasperoid bodies (double dashes) form along faults. $E$, Strongly acidic solutions move down (wiggly arrows) and leach and oxidize ores (light gray) and host rocks; circles denote zone of acid leaching. Barite veins (rows of dashes) extend downward from surface through acid-leached zone and deeper rocks. Jasperoid bodies (double dashes) continue to form, and late sulfide minerals (triple dashes) are deposited. F, Final geologic conditions, showing rocks and ores affected by posthydrothermal late supergene oxidation (light dots). 
Numerous other experimental studies of the reaction between silty carbonaceous calcareous dolomite and $\mathrm{H}_{2} \mathrm{O}$, $\mathrm{NaCl}-\mathrm{H}_{2} \mathrm{O}$, and $\mathrm{NaCl}-\mathrm{Na}_{2} \mathrm{~S}-\mathrm{H}_{2} \mathrm{O}$ solutions have confirmed that these rocks, which contain amounts of minor elements near the average crustal abundances (Turekian and Wedepohl, 1961), are an excellent source for the ore metals in Carlin-type gold deposits (F. W. Dickson and A. S. Radtke, unpub. data, 1978; Dickson and others, 1978, 1979).

In summary, the hot meteoric-water ore solution at $350^{\circ} \mathrm{C}$ and $100 \mathrm{MPa}(1,000$ bars) would be saturated with regard to calcite, quartz, magnesium silicate, pyrite, and possibly barite, and would contain large amounts of silica, important amounts of iron and sulfide sulfur, and minor amounts of barium, gold, and the other heavy metals. The sulfide/sulfate ratio in solution would be large, owing to the low $f_{\mathrm{O} 2}$; the $\delta^{34} \mathrm{~S}$ value of sulfide sulfur would be close to that of diagenetic pyrite (10-13 permil); and the $\delta^{34} \mathrm{~S}$ value of sulfate sulfur ( 24 permil) would be determined by equilibrium with sulfide sulfur at $350^{\circ} \mathrm{C}$.

Taking into account total content of gold in the deposit, taking $0.03 \mathrm{ppm}$ as the gold content in the source carbonate rocks, and assuming 90-percent extraction, $5 \times 10^{9}$ t or about $0.3 \mathrm{mi}^{3}$ of sedimentary carbonate source rock would have been required to supply the gold in the deposit. The ratios of the contents of gold, mercury, arsenic, and antimony in mineralized relative to nonmineralized rocks of the Roberts Mountains Formation range from 150 to 300 , and so apparently all these metals could have been supplied from the same volume of rock.

If most of the components in the deposit were removed from deeper sedimentary units by a hot weakly saline fluid, then probably only small amounts of the base-metal elements were removed and transported in the solutions. Enrichment factors for copper, lead, zinc, and molybdenum range from 2 to 10 .

Igneous rocks at depth, including late Mesozoic hypabyssal plutonic and Tertiary volcanic rocks, may also have been a source of ore components. Circulating solutions may well have moved through the hot consolidated Tertiary igneous rocks, altered them, and extracted the ore components. No data are available, and no water-rock interaction studies have been performed to date, on igneous rocks near the Carlin deposit.

\section{MIGRATION OF FLUIDS}

Waters in rocks close to the igneous heat source would have been heated and risen because of lower density, moved through appropriate source rocks, exchanged components, and become ore solutions. These solutions would have moved upward relatively rapidly along steeply dipping faults and fractures and into near-surface zones. The solutions would have cooled as they rose and mixed with other waters, spread out through favorable

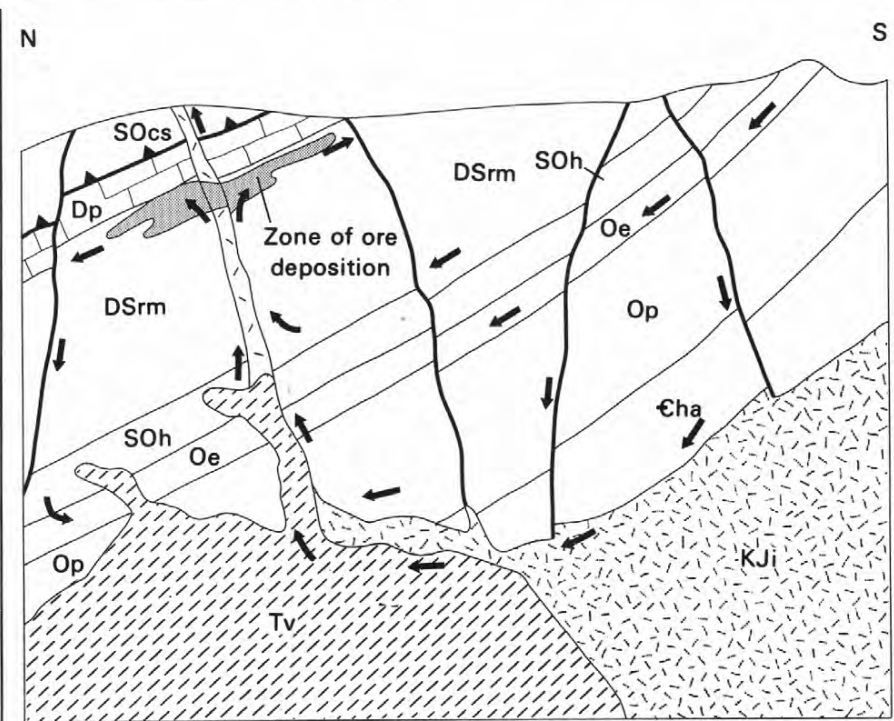

FIGURE 49.-Hydrothermal system inferred for formation of Carlin gold deposit. Arrows show paths of solution movement. Dp, Popovich Formation; DSrm, Roberts Mountains Formation; KJi, quartz diorite, diorite, and granodiorite; Oe, Eureka Quartzite; eha, Hamburg Dolomite; Op, Poponip Group; SOcs, chert and shale; SOh, Hanson Creek Formation; Tv, Tertiary volcanic rocks.

beds and moved laterally near the ground-water table, and deposited ore components. Colder surficial water would have moved downward to replace the heated upward-moving fluids, and a circulating hydrothermal system (cell), similar to those reported in New Zealand (Elder, 1965) and inferred at Steamboat Springs, Nev. (White and others, 1964), would have been formed. The circulating solutions may have passed through hot consolidated igneous rocks and altered and exchanged components with them.

Figure 49 presents a generalized cross section illustrating the structural and stratigraphic setting and the proposed hydrothermal system at Carlin. In addition to breccia zones along faults, the highly fractured and brecciated permeable Eureka Quartzite would have been an excellent unit to facilitate deep recharge by shallow meteoric waters.

\section{HYDROTHERMAL ORE DEPOSITION}

Early-stage hydrothermal fluids dissolved calcite and deposited quartz. Main-stage fluids introduced silicon, aluminum, potassium, barium, iron, sulfur, and organic material, as well as gold, arsenic, antimony, mercury, and thallium; calcite continued to be removed or replaced; and pyrite and potassic clays were formed. The remnant calcite was extensively recrystallized and exchanged with the ore fluids; little exchange occurred between host-rock dolomite and the ore fluids. Late main-stage fluids introduced sulfide and sulfosalt minerals containing arsenic, 
antimony, mercury, and thallium, and late-stage fluids introduced base-metal sulfide minerals of lead, zinc, and copper. Most of the base-metal minerals were deposited late in the period of solution boiling and acid-leaching alteration. Temperatures and salinities of the fluids during the main stage of hydrothermal mineralization ranged from about $175^{\circ}$ to $200^{\circ} \mathrm{C}$ or greater and from 2 to 4 equivalent-weight percent $\mathrm{NaCl}$, respectively. Experimental studies show that the fluids transported large amounts of $\mathrm{CO}_{2}$. This suggests that the ore fluids in open fractures in areas of ore deposition could have been at much higher temperatures, perhaps oveŕ $300^{\circ} \mathrm{C}$.

Under the strong influence of lower temperatures and, to a lesser degree, because of lower pressures, the hydrothermal fluids in the areas of ore deposition were highly supersaturated with regard to quartz, pyrite, and gold and other heavy elements, and undersaturated with regard to calcite. The presence of $\mathrm{CO}_{2}$ and $\mathrm{H}_{2} \mathrm{~S}$ caused the solutions to remain somewhat acidic, and reducing conditions controlled by dissolved hydrocarbons precluded any appreciable increase in $f_{\mathrm{O} 2}$ (Radtke and others, 1980). With decreasing temperatures, the solutions were able simultaneously to dissolve out calcite and deposit quartz, pyrite, gold, and the associated elements.

Using data on the amounts of silica, barium, pyrite, gold, and mercury introduced by the ore solutions to form the deposit (table 32), and the known or estimated solubilities of quartz, barite, pyrite, gold, and cinnabar in low-sulfur $1-\mathrm{m} \mathrm{NaCl}$ solution over the temperature range $200^{\circ}-350^{\circ} \mathrm{C}$, the amount of fluid in the main hydrothermal stage can be estimated. The calculated amount of solution required ranges from 2.9 billion $t$ for quartz to 0.7 billion $t$ for barite, and averages 1.2 billion $t$. The large amount of aluminum apparently introduced is not readily explainable from known solubility data on the element; no data are available on aluminum solubility in acidic saline solutions at elevated temperatures. The solutions might have passed through a strongly acidic phase at elevated temperatures, or else $\mathrm{H}_{2} \mathrm{~S}-\mathrm{CO}_{2}$ solutions may be sufficiently acidic to dissolve and transport more aluminum at higher temperatures than is presently known. However, the mechanisms for transport and deposition of aluminum in the Carlin deposit are poorly understood. It is difficult to establish the length of time involved in the main stage of hydrothermal mineralization at Carlin. Using the total flow rate at Steamboat Springs, Nev., estimated by White (1967) at $4 \mathrm{~m}^{3} / \mathrm{min}$ or approximately 2 million t/yr, the fluid flow required during ore deposition would take place in about 500 years. Using a fluid flow rate one-tenth that at Steamboat Springs $\left(0.4 \mathrm{~m}^{3} / \mathrm{min}\right)$, only 5,000 years would be required, considerably less time than the $1 \mathrm{~m} . \mathrm{y}$. suggested by Silberman and others (1979) as the duration of major hydrothermal episodes.
TABLE 32.-Amounts of solution required to transport selected ore components within the Carlin gold deposit

\begin{tabular}{|c|c|c|c|c|}
\hline Sample & $\begin{array}{l}\text { Average content } \\
\text { introduced } \\
(\mathrm{ppm})\end{array}$ & $\begin{array}{l}\text { Total amount } \\
\text { in deposit } \\
\text { (t) }\end{array}$ & $\begin{array}{c}\text { Solubility } \\
\text { difference } \\
\text { between } 200^{\circ} \\
\text { and } 350^{\circ}(\mathrm{ppm})\end{array}$ & $\begin{array}{l}\text { Amount of } \\
\text { transport fluid } \\
\text { required } \\
\text { (billion } \mathrm{t} \text { ) }\end{array}$ \\
\hline $\mathrm{SiO}_{2} \ldots \ldots$ & 132,000 & 2 million & 1700 & 2.9 \\
\hline $\mathrm{FeS}_{2}$ & 15,000 & 225,000 & 2300 & .8 \\
\hline $\mathrm{Ba}$ (in ore) ............ & 300 & 4,500 & ${ }^{3} 6$ & .7 \\
\hline $\mathrm{Hg}$ & 25 & 380 & ${ }^{4} .50$ & .8 \\
\hline $\mathrm{Au}$ & 7 & 100 & ${ }^{5} .10$ & 1.0 \\
\hline 1.viciag & & & & \\
\hline $\mathrm{Ba}$ (in veins) $\ldots .$. & --- & 150,000 & --- & 20 \\
\hline $\mathrm{Al}$ (in ore) ............ & 19,000 & 300,000 & 6250 & 20 \\
\hline
\end{tabular}

Quartz solubilities of Kennedy (1950).

Pyrite solubilities of J. J. Rytuba and F. W. Dickson (unpub. data. 1974).

${ }^{3}$ Barite solubilities of Blount (1977).

+ Cinnabar solubilities of Dickson and Tunell (1968).

"Gold solubilities of Seward (1973) and J.J. Rytuba and F. W. Dickson (unpub. data, 1974).

${ }^{6}$ Calculated on basis of average amount of transport fluid ( 1.2 billion $\left.t\right)$.

\section{LATE-STAGE VEINS}

The main episode of ore deposition was terminated, at least in the upper part of the deposit, by a rise in temperature of the ore fluids to as high as $275^{\circ}$ to $300^{\circ} \mathrm{C}$ that resulted in widespread boiling of the fluids and coincided with the formation of barite veins. Boiling of the fluids increased the salinity to as high as 17.4 equivalent- weight percent $\mathrm{NaCl}$ and the $\delta^{18} \mathrm{O}$ value to as much as 11.5 permil. Loss of $\mathrm{H}_{2} \mathrm{~S}$ during boiling led to the production of $\mathrm{H}_{2} \mathrm{SO}_{4}$ in the upper part of the deposit and to the subsequent intense acid leaching and oxidation of ores and surrounding rocks in an upper zone. Within that zone, calcite and large amounts of dolomite were removed, sulfides and organic compounds were oxidized, kaolinite and anhydrite were formed, and silica was added. Some of the calcite may have been reprecipitated to form the abundant veinlets above the acid-leached zone. Since the boiling event, the upper part of the ore deposit has continued to undergo weak oxidation and removal of nearly all the anhydrite by surface waters.

Boiling would cause important changes in fluid-flow patterns as well as in the physical and chemical conditions in the deposit (fig. 50). Solutions in the rocks would move toward the open channels, and $\mathrm{CO}_{2}, \mathrm{H}_{2} \mathrm{~S}$, and steam would move upward along the channels to vent at the surface or at the ground-water table. The losses of gas and liquid from the system would lower the pressure, and the resulting increase in the rate of solution flow from depth would permit hotter fluids to reach higher levels and, in turn, cause boiling at deeper levels. Boiling and the rapid flow rate would probably continue until a sufficient amount of solution had moved out of the deep high-temperature region to relieve the excess pressures. The volume of fluid that passed through the system during that period could have been much larger than during the main hydrothermal stage. 


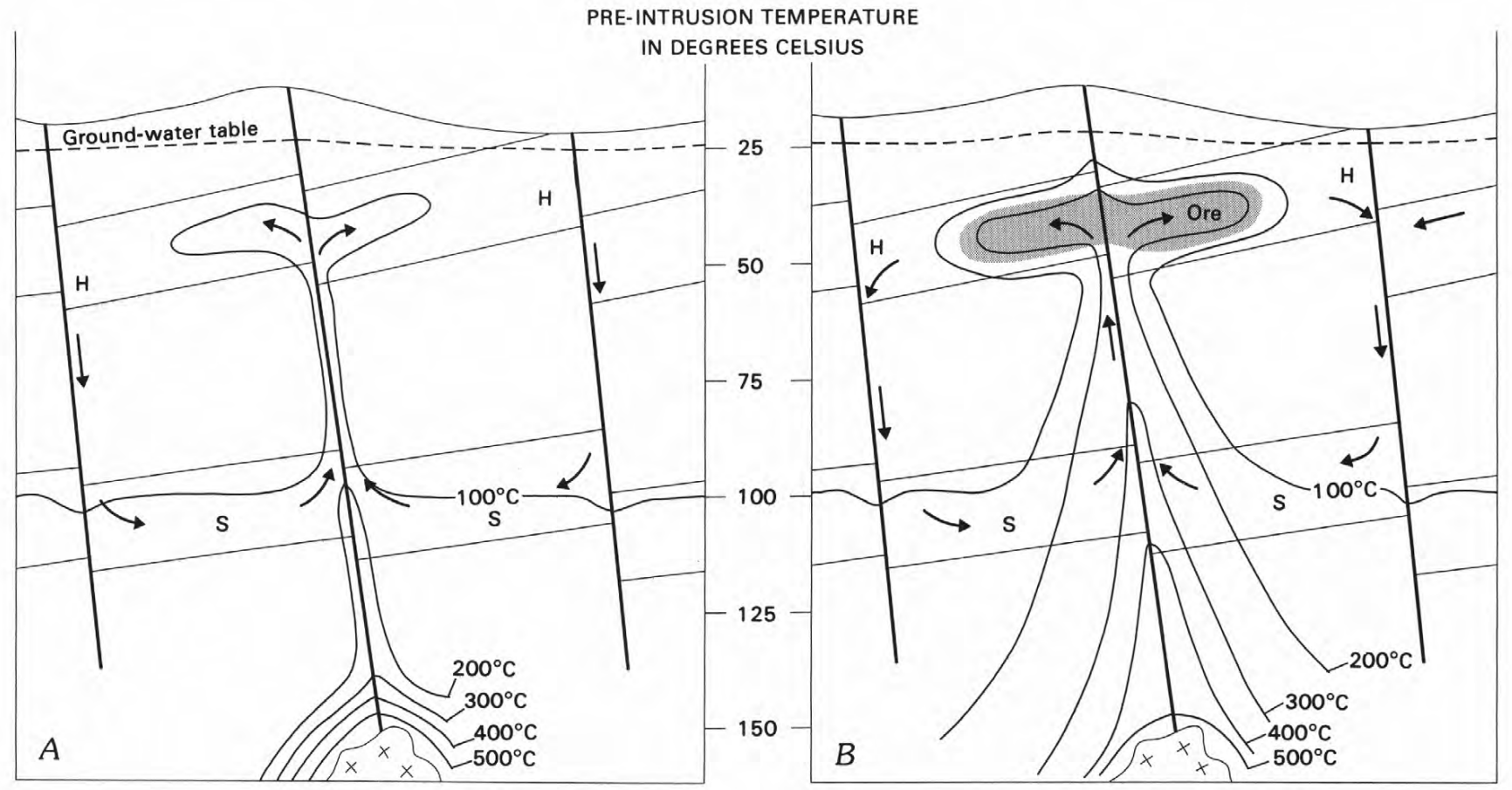

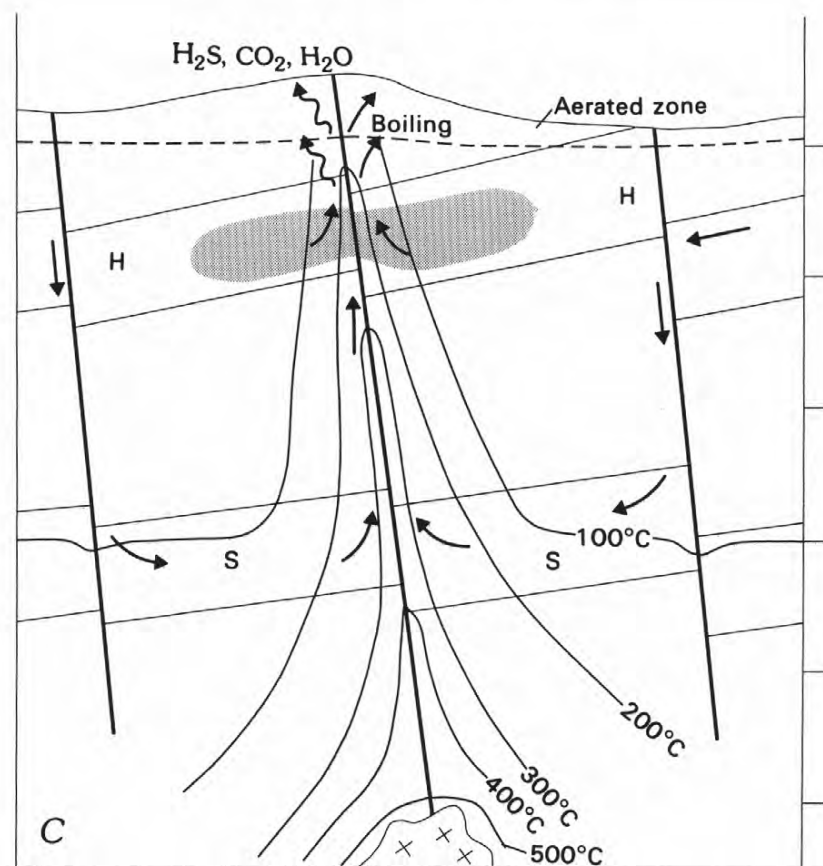

Figure 50.-Hydrothermal evolution of Carlin gold deposit. Tertiary intrusion (X's) at shallow depth provides heat to meteoric solutions. Light lines, thermal isograds; $\mathrm{S}$, source rocks for ore and gangue components; $\mathrm{H}$, host rocks favorable for ore deposition. $A$, Early hydrothermal stage, with initial penetration of host rocks by low-temperature fluids. Arrows show solution paths (stage 1). B. Main hydrothermal stage accompanying ore deposition. Dotted areas denote ore bodies. Solutions rise along faults, spread laterally through hostrocks below cold surface waters and

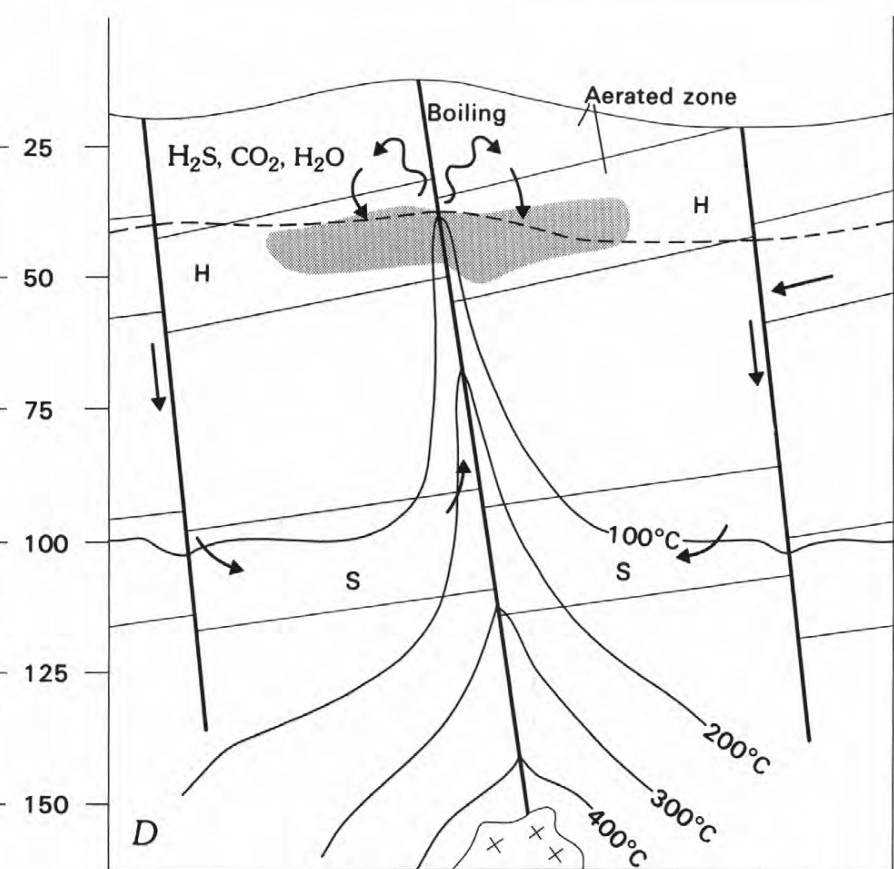

create typical mushroom-shaped convection cell (stage 2). C. Early acid-leaching oxidation. Wiggly arrows represent vapors driven off by solution boiling. Note high-level penetration of hot fluids that punch through cold near-surface waters. Fluids in ores and host rocks move toward open faults (early stage 3 ). $D$. Acid leaching accompanying lowering of ground-water table and retreat of higher temperature isograds near close of period of hydrothermal activity (late stage 3). 
The $\mathrm{H}_{2} \mathrm{~S}$ driven off by boiling would have been oxidized to $\mathrm{H}_{2} \mathrm{SO}_{4}$ in the aerated zone or by mixing with oxygenated ground waters, and the $\mathrm{H}_{2} \mathrm{SO}_{4}$, in turn, would have attacked the country rocks and the shallow parts of previously mineralized zones. The amount of acid required for leaching, generated by oxidation of $\mathrm{H}_{2} \mathrm{~S}$, is about 3 equivalents $\mathrm{H}^{+}$per kilogram of ore (the relatively small amount of acid generated by oxidation of $\mathrm{FeS}_{2}$ is not included), or $3 \times 10^{9}$ equivalents $\mathrm{H}^{+}$per million tons. Converted to equivalent hydrogen sulfide, about $7.5 \times 10^{9}$ equivalents $\mathrm{H}_{2} \mathrm{~S}$ would have been needed, or 255 million $t \mathrm{H}_{2} \mathrm{~S}$ total; this amount of $\mathrm{H}_{2} \mathrm{~S}$ would be contained in 2.55 billion $\mathrm{t}$ of solution if the $\mathrm{H}_{2} \mathrm{~S}$ content were as high as 100 $\mathrm{ppm}$. Natural solutions probably range from 1 to $200 \mathrm{ppm}$ $\mathrm{H}_{2} \mathrm{~S}$, and 3 billion $\mathrm{t}$ of solution is a minimal estimate if the solution contained as much as $100 \mathrm{ppm} \mathrm{H}_{2} \mathrm{~S}$. The actual amount of solution would be even larger from another consideration because the estimated weight of leached rock includes only acid-leached ore and not the more extensive zone of acid-leached unmineralized rocks at least threefold larger. Therefore, a conservative estimate of the total mass of fluid that traversed the rocks is 10 billion $t$. Thus, the amount of latestage vein-forming fluids would have been tenfold greater than the amount of main-stage ore-depositing fluids ( 1 billion $\mathrm{t}$ ).

The veins in the Carlin deposit contain about $150,000 \mathrm{t}$ of barite. The amount of fluid required to transport this amount of $\mathrm{BaSO}_{4}$, using a difference in solubility between $350^{\circ} \mathrm{C}(58 \mathrm{ppm})$ and $250^{\circ} \mathrm{C}(52 \mathrm{ppm})$ of $6 \mathrm{ppm}$ in a $1-\mathrm{m} \mathrm{NaCl}$ solution, would be about 25 billion $t$, in close agreement with the conservative value of 10 billion $t$ determined from the amount of $\mathrm{H}_{2} \mathrm{SO}_{4}$ needed for acid leaching.

The $\mathrm{pH}$ of the hydrothermal solutions would shift toward less acidic conditions in response to the losses of $\mathrm{H}_{2} \mathrm{~S}$ and $\mathrm{CO}_{2}$. In shallower parts of the conduits under low pressures, the amount of $\mathrm{CO}_{2}$ in solution would have decreased, and calcite would have been deposited. At greater depth, a moderate amount of $\mathrm{CO}_{2}$ was held in solution by higher pressures, and the solutions were sufficiently acidic to preclude deposition of calcite and other carbonate minerals.

The erratic distribution of sulfide and sulfosalt minerals in deeper parts of barite veins and as fillings in fractures at depth, the close spatial association of phases with incompatible compositions, and the apparent separation of base-metal from heavy-metal sulfides indicate that the metallic-sulfide contents of the fluids varied over time and space. The deposition of sulfide and sulfosalt minerals was probably controlled by a combination of factors, including changes in ionic strength and $\mathrm{pH}$ due to boiling, and supersaturation due to temperature decreases.

\section{SUMMARY OF PROGESSES}

The Carlin gold deposit formed as a result of hydrothermal fluids of meteoric origin, heated by Tertiary igneous activity, moving through and reacting with thin- bedded carbonate rocks in a zone of cold ground waters. The process may be divided into four stages: (1) early hydrothermal activity, (2) main hydrothermal mineralization, (3) late hydrothermal acid-leaching oxidation, and (4) posthydrothermal late supergene oxidation. Stages 1 through 3 are illustrated diagrammatically in figure 50 .

\section{STAGE 1}

Increases in the rate of convective heat transfer from the volcanic source region caused the temperature of fluids in deep zones and along channels to rise. The early low- temperature hydrothermal fluids encountered and penetrated the lower part of a mass of shallower cold waters, and spread out laterally through thin-bedded carbonate rocks. The initial solutionswhich were weakly undersaturated with regard to calcite and mildly supersaturated with regard to quartz, dissolved out small amounts of calcite and deposited lesser amounts of quartz (fig. 50 A).

\section{STAGE 2}

Main-stage hydrothermal processes began as hotter fluids containing larger amounts of ore components moved into and through the host rocks (fig. $50 \mathrm{~B}$ ). The flow rate of the hydrothermal solutions probably increased in response to decreases in fluid viscosity at the higher temperatures.

\section{STAGE 3}

The onset of boiling signaled the end stage of hydrothermal activity, and the processes that operated during boiling differed from those during stage 2 . The flow regime of the fluids changed as solutions tended to move toward open channels, and the chemical composition of the fluids continued to evolve (fig. $50 \mathrm{C}$ ). The boiling solutions deposited only small amounts of silica and pyrite and little, if any, gold.

Veins of barite, calcite, and barren quartz formed locally in open fractures; elsewhere, boiling solutions opened channels that enhanced the rapid flow of solutions tenfold above that during stage $2 . \mathrm{H}_{2} \mathrm{SO}_{4}$, formed by oxidation of $\mathrm{H}_{2} \mathrm{~S}$, leached about 5 million $\mathrm{t}$ of ore and 15 million $\mathrm{t}$ of country rock.

Fluctuations in the ground-water table affected the rocks under attack by acidic solutions. These solutions leached out carbonate minerals and small amounts of 
kaolinite, alunite, anhydrite, gypsum, and quartz formed when the water table was low, and $\mathrm{CaSO}_{4}$ and other relatively soluble phases when the ground-water level rose. The overall effect was to create a permeable, porous rock composed of remnant detrital silt and fine-grained hydrothermal quartz, clay, remnant dolomite, and very minor calcite, from which the hydrocarbon compounds and pyrite were oxidized and removed.

Ground waters interacted with the hydrothermal fluids during this stage. As the hydrothermal system faded (fig. $50 \mathrm{D}$ ), ground waters and low-temperature surficial processes dominated the system. Stage 3 may have lasted about 50,000 years, about as long as stage 2 .

\section{STAGE 4}

Ground waters and descending surface waters containing atmospheric oxygen interacted with shallow rocks after the hydrothermal activity ceased. The overall effect of these late processes was minor and included the partial oxidation of some sulfides and carbonaceous materials in unleached rocks and the removal of minor amounts of calcite. Extension of the zone of late supergene alteration below the acid-leached zone indicates that the water table continued to fall after the hydrothermal episode ceased.

\section{REFERENGES GITED}

Akright, R. L., Radtke, A. S., and Grimes, D. J., 1969, Minor elements as guides to gold in the Roberts Mountains Formation, Carlin gold mine, Eureka County, Nevada, in Canney, F. C., ed., International Geochemical Exploration Symposium, Golden, Colo., 1968, Proceedings: Colorado School of Mines Quarterly, v. 64 , no. 1 , p. $49-66$.

Axelrod, D. I., 1939, Late Tertiary vegetation and climate of the Great Basin and border areas [abs.]: Geological Society of America Bulletin, v. 50 , no. 12 , pt. 2, p. 1945-1946.

-1966, The Eocene Copper Basin flora of northeastern Nevada: University of California Publications in Geological Sciences, v. $59,125 \mathrm{p}$.

Bailey, G. B., 1974, The occurrence, origin, and economic significance of gold-bearing jasperoids in the central Drum Mountains, Utah: Stanford, Calif., Stanford University, Ph. D. thesis, 300 p.

Berry, W. B. N., and Roen, J. B., 1963, Early Wenlock graptolites from Roberts Mountains Formation, Tuscarora Mountains, Nevada: Journal of Paleontology, v. 37, no. 5, p. 1123-1126.

Blixt, J. E., 1933, Geology and gold deposits of the North Moccasin Mountains, Fergus County, Montana: Montana Bureau of Mines and Geology Memoir 8, 25 p.

Bohac, P., Bronnimann, E., and Gaumann, A., 1974, On the ternary compound $\mathrm{TlSbS}_{2}$ and its photoelectric properties: Materials Research Bulletin, v. 9, no. 8, p. 1033-1039.

Botinelly, Theodore, Neuerburg, G. J., and Conklin, N. M., 1973, Galkhaite, $(\mathrm{Hg}, \mathrm{Cu}, \mathrm{Tl}, \mathrm{Zn})(\mathrm{As}, \mathrm{Sb}) \mathrm{S}_{2}$, from the Getchell mine, Humboldt County, Nevada: U.S. Geological Survey Journal of Research, v.1, no.5, p. 515-517.

Bottinga, Yan, 1968, Calculation of fractionation factors for carbon and oxygen isotopic exchange in the system calcite-carbon dioxide-water: Journal of Physical Chemistry, v. 72 , no. 3, p. $800-808$.
Bottinga, Yan, and Javoy, Marc, 1973, Comments on oxygen isotope geothermometry: Earth and Planetary Science Letters, v.20, no. 2 , p. $250-265$.

Browne, P. R. L., and Ellis, A. J., 1970, The Ohaki-Broadlands hydrothermal area, New Zealand: Mineralogy and related geochemistry: American Journal of Science, v. 269, no. 2, p. 97131.

Butler, B. S., Loughlin, G. F., Heikes, V. C., and others, 1920, The ore deposits of Utah: U.S. Geological Survey Professional Paper $111,672 \mathrm{p}$.

Chapman, P., 1976, Geology of the White Caps deposit [abs.], in Geology and exploration aspects of fine-grained, Carlin-type gold deposits: Geological Society of Nevada and Mackay School of Mines Symposium, Reno, Nev., 1976, Abstracts, p. 9.

Christ, C. L ., 1965, Substitution of boron in silicate crystals: Norsk Geologisk Tidsskrift, v. 45 , no. 4 , p. $423-428$.

Clayton, R. N., O'Neil, J. R., and Mayeda, T. K., 1972, Oxygen isotope exchange between quartz and water: Journal of Geophysical Research, v.77, no. 17, p. 3057-3067.

Cloke, P. L., and Kelly, W. C., 1964, Solubility of gold under inorganic supergene conditions: Economic Geology, v. 59, no. 2, p. 259-270.

Dickson, F. W., and Radtke, A. S., 1977, The unique mineralogy of $\mathrm{Hg}$-As-Sb-Tl sulfides at the Carlin gold deposit, Nevada, and implications as to the origin of the deposit [abs.]: Mineralogical Society of America-Friends of Mineralogy Joint Symposium on Crystal Growth and Habit, 3d, Tueson, Ariz., 1977, Abstracts, p. 13-14.

-1978, Weissbergite, $\mathrm{TlSb}_{2}$, a new mineral from the Carlin gold deposit, Nevada: American Mineralogist, v. 63, no. 7-8, p. 720-724.

Dickson, F. W., Radtke, A. S., and Peterson, J. A., 1979, Ellisite, $\mathrm{Tl}_{3} \mathrm{AsS}_{3}$, a new mineral from the Carlin gold deposit, Nevada, and associated sulfide and sulfosalt minerals: American Mineralogist, v. 64, no. 7-8, p. 701-707.

Dickson, F. W., Radtke, A. S., and Rye, R. O., 1975a, Implications of the occurrence of barium minerals and sulfur isotopic compositions of barite on late-stage processes in Carlin-type gold deposits [abs.]: Geological Society of America Abstracts with Programs, v.7, no. 5, p. 604-605.

Dickson, F. W., Radtke, A. S., and Seeley, J. L., 1977, The reaction of silty calcareous dolomite with $\mathrm{NaCl}-\mathrm{H}_{2} \mathrm{O}$ solution at $275^{\circ} \mathrm{C}$ and 500 bars, and implications as to the genesis of epithermal disseminated replacement type gold deposits [abs.], in Solid-fluid interactions: Mineralogical Society of Great Britain and Ireland Triennial Meeting, Leeds, England, 1977, Abstracts, p. 15.

Dickson, F. W., Radtke, A. S., Weissberg, B. G., and Heropoulos, Chris, 1975b, Solid solutions of antimony, arsenic, and gold in stibnite $\left(\mathrm{Sb}_{2} \mathrm{~S}_{3}\right)$ orpiment $\left(\mathrm{As}_{2} \mathrm{~S}_{3}\right)$, and realgar $\left(\mathrm{As}_{2} \mathrm{~S}_{2}\right)$ : Economic Geology, v. 70, no. 3, p. 591-594.

Dickson, F. W., Rye, R. O., and Radtke, A. S., 1978, The Carlin gold deposit: Product of an ancient geothermal system that extracted ore and gangue components from sedimentary rocks [abs.]: International Association on the Genesis of Ore Deposits Symposium, 5th, Alta, Utah, 1978, Programs and Abstracts, p. 82.

1979, The Carlin gold deposit as a product of rock-water interactions, in Ridge, J. D., ed., Papers on mineral deposits of western North America: Nevada Bureau of Mines and Geology Report 33, p. 101-108.

Dickson, F. W., and Tunell, George, 1968, Mercury and antimony deposits associated with active hot springs in the western United States, in Ridge, J. D., ed., Ore deposits of the United States, 1933-1967: (Graton-Sales volume) (1st ed.): New York, American Institute of Mining, Metallurgical, and Petroleum Engineers, v. 2, p. 1673-1701. 
Dixon, W. J., 1964, Biomedical computer programs: Los Angeles, University of California School of Medicine, Department of Preventive Medicine and Public Health, 585 p.

Dott, R. H., Jr., 1955, Pennsylvanian stratigraphy of Elko and northern Diamond Ranges, northeastern Nevada: American Association of Petroleum Geologists Bulletin, v. 39, no. 11, p. 2211-2305.

Elder, J. W., 1965, Physical processes in geothermal areas, in Lee, W. H. K., ed., Terrestrial heat flow: American Geophysical Union Geophysical Monograph 8, p. 211-239.

Emmons, W. H., 1910, A reconnaissance of some mining camps in Elko, Lander, and Eureka Counties, Nevada: U.S. Geological Survey Bulletin 408, 130 p.

Erickson, R. L., Marranzino, A. P., Oda, Uteana, and Janes, W. W., 1964a, Geochemical exploration near the Getchell mine, Humboldt County, Nevada: U.S. Geological Survey Bulletin 1198-A, p. A1A26.

Erickson, R. L., Masursky, Harold, Marranzino, A. P., Oda, Uteana, and Janes, W. W., 1964b, Geochemical anomalies in the lower plate of the Roberts thrust near Cortez, Nevada, in Geological Survey research 1964: U.S. Geological Survey Professional Paper 501-B, p. B92-B94.

Erickson, R. L., Van Sickle, G. H., Nakagawa, H. M., McCarthy, J. H., Jr., and Leong, K. H., 1966, Gold geochemical anomaly in the Cortez district, Nevada: U.S. Geological Survey Circular 534, 9 p.

Evans, J. G., 1972a, Preliminary geologic map of the Rodeo Creek northeast quadrangle, Nevada: U.S. Geological Survey Miscellaneous Field Studies Map MF-325, scale 1:24,000.

1972b, Preliminary geologic map of the Welches Canyon quadrangle, Nevada: U.S. Geological Survey Miscellaneous Field Studies Map MF-326, scale 1:24,000, 2 sheets.

1974a, Geologic map of the Rodeo Creek NE quadrangle, Eureka County, Nevada: U.S. Geological Survey Geologic Quadrangle Map GQ-1116, scale 1:24,000.

$1974 \mathrm{~b}$, Geologic map of the Welches Canyon quadrangle, Eureka County, Nevada: U.S. Geological Survey Geologic Quadrangle Map GQ-1117, scale 1:24,000.

Evans, J. G., and Mullens, T. E., 1975, The Bootstrap window, Elko and Eureka Counties, Nevada: U.S. Geological Survey Journal of Research, v.4, no.1, p. 119-125.

Evernden, J. G., and Kistler, R. W., 1970, Chronology of emplacement of Mesozoic batholithic complexes in California and western Nevada: U.S. Geological Survey Professional Paper 623, 42 p.

Ferguson, H. G., 1924, Geology and ore deposits of the Manhattan district, Nevada: U.S. Geological Survey Bulletin 723, 163 p.

Galli, P. E., Livermore, J. S., and Reeve, L. G., 1976, Pinson and Preble gold deposits near Golconda, Humboldt County, Nevada [abs.], in Geology and exploration aspects of fine-grained, Carlin-type gold deposits: Geological Society of Nevada and Mackay School of Mines Symposium, Reno, Nev., 1976, Abstracts, p. 4.

Garrels, R. M., and Christ, C. L., 1965, Solutions, minerals, and equilibria: New York, Harper \& Row, 450 p.

Gilluly, James, 1932, Geology and ore deposits of the Stockton and Fairfield quadrangles, Utah: U.S. Geological Survey Professional Paper $173,171 \mathrm{p}$.

-1954, Further light on the Roberts Mountains thrust, north-central Nevada: Science, v. 119, no. 3091, p. 423.

Gilluly, James, and Masursky, Harold, 1965, Geology of the Cortez quadrangle, Nevada, with a section on Gravity and aeromagnetic survey, by D. R. Mabey: U.S. Geological Survey Bulletin 1175, 117 p.

Godfrey, J. D., 1962, The deuterium content of hydrous minerals from the east-central Sierra Nevada and Yosemite National Park: Geochimica et Cosmochimica Acta, v. 26, no. 12, p. 1215-1245.
Graf, D. L., 1960, Geochemistry of carbonate sediments and sedimentary carbonate rocks - part 3, Minor element distribution: Illinois Geological Survey Division Circular 301, 71 p.

Haas, J. L.,1971, The effect of salinity on the maximum thermal gradient of a hydrostatic system at hydrostatic pressure: Economic Geology, v. 66, no. 6, p. 940-946.

Haas, Winfried, 1969, Lower Devonian trilobites from central Nevada and northern Mexico: Journal of Paleontology, v. 43, no. 3, p. 641 659.

Hague, Arnold, 1883, Abstract of report on geology of the Eureka district, Nevada: U.S. Geological Survey Annual Report 3, p. 237-290.

1892 , Geology of the Eureka district, Nevada: U.S. Geological Survey Monograph 20, 419p.

Hardie, B. S., 1966, Carlin gold mine, Lynn district, Nevada, in AIME Pacific Southwest Mineral Industry Conference, Sparks, Nev., 1965, Papers: Nevada Bureau of Mines Report 13, pt. A, p. 73-83.

Harris, Michael, 1974, Statistical treatment of selected trace elements in unoxidized gold ores of the Carlin gold deposit, Nevada: Stanford, Calif., Stanford University, M. S. thesis, 66 p.

Harris, Michael, and Radtke, A. S., 1974, Relation of statistical findings to the geochemistry and genesis of the Carlin gold deposit, Nevada [abs.]: Geological Society of America Abstracts with Programs, v. 6, no. 7, p. 779 .

1976, Statistical study of selected trace elements with reference to geology and genesis of the Carlin gold deposit, Nevada: U.S. Geological Survey Professional Paper 960, $21 \mathrm{p}$.

Hausen, D. M., 1967, Fine gold occurrence at Carlin, Nevada: New York, Columbia University, Ph. D. thesis, $166 \mathrm{p}$.

Hausen, D. M., and Kerr, P. F., 1968, Fine gold occurrence at Carlin, Nevada, in Ridge, J. D., ed., Ore deposits of the United States, 1933-1967 (Graton-Sales volume) (1st ed.): New York, American Institute of Mining, Metallurgical, and Petroleum Engineers, v. 1, p. 908-940.

Hawkins, R. B., 1973, The geology and mineralization of the Jerrett Creek area, northern Independence Mountains, Nevada: Pocatello, Idaho State University, M.S. thesis, 104 p.

Helgeson, H. C., 1969, Thermodynamics of hydrothermal systems at elevated temperatures and pressures: American Journal of Science, v. 267 , no. 7 , p. $729-804$.

Helgeson, H. C., Brown, T. H., and Leeper, R. H., 1969, Handbook of theoretical activity diagrams depicting chemical equilibria in geologic systems involving an aqueous phase at one atm and $0^{\circ}$ to $300^{\circ} \mathrm{C}$ : San Francisco, Freeman, Cooper \& Co., $253 \mathrm{p}$.

Hemley, J. J., 1959, Some mineralogical equilibria in the system $\mathrm{K}_{2} \mathrm{O}$ $\mathrm{Al}_{2} \mathrm{O}_{3}-\mathrm{SiO}_{2}-\mathrm{H}_{2} \mathrm{O}$ : American Journal of Science, v. 257 , no. 4, p. $241-$ 270.

Hemley, J. J., and Jones, W. R., 1964, Chemical aspects of hydrothermal alteration with emphasis on hydrogen metasomatism: Economic Geology, v. 59, no. 4, p. 538-569.

Hill, J. M., 1912, The mining districts of the western United States, with $a$ Geologic introduction, by Waldemar Lindgren: U.S. Geological Survey Bulletin 507, $309 \mathrm{p}$.

Holser, W. T., and Kaplan, I. R., 1966, Isotope geochemistry of sedimentary sulfates: Chemical Geology, v. 1, no. 2, p. 93-135.

Hotz, D. E., and Willden, Ronald, 1964, Geology and mineral deposits of the Osgood mountain quadrangle, Humboldt County, Nevada: U.S. Geological Survey Professional Paper 431, 128p.

Igumnov, S. A., 1976, Experimental study of isotope exchange between sulfide and sulfate sulfur in hydrothermal solution: Geokhimia, 1976, no. 4,p. 497-503 [in Russian, with English abstract].

Iohnson, J. G., 1965, Lower Devonian stratigraphy and correlation, northern Simpson Park Range, Nevada: Bulletin of Canadian Petroleum Geology, v. 13, no. 3, p. 365-381. 
Iohnson, M. G., 1973, Placer gold deposits of Nevada: U.S. Geological Survey Bulletin 1356,118 p.

1977, Geology and mineral deposits of Pershing County, Nevada: Nevada Bureau of Mines Bulletin 89, $115 \mathrm{p}$.

Ioralemon, Peter, 1951, The occurrence of gold at the Getchell mine, Nevada: Economic Geology, v. 46, no. 3, p. 267-310.

Kennedy, G. C., 1950, A portion of the system silica-water: Economic Geology, v. 45, no. 7, p. 629-653.

Ketner, K. B., 1966, Comparison of the eugeosynclinal and miogeosynclinal quartzites of the Cordilleran geocyncline, in Geological Survey research 1966: U.S. Geological Survey Professional Paper 550-C, p. $\mathrm{C} 54-\mathrm{C} 60$.

1968, Origin of Ordovician quartzite in the Cordilleran miogeosyncline, in Geological Survey research 1968: U.S. Geological Survey Professional Paper 600-B, p. B169-B177.

King, Clarence, 1876, Geological and topographical atlas accompanying the report of the geological exploration of the Fortieth Parallel: Washington, U.S. Government Printing Office.

1878, Systematic geology: United States geological exploration of the Fortieth Parallel, v. 1: Washington, U.S. Government Printing Office, $803 \mathrm{p}$.

Kirk, Edwin, 1933, The Eureka quartzite of the Great Basin region: American Journal of Science, ser. 5, v. 26, no. 151, p. 27-44.

Knauth, L. P., and Epstein, Samuel, 1976, Hydrogen and oxygen isotope ratios in nodular and bedded cherts: Geochimica et Cosmochimica Acta, v. 40, no. 9, p. 1095-1108.

Koschmann, A. H., and Bergendahl, M. H., 1968, Principal gold-producing districts of the United States: U.S. Geological Survey Professional Paper 610, $283 \mathrm{p}$.

Kral, V. E., 1950, Mineral resources of Nye County, Nevada: University of Nevada Bulletin, v. 45, no. 3 (Geology and Mining Series, no. 50), $223 \mathrm{p}$.

Krumbein, W. C., 1959, The "sorting out" of geologic variables illustrated by regression analysis of factors controlling beach firmness: Journal of Sedimentary Petrology, v. 29, no. 4, p. 575-585.

Kusakabe, Minoru, and Robinson, B. W., 1977, Oxygen and sulfur isotope equilibria in the $\mathrm{BaSO}_{4}-\mathrm{HSO}_{4}-\mathrm{H}_{2} \mathrm{O}$ system from 110 to $350^{\circ} \mathrm{C}$ and applications: Geochimica et Cosmochimica Acta, v. 41, no. 8, p. 1033-1040.

Lawrence, E. F., 1963, Antimony deposits of Nevada: Nevada Bureau of Mines Bulletin 61, 248 p.

Lee, A. G., 1971, The chemistry of thallium: Amsterdam, Elsevier, 336 p.

Lee, W. T., Stone, R. W., Gale, H. S., and others, 1916, Guidebook of the western United States. Part B. The overland route, with a side trip to Yellowstone Park: U.S. Geological Survey Bulletin 612, 251 p.

Lincoln, F. C., 1923, Mining districts and minerals resources of Nevada: Reno, Nev., Newsletter Publishing Co., 295 p.

Matti, J. C., Murphy, M. A., and Finney, S. C., 1975, Silurian and Lower Devonian basin and basin-slope limestones, Copenhagen Canyon, Nevada: Geological Society of America Special Paper 159, 48 p.

McKee, E. H., Silberman, M. L., Marvin, R. E., and Obradovich, J. D., 1971 , A summary of radiometric ages of Tertiary volcanic rocks in Nevada and eastern California. Part I-central Nevada: Isochron/ West, no. 2, p. 21-42.

Merriam, C. W., 1940, Devonian stratigraphy and paleontology of the Roberts Mountains region, Nevada: Geological Society of America SpecialPaper 25, $114 \mathrm{p}$

-1973, Paleontology and stratigraphy of the Rabbit Hill Limestone and Lone Mountain Dolomite of central Nevada: U.S. Geological Survey Professional Paper 808, 50 p.
Merriam, C. W., and Anderson, C. A., 1942, Reconnaissance survey of the Roberts Mountains, Nevada: Geological Society of America Bulletin, v. 53, no. 12, p. 1675-1727.

Merriam, C. W., and McKee, E. H., 1976, The Roberts Mountains Formation, a regional stratigraphic study with emphasis on rugose coral distribution, with a section on Conodonts, by J. W. Huddle: U.S. Geological Survey Professional Paper 973, 51 p.

Moore, D. E., and Dickson, F. W., 1973, Phases of the system $\mathrm{Sb}_{2} \mathrm{~S}_{3-}$ $\mathrm{As}_{2} \mathrm{~S}_{3}$ [abs.]: American Geophysical Union Annual Meeting, San Francisco, 1973, Abstracts, p. 1223-1224.

Morey, G. W., Fournier, R. O., and Rowe, J. J., 1962, The solubility of quartz in water in the temperature interval from $25^{\circ}$ to $300^{\circ} \mathrm{C}$ : Geochimica et Cosmochimica Acta, v. 26, no. 10, p. 1029-1043.

Mullens, T. E., 1980, Stratigraphy, petrology, and some fossil data of the Roberts Mountains Formation, north-central Nevada: U.S. Geological Survey Professional Paper 1063, 67p.

Mullens, T. E., and Poole, F. G., 1972, Quartz-sand-bearing zone and Early Silurian age of upper part of the Hanson Creek Formation in Eureka County, Nevada, in Geological Survey research 1972: U.S. Geological Survey Professional Paper 800-B, p. B21-B24.

Murphy, J. B., 1964, Gems and gem minerals, in Mineral and water resources of Nevada: Nevada Bureau of Mines Bulletin 65, p. 207.

Naramore, Chester, 1911, Nevada, in Mineral resources of the United States, calendar year 1909, part I-metals: Washington, U.S. Government Printing Office, p. 386-430.

Nash, J. T., 1972, Fluid-inclusion studies of some gold deposits in Nevada, in Geological Survey research 1972: U.S. Geological Survey Professional Paper 800-C, p. C15-C19.

Nicoll, R. S., and Rexroad, C. B., 1968, Stratigraphy and conodont paleontology of the Salamonie Dolomite and Lee Creek Member of the Brassfield Limestone (Silurian) in southeastern Indiana and adjacent Kentucky: Indiana Geological Survey Bulletin 40, 73 p.

Noble, L. L., Valiquett, J., and Ekburg, C., 1977, Geology of the Blue Star gold deposit near Carlin, Nevada: Report distributed at Pacific Southwest Minerals Industries Conference, Stateline, Nev., 1977, $11 \mathrm{p}$.

Noble, L. L., and Radtke, A. S., 1978, Geology of the Carlin disseminated replacement gold deposit, Nevada, in Shawe, D. R., ed., Guidebook to mineral deposits of the central Great Basin: Nevada Bureau of Mines and Geology Report 32, p. 40-44.

Nolan, T. B., 1962, The Eureka mining district, Nevada: U.S. Geological Survey Professional Paper 406, 78p.

Nolan, T. B., Merriam, C. W., and Williams, J. S., 1956, The stratig raphic section in the vicinity of Eureka, Nevada: U.S. Geological Survey Professional Paper 276, 77p.

Ohmoto, Hiroshi, 1972, Systematics of sulfur and carbon isotopes in hydrothermal ore deposits: Economic Geology, v. 67, no. 5,

Ohmoto, Hiroshi, and Rye, R. O., 1979, Isotopes of sulfur and carbon, chap. 10 of Barnes, H. L., ed., Geochemistry of hydrothermal ore deposits(2d ed.): New York, Wiley-Interscience, p. 509-567.

O'Neil, J. R., and Silberman, M. L., 1974, Stable isotope relations in epithermal Au-Ag deposits: Economic Geology, v. 69, no. 6, p. 902 909.

Peterson, J. A., 1976, Phase relations in the system $\mathrm{Tl}_{2} \mathrm{~S}-\mathrm{As}_{2} \mathrm{~S}_{3}$ : Stanford, Calif., Stanford University, M.S. thesis, $50 \mathrm{p}$.

Pinckney, D. M., and Rye, R. O., 1972, Variations of $0^{18} / 0^{16}, \mathrm{C}^{13} / \mathrm{C}^{12}$, texture, and mineralogy in altered limestone in the Hill mine, Cavein-Rock district, Illinois: Economic Geology, v. 67, no. 1, p. 1-18.

Pinsak, A. P., and Shaver, R. H., 1964, The Silurian formations of northern Indiana: Indiana Geological Survey Bulletin 32, $87 \mathrm{p}$.

Pollock, C. A., Rexroad, C. B., and Nicoll, R. S., 1970, Lower Silurian conodonts from northern Michigan and Ontario: Journal of Paleontology, v. 44, no. 4, p. 743-764. 
Radtke, A. S., 1973, Preliminary geologic map of the Carlin gold mine, Eureka County, Nevada: U.S. Geological Survey Miscellaneous Field Studies Map MF-537, scale 1:3,600.

1974, Preliminary geologic map of the area of the Carlin and Blue Star gold deposits, Eureka County, Nevada: U.S. Geological Survey Miscellaneous Field Studies Map MF-552, scale 1:12,000.

Radtke, A. S., and Brown, G. E., 1974, Frankdicksonite, $\mathrm{BaF}_{2}$, a new mineral from Nevada: American Mineralogist, v. 50, no. 9-10, p. 885-888.

Radtke, A. S., and Dickson, F. W., 1974a, Controls on the vertical position of fine-grained replacement-type gold deposits [abs.]: International Association on the Genesis of Ore Deposits Symposium, 4th, Varna, Bulgaria, 1974, Abstracts, p. 68-69.

$-1974 \mathrm{~b}$, Genesis and vertical position of fine-grained disseminated replacement-type gold deposits in Nevada and Utah, U.S.A., in Problems of ore deposition, v. 1, Volcanic ore deposits: International Association on the Genesis of Ore Deposits Symposium, 4th, Varna, Bulgaria, 1974, Proceedings, p. 71-78.

1975a, Carlinite, $\mathrm{Tl}_{2} \mathrm{~S}$, a new mineral from Nevada: American Mineralogist, v. 60 , no. 7-8, p. 559-565.

$-1975 \mathrm{~b}$, Characteristics of the Carlin and other disseminated replacement-type gold deposits [abs.]: Pacific Northwest Metals and Minerals Conference, Portland, Oreg., 1975, Abstracts, p. 8.

-1976 , General features of disseminated replacement gold deposits of the Carlin type [abs.], in Geology and exploration aspects of finegrained, Carlin-type gold deposits: Geological Society of Nevada and Mackay School of Mines Symposium, Reno, Nev., 1976, Preprints with Program, p.1-2.

Radtke, A. S., Dickson, F. W., and Rytuba, J. J., 1974a, Genesis of disseminated gold deposits of the Carlin type [abs.]: Geological Society of America Abstracts with Programs, v. 6, no. 3, p. 239-240.

Radtke, A. S., Dickson, F. W., and Slack, J. F., 1978, Occurrence and form of avicennite, $\mathrm{Tl}_{2} \mathrm{O}_{3}$, a secondary mineral at the Carlin gold deposit, Nevada: U.S. Geological Survey Journal of Research, v. 6, no. $2,241-245$.

Radtke, A. S., Dickson, F. W., Slack, J. F., and Brown, K. L., 1977, Christite, a new thallium mineral from the Carlin gold deposit, Nevada: American Mineralogist, v. 62, no. 5-6, p. 421-425.

Radtke, A. S., Heropoulos, Chris, Fabbi, B. P., Scheiner, B. J., and Essington, Mel, 1972a, Data on major and minor elements in host rocks and ores, Carlin deposit, Nevada: Economic Geology, v. 67, no. 7, p. $975-978$.

Radtke, A.S., Rye, R.O., and Dickson, F.W., 1980, Geology and stable isotope studies of the Carlin gold deposit, Nevada: Econ. Geology, V.75, no.5., p. 641-672.

Radtke, A. S., and Scheiner, B. J., 1970a, Influence of organic carbon on gold deposition at the Carlin and Cortez deposits, Nevada [abs.]: Geological Society of America Abstracts with Programs, v. 2, no. 7, p. 660 .

1970b, Studies of hydrothermal gold deposition (I). Carlin gold deposit, Nevada: The role of carbonaceous materials in gold deposition: Economic Geology, v. 65, no. 2, p. 87-102.

Radtke, A. S., Taylor, C. M., and Christ, C. L., 1972b, Chemical distribution of gold and mercury at the Carlin deposit, Nevada [abs.]: Geological Society of America Abstracts with Programs, v. 4, no. 7 , p. 632.

Radtke, A. S., Taylor, C. M., Dickson, F. W., and Heropoulos, Chris, 1974b, Thallium-bearing orpiment, Carlin gold deposit, Nevada: U.S. Geological Survey Journal of Research, v. 2, no. 3, p. 341-342.

Radtke, A. S., Taylor, C. M., Erd, R. C., and Dickson, F. W., 1974c, Occurrence of lorandite, TlAsS 2 , at the Carlin gold deposit, Nevada: Economic Geology, v. 69, no. 1, p. 121-123.

Radtke, A. S., Taylor, C. M., and Heropoulos, Chris, 1973, Antimonybearing orpiment, Carlin gold deposit, Nevada: U.S. Geological Survey Journal of Research, v. 1, no. 1, p. 85-87.
Regnier, Jerome, 1960, Cenozoic geology in the vicinity of Carlin, Nevada: Geological Society of America Bulletin, v. 71 , no. 8, p.1189-1210.

Rexroad, C. B., 1967, Stratigraphy and conodont paleontology of the Brassfield (Silurian) in the Cincinnati Arch area: Indiana Geological Survey Bulletin 36, $64 \mathrm{p}$.

Roberts, R. J., 1960, Alignment of mining districts in north-central Nevada, in Geological Survey research 1960: U.S. Geological Survey Professional Paper 400-B, p. B17-B19.

-1966, Metallogenic provinces and mineral belts in Nevada, in AIME Pacific Southwest Mineral Industry Conference, Sparks, Nev., 1965, Papers: Nevada Bureau of Mines Report 13, pt. A, p. 47-72.

Roberts, R. J., Hotz, P. E., Gilluly, James, and Ferguson, H. G., 1958, Paleozoic rocks of north-central Nevada: American Association of Petroleum Geologists Bulletin, v. 42, n. 12, p. 2813-2857.

Roberts, R. J., and Lehner, R. E., 1955, Additional data on the age and extent of the Roberts Mountains thrust fault, north-central Nevada [abs.]: Geological Society of America Bulletin, v. 66, no. 12, pt. 2, p. 1661.

Roberts, R. J., Montgomery, K. M., and Lehner, R. E., 1967, Geology and mineral resources of Eureka County, Nevada: Nevada Bureau of Mines Bulletin 64, $152 \mathrm{p}$.

Roberts, R. J., Radtke, A. S., and Coats, R. R., 1971, Gold-bearing deposits in north-central Nevada and southwestern Idaho: Economic Geology, v.66, no. 1, p. 14-33.

Roen, J. B., 1961, The geology of the Lynn Window, Tuscarora Mountains, Eureka County, Nevada: Los Angeles, University of California, M.S. thesis, 99 p.

Rye, R. O., 1966, The carbon, hydrogen, and oxygen isotopic composition of the hydrothermal fluids responsible for the lead-zinc deposits at Providencia, Zacatecas, Mexico: Economic Geology, v. 69, no. 9, p. 1399-1427.

Rye, R. O., Doe, B. R., and Wells, J. D., 1974, Stable isotope and lead isotope study of the Cortez, Nevada, gold deposit and surrounding area: U.S. Geological Survey Journal of Research, v. 2, no. 1, p. 1323.

Rye, R. O., and Ohmoto, Hiroshi, 1974, Sulfur and carbon isotopes and ore genesis - a review: Economic Geology, v. 69, no. 6, p. 826-842.

Rye, R. O., and Sawkins, F. J., 1974, Fluid inclusion and stable isotope studies on the Casapalca $\mathrm{Ag}-\mathrm{Pb}-\mathrm{Zn}$ - $\mathrm{Cu}$ deposit, central Andes, Peru: Economic Geology, v. 69, no. 2, p. 181-205.

Rye, R. O., Shawe, D. R., and Poole, F. G., 1978, Stable isotope studies of bedded barite at East Northumberland Canyon in Toquima Range, central Nevada: U.S. Geological Survey Journal of Research, v. 6, no. 2, p. 221-239.

Rytuba, J. J., and Dickson, F. W., 1974, Reaction of pyrite + pyrrhotite + quartz + gold with $\mathrm{NaCl}-\mathrm{H}_{2} \mathrm{O}$ solutions, $300^{\circ}-500^{\circ} \mathrm{C}, 500-1500$ bars, and genetic implications [abs.]: International Association on the Genesis of Ore Deposits Symposium, 4th, Varna, Bulgaria, 1974, Abstracts, p. 312-313.

Sakai, Hitoshi, and Dickson, F. W., 1978, Experimental determination of the rate and equilibrium fractionation factors of sulfur isotope exchange between sulfate and sulfide in slightly acid solutions at $300^{\circ} \mathrm{C}$ and 1000 bars: Earth and Planetary Science Letters, v. 39, no. 1, p. 151-161.

Scheiner, B. J., Lindstrom, R. E., and Henrie, T. A., 1968, Investigation of oxidation systems for improving gold recovery from carbonaceous materials: U.S. Bureau of Mines Technical Progress Report $2,8 \mathrm{p}$.

Schoen, Robert, and Rye, R. O., 1970, Sulfur isotope distribution in solfataras, Yellowstone National Park: Science, v. 170, no. 3962, p. 1082-1084. 
Schoen, Robert, and White, D. E., 1965, Hydrothermal alteration in GS-3 and GS-4 drill holes, Mai Terrace, Steamboat Springs, Nevada: Economic Geology, v.60, no. 7, p. 1411-1421.

Seward, T. M., 1973, Thio complexes of gold and the transport of gold in hydrothermal ore solutions: Geochimica et Cosmochimica Acta, v. 37, no.3, p.379-399.

Shackleton, N. J., and Kennett, J. P., 1975, Late Cenozoic oxygen and carbon isotopic changes at DSDP Site 284: Implications for glacial history of the Northern Hemisphere and Antarctica: Deep Sea Drilling Project Initial Reports, v. 29, p. 801-807.

Shapiro, Leonard, 1967, Rapid analysis of rocks and minerals by a single- solution method, in Geological Survey research 1967: U.S. Geological Survey Professional Paper 575-B, p. B187-B191.

Shapiro, Leonard, and Brannock, W. W., 1962, Rapid analysis of silicate, carbonate, and phosphate rocks: U.S. Geological Survey Bulletin 1144-A, p. A1-A56.

Silberman, M. L., Berger, B. R., and Koski, R. A., 1974, K-Ar ages of granodiorite emplacement and tungsten and gold mineralization near the Getchell mine, Humboldt County, Nevada: Economic Geology, v.69, no.5, p. 646-656.

Silberman, M. L., and McKee, E. H., 1971, K-Ar ages of granitic plutons in north-central Nevada: Isochron/West, no. 1, p. 15-32.

-1974, Ages of Tertiary volcanic rocks and hydrothermal preciousmetal deposits in central and western Nevada in Guidebook to the geology of four Tertiary volcanic centers in central Nevada: Nevada Bureau of Mines and Geology Report 19, p. 67-72.

Silberman, M. L., White, D. E., Keith, T. E. C., and Dockter, R. D. 1979, Duration of hydrothermal activity at Steamboat Springs, Nevada, from ages of spatially associated volcanic rocks: U.S. Geological Survey Professional Paper 458-D, p. D1-D14.

Smith, J. F., Jr., and Ketner, K. B., 1975, Stratigraphy of Paleozoic rocks in the Carlin-Pinon Range area, Nevada: U.S. Geological Survey Professional Paper 867-A, p. A1-A87.

1977, Tectonic events since early Paleozoic in the Carlin-Pinon Range area, Nevada: U.S. Geological Survey Professional Paper 867-C, p. C1-C18.

Smith, A. M., and Vanderburg, W. O., 1932, Placer mining in Nevada: Nevada Bureau of Mines Bulletin 18, $104 p$.

Southern Pacific Co., 1964, Minerals for industry-northern Nevada and northwestern Utah, summary of geological survey of 19551961, v. 1: San Francisco, 188 p.

Tafuri, W. J., 1976, Geology and geochemistry of the gold deposits at Mercur, Utah [abs.], in Geology and exploration aspects of finegrained, Carlin-type gold deposits: Geological Society of Nevada and Mackay School of Mines Symposium, Reno, Nev., 1976, Abstracts, p.10.

Taylor, H. P., Jr., 1974, The application of oxygen and hydrogen isotope studies to problems of hydrothermal alteration and ore deposition: Economic Geology, v. 69, no. 6, p. 843-883.

Thode, H. G., and Monster, Jan, 1965, Sulfur-isotope geochemistry of petroleum, evaporites, and ancient seas, in Young, Addison, and Galley, J. E., eds., Fluids in subsurface environments: American Association of Petroleum Geologists Memoir 4, p. 367-377.

Turekian, K. K., and Wedepohl, K. H., 1961, Distribution of the elements in some major units of the Earth's crust: Geological Society of America Bulletin, v. 72, no. 2, p. 175-192.

Vanderburg, W. O., 1936, Placer mining in Nevada: Nevada Bureau, Mines Bulletin 30, 178 p.
1938, Reconnaissance of mining districts in Eureka County, Nevada: U.S. Bureau of Mines Information Circular 7022, 66 p.

Webb, G. W., 1958, Middle Ordovician stratigraphy in eastern Nevada and western Utah: American Association of Petroleum Geologists Bulletin, v.42, no.10, p. 2335-2377.

Weissberg, B. W., 1969, Gold-silver ore-grade precipitates from New Zealand thermal waters: Economic Geology, v. 64, no. 1, p. 95-108.

Wells, J. D., Elliott, J. E., and Obradovich, J. D., 1971, Age of the igneous rocks associated with ore deposits, Cortez-Buckhorn area, Nevada, in Geological Survey research 1971: U.S. Geological Survey Professional Paper 750-C, p. C127-C135.

Wells, J. D., and Mullens, T. E., 1973, Gold-bearing arsenian pyrite determined by microprobe analysis, Cortez and Carlin gold mines, Nevada: Economic Geology, v. 68, no. 2, p. 187-201.

Wells, J. D., Stoiser, L. R., and Elliott, J. E., 1969, Geology and geochemistry of the Cortez gold deposit, Nevada: Economic Geology, v. 64, no.5, p. 526-537.

White, D. E., 1955, Thermal springs and epithermal ore deposits, in Bateman, A. M., ed., Economic Geology-fiftieth anniversary volume, 1905-1955, pt. 1: p. 99-154.

1957a, Thermal waters of voleanic origin: Geological Society of America Bulletin, v. 68, nө. 12, p. 1637-1657.

1957b, Magmatic, connate, and metamorphic waters: Geological Society of America Bulletin, v. 68, no. 12, p. 1659-1682.

1965, Metal contents of some geothermal fluids, in Stemprok, Miroslav, ed., Symposium: Problems of postmagmatic ore deposition with special reference to the geochemistry of ore veins: Prague, 1963: Geological Survey of Czechoslovakia, v. 2, p. 432-443.

-1967, Mercury and base-metal deposits with associated thermal and mineral waters, in Barnes, H. L., ed., Geochemistry of hydrothermal ore deposits: New York, Holt, Rinehart and Winston, p. 575-631.

White, D. E., and Brannock, W. W., 1950, The sources of heat and water supply of thermal springs, with particular reference to Steamboat Springs, Nevada: American Geophysical Union Transactions, v. 31, no. 4, p. 566-574.

White, D. E., Thompson, G. A., and Sandberg, C. H., 1964, Rocks, structure, and geologic history of Steamboat Springs thermal area, Washoe County, Nevada: U.S. Geological Survey Professional Paper 458-B, p. B1-B63.

Willden, Ronald, 1964, Geology and mineral deposits of Humboldt County, Nevada: Nevada Bureau of Mines Bulletin 59, $154 \mathrm{p}$.

Wilson, W. L., 1976, The Eureka Windfall gold mine [abs.], in Geology and exploration aspects of fine-grained, Carlin-type gold deposits: Geological Society of Nevada and Mackay School of Mines Symposium, Reno, Nev., 1976, Abstracts, p. 8.

Winterer, E. W., and Murphy, M. A., 1960, Silurian reef complex and associated facies, central Nevada: Journal of Geology, v. 68, no. 2, p. 117-139.

Wrucke, C. T., and Armbrustmacher, T. J., 1969, Structural controls of the gold deposit at the open-pit mine, Gold Acres, Lander County, Nevada [abs.]: Geological Society of America Abstracts with Programs, v. 1 , no. 3 , p. 75.

-1975 , Geochemical and geologic relations of gold and other elements at the Gold Acres open-pit mine, Lander County, Nevada: U.S. Geological Survey Professional Paper 860, 27p.

Wrucke, C. T., Armbrustmacher, T. J., and Hessin, T. D., 1968, Distribution of gold, silver, and other metals near Gold Acres and Tenabo, Lander County, Nevada: U.S. Geological Survey Circular 589, 19 p. 
